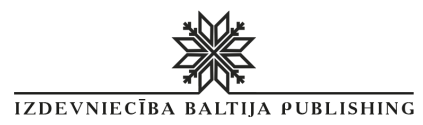

\title{
ECONOMIC SYSTEM
}

\section{DEVELOPMENT TRENDS: THE EXPERIENCE OF COUNTRIES OF EASTERN EUROPE AND PROSPECTS OF UKRAINE}

\author{
Monograph
}

Riga, Latvia

2018 
UDC 33(4-11)(082)

Ec 393

Title: Economic system development trends: the experience of countries of Eastern Europe and prospects of Ukraine

Subtitle: Monograph

Scientific editor and

project director: Anita Jankovska

Authors: Aleskerova Yuliia, Fedoryshyna Lidiia, Berezianko Tamara, Belobrovenko Tatiana, Bogush Larysa, Borysiuk Olena, Stashchuk Olena, Vasylchenko Mariana, Khrystenko Olena, Hbur Zoriana, Hlubish Lesia, Derevianchenko Tatyana, Dzhedzhula Vyacheslav, Yepifanova Iryna, Dovbenko Viacheslav, Yekhalova Anna, Zhukov Vladlen, Kornieieva Iuliia, Kureda Nina, Yukhnovska Yuliya, Levchuk Katerina, Romanyuk Roman, Kaflevska Svitlana, Lysiuk Oleksandra, Makarov Vitaliy, Markova Ievgeniia, Shestakovska Tatyana, Mykolaichuk Mykola, Mykolaichuk Natalia, Otsabryk Iryna, Polishchuk Vadym, Puhalsky Vadym, Saiensus Mariia, Strishenets Olena, Pavlov Kostiantyn, Tomchuk-Ponomarenko Nataliia, Chupryna Natalia, Haievskyi Vladyslav, Yarygina Irina

Publisher: SIA “Izdevnieciba "Baltija Publishing", Valdeku iela 62-156, Riga, LV-1058

Available from: http://www.baltijapublishing.lv/index.php/econom-science

Year of issue: 2018

All rights reserved. No part of this book may be reprinted or reproduced or utilized in any form or by any electronic, mechanical, or other means, now known or hereafter invented, including photocopying and recording, or in any information storage or retrieval system, without permission in writing from the publisher and autor.

Economic system development trends: the experience of countries of Eastern Europe and prospects of Ukraine: monograph / edited by authors. - Riga, Latvia : "Baltija Publishing", 2018. - 546 p.

ISBN: 978-9934-571-28-2

DOI: https://doi.org/10.30525/978-9934-571-28-2

The monograph studies theoretical and practical development trends of economic science and practice, taking into account the experience of countries of Eastern Europe and prospects of Ukraine. General issues of the world economy and international economic relations, business economics and management, innovative and investment activity, accounting, analysis and audit, marketing etc. are considered. The publication is designed for scientists, lecturers, postgraduate students, and students of economic specialties, as well as a wide range of readers interested in economics.

C) Publishing House "Baltija Publishing", 2018

(C) Authors of the articles, 2018 


\section{Table of Contents}

Aleskerova Yuliia, Fedoryshyna Lidiia

ANALYSIS OF INVESTMENT ACTIVITIES

OF ENTERPRISES OF UKRAINE.

Berezianko Tamara

ECONOMETRIC ACCEPTANCE OF USE

OF CORPORATE SOCIAL RESPONSIBILITY

\section{Belobrovenko Tatiana}

THE HISTORICAL ASPECT OF THE DETERMINATION

AND DEVELOPMENT OF VAT IN THE WORLD

AND THE PROBLEM OF ITS APPLICATION IN UKRAINE

\section{Bogush Larysa}

BALANCING SOCIO-ECONOMIC DEVELOPMENT

OF UKRAINE' REGIONS ON THE PRIORITY

OF THE SOCIO-HUMANITARIAN POTENTIAL'

EFFICIENT CAPITALIZATION

Borysiuk Olena, Stashchuk Olena

SECURITY OF FINANCIAL MARKET OF UKRAINE

IN CONDITIONS OF UNSTABLE FINANCIAL ENVIRONMENT.

Vasylchenko Mariana, Khrystenko Olena

NATIONAL INNOVATION SYSTEM DEVELOPMENT:

EVIDENCE FROM THE COUNTRIES OF THE CENTRAL

AND EASTERN EUROPE REGION.

\section{Hbur Zoriana}

ECONOMIC SECURITY OF THE STATE:

EXPERIENCE OF DEVELOPED COUNTRIES OF THE WORLD.

\section{Hlubish Lesia}

EXPEDIENCY OF USING THE STAKEHOLDER'S APPROACH

FOR ACHIEVING THE SYSTEM STABILITY OF THE PROCESS

OF FOOD SECURITY

Derevianchenko Tatyana

MARKETING AUDIT OF THE ENTERPRISE. 
Dzhedzhula Vyacheslav, Yepifanova Iryna

CROWDSOURCING AS A WAY TO INCREASE

THE COMPANY'S INTELLECTUAL CAPITAL.

Dovbenko Viacheslav

STRATEGIES OF EFFECTIVE DEVELOPMENT

OF PARTICIPANTS THE INNOVATIVE PROCESS

\section{Yekhalova Anna}

THE MECHANISM OF STATE REGULATION

OF THE INSURANCE MARKET: A SYSTEMATIC APPROACH

Zhukov Vladlen

METHODOLOGICAL BASIS OF THE FORMATION

OF EFFECTIVE FORMS OF INVESTMENT ACTIVITY

IN THE CONDITIONS OF THE STRUCTURAL ADJUSTMENT

OF THE ECONOMY.

Kornieieva Iuliia

INVESTMENT COOPERATION

THROUGH DIGITAL DEVELOPMENT

Kureda Nina, Yukhnovska Yuliya

CONSUMER AND ECONOMIC PROPOSALS OF BALANCES

ON THE MARKET OF TREATMENT AND RECREATION TOURISM

OF THE COUNTRIES OF THE CARPATHIAN REGION

Levchuk Katerina, Romanyuk Roman

STRATEGY OF ECONOMIC GOVERNANCE

OF METALLURGICAL ENTERPRISE

VIA INNOVATIVE APPROACHES

Kaflevska Svitlana, Lysiuk Oleksandra

THE CURRENT STATE OF DEVELOPMENT

OF AGRICULTURAL ENTERPRISES OF VINNYTSYA REGION.

Makarov Vitaliy

OPTIMIZATION OF TECHNOLOGICAL DEVELOPMENT

OF COAL MINING IN UKRAINE.

Markova Ievgeniia, Shestakovska Tatyana

THE IMPACT OF THE INTEGRATION OF COOPERATION WITH THE EUROPEAN UNION ON THE DEVELOPMENT OF THE AGRARIAN SECTOR OF UKRAINE 
Mykolaichuk Mykola, Mykolaichuk Natalia

POTENTIAL POSSIBILITIES, GAPS AND PROSPECTS

FOR DEVELOPMENT OF ECONOMY OF UKRAINE

\section{Otsabryk Iryna}

THE DEFENDENCE INDUSTRIAL COMPLEX OF UKRAINE

IN AN ECONOMY OF POSTINDUSTRIAL SOCIETY:

ANALYSIS AND PERSPECTIVES

404

\section{Polishchuk Vadym}

FEATURES OF FISCAL STIMULATION

OF SUSTAINABLE DEVELOPMENT OF REGIONS

IN MODERN CONDITIONS.

\section{Puhalsky Vadym}

THE MODERN STATUS OF NORMATIVELY-LEGISLATIVE

REGULATION OF TAX CONTROL IN UKRAINE

AND PROPOSALS FOR ITS IMPROVEMENT.

\section{Saiensus Mariia}

GENERAL APPROACHES TO THE FORMATION OF MODEL

OF LOGISTICS OPERATORS IN SUPPLY CHAINS

Strishenets Olena, Pavlov Kostiantyn

SOCIAL-ECONOMIC ESTIMATION OF COMPETITIVE POSITIONS

FORMATION OF UKRAINIAN REGIONAL RESIDENTIAL

REAL ESTATE MARKETS

\section{Tomchuk-Ponomarenko Nataliia}

ESTABLISHMENT AND DEVELOPMENT

OF ECONOMIC WELFARE THEORY.

Chupryna Natalia, Haievskyi Vladyslav

THE MAIN THEORETICAL ASPECTS OF SYSTEM

OF CRISIS MANAGEMENT AT THE ENTERPRISE.

Yarygina Irina

BANKS FOR BRICS ECONOMIC DEVELOPMENT. 



\title{
ANALYSIS OF INVESTMENT ACTIVITIES OF ENTERPRISES OF UKRAINE
}

\author{
Aleskerova Yuliia ${ }^{1}$ \\ Fedoryshyna Lidiia ${ }^{2}$
}

DOI: http://dx.doi.org/10.30525/978-9934-571-28-2_1

\begin{abstract}
The current methods of investment activity, usually aimed at addressing local issues of determining their effectiveness without creating a single mechanism for ensuring reliability under the influence of "risk management" measures. The current mechanism of regulation of investment activity is not yet fully in line with modern requirements and does not have the necessary methodological basis. Also, such issues as regulation of the financial aspect of the investment process of capital reproduction, the formation of resources and sources of investment, the functioning of a fullfledged securities market, etc., have not been worked out.

In modern Ukraine, the notion of investment and investment has become a scientific turning point as a result of the reform of the economy into a market economy. Domestic and foreign economists consider investments as long-term capital investments in various spheres and sectors of the economy, infrastructure, social programs, environmental protection both inside the country and abroad for the purpose of development of production, social sphere, entrepreneurship, and profit.

In conditions of structural adjustment of the Ukrainian economy, the need for large foreign investments is a very acute problem. In most countries (USA, Germany, France, Great Britain), it was the foreign capital that was the catalyst for investment activity, which played an active role in the development and restructuring of the economy. The general state of the economy is significantly influenced by tax legislation, which has a number of shortcomings in Ukraine. Therefore, in the future, it should be foreseen to reduce the tax pressure on production, differentiate tax rates depend-
\end{abstract}

\footnotetext{
${ }^{1}$ Doctor of Economics, Senior Researcher, Associate Professor of the Department of Finance, Banking and Insurance, Vinnitsa National Agrarian University, Ukraine

${ }^{2}$ Candidate of Historical Studies,

Associate Professor of the Department of Analysis and Statistics,

Vinnitsa National Agrarian University, Ukraine

(C) Aleskerova Yuliia, Fedoryshyna Lidiia
} 
ing on the priority of the production sectors, the application of tax breaks (holidays) when taxing profits used to develop production. The costs and profits of enterprises are significantly affected by depreciation rates. The introduction of accelerated depreciation at enterprises would enable them to increase profits in the near future, and hence deductions for investments. International investment activities carried out on financial markets can positively influence the scale and pace of market transformation of national economies, both host and host countries, by developing conditions and factors for their international competitiveness. The analysis of the financial stability of the dairy enterprise by the coefficient of autonomy, the results of which are calculated in the table, allowed to establish such tendencies. The actual values of the autonomy factor in the analyzed period for the enterprise are higher than 2014, than its minimum threshold and have steady growth dynamics. However, since 2014, the company has been tracking a downward trend in this ratio. Accordingly, for these enterprises there is an increase in financial dependence. This indicates a reduction in its potential and a reduction in opportunities for attracting financial resources at the expense of external sources.

\section{Introduction}

In modern Ukrainethe activation of investment activity is particularly important, since without it it is impossible to make progressive changes in the economy, to increase competitiveness and in general, to ensure sustainable socio-economic development of the state.

The current methods of investment activity usually aimed at addressing local issues of determining their effectiveness without creating a single mechanism for ensuring reliability under the influence of "risk management" measures. The current mechanism of regulation of investment activity is not yet fully in line with modern requirements and does not have the necessary methodological basis. Also, such issues as regulation of the financial aspect of the investment process of capital reproduction, the formation of resources and sources of investment, the functioning of a full-fledged securities market, etc., have not been worked out.

The development of investment projects requires consideration of many factors, since external conditions are constantly changing. In assessing an investment project it is necessary to further take into account the risk associated with the temporary value of money especially with the 


\section{Analysis of investment activities of enterprises of Ukraine}

growth of inflation. The return on investment should always be higher than the inflation rate. The correctness and objectivity of such an estimate depends on the timing of return on investment and the prospects of enterprise development. Investing in real projects is a long-term process. Therefore the project must be thoroughly evaluated with maximum consideration of all factors.

The urgency of this topic of work is that our country is in the process of development for which it is necessary to apply attraction of funds from different sources: investment funds, funds of private investors, and especially foreign investments. That is the efficiency of investment activity is one of the first places in the conditions of development of our state.

The purpose of the study is to analyze the investment activity of ROSHEN and justify its improvement.

\section{The concept of investment}

In modern Ukraine the notion of investment and investment has become a scientific turning point as a result of the reform of the economy into a market economy. Domestic and foreign economists consider investments as long-term capital investments in various spheres and sectors of the economy, infrastructure, social programs, environmental protection both inside the country and abroad for the purpose of development of production, social sphere, entrepreneurship, and profit.

The term "investment" comes from the Latin. "Invest", which means "invest". In the broadest sense of the word investment represents a capital investment in order to increase it in the future [4]. Thus, an investment is something that is postponed for tomorrow. One part of them is the consumer goods that are not used in the current period, they are delayed to increase stocks, the other - the resources that are sent to expand production. Investments can be both cash and equities, securities, royalties, movable and immovable property, copyrights.

In terms of finance investments are all types of assets (funds) that are invested in economic activity in order to receive income and from the economic point of view, investments are the costs of creating, enlarging and technical re-equipment of capital.

In modern economic literature the term "investment" is generally interpreted as any investment of funds which can neither lead to capital growth, not to profit. 


\section{Aleskerova Yuliia, Fedoryshyna Lidiia}

These are often referred to as so-called consumer investments that is the purchase of items of long-term use, which in their economic content can not be attributed to investment. It should be borne in mind that investing capital can be carried out not only in cash but also in the forms of movable and immovable property, various financial instruments (securities), intangible assets.

In the Law of Ukraine "On Investment Activity" [3], investments are treated as all types of property and intellectual property that are invested in objects of entrepreneurial activity and other activities that result in the creation of profit (income) or social effect. These values define the law:

- funds, target bank deposits, shares, stocks and other securities;

- movable and immovable property;

- property rights arising from copyright, experience and other intellectual property;

- a set of technical, technological and other knowledge, drawn up in the form of technical documentation, skills and production experience necessary for the organization of one or another type of production, but not patented;

- rights to use land, water, resources, buildings, structures, equipmentas well as other property rights;

- other values.

Foreign experts in the research of the economic content of investments emphasize such factors [6]:

a)growth of functioning capital;

b)obtaining additional income;

c)refusal of a part of the current consumption in favor of the expected expansion of consumption in the future.

Investing is a process of accumulation of funds in different forms (money, stocks, securities, share capital, movable and immovable property, copyrights, etc.), their conversion into investment products and resources, the introduction of the latter into the production stage and the transformation into transforming innovative factors - resources and then in capital [5].

On the basis of the specificity of reproduction of various types of investment resources in today's conditions, there is a need to clarify the classification of investments by individual features.

Particular attention deserves the classification of sources of investment, they are divided into external and internal and they in turn consist of three main blocks. 


\section{Analysis of investment activities of enterprises of Ukraine}

In Ukraine the factors affecting the investment process are in a state that can not contribute to the development of this process. However, world experience suggests that it is impossible to get out of the crisis without increasing the volume of investments.

In conditions of structural adjustment of the Ukrainian economy, the need for large foreign investments is a very acute problem. In most countries (USA, Germany, France, Great Britain), it was the foreign capital that was the catalyst for investment activity, which played an active role in the development and restructuring of the economy. In recent years this trend is particularly characteristic of the economy of the new industrialized countries of Southeast Asia. The volume of direct investment in these relatively small countries in the late 80 -ies exceeded 20 billion dollars USA. In the volume of industrial production in Brazil the share of joint and foreign enterprises in mechanical engineering, metallurgy, chemistry, and petrochemicals is more than $30 \%$. Ukraine should use the experience of these countries (especially the industrialized developed countries of Asia) to attract foreign direct investment on mutually beneficial terms in order to solve the problems of structural transformation, the development of import-substituting industries and consistent expansion of export potential.

According to calculations the total volume of necessary foreign investments in the economy of Ukraine should exceed 40 billion dollars USA, including for metallurgy -7 , machine building -5.1 , transport -3.7 , chemistry and petrochemistry -3.3 billion dollars USA. To date 30 times less money has been invested. Ukraine has potential for effective development of investments in the amount of 2-2.5 billion dollars USA. Such amount will allow to reconstruct the priority industries for 5 years. But annual volumes of foreign investments are 3-7 times less. It should be borne in mind that attraction of foreign investments also requires some expenses. According to calculations for attracting 1 million dollars USA it is necessary to pay an average of 30 thousand dollars USA.

According to experts from the European Center for Research, the entrepreneurial risk of investment in Ukraine is $80 \%$. It is he who causes a small flow of direct investment. According to our calculations, the world's direct investment in the domestic economy accounts for about $1 \%$ or an average of somewhat more than 5 dollars USA per capita.

The general state of the economy is significantly influenced by tax legislation which has a number of shortcomings in Ukraine. Therefore, in the 
future it should be foreseen to reduce the tax pressure on production, differentiate tax rates depending on the priority of the production sectors, the application of tax breaks (holidays) when taxing profits used to develop production.

The costs and profits of enterprises are significantly affected by depreciation rates. The introduction of accelerated depreciation at enterprises would enable them to increase profits in the near future and hence deductions for investments.

Worldwide capital investment is largely carried out in the form of credit resources. However, the banking system of Ukraine does not have the capacity to lend its own producer sufficiently. This is due to the lack of a system of credit risk insurance and bank deposits.

With the insurance system you can significantly increase the source of investment such as saving the population. In Ukraine the population saves its savings in freely convertible currency. Despite the relatively low level of current consumption, some estimates suggest that these savings amount to 10 billion dollars USA. If you create the appropriate conditions these funds would work for the development of the economy.

\section{Characteristics of the investment project Roshen}

PJSC "Bershadmoloko" is a milk processing enterprise which is located in the village Florin Bershad district of Vinnytsia region.

The plant is the main provider of dairy products for Roshen sweets. The capacity of the plant is to process up to 320 tons of milk per day. The plant is among the top ten producer leaders in Ukraine, as the largest dairy processor. Bershadmoloko can produce more than 20 tons of dry dairy products: 18 tons of skimmed milk powder, 24 tons of dry cream, 22 tons of whole wheat milk, over 40 tons of condensed milk and about 10 tons of cream butter per day.

PJSC "Bershadmoloko" conducts its activity exclusively at the expense of own funds on the basis of self-financing and self-sustainment has enough own working capital.

At present the competitive development of PJSC "Bershadmoloko", its profitability and large volumes of sales is provided by Roshen Corporation, as the dairy factory is the main supplier of dry milk for the confectionery giant. Competitive positions of the enterprise are kept at the expense of economy of expenses, productivity, rational use of fixed assets, provision 
of material and technical resources, technological components, price and sales levers. However, the following components of the competitive development of the enterprise, such as the uniqueness of products and the ecological image, should be mentioned separately.First of all it applies to products such as condensed milk that is in demand on the market, which provides the plant with high volumes of sales. PJSC "Bershadmoloko" began to produce this product for the needs of the confectionery corporation "Roshen" and each year, this product is growing demand. The famous enterprise has such unique products as dry whole milk and extra cream "Extra" which are used by confectionery enterprises of our state for the production of milk and white chocolate.Milk at PJSC "Bershadmoloko" passes three stages of control systems in several laboratories equipped with modern technology. Dairy raw materials are taken to the plant according to indicators that are much tougher than domestic requirements than required by the state standard. In the 2013 season Bershadmoloko achieved production of dry extra cream "Extra" in the amount of 300 tons per month, and began with 70-80 tons. Another competitive and unique product of PJSC "Bershadmoloko" is buttermilk, which is used for the production of cakes, therefore the "Kiev Cake" produced by "Roshen" has unmatched taste qualities and is well known far beyond Ukraine.

Sustainable competitive position of the leader of the dairy industry of Vinnytsia and Ukraine, all this primarily due to the constant and guaranteed market for the sale of its own products, which provides for Roshen Corporation, which owns $86 \%$ of the shares of PJSC "Bershadmoloko", for the PJSC "Bershadmoloko". Due to the fact that the main customer of products - Roshen corporation - Bershadmoloko company works at full capacity and increases the production of its products, which is high quality and competitive. One of the decisive preconditions for such a level of competitive development of the enterprise was the fact that in the case of PJSC "Bershadmoloko" and the producer and the seller are interested in increasing profits, there are marketing mechanisms for managing the activities of the enterprise, introduced by the owners.

The Supervisory Board of PJSC "Bershadmoloko" in 2013 decided to transfer the production capacities (in part) to the city of Vinnitsa and the creation of PJSCVinnitskydairy plant Roshen. In 2014 the company has already started to produce dairy products. After analyzing the enterprise we can conclude that the largest share of the structure of available financial 


\section{Aleskerova Yuliia, Fedoryshyna Lidiia}

resources is occupied by stable liabilities and other current liabilities. When they are at the disposal of the company before their use they can be used to finance expanded reproduction.

An important source of financial resources are depreciation, they remain in the enterprise and should be used for renewal in fixed assets. The amount of depreciation deductions during this period is almost unchanged: $2011-1.14 ; 2012-1,40 ; 2013-1.29 ; 2014-0.98$.

PJSC "Bershadmoloko" demonstrates stable growth of own capital. It was noted that the value of the invested capital (statutory + additional) at the specified enterprise did not increase. In general the growth of equity capital was due to the resulting retained earnings and accumulated capital. The size of the reserve capital has not changed during the investigated period, which indicates the stability of the operation of the enterprise, the absence of additional emissions.

Due to the transfer of separate production facilities to the newly created milk processing enterprise in the city of Vinnytsia in 2014 and 2015 PJSC "Bershadmoloko" suffered losses.

Efficient use of capital at the enterprise contributes to profitability at the enterprise. As can be seen from the data in table 1 the indicator of profitability of products in all societies tends to increase, which indicates an increase in the ability to turn profit into profit.

Table 1

Analysis of profitability of enterprises in terms of profitability

\begin{tabular}{|c|c|c|c|c|c|c|c|c|c|}
\hline \multirow[b]{2}{*}{ Enterprise } & \multicolumn{3}{|c|}{2011} & \multicolumn{3}{|c|}{2012} & \multicolumn{3}{|c|}{2013} \\
\hline & 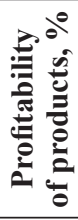 & 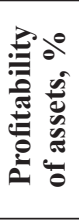 & 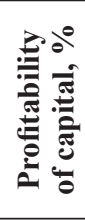 & 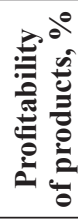 & 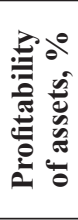 & 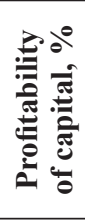 & 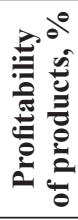 & 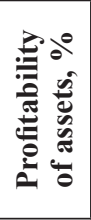 & 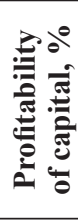 \\
\hline $\begin{array}{l}\text { PJSC } \\
\text { "Bershadmoloko" }\end{array}$ & 6,3 & 29,4 & 37,97 & 9,7 & 25,7 & 33,55 & 9,26 & 21,79 & 25,33 \\
\hline
\end{tabular}

Also, we note that the enterprise on the main indicators during the investigated period worked profitable. Thus, PJSC "Bershadmoloko" worked profitable for 2011-2013, but the level of these indicators fell every year and at the end of the period fluctuated within $3-4 \%$. 


\section{Increase of production capacities at the expense of capital investments of PJSC "Bershadmoloko"}

An increase in capital investment is a prerequisite for the growth of production capacity on a new technological basis and accordingly, an increase in labor productivity.

Table 2

Dynamics of capital investments of PJSC "Bershadmoloko" (PJSC Vinnytsia Dairy Plant "Roshen") for 2011-2016

\begin{tabular}{|l|c|c|c|c|c|c|c|}
\hline $\begin{array}{c}\text { Name of } \\
\text { Company }\end{array}$ & $\mathbf{2 0 1 1}$ & $\mathbf{2 0 1 2}$ & $\mathbf{2 0 1 3}$ & $\mathbf{2 0 1 4}$ & $\mathbf{2 0 1 5}$ & $\mathbf{2 0 1 6}$ & $\begin{array}{c}\text { Absolute } \\
\text { deviation } \\
(+;-)\end{array}$ \\
\hline $\begin{array}{l}\text { PJSC } \\
\text { "Bershadmoloko" }\end{array}$ & 6617 & 6303 & 6070 & 8941 & 11810 & 16580 & +9963 \\
\hline
\end{tabular}

In analyzing the dynamics of capital investment for a dairy enterprise, which is reflected in the "Notes to the Annual Financial Statements", Section III "Capital Investments", it should be noted that for the period 2011-2016 the company invested in capital investments, gradually increasing the amount of investment. Worldwide practice shows that capital investment needs to be continuously optimized, as in a changing global economy, this instrument will generate a sustained loss and the ability to sell assets at fair value will be low.

The bulk of the capital investments of PJSC "Bershadmoloko" is aimed at the acquisition (creation) of intangible assets and fixed assets. According to the annual accounts, the company actively procured technological equipment. This will further enable enterprises to improve the quality of finished products and to make full use of raw materials. Thus, during the investigated period, the volume of commissioning of the active part of fixed assets increased 3.5 times, and the average annual value of fixed assets increased 4 times.Accordingly, the refinancing factor for this stage increased and in 2016 it was $0.17 \%$. It should be noted that $75 \%$ of capital investment was used to purchase (create) intangible assets - rights to use property and industrial property.

The main source of capital investment for enterprises is net profit. Profit is the most important criterion for any entrepreneurial activity and the most important source of accumulation, expanded production. 
The investigated dairy business has had very different financial results over the last five years. But even with loss-making activity (2015), they made investments. This situation suggests that these companies are at risk, which will further have an economic effect.

Obviously, investment activity is inextricably linked with innovation, because the creation of an innovative product is a process that requires a lot of time and money, that is, investment. The successful functioning of dairy enterprises and the achievement of strategic advantages in a competitive environment depends to a large extent on the financing of their innovation activities. According to the State Statistics Committee of Ukraine, dairy processing enterprises of Ukraine for 2011-2016 have increased the volume of investments in fixed assets by 1.5 times, while the volume of investment in innovation has increased by 1.2 times.Funding for innovations is carried out mainly at the expense of own funds, the share of which is on average $80 \%$ of the total investment in innovation. During the investigated period also there was a positive dynamics of financing of innovations at the expense of loans, the annual growth of which is an average of $10 \%$.

Studies have shown that the main areas of innovation in dairy processing enterprises are first of all technological innovations.

Roshen Corporation creates its own developed integrated structure investing resources in the development of its own business. PJSC Vinnytsia Dairy Plant Roshen uses milk from the "Litinsky Plemise Plant" LLC and the "Ukrayina" agricultural company which is part of the corporation, avoiding production risks (supply and quality of raw materials). Finished products (butter, milk powder) are sold to the confectionery factory "ROSHEN". Such integration ties increase the profitability of the participants in the integration since production is carried out from its own raw materials, bypassing the intermediaries. Such vertical integration contributes to the development of the enterprise.

Net profit is one of the most important economic indicators contributing to investment activity. Quantitativelyit represents the difference between the amount of profit before tax and the amount of taxes paid in the budget from profits, economic sanctions and other mandatory payments of the enterprise which are covered by profit.

The final financial result of the investigated milk processing enterprise is characterized by a gradual decrease in losses before the formation of net profit in 2012-2016. 
Studies show that depending on which criteria of effectiveness are chosen as the basis for this organization the conclusions can be made diametrically opposite. Even with regard to a single project the decision to accept it is not always obvious, since the choice of a particular criterion may, under certain conditions, justify one or another solution. The situation is sharply complicated if you have to evaluate several projects, and those that are in different interdependencies.Contradictions arise between the criteria of different groups - based on discounted and undiscounted estimatesbut even in the intuitive level it can be assumed that such differences may arise among groups of homogeneous criteria.

Thus, the main conclusion is that, from all the criteria considered the criteria for NPV, IRR and $\mathrm{Pl}$ are the most acceptable for making investment decisions. Despite the interconnection between these indicators when evaluating alternative investment projects, the problem of choosing a criterion remains. The main reason for this lies in the fact that NPV is an absolute index, while Pl i IRR is relative.

When making a decision, one should be guided by the following considerations:

a) choose an option with a higher NPV, since this indicator characterizes the potential increase in the economic potential of the organization (increasing the economic strength of the enterprise is one of the most important guidelines);

b) it is also possible to calculate the IRR for indicators of growth of capital investments and incomes; with IRR $>\mathrm{CC}$, then the incremental costs are justified and it is advisable to accept the project with larger capital investments.

Consequently, after identifying the main problems in assessing the reliability of investment projects we see that there is no single defined evaluation system that complicates the adoption of an investment decision.

The transition to a new model of Ukraine's economic development makes the research of new approaches to the management of investment activities of industrial enterprises, especially those that are still in a crisis situation is particularly relevant.

Current methods of evaluating investment projects are usually aimed at solving local issues of determining their effectiveness without creating a single mechanism for ensuring reliability under the influence of "risk management" measures.At the same time existing developments require a deeper consideration of the degree of risk in investment calculations, further 


\section{Aleskerova Yuliia, Fedoryshyna Lidiia}

development in the direction of forming an integral system of reliability, improvement of methodological approaches to determining the investment characteristics of the project, the process of risk management and optimization of its consequences, which is a prerequisite for the creation of a comprehensive effective economic the mechanism of ensuring the reliability of the investment project.Systemic consideration of the ways and suggestions for significant acceleration and increase of efficiency of investment activity allows to group them around the following main problems:

- Creation of an investment-friendly environment for investors;

- Identification of state, sectoral and regional priorities;

- Formation of an integrated system of public management of investment activities;

- Consolidation and development of sources of investment financing;

- Creation of a system of state support of investment activity of branches, territories, economic entities and investment projects.

In order to increase the efficiency of investment activity in Ukraine it is expedient:

a) to develop support for domestic producers, competitive products, export and displacement from the Ukrainian market of imported goods;

b) to work out mechanisms for the establishment and realization of investment priorities;

c) develop and comprehensively use all possible sources of investment attraction, both domestic and foreign;

d) to implement effective state depreciation policy which would ensure tangible accumulation of investment funds and accelerated updating of the capital stock of the enterprise of all forms of ownership;

e) to restore and implement an effective system of state examination of investment projects, providing state support for priority projects;

f) to introduce mechanisms of guaranteeing and insurance of all kinds of investments from possible risks;

g) to actively use the investment potential of the regions of Ukraine, ensuring their orientation to the implementation of national priorities;

h) to broadly study and implement a positive experience of investing in the economies of the CIS and foreign countries.

In order to intensify investment activity necessary conditions should be created in which positive factors of influence and growth of the internal investment potential of enterprises, industries and regions will operate. To 
do this it is necessary to overcome the non-payment crisis, strengthen the financial and credit sphere, and create conditions for the effective operation of privatized enterprises. In the absence of these conditions the state investment policy will solve only the current tasks of socio-economic survival of the country and the population, and will not create conditions for activation of investment processes.

In order to improve the state of investment environment in Ukraine, institutions of state power need to be strengthened: to improve the legislation, to work effectively the courts, to eliminate crime and corruption. This work should be carried out in parallel with exceptionally important structural shifts - equalization of the conditions of competition and further liberalization of the economy. Inefficient enterprises should not be supported by the state and the local administration either directly or indirectly. There is an acute need to create a complete investment infrastructure, primarily distribution and accumulation systems (banks, insurance companies, mutual funds and pension funds, stock market, in relation to). Investors should be able to reduce or eliminate risks through generally accepted financial and legal instruments in world practice.

Consequently, the main purpose of investment activity management is to determine the directions, methods, means and forms of investment in order to increase the efficiency of production and increase the profit of the enterprise.

\section{Findings}

Based on the experience of the Czech Republic in our opinion in Ukraine it would also be advisable to create an organization that would negotiate internationally with potential investors regarding the placement of their enterprises and service centers in Ukraine and cooperated with local communities in preparing their specialists and territories for work with such investors. It is also appropriate in each regional center of Ukraine to create branches of this organization which would ensure the coordination of activities with local authorities, regional agencies, construction and design companies, universities and educational institutions.

As in the Czech Republic, in Ukraine, such a network would help to respond promptly to requests and investment proposals of foreign companies, offer them several alternative locations for the placement of their productions, and accompany them throughout the entire business start-up process. 
It should be noted that the largest capital was invested by foreign investors in production activities $(42.5 \%)$, in the financial and banking sector (22.7\%), transport and communications $(12.2 \%)$, trade and repair $(8,7 \%)$, construction $(5.4 \%)$, services $(3.5 \%)$, energy, gas and water supply $(2.3 \%)$, hotels and restaurants (1.5\%) [2].

Foreign investors are convinced that the biggest obstacles to investing in Ukraine are large-scale corruption (an average score of 8.5 points out of 10 possible) and lack of trust in the judiciary (7.5 points). The military conflict with Russia (6.1 points), as well as the unpredictable exchange rate and the unstable financial system ( 6 points) rank third.

Broad-mass corruption and lack of trust in the judiciary are the first and second place for all investor groups: portfolio and strategic, those who have already invested in Ukraine and those who have not dared to do so. Interestingly for the investors who are actively seeking opportunities to conduct business in Ukraine the existing military conflict is one of the least significant obstacles - they put it 7 th place ( 4.9 points). Instead the top three obstacles in addition to corruption and the judicial system for this group are complex tax administration (6.1 points).

As to the actions to be taken by the Ukrainian authorities to attract foreign investment the priority tasks of investors are to restart the judicial system by testing existing ones and attracting new judges (an average score of 7.6 points out of 10 possible), as well as bringing to justice a large number Senior Officials and Judges for Corruption (7.4 points). At the same time, the third step in rating the important actions of the government are such actions as ensuring the further timely implementation of the IMF program, the liberalization of currency control (including the lifting of the ban on repatriation of dividends) - by 6.2 points.

On the initiative of local authorities there are areas of active management. They are being modified and aimed at strengthening entrepreneurship in the region. Attractive investors offering them in the first place benefits from taxation and local payments, land rent (on preferential grounds) with the possibility of its redemption.

It is also important for Ukraine to use a certain foreign experience of business incubation on the basis of large enterprises.

For example in Sweden the type of incubator, the so-called "internal" incubator, which is created by large enterprises to stimulate new ideas and projects is common. Although some projects can be implemented within a 


\section{Analysis of investment activities of enterprises of Ukraine}

large enterprise, most of them are separated from it especially in those cases where the business project is not related to the main direction of the large enterprise [2].

In Finland an incubator in the business center in the southwest of Khayma covering an area of 1,750 square meters, setting itself the task of creating jobs in the processing industry by establishing links between industrial enterprises and educational institutions.

The incubator collaborates with a local technical college as well as with universities and research institutes in the southern and central parts of Finland. The business clients of this business incubator created half the jobs in the local electronics industry. As for other business incubators, their cooperation with existing companies is important: incubators contribute to the formation of new services and subcontracting in the region. Mostly they are based on a specific industrial sector.

Although incubators create few new businesses as compared to their total number, they play an important role in targeting and stimulating the development of innovative business, reforming local business structures and service systems.

The practice of functioning of innovative investment structures in Norway is rather interesting and peculiar. The Oslo Economic Development Agency employs 100 people, of which 35 are the administration and business development department.

The main task of the department of business development is to facilitate the opening of as many new enterprises as possible. The agency's principle of operation is "one stop shop", that is the provision in one place of a complete package of information and documentation for the opening of the firm. In addition to the Municipal Agency, there are six other business incubators operating in Oslo [1].

Now let's turn to the practice of the Business Incubator of the Innovation Technopark in the Hedmark region (Hamer, Norway). The city of Hamer is the center of the 85,000th Hedmark region. The local budget of the city is NOK 1.5 billion.

The industrial park includes an industrial cluster and a business incubator, and the main areas of work of the technopark are bio-industries as well as bio- and computer technologies.

The aim of the technopark is the economic growth of the Hedmark region. Today the technopark receives investment from the state-owned 
Norwegian Innovation Corporation and Norwegian Banks, while 25\% of the incubator is owned by the Hamer municipality. The Technopark is part of the State Corporation for Industrial Growth.

It should be noted that the above-mentioned practices of creating different centers of innovation are already beginning to be applied in Ukraine and are of great importance for strengthening the European integration of Ukrainian cities.

\section{Conclusions}

Based on the results of the research we can conclude that the investment project is a complex development which presents the maximum amount of information about the source of investment, taking into account all external and internal factors of influence, the amount of expected income and the timing of the project.

Having considered the various methods of evaluating investment projects we can say that one chosen method can not be used to evaluate all projects because it will characterize only one project indicator which is inappropriate. Some methods have malfunctions on a mathematical basis, therefore, it is necessary to apply several methods for assessing projects, which will make it possible to more realistically assess the feasibility of investing in a particular project.

Studies have shown that the main areas of innovation in dairy processing enterprises are first of all technological innovations.

The analysis of the financial stability of the dairy enterprise by the coefficient of autonomy, the results of which are calculated in the table, allowed to establish such tendencies. The actual values of the autonomy factor in the analyzed period for the enterprise are higher than 2014, than its minimum threshold and have steady growth dynamics. However, since 2014, the company has been tracking a downward trend in this ratio. Accordingly for these enterprises there is an increase in financial dependence. This indicates a reduction in its potential and a reduction in opportunities for attracting financial resources at the expense of external sources.

Having considered the main problems in making investment decisions we see there is no single system for evaluating investment projects. We also saw that the project was evaluated by different methodsshowing different results. That is, evaluation of the project only by calculation is unacceptable. 
In the formation of the cash flow of the project and therefore, its factors are involved in the positive (profitable) and negative (costly) nature. That is, the expected cash receipts identified in the project can vary significantly when changing external or internal conditions.

Therefore, it is important to evaluate it as precisely as possible before adopting a particular investment project, to determine the minimum profit from it, provided that there is a risk situation and if necessary involve a co-investor in order to guarantee proper project implementation.

It should be noted that today in Ukraine there is a fragmented and underdeveloped market of investment resources. Organizations working on it operate inadequately coordinated and inefficient. The weak development of the information infrastructure of the market has become an obstacle to active actions of domestic entrepreneurs and potential investors.

\section{References:}

1. Abramovich I.V. (2007) Investuvannya $\mathrm{v}$ agrarniy sektor ekonomiki Ukrayni: problemi ta napryami ïkh virishennya. Derzhava ta regioni. Seriya: Ekonomika ta pidpriymnitstvo, № 1, p. 7-9.

2. Investitsiyna analitika. [Elektronniy resurs]. - Rezhim dostupu: http://www.inventure.com.ua

3. Kiryan S.M., Radchenko O.D. (2006) Model' obliku investitsiy dlya malikh sil's'kogospodars'kikh pidpriymstv. Agrarniy forum - 2006, № 9, p. 235.

4. Koyuda V.O., Lepeyko T.I., Koyuda O.P. (2011) Osnovi investitsiynogo menedzhmentu. K. : Kondor, p. 165-181.

5. Ladichenko N. (2007) Otsinka finansovikh investitsiy. Bukhgalteriya, № 27/1(442), p. 64.

6. Len' V.S., Glivenko V.V. (2008) Bukhgalters'kiy oblik v Ukrayni: osnovi ta praktika: 3-te vidannya. navch. pos., K.: TsUL, 608 p. 


\title{
ECONOMETRIC ACCEPTANCE OF USE \\ OF CORPORATE SOCIAL RESPONSIBILITY
}

\section{ЕКОНОМЕТРИЧНА ДОЦІЛЬНІСТЬ ВИКОРИСТАННЯ КОРПОРАТИВНОЇ СОЦІАЛЬНОЇ ВІДПОВІДАЛЬНОСТІ}

\section{Berezianko Tamara ${ }^{1}$}

DOI: http://dx.doi.org/10.30525/978-9934-571-28-2_2

\begin{abstract}
There is ongoing polemics in the scientific journals about the level, scale and directions of development of core business structures. The approaches that were realized in this research support the fourth political-economic theory and aimed at regulation of corporate sector activity together with adjusting of society relations. Implementation of the European system of economy should go together with the social responsibility of corporates as key institutional non-formalized component of their activity on the national market to ensure sustainable development that would be acceptable to all parties. The overall strategy in food production can be effective only under condition that the society reaches consensus between multi-facet interests of corporate sector as a producer, expectations coming from the society as well as the state and country border regulations. Purpose. The purpose of this study is to combine and develop the theoretical and methodology basis together with practical recommendations regarding the implementation of institutional instruments of sustainable growth for corporate sector in the format of social state, allowing to contribute to meeting the requirements to align the activities of national entities to European practices. Methodology and methods. Theoretical and methodological groundwork of the study derives from key statements, principles and methods of modern economic, political and institutional theory as well as corporate management theory. The following methods were used in the study: statistical analysis - for definition of econometric parameters, results of activity and corporate sector impact; comparison - for identification of trends and specifics of development of social, corporate and wider soci-
\end{abstract}

${ }^{1}$ Doctor of Economic Sciences, Associate Professor,

Head of the Department of Personnel Management and Labor Economics, National University of Food Technologies, Ukraine 
ety spheres of national and world economy; economic and mathematical forecasting using the game theory to confirm the hypothesises and check the evidential part of the study. Results. The study provides a summary of the nature, policies and the instruments of corporate sector development as part of building of social state and the welfare state using example of EU countries. Based on the conclusions of research we analysed the practice of responsible behaviour of the oligopoly core entities of oil \& fat industry. We developed a methodology and econometric models that were used as a basis for forecasting of consequences of proposed corrections of development of corporates of oil\& fat industry. We proposed an algorithm, the model and practical aspects of implementation of the economic and corporate mediation concept on the level of entity and the industry. The effectiveness of proposed approach is justified by calculations; the study suggests a methodological approach towards implementation of the corporate management theories and is focused at combination, on a mediation basis of the social benefits and national welfare theory by Kaldor-Hiks, of principles of oligopoly entities optimal management by Jean Tirole and J-J. Lafonte and considerations of oligopoly market structure by Cournot. As a result, correct general outcome for optimal regulation and ensuring the Nash equilibrium was reached.

\section{1. Вступ}

Ринкове суспільство особливо в умовах поточної фінансової кризи, знаходиться в пошуку активних засобів впливу на внутрішній та транснаціональний корпоративний сектор. У результуючих документах міжнародної спільноти: формат G-20 - наголос зроблено не тільки на завданнях пом'якшення впливу кризи, але і на реформуванні головних чинників та інструментів регуляції в інституціональному середовищі [1]. Основним інструментом реформування визнано впровадження «економічного соціалізму», реформуванню МВФ та СБ на користь підвищення ролі країн, що розвиваються та реалізації завдання подолання розбіжностей у статках та багатстві між ними та країнами «золотого міліарду ». Європейська спільнота зажадала від власних урядів більш рішучих державних заходів щодо трансграничного регулювання. Сполучені Штати висловили різку незгоду з цього питання і закликали до подолання протекціонізму, колективізму та настроїв поразки ідей ліберальної економіки. 


\section{Berezianko Tamara}

Між тим, оцінювання Світового банку проходять у ракурсі підтримки думки світової спільноти щодо необхідності зниження тиску на бізнес. Це підтверджує тезу щодо конфронтації теоретичного та практичного підходів стосовно регулювання діяльності корпоративного сектору між прихильниками маржиналістської та соціальної концепції, що реалізуються у рамках англо-американської та європейської конструкції партнерства бізнесу та суспільства. В матеріалах Саміту G-20, безпосередньо зазначено: уряди мають розробляти прозоре, справедливе та надійне регулювання бізнесу, включаючи постійний моніторинг та нагляд за його діяльністю [2].

Соціальна відповідальність корпоративного сектору використовується як головна інституціональна неформалізована складова функціонування бізнесу в розвиненому ринковому середовищі. В європейській практиці коригування поведінки та діяльності корпоративного сектору досягається на рівні спільних та національних політик з дуже прискіпливою деталізацію бажаних напрямків впливу в секторах діяльності та галузях господарства.

На рівні світового регулювання наголоси корпоративної відповідальності набули статусу глобальних правил встановлення господарського порядку та перетворено у інструменти забезпечення розвитку у прийнятний для усіх членів суспільства спосіб.

Мета. Метою дослідження є об'єднання та розробка теоретико-методологічних положень та практичних рекомендацій щодо запровадження інституціональних інструментів сталого розвитку корпоративного сектору у форматі соціальної держави.

Завдання. Досягнення поставленої мети зумовило постановку та вирішення наступного завдання: сформулювати методологічний підхід до визначення суспільної корисності діяльності підприємства корпоративного сектора через оцінювання рівня корпоративної соціальної відповідальності.

Методологія. Головним питанням сучасної теорії олігопольного ринку треба визнати формування ефективних засобів регуляції поведінки та стосунків із суспільством провідних олігопольних структур та їх сателітів, стосовно яких ми можемо використати визначення «корпоративний сектор» та «олігопольне ядро». 3 огляду на зазначене особливої уваги потребує можливість застосування державних та суспільних засобів регулювання [3]. Традиційно вплив олігополістичного 
формату ринку розглядався науковцями під кутом зору забезпечення рівних можливостей у конкуренції. Основу теорій недосконалої конкуренції було закладено Е. Чемберліном [4], Дж. Робінсон [5], В. Парето [6], П. Самуельсоном, Дж. Гелбрейтом [7], Г. Штакельберг, Дж. Бейном та С. Фішером [8]. Автори намагались пояснити новий тип ринку, тому особливості монополізму та недосконалої конкуренції було об'єднано, запропоновано будувати теорії рівноваги на основі аналізу монополій, а не вільної конкуренції. 3 метою побудови економіко-математичних моделей стійкості, в рамках інституціонального напрямку (Гэлбрейт Дж., Уильямсон О., Кейвз С, Эрнст Д., ОзаваТ.), розроблялись моделі впливу інститутів на олігополії, глобалісти (Хаймер С, Киндлбергер Ч., Берман Дж., Нейдер Р., Хольман М.) досліджували оцінку впливу міжнародних олігополій на світову економіку та наслідки формування транс-національних монополій. Проте отримано було проміжні результати, які змогли набути статусу теорій реформації ринку.

Нарешті, напередодні розгортанні світової фінансової кризи було започатковано нову економіку (Духроу У., Хінкельмерт Ф., Гросс Д., Стюарт Дж., Белл Д., Бенуа А., Норт Д., Ж. Тіроль), яка обгрунтувала необхідність зміни цілі існування ринку: від придбання та накопичення до розподілу (поширення багатства на все більшу кількість країн та соціальних груп).

Логіка. Що стосується інституціональних можливостей обмеження деструктивної та анти конкурентної поведінки учасників олігопольного ринку це питання недостатньо опрацьоване наукою і потребує дослідження. Хоча, останнім часом стали з'являються дослідження, присвячені опортуністичності поведінки гравців ринку: власників, менеджменту, персоналу (соціуму) та державного управління (деструктивна боротьба еліт).

Ринкове суспільство особливо в умовах зростаючої фінансової кризи, знаходиться в пошуку активних засобів впливу на внутрішній та транснаціональний корпоративний сектор. Призначення таких пошуків - розширення сфери розподілу та співучасті у результатах, приведення діяльності учасників бізнес-середовища до потреб системи цінностей суспільства та розширення можливостей зростання.

Ми вважаємо, що для розгляду специфіки олігопольного ринку в умовах інституціональної теорії достатньо досліджувати поведінку його очільників - олігопольного ядра або корпоративного сектору, яке 


\section{Berezianko Tamara}

по суті $є$ не тільки виразником його інтересів, але і провідним господарюючим об’єктом його структури.

\section{2. Виклад основного матеріалу дослідження}

Світове ринкове співтовариство почало приділяти увагу розвитку процесу зближення інтересів суспільства та корпоративного сектора ще $з$ 90-х років минулого століття.

Олігопольний ринок в пост трансформаційних суспільствах перетворюється у ринок фізичних осіб, що конкурентні відносини перестають такими бути. Отримувати постійний прибуток в рамках олігопольного ринку вдається за рахунок маніпулювання цінами із використанням домовленостей та почергового використання ролі лідера, уникання контролю з боку держави, збереження масштабу прибутків та уявності конкуренції між господарськими одиницями [9].

Олігополісти вдаються до скорочення виробництва, масових звільнень та використовують макроекономічні засоби компенсації та створення надприбутку. Сучасні дослідження визнають найбільшою вадою олігопольного ринку - спроможність блокувати механізми саморегуляції ринку [10].

Євроінтеграційні прагнення України потребують розглядати оцінку впливу олігополій на соціум у контексті бачення Директив, Регламентів та стандартів спільного та галузевого ринків. Центр «Розвиток КСВ» радить проводити оцінку впливу та складання карти стейкхолдерів на основі матриці (рис. ). Означений підхід передбачає визначення груп впливу щоразу при виникненні потреби, зміни ринкової ситуації, розробці нової стратегії або переходу у інші територіальні координати.

Ю.С. Благов, із посиланням на А. Керолла [11] пропонує розширений варіант формування матриці стейкхолдерів [12]. Цей варіант дозволяє повномасштабним чином розглядати ситуацію та визначати способи ії вирішення. Недоліком, на наш погляд можна вважати надмірну комбінаторність, що потребує врахування понад 6500 варіантів розвитку ситуації.

Ми вважаємо за доцільне запропонувати власний підхід до визначення економічної складової матриці впливових груп, врахування інтересів яких забезпечує ефективний розвиток (рис. 1). Узагальнюючи запропоновану матрицю впливу ми можемо умовно представити сферу зацікавлених сторін як триграму пов'язаних стосунків. 
Econometric acceptance of use of corporate social responsibility

\begin{tabular}{|c|c|c|c|}
\hline Суспільний сектор & \multicolumn{2}{|c|}{ Соціальний сектор } & $\begin{array}{c}\text { Корпоративний } \\
\text { сектор }\end{array}$ \\
\hline \multicolumn{4}{|c|}{ Національне суспільство у цілому } \\
\hline \multicolumn{2}{|c|}{ Місцева громада } & $\begin{array}{l}\text { Члени сімей } \\
\text { персоналу }\end{array}$ & $\begin{array}{c}\text { Власники } \\
\text { та інвестори }\end{array}$ \\
\hline Державні установи & Впливові особи & Споживачі & Клієнти-користувачі \\
\hline Органи управління & 3MI & $\begin{array}{c}\text { Громадяни } \\
\text { суспільства } \\
\text { як користувачі } \\
\text { сукупного продукту }\end{array}$ & Постачальники \\
\hline Органи влади & \multirow{3}{*}{$\begin{array}{c}\text { Благодійні } \\
\text { організації, } \\
\text { громадські фонди }\end{array}$} & & Конкуренти \\
\hline Органи контролю & & \multicolumn{2}{|c|}{ Менеджмент } \\
\hline та покарання & & \multicolumn{2}{|c|}{ Працівники } \\
\hline
\end{tabular}

\section{Рис. 1. Схема взасмного впливу учасників в сучасному ринковому суспільстві}

У Давосі на при кінці січня 2011 р. обговорено питання переходу до нової конструкції світового порядку: головними стають завдання збалансування потреб економіки та вимог екології, а також економічного зростання та потреб суспільства. Досягнення поставлених завдань $є$ можливим лише через суспільну регламентацію діяльності корпоративного сектора.

\section{3. Специфіка розвитку корпоративного сектору України}

Сучасна індустрія виробництва харчової продукції країни налічує 21216 підприємств (станом на 01.01.2014 р.) різних форм власності. При цьому підприємства малого формату складають понад 93\%. В структурі корпоративного сектору як ніде інде представлена група середніх підприємств, які складають 26,7\%, у порівнянні: вага середніх підприємств у національному господарств становить 5,7\%, а у промисловості - 10,9\%.

Найбільше прибуткових підприємств зосереджено у виробництві солоду $(83,3 \%)$, тютюнових виробів $(80,0 \%)$, молокопродуктів та морозива (71,8\%), печива (70,9\%), шоколаду та кондитерських виробів (70,2\%), добування солі $(66,7 \%)$, виробництво олії та жирів $(65,8 \%)$, мінеральної та солодкої води $(63,5 \%)$, пива $(63,6 \%)$. Найбільшу кількість збиткових підприємств зосереджено у секторі виробництва спирту етилового (72,4 \%) та макаронних виробів (58,8\%).

Олігопольне ядро секторальних харчових ринків складають:

- у секторі виробництва кондитерської продукції 5 компаній, які сукупно займають $65 \%$ внутрішнього ринку і $40 \%$ кондитерського експорту; 


\section{Berezianko Tamara}

- у секторі імпорту риби та морепродуктів 5 компаній, які контролюють 75\% постачання в Україну;

- у секторі виробництва лікеро-горілчаної продукції ринок контролюють 5 компаній, які займають понад 70\% національного ринку та $54 \%$ експорту;

- у оліє-жировому секторі лідирують 3 компанії, сукупна вага яких перевищує $62 \%$;

- у секторі переробки молока та виробництва сирів -3 компанії, які сукупно контролюють понад 65\% внутрішнього ринку та понад $80 \%$ експорту;

- у секторі виробництва соків ядро складається із 5 компаній іноземного підпорядкування, які займають $90 \%$ ринку соку.

Наведені данні свідчать, що $72 \%$ складу олігопольного ядра харчової промисловості, яке контролює майже $90 \%$ сукупного виробництва, вже не належить національній юрисдикції.

При цьому за українським законодавством [13] монопольним визнається положення, коли контрольована частка ринку перевищує $35 \%$, якщо підприємство не доведе що зазнає сильної конкуренції. Європейське законодавство визнає монопольною консолідовану частку понад $4 \%$.

Нами було виконано пряме вимірювання прямого та похідних економічних ефектів від діяльності олігопольного ядра оліє-жирової промисловості України, як провідної експорто орієнтованої галузі, що займає лідируючи позиції в світі.

В процесі оцінки похідних ефектів було використано ефект мультиплікатора споживання, який демонструє, як витрати одного економічного суб'єкта призводять до доходів і подальших витрат інших економічних агентів.

Аби виміряти похідний ефект у споживчо-соціальній сфері, зміну доходів домогосподарств було скориговано на коефіцієнт-мультиплікатор. Державні витрати розраховують як суму податків, сплачених відповідними компаніями, а також податків, які було сплачено їх агентами.

Для оцінки впливу було обрано заробітну плату у компаніях постачальників, рівень податків, отримані прибутки та розмір обігового капіталу. Для визначення витрат, які відбуваються через придбання імпортних товарів та послуг, частку обігового капіталу було 
помножено на одиницю мінус частка імпорту у внутрішній валовий продукт (ВВП). Оскільки компанії олігопольного ядра мають значний перелік постачальників для аналізу відібрані лише ті підприємства, у обсягах поставки яких компанії олігопольного ядра займають понад $80 \%$.

Здійснення продажу відбувається у рамках встановленої торгівельної націнки 8\%, націнка на продукцію торгівельної мережі складає 20-25\%. Таким чином сукупна дистриб'юторська маржа на продукцію дорівнює 33\%. Використовуючи дані розрахунків було визначено суспільний та сукупний суспільний ефекти від відповідальної діяльності компаній олігопольного ядра галузі. Доброчинну та благодійну діяльність було враховано у підсумковому результаті.

Таблиця 1

Оцінка ефекту від відповідальної діяльності олігопольного ядра оліс-жирової промисловості України, \%

\begin{tabular}{|l|c|c|c|c|}
\hline $\begin{array}{c}\text { Олігопольне } \\
\text { ядро }\end{array}$ & $\begin{array}{c}\text { Соціальний } \\
\text { ефект }\end{array}$ & $\begin{array}{c}\text { Корпоративний } \\
\text { ефект }\end{array}$ & $\begin{array}{c}\text { Суспільний } \\
\text { ефект }\end{array}$ & Усього \\
\hline Кернел & 4,5 & 66,7 & 28,8 & 48,0 \\
\hline ДнОЕ3 & 2,9 & 90,9 & 6,1 & 25,5 \\
\hline Віолія & 3,5 & 72,5 & 23,9 & 26,5 \\
\hline Усього & 3,8 & 74,4 & 21,8 & 100 \\
\hline
\end{tabular}

Відносне співставлення дозволяє наочно впевнитись, що ефекти від діяльності в основному зосереджено в корпоративному секторі, а соціальний ефект виглядає зовсім незначним. Означена економічна ситуація, розвиток національного ринку та євроінтеграційні прагнення спонукають ділове середовище до формалізації цього напрямку.

\section{4. Підходи до формування економетричної моделі оцінки впливу олігополій}

В результаті опрацювання значної кількості варіантів рішень та теорій, нами пропонується методологічний підхід до моделювання задачі щодо регулювання діяльності корпоративного сектору з метою максимізації суспільної та соціальної компоненти.

У якості відправної крапки нами обрано модель Лафонта-Тіроля максимізації суспільних благ в умовах специфіки олігопольного ринку. 


\section{Berezianko Tamara}

При цьому ми свідомо припускаємо наявність зворотного зв'язку між рівнем вироблених суспільно-соціальних благ та існування зусиль корпоративного сектору щодо мінімізації власних витрат. Також враховується той факт, що від держави та соціуму приховується інформація стосовно реальної вартості вироблених послуг та продуктів, що вкладається у основні висновки теорії опортунізму. Загальне моделювання спирається на основні канони теорії контракту і дозволяє розглядати стосунки між основними гравцями як контракт між замовником (соціумом), виконавцем (корпоративним сектором) та регулятором (державою), за обов'язкового врахування діяльності усіх учасників гри у форматі соціальної держави.

Загальна постановка задачі досить добре інтегрується із базовими принципами, викладеними в роботах Ж. Тіроля [14] та Ж.-Ж. Лафонта [15] про оптимальне керування замовленням бізнесу вироблення суспільно корисних благ. В нашому випадку, в категорію таких благ природним чином потрапляє суспільна та соціальна компоненти.

При цьому, теоретична база суттєво вирішує задачу опортуністичності бізнесу та асиметрію інформації: адже мінімізація видатків бізнесу при виробленні таких благ необхідно буде використовувати інформацію, яка буде значною мірою прихована від Регулятора та суспільства. Зокрема справедлива вартість (в тому числі і найманої праці). Для розв'язання, зокрема, пропонується підхід, що переходить від детермінованої до стохастичної моделі максимізації.

При цьому зазначимо, що перехід до динамічної структури є цілком виправданим і більш точно моделює реальний світ, застосований інструментарій включає в себе, зокрема, теорію ланцюгів Маркова.

Змістовним висновком наведених нижче результатів може бути те, що максимізація суспільного та соціального ефекту буде тим краще досягатися, чим меншою є похибка у вимірюванні як цільової змінної, так і прихованої інформації, що активно використовується бізнесом задля мінімізації власних витрат.

В першому випадку практичне вирішення може полягати у дослідженні суспільної користі від діяльності бізнесу: при цьому враховано як монетарні показники (наприклад, сплачені податки, заробітна плата, відрахування на соціальні заходи), так і індексні (наприклад, які вимірюють задоволеність умовами праці, безпека праці, екологічна відповідальність бізнесу тощо). 


\section{Econometric acceptance of use of corporate social responsibility}

У другому випадку, висновок лежить у площині вдосконалення «регулятором» прозорості економічного середовища, створення конкурентних умов та підсилення ролі інформаційно-аналітичної складової національної економічної безпеки. Типовий приклад елементу реалізації подібних завдань - періодичне вимірювання індексу прозорості найбільших публічних компаній Ізраїлю.

Функція корисності для виконавця (олігопольного ядра) буде дорівнювати:

$$
U=t-\psi(e)=t-\psi(\beta-C),
$$

де

$\mathrm{t}$ - вартість трансферу за реалізацію вироблення замовлених благ, вираженого монетарно, від суспільства до бізнесу.

Тоді, соціальне та суспільне благо (ефект) буде мати форму:

$$
S-(1+\lambda)(t+C)+U=S-(1+\lambda)(\beta-e+\psi(e))-\lambda U,
$$

де $\lambda$ - рівень податкового навантаження.

Оптимальне регулювання э результатом максимізації очікуваного суспільного та соціального ефекту від діяльності корпоративного сектору (у нашому випадку олігопольного ядра), за обмежень стимулювання та індивідуальної раціоналістичності, тобто:

$$
\begin{gathered}
\operatorname{Max} \int_{\underline{\beta}}^{\bar{\beta}}(S-(1+\lambda)(\beta-e+\psi(e))-\lambda U) d F(\beta), \\
\dot{U}(\beta)=-\psi^{\prime}(e(\beta)), U(\beta) \geq 0 \text { для будь-якого } \beta
\end{gathered}
$$

В наведених вище умовах, оптимальний контракт суспільства та бізнесу на вироблення суспільних та соціальних благ, є імплементований шляхом набору (меню) правил лінійного (пропорційного) поділу витрат, за яких виконавець обирається шляхом самоселекції. Відповідно випадковість (похибка у вимірювання показників діяльності виконавців), незважаючи на походження, не призводить до втрати корисності, якщо тільки виконавець є нейтральним до ризику.

Зауважимо, що змістовні результати були отримані МакАфі та МакМілланом (1991) та Пікардом та Реєм (1990) для випадку інтерпретації, коли в якості виконавця виступала команда фірм або агентів. Це повністю відповідає поточній конструкції олігополічного ринку, а саме дозволяє використати означене припущення до олігопольного ядра ринку, що досліджується. 
Таблиця 2

Синергія та взаємодія дефініцій «соціальний, суспільний та корпоративні ефект» у процесі моделювання

\begin{tabular}{|c|c|c|c|c|}
\hline $\begin{array}{c}\text { Стратегія/i-та } \\
\text { компанія }\end{array}$ & $\begin{array}{c}\text { Обрання зусиль } \\
\text { протидії } e_{1}^{i}, \text { за } \\
\text { умови інформації } \beta^{i}\end{array}$ & $\begin{array}{c}\text { Обрання зусиль } \\
\text { протидії } e_{2}^{i}, \text { за } \\
\text { умови інформації } \beta^{i}\end{array}$ & $\cdots$ & $\cdots$ \\
\hline $\begin{array}{l}\text { Стратегія/ } \\
\text { Регулятор }\end{array}$ & & & $\cdots$ & $\cdots$ \\
\hline $\begin{array}{l}\text { Обрання } \\
\text { стратегії поділу } \\
\text { витрат за про- } \\
\text { цедурою Р1 }\end{array}$ & $\begin{array}{c}\mathrm{HS}= \\
S-(1+\lambda)(t+C)+U \\
\mathrm{HC}= \\
t-\psi\left(e_{1}^{i}\right)\end{array}$ & $\begin{array}{c}\mathrm{HS}= \\
S-(1+\lambda)(t+C)+U \\
\mathrm{HC}= \\
t-\psi\left(e_{2}^{i}\right)\end{array}$ & $\cdots$ & $\cdots$ \\
\hline $\begin{array}{l}\text { Обрання } \\
\text { стратегії поділу } \\
\text { витрат за про- } \\
\text { цедурою Р2 }\end{array}$ & $\begin{array}{c}\mathrm{HS}= \\
S-(1+\lambda)(t+C)+U \\
\mathrm{HC}= \\
t-\psi\left(e_{1}^{i}\right)\end{array}$ & $\begin{array}{c}\mathrm{HS}= \\
S-(1+\lambda)(t+C)+U \\
\mathrm{HC}= \\
t-\psi\left(e_{2}^{i}\right)\end{array}$ & $\cdots$ & $\cdots$ \\
\hline$\ldots$ & $\cdots$ & $\cdots$ & $\begin{array}{c}\text { крапка } \\
\text { рівноваги } \\
\text { Неша] } \\
\end{array}$ & $\ldots$ \\
\hline$\ldots$ & $\ldots$ & $\ldots$ & $\ldots$ & $\ldots$ \\
\hline
\end{tabular}

- $H S$ - сукупність суспільного та соціального ефекту,

- $H C$ - корпоративний ефект

У випадку, коли імплементація наборів (меню) лінійних контрактів $\epsilon$ можливою для кожної фірми, $C^{i}$ можна замінити на $C^{i}+\sum_{j \neq i} C^{j}, \mathrm{i}$ таке саме розміщення витрат також можливо імплементувати. Насправді, додаток $\sum_{j \neq i} C^{j}$ грає таку саму роль, як і випадкове збурення $\tilde{\varepsilon}$ вище. Оскільки воно $€$ функцією лише від $\beta^{j}, j \neq i$, то в точциі рівноваги гри Неша, то тоді його зміст буде сприйматися фірмою «і» як зовнішній чинник.

На основі наведених вище теоретичних узагальнень, суспільне замовлення певних благ (які б водночас повертали би у вигляді як продукції, так і соціальної складової у вигляді майбутніх індукованих витрат домогосподарств, заробітної платні, похідних бенефітів для держави тощо) буде оптимальним, якщо для їх створення формуються умови, за яких працює метод. Йдеться, насамперед, про створення низки правил поділу видатків між замовником та виконавцем. 
Це фактично слугує фундаментом для обгрунтування корпоративної соціальної відповідальності як інструмента, що забезпечує досягнення рівноважного стану із заданим цільовим розподілом сукупного суспільного ефекту.

Тепер ми можемо перейти до визначення ключових параметрів розширення базової моделі Тіроля-Лафонта.

\section{5. Оцінка суспільного та соціального ефекту діяльності олігопольних компаній}

В межах теорії Тіроля припускається, що в оптимальному розв'язку задачі максимізації суспільної корисності, перед вимаганням певних благ та бенефітів від виконавця - фірми-олігополіста, олігопольного ядра, тощо, держава та соціум повинні інвестувати певний початковий капітал.

В нашому випадку, олігополія, що склалася на ринку, вже функціонує багато років і майже не потребує у явному вигляді дотацій, субсидій чи капітальних інвестицій з боку держави або громади чи суспільства (практично вони були отримані у вигляді пільгових приватизацій, свідомого нерегулювання діяльності, відмови від жорсткого податкового та офшорного контролю). Крім того, деякі суспільні інвестиції було зроблено раніше, зокрема, як: інфраструктура, якою користується олігопольне ядро/компанія-олігополіст; людський капітал, зокрема освіта та відповідна додана вартість; можливість користуватися економічним середовищем, зокрема створення певного клімату, відмінний від інших середовищ сприятливий рівень та структура видатків (наприклад, вартість електроенергії, виробленої на атомних станціях) та інш.

Суспільний та соціальний ефект від корпоративної відповідальності оцінюється як в монетарній формі, так і за допомогою експертних оцінок відповідності потреб суспільства та результатам функціонування бізнесу, що можуть бути спостережними. Це означає, вихідна функція суспільної та соціальної корисності буде отримано як скориговану модель із чисельними та експертними показниками. Моделювання було проведене із відносним рівнем похибки в розмірі 5\%, порядок якої емпірично підтверджується флуктуаціями показників діяльності галузі.

На практиці доцільно проводити зворотне оцінювання та відповідних ваг, обираючи експертну загальну оцінку підприємства та шляхом 


\section{Berezianko Tamara}

регресійного аналізу (наприклад, узагальнених лінійних моделей) оцінювати коригувальні коефіцієнти та ваги.

Так, Перекрестов Д.Г, Поварич І.П., Шебашев В.А [16] пропонують наступний трикроковий підхід. На першому кроці, з урахуванням міжнародних стандартів з соціальної звітності, визначаються основні напрямки («номінації»), зокрема:

- відповідальність перед споживачами;

- розвиток HR, вкладення в людський капітал;

- добросовісна ділова практика;

- корпоративне громадянство;

- екологія і безпека;

- участь в розвитку громадянського суспільства.

На наступному етапі визначаються показники по кожній з «номінацій». Вони формуються в три групи: обсягу (кількості), якості та ефективності КСВ. третьому етапі, кожній з груп показників (обсягу, якості та ефективності КСВ) присвоюється базова сума балів.

Зауважимо, що питання достовірності використаних показників $€$ також актуальним. На це звертають деякі автори, наприклад Тарасова Н.А. [17].

Зворотній зв'язок в рамках досліджуваної моделі дається формою залежності результуючих зусиль бізнесу на мінімізацію власних витрат та вироблених суспільних благ, що на загальному рівні характеризується певним індексом. На практиці такий взаємозв'язок виражено у зростанні продуктивності праці на підприємствах із високим рівнем корпоративної соціальної відповідальності.

Таким чином, задача відшукання точки рівноваги Неша вирішується для гри із трьома учасниками:

- державою (регулятором, основна задача якого - максимізація поточної вартості власного прибутку від функціонування системи замовлення соціально-суспільних благ),

- соціальною компонентою - одним із основних бенефіціарів благ, що виробляються та учасником такого процесу,

- олігопольним ядром (корпоративним сектором або компанією-виконавцем замовлення, основний прибуток якого - поточна вартість грошових потоків, пов'язаних із основним видом діяльності - «носієм» бізнесу (наприклад, конкретна галузь промисловості - у нашу випадку оліє-жирова галузь). 
Загально відомо, що моделі рівноваги Курно є частковими випадками рівноваги за Нешем. Відповідно, дослідження конкурентності для олігополічного середовища 3 необхідністю використовує методи теорії ігор та узагальнення концепції рівноваги.

В основі такого підходу лежить теорема Неша: «В кожній безкоаліційній грі існує хоча б одна ситуація рівноваги (в змішаних стратегіях)».

Як наслідок, отримується рівноважний стан. На підставі отриманих результатів, знов застосовується модіфікована модель Тіроля. Визначений таким чином ітераційний процес збігається до певної точки рівноваги із визначенням оптимальної системи регулювання та асимптотичних параметрів ринку.

Підкреслимо, що в ітераційній стадії переструктуризації олігопольного ринку та оцінки відповідного впливу на параметри моделі, модель Курно може бути замінена на іншу, що більш точно відображає очікування від потенційного застосування моделі.

Моделювання залежності підвищення ефективності праці та чинників, що визначаються індексом зростання ФЗП отримано шляхом застосування скорингової моделі на підставі як даних експертної оцінки рівня факторів, пов'язаних із ефективністю праці та кожному підприємстві

Основні змінні, що входили до моделі є дані про рентабельність, структуру виробництва, ринкову долю кожного підприємства та ступінь пов'язаності із іншими бізнесами (дистриб'юторами та постачальниками), дані чинники, що пов'язані із поточним рівнем продуктивності праці (рівень контрактної культури, понаднормове навантаження, гендерна рівність тощо).

Оцінка шуканих структурних змін в розподілі сукупного суспільного ефекту від відповідальної діяльності отримується шляхом симуляцій структури ринку та змін у продуктивності праці, викликаних підвищенням ФЗП. Одним із ключових припущень буде переважно інтенсивний шлях зростання якості та продуктивності праці.

Синергію розвитку часток по олігопольному ядрі представлено на рис. 2.

До базових припущень відноситься зростання прибутків та обігового капіталу пов'язаних із олігопольним ядром структур (дистриб'юторів та постачальників). Оцінка залежності будується на базі моделі, викладеної вище. Зміни в структурі сукупного суспільного ефекту, за умови впровадження корпоративної соціальної відповідальності оцінено вище. 


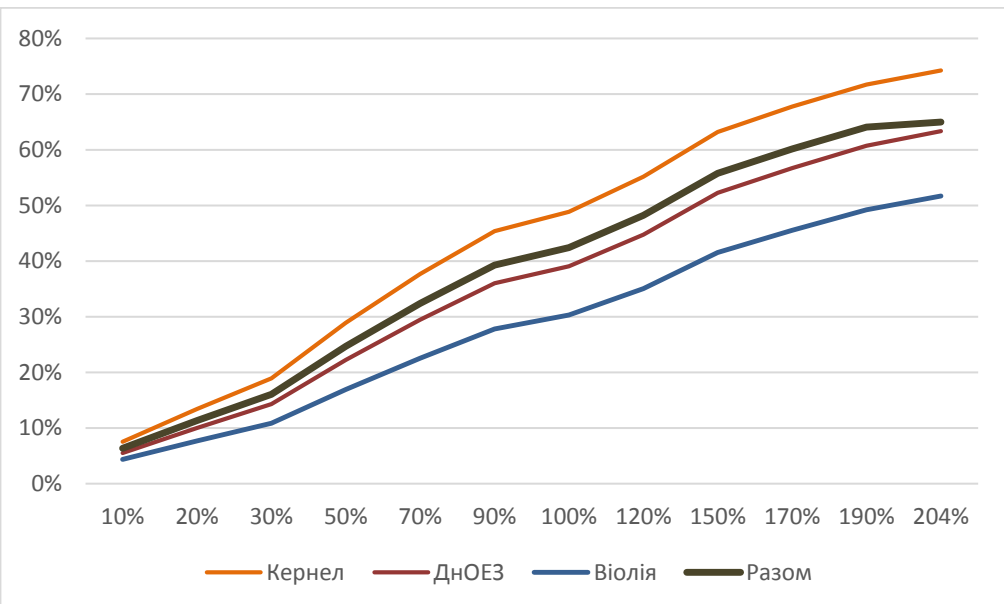

Рис. 2. Графічна інтерпретація сценарію розвитку в олігопольному ядрі при зміні політики соціальної відповідальності

Таблиця 3

Зміни в ланцюжку залежних структур у наслідок підвищення відповідальності олігопольного ядра

\begin{tabular}{|c|c|c|c|c|c|c|}
\hline \multirow[b]{2}{*}{ Компанії } & \multicolumn{2}{|c|}{ Постачальники } & \multicolumn{2}{|c|}{$\begin{array}{l}\text { Дистриб'ютори i } \\
\text { роздрібні торговці }\end{array}$} & \multicolumn{2}{|c|}{$\begin{array}{c}\text { Зростання } \\
\text { корпоративного } \\
\text { ефекту }\end{array}$} \\
\hline & 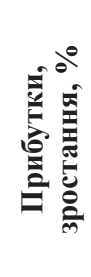 & 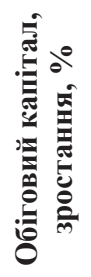 & 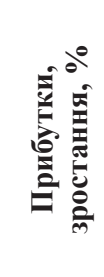 & 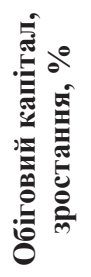 & 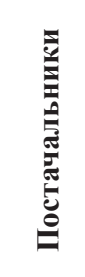 & 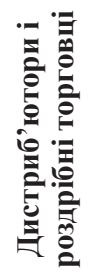 \\
\hline Кернел & 9,5 & 6,0 & 6,0 & 4,4 & 4,58 & 3,13 \\
\hline ДнОЕЗ & 9,0 & 5,0 & 7,0 & 4,3 & 4,03 & 3.54 \\
\hline Віолія & 10,0 & 5,0 & 5,0 & 4,1 & 4,62 & 2,70 \\
\hline Усього & 9,51 & 5,4 & 6,1 & 4,29 & 4,43 & 3,16 \\
\hline
\end{tabular}


Оцінка зростання соціальної складової від корпоративної соціальної відповідальності ядра будується на оцінці коефіцієнту зворотного зв'язку корпоративного та соціального ефекту.

Моделювання проводиться для кожної компоненти суспільного ефекту: витрат домогосподарств, податків тощо. Основними чинниками, що приводить до такого зростання, $є$ зростання прибутковості бізнесу (i, як наслідок, очікуване збільшення бази оподаткування), зростання якості та обсягів реалізованої продукції (зокрема внаслідок ефекту від підвищення продуктивності праці) тощо. Тепер можемо оцінити наслідки підвищення відповідальності комплексно.

Таблиця 4

Очікувані зміни співвідношень у результаті регуляції діяльності олігопольного ядра оліє-жирової галузі,\%

\begin{tabular}{|l|c|c|c|}
\hline Олігопольне ядро & $\begin{array}{c}\text { Соціальний } \\
\text { ефект }\end{array}$ & $\begin{array}{c}\text { Корпоративний } \\
\text { ефект }\end{array}$ & $\begin{array}{c}\text { Суспільний } \\
\text { ефект }\end{array}$ \\
\hline Кернел & 10,0 & 60,9 & 29,1 \\
\hline ДнОЕЗ & 9,4 & 53,0 & 37,6 \\
\hline Віолія & 10,6 & 65,0 & 24,3 \\
\hline Усього & 10,0 & 59,1 & 30,9 \\
\hline
\end{tabular}

Таким чином, зростання за базовим сиенарієм запровадження корпоративної соиіальної відповідальності, щзо приводить до зростання корпоративного ефекту на 3-4\% (в залежності від складової-постачальники або дистриб 'ютори), дає зростання долі сочіальної компоненти до $10 \%$.

\section{6. Висновки}

Проведене моделювання, та розрахунки дозволяють зробити низку пов'язаних висновків: отримано позитивні суспільні, соціальні, галузеві та корпоративні наслідки.

Позитивні суспільні наслідки:

- можна вважати доведеною гіпотезу, що впровадження відповідальної поведінки надає очікуване вирішення проблеми: отримання прибутків корпоративним сектором у соціально виправданий спосіб;

- похідним ефектом від цього суспільство отримує позитивні та суспільні наслідки у вигляді зближення напрямків розвитку та співпадіння інтересів; 


\section{Berezianko Tamara}

- у якості додаткового суспільного ефекту слід очікувати не інфляційного розігріву економіки, відновлення зростання та зниження соціальної напруги у суспільстві;

- проведені розрахунки дозволяють наочно впевнитись, що корпоративний сектор має великий потенціал для делегування та стимуляції росту у соціумі та суспільстві.

Соиіальні ефекти:

- впровадження відповідальної поведінки в олігопольному ядрі галузі забезпечує кумулятивний ефект у пов'язаних структура ланцюжка постачання-дистрибуції із належним отриманням додаткових економічних профітів;

- зростання соціальної компоненти до 10\%, дає додаткове зростання частки корпоративного сектору на 3-4\%;

- підтримка соціального потенціалу дозволяє отримати на місцевому рівні додаткові надходження близько 35\% за рахунок підвищення платоспроможності громади.

Корпоративні ефекти:

- запровадження корпоративної соціальної відповідальності в олігопольному ядрі, що приводить до зростання галузевого корпоративного ефекту на 3-4\% (в залежності від складової - постачальники або дистриб'ютори),

- розігрів соціальної складової корпоративного ядра галузі додатково забезпечує у корпоративному секторі 9,51\% прибутку постачальників; 6,1\% прибутку - дистриб'ютерам; або 4,43\% прибутку - пов'язаних 3 ядром структур корпоративного сектору оліє-жирової галузі у цілому;

- додаткові наслідки корпоративного сектору отримано і в зростання капітальної складової: постачальники отримують зростання на 5,4\%, а дистриб'ютери - на 4,29\%. Задовольняє і той факт, що учасники виробничого ланцюжка мають більш значне зростання обігового капіталу, ніж посередники та торгівля, що слугує забезпеченню розвитку темпів зростання у майбутньому.

Додатково зазначимо, що розрахунками підтверджено не тільки факт можливості використання корпоративної соціальної відповідальності у якості засобу злагоди та відновлення зростання, а і доведено, що використання оцінки корпоративної соціальної відповідальності компаній може слугувати індикатором належного розвитку корпоративного сектору у цілому. 


\section{Econometric acceptance of use of corporate social responsibility}

Ми вважаємо, що впровадження корпоративної соціальної відповідальності у якості галузевого стандарту має значний потенціал забезпечення суспільно адекватного росту бізнесу та ринкової орієнтації суспільства. Потенціал використання КСВ у якості напрямку росту дозволить подолати національній економіці потужну рецесію останніх років, адже нами свідомо було використано в розрахунках лише частину сукупних можливостей, аби забезпечити м'який та поступовий перехід національного бізнесу та системи регуляції у напрямку зближення із засадами європейської системи господарського порядку та соціальної держави.

\section{Список літератури:}

1. Декларация саммита «Группы двадцати» по финансовым рынкам и мировой экономике [Електронний ресурс] - Режим доступу: http://archive.kremlin.ru/events/articles/2008/11/209291/209303.shtml - Перевірено 10.10.2014 р. - доступ до російського ресурсу обмежено згідно із Указом Президента України № 133/2017 від 15.05.2017 р.

2. Содействие более долгосрочному инвестированию институциональными инвесторами: отдельные вопросы и меры политики [Електронний pecypc] - Режим доступу: http://www.oecd.org/daf/fin/private-pensions/ 48616812.pdf - Перевірено 22.02.2018 p.

3. Бенуа А. Де Против либерализма: (к Четвертой политической теории) / Ален де Бенуа : [пер. с фр.;]. - Спб.: Амфора, 2009. - 476 с.

4. Chamberlin Ed. The Theory of Monopolistic Competition. Cambridge / Ed. Chamberlin // Journal Of Business \& Economics Research, Vol. 2, namber 4, pp. 17-26.

5. Robinson J. The Economics of Imperfect Competition. / Joan Robinson London: MacMillan; Reprint edition, 1965. - 132 p.

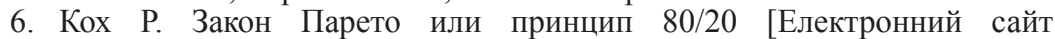
Elitarium] - Режим доступу: http://www.elitarium.ru/2004/07/08/zakon_pareto_ ili_princip_8020.html - Перевірено 05.03.2018

7. Гелбрейт Дж. Новое индустриальное общество: Пер. с англ. / Дж. Гэлбрейт. - М.: ООО «Издательство АСТ»: ООО «Транзиткнига»; СПб.: Terra Fantastica, 2004. - 602 c.

8. Фишер С., Дорнбуш Р., Шмалензи Р. Экономика / С. Фишер, Р. Дорнбуш, Р. Шмалензи: Пер. с англ. со 2-го изд. - М.: Дело, 1999. - С. 231.

9. Казанцева Е.Г. Олигополистические рынки в современной экономике/ Е.Г. Казанцева/Автореферат дис.докт.экон.наук, Томск, 2013. - 40 с.

10. Ietto-Gillies Gr. Transnational Corporations and International Production. L.: Edward Elgar, 2005. P. 88.

11. Carroll A. B. 1999. Corporate social responsibility: Evolution of definitional construct. Business and Society 38 (3): 268-295.

12. Благов Ю.Е. Концепция корпоративной социальной отвественности и стратегическое управление / Ю.Е. Благов // Российский журнал менеджмента, 2004, № 3. - C. 17-34. 


\section{Berezianko Tamara}

13. Про захист економічної конкуренції. - Закон України від 11.01.2001 p. № 2210-III - [Електроний ресурс]. - Режим доступу: http://zakon.rada.gov.ua/ laws/show/2210-14 - Перевірено 05.03.2018.

14. Laffont J.-J., Tirole J. (1993) A Theory of Incentives in Procurement and Regulation - Cambridge: The MIT Press, 1993 - 705 p.

15. Gasmi F., Kennet D. M., Laffont J.-J., Sharkey W. W. (2002) Cost Proxy Models and Telecommunications Policy. A New Empirical Approach to RegulationCambridge: The MIT Press, $2002-274 \mathrm{p}$.

16. Перекрестов Д.Г., Поварич И.П., Шебашев В.А. Корпоративная социальная тветственность: вопросы теории и практики / Д.Г. Перекрестов, И.П. Поварич, В.А. Шебашев - М.: Академия Естествознания, 2011. - 437 с.

17. Тарасова Н.А. Достоверность социально-экономических показателей: семиотический поход / Н.А. Тарасова - М. ; СПб. : Нестор-История, 2012. $288 \mathrm{c}$.

\section{References:}

1. Deklaratsyia sammyta "Hruppy dvadtsaty" po fynansovym rynkam y myrovoi ekonomyke [Declaration of the Group of Twenty's Summit on Financial Markets and the World Economy]. Rezhym dostupu: http://archive.kremlin.ru/ events/articles/2008/11/209291/209303.shtml - Perevireno 10.10.2014 r. dostup do rosiiskoho resursu obmezheno zghidno iz Ukazom Prezydenta Ukrainy № 133/2017 vid 15.05.2017 r.

2. Sodeistvye bolee dolhosrochnomu ynvestyrovanyiu ynstytutsyonalnymy ynvestoramy: otdelnye voprosy y mery polytyky [Promoting a long-term investing by institutional investors: separate issues and policies]. Rezhym dostupu: http://www.oecd.org/daf/fin/private-pensions/48616812.pdf - Perevireno 22.02.2018 r.

3. Benua A. (2009). De Protyv lyberalyzma: (k Chetvertoi polytycheskoi teoryy) [Against Liberalism (Towards the Fourth Political Theory)]. Alen de Benua, Spb.: Amfora, $476 \mathrm{p}$.

4. Chamberlin Ed. The Theory of Monopolistic Competition. Cambridge. Journal Of Business \& Economics Research, Vol. 2, namber 4, pp. 17-26.

5. Robinson J. (1965). The Economics of Imperfect Competition. London: MacMillan; Reprint edition, $132 \mathrm{p}$.

6. Kokh R. Zakon Pareto yly pryntsyp 80/20 [Pareto's Law or The 80/20 Principle] [Elektronnyi sait Elitarium] - Rezhym dostupu: http://www.elitarium.ru/ 2004/07/08/zakon pareto ili princip 8020.html - Perevireno 05.03.2018

7. Helbreit Dzh. (200̄4). Novoe yndustryalnoe obshchestvo: Per. s anhl. M.: OOO "Yzdatelstvo AST": OOO "Tranzytknyha"; SPb.: Terra Fantastica, 602 p.

8. Fysher S., Dornbush R., Shmalenzy R. (1999). Ekonomyka [Economy] Per. s anhl. so 2-ho yzd. M.: Delo, 231 p.

9. Kazantseva E.H. (2013). Olyhopolystycheskye rynky v sovremennoi ekonomyke [Oligopolistic markets in the modern economy] Avtoreferat dys. dokt. ekon. nauk, Tomsk, $40 \mathrm{p}$.

10. Ietto-Gillies Gr. (2005). Transnational Corporations and International Production. L.: Edward Elgar, 88 p. 
11. Carroll A. B. (1999). Corporate social responsibility: Evolution of definitional construct. Business and Society 38 (3): 268-295.

12. Blahov Yu.E. (2004). Kontseptsyia korporatyvnoi sotsyalnoi otvestvennosty y stratehycheskoe upravlenye [Corporate social responsibility concept and strategic management]. Rossyiskyi zhurnal menedzhmenta, № 3, p. 17-34.

13. Pro zakhyst ekonomichnoi konkurentsii. [On Protection of Economic Competition] Zakon Ukrainy vid 11.01.2001 r. № 2210-III. Rezhym dostupu: http://zakon.rada.gov.ua/laws/show/2210-14-Perevireno 05.03.2018

14. Laffont J.-J., Tirole J. (1993). A Theory of Incentives in Procurement and Regulation - Cambridge: The MIT Press, $705 \mathrm{p}$.

15. Gasmi F., Kennet D. M., Laffont J.-J., Sharkey W. W. (2002). Cost Proxy Models and Telecommunications Policy. A New Empirical Approach to RegulationCambridge: The MIT Press, $274 \mathrm{p}$.

16. Perekrestov D.H., Povarych Y.P., Shebashev V.A. (2011). Korporatyvnaia sotsyalnaia tvetstvennost: voprosy teoryy i praktyky [Corporate social responsibility: issues of theory and practice]. M.: Akademyia Estestvoznanyia, 437 p.

17. Tarasova N.A. (2012). Dostovernost sotsyalno-эkonomycheskykh pokazatelei: semyotycheskyi pokhod [Reliability of socio-economic indicators: semiotic approach]. M.; SPb.: Nestor-Ystoryia, 288 p. 


\title{
THE HISTORICAL ASPECT OF THE DETERMINATION \\ AND DEVELOPMENT OF VAT IN THE WORLD \\ AND THE PROBLEM OF ITS APPLICATION IN UKRAINE
}

\section{ІСТОРИЧНИЙ АСПЕКТ ВИНИКНЕННЯ \\ ТА ПОШИРЕННЯ ПДВ У СВІТІ ТА ОСОБЛИВОСТІ ЙОГО ЗАСТОСУВАННЯ В УКРАЇНІ}

\section{Belobrovenko Tatiana ${ }^{1}$}

DOI: http://dx.doi.org/10.30525/978-9934-571-28-2_3

\begin{abstract}
For Ukraine the VAT plays a significant budget forming role. However VAT potential in the modern tax system of Ukraine is realized not completely. For the first time, the value added tax was introduced in France in 1954. Then the VAT became widespread - first in other European countries, and later in the countries of Asia, Africa and Latin America. Today, VAT is levied more than in 140 countries. Such a scale of its application shows the acceptability and effectiveness of this tax to provide a reliable source of income for many governments. It should also be noted that the availability of VAT is a prerequisite for the admission of new members to the European Union. The purpose of the article is to study and generalize the historical aspects of the emergence and spread of VAT in the world, as well as the peculiarities of its application in Ukraine. Most countries in Europe and around the world have undergone a sufficiently long evolutionary path for the establishment and improvement of the VAT administration mechanism. From the analysis of the EU Directives on VAT, one can conclude that the EU does not stop at the achieved result, but continues to work towards harmonization and creation of a single VAT area. Of course, this process does not go without obstacles and certain problems, but the process of rebuilding and improving without them is impossible. The changes that may be made to the VAT administration mechanism in Ukraine, based on the analysis carried out, include an increase in the tax rate differentiation (this process has already started in Ukraine with the beginning of the $7 \%$ tax on medicines and medical equipment and equipment).
\end{abstract}

${ }^{1}$ Senior Assistant at Audit and Economic Analysis Department, University of State Tax Service of Ukraine, Ukraine 


\section{1. Ветуп}

У світовій практиці податок на додану вартість (ПДВ) вважається одним з найбільш ефективно працюючих податків, що стимулює національного виробника. Це непрямий бюджетоутворюючий податок. $\mathrm{У}$ другій половині $\mathrm{XX}$ століття в розвинених країнах світу його ввели, щоб обмежити перевиробництво.

Вперше податок на додану вартість було запроваджено у Франції в 1954 р. Потім ПДВ набув великого поширення - спочатку в інших країнах Європи, а пізніше - в країнах Азії, Африки та Латинської Америки. На сьогодні податок на додану вартість стягується більше, ніж у 140 країнах світу. Його розмір різниться від 5 до 28\%. 3 економічно розвинених країн ПДВ відсутній в США, довго не вводився в Швейцарії, Японії та Австралії, де діяв податок з продажу за ставкою від 2 до $11 \%$.

Також слід відмітити, що наявність ПДВ є обов'язковою умовою для вступу нових членів до Свропейського Союзу.

Метою статті є дослідження та узагальнення історичних аспектів виникнення та поширення ПДВ у світі, а також деякі особливості його застосування в Україні.

ПДВ як один із головних податків, на якому базується податкова система України, є предметом широких дискусій щодо доцільності його застосування та наслідків справляння для економічного розвитку і бюджету країни.

Деякі вітчизняні науковці та державні діячі вважають, що «діюча ставка ПДВ є дещо завищеною та наголошують на необхідності іiі зниження. I хоча зниження ставки податку має позитивне значення, оскільки воно буде сприяти збільшенню обсягів реалізації за рахунок зниження цін, що призведе до прискорення кругообігу фінансових ресурсів, що вкрай важливо для ефективного функціонування фінансової системи, все ж основні проблеми ПДВ полягають у невідпрацьованому механізмі його справляння» [1, с. 89].

Гострота дискусій щодо ПДВ у світі та в Україні викликана істотними побічними ефектами, з якими на практиці виявилось пов'язане запровадження найпривабливішої його риси - механізму відшкодування сум податку, сплачених у складі ціни товарів (робіт, послуг). Суми відшкодування з кожним роком зростають і досягли таких розмірів, що здатні впливати на інфляційні процеси в Україні. 


\section{2. Переваги та недоліки ПДВ}

Податок на додану вартість в Україні було запроваджено у 1992 році, і нині порядок розрахунків регулюється на підставі вимог Податкового кодексу України. Здавалося б за 26 років податкове законодавство України щодо ПДВ мало стати прозорим і досконалим.

Водночас тривожним фактом є те, що в дохідній частині бюджету збільшується частка податку на додану вартість. Це означає, що наша податкова система стає ще більш ПДВ-залежною. Уряд з кожним роком закладає ще більшу частку ПДВ у податкових надходженнях і робить таким чином нашу економіку ще більш залежною від одного податку як у дохідній, так і у видатковій частині.

Як свідчить моніторинг надходжень податків до бюджету у формуванні дохідної частини держбюджету України ПДВ належить 40-50\% [2]. Крім того, ПДВ становить третину від усіх надходжень державного бюджету і 9\% ВВП України. Компенсувати втрату такого джерела можна лише іншим споживчим податком. Ним міг би бути податок $з$ продажу. Але так як Україна поставила за мету вступ до Євросоюзу, то вона мусить врегулювати стабільні надходження з ПДВ, забезпечити повноту та прозорість адміністрування податку. Перш за все законодавство і практика цього податку мають відповідати його суті та призначенню.

Непрямі податки встановлюють в цінах товарів та послуг, їх розмір для окремого платника прямо не залежить від його доходів. Це так звані податки на споживання. Характеризуючи їх, Адам Сміт писав: «За відсутністю коштів для оподаткування підданих прямим податком, в розмірах отриманого ними доходу, уряд використав непрямі податки на їхні витрати, вважаючи, що витрати їхні в більшій частині випадків майже точно відповідають їхнім доходам» [3, с. 145].

Україна, яка розвивається із застосуванням зарубіжного досвіду, взяла за основу французьку модель ПДВ. На початку 90-х років цей податок був запроваджений для наповнення бюджету, тобто виконував і виконує по цей день яскраво виражену фіскальну функцію. На той час діяла ставка в розмірі $28 \%$, на сьогодні основна ставка становить 20\%, при цьому, Податковим кодексом України передбачається поступове іiі зниження до 17\% [4].

Головна особливість цього податку полягає в тому, що його платниками фактично є кінцеві споживачі товарів і послуг, причому як споживачі товарів і послуг виробничого призначення, так і споживачі това- 
рів і послуг особистого призначення. За допомогою цього податку між кінцевими споживачами рівномірно розподіляється та частина створеного в суспільстві продукту, яка має централізуватись і задовольняти загальнодержавні потреби. ПДВ стимулює економію витрат усіх видів матеріальних ресурсів, які не входять до складу собівартості продукції i, отже, не відшкодовуються підприємству, яке в такому разі виступає не як проміжний, а як кінцевий споживач (ряд витрат, не пов'язаних 3 веденням господарської діяльності, наприклад придбання основних засобів невиробничого призначення). У сфері обігу ПДВ стимулює продавців до стримування продажних цін на товари та послуги.

ПДВ має високу ефективність із фіскальної точки зору. Широка база оподаткування, яка включає не лише товари, але й роботи і послуги, забезпечує надійність та стабільність надходжень до бюджету. Універсальні ставки полегшують як обчислення податку для його платників, так і контроль органів ДФС за правильністю та своєчасністю його сплати. Стягнення ПДВ на всіх етапах руху товарів, робіт, послуг має наслідком рівномірний розподіл податкового тягаря між усіма суб'єктами господарювання.

Отже, по-перше, непрямим податкам (зокрема ПДВ) властиве швидке надходження. Перерахування податку у бюджет проводиться, як тільки відбулася реалізація. Крім того, фіскальна ефективність непрямих податків пов'язана з тим, що вони падають на широке коло предметів, тому сплачує їх величезна кількість населення, через що вони дають фіксований дохід, який важко одержати при прямому оподаткуванні.

По-друге, оскільки непрямими податками охоплюються товари народного споживання і послуги, то досить високою є ймовірність ïx повного чи майже повного надходження. Зупинити процес споживання ніхто не в змозі. А прибуток підприємство може і не одержати. Отже, споживання є надійним об'єктом оподаткування.

По-третє, непрямі податки менш помітні для споживачів, оскільки сплачуються шляхом включення їх до ціни товарів, що купуються. Крім того, сплачуються вони дрібними частками при придбанні кожної одиниці оподатковуваного товару, тому вони менш чутливі для платників, ніж прямі податки, де одразу вимагається сплата більш-менш значної суми. Нарешті, непомітність цих податків і в тому, що їх стягнення не пов'язане 3 неприємним для платника втручанням фіскальних органів 
у його приватне життя. Тому протидія непрямим податкам із сторони платників значно менша, ніж прямим.

Непрямі податки всеодно залишаються не помітнішими для платника, ніж прямі. Покупець при непрямому оподаткуванні не буде розраховувати, обчислювати, з'ясовувати розмір надбавки до ціни.

По-четверте, якщо платник ухиляється від сплати прямого податку, то це загрожує йому санкціями, а не придбавши того чи іншого товару, можна цілком легально ухилитися від сплати посереднього податку, особливо, коли цей товар є предметом не першої необхідності. Таким чином, споживач, збільшуючи або зменшуючи задоволення своїх потреб, сам регулює суму непрямих податків, яку він сплачує державі.

По-п'яте, якщо доходи бюджету базуються на доходах підприємств, то внаслідок нерівномірності економічного розвитку регіонів виникає проблема нерівномірності доходної бази різних бюджетів. Споживання ж більш рівномірне в територіальному розрізі, а тому застосування непрямих податків дає можливість збалансувати місцеві бюджети.

По-шосте, найкраща система прямих податків не може гарантувати того, що всі види прибутків справді будуть оподатковані. Ці види та частини прибутку, що вислизають від прямого оподаткування, якраз і можна захопити непрямим оподаткуванням. Крім того, лише воно дає змогу оподатковувати платника за його індивідуальною платоспроможністю.

По-сьоме, контроль за сплатою непрямих податків значно простіший, оскільки фіскальні органи мають справу з обмеженою групою платників непрямих податків, кількість яких порівняно 3 кількістю платників прямих податків досить незначна. Це пояснює значне поширення непрямих податків у ранніх податкових системах із низькою податковою технікою.

По-восьме, непрямі податки також справляють значний стимулюючий вплив і на саму державу, яка повинна забезпечити відповідні умови для розвитку виробництва і сфери послуг, адже чим більший обсяг реалізації в масштабі всієї економіки, тим більші надходження до бюджету.

ПДВ є могутнім фіскальним інструментом держави завдяки притаманним йому перевагам, а саме: простотою нарахування, зручністю сплати за місцем і часом, відсутністю примусового характеру, не вимагає накопичення певних сум. Цей податок визначається розміром 
споживання, тому виступає чинником, який стримує кризу перевиробництва і прискореного витіснення з ринку слабких виробників [5]. До недоліків ПДВ слід віднести значний його вплив на загальний рівень цін та регресивність, особливо щодо малозабезпечених верств населення. Встановлення нульових ставок на експортні товари створює позитивні передумови для збільшення обсягу експорту та підвищення конкурентоспроможності вітчизняних товарів на світовому ринку.

Якщо аналізувати ключові зміни, які прийняті у Податковому кодексі, то можна стверджувати, що в Україні законодавство передбачає необхідність гармонізації податкової системи $з$ європейськими стандартами, відтак ПДВ у Податковому кодексі був збережений. Дещо змінилося лише його адміністрування. Розробники Податкового кодексу намагалися вирішити комплекс завдань: перекрити найпоширеніші незаконні схеми мінімізації оподаткування, вирішити проблему з відшкодування ПДВ, а також знизити внутрішні ціни на зерно та металобрухт. Переваги та недоліки ПДВ наведені у табл. 1.

Таблиця 1

\section{Переваги та недоліки податку на додану вартість}

\begin{tabular}{|c|c|}
\hline Переваги ПДВ & Недоліки ПДВ \\
\hline $\begin{array}{l}\text { Відсутність подвійного оподатку- } \\
\text { вання і кумулятивного (каскадного) } \\
\text { ефекту }\end{array}$ & $\begin{array}{l}\text { Складний механізм нарахування та } \\
\text { сплати, прихована форма оподаткування } \\
\text { (платник-кінцевий споживач) }\end{array}$ \\
\hline $\begin{array}{l}\text { Платниками є всі учасники руху } \\
\text { товару від виробника до кінцевого } \\
\text { споживача }\end{array}$ & $\begin{array}{l}\text { Можливість ухилення від сплати } \\
\text { податку, в т.ч. за рахунок неузгоджено- } \\
\text { сті законодавчих актів з оподаткування, } \\
\text { недосконалої системи бухгалтерського } \\
\text { обліку та розрахунків за ПдВ }\end{array}$ \\
\hline $\begin{array}{l}\text { Як правило, рівні умови серед } \\
\text { виробників та продавців щодо } \\
\text { сплати податку }\end{array}$ & $\begin{array}{l}\text { Велика кількість пільг та операцій, звіль- } \\
\text { нених від оподаткування, через що ПДВ } \\
\text { виконує поряд з фіскальною функцією } \\
\text { регулюючу та стимулюючу }\end{array}$ \\
\hline $\begin{array}{l}\text { Ритмічність та стабільність податко- } \\
\text { вих надходжень }\end{array}$ & $\begin{array}{l}\text { При відсутності прозорої системи над- } \\
\text { ходжень до бюджету можлива наявність } \\
\text { бюджетної заборгованості, можливість } \\
\text { використання незаконних схем відшко- } \\
\text { дування ПДВ }\end{array}$ \\
\hline $\begin{array}{l}\text { Має широку базу оподаткування, } \\
\text { так як охоплює предмети широкого } \\
\text { вжитку і всі стадії руху продукції } \\
\end{array}$ & $\begin{array}{l}\text { Регресивний вплив, особливо на малоза- } \\
\text { безпечені верстви населення }\end{array}$ \\
\hline
\end{tabular}


Закінчення таблиці 1

\begin{tabular}{|l|l|}
\hline $\begin{array}{l}\text { Дає можливість стримувати } \\
\text { зростання цін }\end{array}$ & $\begin{array}{l}\text { Значні втрати бюджету від його мініміза- } \\
\text { ції та проблеми з відшкодуванням }\end{array}$ \\
\hline $\begin{array}{l}\text { Стримує кризу перевиробництва, } \\
\text { вирівнює можливість отримання } \\
\text { надприбутків та регулює процеси } \\
\text { споживання }\end{array}$ & $\begin{array}{l}\text { Негативно впливає на високотехноло- } \\
\text { гічні та науково місткі процеси }\end{array}$ \\
\hline $\begin{array}{l}\text { Збалансовує фіскальні потреби } \\
\text { уряду та необідність створення } \\
\text { умов для розвитку бізнесу }\end{array}$ & Фактор, що стимулює інфляцію \\
\hline $\begin{array}{l}\text { Податкове навантаження з ПДВ на } \\
\text { кінцевий товар не залежить від числа } \\
\text { оборотів і стадій створення вартості }\end{array}$ & \\
\hline
\end{tabular}

Джерело: узагальнено автором за даними [5]

Звісно, зваживши основні переваги та недоліки, можна стверджувати, що ПДВ має місце на існування та подальше удосконалення механізму його адміністрування.

\section{3. Виникнення та поширення ПДВ у світі}

На сьогодні ПДВ є прийнятим у більшості країн світу і на нього припадає близько $20 \%$ світового обсягу податкових надходжень. Майже наскрізне введення ПДВ вважається найважливішою подією в еволюції структури податків у першій половині ХХ ст.

ПДВ є досить молодим податком, так як більшість 3 нині діючих податків були введені в XIX столітті. Деякі з них, зокрема акцизи, земельний податок, відомі ще $з$ давніх часів, а ПДВ почали застосовувати лише в XX ст.

В міжнародній практиці непрямі податки позначаються як податки на споживання і включають три непрямі податки: податок на додану вартість, податок на продажі та податок з обороту.

Загалом момент запровадження ПДВ ніколи не був чітко визначений, оскільки існує два погляди на зародження даного податку:

ПДВ запропонований німецьким підприємцем В. фон Сіменсом у 1918 p.;

ПДВ розроблений американським економістом Т. Адамсом в його роботах у період між 1910 і 1921-1923 pp.

ПДВ в концепції В. фон Сіменса розглядався як технічна інновація, яка призвела до поліпшення функціонування основних податків. Він 
забезпечував повернення податків, які сплачувались за вхідні ресурси підприємства і тому дозволяв уникнути каскадної проблеми, яка виникала при використанні податку з обороту. У той час, як інновації явно були важливими, фон Сіменс не мав на увазі революційне повалення фінансового порядку [6, с. 15-16].

Т. Адамс запропонував ПДВ в якості альтернативи податку на доходи від підприємницької діяльності. Він був зосереджений на федеральній податковій політиці і, оскільки не було національного податку з продажів, його робота направлялася не на технічну модифікацію існуючого режиму, а грунтовну перебудову існуючої федеральної системи прибуткового податку. Німеччина, разом з більшістю країн Західної Європи, ввели ПДВ як зміну та удосконалення уже існуючого на той момент податку з продажу і як доповнення до податку на прибуток [6, с. 15-16].

В більшості наукових джерел першість щодо застосування ПДВ належить Франції. Точніше сказати ідея виникнення належить Німеччині, а практичне запровадження ПДВ відбулося у Франції. Це пояснюється тим, що ПДВ, який був там запроваджений найбільше схожий на сучасну модель даного податку. Кілька десятків років ПДВ існував винятково у вигляді ідеї, поки не було детально розписано механізм його дії та обгрунтовано переваги необхідності його застосування.

В основу механізму ПДВ покладено розвиток методології справляння та застосування податку з обороту, який пройшов послідовно три етапи. Перший етап ознаменований переходом в 1937 р. від податку з обороту до єдиного податку на виробництво. Другий - створенням в 1948 р. системи розподілених платежів, відповідно до якої кожен виробник платив податок з загальної суми своїх продажів за вирахуванням податку, що входив в ціну куплених ним комплектуючих, з різницею в один місяць. Третім етапом стало власне введення в податкову практику в 1954 р., як альтернатива єдиного податку на виробництво, ПДВ.

Тобто ПДВ прийшов як альтернатива на заміну інших непрямих податків, що не виправдали сподівань. Заміна податків є складним і тривалим процесом, з точки зору втрати частини доходів на початкових стадіях або економічної неефективності, або одразу того та іншого [6, с. 16].

Однією із перших форм непрямого оподаткування виявився податок 3 продажів, схожий за характером із ПДВ. Передумовою виникнення податку з продажів послужив гострий брак коштів у зв'язку з вели- 
чезними військовими витратами в період I Світової війни [7]. Даний податок стягувався багато разів на кожній стадії руху товару від виробника до споживача. Тому основним недоліком застосування податку 3 обороту був кумулятивний «каскадний ефект», який буквально можна розуміти як податок-на-податок. Даний податок створював ланцюг накопичених податків, що сплачувалися від першої стадії виробництва і до останнього етапу продажу. В результаті його функціонування ціна товару значно підвищувалась, що викликало величезне невдоволення як покупців, так і виробників. Перш за все, це було пов'язано з тим, що споживачі вимушені були купувати товари за досить завищеною ціною, яка витікала з багатократного оподаткування оборотів 3 продажів. 3 іншого боку, виробники зазнавали значних збитків унаслідок зниження попиту на свою продукцію. Це стало передумовою до того, що після I Світової війни неефективний та непопулярний податок був скасований у переважній більшості країн [8].

Першим досконало описав механізм дії ПДВ французький економіст Моріс Лоре у 1954 р. Він обгрунтував переваги ПДВ перед іншими універсальними акцизами - податком з обороту і податком з продажу. У 1967 р. ПДВ вперше запроваджується у Данії, 1968 р. - у Франції та Німеччині (ФРН), у 1969p. - у Нідерландах та Швеції.

Однак протягом більше десяти років ПДВ застосовувався в експериментальному варіанті, а дослідним полігоном для його застосування послужила залежна від Франції африканська держава Кот д’Вуар. Велика географія розповсюдження ПДВ свідчить про його життєздатність та відповідність вимогам ринкової економіки.

У Франції ПДВ у тому вигляді, який він має сьогодні, введений $з$ 1968p. з набуттям чинності Закону П’ятої Республіки № 66-10. Своєю метою Закон ставив: об'єднати, спростити і узагальнити порядок справляння ПДВ з тим, щоб перетворити його в єдиний і сучасний податок на виробничі витрати [8].

Наступним кроком у розповсюдженні ПДВ було підписання в Римі договору про створення Свропейського економічного співтовариства (СЕС) (1957р.), згідно з яким країни-учасниці повинні були гармонізувати свої податкові системи на користь створення спільного ринку, що поклало початок широкому розповсюдженню ПДВ в усьому світі.

В 1967 р. друга директива Ради СЕС проголосила ПДВ основним непрямим податком Свропи, зобов'язуючи всіх членів ЄЕС до 
1972 р. запровадити даний податок у свої податкові системи. Рада також висловила сподівання, що нова система призведе до зростання зовнішньої торгівлі, якій раніше перешкоджала складна та неефективна система податку з обороту. Після прийняття другої директиви, країни, що не входили в СЕС (Австрія, Греція, Швеція) внесли деякі зміни до системи адміністрування ПДВ, або як доповнення до вже існуючих податкових систем, або в якості заміни деяких податкових структур [9]. Роки запровадження ПДВ в деяких країнах світу наведені в табл. 2 [6, с. 16].

Таблиця 2

Хронологія запровадження ПДВ в різних країнах світу

\begin{tabular}{|l|c|l|}
\hline Країна запровадження ПДВ & Рік & \multicolumn{1}{|c|}{ Назва податку мовою країни } \\
\hline Франція & 1954 & TVA (Taxe sur la Valeur Ajoutée) \\
\hline Данія & 1967 & Moms (Merværdiafgift) \\
\hline Німеччина & 1968 & MwSt./USt. (Mehrwertsteuer) \\
\hline Нідерланди & 1969 & BTW (Belasting over de toegevoegde waarde) \\
\hline Швеція & 1969 & Moms (Mervärdesskatt) \\
\hline Великобританія & 1973 & VAT (Value Added Tax) \\
\hline Ізраїль & 1976 & Ma’am \\
\hline Австралія & 2000 & GST (Goods and Services Tax) \\
\hline Нова Зеландія & 1986 & GST (Goods and Services Taх) \\
\hline Канада & 1991 & GST (Goods and Services Тах) \\
\hline Україна & 1992 & ПДВ (Податок на додану вартість) \\
\hline Росія & 1992 & НДС (Налог на добавленную стоимость) \\
\hline Індія & 2005 & VAТ (Value Аdded Тах) \\
\hline
\end{tabular}

Джерело: узагальнено автором на основі [10, с. 280]

Шоста директива Ради СЕС, прийнята в 1977 р. остаточно затвердила базу сучасної європейської системи адміністрування ПДВ, чим сприяла уніфікації застосування його в Європі. Також уточнення в механізмі адміністрування ПДВ відбулись у 1991 р. через прийняття Десятої директиви СЕС, так як іiї положення були включені у податкове законодавство усіх країн-членів СЕС.

З 1987 по 1997 р. ПДВ був введений в багатьох країнах Східної Європи, країнах пострадянського простору, а також Азії. Бангладеш, Китай, Таїланд, Філіппіни, ввели ПДВ в середині 90-х рр. ХХ століття. 
Отже, ПДВ став одним з основних складових у податкових системах у більш ніж 140 країнах, з податковими ставками в діапазоні від 5 до 28\%.

Запровадження ПДВ також можна поділити на чотири умовні періоди, доцільно розглянути частку ПДВ у податкових надходженнях тих часів та частку у ВВП, щоб підкреслити значущість даного податку (табл. 3).

Значну частку (більше 20\%) у податкових надходженнях ПДВ займав на той час у Швеції, Данії, Великій Британії, Ірландії, Греції та Португалії. Найбільша частка ПДВ у ВВП належала таким країнам, як Швеція, Данія та Україна. Найбільшу початкову ставку ПДВ було введено в Україні, дещо менші в Франції та Норвегії.

Таблиця 3

Етапи введення ПДВ у світовій практиці

\begin{tabular}{|c|c|c|c|c|}
\hline $\begin{array}{c}\text { Період } \\
\text { введення } \\
\text { ПДВ }\end{array}$ & Країна & $\begin{array}{c}\text { Частка у } \\
\text { податкових } \\
\text { надходженнях, \% }\end{array}$ & $\begin{array}{l}\text { Частка у } \\
\text { ВВП, \% }\end{array}$ & $\begin{array}{r}\text { Стартова } \\
\text { ставка, \% }\end{array}$ \\
\hline \multirow{6}{*}{$\begin{array}{l}60-70 \text { pp. } \\
\text { ХХ ст. }\end{array}$} & Франція & 15,4 & 5,3 & 20 \\
\hline & Німеччина & 19,4 & 7,4 & 10 \\
\hline & Нідерланди & 18 & 6,9 & 12 \\
\hline & Швеція & 20,9 & 9,3 & 11,1 \\
\hline & Данія & 20,7 & 9,9 & 10 \\
\hline & Норвегія & 18,2 & 7,7 & 20 \\
\hline \multirow{6}{*}{$\begin{array}{l}70-80 \text { pp. } \\
\text { ХХ ст. }\end{array}$} & Австрія & 18,6 & 8 & 16 \\
\hline & Люксембург & 18,1 & 6,8 & 8 \\
\hline & Бельгія & 15,8 & 7,1 & 18 \\
\hline & Велика Британія & 20,9 & 7,4 & 10 \\
\hline & Ірландія & 21,6 & 6 & 16,4 \\
\hline & Італія & 13,7 & 6,1 & 12 \\
\hline \multirow{3}{*}{$\begin{array}{l}80-90 \text { pp. } \\
\text { ХХ ст. }\end{array}$} & Греція & 21 & 7,2 & 16 \\
\hline & Португалія & 26,1 & 8,5 & 16 \\
\hline & Іспанія & 16,6 & 5,4 & 12 \\
\hline \multirow{2}{*}{$\begin{array}{c}90 \text { рр. ХX ст.- } \\
\text { до XXI ст. }\end{array}$} & Швейцарія & 12,4 & 3,5 & 6,5 \\
\hline & Україна & 19,7 & 9,9 & 28 \\
\hline
\end{tabular}

Джерело: складено автором на основі [10, с. 281-282]

Також існує підхід, згідно якого прийняття ПДВ поділяється на два етапи. Перший етап мав місце в основному в Західній Європі і Латинській Америці у 1960-1970рр. Поширення ПДВ у Західній Європі при- 
скорилося прийняттям ряду Директив $\mathrm{CC}$, які вимагали від держав-членів введення гармонізованого ПДВ після вступу до ЄС. Другий етап впровадження ПДВ мав місце з кінця 1980-х рр. $з$ введенням ПДВ у деяких промислово-розвинутих країнах, що не входили в СС, таких як Австралія, Канада, Японія та Швейцарія. Цей етап також характеризується широким поширенням ПДВ в країнах з перехідною економікою $\mathrm{i}$ країнах, що розвиваються, особливо в країнах Африки та Азії [9].

На основі дослідження підходів до поділу історії становлення та розвитку ПДВ, можемо виділити такі етапи: перший етап (1910 1953 рр.) - виникнення ідеї застосування ПДВ, доведення його переваг в порівнянні з подібними податками; другий етап (1954 - 1966 рр.) введення ПДВ у практику країн Свропейського економічного співтовариства; третій етап (1967 - 1990 рр.) - впровадження ПДВ у країнах Західної та Центральної Європи, Латинської Америки у деяких промислово-розвинутих країнах, що не входили в СС, таких як Австралія, Канада, Японія та Швейцарія в країнах з перехідною економікою і країнах, що розвиваються, особливо в країнах Африки та Азії; четвертий етап (1990 - 2000 рр.) - поширення ПДВ у країнах Східної Свропи, Азії, Австралії, Африки; п'ятий етап (починаючи 32001 р. до сьогодні) - гармонізація та уніфікація законодавства з ПДВ у країнах-членах $Є С$ та подальше удосконалення механізму адміністрування ПДВ у інших країнах світу.

I хоча ПДВ набув широкого поширення у світовій практиці, його часто називають «європейським податком», віддаючи належне країнам появи даного податку, так і ролі ПДВ у становленні та розвитку західноєвропейського, а надалі загальноєвропейського інтеграційного процесу.

ПДВ є важливим джерелом бюджетної бази Свропейського співтовариства: кожна країна-учасниця ЄС перераховує 1\% надходжень від податку в «європейський» бюджет [11].

Гармонізація непрямого оподаткування, особливо ПДВ є важливим етапом для наближення законодавства України з законодавством країн-членів СС. Даний процес повинен проводитися системно, враховуючи усі сторони, переваги та недоліки, що дозволить уникнути неузгодженостей при внесенні змін та доповнень до діючих нормативно-правових актів України.

Процес гармонізації системи непрямого оподаткування ЄС, загалом, та ПДВ, зокрема, у країнах Свропи пройшов певні етапи, а саме: 


\section{Belobrovenko Tatiana}

Римський договір про створення ЄС (1957 р.): встановлював принципи створення Свропейського економічного співтовариства (СЕС), а також основи гармонізації податку з обороту країн-членів, з метою оптимізації роботи загального ринку;

Перша Директива СС по ПДВ (1967р.): встановила вимоги до країн-учасниць, щодо заміни податку з обороту ПДВ;

Друга Директива по ПДВ (1967р.): визначила більш-менш точні правила із введення ПДВ країнами-членами $\mathrm{CEC}$;

Шоста Директива по ПДВ (1977р.): скасувала дію Другої Директиви та частково Першої. Нові правила зазначені в даній Директиві врегулювали важливі питання: територіальну дію, операції, які підлягали оподаткуванню, види ставок, пільги, визначення платника податків, бази оподаткування та місця здійснення операції. Окремі вимоги стосувались лише малого підприємництва та земле володільців;

перехідна Директива (1993р.): скасовувала податкові бар'єри торгівлі між країнами-членами СС, встановлено єдині вимоги до країн, щодо впровадження законодавства з ПДВ та механізму його адміністрування. Особливу увагу було приділено механізму відшкодування ПДВ при здійсненні операцій із партнерами, що розташовані за межами території Співтовариства, запровадженню ідентифікаційних номерів, визначенню вимог щодо оформлення та збереження податкової документації;

Директива по електронному підприємництву (2002р.): визначено порядок розрахунку ПДВ при наданні електронних послуг країнами-членами СС покупцям з інших країн та навпаки. Місцем надання таких послуг є місце розташування покупця;

перероблена Шоста Директива (2006 р.): врахувала значну кількість поправок, що вносились від часу прийняття попередньої Шостої Директиви;

пакет Директив по ПДВ (2007р.): вводиться з метою спрощення та удосконалення системи ПДВ для міжнародної торгівлі і для боротьби 3 шахрайством. Даний пакет включає в себе такі зміни: нові правила, щодо визначення місця надання послуг (реалізація послуг обкладаєТься ПДВ саме в країні місцезнаходження замовника за принципом «зворотного оподаткування»), введення обов'язкової Зведеної Свропейської Декларації (Obligatory European Sales List (ESL)), в якій зазначаються міжнародні послуги і зміни до ESL щодо товарів, нова проце- 
дура відшкодування ПДВ, що здійснюється в електронній формі, щодо податку сплаченого в інших державах-членах СС. Правило «зворотного оподаткування» застосовується до замовників, які є платниками податків (Business to Business або В2B) та випадків, якщо послуги надає оподатковувана особа неоподатковуваній особі (Business to Consumer або В2С). В останньому випадку правило залишилося колишнім: місцем надання послуг є місцезнаходження постачальника послуг [12].

Ставки ПДВ в СС встановлюються кожною країною самостійно (табл. 4). Законодавством СС не визначаються ставки, а лише мінімальний розмір основної (стандартної) ставки [12].

На ряд пільгових товарів передбачено застосування зниженої ставки, які не повинні бути нижчими ніж 5 \%. Країни-члени СС можуть використовувати знижену ставку, щодо операцій із постачання природного газу, електрики та централізованого теплопостачання.

Таблиця 4

Ставки ПДВ в країнах ЄС

\begin{tabular}{|c|c|c|c|}
\hline \multirow{2}{*}{ Країна } & \multicolumn{2}{|r|}{ Ставка } & \multirow{2}{*}{ Абревіатура } \\
\hline & Стандартна & Знижена & \\
\hline 1 & 2 & 3 & 4 \\
\hline Австрія & $20 \%$ & $12 \%$ або $10 \%$ & USt. \\
\hline Бельгія & $21 \%$ & $12 \%$ або 6\% & BTW/TVA/MWSt \\
\hline Болгарія & $20 \%$ & $9 \%$ & DDS = ДДС \\
\hline Велика Британія & $20 \%$ & $5 \%$ або $0 \%$ & VAT \\
\hline Данія & $25 \%$ & & moms \\
\hline Німеччина & $19 \%$ & $7 \%$ & MwSt./USt. \\
\hline Греція & $23 \%$ & \begin{tabular}{|l}
$13 \%$ або $6,5 \%$ (зниже- \\
ний на $30 \%$ до $13 \%$, \\
$6 \%$ і $3 \%$ на островах) \\
\end{tabular} & ФПА \\
\hline Ірландія & $21 \%$ & $13.5 \%, 4,8 \%$ або $0 \%$ & $\begin{array}{l}\text { CBL } \\
\text { VAT }\end{array}$ \\
\hline Іспанія & $18 \%$ & $8 \%$ або 4\% & IVA \\
\hline Італія & $22 \%$ & $10 \%, 6 \%$, або 4\% & IVA \\
\hline Кіпр & $15 \%$ & $5 \%$ & ФПА \\
\hline Латвія & $22 \%$ & $12 \%$ & PVN \\
\hline Литва & $21 \% 0^{[4]}$ & 9\% або 5\% & PVM \\
\hline Люксембург & $15 \%$ & $12 \%, 9 \%, 6 \%$, або $3 \%$ & TVA \\
\hline Мальта & $18 \%$ & $5 \%$ & TVM \\
\hline
\end{tabular}


Belobrovenko Tatiana

Закінчення таблиці 4

\begin{tabular}{|l|l|l|l|}
\hline \multicolumn{1}{|c|}{1} & \multicolumn{1}{c|}{3} & \multicolumn{1}{c|}{4} \\
\hline Нідерланди & $21 \%$ & $6 \%$ або $0 \%$ & BTW \\
\hline Польща & $23 \%$ & $8 \%, 5 \%$ або $0 \%$ & PTU/VAT \\
\hline Португалія & $23 \%$ & $13 \%$ або $6 \%$ & IVA \\
\hline Румунія & $19 \%$ & $9 \%$ & TVA \\
\hline Словаччина & $20 \%$ & - & DPH \\
\hline Словенія & $20 \%$ & $8.5 \%$ & DDV \\
\hline Угорщина & $27 \%$ & $18 \%, 5 \%$ & ÁFA \\
\hline Фінляндія & $22 \%$ & $17 \%$ або $8 \%$ & ALV/ Moms \\
\hline Франція & $20 \%$ & $5.5 \%$ або $2,1 \%$ & TVA \\
\hline Швеція & $25 \%$ & $12 \%$ або 6\% & Moms \\
\hline Чехія & $21 \%$ & $10 \%$ & DPH \\
\hline Естонія & $18 \%$ & $5 \%$ & $\mathrm{~km}$ \\
\hline
\end{tabular}

Джерело: складено автором

При застосуванні ПДВ перед країнами-членами СС виникла проблема, щодо оподаткування операцій всередині $\mathrm{CC}$, оскільки ставки у країнах значно відрізнялися і відрізняються. Окрім того, оскільки митне оформлення товарообороту припинялося, то все адміністрування ПДВ-ланцюга ставало дещо проблематичним. Фактично СС був змушений вирішувати, яким чином справляння ПДВ на регіональному рівні. Для вирішення цієї проблеми було прийнято рішення не оподатковувати експортно-імпортні операції між країнами-членами, а нараховувати ПДВ у бюджет тієї країни, в якій відбувся продаж кінцевому споживачеві (рис. 1). Таке виключення застосовується лише щодо

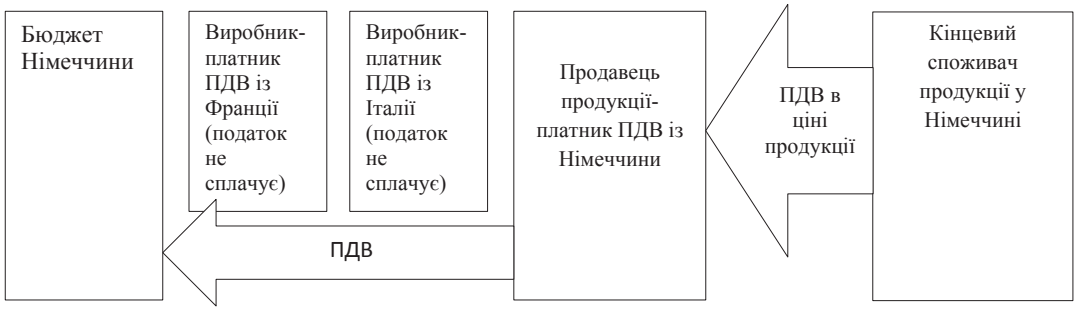

Рис. 1. Умовна схема адміністрування ПДВ у СС при експортно-імпортних операціях між країнами-членами $\mathbf{C C}$ Джерело: складено автором за даними [13, с. 11] 
The historical aspect of the determination and development of VAT in the...

операцій між країнами-членами, всередині країни-члена ЄС операції оподатковуються та обліковуються за стандартною процедурою 3 наявністю податкового кредиту з ПДВ та сплатою ПДВ до бюджету на кожному етапі виробництва чи реалізації продукції.

Щодо інших країн, то їх стандартні та знижені ставки можна дослідити в таблиці 5.

Таблиця 5

Ставки ПДВ в інших країнах світу, що не входять до ЄС

\begin{tabular}{|c|c|c|}
\hline \multirow{2}{*}{ Країна } & \multicolumn{2}{|c|}{ Ставка } \\
\hline & Стандартна & Знижена \\
\hline Австралія & $10 \%$ & $0 \%$ \\
\hline Аргентина & $21 \%$ & $10.5 \%$ або $0 \%$ \\
\hline Білорусь & $20 \%$ & - \\
\hline Боснія і Герцеговина & $17 \%$ & - \\
\hline Венесуела & $11 \%$ & $8 \%$ \\
\hline В'єтнам & $10 \%$ & $5 \%$ або $0 \%$ \\
\hline Ісландія & $24.5 \%$ & $14 \%^{3}$ \\
\hline Індія & $12.5 \%$ & $4 \%, 1 \%$, або $0 \%$ \\
\hline Ізраїль & $15.5 \%$ & - \\
\hline Казахстан & $13 \%$ & - \\
\hline Канада & $6 \%$ або $14 \%$ & $4.5 \%$ \\
\hline КНР & $17 \%$ & $6 \%$ або $3 \%$ \\
\hline Мексика & $16 \%$ & $0 \%$ \\
\hline Молдова & $20 \%$ & $5 \%$ \\
\hline Норвегія & $25 \%$ & $14 \%$ або $8 \%$ \\
\hline Парагвай & $10 \%$ & $5 \%$ \\
\hline Росія & $18 \%$ & $10 \%$ або $0 \%$ \\
\hline Сербія & $18 \%$ & $8 \%$ або $0 \%$ \\
\hline Таїланд & $7 \%$ & - \\
\hline Туреччина & $18 \%$ & $8 \%$ або $1 \%$ \\
\hline Україна & $20 \%$ & $7 \%$ або $0 \%$ \\
\hline Уругвай & $23 \%$ & $14 \%$ \\
\hline Філіппіни & $12 \%$ & - \\
\hline Хорватія & $22 \%$ & $0 \%$ \\
\hline Чилі & $19 \%$ & - \\
\hline Швейцарія & $7.6 \%$ & $3.6 \%$ або $2,4 \%$ \\
\hline Японія & $8 \%$ & - \\
\hline
\end{tabular}

Джерело: складено автором 


\section{Belobrovenko Tatiana}

\section{4. Пропозиції}

Без сумніву, досвід європейських країн повинен використовуватися при реформуванні української податкової системи в частині ПДВ із врахування особливостей, рівня розвитку та готовності вітчизняної економіки.

Дослідивши зарубіжний досвід застосування ПДВ, можна зробити висновок, що основними причинами зниження фіскального потенціалу ПДВ в Україні є: тіньовий сектор економіки; незаконні схеми відшкодування ПДВ; використання недиференційованих ставок ПДВ, що $\epsilon$ соціально несправедливим явищем.

Зазначимо, що переважна частина пільг з ПДВ формується за рахунок нульової ставки ПДВ та господарських операцій, звільнених від оподаткування, тобто наявна широка база податкових пільг та операцій, по яким не передбачена сплата цього податку, в той час як пільги соціального спрямування не набули поширення. Використання єдиної ставки ПДВ, зумовлює його регресивність і соціальну несправедливість, адже в структурі витрат бідніших верств населення частка ПДВ $\epsilon$ вищою, ніж у доходах заможних громадян. Такий недолік податку може бути подоланий диференціацією ставок щодо різних груп товарів або зниженням існуючої ставки ПДВ.

Слушною є думка науковців про те, що сьогодні виникає необхідність зміни розмірів ставок ПДВ у бік зниження або диференціації. 3 метою зменшення диференціації рівня життя громадян ставки непрямих податків, в тому числі і ПДВ, доцільно встановлювати диференційовані: використовувати занижені ставки для товарів, які включені до мінімального споживчого кошика, і завищені - для предметів розкоші. Ми пропонуємо, використовуючи досвід зарубіжних країн, запровадити в Україні диференційовані ставки ПДВ (табл. 6), адже використання цих ставок забезпечить регулюючу функцію та функцію соціальної справедливості податку.

Крім того не слід забувати, про регулюючу функцію ПДВ. Щоб підвищити ступінь ділової активності економіки України в цілому, податкове навантаження з ПДВ треба послабити.

Якщо зменшити основну ставку податку та ввести кілька пільгових, то у суб'єктів господарювання можуть з'явитися додаткові стимули для збільшення обсягів виробництва. Таким чином розшириться база оподаткування, і зросте загальна сума доходів зведеного бюджету. Також через зниження ставок ПДВ зросте сукупний попит населення. 
Запропонована диференціація ставок ПДВ

в залежності від категорії товарів

\begin{tabular}{|c|c|}
\hline Категорія товару & Ставка ПДВ, \% \\
\hline $\begin{array}{l}\text { Основні види продукції зі стабільним } \\
\text { попитом }\end{array}$ & $\begin{array}{l}\text { Основна ставка - } 20 \text { і поступове змен- } \\
\text { шення її до } 17, \text { як це передбачено ПК }\end{array}$ \\
\hline $\begin{array}{l}\text { Предмети розкоші, підакцизні та } \\
\text { імпортні товари }\end{array}$ & Підвищена - 20, 25 \\
\hline $\begin{array}{l}\text { Продукція на експорт, продукти хар- } \\
\text { чування, ліки, дитячий одяг та взуття, } \\
\text { дитяче харчування, товари щоденного } \\
\text { попиту та першої необхідності }\end{array}$ & Пільгові ставки - 0;7;10 \\
\hline
\end{tabular}

Джерело: складено автором

Знижені ставки доцільно застосовувати під час реалізації деяких товарів вітчизняного виробництва: продукти харчування, ліки, дитячий одяг та взуття, дитяче харчування, товари щоденного попиту та першої необхідності та товари, призначені на експорт.

Що стосується підвищених ставок, то, наприклад, обороти з реалізації підакцизної продукції вітчизняного виробництва можна оподатковувати ПДВ за ставкою 20 \%, а іноземного виробництва - за ставкою 25 \%. Вибір підакцизної та імпортної продукції як бази оподаткування підвищеними ставками ПДВ дозволить максимально реалізувати регулюючу функцію цього податку шляхом обмеження споживання імпортної та шкідливої для здоров'я продукції та шляхом підтримки вітчизняного виробника та застосування підвищених ставок до заможних громадян, які можуть собі дозволити предмети розкоші. Це в свою чергу забезпечить прогресивний характер ПДВ, тобто, хто більше заробляє, більше і сплачує.

\section{5. Висновки}

Більшість країн Європи та всього світу пройшли достатньо довгий еволюційний шлях становлення та удосконалення механізму адміністрування ПДВ. 3 аналізу Директив СС, щодо ПДВ, можна зробити висновок, що ЄС не зупиняється на досягнутому результаті, а продовжує роботу у напрямі гармонізації та уніфікації ПДВ. Звісно, що даний процес не проходить без перешкод та певних проблем, але процес перебудови та удосконалення без них неможливий.

До змін, що можуть бути внесені в механізм адміністрування ПДВ в Україні, на основі проведеного дослідження, належить 


\section{Belobrovenko Tatiana}

поглиблення диференціації ставки ПДВ (даний процес уже розпочався в Україні із початком використання 7 \% податку щодо ліків та медичних препаратів та медичного приладдя згідно переліку, затвердженого КМУ).

\section{Список літератури:}

1. Тулуш Л.Д. Сутність і роль податку на додану вартість в економічній системі держави // Економіка АПК. - 2008. - N 12. - С. 85-89.

2. Анализ фискальной эффективности НДС в Украине [Електронний pecypc] / сайт Экономика и финансы - Режим доступу до ресурсу : http://portfinance.ru/ukraine-1.html.

3. Смит А. Исследование о природе и причинах богатства народов. Т.1. М.: Соцэгиз, 1935. $-256 \mathrm{c}$.

4. Податковий кодекс України № 2755-VI від 02 грудня 2010 року [Електронний ресурс] / сайт Верховної ради України - Режим доступу до pecypcy : http://zakon4.rada.gov.ua/laws/show/2755-17.

5. Семенко Т. М. Податковий і фінансовий облік ПДВ згідно Податкового кодексу України / Т. М. Семенко [Електронний ресурс]. - Режим доступу: http://www.nbuv.gov.ua/portal/Soc_Gum/Oif_apk/2011_2/12_Semen.pdf

6. James K. Exploring the origins and global rise of VĀT / K. James // Tax Analyst. - 2011. - № 2. - P. 15-22.

7. Бровенко М. О. Удосконалення системи непрямого оподаткування в сучасних умовах розвитку економіки [Електронний ресурс] / М. О. Бровенко, C. А. Клімовська - Режим доступу до ресурсу : http://www.rusnauka.com/29 DWS 2009/Economics/53718. doc.Htm

8. Tuan Minh Le. Value Added Taxation: Mechanism, Design, and Policy Issues [Електронний ресурс] / Tuan Minh Le // Washington D.C. - 2003. - Режим доступу до ресурсу : http://www1.worldbank.org/publicsector/LearningProgram/ PracticalIssues/papers/Value20added\%20taxation/Value\%20Added\%20Taxation.doc.

9. Value added tax [Електронний ресурс] / сайт Reference for business Режим доступу до ресурсу : http://www.referenceforbusiness.com/management/ TrZ/Value-Added-Tax.html.

10. Worldwide VAT, GST and Sales tax guide 2014 // Ernst and Young. 2014. - P. 279-292.

11. Study to quantify and analyse the VAT gap in the EU-27 Member States Final report [Електронний pecypc] / European Commission - Режим доступу до ресурсу: http://ec.europa.eu/taxation_customs/resources/documents/common/ publicats/studies/vat-gap.pdf.

12. VAT: Overview of EU legislation [Електронний ресурс] / European Commission - Режим доступу до pecyрсу : http://ec.europa.eu/taxation_customs/ taxation/vat/how_vat_works/index_en.htm\#vat_overview.

13. Боярчук Д. Ц Цікаві факти про ПДВ / Д. Боярчук // Популярна економіка: ціна держави. - 2014. - № 26. - С. 1-13. 


\section{References:}

1. Tulush L.D. (2008) Sutnist' i rol' podatku na dodanu vartist' $v$ ekonomichniy systemi derzhavy [The essence and role of the value added tax in the economic system of the state]. Ekonomika APK., no 12, pp. 85-89.

2. Analyz fyskal'noy éffektyvnosty NDS $v$ Ukrayne [Analysis of fiscal efficiency of VAT in Ukraine]. site Economy and finance. Retrieved from: http://portfinance.ru/ukraine-1.html. (accessed 10 January 2018).

3. Smyt A. (1935) Yssledovanye o pryrode y prychynakh bohat•stva narodov [Study on the nature and causes of wealth of peoples] no.1, Moscow: Sotséhyz, $256 \mathrm{pp}$.

4. Podatkovyy kodeks Ukrayiny no. 2755-VI vid 02 hrudnya 2010 roku [Tax Code of Ukraine] sayt Verkhovnoyi rady Ukrayiny. Retrieved from: http://zakon4.rada.gov.ua/laws/show/2755-17 (accessed 10 January 2018).

5. Semenko T. M. Podatkovyy i finansovyy oblik PDV z $\bullet$ hidno Podatkovoho kodeksu Ukrayiny [Tax and financial accounting of VAT according to the Tax Code of Ukraine]. Retrieved from: http://www.nbuv.gov.ua/portal/Soc_Gum/Oif_ apk/2011_2/12_Semen.pdf (accessed 10 January 2018).

6. James $\overline{\mathrm{K}}$. Exploring the origins and global rise of VAT / K. James // Tax Analyst. - 2011. - № 2. - P. 15-22.

7. Brovenko M. O., S. A. Klimovska (2009) Udoskonalennya systemy nepryamoho opodatkuvannya $\mathrm{v}$ suchasnykh umovakh rozvytku ekonomiky [Improvement of the system of indirect taxation in the current conditions of economic development] / Retrieved from:: http://www.rusnauka.com/29 DWS_2009/Economics/53718. doc.Htm (accessed 10 January 2018).

8. Tuan Minh Le. Value Added Taxation: Mechanism, Design, and Policy Issues [Electronic resource] / Tuan Minh Le // Washington D.C. - 2003. - Retrieved from:: http://wwwl.worldbank.org/publicsector/LearningProgram/PracticalIssues/ papers/Value20added\%20taxation/Value\%20Added\%20Taxation.doc.

9. Value added tax [Electronic resource] / сайт Reference for business - Retrieved from:: http://www.referenceforbusiness.com/management/TrZ/Value-Added-Tax.html.

10. Worldwide VAT, GST and Sales tax guide 2014 // Ernst and Young. 2014. - P. 279-292.

11. Study to quantify and analyse the VAT gap in the EU-27 Member States Final report [Electronic resource] / European Commission. Retrieved from: http://ec.europa.eu/taxation_customs/resources/documents/common/publicats/ studies/vat-gap.pdf.

12. VAT: Overview of EU legislation [Electronic resource] / European Commission - Retrieved from: http://ec.europa.eu/taxation_customs/taxation/vat/ how vat works/index en.htm\#vat overview.

13. Boyarchuk D. (2014)Tsikavi fakty pro PDV [nteresting Facts About VAT] Populyarna ekonomika : tsina derzhavy, no. 26, pp. 1-13. 


\title{
BALANCING SOCIO-ECONOMIC DEVELOPMENT OF UKRAINE' REGIONS ON THE PRIORITY OF THE SOCIO-HUMANITARIAN POTENTIAL' EFFICIENT CAPITALIZATION
}

\section{Bogush Larysa ${ }^{1}$}

DOI: http://dx.doi.org/10.30525/978-9934-571-28-2_4

\begin{abstract}
The purpose of the study is to substantiate the approaches and priorities, to determine the prospects for balancing the socio-economic development of the Ukraine' regions through the systematic realization of the national socio-humanitarian resources. Methodology. The experience of their reproduction and effective capitalization in the process of balancing and mitigating territorial disparities in the countries worldwide has approved regional policy, acceptable for dissemination in Ukraine. Along with this, the methodological basis for studying the social aspects and guidelines of the development of the Ukrainian economy' regional subsystems consists of numerous works on: problems of increasing the efficiency of system management by a set of social processes; diversifying the employment sphere, balancing supply and demand in the labor market, adjusting the property stratification of the economically active population; improvement of mechanisms for satisfying its socially necessary needs; solving acute problems of optimization of start-up opportunities and social protection. Conclusions. The social orientation of economy' regional subsystems is an essential condition for establishing the pace and optimizing the proportions of state development, as it ensures the proper reproduction and growth of its human, vocational, qualification and innovation potential, supports the social harmony foundations, stimulates social responsibility of business and implementation of humanistic management concepts. The main criteria for the Ukrainian regional policy' quality include: the level and tendencies of diversification of economic complexes in accordance with the regional resource potential and the need to strengthen their science-intense and innovative orientation, as well as the level of formation and results of functioning of the regional
\end{abstract}

\footnotetext{
${ }^{1}$ Candidate of Economic Sciences, Senior Researcher, Leading Researcher,

Ptoukha Institute for Demography and Social Studies

of the National Academy of Sciences of Ukraine, Ukraine
} 
closed-loop production clusters; the level and dynam-ics of the population differentiation by characteristics of property, income and expenses; dynamics of medical and demographic characteristics of local and regional communities; availability and quality of satisfaction of their living, social and cultural needs in terms of socially necessary and private components; the level of ecological safety of the local and regional communities' living environment, including in the context of closer and remote prospects of resource development and economic use of territories. The balance of regional policy for reproduction and efficient capitalization of the socio-humanitarian potential should be achieved through the implementation of the quantitative and qualitative state obligations regarding: the ensuring a decent level and a safe liv-ing environment of the population; stimulation of its productive employment; intervention in the development of regions and local communities in order to optimize the reverse influences on the whole country' activity due to the negative dynamics of the monitoring indicators' system.

\section{Introduction}

The social orientation of economy and its regional subsystems is an essential condition for establishing the pace and optimizing the proportions of state development, as it ensures the proper reproduction and growth of its human, vocational, qualification and innovation potential, supports the foundation of social harmony, stimulates social responsibility of business and implementation of humanistic management concepts. The consolidation of the socially oriented market economy in the Ukrainian regions is based on the stabilization and expansion of the labor market, the growth of intellectual, professional and qualification potential, the promotion of productive em-ployment, the application of reasonable standards in the normalization of the foundations of the population social protection, the development of regulating and controlling civil society institutions.

Therefore, the purpose of the study is to substantiate the approaches and priorities, as well as to determine the prospects for balancing the socio-economic development of the Ukraine' regions through the systematic realization of the national socio-humanitarian resources in the spectrum of their human, intellectual, innovative, communicative, organizational, interface components [2, p. 103-112].

The experience of their reproduction and effective capitalization in the process of balancing and mitigating territorial disparities in the countries 
worldwide has formed a significant part of the approved regional policy, acceptable for dissemination in Ukraine [1; 5, p. 11-15; 6; 11; 13, p. 57-71]. Along with this, the methodological basis for studying the social aspects and guidelines of the current and future development of the Ukrainian economy' regional subsystems consists of numerous works on: problems of increasing the efficiency of system management by a set of social processes $[4$, p. 51-57; 5, p. 11-15; 7, p. 12-26; 9, p. 103-107]; diversifying the employment sphere, balancing supply and demand in the labor market and adjusting the property stratification of the economically active population $[3$, p. $4-10 ; 7$, p. $102-138 ; 8$, p. 74-76; 10, p. 97-102]; improvement of mechanisms for satisfying its socially necessary needs [4, p. 51-57; 7, p. 206-244; 13, p. 178-239]; solving acute problems of optimization of start-up opportunities and social protection [8, p. 74-76; 9, p. 103-107; 15 , p. 57-66]. Experts have proved the dependence of economic performance and perspectives of regional sustainable development on the systematic implementation of existing guarantees in the field of reproduction of human capital and labor supply, as well as on the competitiveness of employed and economic entities [5; 12, p. 4-8; 13, p. 345-406, 515-556; 14; p. 63-66], which in turn is primarily related to the territorial conditions of improvement and realization of their professional, qualification, entrepreneurial and innovative potential.

\section{Implementation of the developed countries' experience in balancing Ukrainian regional disparities}

Approaches and trends in the development and implementation of regional policy in countries that today are characterized by the most financial, economic, social and political stability, combine: reduction of regional socioeconomic imbalances by redistributing resources between developed, depressed and crisis territories; provision of social equity through targeted support for regions parity based on the main social indicators; formation and improvement of the effectiveness of the adaptation mechanisms of the backward and other problematic regions to changes in the organizational and economic mechanism in the current period of socio-economic development.

Among the important measures within the first main direction of the policy for balancing regional disparities we should note: direct state interference in the regions activity in order to equalize their quantitative socio-economic characteristics, including on the basis of structural adjustment and 
strengthening the complexity of territorial economies; stimulation of the large enterprises construction in the basic specialization sectors, including those with a significant share of state capital; targeted investment in infrastructure and public works; stimulation of territorial workforce mobility; provision of privileges, loans and grants to economic entities in the specialization sectors of the backward regions; establishment of tax and financial incentives for national and foreign investors in the economy of these regions and free economic zones.

The implementation of the second of aforementioned directions takes place primarily due to:

- decentralization of decision-making and a balanced division of powers between the center and the regions based on:

- the subsidiarity (i.e., the preservation under central government of the general planning functions and those social ones that are not capable to organize adequately by local authorities, in conjunction with the formation of fiscal and tax relations system, guaranteeing the resources provision of functions assigned to territorial bodies of a certain level);

- the increase of the responsibility of sub-national (municipal, regional) authorities for defining the directions and perspectives of territorial communities sustainable development on the basis of raising the level of their financial provision with local resources;

- the control over the compliance of decisions and financial transactions of local administrations with the national legal and regulatory framework;

- involvement of self-development incentives of regions and territorial communities related to reserves of natural and manpower resources, organizational technologies, in particular by:

- optimizing their educational policy, including on the basis of: conducting training, advanced training and retraining of personnel at production facilities; developing training for new technologies, subsidizing scientific activity, as well as entrepreneurship in the field of various scientific services and higher management; involving higher educational institutions to the regional programs for $\mathrm{R} \& \mathrm{D}$, environmental protection, preparation of technical and technological justifications for the development of the territory and the construction of separate objects, fulfillment of labor resources' planned training financed from local budgets;

- stimulating the creation and application of science-intensive technologies, including through the support of small high-tech firms, the formation 


\section{Bogush Larysa}

of innovative complexes, centers for the advanced technologies' dissemination, techno-parks at higher educational institutions and techno-polises in places of science-intensive industries' concentration;

- encouraging small and medium-sized enterprises in the service sector;

- increasing economic efficiency of use of natural recreational potential, historical and cultural heritage in regions where natural conditions allow to develop tourism as a branch of specialization of local and national economies.

Consequently, the main criteria for the Ukrainian regional policy' quality include: the level and tendencies of diversification of economic complexes in accordance with the regional resource potential and the need to strengthen their science-intense and innovative orientation, as well as the level of formation and results of functioning of closed-loop production clusters in the regional economies; the level and dynamics of the population differentiation by characteristics of property, income and expenses; dynamics of medical and demographic characteristics of local and regional communities in general; availability and quality of satisfaction of their living, social and cultural needs in terms of socially necessary and private components; the level of ecological safety of the living environment of local and regional communities, including in the context of closer and remote prospects of resource development and economic use of territories.

\section{Positives and problems of Ukraine' territorial development in the context of its socio-humanitarian potential' reproduction and realization}

According to the aforementioned quality criteria, the results of the implementation of Ukraine' regional policy (as an integral part of the public administration of socio-economic development) in the last decade acquire ambiguous assessments. Positive effects and trends of the regional development, in particular, include: the decentralization of social powers and obligations, that has been already started; the local projects on the revival and improvement of the infrastructure of preschool and secondary education, health care, culture; the further development of the organizational and economic mechanism for providing socially necessary services on the basis of compulsory insurance; the realization of a number of different scale projects for modernization and further development of road, transport and communal infrastructure; the financial, tax, informational and methodical stimulation of regional and local 
initiatives aimed at revitalizing the entrepreneurial activity of the population in the areas of small-scale agricultural production, processing industry, individual housing construction, services, tourism.

Along with them, it should be noted a number of negatives and threats, among which:

- ineffectiveness of the state policy regarding the innovation transformation of regional economic complexes, including in terms of ensuring the corresponding specialization of the free economic zones, stimulating the formation of territorial clusters in services and innovation infrastructure;

- permanent shortage of budgetary resources for providing the socially necessary living, social and cultural needs of the population (the definition of the latter is carried out practically without taking into account sectoral standards and norms, only on the basis of the financing practice in the short-term retrospective, and recently - exclusively on the actual budget provision), as well as for the complete infrastructure modernizing and maintaining the staff of the territorial communities' institutions of social purpose, which is exacerbated on the local budgets' level, including newly created integrated communities;

- instability of mechanisms and situational practice of subsidizing relevant items of regional and other local budgets expenditures, as well as of distributing these funds at the local communities level;

- low level of financing of state and regional programs for: controlling the sanitary and epidemiological situation; preventing morbidity among the population of pre-working and working age; renovating engineering networks and complying the requirements of the economy' ecological safety;

- inefficiency of mechanisms of state control over the conditions of employment and labor remuneration at non-state enterprises, as well as in non-standard labor relations in general.

Important factors of low efficiency of Ukraine' regional policy remain as follows:

- insufficient consistency and numerous problems of implementation of legal and regulatory framework of the population social protection (in particular, as to the Law of Ukraine of 5.10.2000 No. 2017-III "On state social standards and state social guarantees"). Multifacetedness of government obligations concerning social security and protection, outlined in this act and stipulated by it State classifier of social standards and criteria, still has not been duly accounted in methods of determination of the minimum living wage and other financial guarantees. Valid method of minimum living 


\section{Bogush Larysa}

wage calculation rather weakly accounts the content of its social component (as a value representation of a range of needs in cultural and educational, medical, recreational and other goods and services, consumption of which provides proper quality of individual and territorial social reproduction). The delay in development and adaptation of state social standards at the regional level leads to the imbalance of legal guarantees and budget commitments, the approval of financially weak and mutually reinforcing state and regional programs, contributes to the subjective distribution of available resources by authorities at different levels and their non-targeted use;

- conjunctural mechanisms for identifying priority measures of state social policy and their implementation at the regional level, which is reflected in the dispersion of the relevant resource supply, inadequate consideration of the needs of specific territorial communities;

- efficiency deterioration of the social mechanisms of vertical social mobility and cultural and ideological integration;

- insufficient development of the legal and regulatory framework for the development of the social services market, as well as the inconsistency between the proposed mechanisms for the accumulation of extra-budgetary resources for providing the needs in housing, health care, vocational education, on the one hand, and the financial and property realities of the population' most stratums, on the other;

- numerous deficiencies of the consumer rights protection mechanism, con-nected with inappropriate development and lack of coordination of sectoral legislation in the field of the individual demand service.

The analysis of the volumes and production structure of gross added value in the Ukrainian regions reflects a marked increase in the substantial territorial differentiation of economic potential, generally indicating:

- the inefficiency of the state policy concerning: innovative transformation of the regional economic complexes, including the provision of appropriate specialization of free economic zones, stimulation of the formation of services and innovation infrastructure' territorial clusters; assistance to the depressed regions development (primarily ones with surplus labor resources and traditional agricultural specialization, as well as other areas of monospecialization and increased technogenic risks);

- the shortcomings in the regulation of the Ukrainian fiscal system, which are manifested in the taxation at the location of the companies' central offices rather than production locations directly; 
- the low proportion of closed-loop productions in combination with a significant level of the regional economies' shadow sectors;

- specialization of the economy as a whole on the export of raw materials and semi-finished products, as well as on transit.

A rather close correlation between the volumes of gross regional product, gross added value and the level of incomes, wages and expenditures of the Ukrainian regions' population (first of all, in the "obligatory" articles of payment for housing, communal and transport services) plays a significant direct and indirect role (related to the potential of filling the local and regional budgets, the level of their subsidizing from the state budget, and therefore - the scale of expenditures for providing social needs and developing infrastructure) in the formation and maintaining a spatial parameters of unjustified social inequality, as well as the social and individual factors and mechanisms for limiting or stimulating educational and labor migrations, other active measures for ensuring productive employment and vertical social mobility of the population.

\section{Essential social priorities of the Ukraine' regional policy on the medium-term prospect}

The Ukraine' regional policy for the medium-term period includes the main directions for: balancing the territorial and sectoral proportions of the regional development, confirming the post-industrial and social orientation of their economies, stimulating consumer demand as the driving force of economic growth, optimizing the general conditions of social reproduction in general; increasing the investment volume of regional clusters of science-intense and high-tech industries and their output, improving innovation activity in all economy spheres, management and public life; ensuring a decent life quality of the population (primarily on the basis of full implementation of legally regulated human rights as guarantees of equal access to socially necessary goods and services, optimization of the parameters of vulnerable strata' targeted social protection), creating conditions for the harmonious development of territorial communities and individuals; balancing the proportions and interactions of the spectrum of life activity forms (labor, consumer, reproductive, socio-ecological) of the population in regions and settlement systems; providing the territorial communities' development based on the principles of self-governance and establishment of the civil society' regulating institutions; 


\section{Bogush Larysa}

maintaining the set of principles and parameters on the key aspects of the national security.

In this context, the hierarchy of challenges for Ukraine' regional policy at the current stage of socio-economic development includes:

- the urgency of formation and implementation of a holistic system of social standards and guarantees designed to ensure the proper quality of the population' reproduction and life, as well as methods and mechanisms for their adaptation, implementation and correction at the regional and local levels;

- the requirement of balancing the volumes and establishing the mechanisms for financing expenditures of the local and regional budgets for providing socially necessary living and intangible needs of the population;

- the importance of ensuring effective control and adjustment of negative changes and threats of the sanitary-epidemiological, demographic and migration situation' complication;

- the need to increase the efficiency of mechanisms for stimulating productive employment of the population in the settlement systems within the framework of measures presented by relevant national and regional programs, financial, methodical (both organizational and informational) initiatives of employment services, employers, entrepreneurial structures, voluntary public associations;

- the expediency of targeted adjustment of the investment climate in the regional and local entities of territorial division by regulatory, fiscal, program and administrative measures;

- the importance of maintaining social harmony and stability, in particular, in its socio-political, cultural and ideological, interethnic, inter-confessional aspects;

- the need to optimize the methods of determining the problem territories' main types (depressive, backward, crisis, areas of special functional or problem orientation, areas of special economic modes), the procedures for monitoring the systems of their socio-economic characteristics, as well as the mechanisms of rehabilitation, including on the basis of: implementing joint programs of mutually beneficial development of problem and advanced regions; establishing local growth points in the branches of processing industry, which operates on the local raw materials, services and tourism, the modern technologies and innovative support of entrepreneurial activity; 


\section{Balancing socio-economic development of Ukraine' regions on the priority...}

- the urgency of improving mechanisms for solving acute social problems of territorial development, in particular, regarding provision of opportunities for vertical social mobility of the population, prevention of its marginalization, adaptation of youth in society and in the labor market.

The most important problems that urgently require a systemic solution (with using an integrated program approach and indicative planning) in order to optimize the regional socio-economic development' proportions and to activate the advantageous growth opportunities (particularly in social subsystem), include:

- structural reorganization and modernization of the housing stock, housing and communal services, scientific and educational complex, recreational and entertainment industry, health protection sector; improvement of ecological safety of the housing, communal and recreational sectors, as well as natural and anthropogenic (household, industrial) environment of the population vital activity;

- improvement of the investment climate and competitive environment in the sectors for producing domestic goods and services of social purpose; regulation of their domestic market and competitiveness on the basis of ensuring proper quality control, as well as accessibility, taking into account legislative guarantees and dynamics of the population solvent demand;

- strengthening and increasing the economic efficiency of the use of scientific, technical, socio-economic and natural potential of export-oriented sectors for the production of social services (primarily, in vocational education, specialized medical care, sanatorium and resort recreation, tourism, exhibition activities);

- increasing the contribution of education to the economy modernizing on the basis of forming the system of life-long education, updating the content and optimizing the structure of vocational education, optimizing the mechanisms for providing the needs of regional economic complexes in the specialists and skilled workers' training, forming the territorial clusters of venture production based on innovations and start-ups in educational and scientific services;

- preservation and improvement of qualitative characteristics of human and other components of social capital, including on the basis of: restoring the stimulating function of remuneration in the budget sector and lowpaid types of the social purpose' economic activities of the other ownership forms; increasing the solvency and optimizing the level of social protection 
of the middle- and low-income population groups; overcoming organizational and economic problems and territorial deformations in the household-providing, consumer-providing and socio-cultural sectors' functioning, in particular, regional problems of forming and functioning the basic social infrastructure in the settlement systems;

- balancing the demand and supply of specialists and skilled workers in regional labor markets, ensuring productive employment of economically active population, as well as social protection of employees in the non-state sector of the economy.

\section{Measures on the socio-humanitarian potential' reproduction and realization in the strategy for stimulating the problem territories' development}

An indispensable component of the Ukraine' socio-economic development strategy is the regulation of territorial disparities by stimulating the "growth points" in the economy, areas of employment and social protection of problem regions. The latter ones include the following main types of territories:

- depressive - territories that until recently have been relatively well devel-oped and still have a significant potential for socio-economic characteristics' stabilization, but for global and national reasons (for example, due to the impact of radical market and socio-political reforms), became in the systemic crisis characterized by a sharp (compared with pre-crisis period) reduction of indicators of the economy and social sphere' development;

- backward - territories that are characterized by the low (in the background of other regions of the country that are more or less progressive) level of the socio-economic indicators during the long period measured by decades (i.e., chronically);

- crisis - territories of any level of development (average, low, high) that have undergone significant technological or ecological disasters, which, for more or less long time, have destroyed the usual way of life, or even have prevented the economic complex' functioning, or have affected adversely on the opportunities of ensuring its effectiveness measured like in the pre-crisis period;

- territories of a special functional or problem orientation - subjects of administrative-territorial division that are closed to free access now or have been closed previously (from cantonments to the places of compact 


\section{Balancing socio-economic development of Ukraine' regions on the priority...}

placement of regime-based science-intensive industries and other similar objects), areas of ethnic minorities' compact residence, nature reserve fund objects and territories of special protection (including sanitary protection districts of resorts and other recreational zones);

- areas of special economic modes (including foreign economic activity) - special economic zones, technoparks, technopolises, etc.

The main directions for stimulating the development and support of these economically less developed and depressed territories, in particular, combine:

- the implementation of a set of measures to ensure the progress and modernization of the regional economies structure through fiscal, program and administrative stimulation of activities for: increasing the share of closed-loop productions; accelerated development of the processing agro-industrial complex' branches, large-scale agriculture (primarily animal husbandry), science-intensive industries in the mechanical engineering, aircraft construction and instrumentation, communications and telecommunications; forming the regional clusters specialized in services and recreation, innovation infrastructure and applied research, maintaining transit passenger traffic through international transport corridors; preferential lending for housing construction;

- the use of the socio-cultural sectors' potential (education, science and scientific services, specialized medical care, sanatorium and resort treatment) in diversifying and improving the competitiveness of regional economies and settlement systems;

- the implementation of programs for accelerating innovative modernization and increasing the national economy' technological independence, stabilizing labor supply and demographic situation in regions and settlement systems;

- the expansion of the internal consumer market, optimization of proportions "production - consumption", "consumption - accumulation";

- the provision of an effective and secure specialization (in the national interests' context, including requirements for economic, social, environmental safety) of the special economic zones and trans-boundary regions;

- the assistance in the development of foreign markets for domestic goods and services, including through the involving the foreign economic activity' infrastructure, deepening humanitarian relationships, joining the interstate structures; 


\section{Bogush Larysa}

- the normative regulation of the problem territories' justified classification, improvement of the methods' efficiency for their determination, as well as the selection quality of monitoring indicators in the process of their rehabilitation; coordination and definition of the rehabilitation measures' pace according to the type of specific problem area;

- the selection and programming of the development of target territories integrating spatially close problem regions and leading regions "locomotives".

The system of special measures for the removal of depressive territorial tensions (sanitation) must simultaneously influence the situation in the economy, socio-political relations, nature management, environmental protection and other spheres of life; thus, it requires the use of individually directed multifunctional economic and legal, socio-organizational, socio-economic and demographic, as well as other types of regulators, combined with transfers as the general instrument for the territorial development' state regulation.

According to the options for rehabilitation (temporary preservation of a de-pressed situation as an obstacle to further destruction without eliminating its causes due to the necessary resources' lack, restructuring with the transforming of economic potential, solving social problems, eliminating environmental threats and dangers, etc.; formation of a special economic mode), the mechanisms of the corresponding measures include: the selection of specific sanitation objects in the specialization sectors, as well as in the infrastructure and personnel provision of their activities, etc.; the targeted state and program investment, an attraction of private investments on the basis of tax privileges, fiscal vacations, etc.; the support for certain forms and types of economic activity (for example, small businesses, farmers, co-operation of enterprises, their corporatization by labor collectives); the intensification of productive employment, economically feasible migrations and entrepreneurial initiatives of the population, including promoting the new workplaces establishment, finding an effective owner, diversifying the economic spheres in accordance with the local resource potential, etc.; the improvement of the economy' infrastructure and human resources (through the targeted development of the road and transport network, systems of energy supply and communications, spheres of vocational education, scientific services and innovation activities, etc.). 
Measures for the integration of spatially close problem regions and regions - "locomotives", aimed at eliminating significant structural and social differences in their development, in particular, consist of: the implementing the state and regional programs for development and increase of the production and social infrastructure' accessibility of both regions; the stimulating their joint participation in: the partial financing of a number of infrastructure facilities designed to improve transport accessibility and engineering arrangement of the problem region' settlement system; providing the needs of the territorial labor markets; raising the level of the resource potential development and management in the problem region; the subsidizing the problem region' social expenditures to the level of their provision in the region - "locomotive" with the joint participation of the state and relevant macro-regional (oblast) budgets.

\section{Approaches to increasing the Ukrainian regions' competitiveness on the basis of the socio-humanitarian resources' systematic capitalization}

The functions of the spectrum of social capital' subsystems (human, intellectual, innovative, communicative, organizational, interface) in the economy determine the main directions of their improvement in the context of the Ukrainian regions' competitiveness increase, among which we should mention about: improving the availability of the information' sources and channels for separate individuals, socium groups, society as a whole; investing in the process of the innovations' disseminating and stimulating the demand for them; expanding the economic entities' innovative and rent-forming potential, creating the conditions for its realization; improving the motivations' structure of individuals (in particular, on labor, productive employment, employee performance) and business entities; rationalizing the transaction costs associated with mechanisms for conducting and coordinating economic, entrepreneurial and innovative activities; promoting the business' social responsibility; optimizing the institutional structure of all society's life spheres.

The development of the human and intellectual components of the Ukrainian regions' social capital primarily involves: the improvement of tangible grounds of the population well-being; the efficiency increase of structural adjustment, technical and technological modernization of the economic complex.

The implementation of the first of aforementioned main directions should be carried out on the principles of: 


\section{Bogush Larysa}

- observing the proportionality and consistency in the economic, social, innovative and ecological sub-systems of regional policy;

- approving and observing a set of social standards and guarantees as the basis for the development of the state social protection system that implements the social state grounds; applying these standards and guarantees in the calculations of wages, pensions and other social payments, prices and tariffs for goods and services, expenditures of the different levels' budgets, as well as in determining the material, financial, labor needs of regional economic complexes;

- harmonizing a subsistence level, minimal salary and pension with social standards and guarantees, improving the mechanisms for indexing wages and social benefits;

- systemizing and strengthening the financial support for measures to combat poverty, implement the employment guarantees, reduce unemployment, provide socio-economic support to young people, young families and families with children, increase the availability of socially necessary services for vulnerable strata;

- implementing active social protection programs aimed at revitalizing the initiative of low-income and unemployed categories in the field of vocational training and retraining, getting a job, starting their own business, participating in public works, etc.;

- implementing the mechanism for providing graduates of the vocational technical and higher education institutions with the first job; promoting the development of the system of the personnel vocational training in the workplace by: the fiscal stimulation of employers to finance such activity; the workers' motivation through the labor remuneration policy;

- forming the effective mechanisms of the influence of consumers and civil society structures on the social sector functioning, including the processes of financing, control and adjustment of the services' quality within the satisfaction of the household, social and cultural needs of individuals, mass consumers' different categories and territorial communities.

In turn, the efficiency' increasing of the structural adjustment, technical and technological modernization of the economic complex (as another main direction for development of the human and intellectual components of the regional social capital) is based on:

- the transition to integrated regional educational systems oriented to satisfy local staffing needs, improve the mechanism and strengthen the 
incentives of sustainable socio-economic development, increase the region' competitiveness; the improvement of the using efficiency of the education system' resource potential due to its concentration in the regional resource centers established on the basis of the leading regional educational institutions according to its economy' priority sectors and designed to disseminate innovative activity to other educational, scientific institutions and business entities of all ownership forms;

- the increase of the R \& D economic efficiency on the principles of integrating education, science and production, stimulating the formation of elements and integral territorial systems of innovation development through deepening cooperation between educational and scientific institutions, establishing technology parks, research consortia, business incubators, etc.;

- the substantial increase in the share of science-intensive, high-tech and re-source-saving types of economic activity in the service sector (primarily in scientific and IT services, services for ensuring the market functioning, household services for the population, financial and insurance services, services for tourism, recreation and entertainment); the further legal regulation, acceleration of the turnover sphere development, provision for the proper control over maintaining its standards (in particular, in the trade, restaurant business);

- the further regulatory and legal settlement of the problems of realizing the intellectual (creative, knowledge generating, rent-forming) potential of the economically active population;

- the promotion of the further small and medium-sized businesses' expansion in the services sector, stimulation of the innovative infrastructure development;

- the innovative activity' intensification, increase of the business entities' in-vestment attractiveness in the social sphere' export-oriented segments (vocational education, inbound recreational industry, highly specialized medical services, applied R \& D); growth of the international and, in particular, cross-border relations in science, education, culture, tourism;

- the development of tourism and recreation as the specialization sectors of the Ukraine' regions in the international labor division, in particular, by improving the investment climate in the recreation and entertainment industry, increasing the mechanisms efficiency for regulating the quality and prices for tourist, excursion, sanatorium, resort and hotel services, enhancing their information and advertising support on the foreign market; 


\section{Bogush Larysa}

- the priorities selection and forecasts justification for the development of regional tourist and recreational spheres, collaboration coordination of the local authorities and business entities implementing relevant goals; conduction of the investment policy aimed at the regional tourist brands' formation and specific integrated tourism products' market promotion; encouragement of the entrepreneurial activity in the regional tourist and recreational sphere, as well as the new workplaces' creation in the branches associated with this industry; implementation of the programs for the social infrastructure development to ensure the tourists' cultural and household needs;

- the acceleration of the open information society' development on the basis of creating infrastructure networks (including electronic ones) for providing the unified national scientific and educational information space' functioning, integrated into relevant supranational and other international structures.

Adaptation of the above-mentioned measures for expanding the human and creative (intellectual, innovative) components of the Ukrainian regional socio-humanitarian potential and increasing their capitalization efficiency at the local level, in particular, requires: the implementation of the rules and standards for determining the developers' fees for share participation (contributions) in ensuring the proper level of the social infrastructure complexity, working out their payment mechanisms to the local budgets; the local authorities' participation in preparing the government orders for the commercial production of the socially necessary goods and services; the licensing of the utilities services' producers, as well as controlling over their contractual obligations' fulfillment; stimulating the implementation of effective energy-saving technologies for building and exploitation of housing stock and utilities engineering infrastructure; the provision of the social protection services for vulnerable categories' consumers according to their current standards; the involvement of financial instruments (benefits, guarantees, subsidies) in order to assist in obtaining loans for local economic entities in the tourist and recreational industry; the implementation of programs for improving resort and other types of recreation zones, as well as for maintaining public order in these territories.

In the context of diversifying the economy of the leading, less developed and depressed Ukrainian regions, strengthening its science-intensity and postindustrial orientation, increasing the innovative and technological 
progress' efficiency, improving the population' life quality, it is expedient to allocate the following "growth points", such as:

- tourism, in particular by:

- strengthening the positions in the separate segments of the tourist services' international market (first of all in the long-term resort entertainment, sanatorium treatment, cultural-educational, sports-treatment, business, educational and rural green tourism) with further dynamic progress towards obtaining the status of the "active tourist" country, aimed at incorporating the tourism industry into the national economic complex' specialization sectors and gaining strong positions on the tourist and recreational services' world market (the important indicator of this position is the tourist contingent' proportion, when the foreign tourists' number exceeds the trips' number of the own citizens abroad);

- vocational education, sphere of applied research and development, in particular by:

- increasing the presence on the professional and postgraduate education ser-vices' international market due to the rising their volume provided to foreign citizens by higher educational and research institutions (of the NAS system);

- improving the presence on the science-intensive products' international market through the applied research intensification in Ukraine, implementation of institutional conditions for increasing the cooperation efficiency of science and education (due to the: formation of regional venture production clusters on the basis of leading universities of national importance; further development of a network of industrial parks and technopolises in free economic zones, border and trans-boundary regions), adjustment of regulations in the field of intellectual property, copyright and related rights in the compliance with international norms;

- specialized medical care, sanatorium and resort treatment, activities in medical innovations, in particular by:

- expanding the presence on the medical services, goods and technologies' international market, growing their export volumes, including through: the provision of the appropriate competitiveness of export-oriented products of the national medical and pharmaceutical industry according to international standards; the fulfillment of state programs implementing the achievements of domestic specialists and scientific schools in the modern diagnosis, treatment and prevention technologies, as well as research results 


\section{Bogush Larysa}

in various fields of medicine, genetics, biochemistry, biotechnology, etc.; the enrichment of the foreign potential consumers' awareness regarding the services' quality of leading domestic medical centers, sanatorium and resort treatment areas in order to promote their international recognition;

- developing the international cooperation in the healthcare, including through the provision of specialized humanitarian assistance to developing countries and countries affected by ecological and technogenic disasters.

\section{Conclusions}

The balance of regional policy for reproduction and efficient capitalization of the socio-humanitarian potential should be achieved through the implementation of the quantitative and qualitative state obligations regarding: the ensuring a decent level and a safe living environment of the population; stimulation of its productive employment at the place of residence, in conjunction with the improvement of the internal labor migrations' efficiency; intervention in the development of regions and local communities in order to prevent, smooth and equalize territorial socio-economic disparities, to decentralize and adapt general foundations, principles and means for providing state socio-economic policy at the local level, to optimize the reverse regional influences on the whole country' activity in response to the negative dynamics of the relevant monitoring indicators' system.

Considering the mechanism of social reproduction, which allows to stimulate self-development through the satisfaction of the widest range of the population' socially necessary needs, the important role in the Ukrainian regional policy (following the example of the world' leading countries) should be given to its social component, which primarily consists from the measures for: the regulation of the local economic systems' labor supply; the increase of realization efficiency of the economically active population' innovative potential in the process of expansion of its productive employment sphere; the support of inter-ethnic and inter-confessional stability within the local and regional territorial communities.

It is expedient to monitor and to correct the results of the implementation of the government strategy for Ukraine' regional development according to the indicators of: the life level of the population in regions and settlements, as well as satisfying its socially necessary needs and ensuring constitutional rights and freedoms (including freedom of speech, political and religion choices); the employment level, competitiveness in the labor market and 


\section{Balancing socio-economic development of Ukraine' regions on the priority...}

entrepreneurial activity of the population (including organizational, regulatory and investment climate in the field of realization of citizens' entrepreneurial initiatives); the peculiarities of formation and structure of income, property stratification; the situation in the areas of environmental protection and maintaining national security (including in the directions for prevention of socially dangerous diseases, criminality); the resource potential and implementation efficiency of the state and local authorities' social functions, the level of development and functioning efficiency of the territorial communities, the social partnership mechanisms' formation; the implementation of complex and sectoral programs, as well as targeted projects in the areas of living environment' improving.

\section{References:}

1. Babinova, O. (2009). Reghionaljna polityka jak predmet naukovoteoretychnogho analizu [Regional policy as a subject of scientific and theoretical analysis]. Visnyk Nacionaljnoji akademiji derzhavnogho upravlinnja [Bulletin of the National Academy of Public Administration]. Retrieved from: http://visnyk. academy.gov.ua/wp-content/uploads/2013/11/2009-3-19.pdf(accessed 10.03.2018) (in Ukrainian).

2. Bogush, L. (2017). Socio-humanitarian potential of Ukraine's competitiveness worldwide. Transformation of international economic relations: modern challenges, risks, opportunities and prospects. Riga: ISMA University, pp. 103-112.

3. Boretska, N.P. (2005). Vyshcha osvita v konteksti sotsialnoi polityky derzhavy [Higher education in the context of state social policy]. Novi tekhnolohii navchannia [New Learning Technologies], no. 40, pp. 4-10 (in Ukrainian).

4. Hordei, O.D. (2003). Modeli derzhavnoho rehuliuvannia dobrobutu naselennia [Models of state regulation of the population welfare]. Finansy Ukrainy [Finance of Ukraine], no. 11, pp. 51-57 (in Ukrainian).

5. Zgurovsky, M.Z., Gavrish, O.A., Skorobogatova, N.Ye., \& Kukharuk, A.D. (2018). Zabezpechennia sotsialno-ekonomichnoho balansu rehionalnoho rozvytku Ukrainy [Providing the social and economic balance of Ukraine's regional development]. Ekonomika ta derzhava [Economy and the State], no. 2, pp. 11-15 (in Ukrainian).

6. Luchyk, S.D., \& Luchyk, V.Ye. (2013). Svitovyi dosvid formuvannia ta realizatsii polityky rehionalnoho rozvytku ta mozhlyvist yoho zaprovadzhennia $\mathrm{v}$ Ukraini [World experience of formation and realization of regional development policy and the possibility of its implementation in Ukraine]. Naukovyi visnyk Natsionalnoho lisotekhnichnoho universytetu Ukrainy [Scientific herald of the National Forestry University of Ukraine]. Retrieved from: http://nltu.edu.ua/nv/ Archive/2013/23 18/124_Lucz.pdf (accessed 10.03.2018) (in Ukrainian).

7. Libanova, E.M. (ed.) (2012). Liudskyi rozvytok v Ukraini: sotsialni ta demohrafichni chynnyky modernizatsii natsionalnoi ekonomiky [Human development in Ukraine: social and demographic factors of the national economy' 
modernization]. Kyiv: Ptoukha Institute for Demography and Social Studies of the National Academy of Sciences of Ukraine, 320 p. (in Ukrainian).

8. Martinenko, O.M. (2017). Napriamy zabezpechennia zainiatosti molodi v rovynutykh krainakh [Directions for promoting youth employment in developed countries]. Ekonomika ta derzhava [Economy and the State], no. 12, pp. 74-76 (in Ukrainian).

9. Ogienko, M.M., \& Gurina, O.V. (2018). Doslidzhennia stanu ta tendentsiinykh transformatsii liudskoho potentsialu $\mathrm{v}$ rehioni [Study of state and trending transformations of human capacity in the region]. Ekonomika ta derzhava [Economy and the State], no. 2, pp. 103-107 (in Ukrainian).

10. Petkova, L.O. (2004). Klasterna model haluzevo-terytorialnoi orhanizatsii vyrobnytstva yak peredumova yoho innovatsiinoi aktyvizatsii [Cluster model of the production' branch-territorial organization as a background for its innovation activation]. Nauchnye trudy Donetskogo natsional'nogo tekhnicheskogo universiteta. Seriya: Ekonomika [Scientific works of Donetsk National Technical University. Series: The Economy], pp. 97-102 (in Ukrainian).

11. Prokopiuk, A. (2015). Derzhavna rehionalna polityka: naukovi pidkhody ta svitovi praktyky [State regional policy: scientific approaches and world practices]. Sotsialno-ekonomichni problemy suchasnoho periodu Ukrainy [Socio-Economic Problems of the Ukraine' Modern Period]. Retrieved from: http://ird.gov.ua/sep/ sep20156(116)/sep20156(116)_014_ProkopiukA.pdf (accessed 10.03.2018) (in Ukrainian).

12. Pulina, T.V. (2017). Suchasni aspekty ta metody upravlinnia ryzykamy innovatsiinykh proektiv v Ukraini [Modern aspects and methods of risk management of innovative projects in Ukraine]. Ekonomika ta derzhava [Economy and the State], no. 10, pp. 4-8 (in Ukrainian).

13. Dolishnii, M.I. (ed.) (2001). Rehionalna polityka: metodolohiia, metody, praktyka [Regional policy: methodology, methods, practice]. Lviv: Institute for Regional Studies of the National Academy of Sciences of Ukraine, $720 \mathrm{p}$. (in Ukrainian).

14. Sofiichuk. K.K. (2017). Pidvyshchennia turystychnoi pryvablyvosti Ukrainy [Increasing the tourist attractiveness of Ukraine]. Ekonomika ta derzhava [Economy and the State], no. 10, pp. 63-66 (in Ukrainian).

15. Chupryna. O.O. (2011). Sotsialna nerivnist i bidnist v Ukraini [Social inequality and poverty in Ukraine]. Visnyk Natsionalnoi yurydychnoi akademii Ukrainy imeni Yaroslava Mudroho [Bulletin of the Yaroslav Mudryi National Law Academy of Ukraine], no. 2 (5), pp. 57-66 (in Ukrainian). 
Security of financial market of Ukraine in conditions of unstable financial...

SECURITY OF FINANCIAL MARKET OF UKRAINE

IN CONDITIONS OF UNSTABLE FINANCIAL ENVIRONMENT

\section{БЕЗПЕКА ФІНАНСОВОГО РИНКУ УКРАЇНИ \\ В УМОВАХ НЕСТАБІЛЬНОГО ФІНАНСОВОГО СЕРЕДОВИЩА}

\section{Borysiuk Olena ${ }^{1}$ \\ Stashchuk Olena ${ }^{2}$}

DOI: http://dx.doi.org/10.30525/978-9934-571-28-2_5

Abstract. Civilization development proves that the most effective form of organizing social economic public life is market economy, functioning of which is based on that fact that the points of economic life are solved through the interaction of demand and supply on different markets. Considering the whole variety of markets and offered resources, the state of development of financial market is especially important, which directly reflects the effectiveness of functioning of all other markets and the most greatly defines the level of development of the state economic system. Financial market is constantly improving and the range of its tools is expending. The participants of financial market are all economic entities and physical persons of national economy, a state and nonresidents. The role of financial market in the economy of a country is very important considering providing economic entities with necessary resources and services, without which the course of all business processes is impossible.

Ensuring the security of financial market and financial stability is among priority tasks of economic policy of many countries. It is explained by that fact that their security promotes the effective placement of economic resources and allocation of risks and so stimulates economic activity and increases the welfare in the country that is determined as a social public weal. Analysis of the security state in the fields of financial market and financial stability is rather young trend in modern science.

\footnotetext{
${ }^{1}$ Candidate of Economics, Senior lecturer of Finances, Bank Business and Insurance Department, Lesia Ukrainka Eastern European National University, Ukraine

${ }^{2}$ Candidate of Economics, Senior Lecturer of Finances and Credit Department

Lesia Ukrainka Eastern European National University, Ukraine

(C) Borysiuk Olena, Stashchuk Olena
} 
In literature, for example, security of financial stability is studied on three levels: micro level, national and international levels, meanwhile there is a tight connection between these levels. The security of stability on the micro level, that is the level of separate organizations, encourages the establishment of financial stability on the national level. In its turn the security of financial stability on the national level, that is the level of separate countries, encourages the support of financial stability on the international level.

The necessity of the analysis of security in financial spheres on the national level is caused by that fact that its state on the micro level is well studied and in the present theory of finances of an enterprise the particular set of indexes for its estimating was established. At the same time the security state in financial spheres on the national level demands further researches. The security of financial spheres on the international level also remains insufficiently studied, however its analysis is impossible without clear understanding what it is the state of financial stability on the national level and what problem influences public welfare. Security on financial market is identified with its stability. Thus the main aim of existing of financial security is the protection of a financial system from instabilities caused by peculiarities of financial crisis and system risks.

\section{1. Вступ}

У сучасному світі, ризики, пов'язані зі стабільністю фінансових ринків, є одними 3 найбільш важливих показників для економічної безпеки держави. Зрозуміло, що порушення стабільності під впливом заважаючих чинників, загрожує крахом всієї фінансової системи в цілому. У цьому зв'язку концепція безпеки фінансового ринку з методологічної точки зору, вимагає методичного вивчення відповідних індикаторів його секторів.

\section{2. Банківська безпека}

Так, банківський сектор $є$ найбільшою складовою фінансового ринку України з активами, що складають домінуючу частку активів усіх фінансових установ. Саме тому негативні тенденції у фінансовому секторі країни виявились тут найбільш помітними.

В Україні режим функціонування іноземних інвестицій у банківській системі регулюється двома основними законодавчими актами: Законом України «Про банки і банківську діяльність» та Законом Укра- 
їни «Про режими іноземного інвестування», згідно 3 якими банком 3 іноземним капіталом вважається установа, у якій частка капіталу, що належить хоча б одному іноземному інвестору, становить не менше $10 \%$. Натомість контроль поточної діяльності банків 3 іноземним інвестиціями (ліцензування, загальний перелік та моніторинг операцій, нагляд, звітність, режим прозорості, порядок виплати дивідендів тощо) цілком покладений на НБУ, що здійснює регулювання діяльності банків з іноземним капіталом за допомогою відповідних нормативних актів. Проте поточна редакція Закону України «Про банки і банківську діяльність», зокрема, не містить [5, с. 44]:

- граничного рівня статутного капіталу банків з іноземним капіталом відносно загального його обсягу,

- чітких вимог щодо визначення кінцевих власників банків 3 іноземним капіталом,

- механізму запобігання виведення прибутку банків з іноземним капіталом до материнських банків,

- переліку заходів реагування на незадовільну якість активів та кредитного портфеля банків з іноземним капіталом,

- механізму відповідальності та методів впливу за порушення законодавства банків з іноземним капіталом.

Варто зазначити, що обсяг збитків банківської системи України за 2016 рік значно перевищив аналогічний показник 2015 року переважно внаслідок вагомого зростання сум відрахування в резерви протягом IV кв. 2016 року (до 198,31 млрд. грн. станом на 01.01.2017 року), зумовленого виконанням плану врегулювання діяльності ПАТ КБ «Приватбанк» у межах процесу націоналізації установи. Цілком зрозуміло, що збитковість банківської системи негативно впливає на фінансову безпеку держави. Серед індикаторів, які ілюструють цей зв'язок, $€$ показник «Рентабельність активів», оптимальне значення якого має становити від $1 \%$ до 1,5\%. Натомість за умови збитків банківської системи значення цього показника буде від’ємним. При цьому критичним рівнем збитковості вважається значення $-1 \%$. Окрім того, нині стан конкурентного середовища на банківському ринку потребує особливої уваги, адже після націоналізації Приватбанку держава контролює $53 \%$ ринку за активами (32\% до націоналізації) і 55\% ринку за залученими коштами (31\% до націоналізації). За таких умов надзвичайна концентрація банківського бізнесу в руках держави у поєднанні з уря- 
довою політикою преференцій для державної частини ринку сприяє лише посиленню його інвестиційної непривабливості. Показовим для оцінки фінансової безпеки банків $є$ показник частки присутності іноземного капіталу, який станом на 01.10 .2016 року становив $56,0 \%$. Такий рівень цього показника є небезпечним для фінансової безпеки держави через те, що він наближається до критичного значення $60 \%$. Такі обставини зумовлюють потребу посиленої уваги з боку держави 3 метою поступового збільшення частки вітчизняного капіталу у статутному капіталі українських банків.

У табл. 1 представлено основні індикатори банківського сектору.

Дані, наведені в таблиці 2, свідчать про наступне [6, с. 282]:

- банки іноземних банківських груп за 2016 р. збільшили обсяг сплаченого статутного капіталу на 56,6 млрд грн до 143,0 млрд. грн. Натомість банки 3 капіталом українського походження збільшили розмір сплаченого статутного капіталу усього на 1,4 млрд грн до 121,3 млрд. грн. Власний капітал банків іноземних банківських груп за 2016 р. зріс на 39,0 млрд грн (до 71,5 млрд грн). За цей же період банки з капіталом українського походження зрісли на 8,4 млрд грн до 79,5 млрд грн. Це свідчить про поступове відновлення капіталізації банківської системи України в 2016 р., проте рекапіталізація банківської системи відбувається переважно за рахунок банків іноземних банківських груп;

- банки іноземних банківських груп за 2016 р. збільшили корпоративний кредитний портфель у національній валюті на 8,2 млрд грн (до 89 млрд грн) та зменшили корпоративний кредитний портфель в іноземній валюті на 0,9 млрд дол. США (до 4,9 млрд дол. США). Натомість банки 3 капіталом українського походження відповідно збільшили корпоративний кредитний портфель в національній валюті на 22,1 млрд грн (до 280 млрд грн) та зменшили в іноземній валюті на 0,7 млрд. дол. США (до 12,2 млрд дол. США). Отже, динаміка корпоративного кредитного портфеля банків іноземних банківських груп відповідає тенденціям поступового скорочення загального розміру корпоративного кредитного портфеля та поступової заміни валютних кредитів юридичним особам гривневими кредитами, що відбуваються у банківській системі загалом. При цьому банки 3 капіталом українського походження більш активно кредитують юридичні особи у гривні, ніж банки іноземних банківських груп; 
Динаміка показників статутного та власного капіталу, кредитного портфеля, залучених коштів банків з капіталом українського походження та банків іноземних банківських груп в України протягом 2016 р.

\begin{tabular}{|c|c|c|c|}
\hline Показники & $\begin{array}{c}\text { Банки з } \\
\text { капіталом } \\
\text { українського } \\
\text { походження }\end{array}$ & $\begin{array}{l}\text { Банки іноземних } \\
\text { банківських груп }\end{array}$ & $\begin{array}{c}\text { Усього по } \\
\text { банківській } \\
\text { системі }\end{array}$ \\
\hline $\begin{array}{l}\text { Динаміка статутного капі- } \\
\text { талу, млн. грн. }\end{array}$ & 1390 & 56566 & 57965 \\
\hline $\begin{array}{l}\text { Динаміка власного капіталу, } \\
\text { млн. грн. }\end{array}$ & 8364 & 38972 & 47336 \\
\hline $\begin{array}{l}\text { Динаміка кредитного порт- } \\
\text { феля юридичних осіб у наці- } \\
\text { ональній валюті, млн. грн. }\end{array}$ & 22127 & 8211 & 30338 \\
\hline $\begin{array}{l}\text { Динаміка кредитного } \\
\text { портфеля юридичних осіб в } \\
\text { іноземній валюті, млн. дол. } \\
\text { США }\end{array}$ & -707 & -906 & -1613 \\
\hline $\begin{array}{l}\text { Динаміка кредитного порт- } \\
\text { феля фізичних осіб у націо- } \\
\text { нальній валюті, млн. грн. }\end{array}$ & -3139 & 375 & -2764 \\
\hline $\begin{array}{l}\text { Динаміка кредитного } \\
\text { портфеля фізичних осіб в } \\
\text { іноземній валюті, млн. дол. } \\
\text { США }\end{array}$ & -324 & -281 & -605 \\
\hline $\begin{array}{l}\text { Динаміка залучених коштів } \\
\text { юридичних осіб у націо- } \\
\text { нальній валюті, млн. грн. }\end{array}$ & 3212 & 1798 & 5010 \\
\hline $\begin{array}{l}\text { Динаміка залучених коштів } \\
\text { юридичних осіб в іноземній } \\
\text { валюті, млн. дол. США }\end{array}$ & 689 & -45 & 644 \\
\hline $\begin{array}{l}\text { Динаміка залучених коштів } \\
\text { фізичних осіб у національ- } \\
\text { ній валюті, млн. грн. }\end{array}$ & 1459 & 3855 & 5314 \\
\hline $\begin{array}{l}\text { Динаміка залучених коштів } \\
\text { фізичних осіб в іноземній } \\
\text { валюті, млн. грн. }\end{array}$ & 130 & -110 & 20 \\
\hline
\end{tabular}

Джерело: складено на основі джерел [4; 7; 9] 
- банки іноземних банківських груп за 2016 р. збільшили кредитний портфель, наданий фізичним особам у національній валюті на 375 млн грн (до 24,8 млрд грн) та зменшили кредитний портфель, наданий фізичним особам в іноземній валюті на 281 млн дол. США (до 925 млн дол. США). Натомість банки з капіталом українського походження відповідно зменшили кредитний портфель, наданий фізичним особам в національній валюті на 3,1 млрд грн (до 52,4 млрд грн) та зменшили в іноземній валюті на 324 млн дол. США (до 2421 млн дол. США). Отже, кредитний портфель, наданий фізичним особам, по банківській системі в цілому протягом 2016 року скорочувався як у гривні, так і в іноземній валюті, проте банки іноземних банківських груп, на відміну від банків з капіталом українського походження, продовжують кредитувати населення у гривні;

- банки іноземних банківських груп за 2016 р. збільшили обсяг залучених коштів юридичних осіб у національній валюті на 1,8 млрд грн (до 106,3 млрд грн), проте обсяг залучених коштів юридичних осіб в іноземній валюті зменшився на 45 млн. дол. США (до 1687 млн дол. США). Натомість банки з капіталом українського походження зафіксували зростання коштів юридичних осіб як у гривні - на 3,2 млрд грн (до 67,8 млрд грн), так і у валюті - на 689 млн дол. США (до 2972 млн дол. США). Таким чином, в цілому по банківській системі України протягом 2016 р. залучені кошти юридичних осіб зростали як у гривні, так і у валюті;

- банки іноземних банківських груп за 2016 р. збільшили обсяг залучених коштів фізичних осіб у національній валюті на 3,9 млрд грн (до 48,3 млрд грн), проте зафіксували відплив валютних вкладів населення на 110 млн. дол. США (до 2441 млн дол. США). Натомість банки 3 капіталом українського походження зафіксували зростання коштів фізичних осіб як у гривні - на 1,5 млрд грн (до 155,9 млрд грн), так і у валюті - на 130 млн дол. США (до 6413 млн дол. США). Таким чином, в цілому по банківській системі України протягом 2106 р. залучені кошти фізичних осіб зростали в основному у гривні (на 5,3 млрд грн), проте валютні депозити населення загалом зросли усього на 20 млн дол. США. При цьому більш високий рівень довіри населення до банків іноземних банківських груп забезпечує останнім більш високий розмір залучення депозитів у гривні.

Варто зауважити, що у практиці зарубіжних країн не існує єдиного однозначного підходу щодо граничних меж присутності банківського 


\section{Security of financial market of Ukraine in conditions of unstable financial...}

капіталу іноземного походження у банківській системі держави. Кожна країна вирішує це питання для себе самостійно, виходячи 3 власних аргументів. Існують країни 3 мінімальною присутністю нерезидентів на банківському ринку на рівні до 10\% (КНР, Японія, Індія, Швейцарія, Канада, Франція, Італія), більш відкритими для присутності іноземного банківського капіталу (до 20\%) є ФРН, США, Велика Британія. Значно відкритішими для іноземних інвестицій у банківську систему є країни Центральної та Східної Європи, де рівень присутності нерезидентів на банківському ринку досягає 60-95\% (Польща, Чехія, Болгарія, Словаччина, Румунія, Естонія, Литва).

Таким чином, розрахунок індикаторів рівня фінансової безпеки банківського сектору економіки України підтверджує тезу щодо поглиблення кризових явищ та їх дестабілізуючого впливу на фінансову безпеку країни. Сучасні тенденції функціонування банків України свідчать також про значні деструктивні явища, існування реальних та потенційних загроз, які негативним чином впливають на фінансову безпеку країни. За проведеними аналітичними розрахунками проблеми банківського сектора пов'язані не лише із кількісними показниками діяльності банків (зі значним скороченням банківських установ), але i 3 погіршенням якісних параметрів їх функціонування (частка негативно класифікованих кредитів, частка валютних кредитів, значний за розмірами збиток). На наше глибоке переконання, такий стан у банківській системі є наслідком неефективного регулювання банківської діяльності з боку Національного банку України.

Однією з ключових причин повільного виходу з банківської кризи $€$ недовіра клієнтів до банківської системи в цілому. Третина домогосподарств, що мають заощадження, не довіряє комерційним банкам та зберігає власні кошти поза банками, оскільки заборона на обман споживачів фінансових послуг, на жаль, на практиці не завжди діє. Наприклад, банки вдалися до нового інструменту просування позикових продуктів - спільного кредитування. Комерційний банк пропонує беззаставні кредити готівкою, однак тут же дрібним шрифтом зазначає, що тільки оформляє кредит, видає ж готівку інша фінансова установа. Банки співпрацюють не з прямими конкурентами, а з фінансовими компаніями, які вже й ухвалюють рішення про видання кредиту, а банк у цьому разі $є$ просто посередником. Інший приклад, банки «порохотяги» - залучають у регіонах країни депозити пропонуючи дещо вищі ринкових процентні 
ставки, при цьому майже не проводячи кредитування, а всі кошти скеровують у головний офіс, який кредитує фірми власників банку, що їх не повертають (безкоштовне фінансування власного бізнесу). 3 часом банк доводять до банкрутства, а відшкодування коштів перекладають на Фонд гарантування вкладів фізичних осіб.

Капіталізація банківської системи після кризи поступово відновлювалася, проте темпи були дуже низькі та не покривали зменшення власного та регулятивного капіталу банківської системи. Станом на 01 січня 2017 року ліцензію Національного банку України мали 96 банківських установ (у т.ч. 38 банків з іноземним капіталом). 3 початку 2016 року кількість функціонуючих банківських установ зменшилася на 21. Враховуючи затверджений НБУ графік збільшення мінімального обсягу статутного капіталу банків, в подальшому можна очікувати нових випадків самоліквідації комерційних банків в Україні.

\section{3. Валютна безпека}

Окремо зупинимось на проблемах функціонування в країні валютного ринку, зокрема, зазначимо, що [7]:

1.За 2014 -2016 рр. офіційний курс національної валюти зменшився з 7,99 грн/ дол. США станом на 01.01.2014 р. до 15,77 на 01.01.2015 p., 24,0 - на 01.01.2016 р. та 27,19 - на 01.01.2017 р. Динаміка валютного курсу залежить від чистого припливу іноземної валюти. Водночас у структурі валютних надходжень з-за кордону на експорт припадає 50-54 \%. Проте зовнішні умови функціонування економіки України в останні кілька років ускладнилися. Через несприятливу ситуацію для українських експортерів на зовнішніх ринках погіршувалися показники поточного рахунку платіжного балансу.

2 Для підтримання курсу гривні НБУ використовував валютні інтервенції. Так, за 2011-2012 рр. міжнародні резерви НБУ зменшилися на 10,0 млрд дол. США, що відображає хронічну незбалансованість пропозиції та попиту на іноземну валюту в Україні. Ситуація не поліпшилася навіть за рахунок Євро-2012 - у червні 2012 р. міжнародні резерви скоротилися на 1,44 млрд дол. США. Сукупний обсяг інтервенцій НБУ на міжбанківському валютному ринку за підсумком 2015 року (4 250,7 млн дол. США) є значно меншим, ніж аналогічний показник за 2014 рік (11 127,0 млн дол. США). На відміну від 2014 р., коли валютні інтервенції здійснювались переважно у формі 
продажу валюти з метою згладжування курсових коливань, в 2015 р. НБУ значно збільшив обсяги придбання валюти для поповнення власних резервів. Загальна сума інтервенцій з продажу протягом 2015 р. валюти на міжбанківському валютному ринку дещо перевищувала обсяги іi придбання, проте розрив між показниками не був великим (2 046,6 млн. дол. США та 2 204,1 млн дол. США відповідно станом на 01.01.2016 p.).

3. Обсяг валюти поза банками зростає починаючи 32008 p. i на початок осені 2011 р. - це 194 млрд дол. США, що й було однією 3 причин запровадження контролю за готівковими валютними операціями 323 вересня 2011 р. Введення паспортизації купівлі-продажу готівкової валюти за півтора тижні дало змогу регулятору заощадити близько 0,5 млрд дол. США золотовалютних резервів. Тенденцією 2015-2016 р.p. є значне переважання обсягів продажу валюти 3 боку населення над обсягами купівлі. НБУ, зі свого боку стимулює це явище, шляхом пом'якшення адміністративних обмежень на валютному ринку. В той же час така тенденція в значній мірі зумовлена вичерпанням фінансових ресурсів населення та вилученням валютних заощаджень для фінансування поточних витрат. Крім того, валюта поза банками використовується для розрахунків у тіньовому секторі економіки та збереження заощаджень населення.

4. Українці мало зацікавлені у депозитах в екзотичних валютах та мультивалютних вкладах. Загальний обсяг таких вкладів становить не більше 2 \%, 3 них 1 \% у російських рублях, решта у фунтах та франках.

5.За результатом 2015 р. обсяг золотовалютних резервів становив 13,3 млрд дол. США в еквіваленті, збільшившись упродовж року на $87 \%$, а за 2016 р. зріс на $17 \%$ до 15,5 млрд доларів.

Зауважимо, що сьогодні послабити національну валюту можуть як зовнішні, так і внутрішні чинники, найвагомішим 3-поміж перших $€$ погіршення ситуації у світовій економіці, яке, за прогнозами, буде хоч і не катастрофічним, проте тривалим. Утім, серйозніші ризики для гривні можуть бути саме всередині країни, зокрема проблема дефіциту зовнішньоторговельного балансу України та втримання обсягів експорту, зростання державного боргу, дефіцити державного бюджету та пенсійного фонду.

Розроблені НБУ заходи, які спрямовані на підтримання пропозиції іноземної валюти у спосіб підвищення спроможності контролю- 
вати кон'юнктуру валютного ринку, були вкрай необхідні для збереження валютної стабільності у кризовий період. Проте системну проблему доларизації економіки України та девальвації їі валюти неможливо вирішити у спосіб виключно адміністративних заходів, покликаних ускладнити реалізацію права власності на валютні цінності. Короткостроковий позитивний ефект зміниться стійкими викривленнями на валютному ринку і результативними диспропорціями розміщення ресурсів і структури економічної системи, виправлення яких вимагатиме тривалого часу та значних коштів. Саме тому програми співпраці з МВФ передбачають поступову лібералізацію валютного ринку.

\section{4. Бюджетна безпека}

Також визначальний вплив на безпеку фінансового ринку України мають індикатори бюджетної системи.

Результати оцінки стану бюджетної безпеки України за 2011-2017 pp. наведено у таблиці 2.

Таблиця 2

Індикатори бюджетної безпеки України у 2011-2017 рр.

\begin{tabular}{|l|l|l|l|l|l|l|l|l|}
\hline \multicolumn{1}{|c|}{ Індикатор } & & \multicolumn{7}{|c|}{ Рік } \\
\cline { 2 - 10 } & $\mathbf{2 0 1 1}$ & $\mathbf{2 0 1 2}$ & $\mathbf{2 0 1 3}$ & $\mathbf{2 0 1 4}$ & $\mathbf{2 0 1 5}$ & $\mathbf{2 0 1 6}$ & $\mathbf{2 0 1 7}$ \\
\hline $\begin{array}{l}\text { Відношення дефіциту/ } \\
\text { профіциту державного } \\
\text { бюджету до ВВП, \% }\end{array}$ & {$[-3-5]$} & $-1,7$ & $-3,7$ & $-4,3$ & $-5,0$ & $-3,7$ & $-3,0$ & $-3,0$ \\
\hline $\begin{array}{l}\text { Відношення дефіциту/ } \\
\text { профіциту бюджетних } \\
\text { та позабюджетних фон- } \\
\text { дів сектору загальнодер- } \\
\text { жавного управління до } \\
\text { ВВП, \% }\end{array}$ & {$[-1-1]$} & 0,84 & 0,51 & $-0,05$ & 0,23 & 2,69 & н/д & н/д \\
\hline $\begin{array}{l}\text { Рівень перерозподілу } \\
\text { ВВП через зведений } \\
\text { бюджет,\% }\end{array}$ & {$[23-30]$} & 30,7 & 31,7 & 30,2 & 29,1 & 29,9 & 27,9 & 27,9 \\
\hline $\begin{array}{l}\text { Відношення объему } \\
\text { сукупних платежів } \\
\text { по обслуговуванню і } \\
\text { погашенню державного } \\
\begin{array}{l}\text { боргу до доходів дер- } \\
\text { жавного бюджету,\% }\end{array}\end{array}$ & {$[0-7]$} & 21,5 & 26,4 & 32,9 & 47,7 & 38,9 & 33,4 & 33,4 \\
\hline
\end{tabular}

Джерело: складено на основі джерел [4; 7; 9] 
За аналізований період індикатори бюджетної безпеки мали різноспрямовані тенденції: вони знаходилися як у межах задовільного значення, так і перевищували граничне задовільне значення індикатора, переходячи у зону небезпеки.

Зміна значень індикатора відношення дефіциту/профіциту державного бюджету до ВВП свідчить про позитивні результати у сфері управління бюджетним дефіцитом завдяки заходам бюджетної консолідації 2015 року, після загострення проблем у 2011-2014 рр., коли відбувалось нарощування дефіцитної незбалансованості до небезпечного рівня. Це вимагало вжиття заходів щодо іiї подолання, у тому числі через формування оптимальної структури видатків бюджету, створення дієвої системи контролю за раціональним і ефективним використання бюджетних коштів. Хоча передбачався очікуваний «перехід» цього індикатора у небезпечну зону на кінець 2017 року.

Значення індикатора відношення дефіциту/профіциту бюджетних та позабюджетних фондів сектору загальнодержавного управління до ВВП тривалий час знаходилися у небезпечній зоні, що обумовлювалось необхідністю бюджетної підтримки позабюджетних фондів. Насамперед, покриття дефіциту Пенсійного фонду України відбувалось за рахунок бюджетних коштів і щорічно цей показник має тенденцію зростання. Національна пенсійна система є одним з основних чинників, які призводить до фіскальної вразливості економіки - наприклад, у 2015 році пенсійна система «коштувала» 13,4\% ВВП.

У небезпечній зоні також перебуває індикатор відношення обсягу сукупних платежів з обслуговування та погашення державного боргу до доходів державного бюджету. Він є суттєвим чинником, що тривалий час породжує проблеми у сфері державних фінансів і здійснює вплив на бюджетну безпеку. 3 рівня 4,23 \% у 2008 році він стрімко зріс до 19,2 \% у 2009 році та до 47,7 \% у 2014 році. Стрімке нарощування обсягу дефіциту бюджету, інфляційні процеси, девальвація гривні, обмежений доступ до дешевих фінансових ресурсів на фінансових ринках сприяли зростанню вартості обслуговування державного боргу. Завдяки вжитим заходам зі реструктуризації та погашення частини боргу, цей показник знизився у 2015 році до 38,9 \%, а на 2016-2017 рр. за прогнозними розрахунками очікувалося, що він складе 33,4 \% [4].

Єдиним показником, який за аналізований період перебував на межі переходу в небезпечну зону, є рівень перерозподілу ВВП через 
зведений бюджет. Проте це свідчить про наявність численних проблем у фіскальній сфері, які накопичилися протягом років і мають системний характер, призводять до зниження стимулюючої та соціальної функції податкової системи, а також загострення проблем у митно-податковому адмініструванні. Визначальними показниками $є$ не стільки рівень перерозподілу, скільки структура фіскальних вилучень.

\section{5. Боргова безпека}

Разом із тим, дестабілізуючий вплив на фінансовий ринок України мало зростання державного боргу. Проаналізовані індикатори свідчать про недостатню стійкість державних фінансів та, як наслідок, загрози фінансового ринку України.

Про загальну суму державою боргу України, в тому числі внутрішнього та зовнішнього, можна довідатися з таблиці 3.

Таблиця 3

\section{Зовнішній і внутрішній борг України станом}

на 30.12. $2014-30.12 .2016$ pp.

\begin{tabular}{|c|c|c|c|}
\hline & $31.12 .2014 \mathrm{p}$. & $31.12 .2015 \mathrm{p}$. & $31.12 .2016 \mathrm{p}$ \\
\hline \multicolumn{4}{|c|}{ Внутрішній борг } \\
\hline дол. США & 29,23 & 21,17 & 24,66 \\
\hline млрд грн & 461,00 & 508,00 & 670,65 \\
\hline$\%$ & 41,88 & 32,32 & 34,75 \\
\hline \multicolumn{4}{|c|}{ Зовнішній борг } \\
\hline дол. США & 30,82 & 34,41 & 36,05 \\
\hline млрд грн & 486,03 & 825,86 & 980,19 \\
\hline$\%$ & 58,12 & 67,68 & 65,25 \\
\hline
\end{tabular}

Джерело: складено на основі даних [4]

Основними причинами зростання обсягу державного боргу в 2014-2016 рр. були наступні [2, с. 239]:

- політична криза та тривалий військовий конфлікт на сході країни;

- глибока економічна рецесія, викликана перегрупуванням економічних зав'язків з міжнародними партнерами та руйнуванням інфраструктури та промислових об'єктів на частині території країни;

- фінансування за рахунок державних запозичень дефіциту державного бюджету, зростання якого обумовлене в значній мірі збіль- 


\section{Security of financial market of Ukraine in conditions of unstable financial...}

шенням видатків на оборону та обслуговування державного боргу;

- необхідність потужної державної підтримки державних підприємств та банків, зокрема НАК «Нафтогаз України» тощо.

Зокрема, в 2014 році дефіцит НАК «Нафтогаз України», фінансування якого за відсутності інших джерел здійснювалось здебільшого за рахунок державних запозичень, склав 5,7 \% від ВВП, а загальний дефіцит (сальдо) сектору загальнодержавного управління та НАК «Нафтогазу» близько 10,3% ВВП. Впродовж 2014 року 38,2 \% від загального обсягу запозичень на фінансування потреб сектору загальнодержавного управління до загального фонду Державного бюджету було випущено ОВДП обсягом 123,3 млрд грн в т.ч. на збільшення статутного капіталу: НАК«Нафтогаз України» на суму 96,6 млрд грн. Змінами до Закону України «Про Державний бюджет України на 2015 рік» була передбачена необхідність збільшення статутного капіталу НАК «Нафтогаз України» - на 29,7 млрд грн, що за підсумками року фактично було профінансовано.

Основні тенденції фондового ринку, як сегмента фінансового ринку України характеризувались тим, що урядом за рахунок запозичень активно проводилась капіталізація державних банків. Якщо у 2013 р. за рахунок випуску ОВДП було капіталізовано лише ПАТ «Ощадбанк» в обсязі 1,4 млрд грн, то впродовж 2014 р. загальний обсяг бюджетної підтримки державних банків становив 26,7 млрд грн, 3 них: на поповнення статутного капіталу АТ «Ощадбанк» - 11,6 млрд грн, АТ «Укрексімбанк» - 5,0 млрд грн; підтримку «Фонду гарантування вкладів фізичних осіб» - 10,1 млрд грн. За підсумками фактичного виконання державного бюджету 2015 року за рахунок випуску ОВДП збільшено капіталізацію «Укргазбанку» на суму 3,8 млрд грн та надано кредит Фонду гарантування вкладів фізичних осіб на суму 41,5 млрд. грн із середньозваженою дохідністю 11,43 \% (змінами до Закону про бюджет передбачалась необхідність капіталізації банківських установ обсягом 36,5 млрд грн та підтримка Фонду гарантування вкладів фізичних осіб на суму 20 млрд грн). За I півріччя 2016 року на поповнення статутного капіталу державних банків було здійснено запозичень в обсязі 14,5 млрд грн, 3 них для АТ «Ощадбанк» - 5,0 млрд грн, а для АТ «Укрексімбанк»-9,5 млрд грн.

Зростання обсягу державних запозичень, здійснених у зв'язку 3 проведенням капіталізації банків суттєво збільшувало обсяг видат- 
ків державного бюджету, спрямованих на обслуговування цих ОВДП. Загалом, впродовж останніх восьми років обсяги збільшення статутних капіталів державних банків внутрішніх запозичень сягнули 88,1 млрд грн, а обсяги бюджетних видатків 3 обслуговування капіталізаційних ОВДП (з урахуванням необхідності обслуговування отриманих початку 2016 року позик) на кінець 2016 року складуть близько 39,87 млрд грн.

За висновками МВФ світова криза позначилася на Україні сильніше, ніж на інших країнах, які отримували допомогу в рамках програми stand-by. Тим не менше, програма допомогла уникнути погіршення макроекономічних змін в короткостроковій перспективі. Аналогічно співпраця з МВФ після російської агресії запобігла фінансовому колапсу та стабілізувала банківську систему. Проте, рекапіталізація банків відбувається повільніше, ніж це було передбачено програмою. Україні рекомендують посилити регулювання, нагляд та контроль за діяльністю фінансового сектора і поліпшити законодавство.

Проведений аналіз засвідчує, що зараз вітчизняний фінансовий ринок та система бюджетного менеджменту, на жаль, також є мало ефективними і не повністю виконують свої функції. Окрім цього нерозвиненість фінансового ринку України створює низку перешкод для проведення економічної політики і $є$ фактором стримування подальшого економічного розвитку. Через практичну відсутність високоліквідних інструментів з низькими ризиками, суттєво обмежені наявні інструменти монетарної політики. НБУ здебільшого покладається на використання резервних вимог, що не є гнучким i ефективним інструментом. Проблема ще більше загострилася з переходом до таргетування інфляції. Середньо- і довгострокова бюджетна політика також сильно залежить від розвитку фінансового сектору, зокрема фондового ринку - ефективна пенсійна та інші реформи неможливі без розвинених небанківських установ, як приватних, так і державних. Уже зараз нестача надійних інструментів на внутрішньому ринку цінних паперів $є$ серйозним стримуючим фактором для розвитку інституційних учасників та гальмує розвиток усього фінансового ринку. Це стримує можливості інвестиційної та інноваційної діяльності в Україні.

Першочерговими заходами для подолання загроз фінансовго ринку мають стати: 
1.Забезпечення збалансованості державних фінансів шляхом зниження бюджетного дефіциту.

Дефіцит державного бюджету на 2016 р. Було заплановано утримувати на рівні -3,7 \% ВВП, а згідно проекту держбюджет на 2017 р. $-3,0$ \% ВВП. Проектом Закону України «Про Державний бюджет на 2017 рік» було передбачено зростання доходів, порівняно із 2016 роком, на 17,3 \% до 706,3 млрд, видатків - на 14,9 \%, до 775,3 млрд. Таким чином, дефіцит держбюджету склав 3 \% від ВВП, або 77,5 млрд грн, що відповідало рівню інфляції у 2016 році і дало змогу забезпечити збалансованість бюджету. Крім того, нині інфляція і девальвація національної валюти є одним із чинників макроекономічної нестабільності та розбалансованості державних фінансів, зокрема. Скорочення дефіциту бюджету до 3 \% ВВП є позитивним кроком у стабілізації державних фінансів і потребуватиме виважених кроків у формуванні видаткової частини бюджету.

2.Розвиток системи середньострокового бюджетного прогнозування і планування.

Середньострокове бюджетне планування нині визнане Міністерством фінансів України одним з найголовніших пріоритетів діяльності. Разом із проектом Закону України «Про Державний бюджет на 2017 рік» було вперше оприлюднено прогнозні показники доходів та видатків на 2018-2019 рр., проте методики формування бюджетів всіх рівнів на середньострокову перспективу потребують подальшого удосконалення. Ухвалення трирічної бюджетної декларації знов було перенесене на 2017 р, що також обмовлене недоліками методологічного забезпечення [9, с. 40].

Запровадження середньострокового бюджетного планування має надати позитивний сигнал для підприємців та інвесторів щодо передбачуваності державної фіскальної політики. Капітальні інвестиції, в свою чергу, передбачають тривалий термін реалізації. Відтак прогнозованість фіскального курсу держави надасть грунтовну основу для розробки реалістично окупних бізнес-планів.

3.Прийняття державних соціальних стандартів для забезпечення підвищення якості державних послуг. На сьогодні Урядом не затверджено від соціальні стандарти і нормативи в описовому та вартісному вигляді, що надаються та делегуються державою місцевому самоврядуванню, а фінансові нормативи бюджетної забезпеченості по галу- 
зях бюджетної сфери не відповідають реальним потребам споживачів. Розрахунок та запровадження соціальних стандартів за всіма видами соціальних послуг, що надаються державою, перехід на фінансування соціальних послуг відповідно до затверджених державних соціальних стандартів були передбачені у Плані заходів з виконання Програми діяльності Кабінету Міністрів України та Стратегії сталого розвитку «Україна - 2020» у 2015 р. Особливо гостро стоїть це питання у Донецькій та Луганській областях, де бюджетні розрахунки мають здійснюватися з урахуванням специфіки цього регіону щодо потреб у державних послугах. Як свідчить бюджетна практика 2015-2016 рр., обсяги медичної та освітньої субвенцій, що надаються з державного бюджету не забезпечують мінімальну потребу в коштах навіть на виплату захищених статей видатків цих галузей.

\section{6. Висновки}

Виходячи з переліку окреслених проблем, притаманних фінансовому ринку України, головними напрямами його активізації, відновлення та інвестиційного спрямування мають бути наступні;

- перехід до агрегованого регулювання і пруденційного нагляду за суб'єктами фінансового ринку для послаблення регулятивного арбітражу, удосконалення його інфраструктури, синхронізації регулювання та функціонування всіх його секторів шляхом подолання розриву між діями різних фінансових регуляторів;

- підвищення організаційної ефективності регуляторів фінансового ринку - визначити цільову модель функціонування та дорожню карту трансформації регуляторів;

- посилення процесу комунікації регуляторів із зовнішнім середовищем та суспільством на основі використання рекомендацій суб'єктів фінансового ринку, науковців та експертів щодо розвитку фінансового регулювання, а також своєчасне відображення на сайті НБУ інформації щодо статистичних показників банківської системи та окремих комерційних банків, грошово-кредитної політики, платіжного балансу тощо; за несвоєчасність передбачити відповідальність посадових осіб регуляторів;

- удосконалення чинних і розроблення нових нормативно- правових актів банківського нагляду і регулювання на основі врахування сучасних рекомендацій Базельського та Європейського комітету в частині запровадження ризик-орієнтованого нагляду та контролю за 
відповідністю внутрішніх банківських систем управління ризиками новим вимогам;

- налагодження автоматичного обміну інформацією між вітчизняними державними фінансовими органами (інтеграція баз даних), а також між ними та органами інших країн, передусім митними, податковими тощо;

- внесення змін до Закону України «Про банки і банківську діяльність» у частині встановлення додаткової майнової відповідальності власників істотної участі банку належним їм майном у разі віднесення банку до категорії неплатоспроможних;

- посилення захисту майнових прав кредиторів при ліквідації банків шляхом проведення обов'язкових загальних зборів кредиторів, крім пов'язаних з банком осіб і структур, створення комітету кредиторів з наданням йому права контролю за діяльністю ліквідатора банку;

- стимулювання збільшення частки угод з фінансовими інструментами на організованому сегменті ринку;

- запровадження податку на короткотермінові інвестиції в країну або інших м'яких обмежень відповідно до міжнародної практики;

- обмеження практики випуску державних цінних паперів (як боргових облігацій уряду, так і сертифікатів НБУ) для зниження ринкових ставок за кредитами і стимулювання таким чином економічного розвитку реального сектору економіки;

- запровадження ефективної системи контролю за витрачанням бюджетних коштів та реформування сектору державних підприємств 3 метою зменшення втрати бюджетних коштів, а також збільшити доходи уряду від державного сектору шляхом продажу лише збиткових компаній (продаж державних компаній, які приносять прибутки заборонити);

- розміщення річних звітів про результати використання коштів за проектами міжнародних фінансових організацій та незалежну експертну оцінку ефективності виконання відповідних програм у цілому на інтернет-сторінці МФУ;

- розробити й запровадити заходи, спрямовані на заохочення грошових переказів трудових мігрантів на Батьківщину, та стимулювати їхне інвестиційне використання. Для цього провадити політику здешевлення послуг з переказу коштів, розглянути можливість випуску спеціальних державних облігацій для діаспори й мігрантів. 
Впровадження описаних вище заходів має сприяти розвитку вітчизняного фінансового ринку, стабілізації фінансової системи країни як ключового елементу макроекономічної стабільності у державі.

Удосконалення підходів до організації функціонування фінансового ринку в Україні має відбуватися з урахуванням того факту, що держава повинна регулювати економіку, як наочно довела глобальна фінансова криза, але процес державного втручання не повинен зводитись лише до регулювання - держава має визначати пріоритети іiі розвитку (у тому числі фінансового ринку). На сьогодні в Україні, як і в цілому світі, головне завдання - це розроблення та запровадження постійно діючого механізму вдосконалення й розвитку фінансового ринку з урахуванням світових тенденцій сучасної епохи.

\section{Список літератури:}

1. Борисюк О. В. Основні загрози фінансової безпеки України / O. В. Борисюк // Modern Transformation of Economics and Management in the Era of Globalization: international Scientific-Practical Conference Conference (January 29, 2016, Klaipeda). - 2016. - P. 270-271.

2. Борисюк О.В. Фінансовий ринок України : тенденції розвитку в умовах глобальних викликів / О. В. Борисюк // Східна Європа: економіка, бізнес та управління. - Випуск 7. - 2017. - С. 239-242.

3. Василик О. Фінансова безпека // Економічна енциклопедія: у 3 т. - Т.3 / О. Василик, С. Мочерний. - К.: Вид. центр «Академія», 2002. - 952 с.

4. Державна служба статистики України. Статистична інформація [Електронний ресурс]. - Режим доступу: http://www.ukrstat.gov.ua.

5. Карлін М. І. Управління державними фінансами: [навч. посібн.] / М. І. Карлін, О. В. Борисюк. - Луцьк : ПП Іванюк, 2013. - 273 с.

6. Нечипорук Л. В. Посилення загроз фінансовій безпеці держави в умовах фінансової глобалізації / Л. В. Нечипорук // Збірник наукових праць Національного університету державної податкової служби України. - 2012. № 1. - C. $282-298$.

7. Панков Ю.В. Региональные особенности страховой культуры и финансовая безопасность страховщика. / Ю.В.Панков // [Электронный ресурс]. Режим доступа: http://zhurnal.lib.ru.

8. Плєшакова Н. А. Взаємодія механізмів грошово-кредитної політики в забезпеченні фінансової стабільності України / Н.А. Плєшакова, П.А. Мороз // Фінанси. Банківська справа. - Науковий вісник ЧДІЕУ. - 2012. № 2 (14). - С. $182-188$.

9. Стащук О.В. Теоретичні аспекти фінансової безпеки акціонерних товариств / О.В. Стащук // Економічний часопис Східноєвропейського національного університету імені Лесі Українки. - 2015. - № 3. - С. 40 - 43. 


\section{References:}

1. Borysjuk O. V. (2016) Osnovni zahrozy finansovoji bezpeky Ukrajiny. [Modern Transformation of Economics and Management in the Era of Globalization: international Scientific-Practical Conference Conference]. (Klaipeda, January 29, 2016) - Klaipeda, pp. 270-271.

2. Borysjuk O. V. (2017) [Finansovyj rynok Ukrajiny : tendenciji rozvytku v umovax hlobal'nyx vyklykiv]. Sxidna Jevropa: ekonomika, biznes ta upravlinnja. Vypusk 7, pp. 239-242.

3. Vasylyk O. V. (2002) [Finansova bezpeka Ekonomichna enciyklopedija: u 3 t]. T.3. K.: Vyd. centr "Akademija", 952 p.

4. Derzhavna sluzhba statystyky Ukrainy. Statystychna informatsiia [Elektronnyj resurs]. - Rezhym dostupu: http://www.ukrstat.gov.ua.

5. Karlin M. I. (2013) [Upravlinnja derzhavnymy finansamy: [navch. posibn.]/ M. I. Karlin, O. V. Borysjuk. - Luc'k : PP Ivanjuk. -273 p.

6. Nechyporuk L. V. (2012) [Posylennja zahroz finansovij bezpeci derzhavy v umovax finansovoji hlobalizaciji]. (Zbirnyk naukovyx prac' Nacional'noho universytetu derzhavnoji podatkovoji sluzhby Ukrajiny). № 1, pp. 282-298.

7. Pankov Ju.V. Rehyonalnye osobennosty straxovoj kultury i fynansovaja bezopasnost straxovščyka. [Elektronnyj resurs]. - Rezhym dostupa: http://zhurnal.lib.ru.

8. Plješakova N. A. (2012) [Vzajemodija mexanizmiv hrošovo-kredytnoji polityky v zabezpechenni finansovoji stabil'nosti Ukrajiny]. - (Finansy. Bankivs'ka sprava). - Naukovyj visnyk ČDIEU, № 2 (14), pp. 182-188.

9. Staščuk O.V. (2015) [Teoretychni aspekty finansovoji bezpeky akcionernyx tovarystv]. - (Ekonomichnyj chasopys Sxidnojevropejs'koho nacional'noho universytetu imeni Lesi Ukrajinky). - 2015. - № 3. - S. $40-43$. 


\title{
NATIONAL INNOVATION SYSTEM DEVELOPMENT: EVIDENCE FROM THE COUNTRIES OF THE CENTRAL AND EASTERN EUROPE REGION
}

\section{Vasylchenko Mariana ${ }^{1}$ \\ Khrystenko Olena ${ }^{2}$}

DOI: http://dx.doi.org/10.30525/978-9934-571-28-2_6

\begin{abstract}
The given paper is dedicated to the determination of the theoretical aspects of a national innovation system as an analytical tool to evaluate the technological development of any country. The notion of the term "national innovation system" (NIS) is considered by authors. It is emphasized that the concept of NIS became widely used in the last decade of the $\mathrm{XX}$ century due to an intensification of interest in studying of how the relationships among industries, various research and development institutions, government bodies and academia could be harnessed to sustain innovation initiatives at micro and macro level. It is proved that the innovation capability of each country greatly depends on the efficiency of its national innovation system. The findings of the analysis indicate that in many cases such a system requires the generation and dissemination of knowledge, along with the utilization of innovation. Consi-derable attention is given to the analysis of the available experience of the countries of the Central and Eastern Europe region in this field.
\end{abstract}

Therefore, the main purpose of the given paper is to put everyone in the picture about the economic essence of the concept of a national innovation system, to analyze the national innovation systems in the Central and Eastern Europe as a region, which is trying to find its identity in the present-day context, and to determine potential policy options for improving the innovation capacity of Ukraine. The methodology has been designed through a critical literature review. The study is descriptive and analytical in nature, because the relevant publications were consulted to

\footnotetext{
${ }^{1}$ Candidate of Economic Sciences, Associate Professor,

Associate Professor of the Department of Management and Logistics,

Poltava National Technical Yuri Kondratyuk University, Ukraine

${ }^{2}$ Candidate of Economic Sciences,

Associate Professor of the Department of Management and Logistics,

Poltava National Technical Yuri Kondratyuk University, Ukraine
} 
investigate the changing concepts of a national innovation system in the world and to identify the best practices of the innovation management in the countries of the Central and Eastern Europe region in order to determine the contemporary approach to the innovation system development in Ukraine.

The findings of the analysis indicate that on the one hand, there are low indexes of competitiveness of the national economy and the readiness of Ukraine to function in the global market. On the other hand, in many fields of scientific research and innovation the priority positions of the country remain competitive. Consequently, it should be emphasized that the implementation of the integrated approach in promoting innovative initiatives is expedient in Ukraine.

\section{Introduction}

In the present-day context, innovations still remain critical to the success of businesses in the global trading system. The development of ideas into some con-structive goods and services further results in increase of the consumer interest and demand. As a result, millions of new jobs are created, national economies continue to grow and advanced societies still advance.

Each region or part of "the world chessboard" has its own driving and restraining factors of innovation engagement. For a long period of time, Europe was considered to be the main knowledge production centre in the global economy, "accounting for one-third of the world's science and technology production" [1]. But during the last five years, the authorized experts have been highlighted the fact that "Europe's research and innovation performance has declined, causing a broadening of the already sizeable innovation gap with US and Japan" [2]. And, finally, "Asia has for the first time overtaken Europe in its number of innovation centers built and operated with the region now host to nearly a third (29\%) of all such centers globally. So strong is Asia's growth that it could soon overtake the US as the biggest hub of innovation centers, if it continues to grow at the same rate" [1]. Consequently, "Europe and its policymakers must become more open to innovation and new technologies. Moreover, this region should embrace the many opportunities and manage the respective risks rather than banning or restricting technologies pre-emptively" [3, p. 3].

According to the last official edition of the "European Innovation Scoreboard 2017" [4, p. 14], which releases the information on the 
comparative analysis of innovation performance in the EU region and addresses the core strengths and weaknesses of the existing national innovation systems, all the countries of the EU can be grouped into the following performance groups: innovation leaders (Denmark, Finland, Germany, the Netherlands, Sweden and the United Kingdom), whose performance is more than $20 \%$ above the average level of the EU; strong innovators (Austria, Belgium, France, Ireland, Luxembourg, and Slovenia) with a total performance between $90 \%$ and $120 \%$ of the EU average; moderate innovators (Croatia, Cyprus, the Czech Republic, Estonia, Greece, Hungary, Italy, Latvia, Lithuania, Malta, Poland, Portugal, Slovakia and Spain), whose performance is estimated between $50 \%$ and $90 \%$ of the EU average; modest innovators (Bulgaria and Romania only), with a performance below $50 \%$ of the EU average level.

Obviously, all the above-mentioned groups of the EU countries tend to be geographically concentrated. The most innovative countries in Europe "are surrounded by different zones of countries and their average performance decreases with increasing geographical distance from the recognized innovation leaders" [4, p. 14].

That is why the overall purpose of this paper is to put everyone in the picture about the economic essence of the concept of a national innovation system, to analyze the national innovation systems in the Central and Eastern Europe as a region, which is trying to find its identity following the breakdown of the Soviet Union almost three decades ago, and to determine potential policy options for improving the innovation capacity of Ukraine.

The design of the study consists of four main steps, namely: an overview of the changing concepts of national innovation systems in the world; determination of the challenges facing the national innovation system development in the countries of the Central and Eastern Europe region; analysis of the possibility of implementation of the integrated innovation approach in Ukraine.

Within the present study we understand that there are many different ways that research could be done. However, what all research has in common is that it embraces a sequence or set of activities that are highly interrelated and that together generate the research process. Various studies have found that the ordinary activities in the research process usually follow a straight order, but it's quite possible to describe and explain the common pattern. The research is a flexible cyclical process, because the main 


\section{National innovation system development: evidence from the countries of...}

research findings often create new issues and ideas that need to be further investigated.

This study builds on primary and secondary data sources. The study has been developed through a critical review of literature related to national innovation systems all over the world. The information is derived from the reputable paper-based and electronic information sources, such as wellknown academic journals and official reports. The literature review has enabled an analysis of the key challenges to national innovation system development in the countries of Central and Eastern Europe region and has facilitated the identification of the approach to develop innovation engagement in Ukraine.

\section{Changing concepts of national innovation systems in the world}

The concept of a national innovation system was initially put forward as a qualitative concept for describing the technological, economic, social and institutional dimensions of innovation in advanced economies [5]. As Ramanathan K. [6] states, the interest in NIS came about because experience suggested that in the economically advanced countries of Europe, North America and Asia, government research institutes, universities and the industries worked in collaboration to promote innovation at the micro level and thus spur economic development. The role that the state governments played in stimulating such collaboration attracted interest in many countries.

The desire to understand this global phenomenon better, led us to consider the origins of a national innovation system. This term was first coined in 1980s by C. Freeman, who defined it as "the network of institutions in the public and private sectors whose activities and interactions initiate, import, modify and diffuse new technologies" [7] and B.-A. Lundvall, who emphasized it as "the elements and relationships which interact in the production, diffusion and use of new, and economically useful, knowledge... and are either located within or rooted inside the borders of a nation state" [8]. The third main author in the field, R. Nelson, focused on the set-up of actors and the specifics of collaboration be-tween all of them [9].

Drawing on these scientific approaches, the main distinctions and commonalities of the concept of a national innovation system can be determined (See Table 1). 


\section{Comparative characteristics of the original versions of the concept of a national innovation system [5, p. 7]}

\begin{tabular}{|c|c|c|c|}
\hline \multirow{2}{*}{$\begin{array}{l}\text { Criteria of } \\
\text { comparison }\end{array}$} & \multicolumn{3}{|c|}{ The "fathers" of the concept of a national innovation system } \\
\hline & C. Freeman & B.-A. Lundvall & R. Nelson \\
\hline 1 & 2 & 3 & 4 \\
\hline $\begin{array}{l}\text { Term } \\
\text { "National" }\end{array}$ & Not explicitly defined. & $\begin{array}{l}\text { National differences } \\
\text { and boundaries } \\
\text { define the national } \\
\text { innovationsystem. }\end{array}$ & $\begin{array}{l}\text { National system } \\
\text { encompasses elements } \\
\text { and relationship, either } \\
\text { located within or rooted } \\
\text { inside the borders of the } \\
\text { nation state. }\end{array}$ \\
\hline $\begin{array}{l}\text { Term } \\
\text { "System" }\end{array}$ & Not explicitly defined. & $\begin{array}{l}\text { A set of institutional } \\
\text { actors that, together, } \\
\text { play the major role in } \\
\text { influencing innovative } \\
\text { performances. }\end{array}$ & $\begin{array}{l}\text { A system of innovation } \\
\text { is constituted } \\
\text { by elements and } \\
\text { relationships which } \\
\text { interact in the } \\
\text { production, diffusion } \\
\text { and use of new and } \\
\text { economically useful } \\
\text { knowledge. }\end{array}$ \\
\hline $\begin{array}{l}\text { Term } \\
\text { "Innovation", }\end{array}$ & $\begin{array}{l}\text { Continuing process } \\
\text { of technical change, } \\
\text { involving the } \\
\text { introduction of new } \\
\text { products and the new } \\
\text { ways of organizing } \\
\text { production, distribution } \\
\text { and marketing. }\end{array}$ & $\begin{array}{l}\text { The process by which } \\
\text { business entities master } \\
\text { and get into practice } \\
\text { product design and } \\
\text { manufacturing process } \\
\text { that are new to them. }\end{array}$ & $\begin{array}{l}\text { On-going process of } \\
\text { learning, searching and } \\
\text { exploring, which result } \\
\text { in new products, new } \\
\text { techniques, new forms } \\
\text { of organization and } \\
\text { new markets. }\end{array}$ \\
\hline $\begin{array}{l}\text { Analytical } \\
\text { framework }\end{array}$ & $\begin{array}{l}\text { Relationship between } \\
\text { technology, socio- } \\
\text { economic structures } \\
\text { and institutions. }\end{array}$ & $\begin{array}{l}\text { Linking institutional } \\
\text { arrangements } \\
\text { to technological } \\
\text { and economic } \\
\text { performances }\end{array}$ & $\begin{array}{l}\text { Interactive learning } \\
\text { anchored in the } \\
\text { production structure. } \\
\text { Institutional set-up } \\
\text { including "firm } \\
\text { strategy". } \\
\text { Modes of cooperation } \\
\text { and competition. }\end{array}$ \\
\hline $\begin{array}{l}\text { Elements of } \\
\text { the system } \\
\text { put forward }\end{array}$ & $\begin{array}{l}\text { Quantitative aspects: } \\
\text { long-term trends } \\
\text { in the growth and } \\
\text { distribution of the } \\
\text { national levels } \\
\text { of research and } \\
\text { development;. }\end{array}$ & $\begin{array}{l}\text { The allocation } \\
\text { of research and } \\
\text { development activity } \\
\text { and the sources of its } \\
\text { funding. } \\
\text { The characteristics of } \\
\text { business entities }\end{array}$ & $\begin{array}{l}\text { The internal } \\
\text { organization of firms. } \\
\text { Inter-firm relationships. } \\
\text { Role of the public } \\
\text { sector. } \\
\text { Institutional set-up of } \\
\text { the financial sector of }\end{array}$ \\
\hline
\end{tabular}


National innovation system development: evidence from the countries of...

Ending of Table 1

\begin{tabular}{|c|c|c|c|}
\hline 1 & 2 & 3 & 4 \\
\hline $\begin{array}{l}\text { Elements of } \\
\text { the system } \\
\text { put forward }\end{array}$ & $\begin{array}{l}\text { comparison of the } \\
\text { indicators of science } \\
\text { and technology at } \\
\text { disaggregated level; } \\
\text { the relationship } \\
\text { between these } \\
\text { indicators and } \\
\text { measures of economic } \\
\text { performances. } \\
\text { Qualitative aspects: } \\
\text { the role of the } \\
\text { company research and } \\
\text { development strategy } \\
\text { in relation to imported } \\
\text { technology and reverse } \\
\text { engineering; } \\
\text { the role of education } \\
\text { and training and } \\
\text { related social } \\
\text { innovations; } \\
\text { the conglomerate } \\
\text { structure of industry. } \\
\end{array}$ & $\begin{array}{l}\text { and the important } \\
\text { industries. } \\
\text { The role of universities } \\
\text { and government } \\
\text { laboratories. } \\
\text { Government policies } \\
\text { aimed at industrial } \\
\text { innovation. } \\
\text { Key interactions or } \\
\text { networks of actors. } \\
\text { Component and system } \\
\text { producers. } \\
\text { Upstream and } \\
\text { downstream firms. } \\
\text { Universities and } \\
\text { industry. } \\
\text { Government agencies, } \\
\text { university and industry. }\end{array}$ & $\begin{array}{l}\text { the economy. } \\
\text { Research and } \\
\text { development } \\
\text { organization. }\end{array}$ \\
\hline $\begin{array}{l}\text { Main } \\
\text { orientation }\end{array}$ & $\begin{array}{l}\text { To develop the } \\
\text { national innovation } \\
\text { system concept. }\end{array}$ & $\begin{array}{l}\text { To describe differences } \\
\text { and similarities } \\
\text { between national } \\
\text { systems and the } \\
\text { extent that these } \\
\text { differences explain } \\
\text { in national economic } \\
\text { performances. }\end{array}$ & $\begin{array}{l}\text { To provide a } \\
\text { theoretical perspective } \\
\text { that might be used in } \\
\text { case studies and to } \\
\text { discuss some important } \\
\text { subsystems. }\end{array}$ \\
\hline $\begin{array}{l}\text { Type of the } \\
\text { analysis }\end{array}$ & $\begin{array}{l}\text { Single case study } \\
\text { (Japan). }\end{array}$ & $\begin{array}{l}\text { Comparative case } \\
\text { study ( } 15 \text { countries } \\
\text { divided into large } \\
\text { high-income, small } \\
\text { high-income and low } \\
\text { income countries). }\end{array}$ & $\begin{array}{l}\text { Conceptual / } \\
\text { Theoretical analysis. }\end{array}$ \\
\hline
\end{tabular}

From the Table 1 it can be argued that the focus on the constituents of systems of innovation (institutions, organizations and interactions) is common to all three presented approaches to the definition of the concept of a national innovation system.

Since the 90s of the XX century, the given concept has attracted the attention of many researchers all over the world, as well as the policy-makers working 
on new architectures for the development of the knowledge-based economies. It is widely considered as one of the most important concepts to emerge in the field of innovation studies [10]. The national innovation system has proven to be "the national institutions, their incentive structures and their competencies, that determine the rate and direction of technological learning (or the volume and composition of change generating activities) in a country [11]. According to Balzat and Hanush (as cited by Santoned T., Kaivo-oja J. and Suomala J. [12]), a national innovation system is a historically grown subsystem of the national economy in which various organizations and institutions interact with and influence one another in the carrying out innovative activity.

On the basis of the above considerations, it's reasonable to assume that there is no single accepted definition of national innovation system. However, there is a semantic core that can be seen in most of the definitions, which is related to the major characteristics of the national innovation systems (See Table 1).

Table 2

\section{The characteristics of the national innovation systems [generalized by authors]}

\begin{tabular}{|l|l|}
\hline \multicolumn{1}{|c|}{$\begin{array}{c}\text { NIS major } \\
\text { characteristics }\end{array}$} & \multicolumn{1}{c|}{ Explanation } \\
\hline $\begin{array}{l}\text { The national } \\
\text { innovation system } \\
\text { is based on the } \\
\text { systemic approach }\end{array}$ & $\begin{array}{l}\text { Today the ideas for innovation can come from various sources. } \\
\text { They can also appear at any stage of the process of research, } \\
\text { development, marketing and diffusion. As a result, the systemic } \\
\text { approach is considered to be better for policy-makers, because of } \\
\text { its ability to identify leverage points and weak links within the } \\
\text { national innovation system. }\end{array}$ \\
\hline $\begin{array}{l}\text { Innovation is the } \\
\text { focus of any national } \\
\text { innovation system }\end{array}$ & $\begin{array}{l}\text { Innovation is the natural result of an interaction between different } \\
\text { actors and institutions of the national innovation system. }\end{array}$ \\
\hline $\begin{array}{l}\text { A flow of } \\
\text { knowledge } \\
\text { contributes to the } \\
\text { formation of the } \\
\text { national innovation } \\
\text { system }\end{array}$ & $\begin{array}{l}\text { There are many channels and mechanisms through which knowledge } \\
\text { can flow among the institutions of the national innovation system. } \\
\text { Actually, these flows are as follows: interactions among business } \\
\text { entities; interactions among business entities, universities and public } \\
\text { research laboratories; diffusion of knowledge and technology to the } \\
\text { enterprises; and personnel mobility. }\end{array}$ \\
\hline $\begin{array}{l}\text { NIS is the network } \\
\text { of the stakeholders } \\
\text { involved in } \\
\text { innovation } \\
\text { processes }\end{array}$ & $\begin{array}{l}\text { Business entities, public research institutes, universities, financial } \\
\text { institutions, educational system government regulatory bodies } \\
\text { and other actors are interdependence each other, but the linkages } \\
\text { among them are key to improving technology performance. }\end{array}$ \\
\hline
\end{tabular}


As we can observe from the Table 2, national innovation system is a set of interrelated institutions that produce, diffuse and adapt new technical knowledge. The links between these institutions consist of various flows: knowledge, financial, human, regulatory, and commercial. "As such, a national innovation system includes not just the institutions performing research and development and the level and sources of funding for such research and development, but also policies, such as antitrust policy, intellectual property rights and regulatory policy that affect technology development, the training of scientists and engineer, and technology adoption" [13].

The following paradigm traces the interaction of the national innovation system to innovation, investment and growth (See Figure 1).

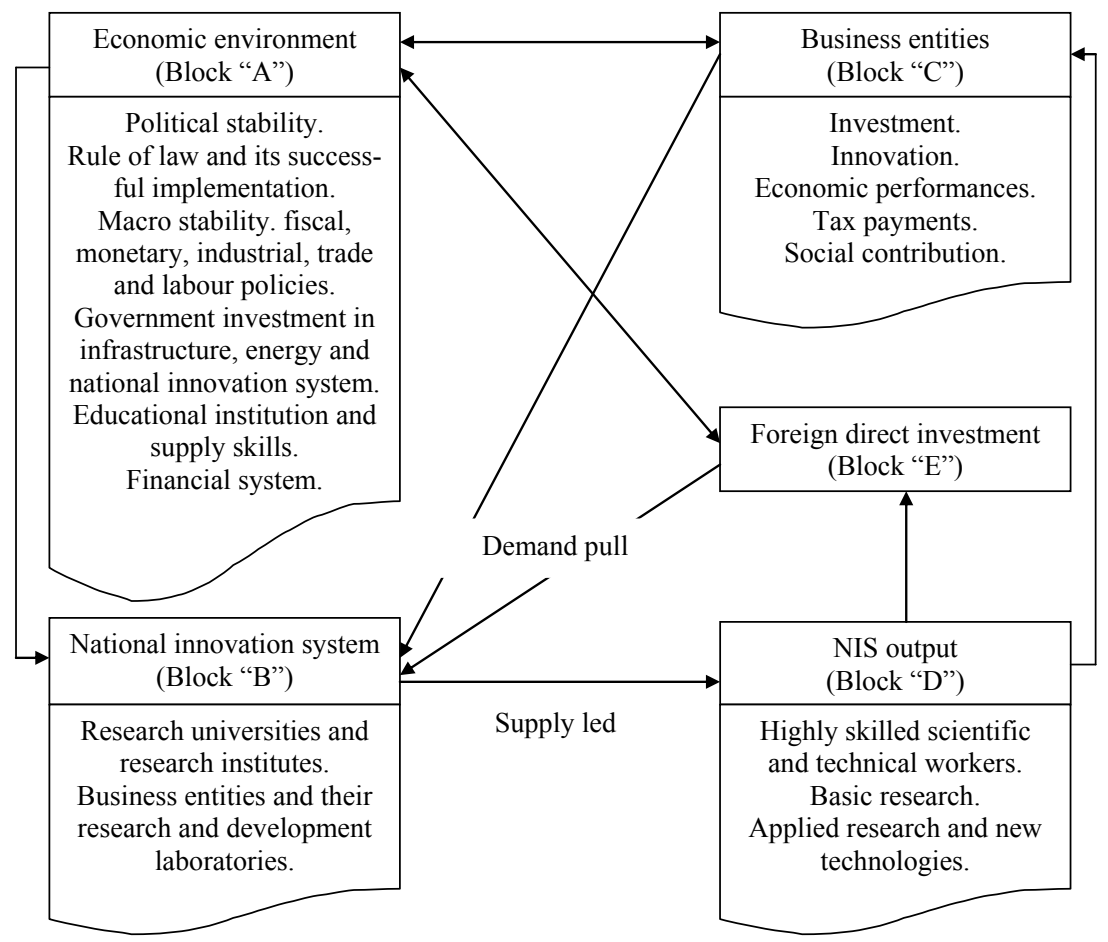

Fig. 1. A general framework of interaction between the national innovation system, economic environment and business entities [developed by authors] 
According to the Figure 1, block " $A$ " is related to the constraints or motives to investment and innovation. In other words, it consists of macro and political stability, as well as quality of labour and labour policy, quality of governance, financial system, trade and industrial policy, infrastructure etc. At the same time, block " $\mathrm{B}$ " is the national innovation system comprising of research and academic institutions that undertake research and development and contribute to the stock of knowledge and technology. On the contrary, block "C" shows NIS output only. As regards another block "D", it has the country's business entities as they are impacted by conditions in the previous blocks " $\mathrm{A}$ " and "B". Business decisions concerning the investment and innovation should be made in response to conditions determined in blocks "A" and "B" only.

It should be understood that these conditions may be not only favourable (able to stimulate business investment and innovation, which in turn create the demand for national innovation system services, employment opportunities for scientific and technical workers, and demand for advanced scientific and technical education), but also unfavourable ones.

Therefore, a national innovation system is an expected result of innovation process governance and knowledge resources management through an ap-propriate institutional set up and legal framework. The unprecedented increase in the ability of society to social and institutional change through such an institutional set-up ultimately points out the importance of socio-cultural factors of sustainable economic growth. In general, the concept of a national innovation system provides a tool for analysis of the specifics of any country in the global economy, as well as a guide for effective innovation policy formulation.

\section{Challenges facing the national innovation system development}

The European Union is a unique partnership in which member states have pooled sovereignty in certain policy areas and harmonized laws on a wide range of economic and political issues. Today the EU consists of 28 member states, including the formerly communist countries of Central and Eastern Europe [14].

The move towards globalization and regionalization - that has increased pace over the past decades - has had a strong influence on the driving forces and business landscape, which creates and shapes the strategic opportunities and re-quirements for economic development, growth, employment 


\section{National innovation system development: evidence from the countries of...}

levels, and social and environmental sustainability. The Central and Eastern European countries play an important role in the European region as emerging markets, competitive players in manufacturing and services, and political-economic actors. Compared to Western European states and business entities, those in the Central and Eastern Europe region receive limited and sporadic coverage in business literature, although the changing dynamics in the European region makes these a captivating academic subject, a high priority policy-making arena, and an important field for international business strategic decision makers [15, p. 10].

After the turbulent historical experience during the past decades, the process of convergence to Western Europe has delivered tangible results. According to the results of the investigations published in the Workshop report by the Joint Research Centre [16, p. 6], the Central European countries (like Slovenia, the Czech Republic and the Slovak Republic) are exhibiting average performance measures three to four times higher than other countries, like Ukraine, Georgia and Moldova (See Table 3).

On the basis of the data from Table 1 it should be mentioned that the countries from that region that are Members of the European Union, exhibit more than double the income per capita from other, non-EU member countries, on average. The process of convergence is also multifaceted: for countries of this region, membership to the EU is associated with an increase of $14 \%$ in the Human Development Index. In such a diverse landscape, fostering a data-driven economy through the capacity of a public open-data infrastructure addresses key concerns of the region regarding growth and development [16, p. 7].

Despite the efforts carried out to restore economic dynamism through macroeconomic interventions and structural reforms, growth expectations remain tempered across those Central and Eastern Europe economies, where growth rates remain low and unemployment stubbornly high. These countries continue their struggle to increase the level of the competitiveness and to set the national economy on a more solid footing.

Taking into consideration the nature of the national innovation concept, Central and Eastern European economies face several challenges in the race to innovation, which derive from inefficient governance, weak infrastructure and poor quality of the business environment.

Thus, for instance, inefficient governance means that today there are only a very few developing countries in the Central and Eastern Europe 
Table 3

The main Development Indices of the countries in the Central and Eastern Europe region, 2016 [16, p. 7]

\begin{tabular}{|c|c|c|c|c|c|}
\hline Countries & $\begin{array}{c}\text { European } \\
\text { Union }\end{array}$ & OECD & $\begin{array}{c}\text { Gross } \\
\text { national } \\
\text { Income } \\
\text { per capita } \\
(2016)\end{array}$ & $\begin{array}{c}\text { Human } \\
\text { Development } \\
\text { Index }\end{array}$ & $\begin{array}{c}\text { Time } \\
\text { Required } \\
\text { to Register } \\
\text { Property } \\
\text { (days) }\end{array}$ \\
\hline 1 & 2 & 3 & 4 & 5 & 6 \\
\hline Slovenia & $\mathrm{x}$ & $\mathrm{x}$ & 28,664 & 0,89 & 50 \\
\hline Czech Republic & $\mathrm{x}$ & $\mathrm{x}$ & 28,144 & 0,88 & 28 \\
\hline Slovak Republic & $\mathrm{x}$ & $\mathrm{x}$ & 26,764 & 0,84 & 17 \\
\hline Estonia & $\mathrm{x}$ & $\mathrm{x}$ & 26,362 & 0,87 & 18 \\
\hline Poland & $\mathrm{x}$ & $\mathrm{x}$ & 24,117 & 0,86 & 33 \\
\hline Hungary & $\mathrm{x}$ & $\mathrm{x}$ & 23,394 & 0,84 & 18 \\
\hline Latvia & $\mathrm{x}$ & $\mathrm{x}$ & 22,589 & 0,83 & 17 \\
\hline 1 & 2 & 3 & 4 & 5 & 6 \\
\hline Lithuania & $\mathrm{x}$ & & 26,006 & 0,85 & 4 \\
\hline Croatia & $\mathrm{x}$ & & 20,291 & 0,83 & 62 \\
\hline Romania & $\mathrm{x}$ & & 19,428 & 0,80 & 16 \\
\hline Bulgaria & $\mathrm{x}$ & & 16,261 & 0,79 & 19 \\
\hline Montenegro & & & 15,410 & 0,81 & 69 \\
\hline Macedonia & & & 12,405 & 0,75 & 30 \\
\hline Serbia & & & 12,202 & 0,78 & 21 \\
\hline Albania & & & 10,252 & 0,76 & 19 \\
\hline \begin{tabular}{|l} 
Bosnia \& \\
Herzegovina
\end{tabular} & & & 10,091 & 0,75 & 24 \\
\hline Georgia & & & 8,856 & 0,77 & 1 \\
\hline Ukraine & & & 7,361 & 0,74 & 17 \\
\hline Moldova & & & 5,026 & 0,70 & 8 \\
\hline
\end{tabular}

region, that have their own effective innovation strategies or strong innovation policies.

As regards to another challenge in the race to innovation, it should be men-tioned that there is the lack of technological support services and infrastructure (i.e. quality control, quality standards and metrology) in the Central and Eastern Europe economies. That is why not only telecommunications, but also road and other transport infrastructure, sanitation, water and other systems should be of priority importance in the near future. 
Additionally, an equally important problem of innovation engagement in the countries of the Central and Eastern Europe region is concerned with the poor quality of the business environment. This means that in many national economies of the region, chosen for research, formal rules and laws are less developed, and their further enforcement tends to be unreliable and arbitrary. Thus, it is no wonder that the results of such intervention do not stimulate the desired innovative behavior across the country as a whole.

\section{Implementation of an integrated innovation approach: lessons for Ukraine}

One of the important lessons of the past two decades has been the pivotal role of innovation in economic development. The build-up of innovation capacities has played a central role in the growth dynamics of successful developing countries all over the world (See Table 4).

As we can observe from the Table 4, the majority of countries have recognized that innovation is not just about high-technology products and that the national innovation capacity has to be created in the development process in order to possess the learning capacities that will allow "catch up" to happen. Many countries all over the world also need innovation capacity and local innovations to address challenges specific to their local contexts [15].

The future growth of Central and Eastern Europe greatly depends on upgrading technology, exporting and coupling domestic technology efforts while improving their position in global value chains. Current policies in the region are not geared to these tasks, despite the availability of huge financial opportunities in the form of EU structural funds. Existing policies are overly focused on research and development, as well as the neglect sources of productivity growth, such as management practices, skills, quality, and engineering. The challenge is how to design industrial and innovation policies so that they promote modernization and drive structural change [17].

The concept of an effective national innovation system in the countries of Central and Eastern Europe region should be more complex because it consists of the limited types of formal sector actors (enterprises, universities, research institutes, government and financial system bodies) and informal sector actors (various non-governmental organizations and informal companies). Therefore, the main problems in the governance of such an 


\begin{tabular}{|c|c|c|}
\hline \multicolumn{3}{|c|}{$\begin{array}{c}\text { The explanation of the importance of innovation initiatives } \\
\text { for developing and emerging countries } \\
\text { [developed by authors on the basis of the source: } 15]\end{array}$} \\
\hline $\begin{array}{l}\text { Country } \\
\text { category }\end{array}$ & Objective of innovation & Main agents involved \\
\hline 1 & 2 & 3 \\
\hline \multirow[t]{2}{*}{$\begin{array}{l}\text { Developing / low- } \\
\text { income countries } \\
\text { and emerging and } \\
\text { middle income } \\
\text { countries }\end{array}$} & $\begin{array}{l}\text { Adoption requires } \\
\text { adaptation: Innovation } \\
\text { needs to respond to specific } \\
\text { "local" conditions for } \\
\text { outcomes. }\end{array}$ & $\begin{array}{l}\text { Universities and research institutes, } \\
\text { leading private businesses, } \\
\text { especially those with exposure to } \\
\text { foreign markets and businesses }\end{array}$ \\
\hline & $\begin{array}{l}\text { Inclusive innovation: for / } \\
\text { by low- and middle income } \\
\text { households to improve } \\
\text { welfare and access to } \\
\text { business opportunities. }\end{array}$ & $\begin{array}{l}\text { Non-governmental organizations, } \\
\text { small enterprises, public and } \\
\text { private associations engaged in } \\
\text { disseminating knowledge via } \\
\text { networks, private, often large } \\
\text { businesses. }\end{array}$ \\
\hline \multirow[t]{3}{*}{$\begin{array}{l}\text { Mainly middle- } \\
\text { income countries, } \\
\text { but also some } \\
\text { opportunities for } \\
\text { developing / low- } \\
\text { income countries }\end{array}$} & $\begin{array}{l}\text { Build up innovation } \\
\text { capacities that will be key } \\
\text { for reaching the world } \\
\text { technological frontier } \\
\text { in many industries, esp. } \\
\text { relevant to avoid "middle- } \\
\text { income traps". } \\
\end{array}$ & $\begin{array}{l}\text { Requires full development of } \\
\text { innovation systems involving } \\
\text { diasporas as a connector. }\end{array}$ \\
\hline & $\begin{array}{l}\text { Address environmental, } \\
\text { health and social challenges } \\
\text { through global innovation } \\
\text { efforts and local efforts to } \\
\text { address them } \\
\end{array}$ & $\begin{array}{l}\text { Public and private universities and } \\
\text { research institutions connected to } \\
\text { global networks but also major } \\
\text { private businesses operating in } \\
\text { these sectors }\end{array}$ \\
\hline & $\begin{array}{l}\text { Build-up niche } \\
\text { competencies, i.e. growth } \\
\text { / exports in sectors of } \\
\text { comparative advantage } \\
\end{array}$ & $\begin{array}{l}\text { Public institutions to address } \\
\text { coordination challenges, private } \\
\text { sector initiative including foreign } \\
\text { companies. }\end{array}$ \\
\hline \multirow[t]{2}{*}{$\begin{array}{l}\text { Mainly emerging } \\
\text { / middle-income } \\
\text { countries after } \\
\text { initial progress on } \\
\text { dimensions above }\end{array}$} & $\begin{array}{l}\text { Climb the value ladder in } \\
\text { global value chains }\end{array}$ & $\begin{array}{l}\text { Private sectors with support from } \\
\text { public agents, intermediaries, } \\
\text { diasporas can play a central role, } \\
\text { large firms can be important. }\end{array}$ \\
\hline & $\begin{array}{l}\text { Keep competitiveness in } \\
\text { frontier industries when the } \\
\text { country is already at the } \\
\text { frontier }\end{array}$ & $\begin{array}{l}\text { Mainly private sector in } \\
\text { interaction with public research } \\
\text { institutions and universities, global } \\
\text { partnerships often equally of } \\
\text { relevance, role of large firms. }\end{array}$ \\
\hline
\end{tabular}


innovation system are to meet the needs of both above-mentioned sectors of the economy.

Within the present study we consider it appropriate to describe the core principles of the integrated approach in promoting innovations (See Figure 2), which is used in the countries of the Central and Eastern Europe region.

Creating a financial system for Innovation

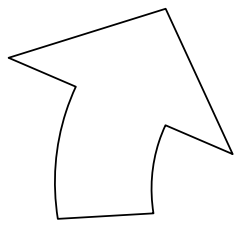

The creation of science parks and technology business incubators
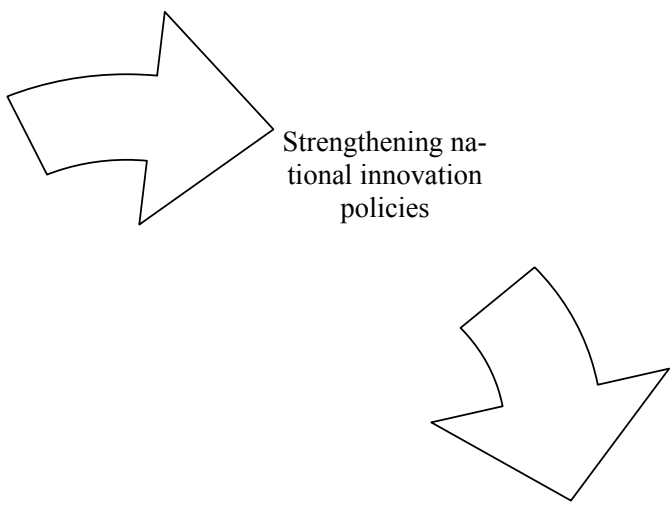

Improving research and development capacities

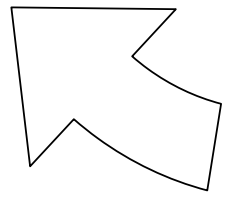

Enhancing the innovation capacity of business entities

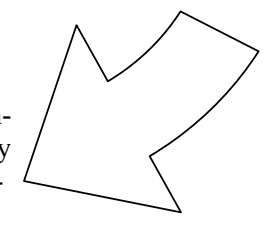

Fig. 2. The core principles of an integrated approach in promoting innovative initiatives in the Central and Eastern European countries [developed by authors]

As we can see from the Figure 2, the first principle or idea of an integrated approach in promoting innovations is related to strengthening national innovation policies. The countries of the Central and Eastern Europe region need to set up the existing innovation policies with the main priorities that are based on certain challenges and opportunities faced by each country 
concerning innovation. "Innovation policy is defined as public intervention to support the generation and diffusion of new products, processes or services" [18]. Rather, it addresses specific problems of the national innovation system, such as the rules of its functioning and regulations able to ensure competition level experience and allow financial markets to provide the necessary signals to investors. To move towards achieving a desired type of innovation policy and its further implementation, broad-based societal participation is required. In this context, state government decision makers, as well as entrepreneurs, researchers and representatives of non-governmental organizations, are fairly considered to be the main agents of change of the existing innovation systems.

Another core principle of the integrated approach in promoting innovative initiatives is related to the improving of the research and development capacities. Research and development activities in the countries of the Central and Eastern Europe still remains very low. It can be explained by the fact of the low investment in this field. In order to improve the existing research systems, the countries of this region should increase their investment in building human resources capacity of and research infrastructure improvement. Innovation and capacity building in most countries covered by this research would benefit from upgrading the skills of workers and training more skilled workers and technicians. This priority can be realized not only by formal education and training, but also by diffusing the concept of learning organizations among business entities; the diffusion should function as heuristic device for local enterprises' experimentation within specific context of learning organizational form. Universities and other higher educational institutions are considered to be the key players in the process of national innovation system development. Universities located in the Central and Eastern Europe region, like in many other regions in the world, successfully produce welltrained human resources and conduct research able to generate knowledge for innovation. Obviously, each of these higher educational institutions already have the considerable intellectual capital that can be deployed to work on the solution of the problem of national innovation system development. Therefore, the universities of the Central and Eastern Europe region should play an important role in dealing with social, economic and environmental challenges. For example, in many countries of this region there is a great opportunity for universities and research centres only to conduct research and development in order to support the important innovation initiatives and to 


\section{National innovation system development: evidence from the countries of...}

develop technology business incubators and science parks to host small and medium enterprises (SMEs).

The next principle of the integrated approach in promoting innovative initiatives is concerned with enhancing the innovation capacity of enterprises. In this regard it should be noted that the given approach is needed to enhance the innovation capacities of business entities in the countries of the Central and Eastern region. Consequently, the approach should take into consideration the multifaceted nature of the existing business entities. Engaging in interactive learning with other actors of the national innovation system is fundamental for development of innovation initiatives.

Equally important is another principle of an integrated approach in promoting innovation initiative, which is related to supporting the creation of knowledge-based small and medium enterprises: science parks and technology business incubators. In modern society the aim of business incubation is to increase the success ratio of start-up enterprises even if the incubator is not a definitive place for the SMEs. The graduated start-up enterprises must relocate to a certain science park. The existence of these business structures is very important to facilitate networking for innovation in the countries of Central and Eastern Europe. Science parks should be particularly interested in enhancing the innovative capacity and foster the enterprises through ensuring and effective interaction and close relationship between government bodies, research and development centres, various research institutes, high-tech industry, launching commercialization and providing financial support. In the present-day context science and technology parks play a significant role in advancement of the in-formation and communication technology, bio- and nanotechnology, electronics and other fields of technology. Many Central and Eastern European economies have also taken the initiative in science parks and incubators development. Nevertheless, most of them are faced with the following problems: low successful rate of incubator tenants, rather slow advancement of innovation, etc. The technology business incubators and science parks in the Central and Eastern European economies should not only host hi-tech start-up enterprises, but also accommodate low-tech start-ups too.

And, finally, the last principle of an integrated approach in promoting innovative initiatives is nothing other than the creation of a financial system for innovation. As we know, in the OECD member countries, thousands of venture capital funds successfully operate to finance knowledge-based 
start-up enterprises. Thus, the aim of the venture capital investor is to invest in rapidly growing business entities in order to sell out, either to another entrepreneur, or the stock market. However, the unreasonably high risk of this type of investment is covered by the high return on successful ventures. Unfortunately such financial systems do not exist in most Central and Eastern Europe economies. Financial institutions are not interested in investing in start-ups because of the complete absence of guarantees and the existence of high risks. However, it is important to establish an existing financial system to support knowledge-based start-ups in the Central and Eastern Europe region.

In general, Central and Eastern European economies do not grow based on research-driven innovation whereby domestic research produces innovation that leads to growth; instead, they rely on the interaction of domestic research and development with more advanced technology from imported equipment and inputs. However, this situation is not reflected in policy, which is geared solely toward the traditional idea of research-driven growth. Central and Eastern European countries would hence be better served by enacting policy that encourages improvements in production capability. This, in turn, would generate demand for local research and development and innovation, which is currently lacking.

In the authors' opinion, the implementation of this approach is expedient in Ukraine. As regard to this country, it should be emphasized that it significantly lags behind the developed countries of the Central and Eastern Europe by the level of innovation economy development. The direct statistical comparison between Ukraine and the countries of Central and Eastern European region is rather difficult. Not all innovation financing related data is available from Ukraine, or it is sometimes not fully comparable with those European countries.

On the one hand, there are low indexes of competitiveness of the national economy and the readiness of Ukraine to function in the global market. On the other hand, in many fields of scientific research and innovation the priority positions of the country remain competitive. However, the implementation of these opportunities is greatly influenced by the national innovation policy specifics and the choice of a single vector of Ukraine's international integration and increasing participation in international scientific and technical collaboration with the world's most leading countries. That is why European integration should be considered as an effective tool to increase economic development of Ukraine and to develop its innovation system. 


\section{National innovation system development: evidence from the countries of...}

\section{Conclusions}

Through this research we have come to certain conclusions.

The concept of the national innovation system first appeared in the $80 \mathrm{~s}$ of the XX century in the framework of institutional and evolutionary economists (C. Freeman, B.-A. Lundwall and R. Nelson) with the main aim to understand and put into action the process through which scientific research and knowledge is produced and transferred into business and innovation.

"The Organization for Economic Cooperation and Development (OECD) provides only one framework for detailing a country's national innovation system, suggesting primary roles for institutional actors. This framework includes as follows: performing research and development, financing research and development, human resource development, diffusing technology, promoting entrepreneurship, and formulating technology and innovation policy" [19]. This broad definition encompasses everything from administrative agencies and conducting public research, private-sector research business entities, higher education and bridging institutions.

The two main features of a certain national innovation system ground for its huge influence on government practices for improving the national competitiveness and economic growth. First of all, national innovation system provides a peculiar "recipe" to national governments on how to cope with globalized innovation-based competition. Such a recipe consists of certain recommendation to governments to establish an institutional set up of private and public institutions that would accelerate creation, storage and transfer the knowledge and skills which produces new technologies and innovation. It calls for public policy induced interaction among sectors and intersectoral knowledge flow.

The second appealing feature of a national innovation system comes from its underlying message that economic growth is not an economic spontaneous process simply driven by the "hidden hand" of market which is beyond the reach of socio-economic entities. Besides, competitiveness of a country in the global chessboard does not depend on the scale of research and development but rather upon the way in which the available resources are managed and organized, both at the micro- and macro level.

Current innovation system of Ukraine is fragmented. It is characterized by poor business environment, a very limited research community, low education levels, weak infrastructure, inefficient public institutions, inefficient governance etc. The implementation of the concepts of national innovation 
system development widely used in other countries needs to be done carefully, by taking into consideration of the local conditions.

By the way, an innovation system, which can accommodate the interaction among the high varieties of stakeholders, such as enterprises, universities, re-search institutes and government, financial system, non-governmental organizations, informal companies must be developed. An integrated approach is needed to establish an appropriate innovation system in Ukraine. An innovation system which is based on relevant innovation policies, able to accommodate innovations, involves the formal and informal sector of the economy and that aims to improve the quality life.

The results obtained during this study can be used as a basis for further practical applications, potentially leading to new management capabilities of national innovation systems. We have found that the ability of the country to manage the quality of its own institutional capital and its interaction with other components of the national innovation system is a key factor of successful innovation in the conditions of globalization. The transformation of infrastructural capacities into effectively functioning human, research, market, and business constituents of national innovation systems is entirely determined by institutional capital and is significantly affected by the innovation output of a country.

\section{References:}

1. Asia to overtake US and Europe in innovation centers. (2017). [Electronic resource].-Retrieved from: http://www.thenextsiliconvalley.com/2017/01/07/4876asia-to-overtake-us-and-europe-in-innovation-centers/

2. State of the Innovation Union 2011. Report from the Commission to the European Parliament, the Council, the European Economic and Social Committee and the Committee of the Region [Electronic Resource]. - Retrieved from: https://ec.europa.eu/research/innovation-union/pdf/state-of-the-union/2011/state of_the_innovation_union_2011_brochure_en.pdf

3. European Competitiveness and Industry 2017: Benchmarking [Electronic resource]. - Retrieved from: http://ert-industry-benchmarking.eu/wp-content/ uploads/2017/12/ERT-Stats_Benchmarking-2017_4web_21122017hyperlinksgrou pedBookmarks.pdf

4. Bieńkowska E., Moedas C. (2017). European Innovation Scoreboard 2017 [Electronic resource]. - Retrieved from: https://www.rvo.nl/sites/default/ files/2017/06/European_Innovation_Scoreboard_2017.pdf

5. Godinho M.M., Mendonça S.F. Towards a taxonomy of innovation systems [Electronic resource] - Retrieved from: http://pascal.iseg.utl.pt/ depeco/wp/ wp132005.pdf 


\section{National innovation system development: evidence from the countries of...}

6. Ramanathan K. The concept and role of a national innovation system (NIS) in national development [Electronic resource]. - Retrieved from: http://apctt.org/ nis/sites/all/themes/nis/pdf/CSNWorkshop_Report P2S1 Ramanathan.pdf

7. Freeman C. (1987). Technology policy and economic performance: Lessons from Japan. London: Pinter Publishers.

8. Lundvall B.-A. (1992) National systems of innovation. London: Anthem Press.

9. Nelson R. (1993) National Innovation Systems. New York: Oxford University Press.

10. Schrempf B., Kaplan D., Schroeder D. (2013). National, regional and sectoral systems of innovation - An overview. Report for FP7 Project "Progress" [Electronic resource]. - Retrieved from: http://www.progressproject.eu/wp-content/uploads/2013/12/Progress D2.2 final.pdf

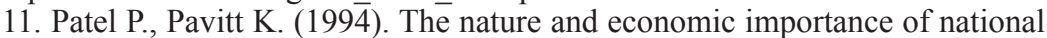
innovation systems. STI Review. No. 14. OECD, Paris.

12. Santonen T., Kaivo-oja J., Suomala J. (2007). Introduction to national open innovation system paradigm. A preliminary concept for interchange [Electronic resource]. - Retrieved from: https://www.utu.fi/fi/yksikot/ffrc/julkaisut/e-tutu/ Documents/eTutu_2007-8.pdf

13. Laredo P., Mustar P. Research and innovative policies in the new global economy [Electronic resource]. - Retrieved from: http://ifris.org/wp-content/blogs. dir/1/files/2014/10/35. -Chap._01_and_14.pdf

14. Archick K. The European Union: Current Challenges and Future Prospects [Electronic resource]. - Retrieved from: https://fas.org/sgp/crs/row/R44249.pdf

15. Myszkowska M. (2015). The competitiveness landscape in Central and Eastern Europe. Economic of the 21st century, Vol. 4 (8), pp. 9-19.

16. Kotsev A., Cetl V., Dusart J., Mavridis D. (2018). Data-driven economies in Central and Eastern Europe: Challenges and Prospects. Joint Research Centre Conference and Workshop Reports [Electronic resource]. - Retrieved from: http://publications.jrc.ec.europa.eu/repository/bitstream/JRC110525/workshop proceeding dataeconomy paper online.pdf

17. Radosevic S. Upgrading technology in Central and Eastern European economies: Existing policies in Eastern Europe will not sufficiently promote technological innovation [Electronic resource]. - Retrieved from: https://wol.iza.org/uploads/ articles/338/pdfs/upgrading-technology-in-central-and-eastern-european-economies.one-pager.pdf

18. Elder J., Cunningham P., Gök A., Shapira P. (2013). Impacts of innovation policy: synthesis and conclusions. Compendium of evidence on the effectiveness of innovation policy intervention project. Manchester Institute of Innovation Research [Electronic resource]. - Retrieved from: http:/www.innovation-policy.org.uk/ share $/ 20$ Impacts $\% 20$ of $\% 20$ Innovation $\% 20$ Policy $\% 20$ Synthesis $\% 20$ and $\% 20$ Conclusion_linked.pdf

19. Chē S.W. (2010). Comparison of national innovation systems in China, Taiwan and Singapoure: Is Bayh Dole one size that fits all? AUTM Technology Transfer Practice Manual. Electronic resource]. - Retrieved from: https://www.autm.net/AUTMMain/media/ThirdEditionPDFs/V4/TTP_V4 AsianNIS.pdf 


\title{
ECONOMIC SECURITY OF THE STATE: EXPERIENCE OF DEVELOPED COUNTRIES OF THE WORLD
}

\section{ЕКОНОМІЧНА БЕЗПЕКА ДЕРЖАВИ: ДОСВІД РОЗВИНУТИХ КРАЇН СВІТУ}

\section{Hbur Zoriana ${ }^{1}$}

DOI: http://dx.doi.org/10.30525/978-9934-571-28-2_7

\begin{abstract}
The article considers approaches to the interpretation of the notion of economic security. The main functions of economic security are described, which are divided into five groups: protective, regulatory, preventive, innovative and social. The system of security of the state economy is analyzed, which is represented by internal and external subsystems that have their components. The main elements of the external security subsystem are technological, commercial, and financial. The subsystem of internal security includes industrial-technical, raw materials, energy, environmental, information components. In accordance with this, internal and external threats to the economic security of the state have been identified, which cause an insufficient level of stability in the economy, and as a consequence, a decrease in the level of economic security of any state. The main approaches to ensuring economic security in European countries are considered, and the dynamics of the index of global economic competitiveness of European countries in 2016-2017 is analyzed.

Economic security is a complex and multifactorial system, which is the material basis for other components formation within the national security. Ensuring economic security is one of the main problems of the state, since the emergence of numerous socio-economic problems in the country, as a rule, exists due to the inability of the state to take preventive measures or their implementation. While taking into account all the above information, the state should ensure the corresponding level of security that guarantees internal and external stability required for normal economic functioning and the country's active participation in international division of labor and competitiveness, and at the same time creating the basis for ensuring an adequate level of security.
\end{abstract}

${ }^{1} \mathrm{PhD}$ in Public Administration, Postdoctoral Student, National Academy of Public Administration under the President of Ukraine, Ukraine 
A lot of scientific works are devoted to the state economic security conditions. In particular, we should note the scientific achievements of the following researchers: V.B. Averyanov, V.G. Atamanchuk, O.M. Bandurka, Yu.P. Bytiak, L.V. Koval, S.I. Lekar, V.F. Opryshko, G.Kh. Popov, V.M. Shapoval, Yu.S. Shemshuchenko, L.P. Yuzkov and others.

The purpose of this article is to study foreign experience in ensuring the country's economic security trough systematizing and generalizing the approaches of different countries to the solution of this problem.

\section{1. Вступ}

Економічна безпека - це складна і багатофакторна система, яка представляє собою матеріальну основу для формування інших компонентів національної безпеки. Забезпечення економічної безпеки є однією з головних проблем держави, оскільки виникнення численних соціально-економічних проблем в країні, як правило, обумовлено неможливістю держави вживати запобіжні заходи або своєчасне їх здійснення. 3 огляду на це, держава повинна забезпечити такий рівень безпеки, який гарантуватиме внутрішню і зовнішню стабільність, необхідну для нормального економічного функціонування, активну участь країни в міжнародному розподілі праці та конкурентоспроможність, одночасно це створить основу для забезпечення достатнього рівня безпеки.

Питанню забезпечення необхідних умов для економічної безпеки держави присвячено чимало наукових праць. Зокрема, варто відзначити наукові здобутки таких дослідників: В. Б. Авер'янова, В. Г. Атаманчука, О. М. Бандурки, Ю. П. Битяка, Л. В. Коваля, С. І. Лекаря, В. Ф. Опришка, Г. Х. Попова, В. М. Шаповала, Ю. С. Шемшученка, Л. П. Юзькова та ін.

Метою статті є дослідження зарубіжного досвіду забезпечення економічної безпеки держави шляхом систематизації та узагальнення підходів різних країн до вирішення даного завдання.

\section{2. Поняття «економічна безпека» у зарубіжній та вітчизняній літературі}

Забезпечення безпеки особистості, суспільства й держави, усього світового співтовариства є ключовою цивілізаційною метою сучасного етапу розвитку світового господарства. 


\section{Hbur Zoriana}

Варто погодитися зі Скорук О. В., яка зазначає, що у зарубіжній та вітчизняній літературі існує багато підходів до тлумачення поняття економічної безпеки держави за допомогою таких характеристик [9]:

- стійкість та стабільність, протидія внутрішнім і зовнішнім загрозам, під якими розуміємо міцність і надійність зв'язків між усіма елементами економічної системи, стабільність економічного розвитку держави, стійкість до стримування та знешкодження дестабілізуючих загроз-факторів;

- економічна незалежність, що характеризує насамперед можливість для будь-якого суб'єкта економічної безпеки самостійно приймати і реалізовувати стратегічні економічні та політичні рішення для розвитку, можливість використовувати національні конкурентні переваги для забезпечення стабільності та розвитку;

- самовідтворення та саморозвиток. Ця характеристика передбачає створення необхідних умов для ведення ефективної економічної політики та розширеного само відтворення, забезпечення конкурентоспроможності національної економіки на світовій арені;

- національні інтереси. Ця характеристика визначає спроможність національної економіки захищати національні економічні інтереси.

Світовий досвід вказує на те, що без активної регулюючої ролі держави не може бути ефективної, соціально орієнтованої ринкової економіки, не говорячи вже про ефективність забезпечення економічної безпеки країни. Немає жодної країни з високорозвиненою економікою, де б держава усунулася від регулювання ключових соціально-економічних процесів [3].

Як правило, економічна безпека держави виступає як система, основні функції якої поділяються на п'ять груп: захисна, регуляторна, попереджувальна, інноваційна та соціальна.

1. Захисна функція виражається здатністю захищати державну економічну систему від внутрішніх та зовнішніх загроз. Реалізація цієї функції безпосередньо пов'язана з формуванням економічного ресурсного потенціалу та його ефективним використанням.

2. Функція регулювання з'являється в різних економічних підсистемах шляхом забезпечення економічної безпеки держави та застосування функціональних механізмів, спрямованих на нейтралізацію ризиків. 
3. Попереджувальна функція державної економічної безпеки зосереджена на передбаченні виникнення потенційних кризових ситуацій під час економічної діяльності та підготовці економічної системи до їхнього протистояння. Це передбачає соціально-економічні та організаційно-технічні заходи, результатом яких $є$ зміцнення оборонної функції системи.

4. Інноваційна функція діє через нетрадиційні рішення держави щодо економічних процесів та інноваційних рішень, спрямованих на прискорення темпів економічного розвитку або на нейтралізацію можливих негативних наслідків останнього. Результати цієї функції виникають в економіці опосередковано i, як правило, виражаються у вигляді підвищення ефективності інших функцій безпеки.

5. Соціальна функція системи державної економічної безпеки передбачає повне задоволення вимог усіх членів суспільства та повного узгодження інтересів. Реалізація цієї функції сприяє підвищенню рівня та якості життя та гарантує захист прав та свобод громадян.

Слід зазначити, що така класифікація функцій державної системи економічної безпеки є загальноприйнятою, оскільки ці функції взаємопов'язані та взаємозалежні, і часто завдання однієї функції можуть повторюватися при визначенні іншої функції. Ефективність забезпечення державної економічної безпеки залежить від можливості повного функціонування цих функцій разом і одночасно. Крім того, проблеми цих функцій можуть бути змінені у забезпеченні окремих компонентів економічної безпеки.

Система безпеки державної економіки представлена внутрішніми та зовнішніми підсистемами, які мають свої компоненти (див. рис. 1):

- підсистема зовнішньої безпеки - технологічна, комерційна, фінансова

- підсистема внутрішньої безпеки - промислово-технічна, сировинна, енергетична, екологічна, інформаційна.

Отже, технологічний компонент державної економічної безпеки характеризується активною участю у міжнародному науково-технічному прогресі, що гарантує здатність держави застосовувати найновіші технологічні рішення у вітчизняному виробництві та забезпечує конкурентоспроможність виробництва національних товарів та послуг на міжнародному ринку. 


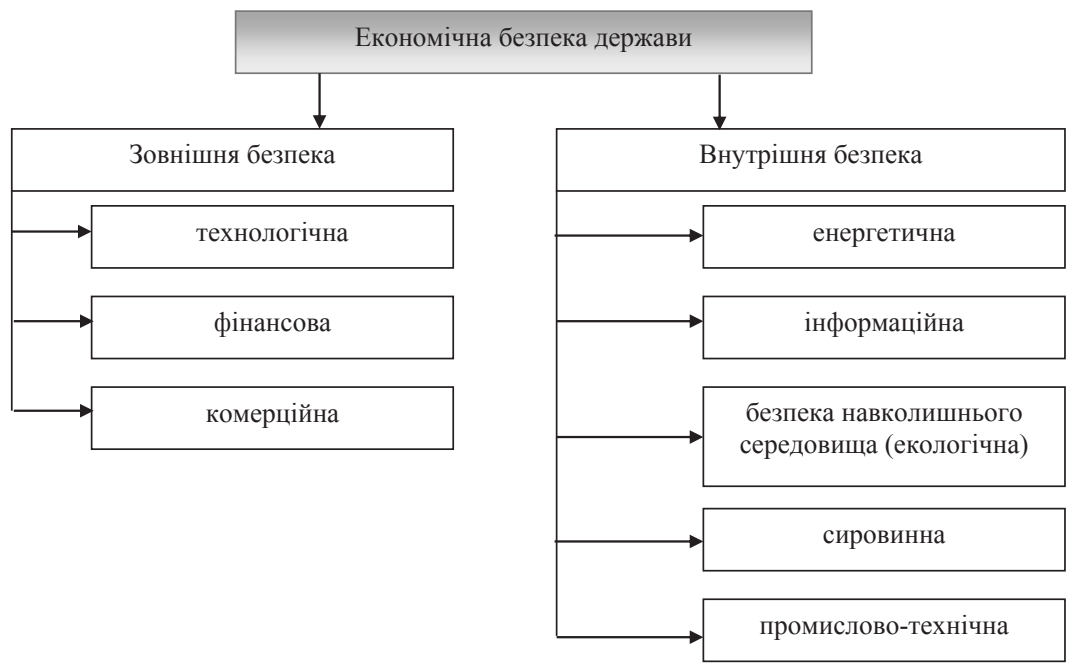

\section{Рис. 1. Структура економічної безпеки держави}

Джерело: власна розробка автора

Комерційна складова державної економічної безпеки є великою гарантією диверсифікації структури експортної та імпортної торгівлі в країні. В умовах географічної диверсифікації експорт та імпорт країни не будуть залежати від впливу одного чи декількох великих центрів.

Фінансовий компонент державної економічної безпеки можна визначити як здатність країни впроваджувати незалежну монетарну політику та забезпечити стабільне функціонування фінансової системи шляхом відшкодування міжнародних кредитів та отримання, розподілу, використання та повернення іноземних інвестицій за наявності несприятливих зовнішніх та внутрішніх умов.

Значення промислово-технічної складової державної економічної безпеки веде до забезпечення виробничих та технічних можливостей впровадження розширеного відтворення економіки. Це передбачає здатність економіки відповідати потребам суспільства, навіть у ситуаціях, коли порушуються зовнішні або внутрішні економічні сприятливі умови.

Сировинна складова державної економічної безпеки передбачає економічну гарантію необхідної кількості продовольства та сировини. 
Забезпечення харчових продуктів та сировини є однією 3 найважливіших складових державної економічної безпеки, а в багатьох країнах світу існують закони, що визначають мінімальні стандарти забезпечення продовольчої безпеки.

Наступним компонентом державної економічної безпеки є енергетична безпека, що передбачає стабільне постачання достатньої кількості необхідної енергії для внутрішнього споживання. Для цього аналізи проводяться послідовно у всіх країнах, виявляючи обставини, поява яких може підірвати діяльність країни в галузі паливно-енергетичної системи.

Екологічною складовою державної економічної безпеки є здатність держави запобігати та усунути розрив між суспільними інтересами та захистом довкілля вчасно. Проблема забруднення навколишнього середовища тісно пов'язана $з$ економічною діяльністю людини, тому для екологічної безпеки необхідно мінімізувати антропогенний вплив на озоновий шар, флору та фауну, генофонд та інші компоненти навколишнього середовища.

Інформаційна складова державної економічної безпеки у випадку наявних внутрішніх та зовнішніх зв'язків передбачає таку економічну діяльність, внаслідок якої надійність обміну інформацією, збільшення частки нематеріальних активів у національне багатство.

Відповідно до розглянутих складових виділяють внутрішні та зовнішні загрози економічній безпеці держави, які зумовлюють недостатній рівень стабільності економіки, а як наслідок і відповідно зниження рівня економічної безпеки будь-якої держави. До зовнішніх загроз слід віднести наступні: нестабільність національної валюти, що відбувається під час нестабільної ситуації в економіці, в період кризи; скорочення іноземних інвестицій; нестабільні умови зовнішньої торгівлі; великий зовнішній борг, що є тягарем для нашої країни та депресивно впливає на розвиток економіки; залежність держави в сфері стабільності постачання енергоносіїв тощо.

До основних внутрішніх загрозам слід віднести: незначну частку інноваційної продукції; неефективне державне регулювання економіки, тобто невідповідність завданням економічного зростання; низьку конкурентоспроможність продукції; корупцію; невисокий рівень життя більшої частини населення, як наслідок нерівномірності розвитку територій, поширення масштабів незайнятості, вплив світо- 


\section{Hbur Zoriana}

вої фінансової кризи і т. д.; витік капіталу за кордон також є фактором, який чинить певний вплив на економічну безпеку тощо.

Як зауважує Притула Н.В. [3], узагальнення зарубіжного досвіду показує, що забезпечення економічної безпеки у масштабах національної економіки істотно впливає на міжнародний авторитет країни. У свою чергу Мельник В.І. [2] додає, що більшість стратегій національної безпеки держав оріснтована на забезпечення національної та економічної безпеки через проведення радикальних економічних реформ, тісну інтеграцію до світових та європейських систем безпеки, приєднання до економічних і політичних союзів та організацій. У зв'язку з цим застосування позитивного досвіду зарубіжних країн щодо забезпечення економічної безпеки має стати одним з найважливіших напрямків розвитку національної економіки України. Розглянемо основні підходи до забезпечення економічної безпеки у країнах Європи (див. табл. 1).

Таким чином, у кожній країні сформовано власне уявлення про економічну безпеку і відповідно про методи іiі забезпечення, які можуть бути спрямовані на досягнення національних, суспільних інтересів або на стійкість економічного розвитку, або на незалежність національної економіки від зовнішнього ринку. Пугач О.А. [8] також підкреслює, що спільною характеристикою та основою представлених систем економічної безпеки в різних країнах $\epsilon$ нормативно-правова база з регулювання внутрішніх та зовнішньо-економічних операцій, в тому числі стосовно участі іноземного капіталу в національній економіці, а також інституціональне забезпечення захисту національних економічних інтересів в умовах міжнародної інтеграції.

Основним показником, який характеризує рівень економічної безпеки за умови його підвищення $є$ індекс економічної конкурентоспроможності. Відповідно до розглянутої характеристики проаналізуємо індекси глобальної економічної конкурентоспроможності вище загаданих країн у 2016-2017 pp.

Відповідно до наведених даних у табл. 2 можемо констатувати факт, що обрані напрямки забезпечення економічної безпеки у країнах Європи здебільшого позитивно впливають на рівень економічної конкурентоспроможності цих країн. Зокрема, зайняли вищий рівень у рейтингу такі країни як: Німеччина, індекс економічної конкурентоспроможності якої зріс на 0,04 пункти, Франція - 3,07 пунктів, Велико- 


\section{Порівняльна характеристика підходів до забезпечення економічної безпеки у країнах Свропи}

\begin{tabular}{|c|c|}
\hline Країна & Характеристика \\
\hline \multicolumn{2}{|c|}{ I. Країни Західної Свропи,у т.ч.: } \\
\hline Німеччина & $\begin{array}{l}\text { Спеціальна законодавча база щодо забезпечення ЕБ відсутня. } \\
\text { Основні питання з цієї проблеми відображаються в директивах } \\
\text { Міністерства оборони, які регламентують найважливіші сфери } \\
\text { ринкової діяльності та визначають контрольні функції держави. } \\
\text { Використовуються методи щодо забезпечення ЕБ, які спрямовані на } \\
\text { підтримку цивілізованих ринкових відносин, забезпечення еконо- } \\
\text { мічного і соціального прогресу, недопущення монополізму в окре- } \\
\text { мих галузях, створення умов для справедливої конкуренції та ста- } \\
\text { більності національної валюти, захист від економічного шантажу. }\end{array}$ \\
\hline Франція & $\begin{array}{l}\text { Спеціальна законодавча база щодо забезпечення ЕБ відсутня. Окремі } \\
\text { положення щодо ЕБ (створення умов для підвищення національного } \\
\text { добробуту і зміцнення економічного потенціалу країни) відображені } \\
\text { в Законі «Про національну безпеку». Методи щодо забезпечення ЕБ } \\
\text { спрямовані на зниження вразливості господарської системи країни, } \\
\text { збереження самостійності зовнішньої політики, усунення диспро- } \\
\text { порцій у рівні економічного розвитку суб'єктів господарювання; } \\
\text { недопущення надмірної зовнішньої залежності в найважливіших } \\
\text { секторах економіки, мінімізацію ризиків, пов'язаних із залежністю } \\
\text { від зовнішнього світу. }\end{array}$ \\
\hline $\begin{array}{l}\text { Велико- } \\
\text { британія }\end{array}$ & $\begin{array}{l}\text { Спеціальна законодавча база щодо забезпечення ЕБ відсутня. } \\
\text { Окремі норми, які регламентують ЕБ, містяться у нормативно-пра- } \\
\text { вових актах у сфері оборонної політики. Вони грунтуються на оцін- } \\
\text { ках національних інтересів і реалізуються через їх захист. Методи } \\
\text { щодо забезпечення ЕБ пов'язані з прогнозуванням і запобіганням } \\
\text { найбільш небезпечних зовнішніх і внутрішніх ризиків. При виро- } \\
\text { бленні та реалізації рішень, що відносяться до забезпечення ЕБ, } \\
\text { акцент робиться на спеціалізовані організації, що представляють } \\
\text { інтереси промисловців і підприємців. }\end{array}$ \\
\hline Іспанія & $\begin{array}{l}\text { Законодавча база щодо забезпечення ЕБ відрізняється гнучкістю, } \\
\text { в ній чітко визначено функції органів управління та організацій } \\
\text { у даній сфері, якими розробляються спеціальні програми еконо- } \\
\text { мічного розвитку. Нормативно-правові акти щодо забезпечення } \\
\text { ЕБ пов'язані з відповідним законодавством СС. Методи щодо } \\
\text { забезпечення ЕБ захищають інтереси пріоритетних галузей про- } \\
\text { мисловості, а також спрямовані на стимулювання інвестицій, } \\
\text { забезпечення валютного контролю, на розробку законодавства про } \\
\text { акціонерні товариства. }\end{array}$ \\
\hline
\end{tabular}


Закінчення таблиці 1

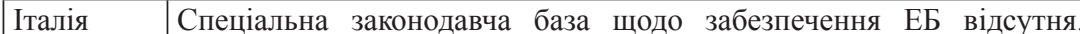
У діяльності по забезпеченню ЕБ Італія керується укладеними нею міжнародними угодами. Методи щодо забезпечення ЕБ спрямовані насамперед на захист інтересів національних виробників на внутрішньому і зовнішньому ринках.

П. Країни Центральної Свропи, у т.ч.:

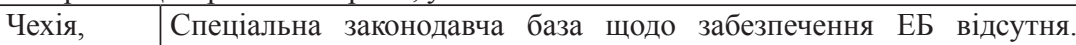
Болгарія, Забезпечення ЕБ орієнтується на відповідні нормативно-правові Угорщина, акти СС. При виборі методів забезпечення ЕБ країни враховують Польща, геополітичну ситуацію, вектор і стратегію розвитку економіки відСловакія повідно до тенденцій регіонального та світового еволюційного процесу, напрямок економічних реформ.

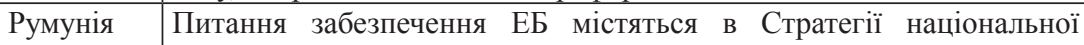
безпеки. Основними напрямами забезпечення ЕБ є: здійснення ефективних заходів макроекономічної стабілізації, прискорення структурних реформ в економіці, створення приватного сектора, залучення іноземних інвестицій та підтримка малого і середнього бізнесу; узгодження фінансово-економічного законодавства, фінансової, економічної і митної політики із законодавством ЄС тощо.

Ш. Країни Східної Свропи, у т.ч.:

Російська $\quad$ Забезпечення ЕБ регулюють Концепція національної безпеки РФ; Федерація Державна стратегія економічної безпеки РФ; Закон РФ «Про безпеку». Відмінною рисою законодавства $є$ наявність у ньому регіонального аспекту та положень про формування критеріїв і показників оцінки стану економічної безпеки. Методи забезпечення ЕБ зорієнтовані на реалізацію економічних реформ на найближчу перспективу, зменшення небезпеки зростання нерівномірності соціально-економічного розвитку регіонів.

Республіка Законодавчо ЕБ відображається у Концепції національної безпеки Білорусь Білорусі. До пріоритетних напрямків забезпечення ЕБ відносяться: розвиток системи економічних відносин, створення механізмів розв'язання виникаючих у суспільстві протиріч та скасування передумов їх виникнення; розробка стратегії забезпечення реалізації життєво важливих економічних інтересів у країні; формування довгострокової програми економічних перетворень; забезпечення сталого соціально-економічного розвитку; використання неінфляційних методів фінансування дефіциту бюджету та ефективний перерозподіл фінансових ресурсів; удосконалення зовнішньоекономічної політики; створення сприятливих умов для підприємницької діяльності та ін.

Латвія, Спеціальна законодавча база щодо забезпечення ЕБ відсутня. Литва, Забезпечення ЕБ орієнтується на відповідні нормативно-правові Естонія акти СС. Методи забезпечення ЕБ спрямовані насамперед на реалізацію фінансово-економічної безпеки.

Джерело: складено автором на основі [1; 6] 
Economic security of the state: experience of developed countries of the...

Таблиця 2

Динаміка індексу глобальної економічної конкурентоспроможності європейських країн у 2016-2017 pp.

\begin{tabular}{|c|c|c|c|c|c|c|}
\hline \multirow[t]{2}{*}{ Країна } & \multicolumn{2}{|c|}{ 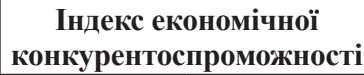 } & \multicolumn{2}{|c|}{$\begin{array}{c}\text { Місце у } \\
\text { рейтингу }\end{array}$} & \multicolumn{2}{|c|}{$\begin{array}{c}\text { Абсолютне } \\
\text { відхилення, +/- }\end{array}$} \\
\hline & 2016 & 2017 & 2016 & 2017 & I e.к. & $\mathbf{R}$ \\
\hline \multicolumn{7}{|c|}{ I. Країни Західної Європи,у т.ч.: } \\
\hline Німеччина & 5,53 & 5,57 & 5 & 4 & 0,04 & -1 \\
\hline Франція & 2,13 & 5,20 & 22 & 21 & 3,07 & -1 \\
\hline Великобританія & 5,43 & 5,49 & 10 & 7 & 0,06 & -3 \\
\hline Іспанія & 4,59 & 4,68 & 33 & 32 & 0,09 & -1 \\
\hline Італія & 4,46 & 4,50 & 43 & 44 & 0,04 & 1 \\
\hline \multicolumn{7}{|c|}{ II. Країни Центральної Європи, у т.ч.: } \\
\hline Чехія & 4,69 & 4,72 & 31 & 31 & 0,03 & 0 \\
\hline Болгарія & 4,32 & 4,44 & 54 & 50 & 0,12 & -4 \\
\hline Угорщина & 4,25 & 4,20 & 63 & 69 & $-0,05$ & 6 \\
\hline Польща & 4,49 & 4,56 & 41 & 36 & 0,07 & -5 \\
\hline Словакія & 4,22 & 4,28 & 67 & 65 & 0,06 & -2 \\
\hline Румунія & 4,32 & 4,30 & 53 & 62 & $-0,02$ & 9 \\
\hline Україна & 4,03 & 4,00 & 79 & 85 & $-0,03$ & 6 \\
\hline \multicolumn{7}{|c|}{ III. Країни Східної Свропи, у т.ч.: } \\
\hline $\begin{array}{l}\text { Російська } \\
\text { Федерація }\end{array}$ & 4,44 & 4,51 & 45 & 43 & 0,07 & -2 \\
\hline Латвія & 4,45 & 4,45 & 44 & 49 & 0 & 5 \\
\hline Литва & 4,55 & 4,60 & 36 & 35 & 0,05 & -1 \\
\hline Естонія & 4,74 & 4,78 & 30 & 30 & 0,04 & 0 \\
\hline
\end{tabular}

Джерело: складено автором на основі [7]

британія - 0,06 пунктів, Іспанія - 0,09 пунктів, Болгарія - 0,12 пунктів, Польща - 0,07 пунктів, Російська Федерація - 0,07 пунктів та Литва на 0,05 пунктів. Однак ряд інших країн погіршили значення даного показника та зменшили свій рейтинг, а саме: Угорщина, індекс економічної конкурентоспроможності якої зменшився на 0,05 пунктів та Румунія - 0,02 пункти.

\section{3. Забезпечення економічної безпеки у розвинутих країнах світу}

У Великобританії економічна безпека $є$ частиною оборонної політики, яка направлена на дотримання національних інтересів. Національні інтереси у сфері економіки - це господарські інтереси 


\section{Hbur Zoriana}

всього суспільства, пріоритетні відносно інших форм суспільних інтересів [6].

Розподіл загроз економічній безпеці країни на зовнішні та внутрішні дозволяє виокремлювати найбільш вірогідні і найбільш важливі з них, і спрямовувати зусилля на їх подолання. Максимальне сприяння надається приватному бізнесу, ефективний розвиток якого має забезпечити національну економічну безпеку.

3 метою забезпечення ефективної взаємодії між парламентом, урядом і великим бізнесом у Великобританії створена система інститутів, яка дозволяє розробляти і реалізовувати рішення національної ваги щодо економічної безпеки. До цієї системи входять Конфедерація британської промисловості, Рада торгівлі зі Східною Європою, ряд спеціалізованих організацій, які представляють інтереси промисловців та підприємців [6].

В Іспанії необхідність забезпечення економічної безпеки держави визначено нормативними актами. Зокрема, здійснено чіткий розподіл компетенції у цій сфері серед міністерств та відомств. Законодавчо затверджується програма економічних пріоритетів на кожен етап розвитку економічної сфери. Створені спеціальні державні служби контролю виконання програми. Загалом економічна безпека в Іспанії формується відповідно до завдань ії забезпечення у Євросоюзі. Стійкий розвиток економіки Іспанії забезпечують пріоритетні галузі національної економіки, які перебувають під захистом державної протекціоністської політики. Для цього призначений спеціальний закон «Про вдосконалення і захист національної промисловості», який визначає митні тарифи, порядок залучення іноземних технологій, пріоритет національних товарів у торгівлі. На державному рівні регулюються процедури стимулювання інвестицій в економіку, валютні процедури, діяльність акціонерних товариств, створення захисних бар'єрів для певних галузей.

В Іспанії діяв закон про іноземні інвестиції, в якому визначалися сфери, куди не допускався іноземний капітал (засоби масової інформації, об'єкти оборони), сектори економіки з обмеженим доступом іноземного капіталу (банківська діяльність, стратегічні галузі, туризм), відкриті сектори економіки (виробництво продовольчих товарів, автомобільна промисловість) [7].

У таких західноєвропейських країнах як Данія, Бельгія, Нідерланди, Люксембург основною стратегічною ціллю щодо захисту наці- 
ональних економічних інтересів є забезпечення стійкого економічного зростання і модернізація економіки відповідно до умов конкуренції на світовому ринку [5].

У «нових» країнах Євросоюзу, зокрема, Чехії, Словакії, Словенії, Польщі основні засади економічної безпеки тісно пов'язані з економічними інтересами Євросоюзу. Відповідно, завдання забезпечення економічної безпеки включають базові кількісні показники розвитку, коректовані для кожної країни. Усі економічні реформи мають на меті зближення національних інтересів з європейськими.

3 початку становлення вільних національних економік у цих країнах була обрана подібна модель забезпечення економічної безпеки. Можна вважати, що вони успішно подолали проблеми формування демократичних і ринкових інституцій. Чехія, Словенія і Словакія взагалі наближуються в економічному розвитку до таких «старих» країн Євросоюзу, як Греція, Іспанія, Португалія.

На сучасному етапі розвитку напрями економічної політики національної безпеки Чехії: забезпечення економічного зростання, розвиток економіки та міжнародного співробітництва; підтримка внутрішньої та зовнішньої стабільності; протидія інфляційним стрибкам; підтримка позитивного сальдо зовнішньої торгівлі; ефективне ринкове регулювання в економічній та фінансовій сферах; боротьба зі злочинністю [5].

Сучасні зовнішні загрози Польщі в економічній сфері пов'язані 3 економічною нестабільністю країн на східному рубежі. Після надання безвізового режиму Україні значно загострилася проблема трудової міграції, яка може порушити соціально-економічну стабільність країни. Разом з тим невизначеними стають фінансово-економічні ризики. Відповідно, потребують корективи положення «Стратегія безпеки Республіки Польща» [9].

Основні аспекти забезпечення економічної безпеки в приєднаних країнах-членах Європейського Союзу визначені в стратегіях нацбезпеки.

Японський підхід до проблеми забезпечення економічної безпеки базується на таких принципах:

- розвиток економічного потенціалу країни;

- формування та утримання економічних переваг країни у світі;

- формування такого глобального середовища, що сприятиме максимальній реалізації національних інтересів. 


\section{Hbur Zoriana}

В Японії доктрина національних інтересів включає три головні аспекти: суспільна безпека (внутрішній соціальний аспект), національна безпека (військовий аспект), мир і глобальна стабільність у світі (зовнішньополітичний аспект).

Політика національної економічної безпеки Японії вкінці минулого століття була спрямована на приведення іiї зовнішньополітичної ролі у світі у відповідність з їі економічним потенціалом [10, с. 38]. Після досягнення цієї мети Японія у сфері економічної безпеки концентрується на створенні зовнішніх умов безпечного функціонування та розвитку власної економіки у сучасному глобалізованому світі.

Сучасні пріоритети політики економічної безпеки Японії: високий рівень конкурентоспроможності експорту, підвищення продуктивності праці, диверсифікування сировинних, паливно-енергетичних і продовольчих ресурсів, забезпечення завдяки цьому їх стабільного надходження, розширення співробітництва 3 «корисними» (стратегічно важливими) державами. В результаті реалізації такої політики економічна могутність Японії зміцнюється, економічна безпека зростає.

Суттєвим елементом забезпечення економічної безпеки Японії $є$ нарощення науково-технічного потенціалу. Держава здійснює політику заохочення використання наукомістких технологій, фінансування науково-дослідних та дослідно-конструкторських робіт (НДДКР). Така політика характерна для всіх високорозвинених країн світу (рис. 2).

У США 3 метою вжиття відповідних заходів щодо забезпечення економічної безпеки президентом у грудні 1990р. був завтерджений меморандум, у якому викладався основний зміст Національної програми забезпечення економічної безпеки. Результатом розробки програми вкінці 1993 року стало створення єдиної в масштабах країни і взаємозалежної у всіх іiі елементах централізованої системи економічної безпеки, спрямованої на збереження лідерства США в технологічних областях і забезпечення економічних інтересів країни [9, с. 51].

Детальним опрацюванням програми і визначенням механізму іiі впровадження в практику займалась Міжвідомча робоча група представників уряду і промисловості, у яку входили заступник міністра оборони, міністр енергетики, заступник директора ЦРУ, представники ФБР і АНБ, керівники провідних фірм і компаній, загальною чисельністю 260 осіб. 


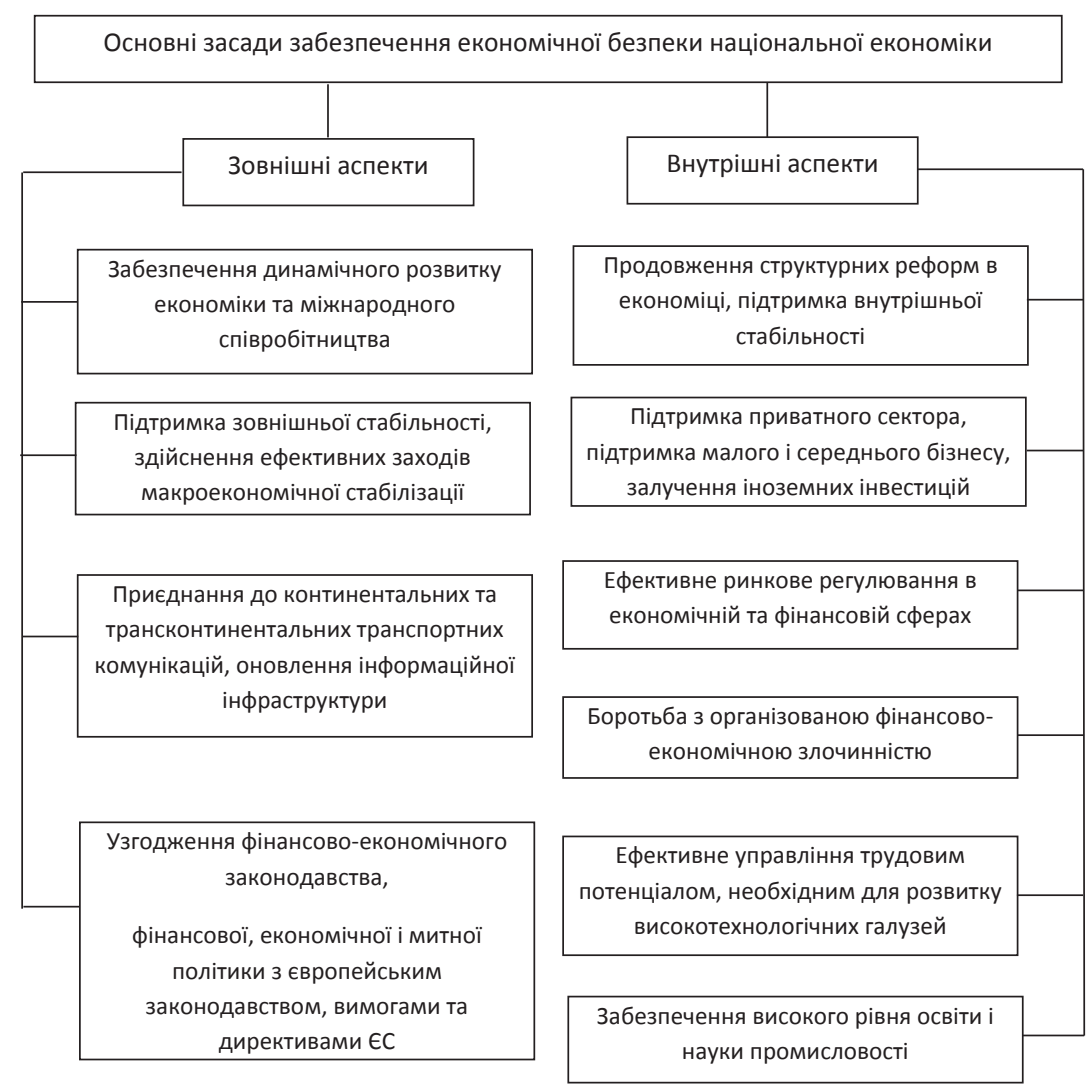

\section{Рис. 2. Частка витрат на НДДКР (\% до ВВП) і обсяг ВВП (тис. дол. на душу населення) у розвинутих країнах світу та Украйні Джерело: складено за [11]}

Вказаною міжвідомчою групою визначені параметри загальної політики в області економічної безпеки і її сучасні критерії, відповідно д яких засновуються вихідна $з$ єдиного центра система управління i єдиний порядок контролю й звітності: вводяться в дію заходи, що забезпечують постійну оцінку діяльності персоналу, що має допуск до таємної інформації, для того щоб вчасно виявити осіб, потенційно уразливих для вербальної розробки іноземними спецслужбами. Цією ж групою вироблено методологію для визначення вартості всіх заходів 


\section{Hbur Zoriana}

щодо забезпечення економічної безпеки, вводиться в дію система відстеження й оцінки щорічних витрат. Розроблено механізм управління системою забезпечення економічної безпеки, запропоновані проекти нових інструкцій та директивів, внесені зміни в систему підготовки і перепідготовки кадрів, забезпечені можливості підвищення по службі урядових чиновників, що займаються питаннями економічної безпеки. Адміністрація США підтвердила пріоритетне значення заходів економічної безпеки. Проблема захисту таємниць у сфері економіки піднята у США до рівня проблеми Національної безпеки і як така стоїть під контролем у Президента і Ради національної безпеки [9, с. 18-19].

У Японії, одній з провідних країн сучасного світу, до теперішнього часу діє концепція Комплексного забезпечення національної безпеки. Цей програмний документ був розроблений групою японських експертів і схвалений Кабінетом міністрів ще у 1980p. і з цього часу служить концептуальною основою політики правлячих кіл Японії у всіх областях, особливо у забезпеченні економічної безпеки. Згідно з концепцією основою забезпечення економічної безпеки $є$ захист від будь-яких форм та прояві зовнішніх загроз. Забезпечення економічної безпеки в Японії здійснюється вжиттям комплексу заходів, спрямованих на усунення загроз, а також на протидію тим загрозам, усунення яких поки що неможливо з тих чи інших причин [9].

У Великобританії основні аспекти забезпечення національної безпеки регламентуються, в основному, таємними директивами уряду, розпорядженнями й інструкціями відповідних міністерств. У Великобританії немає єдиної програми забезпечення економічної безпеки, однак окремі іiі аспекти відображені в ряді законів, зокрема у законах про захист державних таємниць. Забезпечення режиму таємності на промислових підприємствах Великобританії здійснюється службами безпеки відповідних міністерств, що разом 3 англійською контррозвідкою, розробляють свої правила охорони таємниць і вирішують питання допуску співробітників до роботи із таємними матеріалами. Разом $з$ контрактом кожна фірма отримує так званий лист про таємні аспекти [10, с. 34].

У Франції питання забезпечення економічної безпеки відображені у Законі про національну безпеку 1964p. Крім того, існує ряд декретів і розпоряджень президента країни і прем'єр-міністра. У ФРН діяльність спеціальних служб по забезпеченню економічної безпеки рег- 
ламентована низкою законів, постанов і настанов. Однак єдиної програми забезпечення економічної безпеки у ФРН не розроблено. Лише iii окремі положення існують у прийнятому бундестагом законі про охорону конституції, якому визначений порядок захисту таємниць на режимних підприємствах.

Для країн-членів СНД характерне відокремлення економічної складової серед сфер національної безпеки, підвищена увага приділяється внутрішнім чинникам економічних небезпек та чіткій систематизації за сферами національної безпеки. Світовий досвід розв'язання проблем економічної безпеки переконливо свідчить про необхідність удосконалення концептуального забезпечення економічної безпеки у зовнішньоекономічній сфері України, використання позитивних ознак глобалізації для цілей суспільного розвитку держави та пріоритетності забезпечення національних економічних інтересів при формуванні зовнішньої та внутрішньої політики.

Досвід країн Центральної і Східної Свропи базується на орієнтації процесу забезпечення економічної безпеки через проведення радикальних економічних реформ, тісну інтеграцію у світові та європейські системи безпеки, приєднання до економічних і політичних союзів та організацій.

\section{4. Методологія дослідження}

Методологічну основу статті становлять загальнонаукові прийоми дослідження і методи, що грунтуються на сучасних наукових засадах управлінської, юридичної і споріднених із ними наук.

У роботі використано такі методи:

- системний підхід - для дослідження і формулювання поняття економічна безпека, система економічної безпеки та загрози економічній безпеці України;

- метод аналізу і синтезу - для аналізу та опису динаміки індексу глобальної економічної конкурентоспроможності європейських країн у 2016-2017 pp.;

- монографічний - для опису зарубіжного досвіду забезпечення економічної безпеки;

- логічний метод - для дослідження еволюції постановки проблеми й наступності іiі вирішення, для встановлення зв'язків між суспільними явищами та подіями. 


\section{Hbur Zoriana}

\section{5. Пошуки}

Здійснивши аналіз систем економічної безпеки країн 3 найвищим економічним розвитком можна дійти до висновку, що найбільш ефективними $є$ системи забезпечення економічної безпеки в таких країнах Європейського Союзу, як Німеччина, Франція, Великобританія, Італія та Іспанія. Особливості державної політики у даних країнах зорієнтовані у напрямку підвищення рівня ефективності різних сфер національної економіки, при цьому дані країни за пріоритетну ціль ставлять дотримання високого рівня безпеки.

Серед нових країн, які приєдналися до Європейського союзу, а саме: Болгарії, Польщі, Румунії, Словаччини, Чехії, Угорщини відбувається завершення реформи системи забезпечення економічної безпеки держави.

\section{6. Висновки з дослідження}

Механізм державного управління процесом забезпечення економічної безпеки історично сформувався в Україні у складі СРСР у межах державної безпеки, був іiі підсистемою, який не відокремлювався і окремо не визначався у концептуальних, законодавчих та програмних документах.

Правові передумови формування економічної безпеки України були закладені Декларацією про державний суверенітет України, Законом УРСР «Про економічну самостійність України», Конституцією України Закону України «Про основи національної безпеки України».

Проведений аналіз результатів наукових досліджень вітчизняних і зарубіжних фахівців та практики державного управління дозволяє зробити висновок, що теоретична база концептуальних основ економічної безпеки має на сьогодні все ще недостатній ступінь розробленості. Існують значні розбіжності у підходах до визначення сутності та понятійного апарату механізму державного управління економічною безпекою країни.

Опрацювання теоретичних основ економічної безпеки надало можливість систематизувати вимоги щодо формування сутності, змісту, структури економічної безпеки держави. Вони повинні містити орієнтири та цілі системи державного управління з можливостями кількісного виміру іiі рівня, а також обумовлювати механізми забезпечення економічної безпеки України. Визначення економічної безпеки 
повинно враховувати вимоги чинної системи національної безпеки України, бути органічно вбудованою підсистемою, бути стислим i ємним.

Теоретичні узагальнення сутності категорії «економічні інтереси» визначають їх спрямованість на одержання економічних переваг особи, суспільства і держави, забезпечення умов існування й розвитку, економічної незалежності і збагачення. Підставою для формування загроз економічній безпеці є фактори або умови, стан або тенденції, цілеспрямована, випадкова, помилкова діяльність або бездіяльність.

Правове забезпечення економічної безпеки України недостатнє. Адресні нормативно-правові документи - концепція, стратегія, державна програма економічної безпеки - розробляються в державі впродовж восьми років та й досі залишаються не прийнятими. Суттєві недоліки має чинне законодавство, спрямоване на забезпечення економічної безпеки. У Концепції національної безпеки України відсутня збалансованість у структурі та у співвідношенні пріоритетних економічних інтересів, економічних загроз, основних напрямів забезпечення економічної безпеки. Вирішення складних завдань сучасного державотворення потребує врахування світового досвіду розв'язання проблем забезпечення економічної безпеки, переймання з нього позитивних елементів та попередження негативних.

Таким чином, економічна безпека держави - це система, що складається з взаємопов'язаних та комплементарних елементів (компонентів), а рівень економічної безпеки держави залежить від безпеки кожної з них. Крім того, ми вважаємо, що всі дискусії, в яких йдеться про те, що одне з вищезазначених компонентів $є$ більш-менш важливим, і більшу увагу слід приділити державній безпеці. Державна економічна безпека є складною концепцією, і вся безпека пов'язана 3 окремими рівнями безпеки своїх компонентів. Тому головним завданням держави є забезпечення належного рівня безпеки для кожного компоненту державної економічної безпеки, через який буде забезпечена державна економічна безпека. Слід також зазначити, що постійні зміни у світі, що відбуваються навколо політичних, економічних, соціальних, військових та інших питань, також змінюють характер і зміст загроз економічної безпеки, і вони вимагають одночасних та одночасних змін у політиці державна економічна система безпеки. 


\section{Hbur Zoriana}

\section{Список літератури:}

1. Деренуца, А.С. Анализ опыта стран Европейского союза в сфере обеспечения национальной экономической безопасности [Електронний pecypc] / Портал : Global international scientific analytical project. - Режим доступу: http://gisap.eu/ru/node/172.

2. Мельник В. І. Зарубіжний досвід забезпечення економічної безпеки держави (на прикладі країн Східної та Центральної Європи) / В. І. Мельник // Науковий вісник Академії муніципального управління. Серія : Право. - 2015. Вип. 1 (2). - С. 50-57.

3. Данилишин Б.М. Безпека регіонів України і стратегія ії гарантування: Б.М. Данилишин, А.В. Степаненко, О.М. Ральчук та ін. / за ред. д-р екон. наук, проф., чл.-кор. НАН України Б.М. Данилишина. - К. : Вид-во «Наук, думка». 2008. - T. 1. -392 c.

4. Желюк Т. Економічна безпека в системі інституційного вектора збалансованого розвитку [Текст] / Тетяна Желюк // Вісник Тернопільського національного економічного університету. - 2013. - Вип. 1. - С. 19-32.

5. Левчук О.В. Економічна безпека України в контексті глобалізаційних викликів. Економіка і суспільство. 2017. Випуск № 8, с. 59-64.

6. Матвійчук I. О. Інституціоналізація управління економічною безпекою держави / I. О. Матвійчук // Вісник Академії митної служби України. Сер. : Економіка. - 2012. - № 2. - С. 131-141.

7. Притула Н. В. Досвід забезпечення економічної безпеки в зарубіжних країнах / Н. В. Притула // Економіка та управління національним господарством: стан, тенденції та перспективи: Тези доп. I Міжн. наук.-практ. конф. Одеса: Пальміра, 2014. - С. 41-44.

8. Пугач О.А. Світовий досвід упередження загроз економічній безпеці національної економіки / О.А. Пугач // Науковий вісник Херсонського державного університету. - Випуск 12. (Ч. 3). - 2015. - С. 43-46.

9. Скорук О. В. Економічна безпека держави: сутність, складові елементи та проблеми забезпечення / О. В. Скорук // Науковий вісник Ужгородського національного університету. Серія : Міжнародні економічні відносини та світове господарство. - 2016. - Вип. 6(3). - С. 39-42.

10. Ocepek A. Economic Security and the European Dream [Електронний pecypc] / Anthony Louis Ocepek // Портал : Saint Anselm College. - Режим доступу: http://www.anselm.edu/Documents/NHIOP/Global\%20Topics/2010/ Ocepekpaper.pdf.

11. Schwab K. The Global Competitiveness Report / K. Schwab // World Economic Forum. $-2017 .-400$ p.

\section{References:}

1. Derenutsa, A.S. Analysis of European Union experience in the field of national economic security [Electronic resource], Portal: Global international scientific analytical project, available at: http://gisap.eu/ru/node/172.

2. Mel'nyk V. I. (2015) Foreign experience in providing economic security to the state (for example, the countries of Eastern and Central Europe), Naukovyj visnyk Akademii munitsypal'noho upravlinnia. Seriia : Pravo, vol. 1 (2), pp. 50-57. 
3. Danylyshyn B.M. (2008) Bezpeka rehioniv Ukrainy i stratehiia ii harantuvannia [The security of the regions of Ukraine and the strategy of its guarantee], Naukova dumka, Kyiv, Ukraine.

4. Zheliuk T. (2013) Economic security in the system of the institutional vector of balanced development, Visnyk Ternopil's'koho natsional'noho ekonomichnoho universytetu, vol. 1, pp. 19-32.

5. Levchuk O. V. (2017) Ukraine's economic security in the context of globalization challenges, Ekonomika i suspil'stvo, vol. 8, pp. 59-64.

6. Matvijchuk I. O. (2012) Institutionalization of the management of the economic security of the state, Visnyk Akademii mytnoi sluzhby Ukrainy. Ser. : Ekonomika,, no. 2, pp. 131-141.

7. Prytula N. V. (2014) Experience in providing economic security in foreign countries, Ekonomika ta upravlinnia natsional'nym hospodarstvom: stan, tendentsii ta perspektyvy: Tezy dop. I Mizhn. nauk.-prakt. konf, pp. 41-44.

8. Puhach O.A. (2015) Critical experience in preventing threats to the economic security of the national economy, Naukovyj visnyk Khersons'koho derzhavnoho universytetu, vol. 12(3), pp. 43-46.

9. Skoruk O. V. (2016) Economic security of the state: the essence, constituent elements and problems of provision, Naukovyj visnyk Uzhhorods'koho natsional'noho universytetu. Seriia : Mizhnarodni ekonomichni vidnosyny ta svitove hospodarstvo, vol. 6(3), pp. 39-42.

10. Ocepek A. Economic Security and the European Dream, Sen-Ansel'm koledzh. URL: http://www.anselm.edu/Documents/NHIOP/Global\%20Topics/ 2010/Ocepekpaper.pdf.

11. Schwab K. (2017) The Global Competitiveness Report, World Economic Forum, p. 400. 


\title{
EXPEDIENCY OF USING THE STAKEHOLDER'S APPROACH FOR ACHIEVING THE SYSTEM STABILITY OF THE PROCESS OF FOOD SECURITY
}

\author{
ДОЦІЛЬНІСТЬ ЗАСТОСУВАННЯ \\ СТЕЙКХОЛДЕРСЬКОГО ПІДХОДУ ДЛЯ ДОСЯГНЕННЯ \\ СТАНУ СИСТЕМНОЇ СТАБІЛЬНОСТІ ПРОЦЕСУ \\ ПРОДОВОЛЬЧОГО ЗАБЕЗПЕЧЕННЯ
}

\section{Hlubish Lesia ${ }^{1}$}

DOI: http://dx.doi.org/10.30525/978-9934-571-28-2_8

\begin{abstract}
There is a need for eliminating disparities, characteristic for the modern model of functioning of the sphere of food supply, which must guarantee food security in order to preserve food independence, which is a prerequisite for sustainable economic development of the country. It is necessary to use an integrated approach, which would allow to identify ways to optimize the effectiveness of market interaction for all stakeholders as a system-forming component of the sphere of food provision.

Often, the concepts of "food provision" and "food security" are identified, in fact the second category is the result of and the first - the process, aimed at achieving this result. Therefore, the purpose of this scientific study is to clearly delineate the definitions "food provision" and "food security" and proving of their cause-effect relationship, also definition of the concept of the category "sphere of food provision". And on this theoretical basis prove the feasibility of stakeholder approach, the tools of which will help to identify the causes of imbalance of tripartite market interaction and outline the necessary steps to balance economic interests of stakeholders of the sphere of food provision to optimize the economic effect of their market interactions.

According to the results of the study, it was established, that food provision is an action aimed at achieving the result - food security. The essence of the concept of the sphere of food supply is also disclosed from the standpoint of the stakeholders' interaction environment. The expediency of using

\footnotetext{
${ }^{1}$ Candidate of Economic Sciences, Associate Professor, Associate Professor of Technology Management Department, Lviv Polytechnic National University, Ukraine
} 
the stakeholder approach is substantiated a convenient and effective tool to ensure food security, which allows to determine the mission, strategic goal and tactical goal of the functioning of the food provision sphere, as well as its subjective-functional components. The emphasis is placed on the fact, that when formulating the purpose and objectives of economic activity, each subject of market relations should be guided by the general mission of functioning of the sphere of food provision.

It is revealed that the paradigm of values serves as the dominant factor in determine of the targets stakeholders which are regulators of their behavior in the market interaction. Values and goals in aggregate influence the formation of interests of interested parties. In order to harmonize economic relations and problem solving confrontation and different orientations of aspirations about obtaining economic benefit between the sides of market interaction, it is necessary to balance the interests of stakeholders, based on the results of the force field analyses achieving of the system stability of the food provision process, that allows you to define a clear threat and to build an appropriate system of priorities for strategic development of food provision in a concrete perspective.

It was established, that the main effect of interaction of sphere of food provision stakeholders is to achieving the status of systemic stability process of the food provision of the population of our country in order to preserve the health of the nation.

\section{1. Ветуп}

Розвиток людської цивілізації на пряму залежить від продуктивної діяльності людини, тому продовольчому фактору завжди відводилась важлива роль. Динамічність сучасного життя характеризується недостатніми обсягами середньодушового споживання продуктів харчування та невідповідністю енергетичного вмісту добових раціонів, що призвело до зростання смертності, загальної захворюваності та скорочення тривалості життя населення. Поряд зі зниженням технологічних якостей спостерігається погіршення харчової цінності продовольства, в результаті споживання якого організм людини недоотримує необхідних макро- та мікроелементів, що призводить до формування, так званого, «прихованого голоду». Тобто навіть за умови кількісно достатнього споживання продуктів харчування із допустимою енергетичною цінністю споживач недоотримує з їжею низку життєво необ- 


\section{Hlubish Lesia}

хідних речовин. Попри скорочення чисельності населення таке явище $\epsilon$ основною причиною зростаючих потреб у продовольстві. У свою чергу, зростаючі обсяги споживання спонукають до збільшення обсягів виробництва, проте таких же бідних на вітаміни продуктів, реалізація яких приносить виробнику неабияку економічну вигоду. Таке явище спровоковане низьким рівнем купівельної спроможності, через що поряд із дієтичною неповноцінністю існує проблема фізичної та економічної доступності продуктів харчування. Усе це свідчить про розбалансованість ринкової взаємодії виробника і споживача, зумовленої невтручанням держави та вимагає виявлення й дослідження чинників, що провокують загальне відчуття продовольчого неблагополуччя для левової частки населення України.

В умовах окреслених загроз продовольчій безпеці постає проблема збереження здорового генофонду нації. Обов'язковою умовою ï вирішення $є$ усунення диспропорцій, характерних для сучасної моделі функціонування сфери продовольчого забезпечення, покликаної гарантувати продовольчу безпеку задля збереження продовольчої незалежності - обов'язкової умови стійкого економічного розвитку країни. Виникає потреба у впровадженні комплексного підходу, який би гарантував оптимальну ефективність ринкової взаємодії для усіх заінтересованих сторін як системо-утворюючого компонента сфери продовольчого забезпечення. Осмислення проблеми обумовлює доцільність застосування стейкхолдерського підходу, практичний інструментарій якого, враховуючи вітчизняні особливості продовольчого забезпечення та вплив заінтересованих сторін, дозволить виявити причини дисбалансу їх економічних інтересів, що знаходять відповідне відображення в економічних ефектах від їх ринкової взаємодії.

У науковій літературі зустрічаються поодинокі праці, де робляться спроби застосовувати стейкхолдерський підхід для дослідження поведінкових стратегій суб'єктів ринку, керованих їх інтересами та очікуваннями на мезо- та макрорівні, проте стосовно контрагентів сфери продовольчого забезпечення подібні публікації відсутні. Також існує проблема частого ототожнення понять «продовольче забезпечення» та «продовольча безпека», хоча насправді друга із категорій є результатом, а перша - процесом, спрямованим на досягнення цього результату.

3 огляду на вищесказане, метою даного наукового дослідження є чітке розмежування дефініцій «продовольче забезпечення» $\mathrm{i}$ «про- 
довольча безпека» та доведення їх причинно-наслідкового зв'язку, а також визначення сутності категорії «сфера продовольчого забезпечення» в якості теоретичної основи для обгрунтування доцільності застосування стейкхолдерського підходу, орієнтованого на збалансування економічних інтересів заінтересованих сторін сфери продовольчого забезпечення з метою оптимізації економічних ефектів від їх ринкової взаємодії.

\section{2. Сфера продовольчого забезпечення як середовище взаємодії заінтересованих сторін}

Станом на теперішній час у світлі глобальних викликів та інтеграції вітчизняної економіки у світове господарство сформувалися нові тенденції, які є джерелами значних загроз для національної безпеки України, зокрема в частині збереження продовольчої незалежності. Тому створення сприятливих умов для фізичної та економічної доступності продуктів харчування за раціональною кількістю та структурою для усіх верств населення $\epsilon$ важливою умовою на шляху до продовольчого благополуччя.

3 огляду на це, продовольче забезпечення - це економічний процес, що передбачає проведення сукупності заходів щодо досягнення стійкої тенденції зростання кількісних і якісних параметрів продовольчого споживання, усунення ризиків порушення постачання продовольства шляхом створення надійних умов для стабільності виробництва i постачання продуктів харчування для всіх верств населення як запоруки продовольчої безпеки держави. Отже, продовольча безпека - це стан системної стабільності, що характеризується відсутністю загрози щодо отримання та споживання населенням дієтично повноцінних продуктів харчування відповідно до фізіологічних норм. Тому можна стверджувати, що продовольче забезпечення це дія, спрямована на досягнення результату - продовольчої безпеки.

Постачання продуктів харчування на вітчизняний ринок продовольства здійснюється завдяки жвавій міжнародній торгівлі та вітчизняному АПК, існуюча сукупність заінтересованих та/або функціонально взаємопов'язаних й взаємодіючих між собою суб'єктів яких формують простір - сферу продовольчого забезпечення. Вона відіграє роль середовища взаємодії господарюючих суб'єктів сторін ринку тріади «виробник-споживач-держава», кожній з яких властиві відпо- 


\section{Hlubish Lesia}

відні функції. Звідси, під сферою продовольчого забезпечення слід розуміти існуючу сукупність заінтересованих та/або функціонально взаємопов'язаних та взаємодіючих між собою суб'єктів, мотивованих до взаємодії економічною вигодою, відповідно до їх функціональних особливостей. Тобто це своєрідна модель конкурентного економічного середовища, в якому рішення про обсяги і структуру виробництва та споживання продуктів харчування приймаються суб'єктами господарювання в організаційно-правових рамках, продиктованих державою, яка є виробником і постачальником державних послуг як «виробникам», так і «споживачам» в обмін на сплату ними податків, тобто виступає в якості третього партнера, який, адекватно реагуючи на кон'юнктуру продовольчого ринку, своїми організаційно-регулюючими впливами встановлює правильний, необхідний для належного функціонування ринкового середовища порядок взаємодії всіх учасників тристоронніх стосунків [1, с. 72].

\section{3. Стейкхолдерський підхід забезпечення продовольчої безпеки}

Оскільки в ході взаємодії суб'єкти господарювання сторін ринку відіграють певну роль, отже можуть здійснювати вплив на загальну ситуацію у сфері продовольчого забезпечення, це обумовлює необхідність застосування стейкхолдерського підходу в ході дослідження проблеми продовольчого забезпечення населення країни. Означений підхід є одним із теоретичних напрямів у менеджменті, який формує i пояснює стратегію розвитку підприємства чи якоїсь сфери діяльності 3 точки зору врахування інтересів заінтересованих сторін. Аргументами на користь його використання $є$ те, що хоча він і не дає ніякої додаткової інформації про сферу продовольчого забезпечення, а лише дозволяє систематизувати вже наявну, означений підхід передбачає конкретну інституціоналізацію відносин держави із власниками засобів виробництва (й між ними самими), а також зі сторонами, які, через необхідність задоволення потреби у продовольстві, заінтересовані в товарообміні та відповідним чином впливають на функціонування існуючого механізму [2, с. 45-46]. Тому сфера продовольчого забезпечення може бути змодельована із використанням стейкхолдерького підходу, де трьома сторонами ринку є «держава», «виробник» $\mathrm{i}$ «споживач», що взаємодіють у просторі й часі через суб'єктів, мотивованих економічною вигодою, і відповідно до їх функціональних особливостей за допомогою 


\section{Expediency of using the stakeholder's approach for achieving the system...}

економічних, політичних, нормативно-правових, організаційно-управлінських, кадрових, науково-технічних та інших заходів впливають на процес продовольчого забезпечення з метою реалізації власних інтересів (рис. 1). Саме тому господарюючі суб'єкти сфери продовольчого забезпечення $є$ iï заінтересованими сторонами (стейкхолдерами), які будучи задіяні у даній сфері впливають на неї, а вона одночасно здійснює свій вплив на них. Попри те, що всі категорії стейкхолдерів взаємопов'язані та взаємозалежні - головна складність, пов'язана із можливістю оптимізувати взаємодію у сфері продовольчого забезпечення, криється у ідентифікації заінтересованих сторін. Вважаємо, що стейкхолдерів слід ідентифікувати відповідно до ролі, яку вони відіграють у сфері продовольчого забезпечення. Згідно класифікації Іва Фассіна [3, с. 122], стейкхолдери, що наділені потужними інструментами тиску на загальний стан справ у середовищі взаємодії є стейквочерами, сторони, що витупають в ролі регуляторів є стейккіперами, всі інші - стейкхолдерами, тобто тими, хто володіє часткою ринку, і відносини між якими носять конкурентний характер. Більшість стейкхолдерів пов'язані із групами тиску (стейквочерами), пов'язаними 3 певними регуляторами (стейккіперами), які, у свою чергу, впливають на стейкхолдерів. Окрім того, прагнучи лобіювати власні економічні інтереси, задля посилення ступеня впливу заінтересовані сторони можуть об'єднуватись, формуючи, у такий спосіб, групи економічного впливу - стейкхолдери «зливаються» зі стейккіперами, формуючи, у такий спосіб, домінуючу групу інтересів. Стейквочери, «зливаючись» зі стейкхолдерами, формують залежну групу інтересів, а із стейккіперами - небезпечну [4].

На прикладі сфери продовольчого забезпечення в якості стейкхолдерів виступатимуть господарюючі суб'єкти вітчизняного АПК, а також постачальники імпортного продовольства. Роль стейккіперів виконуватимуть державні інституції на кшталт Міністерства аграрної політики та продовольства України, яке розробляє державні програми підтримки та розвитку вітчизняного АПК; Верховна рада України, яка ухвалює подібні програми та законодавчі акти, що становлять правову основу ведення господарської діяльності у цій сфері; ПАТ «Аграрний фонд», головною функцією якого є врегулювання цінових дисбалансів на ринках аграрної продукції. Стейквочерами сфери продовольчого забезпечення є споживачі, потреби у продовольстві яких конче мають 


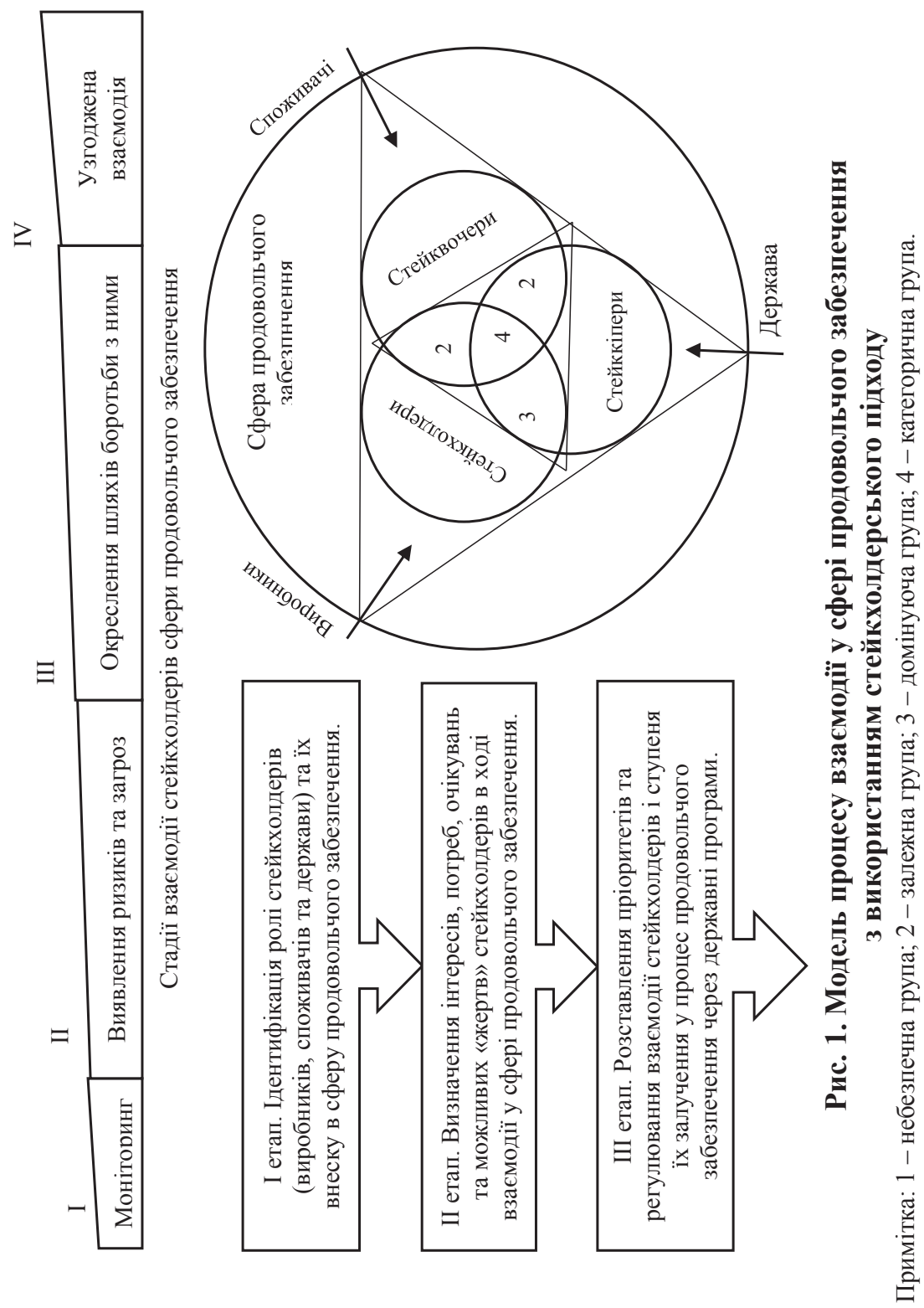




\section{Expediency of using the stakeholder's approach for achieving the system...}

бути задоволені. Незалежно від ролі, кожна із заінтересованих сторін може виступати як в якості потенційних бенефіціаріїв, так і можливих «жертв».

Попри бажання отримати гарантовану вигоду (виграш) усвідомлений частковий програш (втрата) кожної із заінтересованих сторін як своєрідна «жертва» здійснена на користь іншої є життєво необхідною для безперервного функціонування сфери продовольчого забезпечення як такої, оскільки забезпечуватиме відтворення економічних відносин, а отже гарантуватиме загальний виграш - продовольче благополуччя, що свідчитиме про частковий виграш кожної із сторін. Тому заінтересовані сторони сфери продовольчого забезпечення, частково узгоджуючи потреби, свідомо «ідуть» на частковий програш.

3 огляду на це, перефразовуючи Р. Коуза можна стверджувати, що мета продовольчої політики держави полягає у створенні такої ситуації, коли б люди, незалежно від власної ролі у сфері продовольчого забезпечення, приймаючи рішення про свою діяльність, вибирали такі 3 них, які забезпечують найкращі результати для системи загалом..., такі, що максимізують цінність усього іiї функціонування [5, с. 32].

\section{4. Ціннісна парадигма як компонента стейкхолдерського підходу}

Кожна із заінтересованих сторін $є$ виразником різних цінностей, які формують структуру і обсяги потреб та уособлюють особистісне цілісне сприйняття людиною корисності товару, тому у сучасних нестійких економічних умовах ціннісна парадигма виступає домінантою визначення цільових орієнтирів заінтересованих сторін, що $\epsilon$ регуляторами їх поведінки в ході ринкової взаємодії у сферах та галузях національної економіки.

Цінності суб'єктів ринкових відносин сфери продовольчого забезпечення - це ті чинники, що визначають цілі заінтересованих сторін та спонукають їх до певної економічної поведінки у середовищі взаємодії. Саму ж економічну поведінку заінтересованих сторін можна визначити як комбінування цілеспрямованих і спонтанних дій, а також реакцій, обумовлених впливом об'єктивних і суб'єктивних чинників, орієнтовану на досягнення пріоритетних цілей в умовах вибору та адаптації до змінних економічних умов.

Попри те, що деякі базові цінності локальних соціумів і суспільства загалом, з одного боку, і частина базових цінностей бізнесу, з другого - 


\section{Hlubish Lesia}

різняться [6, с. 62] видається цілком можливим гарантування оптимального забезпечення населення продовольством, шляхом ведення грамотної продовольчої політики, яка повинна мати системний характер та охоплювати не лише виробничу, а й споживчу сфери, враховуючи національні особливості, включати питання здорового харчування населення, якості та безпеки продовольства, розвитку сільських територій, наукового його забезпечення.

Стейкхолдерський підхід є досить зручним та достатньо ефективним інструментом, який дозволяє визначити місію, стратегічну мету i тактичну ціль функціонування сфери продовольчого забезпечення, а також ії суб’єктно-функціональних складових (рис. 2).

Перехід від одного політичного ладу до іншого завжди супроводжується боротьбою цінностей. Через розвал Радянського Союзу та відсутність чіткого вектора розвитку України впродовж усього періоду незалежності, для сучасного іiі населення характерна відсутність чіткої системи цінностей. Це спричинило появу певних диспропорцій і у економічній взаємодії, а саме у поведінкових стратегіях господарюючих суб'єктів, що призвело до дисбалансу обсягів виробництва через негативні тенденції у культурі споживання. Не зважаючи на те, що попит на продовольчі товари є постійним, викликає занепокоєння рівень достатності споживання основних продуктів харчування - він свідчить про розбалансованість харчових раціонів населення України.

3 огляду на це, актуалізується питання гармонізації відносин у сфері продовольчого забезпечення. Серед чинників, що спричинили різну динаміку розвитку іiі суб'єктно-функціональних складових важливе значення має різновекторність їх цілеспрямованості. Вважаємо, що формулюючи мету та цілі господарської діяльності, кожен суб'єкт ринкових відносин має орієнтуватися на загальну місію функціонування сфери продовольчого забезпечення - здоров'я нації. Адже, не має значення в якій ролі людина задіяна у процесі продовольчого забезпечення, потреба у продуктах харчування $є$ однією із фізіологічних потреб кожного. Натомість неабияке значення має стан здоров'я, від якого залежить рівень продуктивності праці людини ії інтелектуальний та трудовий потенціал, а отже і розвиток окремих структурно-функціональних складових, сфер, галузей та, зрештою, економіки загалом. 


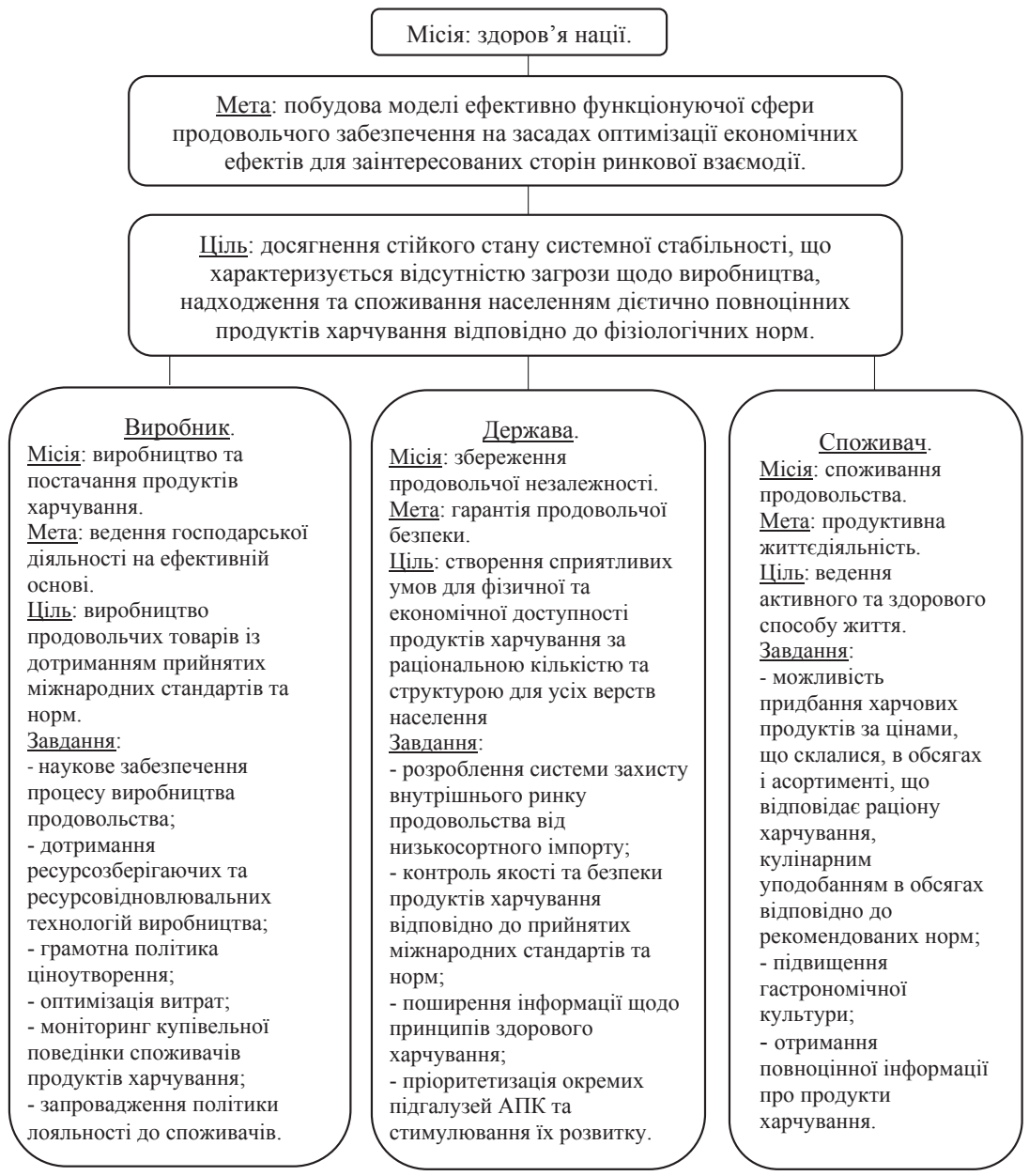

\section{Рис. 2. Дерево цілей функціонування сфери продовольчого забезпечення}

\section{5. Баланс інтересів стейкхолдерів як передумова ефективного функціонування сфери продовольчого забезпечення}

В сукупності цінності та цілі заінтересованих сторін $є$ базисом для формування економічних інтересів, які відіграють важливу роль у стратегії і тактиці політики продовольчої безпеки. Реалізуючи на 


\section{Hlubish Lesia}

практиці своє цільове призначення, кожен із учасників ринкових відносин сфери продовольчого забезпечення, керований усвідомленою вигодою, відповідно до поставленої мети, переслідує власні інтереси і реалізує їх, виконуючи властиві йому функції в ході конкурентних економічних відносин. Звідси, під економічним інтересом слід розуміти усвідомлену заінтересованою стороною економічну вигоду, очікувану від реалізації стратегії взаємодії. Зміст та форма самої ринкової взаємодії визначається множиною факторів впливу і підпорядковується об'єктивним економічним законам та закономірностям, що породжуються існуючими виробничо-господарськими відносинами.

Для кожної заінтересованої сторони властивий власний економічний інтерес, який є причиною виникнення цілеспрямованих та скоординованих соціальних дій i/або господарської діяльності задля отримання вигоди або ж досягнення очікуваної зміни. Досліджуючи економічні інтереси з позицій системного підходу, в якості «входу» в систему реалізації економічних інтересів у процесі продовольчого забезпечення необхідно розглядати внутрішню сутність потреб, усвідомлення якої дозволяє трансформувати їх у інтереси заінтересованих сторін. Тоді як «виходом» 3 даної системи слід вважати, одержані в результаті ринкової взаємодії, реалізовані на практиці цілі економічних суб'єктів - носіїв економічних інтересів. Це свідчить про взаємозалежність заінтересованих сторін, яка обумовлює їх співробітництво, бо не задовольнивши економічні інтереси одна одної, жодна сторона ринкової взаємодії не зможе реалізувати власних. Звідси, система реалізації економічних інтересів уособлює єдність взаємопов'язаних i взаємодіючих між собою структурних елементів сфер та галузей, економічні інтереси яких виникають і реалізуються в ході їх ринкової взаємодії, обумовленої відносинами власності, принципом економічної вигоди, мотивами і стимулами, через досягнення ними конкретних економічних цілей, що виражають міру задоволення їх економічних потреб, спектр яких формується під впливом системи цінностей навіяних нагальними проблемами часу, та еволюціонує відповідно до етапів розвитку економічних відносин.

Таким чином, економічні інтереси заінтересованих сторін сфери продовольчого забезпечення слугують пусковим механізмом ринкових відносин щодо задоволення економічних потреб, через споживання економічних благ, в ході взаємодії в ринковому середовищі, де 
вони реалізуються внаслідок певної діяльності задля досягнення очікуваного економічного ефекту. Тоді як оцінка одержаних економічних ефектів закладає основу для формування економічних інтересів. Обгрунтовуючи такий підхід, слід попередити хибне уявлення про статичність процесу формування, трансформації та реалізації економічних інтересів, що свідчить про циклічний характер процесу реалізації економічного інтересу (рис. 3).

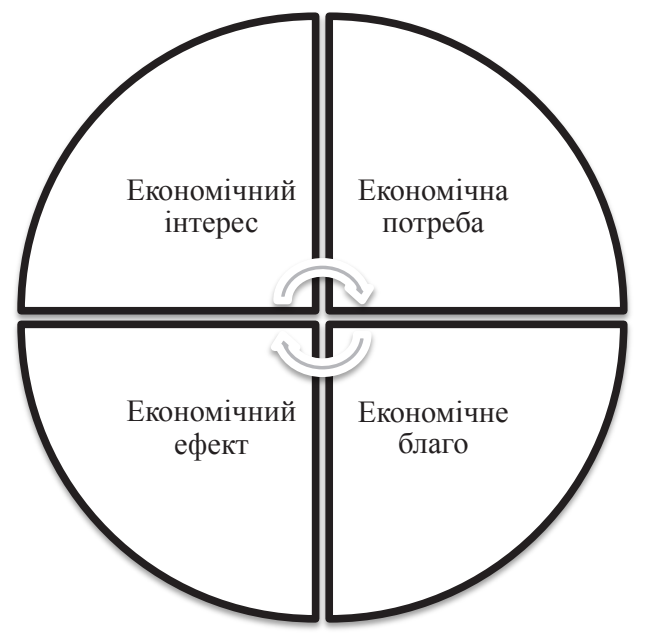

\section{Рис. 3. Циклічність процесу реалізації економічного інтересу}

Беручи до уваги той факт, що вони є суспільною формою прояву, усвідомленим прагненням суб'єктів ринкової взаємодії до задоволення економічних потреб, а також зважаючи на різноманітність чинників, під впливом яких вони розвиваються, цей процес слід вважати явищем динамічним.

Множинність функціонально-суб'єктних складових сфери продовольчого забезпечення і різноспрямованість їх економічних інтересів породжують низку протиріч. Адже держава, виробник та споживач $\epsilon$ протилежними сторонами ринкових відносин, заінтересовані сторони яких переслідують протилежні цілі, тому їх економічні інтереси мають суперечливий характер. Водночас спільним прагненням для усіх $є$ максимізація вигоди за умови мінімізації витрат. 


\section{Hlubish Lesia}

Зокрема, споживач прагне задовольнити свої потреби в продовольстві, отримавши максимум користі від спожитих товарів, заплативши за них низьку ціну. Виробник, навпаки, переслідує ціль реалізувати продовольчу продукцію за максимально високою ціною, мінімізувавши витрати на їі виробництво. Економічні інтереси кожної із заінтересованих сторін мають право бути реалізованими, проте до певної граничної межі - допоки вони не перешкоджають реалізації економічних інтересів інших заінтересованих сторін середовища взаємодії, створюючи загрозу стійкому стану системної стабільності процесу продовольчого забезпечення. Сама ж стійкість забезпечується компромісом заінтересованих сторін щодо збалансування їх економічних інтересів 3 метою недопущення їх опортуністичної поведінки у процесі досягнення поставлених ними цілей. Тобто слід досягти такої структурної пропорції в розподілі економічної вигоди між заінтересованими сторонами, яка б забезпечувала не лише стійкість, але й синергізм господарсько-економічних зав'язків. Цьому процесу передує встановлення співвідношення між чинниками, що сприяють та стримують процес досягнення стану системної стабільності продовольчого забезпечення населення України (рис. 4). Аналіз поля сил дозволяє окреслити чіткі загрози та, відповідно до них, вибудувати систему пріоритетів стратегічного розвитку сфери продовольчого забезпечення на конкретну перспективу, враховуючи отриманий досвід та національні особливості іiі становлення і функціонування.

Усунути виявлені в ході аналізу поля сил стану системної стабільності процесу продовольчого забезпечення слабкі сторони та потенційні загрози повинна саме держава, врівноважуючи, діалектичний взаємозв'язок економічних інтересів виробників і споживачів на принципах часткового узгодження економічних потреб та відповідного їх задоволення. Із частковим узгодженням економічних потреб виробника і споживача та відповідним їх задоволенням ототожнюється рівність граничних жертв, яка є головною умовою узгодженої ринкової взаємодії, бо саме вона $є$ тим інструментом, що дозволяє досягти бажаного результату функціонування сфери продовольчого забезпечення, а не максимально можливої економічної вигоди.

Аналіз поля сил дає підстави для такого загального висновку Україна має необхідний потенціал для досягнення стану системної стабільності процесу продовольчого забезпечення, а наявність загроз 


\section{Expediency of using the stakeholder's approach for achieving the system...}

Досягнення стійкого стану системної стабільності, що характеризується відсутністю загрози щодо виробництва, надходження та споживання населенням дієтично повноцінних продуктів харчування відповідно до фізіологічних норм

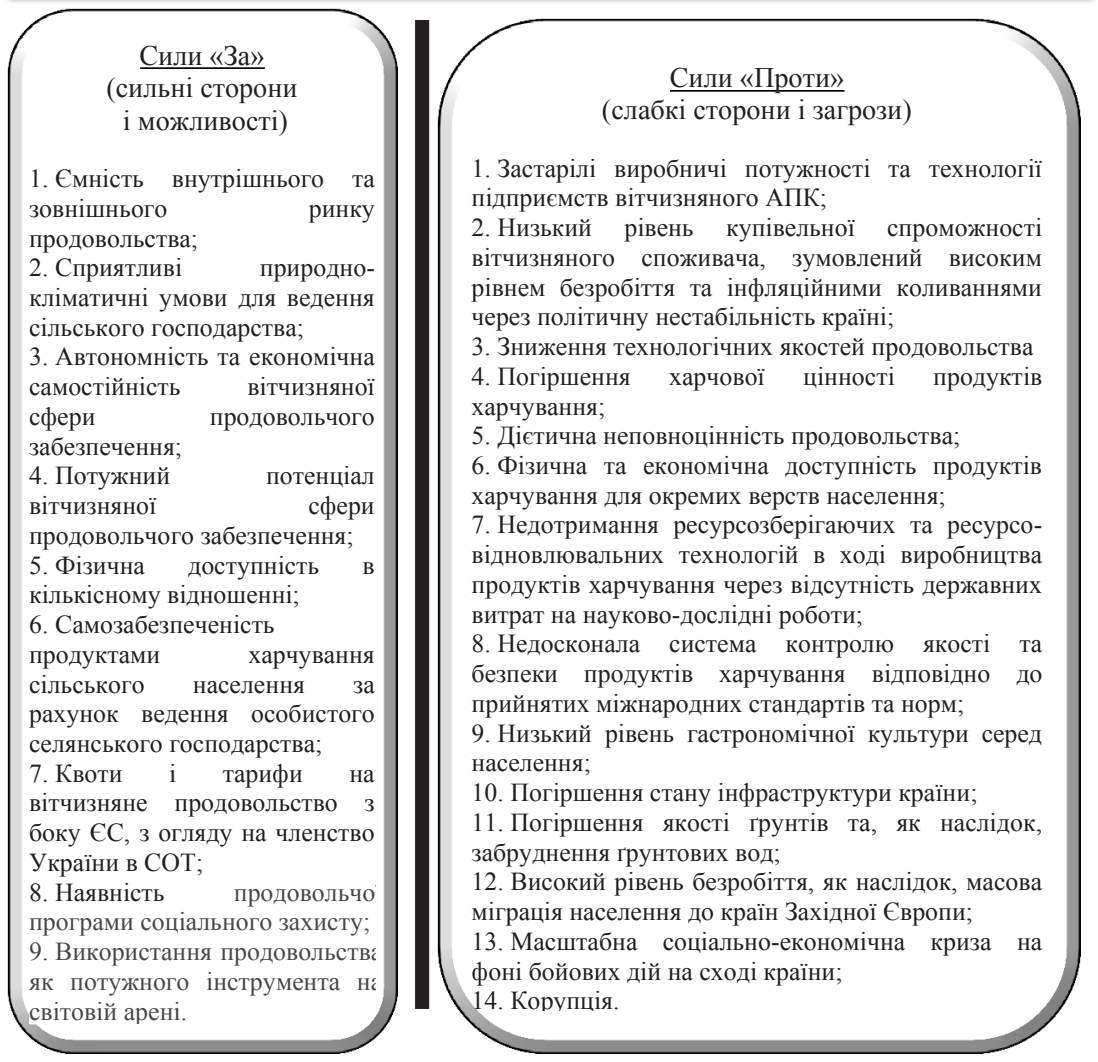

\section{Рис. 4. Аналіз поля сил досягнення стану системної стабільності процесу продовольчого забезпечення}

щодо нього зумовлена відстороненням держави від регуляторних процесів.

Головними напрямами державного втручання має стати здійснення заходів щодо матеріально-технічного та техніко-технологічного оновлення стейкхолдерів вітчизняного АПК, відновлення та розвитку інфраструктури, жорсткого контролю за відповідністю продуктів хар- 


\section{Hlubish Lesia}

чування на вітчизняному ринку продовольства міжнародним нормам і стандартам, а також пропагування гастрономічної культури споживання продуктів харчування населенням. Взаємно-узгоджена реалізація економічних інтересів потребує активізації діяльності держави, яка, вміло використовуючи наявні регуляторні важелі, включаючи правову базу, покликана створити і підтримувати такі умови, які б сприяли ефективній взаємодії та реалізації економічних інтересів всіх іiі учасників. Для гармонізації економічних відносин, зважаючи на обмеженість фінансових ресурсів, держава 3 огляду на чіткі національні пріоритети визначає параметри поведінки ринкових суб'єктів, вводячи певні правові та економічні обмеження, прагне досягти оптимально ефективних результатів функціонування. Вирішення проблем конфронтації та різновекторності прагнень щодо отримання економічної вигоди між сторонами ринкової взаємодії можливе через узгодження економічних інтересів на основі принципу рівності граничних жертв. Він $є$ ключем ефективного функціонування кожної з трьох сторін ринкової взаємодії (споживача, виробника, держави), тоді як слабкість стану будь-якої 3 них зводить до мінімуму ефективність інших та ефективність економічної системи загалом.

\section{6. Ефект взаємодії заінтересованих сторін сфери продовольчого забезпечення}

Економічні інтереси стейкхолдерів, уособлюючи усвідомлену вигоду, реалізуються через досягнення конкретних економічних ефектів, які виражають міру задоволення економічних потреб, спектр яких формується під впливом системи цінностей. Таким чином, цілі та сформовані під їх впливом інтереси мотивують ринкові відносини щодо задоволення економічних потреб через споживання економічних благ, об'єктом яких є найбільш бажаний результат (ефект) з їх множини (рис. 5).

Економічні ефекти оцінюються з різних позицій із використанням відповідного інструментарію. Під ефектом прийнято розуміти результат [7, с. 60-61], наслідок [8, с. 103], зміну стану певного суб'єкта [9, с. 151-152], зумовлену дією зовнішніх або внутрішніх чинників, а також факторів, або їх сукупності.

Відповідно, ефект може бути як позитивним, коли його зміни $\epsilon$ корисними, так і негативним, коли зміни деструктивні, або ж нульо- 


\section{Expediency of using the stakeholder's approach for achieving the system...}

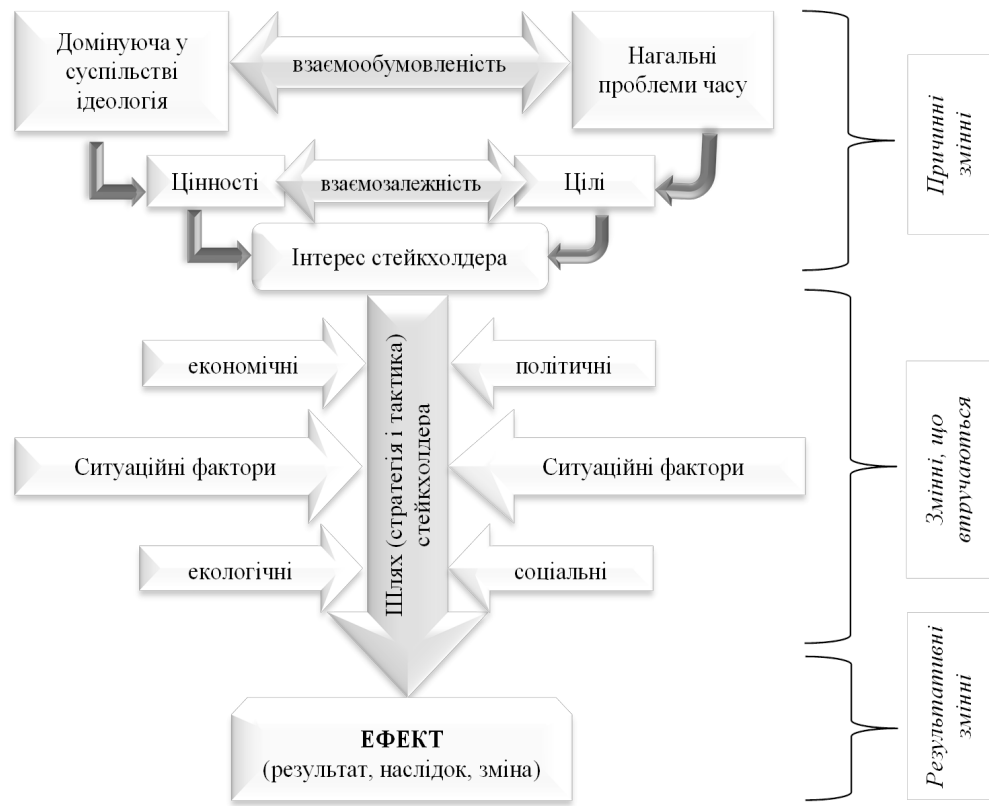

\section{Рис. 5. Формування ефектів поведінкових стратегій заінтересованих сторін}

вим, коли зміни відсутні взагалі [10, с. 134]. Звідси, ефекти різної природи можуть підсилювати або послаблювати однин одного, або бути нейтральними $[11$, с. 70], що в ході ринкової взаємодії стейкхолдерів визначає їх ділову активність, що базується на порівнянні можливих переваг, котрі зможе отримати носій економічного інтересу за умови дотримання ним чіткої послідовності дій (стратегії поведінки).

Головним ефектом взаємодії заінтересованих сторін сфери продовольчого забезпечення є досягнення стану системної стабільності процесу продовольчого забезпечення населення країни, який має гарантувати продовольчу безпеку. Агрегованим показником, що відображає рівень продовольчої безпеки в країні $є$ Глобальний індекс продовольчої безпеки (The Global Food Security Index 2017) [12], який визначається за підтримки американської транснаціональної компанії DuPont Інститутом економічних досліджень (The Economist Intelligence Unit), пропонує 28 унікальних індикаторів, класифікованих за трьома групами: 


\section{Hlubish Lesia}

доступність (питома вага витрат домашніх господарств на харчування в загальному їх обсязі, валовий внутрішній продукт на душу населення та ін.); наявність (достатність харчування, державні витрати на сільськогосподарські НДР, стан сільськогосподарської інфраструктури, політична стабільність, корупція та ін.); якість і безпека (різноманітність харчування та його норми, доступність мікроелементів, якість білка, безпека харчових продуктів та ін.) (табл. 1). Схема визначення індексу базується на положеннях міжнародно визнаного у 1996 році Всесвітнього продовольчого саміту [13].

Таблиця 1

Динаміка стану продовольчої безпеки України

\begin{tabular}{|c|c|c|c|c|c|c|c|c|c|c|c|c|}
\hline \multirow[b]{2}{*}{ Показник } & \multicolumn{6}{|c|}{$\begin{array}{c}\text { Оцінка } \\
\text { (за 100-бальною шкалою) }\end{array}$} & \multicolumn{6}{|c|}{$\begin{array}{l}\text { Місце у рейтингу } \\
\text { (серед } 109 \text { країн) }\end{array}$} \\
\hline & $\frac{\dot{\lambda}}{\stackrel{\sim}{\tilde{~}}}$ & $\stackrel{\dot{m}}{\stackrel{\sim}{\tilde{N}}}$ & $\stackrel{\dot{\sim}}{\dot{\sim}}$ & $\stackrel{\dot{2}}{\stackrel{n}{\bar{\pi}}}$ & 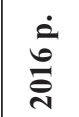 & 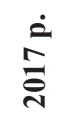 & 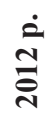 & 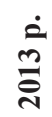 & $\stackrel{\dot{\Delta}}{\stackrel{\dot{d}}{\vec{N}}}$ & $\frac{\dot{a}}{\stackrel{n}{\tilde{N}}}$ & $\stackrel{\dot{a}}{\stackrel{2}{0}}$ & $\frac{\dot{2}}{\stackrel{\sim}{*}}$ \\
\hline Загал & 56,7 & 57,5 & 57,7 & 56,1 & 56,4 & 54,1 & 52 & 51 & 53 & 59 & 52 & 63 \\
\hline Доступність & 55,6 & 55,6 & 58,7 & 58,6 & 50,4 & 55,7 & 53 & 53 & 50 & 54 & 50 & 59 \\
\hline Наявність & 54,2 & 56,3 & 53,6 & 58,6 & 79,9 & 50,2 & 55 & 54 & 59 & 71 & 64 & 78 \\
\hline Якість і безпека & 66,1 & 65,7 & 66,7 & 62,6 & 60,0 & 61,0 & 40 & 44 & 41 & 48 & 42 & 51 \\
\hline
\end{tabular}

До числа проблем, існуючих у вітчизняній сфері продовольчого забезпечення належать: самозабезпеченість продуктами харчування населенням країни (у великих містах (понад 100 тис. жителів) його частка становить близько 2 \%, що наближається до рівня цього показника в розвинутих країнах, у малих містах натуральний сегмент продовольчого ринку сягає вже $12 \%$ його загального обсягу, а в сільській місцевості - перевищує 46 \%); недостатність попиту, зумовлена змінами у статевовіковій структурі населення та падінням його купівельної спроможності через випереджаючі темпи зростання рівня цін на комунальні послуги та інші блага (в т. ч. і на продовольство) порівняно із темпами росту заробітної плати, пенсій, стипендій; скорочення пропозиції продовольства, високий рівень безробіття і низькі темпи економічного зростання у сфері продовольчого забезпечення.

Необхідність своєчасної сплати комунальних платежів а також суттєве подорожчання транспортних послуг змушує пересічного українця 
надавати перевагу відносно дешевим вуглеводовмісним та протеїновмісним продуктам харчування. Нестача у харчових раціонах українців усіх основних харчових продуктів багатих на вітаміни, мікроелементи та білки тваринного походження $є$ причиною погіршення їх здоров'я, працездатності і демографічного відтворення населення. Саме тому пропонується доповнити перелік індикаторів доцільно розширити Глобальний індекс продовольчої безпеки показниками середнього споживання населенням вуглеводів, жирів та білків, вітамінів, а також мікроелементів та жирних кислот, характеристичні значення яких доречно узгодити з рекомендаціями Всесвітньої організації охорони здоров'я [14, с. 17]. Задля усунення існуючих проблем у вітчизняній сфері продовольчого забезпечення, державі одночасно із підвищенням вартості робочої сили та регулюванням цін, слід подбати про зростання доходів громадян шляхом підвищення зайнятості населення, а також скорочення сукупних витрат, використовуючи нестандартні підходи - пропагуючи здоровий спосіб життя, дбаючи про енергетичну безпеку, використовуючи альтернативні джерела енергії, розвиваючи власні нафтогазові родовища.

Отже, проблему продовольчого забезпечення не слід вирішувати відособлено, а навпаки, враховуючи циклічність функціонування економічних систем, явищ і процесів, підпорядкованих дії закону єдності й боротьби протилежностей. Зокрема, для вітчизняної сфери продовольчого забезпечення можна окреслити такі три рівня створення загальних цінностей: вирішити питання харчової цінності харчового раціону, зниження вартості базових продуктів харчування; покращити доступ дрібних товаровиробників до інформації та технічної підтримки для створення більш надійної і високоякісної мережі постачальників продовольства до ринків збуту; забезпечити підтримку розвитку інфраструктури, доступ до фінансових ресурсів.

\section{7. Висновки}

За результатами проведеного дослідження встановлено, що продовольче забезпечення це дія, спрямована на досягнення результату - продовольчої безпеки та визначено сутність поняття сфери продовольчого забезпечення в якості середовища взаємодії заінтересованих сторін. Обгрунтовано доцільність застосування стейкхолдерського підходу як зручного та ефективного інструмента забезпечення продовольчої без- 


\section{Hlubish Lesia}

пеки, який дозволяє визначити місію, стратегічну мету і тактичну ціль функціонування сфери продовольчого забезпечення, а також iіi суб'єктно-функціональних складових. 3'ясовано, що ціннісна парадигма виступає домінантою визначення цільових орієнтирів заінтересованих сторін, що є регуляторами їх поведінки в ході ринкової взаємодії, тоді як цінності та цілі формують інтереси заінтересованих сторін. Для гармонізації економічних відносин та вирішення проблем конфронтації та різновекторності прагнень щодо отримання економічної вигоди між сторонами ринкової взаємодії необхідним є збалансування інтересів заінтересованих сторін на основі результатів аналізу поля сил досягнення стану системної стабільності процесу продовольчого забезпечення, який дозволяє окреслити чіткі загрози та, відповідно до них, вибудувати систему пріоритетів стратегічного розвитку сфери продовольчого забезпечення на конкретну перспективу, враховуючи отриманий досвід та національні особливості ії становлення і функціонування.

Таким чином, сфера продовольчого забезпечення може бути змодельована із використанням стейкхолдерського підходу орієнтованого на збалансування економічних інтересів заінтересованих сторін сфери продовольчого забезпечення з метою оптимізації економічних ефектів від їх ринкової взаємодії.

Перспективи подальших наукових досліджень у цьому напрямку полягають у побудові оптимізаційних моделей функціонування сфери продовольчого забезпечення.

\section{Список літератури:}

1. Петренко В. П. До визначення шляхів оптимізації стосунків держави, виробників і споживачів 3 використанням закономірностей парето-ефективного ринку / В. П. Петренко // Науковий вісник ІФНТУНГ. - 2002. № 4. - С. 71-76.

2. Кушнір Л. Л. Проблема ідентифікації стейкхолдерів у системі ресурсного забезпечення національної економіки / Л. Л. Кушнір // Науковий вісник Полтавського університету економіки і торгівлі. - № 6 (51), Ч. 1. 2011. - C. 43-49.

3. Fassin, Y. (2005), "The Reasons Behind Non-Ethical Behavior in Business and Entrepreneurship", Journal of Business Ethics, Vol. 60, P. 122.

4. Глубіш Л. Я. Взаємозалежність та взаємообумовленість ціннісного та цілісного підходів щодо формування економічних ефектів від взаємодії стейкхолдерів сфери продовольчого забезпечення : [Електронний pecypc] / Л. Я. Глубіш // Ефективна економіка. - Режим доступу: http://www.m.nayka.com.ua/?op=1\&j=efektyvna-ekonomika\&s=ua\&z=5642. 


\section{Expediency of using the stakeholder's approach for achieving the system...}

5. Coase R. The Firm, the Market and the Law. Chicago \& London, The University of Chicago Press, 1988. 226 p. (Russ. ed.: Kouz R. Firma, rynok, pravo. Moscow, Novoe izdatelstvo Publ., 2007. 224 p.).

6. Попов С. А. К созданию общих ценностей... от теории стейкхолдеров к реализации концепции общих ценностей / С. А. Попов, Л. Л. Фомина // Российское предпринимательство. - 2013. - № 2 (224). - С. 60-65.

7. Кісіль М. І. Критерій і показники економічної ефективності малого та середнього бізнесу на селі / М. І. Кісіль // Економіка АПК, 2001. № 8. - С. 59-64.

8. Економіка сільського господарства. / П. П. Руснак, В. В. Жебка, М. М. Рудий, А. А Чалий. - К. : Урожай, 1998. - 320 с.

9. Хашковская О. А. Оценка экономической эффективности функционирования сельскохозяйственных предприятий в условиях социальной переориентации народнохозяйственных комплексов Беларуси / О. А. Хашковская // Економіка АПК. - 2004. - № 11. - С. 149-153.

10. Перекрест Т. В. Методологія оцінювання ефективності діяльності підприємства / Т. В. Перекрест // Держава та регіони. Серія: економіка і підприємництво. - 2011. - № 4. - С. 130-136.

11. Прядко В. В. Теоретико-методологічні аспекти ефективності сільськогосподарського виробництва / В. В. Прядко / Економіка АПК. - 2003. № 10 . - C. 69-77.

12. The Global Food Security Index 2017. [Electronic resource]. - Access mode : http://foodsecurityindex.eiu.com/Index.

13. FAO 1996. Rome Declaration of World Food Security and World Food Summit Plan of Action. [Electronic resource]. - Access mode :http:/www.fao.org

14. Полторак А. С. Комплексна оцінка стану продовольчої безпеки України / А. С. Полторак // Economic Annals-XXI (2015), 7-8(2), p. 15-18.

\section{References:}

1. Petrenko V. P. (2002). Do vyznachennya shlyakhiv optymizatsiyi stosunkiv derzhavy, vyrobnykiv i spozhyvachiv z vykorystannyam zakonomirnostey paretoefektyvnoho rynku [For identify ways of optimizing relationships, manufacturers, consumers and government using regularities Pareto efficient market]. Naukoviy visnyk IFNTUNH, no 4, pp. 71-76 (In Ukr.).

2. Kushnir L. L. (2011). Problema identyfikatsiyi steykkholderiv u systemi resursnoho zabezpechennya natsional'noyi ekonomiky [The problem identification of stakeholders in the resource system of the national economy]. Naukovyy visnyk Poltavs'koho universytetu ekonomiky i torhivli. vol. 1, no 6 (51), pp. 43-49.

3. Fassin, Y. (2005). The Reasons Behind Non-Ethical Behavior in Business and Entrepreneurship. Journal of Business Ethics, vol. 60, P. 122.

4. Hlubish L. Ya. (2017). Vzayemozalezhnist' ta vzayemoobumovlenist' tsinnisnoho ta tsilisnoho pidkhodiv shchodo formuvannya ekonomichnykh efektiv vid vzayemodiyi steykkholderiv sfery prodovol'choho zabezpechennya [The interdependence and interconditionality of worth and aim approaches about of forming economic effects of the stakeholders interaction of provision supply sphere]. Efektyvna ekonomika (electronic journal), no. 6. Retrieved from: 


\section{Hlubish Lesia}

http://www.m.nayka.com.ua/?op=1\&j=efektyvna-ekonomika\&s $=u a \& z=5642$ (accessed 11 june 2017).

5. Coase R. (1988). The Firm, the Market and the Law. Chicago \& London, The University of Chicago Press. 226 p.

6. Popov S. A. \& Fomina L. L. (2013). K sozdanyyu obshchykh tsennostey... ot teoryy steykkholderov k realyzatsyy kontseptsyy obshchykh tsennostey. [To the creation of common values ... from the theory of stakeholders to the realization of the concept of common values]. Rossyyskoe predprynymatel'stvo, no 2 (224), pp. 60-65.

7. Kisil M. I. (2001). Kryteriy i pokaznyky ekonomichnoyi efektyvnosti maloho ta seredn'oho biznesu na seli [Criteria and indicators of economic efficiency of small and medium enterprises in rural areas]. Ekonomika APK, vol. 8, pp. 59-64.

8. Rusnak P. P., Zhebka V. V., Rudyi M. M. \& Chalyi A. A. (1998). Ekonomika silskoho hospodarstva [Agrarian economy]. Kyiv: Urozhai. (in Ukrainian)

9. Khashkovskaia O. A. (2004). Otsenka эkonomycheskoy эffektyvnosty funktsyonyrovanyya sel'skokhozyaystvennukh predpryyatyy v uslovyyakh sotsyal'noy pereoryentatsyy narodnokhozyaystvennыkh kompleksov Belarusy [Estimation of economic efficiency of functioning of agricultural enterprises in conditions of social reorientation of national economic complexes of Belarus]. Ekonomika APK, no. 11, pp. 149-153.

10. Perekrest T. V. (2011). Metodolohiya otsinyuvannya efektyvnosti diyal'nosti pidpryyemstva [Methodology for evaluating the effectiveness of the company]. Derzhava ta rehiony. Seriia: ekonomika i pidpryiemnytstvo, no. 4, pp. 130-136.

11. Priadko V. V. (2003). Teoretyko-metodolohichni aspekty efektyvnosti sil's'kohospodars'koho vyrobnytstva [Theoretical aspects of agricultural production efficiency], Ekonomika APK, no. 10, pp. 69-77.

12. The Global Food Security Index 2017. [Electronic resource]. - Retrieved from : http://foodsecurityindex.eiu.com/Index.

13. FAO 1996. Rome Declaration of World Food Security and World Food Summit Plan of Action. [Electronic resource]. - Retrieved from: http://www.fao.org

14. Poltorak A. S. (2015). Kompleksna otsinka stanu prodovol'choyi bezpeky Ukrayiny [Harmonization of Ukraine's legislation covering the assessment of food security with international standards]. Economic Annals-XXI, no 7-8(2), pp. 15-18. 


\section{MARKETING AUDIT OF THE ENTERPRISE}

\section{МАРКЕТИНГОВИЙ АУДИТ ПІДПРИЕМСТВА}

\section{Derevianchenko Tatyana ${ }^{1}$}

DOI: http://dx.doi.org/10.30525/978-9934-571-28-2_9

Abstract. In the article it was researched the theoretical themeconcerningthe content andthe role of the marketing audit in the modern enterprise activity. In Ukraine, marketing has the development comparatively not long ago, that is why many enterprises have'tyet accumulatedenough experience in this industry.In the marketing activitythe analytical function takesthe extraordinarily important role, that, first of all, envisages the study and the analysis of environment. The importance of analytical activity is predefined by the quality of marketing information, that determines the validity of administrative decisions, and consequently, the efficiency of enterprise activity.

The marketing audit envisages a competent, independent, periodic and all-round research of basic factors of external and internal environment, aims, strategies and enterprise marketing activity with the aim of preventive exposure of problems and hidden potential, and also the development of adequate marketing strategy. After audit providing the reasonable measuresin relation to the increase of efficiency of enterprise marketing activity are taken. In this regard the research of methodical aspects of organization and marketing audit providing demonstrates the research andpractice issue.

The subject of the research work clears up the scientifically-methodical problems of enterprise marketing audit, the conditions of its' development and practical using.

In the basis of research is dialectical aproachto the study of a phenomena and consistency of marketing genesis and also the systemapproach, in accordance with the marketing activity is examined as an inalienable constituent of the wholeenterprise strategy and the management process.

In the process of marketing audit it is used an extraordinarily various tools. Marketing audit uses scientific, specific analytical and calculative

\footnotetext{
${ }^{1}$ Candidate of Economic Sciences, Associate Professor Vadym Hetman Kyiv National Economic University, Ukraine

(C) Derevianchenko Tatyana
} 
methods, mathematically-statistical and various methods of marketing analysis, in other words, the research methods of a certain marketing issue.The most widespread methods of analysis, that are used in a marketing audit, are considered.The professional application of these methods (depends on the investigating problem, direction and type of audit, possibilities of enterprise and other factors) is extraordinarily important.

The aim of the research work is the development of methodological thesis of marketing audit providing at the enterprise. In Ukraine, the problems of marketing audit are examined only fragmentary, without sufficient development of methodical bases thatmotivated the choice of the research theme.

An acceptance and a realization of strategic marketing decisions in many cases is becoming difficult through the unsteady economic situation, the vagueness of political situation, the absence of favourable investment climatefor the Ukrainianenterprises.On account of abovementioned, the determination of marketing steps efficiencyand, accordingly, the development of methodological vehicle, that would allow to take into account all or almost all factors that influence on efficiency of marketing activity at the enterpriseis up-to-date. Within such conditions the manysidedness and variety of marketing audit at the enterprise allows to examine it as an analytical instrument of indentication, evaluation, measuring, motivation and actions realization, which are directed to the achievement of the best marketing results.

\section{1. Ветуп}

Сучасний період економіки України вимагає розробки відповідного господарського механізму, докорінних змін в його функціонуванні, гармонізації інтересів всіх зацікавлених сторін. 3 цієї точки зору сучасна маркетингова діяльність підприємства, яка інтегрована як на створюваний продукт, так і на споживача $є$ найважливішою умовою конкурентоспроможності підприємства та його продукції на внутрішньому і зовнішніх ринках.

3 цієї точки зору, головною метою даної роботи є дослідження обгрунтованості змісту і ролі маркетингового аудиту в діяльності сучасного підприємства. Крім того важливим є обгрунтування процесу маркетингового аудиту, який відповідав би вимогам ринкової економіки, не суперечив Міжнародним стандартам і служив би інформаційною базою контролю та прийняття управлінських і маркетингових рішень. 


\section{Marketing audit of the enterprise}

За умов адміністративно-командної економіки традиційні форми і методи управлінського контролю повною мірою відповідали функціонуючому господарському механізму. Вони виявились неспроможними задовольняти нові інформаційні потреби управління суб'єктів господарювання, власників підприємств, кредиторів, інвесторів та інших споживачів інформації. Проте, докорінна зміна економічного середовища, викликана розвитком недержавних форм власності і нових організаційних форм господарювання вимагала поступового формування нового господарського механізму, який базувався б на ринковій економіці та сприяв би інтеграції економіки України в європейську економічну систему. За цих умов маркетингова діяльність підприємства неминуче повинна адаптуватись до діючої системи господарювання та сприяти впровадженню економічних відносин ринкового спрямування. Саме маркетинговий аудит сприяє оптимізації маркетингу, приведенню його взаємодії з ринком і внутрішніми мікроструктурами до стану, який надає підприємству можливість максимально ефективно задовольнити свої прагнення в рамках прийнятих стратегій. Сьогодні на ринку консалтингових послуг існує багато видів аудиту. Один 3 них - маркетинговий, який набуває все більшої популярності як засіб оцінки рівня активності та реалізації маркетингових рішень.

У зв'язку з цим дослідження методичних аспектів організації і проведення маркетингового аудиту, його ролі і місця в системі управління підприємством являє собою актуальну науково-практичну проблему.

Турбулентні зміни ринкового середовища потребують постійного моніторингу їх розвитку і тенденцій, а також завчасної адаптації стратегій господарських суб'єктів до майбутніх змін. У свою чергу це вимагає активного розвитку маркетингових функцій підприємства. Проблеми маркетингу є об'єктом досліджень вчених і розглядались в роботах Г. Армстронга, Ф. Котлера, П. Друкера, Т. Левіта, Ж.Ж. Ламбена, М. Портера, Л. Фестингера, Гаркавенко С.С., Корягіної С.В., Балабанової Л.В., Я. Дадьо, Катаєва А.В., Перерви П.Г. тощо.

При цьому основна увага приділялась таким питанням як суть $\mathrm{i}$ стратегії маркетингу, удосконалення комплексу маркетингу, планування, інформаційне забезпечення й управління маркетингом. Але проблеми маркетингового аудиту розглядаються лише фрагментарно, без достатньої розробки методичних основ, що й слугувало підставою для вибору теми дослідження. 


\section{2. Зміст і місце маркетингового аудиту \\ в управлінні підприємством}

Маркетинговий аудит - незалежний метод визначення якості реалізації маркетингових функцій в системі управління підприємством, якому, нажаль, приділяють недостатньо уваги. Роль і місце маркетингового аудиту в системі управління підприємством показано на рисунку 1.

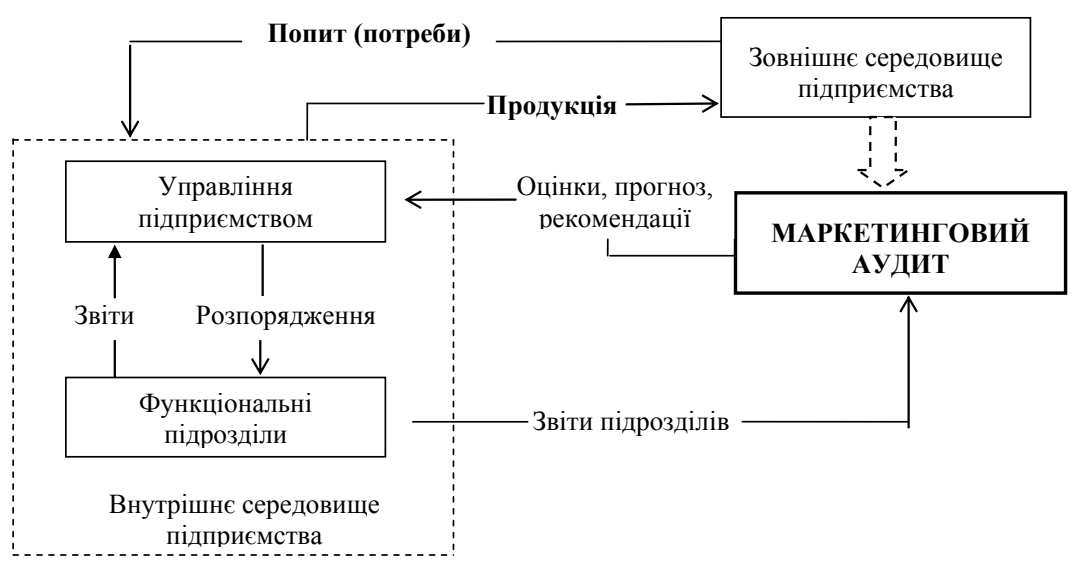

\section{Рис. 1. Маркетинговий аудит у системі управління підприємством}

Ідея маркетингового аудиту виникла у 50 -х роках минулого століття і його розуміння неоднозначне. Рудольф Далмейєр, колишній керівник компанії Booze-Allen-Hamilton, згадує про проведення маркетингового аудиту на початку 1952-го. Роберт Лавідж, президент Elriks and Lavidge, стверджує що маркетинговий аудит його фірма проводила ще наприкінці 1940 р. [6]. У 1959 році Американська асоціація маркетингу опублікувала підбір матеріалів під назвою "Analyzing and Improving Marketing Performance”. 3 60-х років маркетинговий аудит усе частіше згадується у переліку маркетингових послуг консалтингових фірм, що спеціалізуються на проблемах менеджменту. I тільки на початку кризових 1970-х керівництво багатьох компаній почало сприймати його як можливу відповідь на свої проблеми. В останні роки все більше українських маркетологів доходять єдиної думки щодо прогресивності цього напряму. 


\section{Marketing audit of the enterprise}

Поняття «маркетинговий аудит» по різному розглядають як вітчизняні, так і закордонні науковці і практики. Їх визначення у більшості випадків не суперечать один одному, але мають свої відмінності.

Ф. Котлер визначає «маркетинговий аудит як «комплексне, системне, незалежне і регулярне спостереження середовища підприємства, його цілей, стратегії і діяльності з метою визначити проблемних сфер, можливостей і заходів щодо поліпшення ефективності маркетингової діяльності» [1, с. 13].

Я. Дадьо: «Маркетинговий аудит - глибокий стратегічний контроль всієї сукупності маркетингової активності підприємства» [3, с. 10].

C.С. Гаркавенко вважає, що «маркетинговий аудит - комплексна періо-дична перевірка зовнішнього середовища маркетингу, цілей, стратегій та окремих видів маркетингової діяльності фірми» [1, с. 14].

На думку С.В. Корягіної: «Маркетинговий аудит є незалежним методом глибокого стратегічного та оперативного контролю всієї сукупності маркетингової активності або їі частини» [3, с. 12].

Отже, маркетинговий аудит - це компетентне, незалежне, періодичне та всебічне дослідження основних чинників зовнішнього і внутрішнього середо-вища, цілей, стратегій і маркетингової діяльності підприємства 3 метою превентивного виявлення проблем і прихованого потенціалу, а також розробки адекватної маркетингової стратегії $[1$, c. 10$]$.

Маркетинговий аудит - найбільш ефективний і найменш відпрацьований контроль маркетингу, який можна розглядати у трьох аспектах [3, с. 11]:

За першим аспектом - це етап процесу планування маркетингу, процедура аналізу внутрішнього і зовнішнього маркетингового середовища 3 метою виявлення прихованих або недостатньо використовуваних можливостей підприємства, підвищення ефективності його маркетингової діяльності.

За другим - напрям аналітичної маркетингової функції, який спрямова-ний на визначення проблем внутрішнього і зовнішнього середовища, розробки рекомендацій щодо їх запобігання й усунення. 3 такої позиції - це перевірка, що здійснюється керівництвом підприємства і передбачає процедуру перегляду або істотного коригування стратегії й тактики маркетингу підприємства в результаті змін умов як зовнішнього, так і внутрішнього середовища. Таким чином мар- 


\section{Derevianchenko Tatyana}

кетинговий аудит виступає одночасно інформаційним інструментом планування маркетингу і способом контролю досягнення маркетингових цілей.

За третім аспектом аудит - незалежний метод глибокого стратегічного та оперативного контролю всієї сукупності маркетингової активності підприємства або їі частини. Як форма стратегічного контролю він надає можливість отримати інформацію щодо закономірностей розвитку ринків певних товарів та діагностувати відповідність діяльності підприємства споживчому попиту.

Сьогоднішня посилювана увага до маркетингового аудиту з боку українських підприємств обумовлена трьома основними причинами: загостренням іноземної конкуренції, кризою у вітчизняній економіці, боргами, що накопичились у багатьох підприємств.

В українській економіці переважає здебільшого системно-орієнтований аудит: фінансовий, податковий, управлінський, екологічний, соціальний, пра-вовий, маркетинговий. Системно-орієнтований маркетинговий аудит - це більше консультаційна діяльність, ніж безпосередня аудиторська перевірка.

Основними об'єктами маркетингового аудиту підприємства можуть бути: стан маркетингу, його роль і місце в корпоративній стратегії підприємства; зовнішнє i/або внутрішнє середовища маркетингу; система планування, організації і контролю маркетингу; комплекс маркетингу, як загалом, так і за окремими складовими; сегментація ринку; структура маркетингових витрат; досягнення підприємством позитивних ринкових відмінностей у рамках конкурентної стратегії; ефективність маркетингової діяльності підприємства тощо.

Оскільки середовище у кожного окремого підприємства індивідуальне (як і його становище на ринку) то й об'єкти аудиту можуть бути різними, що залежить від багатьох чинників, наприклад, таких як галузь господарювання, форма власності, тип здійснюваного аудиту тощо. То ж і завдання маркетингового аудиту, його методи і дії також не позбавлені індивідуального характеру.

\section{3. Цілі, принципи, завдання і функції маркетингового аудиту}

Маркетинговий аудит сприяє оптимізації діяльності підприємства. Тож і цілі маркетингового аудиту полягають у превентивному коригуванні ринкової діяльності на основі оцінки прийнятих рішень 3 метою 


\section{Marketing audit of the enterprise}

визначення вузьких місць в системі маркетингу, максимального використання потенціалу і спрямуванням на досягнення довгострокового економічного успіху підприємства.

Завдання маркетингового аудиту спрямовані на здійснення всіх дій, пов'язаних із реалізацією його цілей і тим самим із реалізацією корпоративних цілей підприємства. Як цілі, так і завдання маркетингового аудиту обумовлені угодою щодо його проведення. Основними завданнями можуть бути [1, с. 11]:

- оцінювання правильності вибору цілей маркетингу та їх узгодження з цілями підприємства;

- перевірка відповідності стратегії, практики і організації маркетингу умовам функціонування підприємства;

- діагностика ринкової ситуації та іiі прогноз;

- перевірка реалізації підприємством потенційних можливостей i ресурсів щодо ринків збуту, цільових груп споживачів, товарів тощо;

- діагностика ефективності маркетингової діяльності підприємства та розробка рекомендацій щодо їі підвищення;

- інформаційне забезпечення і зменшення ризиків в процесі прийняття маркетингових рішень.

До основних принципів маркетингового аудиту відносять:

Всебічність - передбачає, що аудит охоплює всі основні чинники маркетингового середовища і не обмежується аналізом тільки окремих його аспектів.

Системність маркетингового аудиту містить в собі упорядковану послі-довність превентивних діагностичних кроків, процесу аналізу та розробки рекомендацій, їх представлення й захисту.

Періодичність - проведення аудиту через певний період часу, пов’язаного, наприклад, з періодичним коригуванням маркетингової стратегіï.

Незалежність - аудит проводиться сторонніми консультантами, які відчувають при прийнятті рішень набагато менший тиск внутрішньо фірмових взаємовідносин, ніж маркетологи підприємства. При цьому розробки маркетологів використовуються як важлива складова інформаційної бази аудиту.

Вирізняють такі основні функції маркетингового аудиту:

Ревізійна, тобто перевірка маркетингової діяльності відповідно до завдань і цілей, що обумовлені угодою на проведення аудиту. 


\section{Derevianchenko Tatyana}

Інформаційна - забезпечення підприємства об'єктивною інформацією щодо стану маркетингової діяльності.

Аналітична - пізнання і максимально об'єктивне оцінювання маркетин-гової діяльності підприємства, його навколишнього середовища.

Прогнозна функція - прогноз ефективності маркетингу на основі аналізу попередньої і поточної інформації, превентивного оцінювання перспектив розвитку та кінцевих результатів.

Консультаційна - надання допомоги у вирішенні змісту, процесу або структури маркетингової проблеми, яку підприємство не може подолати самостійно та активізації роботи відповідної служби.

Навчальна - підвищення кваліфікації робітників служби маркетингу, відділу продажу, реклами тощо.

Методологічна, яка полягає у розробці науково-методичного та інформаційного забезпечення маркетингу з метою підвищення його якості.

Актуальність адаптації принципів і методів маркетингового аудиту стосовно українських реалій зумовлена недостатнім досвідом роботи більшості вітчизняних підприємств в умовах конкурентного середовища та його високою нестабільністю.

\section{4. Структуризація процесу маркетингового аудиту}

Процес маркетингового аудиту може бути представлений наступними етапами (рис. 2):

Етап попередньої підготовки процесу аудиту обумовлює високий рівень підготовчої роботи, що програмує ефективність наступного аналізу маркетингової діяльності підприємства і передбачає:

- перший контакт із вищим керівництвом підприємства 3 метою розробки угоди щодо цілей, діапазону, джерел інформації, виду кінцевого звіту; обговорення напрямків, які замовник хотів би змінити на підприємстві та яким чином аудитор може йому в цьому допомогти тобто попередній діагноз проблеми;

- розробку плану аудиту на основі попереднього аналізу проблеми (передбачає підготовку програми аудиту з визначенням термінів і графіку його проведення; підготовки звіту і аудиторського висновку; методів і способів проведення аудиту; розробка правил підбору і роботи з персоналом, документацією.

- переговори й укладання контракту на консультативну допомогу. 


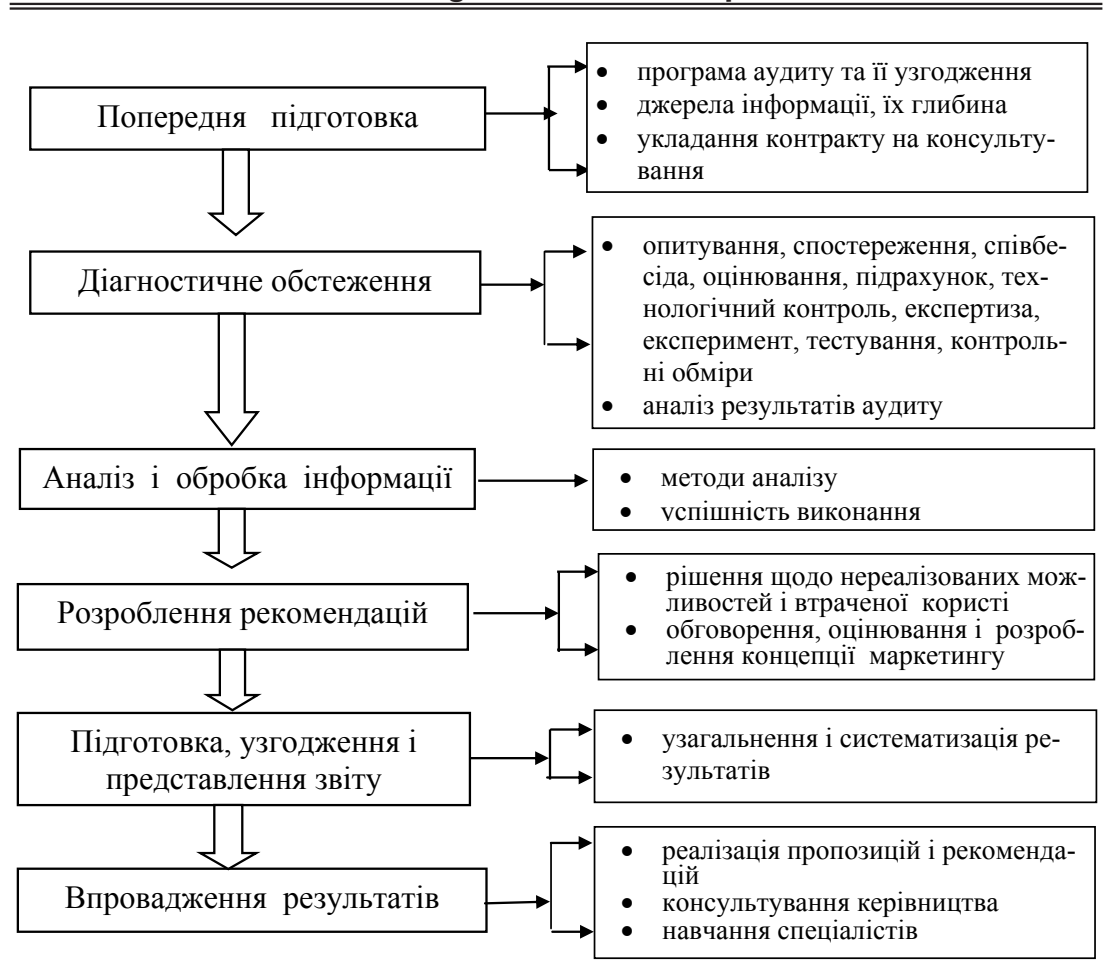

\section{Рис. 2. Алгоритм процесу маркетингового аудиту}

По закінченні загальний план і програма оформлюються документально, затверджуються керівництвом підприємства-замовника та керівництвом аудиторської (консалтингової) фірми. При комплексному аудиті складаються робочі програми за окремими напрямками маркетингової діяльності. Разом з тим, неможливо розробити універсальну програму, оскільки немає повністю схожих підприємств навіть в одній галузі. Завжди існують обставини щодо конкретного підприємства, які вимагають індивідуального підходу.

Другий етап - етап діагностичного обстеження - передбачає визначення існуючого стану справ на підприємстві шляхом збирання і накопичення різноманітної інформації та іiі ретельного аналізу. Тут може використовуватись попередньо надана інформація, а також результати проведення опитувань, спостережень, контактів із споживачами про- 


\section{Derevianchenko Tatyana}

дукції підприємства. Додатково використовується інформація, яку було отримано від менеджерів вищої і середньої ланки, інших працівників підприємства.

Основне правило збирання даних - якомога повніше використати різноманітні джерела інформації, а не тільки обмежуватись отриманою від співробітників досліджуваного підприємства. На цьому етапі здійснюють контроль збору даних, який передбачає моніторинг ретельності збирача інформації, зокрема, тривалістю, місцем, датою, предметом та іншими елементами збору даних.

На етапі аналізу й обробки інформації встановлюють успішність вико-нання взаємопов'язаних і взаємодіючих складових комплексу маркетингу, застосовуючи при цьому різноманітні методи і методики.

Розробка рекомендацій має на меті пошук рішень для отримання втраченої користі від нереалізованих дій, тобто передбачає розробку заходів щодо усунення помилок в маркетинговій системі. Крім того, можливі якісні зміни в діяльності підприємства, зокрема такі як розширення асортименту, вихід на нові ринки; рекомендації з дослідження споживачів; прогноз продажів; зміни комунікаційної політики; впровадження або модернізація служби маркетингу; постановка системи маркетингової інформації; бюджет маркетингу; розробка механізму контролю; положення про службу маркетингу; підбор і тестування кандидатів на маркетингові посади тощо.

Підготовку, узгодження і подання звіту замовнику виділяють в окремий етап маркетингового аудиту, оскільки звіт узагальнює і систематизує отримані результати. Важливою складовою цього етапу є таке звітування про виконану роботу, яке передбачає усну доповідь вищому керівництву про результати аудиту з одночасним представленням письмових матеріалів. При цьому звіт може надаватися конфіденційно для генерального директора підприємства, окремо для власників підприємства, вищого керівництва або спеціалістів маркетингової служби.

Етап впровадження результатів передбачає підготовку й виконання наміченого плану заходів стосовно реалізації прийнятих пропозицій і рекомендацій, маркетингової стратегії підприємства. Якщо передбачено угодою, на цьому етапі здійснюється супроводження аудитором виконання плану намічених дій у формі превентивного консультування вищого керівництва й навчання спеціалістів відповідних підрозділів підприємства. 


\section{Marketing audit of the enterprise}

Залежно від напрямів маркетингового аудиту перевірці підлягатиме робота відповідних підрозділів підприємства та їх працівників. Як засвідчує практика, найбільш поширеними причинами запрошення аудиторів 3 маркетингу вважають: досвід їх роботи 3 аналогічними підприємствами або аналогічними проблемами; наявність спеціальних технологій і знань; потреба у навчанні (пізнання через аудитора); отримання підтвердження правильності дій; інтенсивна допомога у вирішенні конкретної проблеми; «свіжий» погляд на підприємство та його маркетингову діяльність.

\section{5. Основні види маркетингового аудиту}

Багатогранність і різноманітність цілей маркетингового аудиту дозволяють розглядати аудит як аналітичний інструмент ідентифікації, оцінювання, виміру, мотивації й виконання дій 3 досягнення найкращих маркетингових результатів. У зв'язку з певною новизною поняття маркетингового аудиту єдиної його класифікації не існує. Розглянемо найбільш відомі з них.

Під комплексним (горизонтальний, розгорнутий, всеохоплюючий) аудитом розуміють аудит усіх складових маркетингової діяльності підприємства. Він включає зовнішнє і внутрішнє середовище, цілі, стратегії, організацію і структуру маркетингової діяльності підприємства тощо.

Тематичний (вертикальний, поверхневий) - аудит лише однієї зі складових маркетингової діяльності підприємства, наприклад цінової політики.

Внутрішній аудит підприємство здійснює власними силами. Він оперативний і значно дешевший за зовнішній, працівники підприємства на достатньо професійному рівні знайомі зі службовою інформацією стосовно організації виробництва і реалізації продукції (конфіденційною також). Основні його недоліки: складність проведення власними силами масштабних і глибоких перевірок, супроводжуваних сумнівами в об'єктивності оцінювання. Однак, деякі великі підприємства створюють внутрішні контрольні бригади, подібні внутрішнім аудиторським підрозділам в галузі фінансів. Такі бригади особливо корисні, коли служба маркетингу децентралізована в регіональний чи обласний офіси.

Зовнішній аудит передбачає запрошення незалежних експертів, що забезпечує глибоке вивчення проблеми, отримання кращих результатів 


\section{Derevianchenko Tatyana}

дослідження маркетингу й розробки рекомендацій щодо підвищення його ефективності, необхідну об'єктивність і достатню незалежність. Але його проведення обійдеться підприємству значно дорожче.

Антикризовий аудит - $є$ найбільш типовим для українських підприємств 3 метою виправлення кризового положення на ринку.

Мистецтво аудиторів полягає у застосуванні найбільш ефективних методичних прийомів для успішного виконання поставлених завдань. Маркетингові аудитори повинні дотримуватись таких фундаментальних принципів як чесність і об'єктивність; професійна компетентність та належна ретельність; конфіденційність; надання послуг відповідно технічним і професійним стандартам. Ці принципи однакові як для професійних бухгалтерів, так і для аудиторів, що надають будь-які аудиторські послуги (в тому числі й маркетингові).

\section{6. Інструментарій здійснення маркетингового аудиту}

В процесі маркетингового аудиту застосовують надзвичайно різноманітний інструментарій, але в першу чергу, сюди необхідно віднести його методи. Методи маркетингового аудиту - це шляхи, способи та засоби пізнання дійсності, сукупність органічно пов'язаних принципів та прийомів дослідження різноманітних маркетингових явищ.

Маркетинговий аудит послуговується загальнонауковими та специфічними методами. Зокрема, до загальнонаукових методів відносять спостереження, опитування, порівняння, вимірювання, експеримент, аналіз, синтез, індукцію, дедукцію, абстрагування, узагальнення, інтуїцію, аналогію, класифікацію, конкретизацію, гіпотезу, формалізацію, системний аналіз, моделювання тощо.

До специфічних аналітичних та розрахункових методів маркетингового аудиту відносять: традиційний і контент аналіз, групові дискусії (метод фокус-груп, фокусування), проекційні методи, економічний i маркетинговий аналіз, статистичні розрахунки, панельні дослідження, ділові контакти, пілотні дослідження (метод пробних продаж), імітація тощо.

3 математико-статистичних використовують такі методи як кореляційний та регресійний аналіз, факторний аналіз, метод екстраполяції тренда тощо.

Найбільш широко в процесі маркетингового аудиту застосовують різноманітні методи маркетингового аналізу, тобто способи дослі- 


\section{Marketing audit of the enterprise}

дження певної маркетингової проблеми. Маркетинговий аналіз - складова процесу та інструмент маркетингового аудиту підприємства. Застосування того чи іншого методу залежить від досліджуваної проблеми, напрямку і виду аудиту, можливостей підприємства та інших факторів.

Розглянемо, найбільш поширені методи маркетингового аналізу, що використовують в процесі маркетингового аудиту.

Загальновідомий SWOT-аналіз - визначення, аналіз та оцінювання сильних і слабких сторін підприємства, можливостей і загроз ринку. Складовою його є PEST аналіз - метод, що сконцентрований на макрорівні і містить аналіз політико-правового середовища (political and legal environment); економічного (есоnomic environment); соціокультурного (sociocultural environment) і технологічного середовища (technological environment). SWOT- аналіз передбачає аналіз стратегічної позиції підприємства і аналіз сегментів ринку, на яких воно функціонує; аналіз споживчого попиту, аналіз конкуренції тощо.

Визначення і прогноз ключових факторів успіху галузі (КФУ), важливий підсумок галузевого аналізу, дозволяє підприємству визначити найбільш привабливі напрями діяльності. КФУ періодично переглядають(їх змінам сприяють розвиток галузі, насиченість ринку товарами, науково-технічний прогрес).

Аналіз беззбитковості товару пов'язаний з дослідженням витрат, оцінюванням прибутку і ризику, обумовлених виробництвом товару. Визначають точку беззбитковості, яка характеризує мінімальний обсяг продукції, за якого дохід від продажу дорівнює витратам виробництва.

Морфологічний метод передбачає визначення найбільш важливих структурних елементів товару з наступним дослідженням їх взаємозв'язку. Його мета - виявити нові цікаві комбінації.

Метод простого рейтингу - споживач визначає асортименті види товару від найбільш до найменш переважного ( $>>B>C)$. Один з недоліків методу - зазвичай більше 3-5 варіантів не розглядають, другий невідомим залишається рівень переваг товару.

Функціональний аналіз, за допомогою якого оцінюють і функціонально описують конкретний товар та його властивості. Визначають нові функції, які він може виконувати або виконує краще ніж ті товари, які вже є на ринку. Якщо новий товар переважає у виконанні окремих (або усіх) функцій товари-конкуренти, можна розраховувати на успіх. 


\section{Derevianchenko Tatyana}

Логіка цього аналізу: користувачі можуть повідомити корисну інформацію щодо способів удосконалення товару.

Конджойнт-аналіз застосовують для вивчення формування споживчих переваг товару, формулювання прогнозів щодо ставлення ринку до нових його концепцій. Метод дозволяє отримати відповіді щодо часткової корисності кожного рівня властивості та сукупної корисності різноманітних концепцій товару, переваг потенційних споживачів щодо досліджуваних концепцій товару, визначити компроміси між різними рівнями властивостей, на які готові споживачі.

GAP-аналіз спрямований на усунення розриву між бажаною й прогнозованою діяльністю. Його проводять для кожного конкретного підприємства окремо, виходячи 3 коротко- і довгострокових цілей, прогнозу динаміки норми прибутку, рівня здійснення інвестицій, ресурсів підприємства. Основний недолік - прогнози не враховують вплив зовнішніх факторів, а це звужує спроби підприємства усунути розриви між реальними й прогнозними показниками, що може не привести до бажаного результату.

Факторний аналіз - передбачає комплексне, систематичне вивчення і вимірювання впливу факторів на величину результативних показників. Фактори систематизують за допомогою побудови структурно-логічних моделей (факторних систем), де вони розміщуються у певному порядку з урахуванням їх взаємозв'язку. Між досліджувальними ознаками виникають функціональний і кореляційний зв'язки.

АВС-аналіз базується на принципі Парето, за яким 20\% суспільства володіє $80 \%$ багатства, $80 \%$ суспільства володіє $20 \%$ багатства. Ця закономірність зазнала певних змін і у сферах бізнесу діє такий емпіричний закон: 20\% клієнтів підприємства приносять $80 \%$ всіх доходів; 20\% усіх товарів підприємства приносять $80 \%$ сукупних прибутків; 80\% часу, зусиль, матеріалів витрачається на створення $20 \%$ усіх продуктів; $20 \%$ зусиль приносять $80 \%$ результатів.

XYZ - аналіз. Принцип диференціації асортименту за цим аналізом відрізняється від АВС-аналізу - тут весь асортимент поділяють на три групи залежно від рівномірності попиту і точності прогнозу. До групи «Х» включають товари, попит на які рівномірний або незначно коливається, а обсяг реалізації за цими товарами добре передбачений. Група "Y" - товари, які споживаються в обсягах, що коливаються, а 


\section{Marketing audit of the enterprise}

можливості прогнозу попиту - середні. Група “Z” - товари, попит на які виникає лише епізодично, будь-які тенденції відсутні.

Метод парного порівняння - покупцю пропонують вибрати із кожної пари товарних варіантів (AB, $\mathrm{AC}, \mathrm{BC})$ найбільш привабливий товар. Цей метод полегшує вибір переважного товару, дозволяє визначити схожість і відмінність товарних варіантів.

Модель М. Портера, за якої стратегія залишається свідомим i контрольованим процесом, але конкретну для даного підприємства унікальну стратегію замінюють на загальні стратегії, такі як лідерство за витратами, фокусування та диференціація, які підприємству слід використовувати. Завданням є обрати кращу з можливих стратегій (щодо конкурентів і галузі, у якій його підприємство працює).

Бенчмаркінг - процес порівняння товарів, виробничих процесів, методів та інших параметрів досліджуваного підприємства (структурного підрозділу) з аналогічними об'єктами інших підприємств чи структурних підрозділів. Дієвий інструмент для визначення становища підприємства порівняно з іншими (успішними) подібними за розмірами та/або сферою діяльності.

Методика вибору і оцінювання привабливості ринку для підприємства. Одним з варіантів привабливості ринку є перелік чинників за М. Мак-Дональдом: розмір ринку у натуральному або/і вартісному вираженні, розмір і темпи всього ринку або його ключових сегментів, різноманітність ринку, чутливість до ціни, до рівня обслуговування, до зовнішніх чинників, циклічність, сезонність, сила тиску постачальників. Конкурентні чинники - це типи конкурентів, рівень їх концентрації, зміни часток, оновлення технології, рівень і типи інтеграції. До фінансових та економічних чинників відносять: маржинальний дохід, бар'єри входу і виходу (фінансові і не фінансові), можливості ліквідації. Технологічні - зрілість і рівень розвитку, складність технології, диференціація, патенти і права, технології виробництва. Соціально-політичні - соціальні відносини і тенденції, закони і державне регулювання, вплив груп тиску і представників держави та багато інших.

BCG-матриця (Бостонської консультаційної групи) визначає співвідно-шення «зростання ринку (попиту)» $\mathrm{i}$ «відносної частки ринку». Матриця дозволяє визначити стратегічну позицію по кожному стратегічному економічному елементу підприємства, тобто стратегічну позицію бізнесу підприємства і обрати правильну стратегію дій. 


\section{Derevianchenko Tatyana}

«Матриця General Electric», основна відмінність якої від моделі БКГ - синтетичний характер. Якщо модель БКГ заснована на 2 показниках, то модель “General Electric” може містити до 10 показників, які оцінюють продуктовий портфель за двома основними параметрами. Ця модель повинна визначити не тільки привабливість ринку, але й конкурентні позиції підприємства. Перший параметр моделі - інтегральна оцінка привабливості різноманітних ринків, другий - інтегральна оцінка сили бізнесу підприємства на кожному з ринків. Оцінювання проводять відносно обраних галузевих ключових факторів успіху. Цю модель не застосовують разом з моделлю БКГ, але іiі успішно використовують із загальною портфельною матрицею, яка, в свою чергу, сумісна з БКГ.

Система бальних оцінок - індикатор кожного фактора, умови або обставини оцінюють певною кількість балів. Оцінювальні шкали можуть бути різними, але існує обов'язкова вимога - застосування єдиного підходу, єдиної градації при оцінюванні всього комплексу характеристик. Бальне оцінювання використовують, наприклад, для отримання інформації щодо дизайну товару, смакових якостей, популярності торгової марки тощо.

Дейтамайнинг (від англ. Data mining - інтелектуальний аналіз даних) - сучасна технологія виявлення прихованих взаємозв'язків усередині великих баз даних. Прикладами застосування такого аналізу можуть бути: дослідження коливань обсягів продажу в окремі періоди, які надають можливість зробити висновки щодо сезонних коливань ринкової кон'юнктури, прийняття рішення щодо доцільності створення товарних запасів; аналіз даних про замовлення окремих клієнтів, що допомагає виявити категорії клієнтів зі схожими стереотипами поведінки, тобто провести їх сегментацію.

Це далеко неповний перелік методів аналізу, які використовують в процесі маркетингового аудиту. Надзвичайно важливим $є$ фахове їх застосування.

Послуги $з$ проведення маркетингового аудиту, а отже й виконавцями маркетингових аудиторських послуг можуть бути консалтингові компанії (в Україні у 2002p. провідними аудиторськими і консультаційними компаніями різних напрямів діяльності засновано Асоціацію консалтингових фірм), дослідницькі фірми, комунікаційні групи (агенції), які пропонують повний спектр послуг у сфері консалтингу, 


\section{Marketing audit of the enterprise}

маркетингових і комунікаційних досліджень, реклами, медіа, PR-стратегій тощо (зокрема, в Україні працюють Комунікаційна група PRT, HOSHVA PR, Pleon Talan, Publicity Creating, Imageland, Noblet Media, Комунікаційна компанія FRESHPR та інші).

Маркетингові агенції (маркетингові компанії, бізнес маркетингові групи, маркетингові бюро) здійснюють маркетингові дослідження, рекламу, консалтингову діяльність. Серед відомих компаній, що працюють на ринку України: Українська Маркетингова Група (UMG), GFK Ukraine, MarketSense, Міжнародна маркетингова група України, FDF group, Pulse, Promotion Technologies, New point marketing, A-group, Агентство реклами «БИТИЕЛЛ», Research \& Branding Group та інші.

\section{7. Висновки}

Необхідною умовою успішного маркетингового аудиту є наявність комплексної інформації щодо клієнтів, конкурентів підприємства та їх продукцію, особливості конкуренції, основні тенденції у зовнішньому і внутрішньому середовищі тощо. Проблема недостатнього інформаційного забезпечення маркетингової діяльності і низької оперативності зв'язків для більшості українських підприємств є однією 3 найважливіших. Саме маркетинговий аудит спроможний вирішити ці проблеми.

Прийняття і реалізація стратегічних маркетингових рішень у багатьох випадках стає для вітчизняних підприємств скрутним через загальний нестійкий стан економіки, невизначеність політичної ситуації, відсутність сприятливого інвестиційного клімату. Саме через вищевикладене для українських підприємств надзвичайно актуальним $\epsilon$ визначення ефективності маркетингових заходів i, відповідно, розробка методологічного апарату, який дозволяє врахувати всі або майже всі чинники, що впливають на ефективність маркетингової діяльності підприємства.

Нажаль, маркетинговий аудит в Україні поки ще не має законодавчої основи, не контролюються і не регулюються державою, а звідси, розглядається більшістю керівників як дорогий і непотрібний захід, як данина моді. А відсутність стандартів і законодавчої бази маркетингового аудиту стримує розвиток цієї, такої необхідної сьогодні, діяльності.

За таких умов багатогранність і різноманітність цілей маркетингового аудиту підприємства дозволяють його розглядати як аналітичний інструмент ідентифікації, оцінювання, виміру, мотивації й виконання 
дій 3 досягнення найкращих маркетингових результатів. Маркетинговий аудит задовольняє різноманітні і довгострокові інтереси вищого керівництва (або власників) підприємства, а також специфічні і короткострокові потреби фахівців з маркетингу.

\section{Список літератури:}

1. Дерев'янченко Т.С. Маркетинговий аудит. Навчальний посібник. - К.: KHEУ, 2007. - 239 c.

2. Катаєв А. В. Соціально-орієнтований маркетинг-аудит: монографія / А. В. Катаєв.- Харків : Видавець Оберемок В., 2005. - 212 с.

3. Корягіна С.В. Маркетинговий аудит. Навч. посіб. / С.В. Корягіна, М.В. Корягін - К.: «Центр учбової літератури», 2014. - 320 с.

4. Котлер Ф. Привлечение инвесторов: Маркетинговый подход к поиску источников финансирования. Альпина Бизнес Бук, 2009. - 298 с.

5. Перерва П.Г. Становлення та розвиток маркетингового аудиту в Україні. Бізнесінформ № 1, 2012, с. 191-193.

6. The Marketing Audit Comes of Age. Philip Kotler, William T. Gregor, William H. Rodgers III - [Електронний ресурс] - Режим доступу: http://www.hamiltonco.com/features/hampub/SMR.html

\section{References:}

1. Derev'yanchenko T. Marketyngovyi audyt. Navchalnyi posibnyk. - K.: KNEU, 2007. - 239 p.

2. Katayev A.V. Socialno-oriyentovanyi marketyng-audyt: monografiya / A.V. Katayev. - Kharkiv: Vydavec OberemokV., 2005. - 212 p.

3. Koryagina S.V. Marketyngovyi audyt. Navchalnyi posibnyk/S.V. Koryagina, M.V. Koryagin. - K.: "Centr uchbovoyi literatury", 2014. - 320 p.

4. Kotler Ph. Privlicheniye investorov: Marketingovyi podchod k poisku istochnikov finansirovaniya. Alpina Business Book, 2009. - 298 p.

5. Pererva P.G. Stanovlenny ata rozvytok marketyngovogo audytu v Ukrainye. Biznesinform № 1, 2012. - Pp. 191-193.

6. The Marketing Audit Comes of Age. Philip Kotler, William T. Gregor, William H. Rodgers III - [Elektronnyi resurs]: http://www.hamiltonco.com/ features/hampub/SMR.html 


\title{
Dzhedzhula Vyacheslav ${ }^{1}$ \\ Yepifanova Iryna ${ }^{2}$
}

DOI: http://dx.doi.org/10.30525/978-9934-571-28-2_10

\begin{abstract}
In modern conditions of management it is important for enterprises to carry out effective innovative activity to provide the necessary level of competitiveness. This activity involves the formation of the necessary amount of intellectual capital. Most domestic enterprises do not pay enough attention to this issue. That is why it is very important to determine the directions of its growth. The issue of intellectual capital management, its influence on innovation activity has been considered in the works of L. Antonyuk, S. V. Zakharinko, A. Kendiukhov, G. R. Natroshvili, V. Tsipurindy, L. Fedulova. At the same time, it is important to study the issue of using crowdsourcing by domestic enterprises as a way to increase intellectual capital.

The purpose of this work is to investigate the possibility and efficiency of using crowdsourcing as a source of growth of intellectual capital of an enterprise.
\end{abstract}

Research methodology. In order to achieve the goal with the help of system and comparative methods, it is necessary to assess the factors influencing the intellectual capital of industrial enterprises, to determine the possibility of increasing the efficiency of using intellectual capital with the help of crowdsourcing.

The results of the study have shown that in today's conditions, the intellectual component of innovation activity becomes an important factor. The components of intellectual capital have been investigated. The indexes of knowledge economy of Ukraine and developed countries have analyzed. It has been determined that one of the directions of increasing the index of knowledge economy is the active stimulation of growth of intellectual capital of enterprises.

\footnotetext{
${ }^{1}$ Doctor of Economics, Professor of the Department of Finance and Innovation Management, Vinnytsia National Technical University, Ukraine

${ }^{2}$ Candidate of Economic Sciences, Associate Professor,

Department of Finance and Innovation Management,

Vinnytsia National Technical University, Ukraine

(C) Dzhedzhula Vyacheslav, Yepifanova Iryna
} 
The essence of crowdsourcing and its components have been defined; the modern examples of its application in the world and in Ukraine have been researched. It has been determined that this tool is used mainly in the social sphere in Ukraine. The importance of its use in raising the intellectual component of innovation activity of domestic enterprises has been substantiated.

It has been established that active involvement of students in the activity of the enterprise can be very promising for domestic enterprises. For this purpose, enterprises can provide their production facilities for individual practical tasks and students' experimental-design developments, and students will be able to get real practical skills. As a result of such cooperation, the enterprise can use the development and experience of students in their production activities and see potential employees.

The practical significance of the carried out research is to develop recommendations for industrial enterprises to increase attention to crowdsourcing as an important source of intellectual capital growth.

Consequently, increasing the competitiveness of enterprises is reached by increasing the intellectual component in innovation activity.

\section{Introduction}

In modern conditions, due to the limited quantity of natural resources concentrated in the so-called basic industries (fuel, electricity, metallurgy, metalworking), as well as economic inexpediency in the constant growth of the used resources, it is high technologies, intelligence, scientific discoveries; innovations that will be able to create new materials and substances with much higher performance and utility rates are the main factors which determine the prospects and degree of economic growth.

Consequently, those companies that innovate actively in their activities and have significant intellectual capital are more competitive. The questions of intellectual capital management, its influence on innovation activity were considered in the works of L. Antonyuk, S.V. Zakharinko, A. Kendiukhov, G. R. Natroshvili, V. Tsipurindy, L. Fedulova. In the whole world, at this stage, there is a growing interest in opportunities for collective networking, expansion of the expert community, including new interested participants who have their own view on a particular problem. Crowdsourcing is one of the forms of attracting people to direct participation in collective creativity, solving problems and generating offers for providers of tasks. The 
questions related to the consideration of the essence of crowdsourcing, its types and components are considered by such scholars as Howe J., Brabham D.C., Taeihagh A., Whitla P. However, the issue of use of crowdsourcing by domestic enterprises as a way to increase intellectual capital is not sufficiently studied.

\section{Ingredients of Intellectual Capital}

Innovative development of the economy is inherent to all developed countries of the world, which is both a factor and a consequence of the economic rise of the countries. Its efficiency is determined by the content of the relevant innovation directions that meet the needs of the dynamic development of the economy. In the chain "science - education - production" education is of particular importance, since it is both a source of reinforcement of science by personnel, as well as a factor of providing the population with modern knowledge. To assess the environmental friendliness of the country regarding the effective use of knowledge in economic development, they determine the knowledge economy index, which is presented in Table 1.

Table 1

Comparative Knowledge Indices in $\mathbf{2 0 1 2}$

\begin{tabular}{|l|c|c|c|c|c|}
\hline Country & $\begin{array}{c}\text { Index of } \\
\text { knowledge } \\
\text { economy }\end{array}$ & $\begin{array}{c}\text { Index of } \\
\text { economic } \\
\text { stimulus and } \\
\text { institutional } \\
\text { system }\end{array}$ & $\begin{array}{c}\text { Index of } \\
\text { innovation }\end{array}$ & $\begin{array}{c}\text { Index of } \\
\text { education }\end{array}$ & $\begin{array}{c}\text { Index of } \\
\text { information } \\
\text { and } \\
\text { communication } \\
\text { technologies }\end{array}$ \\
\hline Austria & 8,61 & 9,26 & 8,87 & 7,33 & 8,97 \\
\hline Belgium & 8,71 & 8,79 & 9,06 & 8,57 & 8,42 \\
\hline Finland & 9,33 & 9,65 & 9,66 & 8,77 & 9,22 \\
\hline France & 8,21 & 7,76 & 8,66 & 8,26 & 8,16 \\
\hline Germany & 8,90 & 9,10 & 9,11 & 8,20 & 9,17 \\
\hline Italy & 7,89 & 7,76 & 8,01 & 7,58 & 8,21 \\
\hline Latvia & 7,41 & 8,21 & 6,56 & 7,73 & 7,16 \\
\hline Netherlands & 9,11 & 8,79 & 9,46 & 8,75 & 9,45 \\
\hline Poland & 7,41 & 8,01 & 7,16 & 7,76 & 6,70 \\
\hline England & 8,76 & 9,20 & 9,12 & 7,27 & 9,45 \\
\hline Norway & 9,11 & 9,47 & 9,01 & 9,43 & 8,53 \\
\hline Canada & 8,92 & 9,52 & 9,32 & 8,61 & 8,23 \\
\hline USA & 8,77 & 8,41 & 9,46 & 8,70 & 8,51 \\
\hline Ukraine & $\mathbf{5 , 7 3}$ & $\mathbf{3 , 9 5}$ & $\mathbf{5 , 7 6}$ & $\mathbf{8 , 2 6}$ & $\mathbf{4 , 9 6}$ \\
\hline
\end{tabular}


Knowledge economy is an economy in which the source of growth is both specialized (scientific) and everyday knowledge, as a result of their use together with natural resources, capital and labor, the processes of accumulation and use of knowledge become the dominant factor, consequently the competitiveness of the economy is constantly increasing. Table 1 shows that Ukraine remains behind the developed countries of the European Union and the World as a whole according to the index of knowledge economy. The table shows that the knowledge economy index consists of four sub-indixes: "Economic incentives and institutional system", "Education", "Information infrastructure", "Innovation system". For all sub-indexes, except the educational one, Ukraine has rather low rates.

In order to improve the value of the indexes and the country economy as a whole, it is necessary to improve the economic and legal environment, business development, the ability of society in general and its institutions to more effectively use of existing knowledge and creation of new knowledge.

Moreover, it is important to develop information infrastructure, which is a peculiar framework of knowledge economy.

Universities, scientific-research institutions and organizations as a source of new knowledge will need to be improved substantially.

Thus, one of the important directions of increasing the efficiency of the domestic economy is investing in employees and improving the intellectual capital of enterprises.

In economically developed countries the intellectual factors of economic growth in the form of innovation capital, intellectual products are the strategic factor of economic development. At the same time, Ukraine, like many other European countries, has faced the problem of emigration of highly skilled professionals. If in 2011 the total number of highly skilled employees and people with higher education who emigrated to the highly developed OECD countries was 31 million, then in the period of 2005-2015, highly skilled migration increased by $72 \%$. In Europe, over the past ten years, $15 \%$ of emigrants are individuals with such growing professions as science, technology, engineering, as well as occupations in health and education. Another problem associated with emigration is that part of the employees does not work according to their specialty or they are in low-skilled positions, which does not contribute to intellectual development. Thus, in modern conditions, most domestic enterprises face the problem of the lack of sufficient intellectual capital and, in order to 
increase their competitiveness, Western top management should often be involved.

It is a generally recognized fact that capital investments into an employee are as profitable as investments in any other factor of production. Intellectual capital, according to P. Drucker, is a significant resource, and not just another resource along with traditional factors. Under the conditions of an innovative economy, the importance of traditional factors gave way to information-intensive ones, and they benefited in the quest for a competitive advantage [1]. Knowledge is a real beneficial force, a means of achieving social and economic results. Management is the use of knowledge to find the most effective ways to use the available information in order to obtain the necessary results. The scientist also supports the idea that the world is ruled by knowledgeable people. Indeed, many people have access to tangible and financial resources, while only knowledge and intellectual capital can lead to real innovations, including those introduced in the Circus du Soleil, Tesla, Solar City, PayPal, and others.

In our opinion, intellectual capital is a set of knowledge, skills, ideas of employees, which can bring certain economic benefits and / or enhance the image of the enterprise [2]. Intellectual capital is essentially an intangible asset, an integral part of the goodwill, which, given the skillful management of the company, can bring significant growth in income, profits, and ultimately the competitiveness and market value of the enterprise.

In general, most authors believe that intellectual capital consists of three components [3-7]:

1. Human capital is a set of knowledge, skills, creative abilities, as well as the ability of owners and knowledge-intensive employees to meet the requirements and objectives of the enterprise.

2. Organizational or structural capital is computer software, databases, organizational structure, patents, trademarks, organizational mechanisms that ensure the productivity of employees and the operation of the enterprise.

3. Market or consumer capital is future consumers of products of the enterprise, the ability of the product to meet the needs of consumers.

Companies should pay a lot of attention to human and market capital, which involve the active use of knowledge, skills and capabilities for both company and product customers.

First of all, enterprises should increase the level of education of employees, and also cooperate with educational institutions to identify capa- 
ble potential employees. For this purpose, the countries of the European Union define such an indicator as a stock of human resources in science and technology. It can be used as an indicator of development of knowledge economy and it is calculated taking into account people who have higher education and work in the field of science and technology. In 2016, almost 78.6 million people in the EU-28 aged 15-74 worked in science and technology (considered as human resources in science and technology), which is $2.7 \%$ more than in 2015 and represents almost three tenths of the active population [7]. The EU countries pay a lot of attention to intellectual capital, realizing that the employee is the basis that can lead to a significant economic growth of the enterprise. In this regard, in order to increase intellectual capital, it is rather important not only to train personnel, but also to apply an active motivational policy that stimulates the staff of the enterprise to produce innovative ideas and more actively search for ideas to increase the company's income and reduce its costs. The motivation for innovative solutions to issues that are constantly arising in the process of operating activities, the development of innovative products, the introduction of innovative marketing are possible without the involvement of a significant amount of financial resources, provided that effective management and implementation of enterprise management practices and planning in the company's activities.

The management of the company should also pay considerable attention to consumers of products, which can also assess the effectiveness of the enterprise and offer directions for improvement of activities. Hence, one way to increase intellectual capital may be crowdsourcing, which is defined as a term related to the process of outsourcing the company's activities to an online community or crowd in the form of an "open call" [8]. Any member of a society can fulfill the assigned task and receive a fee for their efforts.

\section{The essence of crowdsourcing}

The vast majority of scientists believe that the first mention of the use of crowdsourcing is the contest held by the British Parliament in 1714, which involved the definition of longevity on sailing ships [9].

As an economic category, the term "crowdsourcing" was first proposed by Jeff Hoe in 2006, which defined crowdsourcing as "a process in which the company transfers certain functions that have previously been relied on 
employees and outsourcing companies as well as vendors to an uncertain, rather large number of people in the format of an open request" [10].

Crowdsourcing is also defined as informational engagement of the crowd in order to solve problems, complete tasks, create ideas and production, in which the scattered knowledge of individuals and groups is used by a combination of innovative processes coming out of the crowd to reach effectively the goals set and initiated by the organization [11-12].

Crowdsourcing is also understood as the organization of the work of a group of people over any task for the sake of achieving common good. It is a practice of obtaining the necessary services, ideas or content by requesting assistance, addressing large groups of people, especially the online community, the transfer of certain production functions to an uncertain circle of persons, which does not involve the conclusion of an employment contract [13].

Consequently, all authors agree that crowdsourcing involves attraction of a group of people (which can either be selected by the enterprise itself or be arbitrary) to solve a particular task.

Crowdsourcing is part of what is called "user-based innovation". A key distinction between crowdsourcing and traditional communication tools is the unambiguous focus on action. A person does not just spend his resources; he directs them to a specific task.

Thus, in general terms, crowdsourcing is a process for organizing the possibility of using the knowledge, ideas, and mental skills of a certain group of people to solve the problems. At the same time, such an engagement can take place both on a paid basis and on a royalty-free basis.

The increase in the sales of personal computers and other digital devices and the increase in the share of devices connected to the Internet have significantly reduced the costs of involving participants in the Internet communities, including those engaged in crowdsourcing, and the cost of searching and processing idea; many billions of people have become potential participants in crowdsourcing. Therefore, the emergence and spread of the Internet has intensified this form of cooperation with consumers.

There are plenty of tools that help you to use crowdsourcing on the Internet, including social networks based on information dissemination and approval. The agiotage of "dissemination in social networks" consists in demonstrating knowledge or experience, and in giving preference to a product or service to others through social networks. And the factor that can 
stimulate crowdsourcing is people who want to demonstrate their knowledge by solving common problems.

Any enterprise, provided that it builds efficiently the program of crowdsourcing, has the opportunity to cover a significant network of real and potential consumers of products, goods, works and services in a matter of seconds. This tool is especially interesting for those companies that have their own sites, as well as pages in social networks in several languages, which increases the number of people who consider it necessary to assist the company in solving certain issues.

So, crowdsourcing is at the junction of two phenomena that are widespread in the modern economy: business socialization and open innovation.

Such areas of use of crowdsourcing can be distinguished [14]:

- in the process of creating the results of creative work;

- for use of group intellectual abilities of the society;

- for the purpose of data filtering;

- for aggregation of financial resources.

Today there are three marketing areas in which firms are actively using public opinion, namely product development, advertising and marketing research [8].

Within each of these areas, two different approaches are used where the consumer is widely used:

- the tasks were open to practically anyone who wanted to complete them,

- the enterprise restricts those who could take part in the task that is it chooses those who has some previous experience. To distinguish between these two types of tasks, companies use a variety of service providers from open public sites such as "mechanical coffee pot" to closed communities of previously viewed people, such as "innocent".

Firms often have problems collecting customer feedback, for use in product development. Crowdsourcing has accelerated the process of receiving feedback from end users in the following ways:

1) The large number of consumers / end users who can provide feedback can be greatly increased, since offers and developments can come not only from existing customers, but from potential customers with whom the company had no links before.

2) The enterprises are able to interact with consumers instantly and directly, there is no need for information that needs to be filtered from vendors or other members of the distribution channels. 


\section{Crowdsourcing as a way to increase the company's intellectual capital}

3) Instead of consumers who provide generalized special offers for new products, firms can specifically adapt product development areas that consumers need.

Taking these areas into account, it becomes apparent that crowdsourcing is one of the components of the company's intellectual capital. The active use of this tool can contribute to a significant increase in intellectual capital, an increase in profits at relatively low cost. This is especially true for small and medium enterprises.

\section{Types of crowdsourcing}

Firms use crowdsourcing to get information and advice on their product development efforts from existing end users and experts who can address a particular scientific or design problem. Other firms offer a community of people to develop their own products, which the client firm can then make in their favor by distributing profits.

In general, various approaches to the classification of crowdsourcing are distinguished in the literature (supplemented on the basis of [15-17]):

1) by the sphere of life (business, social, political);

2) by the type of problem solving (creation of a product (content), voting, searching for a solution, searching for people, collecting information, collecting opinions, testing, support, collecting funds (crowd funding);

3 ) by the type (creation, wisdom, financing, voting);

4) depending on the subject of the organizer (crowdsourcing by the company, crowdsourcing, carried out by a third-party organization);

5) depending on periodicity (permanent, temporary, one-time);

6) by the content (aimed at finding a solution to the problem posed by business, aimed at creating a finished solution, product, service according to the requirements, aimed at making an expert examination of the decision, project, document);

7) depending on the participants (employees of the enterprise; local crowdsourcing, national crowdsourcing, global crowdsourcing);

8) depending on the accessibility (open, closed);

9) depending on the availability of economic benefits (with payment, without payment);

10) depending on the goals (cost optimization, increase in sales volumes, search for innovative solutions). 
Depending on the spheres of life in which they are used, the following types of crowdsourcing are distinguished:

- business crowdsourcing, which involves the active involvement of consumers, contractors and all people who are wishing to enter the activity of the enterprise.

With the help of business crowdsourcing, various issues can be solved: interior, rebranding directions, directions for improving the company's activities, etc.

- Social crowdsourcing, which contributes to solving social issues.

Social crowdsourcing consists in involving a large group of users in solving certain issues related to social practices, sponsorship, and people-to-people relationships. This category of crowdsourcing can include such projects as finding the lost people, the collection of financial resources for treatment, the opening of a new school, etc.

- Political crowdsourcing, which involves active involvement of citizens in solving state and regional issues. This type of crowdsourcing includes projects for discussing various laws and governmental initiatives. Discussions can take place both in the form of voting and in the form of gathering specific thoughts.

Principal feature of the technology of political crowdsourcing is the direct involvement of interested consumers of state governmental services in the management of the territory, which involves participation in decision-making, definition of goals, solving problems (social, economic, political, etc.). The use of this tool changes dramatically the motivation of service users: there is a real opportunity to be heard, feel involved in the solution of a problem, and get the opportunity to change something for the better. It should be emphasized that not only regional, municipal authorities and management, but also direct consumers of government services may be the initiator of crowdsourcing.

According to the types the following components of crowdsourcing are distinguished [15]:

- creation - a project which is created by the brainstorming efforts of many people who are not familiar, materially not interested and share their knowledge and experience in writing, thereby creating unique content;

- wisdom - with the help of many different views and thoughts as a result the pure knowledge is crystallized, which is absolutely free;

- financing - a kind of crowdsourcing, when financially-oriented tasks are being transferred to those people who are willing to take part in the 


\section{Crowdsourcing as a way to increase the company's intellectual capital}

project (for example, the "Donate" button is set on the site so that anyone can support the resource materially).

- voting - people's voting (various people's awards, ratings, etc.)

In addition, the following types of crowdsourcing are distinguished in the literature [11]:

- virtual labor markets are an information and marketing markets where individuals can provide online services that can be performed anywhere, which are offered by enterprises, usually through micro-tasks, typing the production model of crowdsourcing in exchange for monetary compensation.

Micro-tasks are actions that can be divided into different stages, which can be completed in parallel and on a scale, using human computing power. Nowadays, most of these tasks require low and intermediate levels of qualification, and the level of compensation for tasks is low.

- Crowdsourcing tournament is a form of crowdsourcing, in which enterprises set out tasks for specialized IT-mediated platforms that form competitions and establish rules and prize places for competitions. Individuals or groups can publish their decisions through a specialized IT-mediated platform for reviewing to get a prize that ranges from several hundred dollars to hundreds of thousands of dollars or even more.

- open cooperation - the company publishes issues that are to be solved through the IT system and citizens voluntarily deal with these issues, usually without waiting for monetary compensation. In this case, the level of engagement of ideas from citizens will depend on a number of factors, such as the effectiveness of the "open call" to the enterprise, coverage and engagement of citizens with the IT platform used.

Moreover, today a number of scientists are paying attention to scientific crowdsourcing [17-18]. In particular, the University of Carlton (the USA) uses crowdsourcing tools, including text messages, voice mail and the Internet to explore the history of the Pontiac region through its community. The Heritage Crowd project creates a database for online exhibits using information from residents who actually live in the region [17].

Positive results and participation in mass events have shown that people find it remarkable that they contribute to academic work as a community. Such projects are a striking example of crowdsourcing used in the organization of education, when without the help of the community the university will have to hire people to conduct research on the topic to get information about historical exhibitions. 
The positive results of universities, colleges and universities that use crowdsourcing show that the best person to do the job is whoever wants to do the job most. Crowdsourcing offers many benefits to the participating students. For example, crowdsourcing gives students the experience of the real world in developing creative solutions to important issues.

Various scientific disciplines can be changed under the influence of new distributed research methods. The first academic discipline that exerted a significant impact of crowdsourcing was the ornithology in which the eBird.org project led to the creation of a worldwide on-line database for bird-watching in real time. The project has come close to a relatively small number of professional ornithologists and a large army of volunteers distributed across the globe.

Consequently, there are a large number of types of crowdsourcing that can be used to increase intellectual capital. In particular, businesses can engage consumers to create a new product, new advertising, and new ideas, to work out a specific area of work that does not contain commercial secrecy and does not require much qualification. Interaction with consumers can take place both through the site of the company, and through social networks, special IT platforms.

The active involvement of students in the activities of the company, in particular as an intellectual asset, is quite promising for domestic enterprises. For this purpose, enterprises can provide their production capacities for carrying out individual practical tasks and scientific and research development of students, and students will have the opportunity to get real practical skills. As a result of this collaboration, enterprises can use the development and experience of students in their production activities and see potential employees.

\section{International experience of applying crowdsourcing}

The use of crowdsourcing brings together both real and potential buyers with the company. The enterprise in this case shows the importance of each consumer and its interest not only in purchasing power, but also in their real desires and needs. In this case, the consumer feels significant and increases the social status of the enterprise. Taking into consideration the modern concept of community development, the social status of the enterprise is very important, which can both contribute to the growth of sales and business activity of the enterprise, as well as to cause financial losses. 


\section{Crowdsourcing as a way to increase the company's intellectual capital}

Wikipedia can be called the most extensive and popular project of crowdsourcing in the history of mankind, which is an example of the use of collective intelligence.

The Social Network to search and establish business contacts LinkedIn is another example of crowdsourcing. LinkedIn has registered more than 85 million users representing 150 branches from 200 countries, which provides the ability to draw the right specialists to discuss the problem.

Today, such a tool as crowdsourcing is actively used by a large number of companies, including Starbucks with its "My Starbucks Idea" project [19]. To improve performance, Howard Schultz approved the creation of this site, where users of Starbucks still have the opportunity to write their ideas for improving the activities of cafes in different directions. The best ideas come true.

The company Muji, which is known for creating interior items from high-tech materials using innovative technology, also uses actively the ideas of its customers. The management of Muji created a section on the company's official website, "Connect with Us and Kaizen", where any user of the site can offer ideas to improve the company's activities in different directions [20]. The most interesting technological ideas are sent to designers who implement them in the production process.

The Chicago T-shirt manufacturing company "Threadless" actively uses crowdsourcing as a tool for intellectual capital and profit growth. The process of designing the company's T-shirt design consists solely of conducting on-line contests: every week the company receives hundreds of ideas from amateurs and professional artists. "Threadless" publishes these pictures on its site, and each registered user can evaluate a particular T-shirt. Every week, production starts from four to six of the most popular designs, but only after a sufficiently large number of buyers make a pre-order so that they could avoid any loss. Winners receive $\$ 2,000$ each week and various prizes, but the real motivation is the desire to see their work launched in production. On the label of each "Threadless" T-shirt, the name of the developer is printed. For designers, this is creative advertising, for customers it is an additional choice. The company does not need to hire a design team, while investing money only in proven, pre-ordered designs, which is a significant reduction in risk.

The company "Procter \& Gamble" on the site "InnoCentive" publishes issues that it cannot solve itself, offering big pecuniary reward for more than 160,000 people who are unofficial free employees of the company. 


\section{Dzhedzhula Vyacheslav, Yepifanova Iryna}

The transnational company producing computer software "Microsoft" uses the crowdsourcing method, involving users of its software to leave suggestions on improving the company's development on the corporate website, and it also conducts public opinion polls.

Crowdsourcing is actively used in educational programs. The company ABBYY, a well-known programmer for reading files in various formats, has created a project to translate the global course Coursera into Russian. Not only professional philologists work on the English translation, but also ordinary users who speak English well on a specially designed SmartCat cloud technology platform.

The world-wide TED conference, which is conducted with the help of volunteers, is also an example of using crowdsourcing.

NASA also has its own crowdsourcing project. "Clickworkers" is a project which involves enthusiasts from outer space to classify the patterns of the crater on Mars. This project began as a pilot study in 2000 to determine whether online volunteers will be interested in whether they can get useful data that can be used to answer interesting scientific questions.

Moreover, entire platforms are created for crowdsourcing. So, uTest is the world's largest test platform for testing software products. uTest offers a complete set of testing with the help of the community of more than 30,000 professional testers from more than 165 countries. This platform can be applied for testing web, mobile, gaming and work applications.

You can conduct various types of testing on this platform. The mission of the company is to provide software makers with the most cost-effective solution taking into account correlation of price and quality of solution that can be used anytime and anywhere.

Talenthouse is a global platform for the relationship between creative professionals that brings together young artists with those who have already proven themselves. Artists use the platform as a tool for collaboration, expanding their audience and getting profit. In doing so, they retain all rights to the fruits of their work. Brands choose Talenthouse to enter into a dialogue with their consumers, doing it in an entertaining and merry form.

Consequently, today there is a significant number of enterprises, platforms, which basing on methods of brainstorming and expert analysis increase intellectual capital, receiving ideas and suggestions from all interested persons. 


\section{Crowdsourcing as a way to increase the company's intellectual capital}

\section{Domestic experience of crowdsourcing}

The Ukrainian-language section of Wikipedia is a multilingual online project to create an encyclopedia that can be edited by anyone interested in the Internet.

Another example is Wikimapia, a multilingual and open multi-user interactive map, where anyone can create a description of the terrain and share their knowledge of it.

The company Bayer, which introduced in 2009 in Ukraine "Grant-

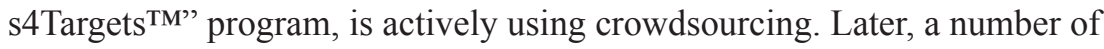
other initiatives were initiated: "Grants4Apps ${ }^{\mathrm{TM}}$ ", "Grants4Indications ${ }^{\mathrm{TM}}$ ", "PartnerYourAntibodies"TM", "Grants4Tech"M" and "Grants4Traits"TM". Having created conditions for innovation, Bayer offers grants to scientists from universities, academic research institutes, and start-up companies or IT developers for the medical industry from around the world with further support for individual projects. Participants can receive financial support and useful experience.

The company "VinnytsiaKartServis" has launched a competition for the creation of an electronic ticket, which is planned to be used in public transport in Vinnytsia. The main requirement of the design is that it should be associated with Vinnytsia. The winner will receive 5 thousand UAH.

Among the examples of social or public crowdsourcing in Ukraine, we can name a project such as "Make Ukraine Clean" (a public campaign to clean up its cities, which occurs every spring: everyone is registered on the site and chooses or creates their places for cleaning).

Crowdsourcing has gained a particular relevance against the background of an increase in volunteer activity and a variety of campaigns to raise humanitarian aid in Ukraine due to an armed conflict in the eastern part of the country. It was the Internet and social networks that became the main tool for finding resources and aid for the army, refugees, victims of hostilities.

The example of crowdsourcing is the initiative of the Vinnytsia Charitable Fund "Podilskaya Hromada" where such social projects are carried out under conditions of crowdsourcing as an auction of projects, "Vinnitsa is my city", "Yard Sport", "Merry Doctor" and others [21]. The essence of these programs is to attract ideas on the improvement of the city in different directions, the implementation of social projects. At the same time, the best projects are realized at the expense of the Charitable Fund, or the winners of the best projects receive funding for these projects. 
The mobile application OSBB.UA, which is designed for residents of multistory buildings, is an example of crowdsourcing. Immediately after registering their building at OSBB.UA, the residents receive tools that help save precious time and solve communication problems between apartment owners, the head of OSBB (association of residents of multistory buildings) and the management company.

Such projects as include "Clean city", "Clean up after the winter" are actively implemented in the city of Vinnitsa, which involve people to clean up the territories and to conscious active public position.

In addition, in other domestic cities, there are free-for-profit social programs. In particular, the project "Lypneva.com" is being implemented in Lviv, in which the initiative group that implemented the project of greening the Galitskaya Square, is currently implementing a project for the arrangement of the street of Lipnya, where once there was a spontaneous market, and then - a huge parking lot.

Consequently, most domestic projects related to the use of crowdsourcing have a social orientation and are practically not used in the economic activities of enterprises.

\section{Conclusions}

Thus, today there is a significant number of enterprises, platforms, which basing on methods of brainstorming and expert analysis increase intellectual capital, obtaining ideas and offers from all interested persons.

The key advantage of crowdsourcing is that its use in companies makes it possible to use existing resources more efficiently than traditional enterprises.

It is expedient for domestic enterprises to use actively the opportunities of crowdsourcing to increase their intellectual capital. For this purpose, active communication with potential and actual consumers is needed through their own sites and through social networking pages.

Active involvement of students in the activities of the company, in particular as an intellectual asset, is quite promising for domestic enterprises.

\section{References:}

1. Drucker P. (1993) Post-Capitalist Society. - Harper Business, New York.

2. Dzhedzhula V. V., Yepifanova I. Yu. (2017) Intelektualnyi kapital yak chynnyk efektyvnosti innovatsiinoi diialnosti [Intellectual capital as a factor in the effectiveness of innovation]. Bulletin of the Khmelnytsky National University. Series of Economic Sciences, no. 4, pp. 158-162. 


\section{Crowdsourcing as a way to increase the company's intellectual capital}

3. Di Stefano Paul J, Kalbaugh G. Edward (1999) Intellectual Capital. Rough Notes, 142 (7), pp. 94-95.

4. Tsipurynda V. (2013) Faktory formuvannia intelektualnoho kapitalu [Factors for the formation of intellectual capital]. Bulletin of the Kiev National Trade and Economic University, no 2, pp. 18-28.

5. Bontis Nick (1996) There's a Price On Your Head: Managing Intellectual Capital Strategically. Business Quarterly, no 60 (4), pp. 40-47.

6. Bassi Laurie J. (1997) Harnessing the power of intelectual capital. Training \& Development, no 51 (12), pp. 25-30.

7. Eurostat regional yearbook 2017. - Retrived from: http://ec.europa.eu/ regional_policy/en/newsroom/news/2017/09/14-09-2017-eurostat-regionalyearbook-2017 (accessed 25 February 2018)

8. Paul Whitla (2009) Crowdsourcing and Its Application in Marketing Activities. Contemporary Management Research, Vol. 5, No. 1, pp. 15-28.

9. Ellis S. A. (2014) History of collaboration, a future in crowdsourcing: Positive impacts of cooperation on British librarianship. Libri, 64 (1), pp. 1-10.

10. Howe J. (2006) The rise of crowdsourcing. Wired Magazine, Vol. 14, Issue 6, pp.1-4.

11. Taeihagh A. (2017) Crowdsourcing, Sharing Economies and Development. Journal of Developing Societies, Vol 33(2), pp. 191-222.

12. Brabham D. C. (2008) Crowdsourcing as a model for problem solving an introduction and cases. Convergence, 14 (1), pp. 75-90.

13. What is crowdsourcing? Types and types, ways to earn money and find new ideas. - Retrived from: http://pro-spo.ru/freelance/3289-chto-takoe-kraudsorsing (accessed 25 February 2018)

14. Howe J. (2008) Crowdsourcing: Why the Power of the Crowd Is Driving the Future of Business. N.Y. : Crown Publishing Group.

15. Maistrenko O. V. (2017) Kraudsorsynh: sutnist, vydy, pryntsypy ta instrumenty zastosuvannia [Crowdsourcing: the essence, types, principles and tools of application]. Economy and Society, no 9, pp. 507-511.

16. Khymych I. (2014) Kraudsorsynh - suchasna finansovo-marketynhova stratehiia pidpryiemstva [Crowdsourcing is a modern financial and marketing strategy of the enterprise]. Socio-economic problems and the state, Issure 1 (10), pp. 242-249.

17. Monika Skaržauskaite (2012) The application of crowd sourcing in educational activities. Social technologies, 2(1), pp. 67-76.

18. Eherev S. V., Zakharova S. A. (2013) Kraudsorsynh v nauke [Crowdsourcing in science] Science. Innovations Education, no. 14, pp. 175-186.

19. Eherev S. V., Zakharova S. A. (2013) Kraudsorsynh v nauke [Crowdsourcing in science ]. Science. Innovations Education, - Вип. 14. - С. 175-186.

20. The official site of the Starbucks ideas - Retrived from: https://ideas.starbucks.com/ (accessed 25 February 2018)

21. The official site Muji. - Retrived from: http://www.muji.eu/pages/contact. asp? opt $=\mathrm{k}$ (accessed 25 February 2018)

22. The official site Charitable Foundation "Podilskaya Hromada". - Retrived from: https://gromada.vn.ua (accessed 25 February 2018) 


\title{
STRATEGIES OF EFFECTIVE DEVELOPMENT OF PARTICIPANTS THE INNOVATIVE PROCESS
}

\section{Dovbenko Viacheslav ${ }^{1}$}

DOI: http://dx.doi.org/10.30525/978-9934-571-28-2_11

\begin{abstract}
In the paper, the process of developing strategies for the effective development of participants in the innovation process in the conditions of the crisis is studied in order to quickly overcome the negative trends in the economy. The purpose of this paper is to summarise the existing opinions and present new approaches in forming the strategies of efficient development of innovation process participants. The method of extended study allows revealing the main causes, opportunities and threads on the way of innovation activity enhancements in Ukrainian economy. The analysis the factors of influence on innovation activity revealed insufficient attention to this problem from the state, lack of purposeful actions aimed at correcting the situation with chronic underfunding of science and especially the sphere of research and development. Methodology. The survey is based on a systematic approach to the consideration the processes of forming a strategy of effective development the participants of innovation process and implementation this strategy despite the economic crisis. For this purpose, methods of induction and deduction, comprehensive analysis of interdependencies of individual components of the potential of innovation development are used. In addition the modeling of interaction the participants in innovation process was actualized. The paper at first to identify the general causes and phenomena with a gradual transition to the consideration of specific problems that hinder the achievement of the assigned goals for the activation the processes of knowledge and technology transfer and the timely commercialization the $R \& D$ results. The purpose of the research is the theoretical questions of the formation a strategy of the effective development the innovation process participants to investigate, the condition of innovation ecosystem to analyze, the prospects a mechanism of commercializing the results of $R \& D$ to create. Practical implications. The open
\end{abstract}

${ }^{1}$ Candidate of Economic Sciences,

Associate Professor at Department of Business Economics and Investment, Lviv Polytechnic National University, Ukraine 


\section{Strategies of effective development of participants the innovative process}

innovation strategy must enable increasing cooperation among different partners and their R\&D activities by greater use of common know-how and resources. Innovation strategy will require a change in the company which should concern to the level of relationship with partners outside, as well as with employees inside the company. The role of innovation ecosystem in economic development in the current circumstances is growing significantly. A favourable business environment allows efficiently combine the interests of the company and its partners to determine the relationship of the parties, and thus ways to achieve the goals of development. Innovation strategy is significantly affected by innovation potential and management, lateral thinking, innovation, investment climate and organizational structure. For increasing the innovation activity it is necessary the established cooperation among different partners involved in innovation process. Conclusion. Importantly for every participants of innovation process is the right selection the individual components of the mechanism of innovation development and creation the conditions for optimal interaction. In this case a synergy effect will ensure a more efficient use of the resource potential and allow acquiring an additional cumulative effect.

\section{Introduction}

In the economic crises conditions, it is important to adopt qualitatively new strategic decisions regarding the renewal of existing potential of country to better utilize opportunities for economic and social development. The solution of this problem is impossible without reorienting the economy to the innovative way of development. These tasks are extremely actual and urgent about time of their solution because Ukraine has become significantly behind its neighbors as well in terms of development rates and as in terms of living standards.

The purpose of the research is to reasoning the theoretical questions of the formation a strategy for the effective development of innovation process participants, the analysis of the condition the innovation ecosystem, the prospects for creating a mechanism for promoting innovation activities and the processes of commercializing the results of R\&D.

The tasks of this paper is to investigate the existing condition of innovation activity in the economy, to analyze approaches to the shaping an innovation strategy that provides for the effective development of the innovation process participants, the possibility of improving the innovation ecosystem 


\section{Dovbenko Viacheslav}

and the formation a mechanism to facilitate the transfer of knowledge and technology using of business-models and modern tools for the implementation of innovative projects.

The basis of the methodology of this study is the systematic approach to the consideration the processes of forming an innovation strategy and its implementation in the context of economic crisis. For this purpose, methods of induction and deduction, analysis of interdependencies of individual components of the potential of innovation development and modeling the interaction of participants in innovation process are used. The material is presented in a logical sequence in order to identify first the general causes and phenomena with a gradual transition to the consideration of specific problems that hinder the achievement of the goals set for the activation the processes of knowledge and technology transfer and the timely commercialization of the results of the R\&D.

The companies must have a good developed strategy for the purpose of its effective development. In modern conditions, this strategy must contain an innovative strategy as its core. However, in the world of new technologies, the requirement for close cooperation between the parties is becoming more and more obvious, as even the large companies experiencing difficulties in providing ever-increasing volumes of $R \& D$ that can maintain a high level of competitiveness. These reasons are associated with growing interdisciplinarity $\mathrm{R} \& \mathrm{D}$ and the need for timely commercialization of their results. In modern conditions, the bases of economic development are innovative factors, which replaced the factors of additional attraction of resources and their effective use. Of course, the recent last listed factors have not completely lost their role, especially those that maximally take into account the possibilities of efficient use of resources.

The state of innovation activity in Ukraine is difficult to consider satisfactory. Despite the presence of significant scientific potential and the experience of creating technologically complex products, the country loses its position in the markets of high-tech goods and services $[1, p .8]$. Currently the development of innovation networks in Ukraine can be characterized as fragmentary. At the national and regional level are deployed a number of network organizations and its elements (innovation centres, technology transfer departments etc) [1, p. 183].

The conditions of economic development of enterprises in Ukraine are at the moment adverse and do not encourage to invest in innovative projects. The 


\section{Strategies of effective development of participants the innovative process}

share of R\&D outlay in GDP over the past decades has been steadily declining and in 2016 it was only $0.48 \%$ while in developed countries it is several times higher. Even such neighbouring countries as Hungary, Poland, Romania and Slovakia, today have much higher levels of outlay for science support in GDP.

Generally, innovative activity, like no other, is associated with high risk. However, with the right policy of supporting the participants of the innovation process by the state, investments in innovation activities provide a much higher level of return than other types of activities. To do this, it is necessary, taking into account the best world experience, to create a modern innovative infrastructure that helps at various stages from idea to commercialization of R\&D results to adequately assess and support the efforts of stakeholders in the process of development and implementation of various innovative projects. Possibilities of establishing effective interaction of the participants of the innovation process can be disclosed only under the condition of a branched network of technology transfer, in where each given idea has a chance to be considered and supported.

The business development strategies require attention to its implementation in terms of the need to consider all of the significant factors of influence on the enterprise. Each concrete new idea may be borne from the subjective mind of an innovator. Therefore, in some cases, forecasts regarding the amount of necessary funds, timing of implementation and expected results of a particular innovation project can significantly deviate from the original proposed option. These risks should be taken into account and covered with the expense of pre-allocated funds and distributed in a limited set of initially selected and approved ideas and projects.

In the current conditions, it becomes increasingly clear that, in a globalized world, social factors are becoming more and more important, as at the same time the barriers to the movement of not only goods but also labour and capital have decreased significantly and this requires the application of new approaches to managing the development of economic relations at different levels. Many industries were transferred to markets with cheap labour. Increasingly important especially in the field of innovation acquire the phenomenon of transferring a number of works to outsourcing. This requires special attention to the issues of interaction of the participants of the innovation process on the basis of transparency of the conclusion of agreements using tender (competitive) procedures, mutual trust and responsibility for fulfilling their commitments. 


\section{Dovbenko Viacheslav}

At present it is growing new type of relationship in the field of innovation on the principles of open innovation and triple helix model. This helps to bring the "fresh blood" into the innovation process by expanding the range of potential participants, reducing the cost to providing $R \& D$, accelerating the processes of commercialization and the launch of new products on the market. It also provides a social effect by creating conditions for discovering the creative potential of inventors and setting up better interactions with the consumers at different stages of the innovation process.

The process of the strategy formation begins with the goals for the business's product innovation effort and a clear understanding of how these innovation goals tie into broader business goals. An important facet of an innovation strategy is resource commitment and allocation. Appropriate environments for businesses, industry, universities and researchers, enabling innovation and delivering impact from research investment provide research and innovation campuses. Open business strategy should create a complementary synergic business environment in where external partners, customers or other stakeholders are more deeply involved in an innovation process. The open innovation strategy provides a close cooperation among different partners and their R\&D activities by greater use of common know-how and resources.

The activation of innovation activity is impossible outside the investment component, which provides innovative development with an appropriate level of financial support. Access to academic networks allows the identification of competences for future collaboration or recruitment and offers an arena to interact with competitors and customers.

Modern tools that improve the conditions for the implementation of innovative strategies of companies are Design Thinking and Agile Methodology. Design Thinking is the most effective way to understand a customer's needs. The derivative of the Agile is Scrum. It is an effective, smart and perfect example of how maximum input equals maximum output. Design Thinking and Agile both offer unique advantages for innovation, productivity and profit making.

There is a high probability of emerging competitiveness in the market through the introduction of new business-models. In the world of practice, there are plenty of examples of companies that have successfully entered the market using the new business-models (Southwest, Amazon, FedEx, Wal-Mart, McDonald's, IKEA, Enterprise, eBay, Priceline, Dell Comput- 


\section{Strategies of effective development of participants the innovative process}

ers, Starbucks, Skype, Groupon, etc.). With the onset of the information and communication technology era, appeared innovation business models developed by companies such as Microsoft, Intel, Dell-Computer, eBay and Amazon.com, IKEA, Google, Apple. These companies today also offer innovative approaches to offering similar products and services, besides continuously improving them. Thus, emerging appeared innovation business models are becoming a powerful competitive tools [2, p. 51].

The solution to the strategic tasks of development is based on clusters, which provide the basis for intensifying the processes of generating ideas, exchanging information and expanding the opportunities for the practical use of excellence and optimal combination of different stages the innovation cycle. The activities of innovative clusters create a favourable environment for successful implementation of innovative projects and achievement of the set goals of the development of some regions.

\section{Choice of innovation development strategy}

In order to ensure a high level of competitiveness in the market, any enterprise is required to form its own development strategy, which should become a means to achieve the set future goals of the activity.

Innovation strategy $\left(\mathrm{I}_{\mathrm{s}}\right)$ is significantly affected by five basic (core) elements. It can be entered in the form of the functions of five variables that affect the implementation and realization of innovative strategies [3, p. 820]:

$$
I_{s}=f\left(I_{m}, I_{p s}, L_{m}, P_{k}, O_{s}\right)
$$

where $I_{m}$ - innovation management, $I_{p s}$ - innovative potential of strategy, $\mathrm{L}_{\mathrm{m}}$ - lateral thinking, $\mathrm{P}_{\mathrm{k}}$ - pro-innovation climate and $\mathrm{O}_{\mathrm{s}}-$ organizational structure.

Before the creation of innovative strategies the enterprise should, an audit of situation is required. An audit includes identification and analysis of human potential, competitors, partners, customers and business needs to create innovations.

For analysis of the initial position of a company may be based on broad methodological apparatus of strategic management: the forecasting method (expert, simulation, projection, and forecast type of scenarios), conceptually methodological tools (SWOT analysis, BCG matrix, matrix product technology, map of project risks, SPACE analysis STEEP analysis, Porter analysis etc.) and innovative graphs (method S-curves, J-curve method, the method of "gap analysis") [3, p. 822]. 
Analysis of internal environment includes the creation of innovation capacity, innovation potential mapping, identifying the current level of use of the innovation capacity of innovation and specification requirements. Innovation capacity is formed by the sum of knowledge, experience, resources, assets and managerial capabilities and skills in business available, or is able to obtain in due time.

An enterprise can make decisions about choosing its development strategy using the matrix of the Boston Consulting Group (BKG). For the assessment of their products, they are divided into four groups by the indicators of market share, market growth rates, risk and profitability. The use of the BCG matrix for selecting enterprise development strategies is shown in Fig. 1.

\begin{tabular}{|l|l|l|l|l|}
\hline Stages of the life cycle & Origin & Development & Maturity & Decline \\
\hline Market share & Low & Moderate & High & Moderate \\
\hline Market growth rates & Low & High & Moderate & Low \\
\hline Risk & Very high & High & Moderate & Low \\
\hline Profitability & Low & High & Moderate & Low \\
\hline Total contribution & Very low & Moderate & High & Low \\
\hline \multicolumn{3}{|c|}{$\begin{array}{c}\text { Question Marks } \\
\text { Market Stars }\end{array}$} & Cash Cows & Dogs \\
\hline \multirow{2}{*}{$\begin{array}{c}\text { Share Stars } \\
\text { Low }\end{array}$} & \multicolumn{2}{|c|}{ Cash Cows } \\
\cline { 2 - 5 } & \multicolumn{2}{c}{ Digh Marks } \\
\cline { 2 - 5 }
\end{tabular}

\section{Fig. 1. Application of the BCG matrix for choosing development strategy}

Source: Composed by the author on the basis of the paper [4, p. 237-238]

The enumeration of upper level strategic aims can be formed for the enterprise's innovation development strategy as a progressive, zero and regressive innovation development. Three types of innovation strategies correspond to these aims: advance strategy, defense strategy, expectation strategy [5, p. 77].

The next level of strategic aim formation is based on the study of those economic advantages which are appealed to while realizing the first level aims. Thus, the major component of the second level classification is "com- 
petitiveness". The main features of the competition are: price, quality, opportunities, novelty of manufactured products, technologies which are used, and markets which are supplied, that include, in particular, improving the quality $(\mathrm{Q})$; reduction of costs $(\mathrm{C})$ and prices $(\mathrm{P})$; increasing of the output of products $(\mathrm{O})$; development of the market for production $(\mathrm{M})$; development of the manufacture of new for the enterprise products $(\mathrm{Np})$; development of the radical product innovations and technologies (Pp).

The main subtypes of innovation strategies for increasing competitiveness in certain areas are given in Tab. 1.

The strategy of innovation development of the enterprise should logically combine different types of the given above strategic development directions.

Table 1

\section{The main types of products reproduction in terms of innovation strategies}

\begin{tabular}{|l|l|l|}
\hline \multicolumn{1}{|c|}{$\begin{array}{c}\text { Subtype } \\
\text { of strategy }\end{array}$} & $\begin{array}{l}\text { The main types of innovations/ } \\
\text { Combination of goals of competitive } \\
\text { strategies }\end{array}$ & Source of innovations \\
\hline Active-advance & $\begin{array}{l}\text { Radical process and product } \\
\text { innovations. Development of new } \\
\text { markets. Improving production } \\
\text { innovations of second generation }\end{array}$ & $\begin{array}{l}\text { Available scientific and } \\
\text { technical achievements }\end{array}$ \\
\hline Passive advance & $\begin{array}{l}\text { Improving and ordinary innovation } \\
\text { in the production of the second } \\
\text { generation }\end{array}$ & $\begin{array}{l}\text { Available scientific and } \\
\text { technical achievements }\end{array}$ \\
\hline Opportunistic & $\begin{array}{l}\text { Improving production innovation, } \\
\text { differentiation of highly profitable } \\
\text { production of the second generation }\end{array}$ & $\begin{array}{l}\text { Available scientific and } \\
\text { technical achievements }\end{array}$ \\
\hline Protective & $\begin{array}{l}\text { Rationalization of production. } \\
\text { Improving and ordinary innovations } \\
\text { of new products }\end{array}$ & $\begin{array}{l}\text { Legally protected } \\
\text { industrial property objects }\end{array}$ \\
\hline Simulating & $\begin{array}{l}\text { Purchasing license-based production } \\
\text { technologies }\end{array}$ & Licenses for technologies \\
\hline Traditional & $\begin{array}{l}\text { Improving of production of long- } \\
\text { lasting, stable demand. Improving of } \\
\text { technology, product quality, marketing } \\
\text { system }\end{array}$ & $\begin{array}{l}\text { Available scientific and } \\
\text { technical achievements }\end{array}$ \\
\hline $\begin{array}{l}\text { Search for own } \\
\text { niche }\end{array}$ & $\begin{array}{l}\text { Ordinary innovations, radical } \\
\text { innovations are possible }\end{array}$ & Own R\&D \\
\hline
\end{tabular}

Source: Composed by the author on the basis of the paper [5, p. 78] 
The development of an innovation strategy involves a number of stages:

- forecasting promising development directions of industry and market in which the enterprise operates;

- identification of priority areas for innovative development;

- elaboration of an innovative development strategy.

At the stage of elaboration is chosen the type of innovation development strategy. The types of innovation strategy include:

- offensive strategy, which involves creation and active implementation of innovations (if the company has strong scientific, research and design departments);

- defensive strategy, which involves improving product and technology of its production, promotion methods etc.;

- simulation strategy, which involves the acquisition of licenses or patents and technical preparation for innovation production;

- dependent strategy adhered by enterprises that manufacture components for innovative products to other businesses (a subtype of offensive or defensive);

- traditional strategy, involving only minor product improvements (company manufactures unique products or technologies);

- niche strategy (used by companies manufacturing innovative products that address specific needs of small groups of consumers);

- licensing strategy, which involves the search of partners for implementation or selling innovations, patents, licenses etc. (it is typical for small companies);

- mixed strategy (as a combination of different strategies).

The strategy type choice based for awareness of the stages of innovative and life cycle of new products. The selection pattern for the choice of innovation strategy is presented in Table 2 .

Companies can choose different forms of how to open their innovation strategies, such as partnerships with external parties (business alliances, joint ventures, joint R\&D), acquisitions, contractual R\&D, purchasing of patents, licensing, etc. In addition to these common forms, an open innovation strategy can be realized through spin-offs or venture capital investment funds too. The open innovation strategy must enable increasing cooperation among different partners and their R\&D activities by greater use of common know-how and resources. Generally, every new member of a group should enhance the synergy of openness in two ways: 
Types innovation strategies and business depending on stage of innovative cycle

\begin{tabular}{|c|c|c|c|c|c|c|c|c|c|}
\hline \multirow{3}{*}{$\begin{array}{c}\text { Strategy } \\
\text { type }\end{array}$} & \multirow{3}{*}{$\begin{array}{c}\text { Innovative } \\
\text { business } \\
\text { type }\end{array}$} & \multicolumn{6}{|c|}{ Stages of innovative cycle } & & \\
\hline & & \multirow[b]{2}{*}{ 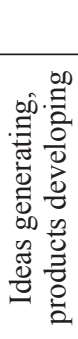 } & \multirow[b]{2}{*}{ 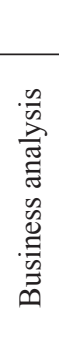 } & \multirow[b]{2}{*}{ 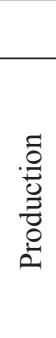 } & \multirow[b]{2}{*}{ 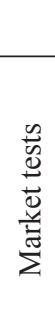 } & \multicolumn{4}{|c|}{ Stages of life cycle } \\
\hline & & & & & & 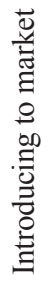 & 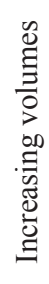 & 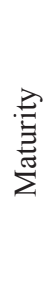 & 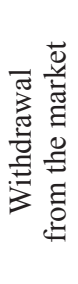 \\
\hline Licensing & \multirow{3}{*}{ Venture } & + & & & & & & & \\
\hline Simulating & & & + & + & + & & & & \\
\hline Licensing & & + & + & + & + & & & & \\
\hline Simulating & Explerent & & & & & + & & & \\
\hline Niche & Patient & & & & & & + & & \\
\hline $\begin{array}{l}\text { Traditional } \\
\text { defensive }\end{array}$ & Violent & & & & & & & + & \\
\hline Niche & Commutant & & & & & & & & + \\
\hline Simulating & \multirow{3}{*}{ Combined } & & + & + & + & + & & & \\
\hline Offensive & & + & + & + & + & + & & & \\
\hline Defensive & & & & & & & + & + & + \\
\hline
\end{tabular}

Source: Composed by the author on the basis of the paper [6, p. 177]

1) contribute to the synergic value creation by its own resources and know-how to a higher level of effectiveness and by avoiding sub-optimal outcomes/biases of the cooperation;

2) promote to improving the social climate [7].

The degree of openness of an innovation strategy differs depending on factors such as importance of technology, autonomy of new organization, risk taking, time for new/ innovative technology adoption, enablement of the main business strategy, dissimilarity in technologies, products or markets, engagement of people cooperating, or complexity of solutions. Based on these factors, in addition to the classical closed innovation strategy and the fully open innovation strategy, it does distinguish an advanced innovation strategy and a limited open innovation strategy [8, p. 19]. 


\section{Dovbenko Viacheslav}

Innovation strategy will require a change in the organizational structure of the company. Successful innovation strategy helps in providing of information to staff about where the company is going with innovations, what motivates employees, what is the meaning of their work.

\section{The role of innovation ecosystem in economic development}

Implementation of the innovation strategy of any subject of management depends on the conditions of the innovation ecosystem. It is important to create the necessary conditions for successful implementation the development strategies of the participants the innovation process, including the availability of developed innovation infrastructure, the modern legislative field, state support, relations of responsible attitude to fulfil their commitments and trust between partners.

We use the term "innovation ecosystem" to refer to the inter-organizational, political, economic, environmental and technological systems of innovation through which a milieu conducive to business growth is catalyzed, sustained and supported. An innovation ecosystem is a network of relationships through which information and talent flow through systems of sustained value co-creation. The systems approach has been used to describe the multifaceted nature of innovation at various levels - national, regional, technological, and sectors - and to describe the processes by which research capabilities build knowledge, and then transfer the knowledge to support business development in the context of the Triple Helix of business, government and academic interaction [9].

Innovation ecosystem is viewed then as a dynamic system, characterized by localized interactions among a huge amount and diversity of agents - universities, business, public institutions, society, resources, etc. Their interaction is based on the principle of self-organization. Innovation ecosystems balance at the "edge of chaos", where the creativity and innovativeness are at the highest level. In such systems, major interventions may fail, while minor changes cause huge outcomes, when the tipping point is being reached and a system moves to another attractor [10, p. 127].

An innovation ecosystem comprises two distinct ecosystems - the knowledge ecosystem and the business ecosystem. The former is driven by research and development, the latter by the market economies. The innovation ecosystem can conceptualize as a complex, interconnected system consisting of three complementary and synergistic sub-ecosystems: science, 


\section{Strategies of effective development of participants the innovative process}

technology, and business ecosystems. Business ecosystem can contain outsourcing partners, technology providers, and complementary product makers. A business ecosystem can be analyzed by extracting information from interviews and desktop research, with a focus on collaboration between key organizations on specific products and services [11].

The main task of strategic development of enterprises in modern conditions is provision the consumer with a special (unique) value, which provides competitive advantages in the market under conditions of trust and commitment of consumers to the offered products and services. As a result, the company becomes an element of the business system, which, due to its network structure, has the opportunity to take into account the interests of its partners as much as possible.

A favourable business environment allows efficiently combine the interests of the company and its partners to determine the relationship of the parties, and thus ways to achieve the goals of development. Best of all, in the current conditions with similar tasks cope with such network structures as clusters. For formation an appropriate institutional environment that integrates individual components of the national innovation system, it is important to create effective networking production systems of innovation orientation. Just the innovation clusters create the conditions for effective innovation cycle from idea generation to obtain economic benefits from innovation. The activities of innovative clusters are aimed at creating of new types of products with long-term competitive advantages.

The role of the environment to support innovation in achieving strategic goals is given in Fig. 2.

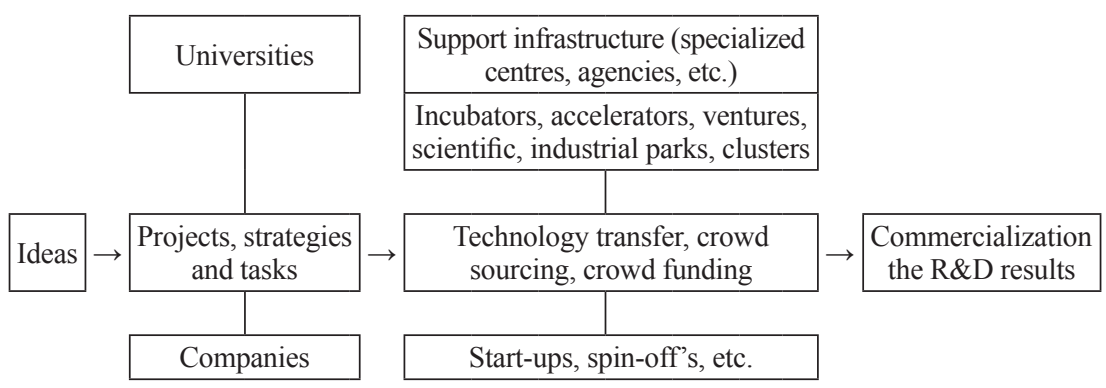

Fig. 2. Environment supporting innovation

Source: Compiled by the author 


\section{Dovbenko Viacheslav}

Under current conditions it imposed higher requirements to expand the circle of persons involved in the innovation process and the formation of new values. Therefore, more and more attention should be directed to open, social and user innovation.

D. Domanski and C. Kaletka argue that the development of a scientific concept of social innovation ecosystems is much more demanding than just trying to adapt concepts such as innovation systems or triple helix to the area of social innovation. This task implies a much better understanding of what social innovation ecosystems are about. One precondition for new ways of developing and diffusing social innovations are necessary (e.g. design thinking, innovation labs etc.) as well as the necessity of a new role of public policy and government for creating suitable environment to the integration of resources of the economy and civil society as well as supporting measures by science and research. Quadruple Helix of social innovation includes as an actors Government, Economy, Academia and Civil Society [12, p. 207-208].

A systemic approach to social innovation focuses on the interfaces of the so far differentiated and largely separate self-referential societal sectors of state, business, civil society and academia, of their corresponding rationalities of action and regulation mechanisms, and at the associated problems and problem-solving capacities. Such collaborations are picked up by at least two different heuristic models, the quadruple helix on the one hand, where government, industry, academia and civil society work together to co-create the future and drive specific structural changes, and the social innovation ecosystem on the other hand, which also asks for interactions between the helix actors, adds the notion of systemic complexity and looks at both, the serendipity and absorptive capacity of a system as a whole. Academic knowledge on social innovation ecosystems is very scarce and the concept is still fuzzy.

Currently, social innovations lack knowledge support, especially from scientific knowledge partners such as universities and research centres. Underpinning the development of social innovations with sufficient expert knowledge and professional models can importantly contribute to a more favourable environment for social innovations. Universities and research centres are not sufficiently integrated in the development of social innovations. In the social innovation ecosystem or quadruple helix they currently still have a minor role, especially when compared with their major role in technological or business innovation [12, p. 227]. 
Questions about transferability and scalability within a given or to another ecosystem dominate social innovation discourses. Scaling in terms of different modes of organisational growth is a typical way. While scaling is a more prominent strategy within a given ecosystem, transfer and adaptive replication more often takes place in a different setting, which helps to reach completely new target groups and goals. Social entrepreneurs, project managers, activists, groups, networks and so on have a motivation to implement a strategy to disseminate their solution for a social problem. In the tab. 3 is given the approaches to implementation of innovative strategy for development and social problems solution.

Table 3

\section{Approaches to implementation of innovative strategy for social problems solution}

\begin{tabular}{|l|l|l|}
\hline \multicolumn{1}{|c|}{ Approach } & \multicolumn{1}{|c|}{ Strategy } & \multicolumn{1}{c|}{ Overview } \\
\hline Replication & Scaling out & $\begin{array}{l}\text { Organisation attempt to replicate their social } \\
\text { innovation in other geographical areas }\end{array}$ \\
\cline { 2 - 3 } & Scaling up & $\begin{array}{l}\text { Organisations attempt to affect a wider } \\
\text { system change by tackling the institutional } \\
\text { causes of a problem }\end{array}$ \\
\cline { 2 - 3 } & Mission networks & $\begin{array}{l}\text { A social entrepreneur rids of traditional } \\
\text { aspects of organisational control (brand, } \\
\text { intellectual property, etc.) to influence and } \\
\text { create other 'change makers' within the } \\
\text { system }\end{array}$ \\
\hline Non-replication & Open Source & $\begin{array}{l}\text { The core intellectual property of the } \\
\text { innovation or organisation is turned into an } \\
\text { open source tool for others to take up }\end{array}$ \\
\hline Mixed & $\begin{array}{l}\text { Other (less explored } \\
\text { potential strategies) }\end{array}$ & $\begin{array}{l}\text { Including: } \\
\text { - Affiliation with new partners } \\
\text { - Direct/indirect dissemination of ideas } \\
\text { - Working to change policy environments } \\
\text { - Social movement building }\end{array}$ \\
\hline
\end{tabular}

Source: Composed by the author on the basis of the paper [12, p. 209]

Innovation management therefore, is a systematic approach to creating an environment based on discovery, invention and commercial exploitation of ideas that meet dissatisfied needs.

Innovation systems involve many actors operating at different stages and scales. Reforming institutions to better align innovation systems with 
sustainable development requires mobilizing collective action across a complex and large set of actors who work at many scales and who engage in activities that overlap and sometimes conflict. The interdependencies of actors may be explicit, such as through technology commercialization licensing agreements that involve a formal contract transferring intellectual property. Alternatively, linkages connecting actors may be implicit, such as the underemphasized dependence of new product development by much computer hardware and pharmaceutical firms on prior government-funded $\mathrm{R} \& \mathrm{D}[13]$.

Need for collective action arise because actors operating across different stages and scales vary widely in their interests and incentives and are not necessarily driven by the goal of sustainable development. For example, a national government usually has little motivation to take into account the needs of citizens beyond its borders, a profit-maximizing firm lacks incentives to invent technologies for people who cannot afford its products, and consumers lack the impetus to consider how their decisions impact to other communities distant in time and space. Therefore, the needs for establishing communication using modern information systems continue to grow.

\section{Mechanism of innovation development}

In order to promote the innovation activity it is important to create an economic mechanism that should provide support and effective regulation of innovation processes in the economy. State support for innovation activities involves a system of measures aimed at stimulating and activating innovation activity. This system includes financial and credit support for the implementation of innovative projects, preferential taxation for innovation actors, support for the functioning and development of modern innovation infrastructure, attraction and encouragement of foreign investments. The formation of innovative model of economic development involves the creation of a favorable legislative field and comprehensive information provision for the participants of innovation process, the formation of state programs of innovation support, raising the level of economic education and innovation culture, reliable protection of intellectual and industrial property rights, improving financing of innovation activity and its tax incentives.

The mechanisms for supporting innovation in the field of science and scientific services in order to obtain the necessary results should be closely linked with similar business mechanisms to ensure the transfer of scien- 


\section{Strategies of effective development of participants the innovative process}

tific outputs to structures that are capable of bringing them to the stage of commercialization. Innovation centers in EU help innovation business in the areas of technology transfer; commercialization of R\&D results; including intellectual property issues; development of adaptation opportunities of companies to new technologies; search of potential partners; implementation of transnational projects. An even more important role in the process of commercialization of innovations plays in particular well-known societies such as Max Plank Gesellschaft, Fraunhofer-Gesellschaft in Germany, the Finnish Innovation Fund SITRA, Finnish Funding Agency for Technology and Innovation and wide range other similar structures in many countries, whose activities are aimed at maintaining the innovation activity of many participants. In general, each country builds its own specific investment model mediation and accumulation of investment in innovation activities, taking into account the specific features of development and situation in the economy.

The system of relationship between participants of the innovation process is formed under the influence of various factors, taking into account the role of a specific subject in the economic process. The most common forms of inter-entity interaction of participants are economic, organizational, logistical, information and legal interaction (Tab. 4).

Table 4

\section{Main types and forms of interaction}

of participants of innovation activity

\begin{tabular}{|l|l|}
\hline \multicolumn{1}{|c|}{ Types of interaction } & \multicolumn{1}{c|}{ Forms of interaction } \\
\hline Economic interaction & $\begin{array}{l}\text { Technological cooperation, coordination of investment } \\
\text { development programs, business planning of innovation } \\
\text { projects }\end{array}$ \\
\hline Organizational interaction & $\begin{array}{l}\text { Association, corporation, innovation centre and park, } \\
\text { innovation cluster, financial and industrial group, } \\
\text { strategic alliance }\end{array}$ \\
\hline Logistic interaction & $\begin{array}{l}\text { Logistics centres, terminal and cargo complexes, } \\
\text { warehouse networks, transport and logistic clusters }\end{array}$ \\
\hline Information interaction & $\begin{array}{l}\text { Network of centres of science and innovations, network } \\
\text { of technology transfer, scientific and resource ICT } \\
\text { centres }\end{array}$ \\
\hline Legal interaction & $\begin{array}{l}\text { Contracts, agreements, regulations, standards, corporate } \\
\text { norms and rules }\end{array}$ \\
\hline
\end{tabular}

Source: Compiled by the author 


\section{Dovbenko Viacheslav}

A firm's overall economic, strategic, and innovation performance is dependent on the degree to which the firm can use all of the knowledge created by the firm and turn this knowledge into value-creating activities. Much of the process and workflow is contained in a mutual understanding of the work or process and it is not easily documented and communicated.

A conceptual model which guides top management at innovative technology companies in the development of intellectual capital should focus corporate resources on the strategic direction and processes needed to increase the intellectual capital of the firm and the delivery of new products to customers. This new intellectual capital would be either patents or trade secrets and would represent a conscious strategy of offensive intellectual capital creation rather than the defensive strategies.

To create a coherent strategy that involves the active use of the relevant capital in the implementation of the innovation strategy is necessary to introduce into the model of innovation development of the company such components [14, p. 318]:

Future Competitive Positioning (FCP)

Product Dynamics

Positioning Dynamics

R\&D Investment

Technology Dynamics

Competitive Dynamics

Environmental Turbulence

Strategy aggressiveness.

The research implications for this model are that changes in an intellectual capital inputs and capabilities can be measured and specific methods related to the most gain for the investment made. A new strategy for knowledge creation would be accompanied by a change in intervening processes using the tacit knowledge measured changes as a proxy for the intellectual capital generated as well as a new set of outputs. The research using this model could be targeted toward technology companies to identify whether the chosen knowledge generation strategy is having the intended effect and what changes need to be made to processes and persons that would yield the desired outputs.

Based on the different possible configurations of business models elements, companies can design different business models to reflect their overall strategic choices. Examples of well-known business model "themes" 


\section{Strategies of effective development of participants the innovative process}

include the "no-frills" model often found in the aviation industry (e.g. Ryanair) or the "customer-lock in" business model of Apple or Nespresso. With the adoption of open innovation practices, "open business models" have emerged as a new design theme [15]. The business-models need to be aligned with the company's overall (innovation) strategy, which implies realign their existing business models to accommodate open innovation practices.

Finally, to effectively harness the potential benefits of open innovation, company need to employ various organizational and managerial practices such as intensive lateral and vertical communication and rewards for knowledge sharing and dedicated incentive systems for innovation, internal research capacity and cross-functional collaboration between departments in the innovation processes as to facilitate accessing and integrating knowledge residing outside the company's boundaries [16].

Open (permission-less) networks are accessible to anyone wishing to join, without restriction on membership. Data stored on these networks is visible to all participants in encrypted format. Digital currency bitcoin is an example. The innovation of blockchain is capable of transforming the infrastructure of our economic systems, not only financial services, where most of the attention is currently concentrated, but entire global value chains and revenue models. It offers a chance to reimaging industries, rebuild financial processes, and build markets once considered improbable or unprofitable [17].

There are also major threats to the application of blockchain. In particular the ability to extraction ("to mining") blockchain is not equal for all, which makes monopoly actions possible. Theoretically, it is believed that selfish miners will tend to unite into pools and thus outperform single miners who will have to join a pool to survive. However the technology of blockchain is dangerous because it can deprive millions of people of jobs, as its implementation will eliminate the need for intermediaries in different areas. But no dangers can stop the implementation of blockchain in most areas of human activity. The blockchain ecosystem is currently in full experimentation mode, bringing new innovations and hybrid solutions. Consortia are emerging globally to discuss and provide solutions, address governance and industry standard issues, and provide regulatory insights. These include The Ethereum Enterprise Alliance and China Ledger, which are attracting participation from dozens of major industry players, innova- 


\section{Dovbenko Viacheslav}

tors, regulators, and governments. The Enterprise Ethereum Alliance connects Fortune 500 enterprises, start-ups, academics, and technology vendors with their experts. The Enterprise Ethereum Alliance (EEA) since February has grown to 200 members.

Collaboration with academic research provides a broader perspective on the potential of a technology. It thus highlights new ways to solve current problems as well as new business opportunities. Research collaboration can help with understanding customer needs better and suggest appropriate directions to seek solutions to technical problems. Innovation is in constant interaction with the customers, suppliers, research institutions and so on. Collaboration also opens direct business opportunities for companies which package and sell academic expertise (consultancies). This also applies to enterprises in which scientists are an important market (instrument manufacturers, computers) and companies for which scientists are key opinion leaders (medical technology) [18, p. 34]. Collaboration provides the opportunity to better combine and exploit the potential of stakeholders interested in developing new products and technologies. The main results of this collaboration are shown in Tab. 5

Table 5

Anticipated results of cooperation with public research

\begin{tabular}{|l|l|l|}
\hline \multirow{2}{*}{ Expected results } & \multicolumn{2}{|c|}{ Area of use } \\
\cline { 2 - 3 } & New innovation opportunities & \multicolumn{1}{|c|}{$\begin{array}{c}\text { Support for current } \\
\text { business areas }\end{array}$} \\
\hline $\begin{array}{l}\text { Directly applicable } \\
\text { results }\end{array}$ & $\begin{array}{l}\text { Commercialisation } \\
\text { of academic research }\end{array}$ & Applied R\&D, problem-solving \\
\hline "Soft" results & $\begin{array}{l}\text { Learning } \\
\text { New perspectives } \\
\text { New business opportunities }\end{array}$ & $\begin{array}{l}\text { Understanding customer needs } \\
\text { Identifying directions for } \\
\text { search }\end{array}$ \\
\hline
\end{tabular}

Source: Composed by the author on the basis of the paper [18, p. 35]

In the state of constant change, companies that are less successful in developing their capability through innovation will fail, while successful companies grow. The interaction between this variety of business experiments and the market's selection of more successful ventures is seen as the main driver of economic renewal.

A great combination for effective innovation is application the combining of Design thinking with Agile. Design Thinking and Agile Methodol- 


\section{Strategies of effective development of participants the innovative process}

ogy are considered two completely different concepts, with the two being viewed as separate and independent of each other. Agile is primarily about the how of a project, with planning done in chunks rather than as a whole; scope of work is usually variable with Agile, while time and quality are fixed. Design thinking on the other hand, is about exploring and generating ideas, understanding users and innovating to meet customer needs [19].

Design Thinking has been central to modern innovations in various fields, from the arts to sciences and engineering and even in business. It has also been a staple of leading brands like GE, IBM and Samsung and the world's top schools like Stanford's school, MIT, and Harvard have integrated Design Thinking into their curriculums. Similarly, Agile has been around for a while, with its own language and methodologies and is widely used in the IT industry. Derivative of the Agile is Scrum that follows the same iterative process. It is an effective, smart and perfect example of how maximum input equals maximum output. And so we see the while design thinking helps us understand what work to do, Scrum gives us vision to decide how to do it. More productive and faster product and service innovation can be achieved combining Agile and Scrum with Stage-Gate. Examples of early adopters of this new system are appearing around the world.

Business model choice determines the nature of complementarity between business models and technology and the paths to monetization. A long-standing distinction between "project based offerings" and "pre-designed (scale) based offerings" often described as the "taxi' and "bus" systems is useful in this context. Organizations such as consulting firms and movie makers use the taxi system to create value, while organizations such as automobile assemblers and providers of fast food utilize the bus system and add value by producing "one-size-fits-all" goods or services in a repetitive manner from a standardized format [20, p. 422]. Examples of the Business-models for companies in several areas are given in Tab. 6.

Making business model choice a moderator, and including the factors that influence business model change in a dynamic manner, will lead to a better understanding of the fundamentals of the relationship. And it will also allow strategists to comment more succinctly and usefully on key contingencies - such as, why so many innovative products fail; how successful firms conceive the relationship between technology and business model; and how they conceive the dynamics of the process of business model adjustment. Making business model choice a moderator, and including the 
Table 6

Examples of the Business Models

\begin{tabular}{|c|c|c|c|c|c|}
\hline & $\begin{array}{c}\text { Fast food } \\
\text { chain - } \\
\text { franchised } \\
\text { BM }\end{array}$ & $\begin{array}{c}\text { Boutique } \\
\text { strategy } \\
\text { consultant } \\
\text { BM }\end{array}$ & $\begin{array}{c}\text { Military } \\
\text { contractor } \\
\text { BM }\end{array}$ & $\begin{array}{l}\text { Newspaper } \\
\text { (1990s) BM }\end{array}$ & $\begin{array}{c}\text { Searching } \\
\text { system BM }\end{array}$ \\
\hline \begin{tabular}{|l}
\multicolumn{1}{c}{ Customer } \\
identification \\
Are users \\
paying, if \\
not who are \\
the other \\
customers
\end{tabular} & $\begin{array}{l}\text { Simple BM } \\
\text { User pays the } \\
\text { intermediary } \\
\text { franchise }\end{array}$ & $\begin{array}{l}\text { Simple } B M \\
\text { User pays }\end{array}$ & $\begin{array}{l}\text { Simple BM } \\
\text { User is } \\
\text { typically the } \\
\text { government } \\
\text { who pays }\end{array}$ & $\begin{array}{l}\text { Hybrid BM } \\
\text { Readers pay } \\
\text { per copy } \\
\text { Advertisers } \\
\text { give bulk of } \\
\text { revenues }\end{array}$ & $\begin{array}{l}\text { Hybrid } B M \\
\text { Free for } \\
\text { users, but } \\
\text { advertisers } \\
\text { pay }\end{array}$ \\
\hline $\begin{array}{l}\text { Customer } \\
\text { engagement } \\
\text { "Taxi" or } \\
\text { "Bus" }\end{array}$ & $\begin{array}{c}\text { Bus } \\
\text { Scale based }\end{array}$ & $\begin{array}{l}\quad \text { Taxi } \\
\text { Projects to } \\
\text { order }\end{array}$ & $\begin{array}{l}\text { Taxi } \\
\text { Usually } \\
\text { project based }\end{array}$ & \begin{tabular}{l}
\multicolumn{1}{c}{ Bus } \\
Readers and \\
advertisers \\
are given bus \\
service
\end{tabular} & \begin{tabular}{|l} 
Bus for \\
users \\
Taxi for \\
advertisers
\end{tabular} \\
\hline \begin{tabular}{l}
\multicolumn{1}{|c}{ Value chain } \\
$\quad$ links \\
Integrated, \\
hierarchy or \\
network
\end{tabular} & $\begin{array}{l}\text { Highly tiered } \\
\text { system of } \\
\text { suppliers and } \\
\text { franchisees, } \\
\text { who are linked } \\
\text { hierarchically }\end{array}$ & $\begin{array}{l}\text { Almost all } \\
\text { value is } \\
\text { delivered by } \\
\text { the firm, little } \\
\text { outsourcing }\end{array}$ & $\begin{array}{l}\text { Complex } \\
\text { system of } \\
\text { arrangements } \\
\text { among many } \\
\text { partners }\end{array}$ & $\begin{array}{l}\text { Content and } \\
\text { production } \\
\text { are } \\
\text { hierarchical } \\
\text { but at times } \\
\text { network } \\
\end{array}$ & \begin{tabular}{|l|} 
Complex \\
tightly \\
controlled \\
links \\
orchestrated \\
by firm \\
\end{tabular} \\
\hline $\begin{array}{l}\text { Monetization } \\
\text { When, What } \\
\text { and How is } \\
\text { money raised }\end{array}$ & $\begin{array}{l}\text { Complementary } \\
\quad \text { assets } \\
\text { Franchisee } \\
\text { collects money } \\
\text { from consumer } \\
\text { and passes on } \\
\text { fee }\end{array}$ & \begin{tabular}{l}
\multicolumn{1}{c}{ Value } \\
Often priced \\
on the basis \\
of fee plus \\
share of the \\
value created
\end{tabular} & \begin{tabular}{l}
\multicolumn{1}{c}{ Cost } \\
Staged \\
payments \\
and often \\
cost plus \\
contract
\end{tabular} & \begin{tabular}{l}
\multicolumn{1}{c}{ Two-sided } \\
Everyone \\
pays close to \\
point of use
\end{tabular} & $\begin{array}{l}\text { Two-sided } \\
\text { Advertisers } \\
\text { pay after } \\
\text { service is } \\
\text { delivered }\end{array}$ \\
\hline
\end{tabular}

Source: Composed by the author on the basis of the paper [20, p. 421]

factors that influence business model change in a dynamic manner, will lead to a better understanding between participants of innovation process.

Open innovation does not mean that companies refuse their own R\&D development, but is a way to effectively access external knowledge and their target use. In order to enhance the synergy effect of the transfer of knowledge and technologies in Ukraine, it is important to make a sharp shift to the needs of science and education, which should foresee obtaining a given area of its corresponding status, and thus financing not only its current, but also perspective needs. But for this purpose, it is necessary to create a new 
mechanism for supporting $R \& D$ on the principles of open innovation with the involvement of business structures. The individual components and features of this mechanism are given in the Tab 7.

To achieve the optimal combination of elements supporting mechanism for implementation the results of $\mathrm{R} \& \mathrm{D}$, it is important to create a modern innovation infrastructure that will promote the process of ideas generation and timely attention to the questions of realization the most promising innovative projects. For the results of perspective scientific research commercialization through the technology transfer of industrial and intellectual property may be created favourable conditions.

Table 7

\section{Components and features of the $R \& D$ mechanism support}

\begin{tabular}{|c|c|c|c|c|}
\hline $\begin{array}{l}\text { Participants } \\
\text { of transfer }\end{array}$ & $\begin{array}{c}\text { Innovation } \\
\text { transfer } \\
\text { infrastructure }\end{array}$ & $\begin{array}{l}\text { Main kinds } \\
\text { of transfer }\end{array}$ & $\begin{array}{l}\text { Opportunities } \\
\text { and results } \\
\text { of transfer }\end{array}$ & $\begin{array}{c}\text { Transfer } \\
\text { effectiveness }\end{array}$ \\
\hline \multirow{2}{*}{ Science } & $\begin{array}{l}\text { Universities, } \\
\text { research firms }\end{array}$ & \multirow{2}{*}{$\begin{array}{l}\text { Transfer of } \\
\text { knowledge and } \\
\text { innovation }\end{array}$} & \multirow{2}{*}{$\begin{array}{l}\text { Getting new } \\
\text { knowledge, } \\
\text { skills and } \\
\text { abilities }\end{array}$} & \multirow{10}{*}{$\begin{array}{l}\text { Identification } \\
\text { of the future } \\
\text { market needs. } \\
\text { Offers new } \\
\text { developments, } \\
\text { products and } \\
\text { technologies. } \\
\text { Formation } \\
\text { of balanced } \\
\text { innovative } \\
\text { ecosystems, } \\
\text { providing } \\
\text { synergy effect } \\
\text { on effective } \\
\text { interaction of } \\
\text { participants }\end{array}$} \\
\hline & $\begin{array}{l}\text { Scientific and } \\
\text { technological parks }\end{array}$ & & & \\
\hline \multirow{4}{*}{ Business } & Business-angels & \multirow{4}{*}{$\begin{array}{l}\text { Technology } \\
\text { transfer }\end{array}$} & \multirow{4}{*}{$\begin{array}{l}\text { Purchase/selling } \\
\text { of patents, } \\
\text { licenses, } \\
\text { equipment, } \\
\text { scientists and } \\
\text { specialists }\end{array}$} & \\
\hline & Business-incubators & & & \\
\hline & Venture companies & & & \\
\hline & $\begin{array}{l}\text { Technology transfer } \\
\text { centres }\end{array}$ & & & \\
\hline \multirow{2}{*}{ State } & Innovations clusters & \multirow{2}{*}{$\begin{array}{l}\text { Financial } \\
\text { transfers }\end{array}$} & \multirow{2}{*}{$\begin{array}{l}\text { New knowledge } \\
\text { and technologies } \\
\text { use }\end{array}$} & \\
\hline & Technopolises & & & \\
\hline \multirow[b]{2}{*}{ Society } & Customers & \multirow{2}{*}{$\begin{array}{l}\text { Crowdsourcing, } \\
\text { crowdfunding }\end{array}$} & \multirow{2}{*}{$\begin{array}{l}\text { Participation } \\
\text { in surveys and } \\
\text { contests }\end{array}$} & \\
\hline & $\begin{array}{l}\text { Inventors, } \\
\text { rationalisers }\end{array}$ & & & \\
\hline
\end{tabular}

Source: Compiled by the author

For this purpose, it is necessary significantly increase the role of the state in implementing economic transformations based on innovations and ensure active participation of each active member of society in the innovation process in the most suitable role for him (innovator, expert, mentor, investor, student, etc.). Such approach will provide a combination of 
interests of the parties and create the necessary conditions for reducing the innovation cycle and enable significantly strengthen the role of innovative component in the economic development.

\section{Conclusions}

Innovations promise often far-reaching changes that can affect the company's business model. An innovation process is absolutely essential to eliminate errors and unnecessary loops due to missing or incorrect information and also to ensure efficiency and productivity.

However, this can not be achieved without due attention to innovation, which, unfortunately, is alien to the overwhelming majority of domestic enterprises, whose activities are primarily related to the survival or work on the basis of the use of outdated and worn-out of $60-90 \%$ equipment. To succeed in economic transformations, management approaches at all levels need to be changed. It should be combined with efforts aimed at saving and efficient use of all resources and implement the transformation of economic and social relations based on the priority of solving various tasks to address glaring disparities in development of different sectors of the economy. For this it is important to achieve a significant enhancement the productivity of labour and through this provide increased levels of loans and increase of its attraction, which requires the necessary level of trust the involved parties. It is necessary to ensure at least twice increase the level of expenditure for science in GDP, establish a privileged tax regime for innovation activity and promote investment in innovative projects and commercialization of $R \& D$ results.

Innovation strategy is significantly affected by innovation potential and management, lateral thinking, innovation, investment climate and organizational structure. Currently for increasing the innovation activity faithfully is set-up of cooperation among different partners involved in innovation process. For this purpose best suited the open innovation strategy which implies greater use of common know-how and resources. Innovation strategy will require a change of organizational structure of the company and raising the level of motivation of employers.

The process of implementation the innovation strategy is highly dependent from quality of innovation ecosystem, which includes the innovation infrastructure, legislative field, level of state support of innovation, investment climate and trust between different parties. Innovation ecosystem is viewed then as a dynamic system, characterized by localized interac- 


\section{Strategies of effective development of participants the innovative process}

tions among a huge amount and diversity of agents - universities, business enterprises, public institutions, society, resources, etc. The lack of existing innovation ecosystem lays in underestimation of role the social innovation. Encourage of social innovations can importantly contribute to a more favourable environment for effective interaction of participants in the innovation process in order to improve the quality of the generated ideas and solutions for their further incarnation. For successful implementation of strategies for the effective development of innovation structures, it is important to establish and properly apply the mechanism for supporting the activities of all parties involved in the innovation process. For achieving the best results in the process of commercialization of $R \& D$ results it is important to use the best foreign experience in the field of innovation, which includes the creation of a modern innovation infrastructure based on science parks, innovative clusters and centres of knowledge and technology transfer. In case of proper selection of the individual components of the mechanism of innovation development and creation the conditions for optimal interaction of all parties, a synergy effect will be obtained that will ensure a more efficient use of the resource potential and allow for an additional cumulative effect manifestation.

In further research will be develop the questions of maintaining the innovation activity in order to enhancing the collaboration native and foreign participants of innovation structures in order to establish a mutually beneficial exchange of experience and ensure the productive use of innovative infrastructure objects.

\section{References:}

1. Innovative Ukraine 2020: National Report / per co. edit. V.M. Geits and others; National Academy of Sciences of Ukraine. - K., 2015. - 336 pp.

2. Fedulova L. Business Models of Innovative Development of Trade Enterprises / L. Fedulova. KNTEU Bulletin. 2017. No. 3. - P. 48-64.

3. Lendel V. Creation and implementation of the innovation strategy in the enterprise / Viliam Lendel, Michal Varmus / Economics and management: 2011. \#16. - P. 819-825.

4. Enterprise Potential Management. Teaching manual / I.Z. Dolzhansky, T.O. Zagornaya, O.O. Udalych. - K.: Center for Educational Literature, 2006. $362 \mathrm{pp}$.

5. Zakharkin O., Zakharkina L. (2014) Substantiation of the enterprise innovation development strategy and its aims. Ekonomichnyi chasopys (Economic Annals-XXI), 7-8. - P. 76-79. (in Eng.). 


\section{Dovbenko Viacheslav}

6. Illiashenko S. M. Knowledge management as a basis for company's innovative development / S. M. Illiashenko, Y. S. Shipulina, N.S. Illiashenko, Actual problems of economics \#6 (168), 2015. - P. 173-181.

7. Chesbrough H. Open innovation and strategy. / H. Chesbrough, M. Appleyard. California Management Review. 2007, vol. 50, no. 1. - P. 57-74.

8. Jemala M. Introduction to open technology innovation strategies /Marek Jemala. Acta Oeconomica Pragensia. 2010. \#18(3). - P. 3-20.

9. Building Knowledge Economy through Innovation Ecosystem: The Role of Innovation Hubs / Brussels, 2014. - 46 pp. Retrieved from: https:// www.knowledge-economy.net/uploads/documents/2014/KEN-2014\%20Analytical\% 20Compendium.pdf

10. Jucevičius G. Smart development of innovation ecosystem / G. Jucevičius, K. Grumadaite. Procedia - Social and Behavioral Sciences 156 (2014). P. 125-129.

11. $\mathrm{Xu}, \mathrm{G}$. Exploring innovation ecosystems across science, technology, and business: A case of 3D printing in China / G. Xu, Y. Wub, T. Minshallc, Y. Zhou // Technological Forecasting \& Social Change. 2017. Retrieved from: http://dx.doi.org/10.1016/j.techfore.2017.06.030 - 14 pp.

12. Atlas of social Innovation: New practices for a better future / edited by J. Howaldt, Ch. Kaletka, A. Schröder, M. Zirngiebl. Technische Universität Dortmund, ZWE Socialforschungstelle. 2018. - 245 pp.

13. Anadon L.D. Making technological innovation work for sustainable development /L.D. Anadon, G. Chan, A.G. Harley, K. Matus, S. Moon etc. PNAS, 2016. August, 113 (35) p. 9682-9690.

14. Harlow H. Strategically Developing Intellectual Capital Effectiveness: A Conceptual Model for Innovative Companies / Harold Harlow. Electronic Journal of Knowledge Management Volume 11 Issue 4, 2013. - P. 309-324.

15. Chesbrough H.W. Open Innovation: The New Imperative for Creating and Profiting from Technology / H.W. Chesbrough. Harvard Business Press, 2006. 227 pp.

16. Saebi T. Business models for open innovation: matching heterogonous open innovation strategies with business-models dimensions / T. Saebi, N.J. Foss. Retrieved from: https://brage.bibsys.no/xmlui/bitsteam/id/360089/Saebi_Business.pdf

17. Blockchain in Development - Part I: A New Mechanism of 'Trust'? / EMCompass: Fresh Ideas about Business in emerging Markets. International Finance Corporation Bulletin. July 2017. N. 40. Retrieved from: http://www.ifc.org/ ThoughtLeadership

18. Lennart E. Innovations and new technology - what is the role of research? Implications for public policy/E. Lennart. VINNOVA Analysis VA. 2014. - 64 pp.

19. Design thinking + Agile: A great combination for effective innovation. Innovation. 16 januar 2017. Retrieved from: https://www.corporate-alchemists. com/design-thinking-agile-innovation/

20. Baden-Fuller C. Business Models and Technological Innovation / C. BadenFuller Stefan, S. Haefliger. Long Range Planning. Volume 46, Issue 6, December 2013. - P. 419-426. 
The mechanism of state regulation of the insurance market: a systematic...

THE MECHANISM OF STATE REGULATION

OF THE INSURANCE MARKET: A SYSTEMATIC APPROACH

\section{Yekhalova Anna ${ }^{1}$}

DOI: http://dx.doi.org/10.30525/978-9934-571-28-2_12

Abstract. This article considers the essence of the mechanism of state regulation of the insurance market as a system, its system properties are investigated. Also direct and indirect methods, their forms and special instruments of state regulation of the insurance market are analyzed. Due to the investigation of direct methods of state regulation of the insurance market their forms are studied; state economic management, administrative and legal regulation, strategic planning, regulation of finance are among them. Due to the analysis of the state economic management such its instruments as state enterpreneurship, government contracts, public funding and antitrust regulation in economic practice are analyzed. Administrative and legal regulation is studied due to its forms: insurance supervision, licensing of insurers, compulsory insurance. Also the issue and forms of strategic planning are discussed in this article; state planning, state programming and state forecasting are among them. Then the state regulation of financial activity of insurers is studied and its forms, such as solvency control, control of investment activity, control of pricing and taxation, are investigated as well. The author says that indirect methods of state regulation of the insurance market affect not so much on market participants, but on their economic and legal environment. Such indirect method of state regulation of the insurance market as the state monetary regulation, as the forms of implementation of which are regulating the rate of refinancing and regulation of foreign exchange, is studied. It is determined that the regulation of the insurance market operates in the horizontal plane at the level of interaction among market participants, and in the vertical plane at the level of interaction between insurers and the state. The possibility of using the foreign economic and legal experience of developed countries in improving the national system of state regulation, typical models of state regulation of insurance of the Continental and British-American law system, as well

\footnotetext{
${ }^{1}$ Assistant Lecturer of the Department of Economic Theory, Taurida National V.I. Vernadsky University, Ukraine

(C) Yekhalova Anna
} 
as non-typical models: the PRC model, the offshore model and the model of Islamic insurance Takaful, regulated due to Sharia law, are researched in this article. In general, the increasingly development of mechanism of state regulation of the insurance market in different countries is associated with the processes of globalization and, as a consequence, with the processes of unification of insurance rules in the leading economies of the world in recent years.

\section{Introduction}

The globalization of the world economy and the spreading of international agreements make regulating of the financial market and, in particular, the insurance market as its subsystem, very important. The necessity of state regulation of the insurance market is not in doubt, because its great social and economic significance and financial potential are in the field of state interests. The purpose of the state is to increase the efficiency of the insurance market, for which, in the framework of the state insurance policy, it needs to improve the mechanism of state regulation in a purpose of coordinating the diversified interests of market participants in a single direction. An analysis of recent works on this and related topics showed that the specific definition of the term "mechanism of state regulation of the insurance market" was not provided by the system approach, but there were described the purpose and instruments of state regulation of the insurance market as practical forms of implementation of the mechanism of state regulation of the insurance market, in particular, in works of N. Nechiporuk, T. Yavorska [5, pp. 226-231] and others. It should be noted that there was not given enough attention to the definition of the essence of the mechanism of state regulation of the insurance market. In particular, in the works of Y. Spletuhov and V. Bazylevych, the greatest attention is paid to the shortcomings of the state insurance policy, but the system qualities of the state regulation mechanism of the insurance market are not highlighted. In the works of T. Yavorska [6, pp. 115-122], N. Tkachenko [4, pp. 157-162], R. Sobol, Z. Plisa, the greatest attention is paid to the peculiarities of the methods and forms of state regulation of the insurance market and the conditions for their application. In particular, the authors of the works analyzed the institutional, legal, economic and administrative methods of regulation and identified the instruments for their practical application. However, the definition of the mechanism of state regulation of the insurance market 
by the system approach and analysis of its elements is not provided there. O. Gamankova considers the mechanism of state regulation as a subsystem of the insurance market system. P. Gorislavets in his works pays special attention to the planning and organization of insurance in the state sector of the economy, while the author's definition of the mechanism of state regulation of the insurance market does not reflect its systemic nature and needs to be supplemented. The systematic study of foreign experience in improving the mechanism of state regulation of the insurance market is carried out in the works of V. Reicher, K. Turbina [1, pp. 298-320] and N. Adamchuk [8, pp. 111-122]. At the same time, in the above-mentioned works, more attention is paid to the peculiarities of the functioning of foreign insurance markets and less attention is paid to the analysis of the mechanisms of state regulation. Also, the analysis of foreign mechanisms of state regulation of the insurance market is made in the scientific works of V. Shakhov, R. Yuldashev, T. Fedorov, T. Plakhov, A. Pleshkov, M. Zhilkina and V. Furman [7, pp. 114-126]. The studies of these authors analyze a wide range of information about the financial and insurance markets of the countries of Europe and North America. In a work "International insurance" by I. Sudarikova features of the functioning of offshore insurance markets as specific economic systems and mechanisms of their state regulation are investigated, in particular, it concerns Bermuda, Switzerland, Luxembourg, Ireland, etc. [2, p. 61]. However, a comprehensive comparative analysis of the insurance market regulation systems and the systematic classification of models of mechanisms of state regulation of the insurance markets operating in particular economies of the world, as well as generalization of foreign experience in improving the mechanism of state regulation of the insurance market with a view to its use in the conditions of the national economy, in the works of these authors are not represented. The most problematic issues regarding to the state regulation of the insurance market is the search for directions and measures to improve the mechanism of state regulation of the insurance market as a system operating within the national economy. It is also important to determine the possibilities and limits of the use of foreign experience on this issue. In advanced economies of the world, well-formed systems of state regulation of the insurance market have developed and accumulated many years of experience in effective implementation of the mechanism of state regulation of the insurance market. The later historical formation of the national insurance market of Ukraine and a lack of the development of 
state regulation, in comparison with Western European countries and the USA, Canada and Japan, determine the actuality of this research. Also, the study of foreign experience in this area is necessary because of the impossibility of effective development of the national insurance market in isolation, without participation in the international distribution of cumulative risks through the mechanism of re-insurance and international insurance pools. In addition, there should be mentioned such non-typical systems of regulation of the insurance market as a system of regulation of the rapidly growing insurance market of the People's Republic of China, a leader in offshore insurance - Bermuda, whose experience can be partly used in the national economy, which are investigated in the works of T. Shatalova and L. Sadikova. Also recent world trends are challenging by the rapid development of Islamic insurance Takaful, the regulation of which is carried out in accordance with the Sharia. This is related to the EU migration policy and the globalization of the world financial system. At the same time, modern insurance activities involve the participation of numerous insurance and re-insurance organizations with a developed network of representative offices and branches both in Ukraine and abroad. At the same time, it is necessary to systematize and generalize the foreign experience in the development of the effective mechanism of state regulation of the insurance market in the national economic practice. The main objective of the article is to determine the essence of the mechanism of state regulation of the insurance market as a system and to make analysis of its structural elements by the system approach, investigation of methods, forms and instruments of state regulation, analysis of typical and non-typical models of state regulation, definition of the general regulatory role of the state in the insurance market by the example of developed economies of the world, searching for opportunities and justifying the limits of the use of foreign experience in improving the mechanism of state regulation of the insurance market, its systematization and synthesis.

\section{The mechanism of state regulation of the insurance market as a system}

In scientific sources and practice of state regulation there are different definitions of the category "mechanism". The word "mechanism" in the Greek translation means "accessory", "machine" [3, p. 908]. In the first definition, it is a sequence of states, processes that determine certain actions; 
in the second - it is a system, an accessory that determines the order of execution of a certain action. This raises the question whether the mechanism of state regulation of the insurance market is an independent economic and legal system, to give an answer to which is possible through the definition of its characteristics by the principle of system analysis. System analysis involves essential qualities inherent in the system, in particular, they are: structuring, hierarchy, stability, emergence, etc. The structurability of the system means the union of elements of the system into a certain structure within which they interact. The elements of the system of the mechanism of state regulation of the insurance market are methods, forms and intruments of regulation. They functionally unite into the structure of the mechanism of state regulation of the insurance market, parts of the institutional whole of which they are and within which they interact. Also the mechanism of state regulation of the insurance market is inherent in the hierarchy as a quality of the system by the system approach. Each system is a subsystem for a higher-level system: the mechanism of state regulation of the insurance market is a subsystem of the insurance market, the insurance market is a subsystem of the financial market, the financial market is a subsystem of the national economy, the national economy is a subsystem of the global economy. In addition, the mechanism of state regulation of the insurance market is also a subsystem of state regulation of the national economy. That is, one system is embedded in another as a subsystem of a higher level system. Also, the mechanism of state regulation of the insurance market has inherent stability as an essential quality of a system, since it functions for a long time. Since the adoption of the Decree of the Cabinet of Ministers of Ukraine "On Insurance" dated May 10, 1993, the work of the mechanism of state regulation of the national insurance market of Ukraine, the basic principles of which stay working in modern conditions, has been initiated. Immergence, or the effect of a system, indicates that the system has properties that are not inherent to its elements and their simple sum. Participants of the mechanism of state regulation of the insurance market have diversified goals of their activities, in particular, insurers pursue the goal of maximizing profits and minimizing insurance payments, insured person has as a main goal timely receipt of insurance payments in the case of happening of the insurance event, insurance agents and brokers - timely receipt of commission payments in full, the state seeks to replenish the state budget and ensure the continuity of the production process. At the same time, in spite of the het- 
erogeneity of the objectives of the system elements, the implementation of insurance carry on due to the mechanism of state regulation of the insurance market. Taking into account that the mechanism of state regulation of the insurance market has essential qualities of a system, we can say that it is an economic system. At the same time, the main problem in the study of the mechanism of state regulation of the economy and the mechanism of state regulation of the insurance market, as its subsystem, is to determine their content and components. In order to explore it, it is necessary to determine what industrial and economic relations are part of the mechanism of state regulation of the insurance market and to identify the limits and effectiveness of economic forms of state management and objective principles of the economic system [4, p. 36].

\section{Direct and indirect methods of state regulation of the insurance market}

The mechanism of state regulation of the insurance market can be characterized as an element of the mechanism of state regulation of the economy, which reflects its features, and represents a complex integrated system that directly and indirectly influences on the national insurance market by government with the help of specific instruments. Direct and indirect methods of state regulation of the insurance market have specific forms (Fig. 1).

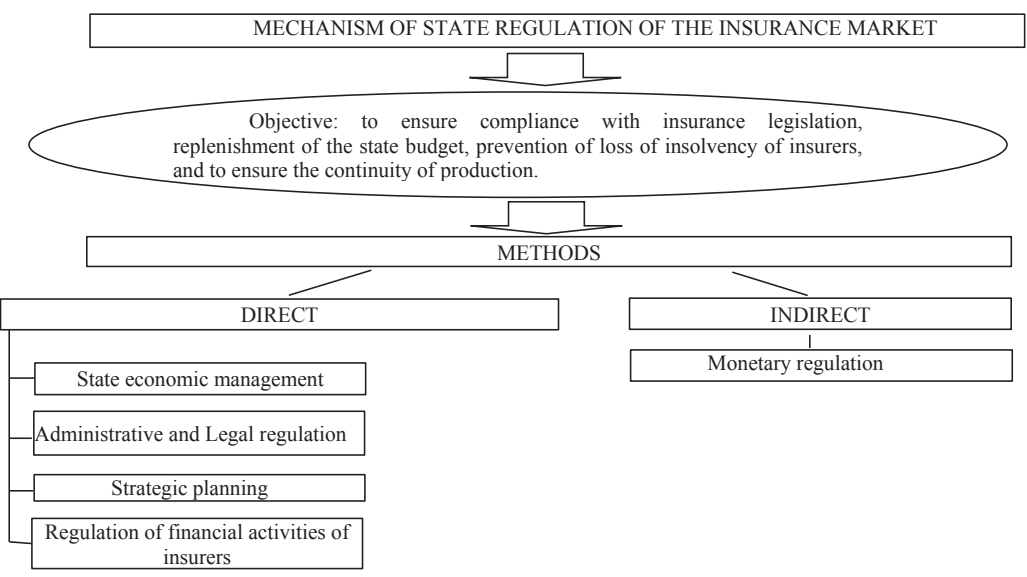

Fig. 1. The mechanism of state regulation of the insurance market Source: developed by the author according to [4, p. 161; 5, p. 226] 
Direct methods of state regulation of the insurance market, for the most part, are of a strict nature.

In implementing the state regulation of the insurance market, the important place is occupied by state economic management, in which state through its authorized bodies act as a participant of economic processes. They adopt forms of state enterpreneurship, government contracts, public funding and antitrust regulation in economic practice (Fig. 2). A state-owned enterprise operating on the basis of state property, in accordance with national insurance law, provides for the creation of state-owned or partially state-owned insurance companies [5, p. 226]. The state can enter into agreements on state property insurance, while among insurers, tenders are conducted in order to select the most reliable insurer with favorable state conditions of insurance.

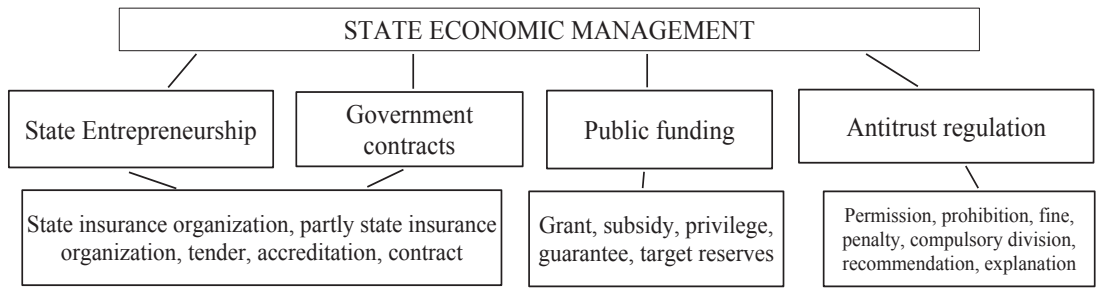

Fig. 2. Forms and instruments of state economic management

Source: developed by the author according to $[4, p .161 ; 5, p .226]$

In some cases, the state provides subsidies and benefits to insurers when they insure cumulative and commercially disadvantageous, but of high social and industrial significance, risks; it provides additional guarantees to insurers that invest in special government guaranteed securities, creates target reserves for security of obligations of insurers due to the long-term life insurance contracts and pension insurance, especially in the event of their bankruptcy [7, p. 115]. Antitrust regulation defines the features of competition and competitive relations in the insurance market and represents a system of measures of state authorities on the influence on the competitive behavior of insurance companies by means of specific methods, for example, verification of documentation, examination, research, investigation, inspection, and forms, for example, permission of actions, prohibition of actions, fines, compulsory division, penalties, recommendations, explanations, etc. [6, p. 116]. Administrative and legal regulation of the insurance 
market determines the conditions of functioning of the insurance market subjects. It defines the legal framework for market participants and takes forms of insurance supervision, licensing of insurers, compulsory insurance (Fig. 3). The main source of law in the Ukrainian insurance is the Law of Ukraine "On Insurance", which regulates the legal relationship among the insurers and insurable subjects, business entities, state institutions, organizations, third parties, insurers' relationships with each other, and regulates the forms, methods and instruments of state regulation of the insurance market.

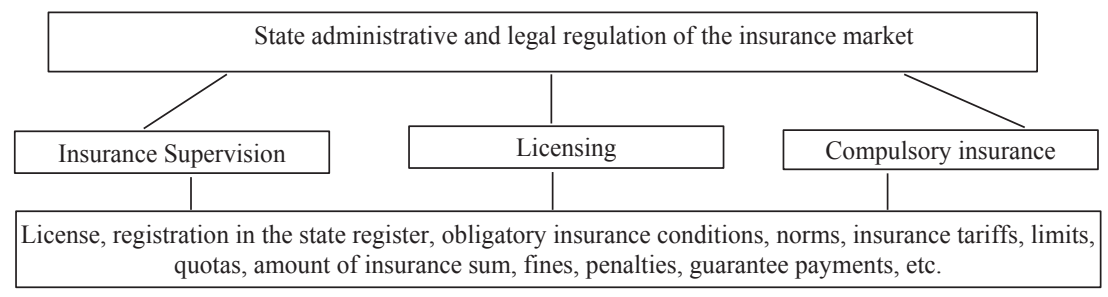

Fig. 3. Forms and instruments of administrative-legal regulation

Source: developed by the author according to [4, p. 161; 6, p. 117]

At the same time, the regulation of the insurance market operates in two planes - in the horizontal plane at the level of interaction among market participants - insurers, re-insurers, insured persons, beneficiaries, insurance agents and brokers, and in the vertical plane - at the level of interaction between insurers and the state. Insurance supervision defines the requirements for fulfilling its obligations by the subjects of the insurance market, compliance with insurance legislation, the development of insurance services, controls the solvency of insurers and protects the interests of policyholders. The authorized body of insurance supervision in Ukraine is the State Commission for Regulation of Financial Services Markets of Ukraine and its regional bodies. The system of insurance supervision, as a subsystem of the system of the mechanism of state regulation of the insurance market, performs primarily functions in the organization of insurance business and technically ensures the possibility of the insurance process, without taking into account the requirements of market participants and the state in accordance with their global economic needs. An important element of the administrative and legal regulation of the insurance market is licens- 
ing, since each insurance product must undergo this procedure in order to confirm compliance of the terms of the policy with certain requirements. In legal terms, a license is an authorization to conduct a particular insurance transaction. Compulsory insurance is carried out at the expense of budget funds for the purpose of providing social protection to defined groups of the population in the legislation and the security of losses of third parties received through actions or inaction of other persons [7, p. 116]. Strategic planning determines the future trend of the development of the national economy as a system and its subsystems, in particular, the insurance market (Fig. 4).

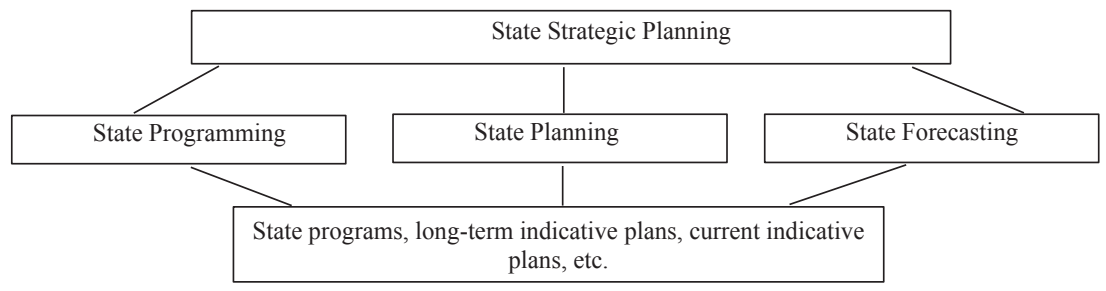

Fig. 4. Forms and instruments of state strategic planning

Source: developed by the author according to [4, p. 161; 7, p. 116]

As a kind of practical economic activity of the state, strategic planning consists in the development of strategic decisions that prescribe compliance with certain goals and strategies for the development of public administration objects, the realization of which ensures their effective functioning in the long term. Strategic planning is indicative by its economical nature (Fig. 4). State regulation of financial activity, on the one hand, can be attributed to direct regulatory methods, and on the other - to indirect ones. Regulation of financial activity in the insurance market consists in introducing measures of influence on the processes of formation, distribution and redistribution of finances of market participants and implemented in the form of controlling the solvency of insurers, control of investment activity, pricing for insurance services (Fig. 5.1).

For example, taxation conditions and fluctuations in bank interest rates indirectly influence the activity of insurance market participants in state regulation of financial activity (Fig. 5.1). Besides, indirect methods of state regulation of the insurance market affect not so much on market 


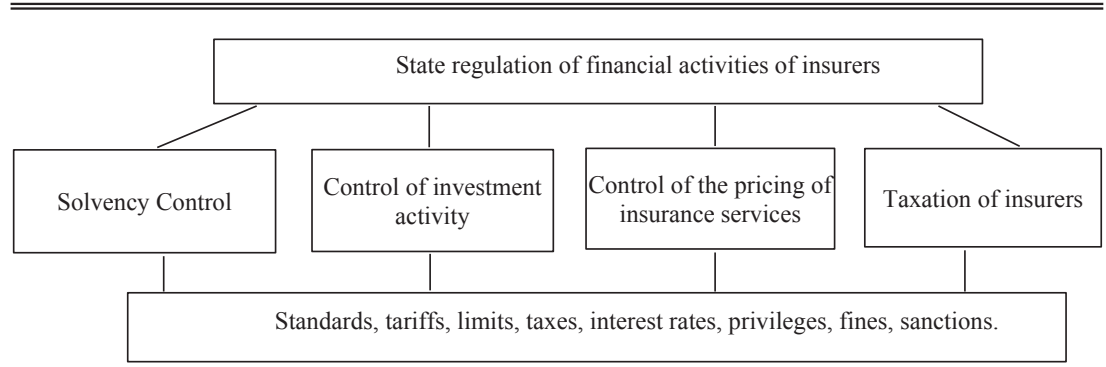

Fig. 5.1. Forms of state regulation of financial activities of insurers

Source: developed by the author according to [4, p. 161; 6, p. 117]

participants, but on their economic and legal environment. Among them, an important place has the state monetary regulation, as the forms of implementation of which are regulating the rate of refinancing and regulation of foreign exchange (Fig. 5.2). The impact of state monetary regulation on the insurance market is to stimulate or inhibit emerging market trends, depending on the peculiarities of the economic situation and the priorities of social and economic development of the state. Such a diversification of forms and instruments of state regulation of the insurance market by bodies is, in general, consistent with the prevailing tendencies of world economical practice, however, modern market requirements and changes in the structure of risks and frequency of occurrence of insurance events, as well as current trends in the field of production, require their improvement.

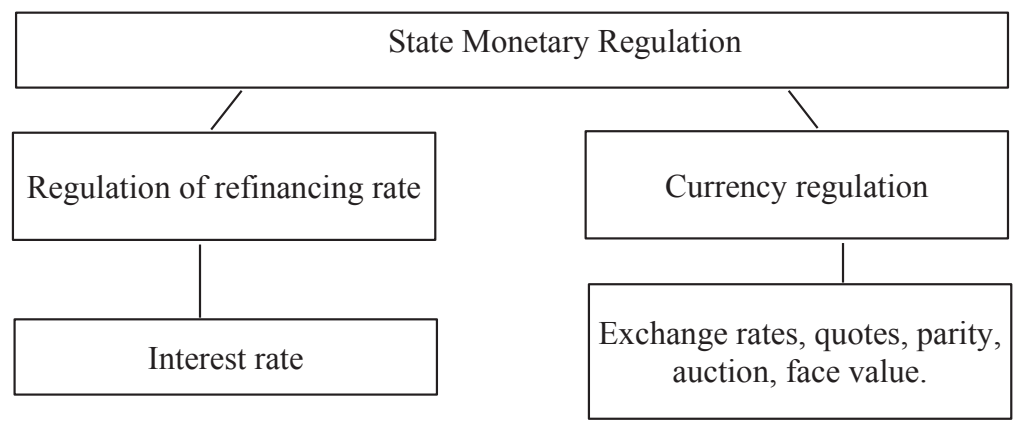

Fig. 5.2. Forms of state monetary regulation

Source: developed by the author according to $[4, p .161 ; 6, p .118]$ 
Therefore, it is important to analyze the effectiveness of the existing system of state regulation of the national insurance market and the mechanism for the practical implementation of its functions, taking into account the experience of industrialized countries and assess their compliance with national social and economic requirements.

\section{Continental and British-American state regulation system}

A diverse approach to the model of state regulation of insurance markets in countries around the world can be systematized according to their belonging to a certain system of law. World economic practice highlights several principle approaches to state regulation of the insurance market. Each of these approaches is implemented within a certain system of law Continental and British-American state regulation systems (Fig. 6). The system of Continental law (Romano-Germanic law, Codified law) is based on strict legal regulation of the activities of market participants, with the main role played by laws and codes. This system is distributed in Germany, France, Italy, Spain, Japan, etc. Within the continental system of law there is a rigid continental model of state regulation of the insurance market, which is characterized by a detailed regulation of the activities of insurers and systematic legislative control of the implementation of insurance operations (Fig. 6). Especially at the initial stages of its development, the continental model, in particular, was provided for the establishment of insurance tariffs, norms for insurance contracts, verification of the investment activity of insurers, strict control of solvency of insurers and re-insurers, supervision of operational activities, but at the present time it becomes more liberal. In the EU member states, the mechanism of state regulation of the insurance market is subjected to the requirements of the EU Insurance Directives, which are based on the principles of the British system of state regulation.

Among the requirements for insurers in the framework of the continental model of state regulation, the greatest attention is paid to the following: compulsory licensing, the list and limit of technical reserves, the amount of technical reserves and equity, the assessment of strategy, risks, business processes of insurers, market transparency and openness of information, and requirements of the antitrust legislation. At the same time, in countries with a continental system of law, in particular, Germany, Italy, Spain, insurance agents and brokers are given the right to operate freely in the market, insurance agents are not subjected to state regulation, but are liable 


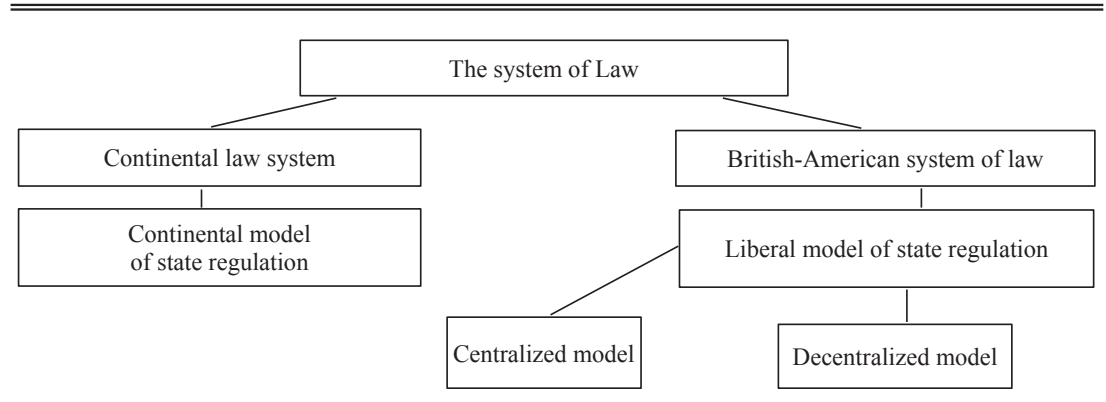

Fig. 6. Systematization of models of state regulation

Source: developed by the author according to [2, p. 104; 8, p. 112]

under insurance contracts; insurance brokers are subjected to registration, but their regulation activity is minimal. In the system of state regulation of Japan, in comparison with other states with the continental system of law, the most rigorous control of insurance tariffs is implemented, and there is also a very complicated procedure for obtaining a license. Equally, for obligatory and voluntary insurance, insurers in Japan must apply for the regulatory authority's general insurance conditions. The Japanese insurance market is one of the most developed in the world, but the protection policy in the country is rigid, so foreign insurers in the market are not represented. It should be noted that within the limits of the continental system of law in one states there is a rigid continental model of state regulation of the insurance market, for example, in Germany, while in others it is more liberal, for example, in France (Table 1).

In France, whose state regulation model occupies an intermediate position between the Continental and the British models, state control of insurance agents is minimal. The British-American system of law (System of the General law or the Case law) differs from the Continental system by the fact that the main source of law is not only laws and codes, but also a judicial precedent. This system operates in the USA, the UK, Canada, Australia, and other countries. The peculiarities of the British-American system of law are: the lack of a detailed codification of the operational, financial and investment business activities of enterprises, and that legislation determines the legal framework for the activities of market participants. Within the British-American system of law, there is a liberal model of state regulation of the insurance market, for 
Table 1

\section{Continental model of state regulation of the insurance market on the example of Germany and France}

\begin{tabular}{|l|l|l|l|}
\hline Country & \multicolumn{1}{|c|}{$\begin{array}{c}\text { Features } \\
\text { of state regulation }\end{array}$} & \multicolumn{1}{|c|}{ Supervisors } & \multicolumn{1}{c|}{$\begin{array}{c}\text { Insurance } \\
\text { legislation }\end{array}$} \\
\hline Germany & $\begin{array}{l}\text { The system of } \\
\text { regulation is centralized } \\
\text { at the federal level. } \\
\text { Regulatory authorities } \\
\text { are maintained at the } \\
\text { expense of insurers from } \\
\text { insurance premiums, } \\
\text { insurers finance the } \\
\text { implementation of } \\
\text { government programs, } \\
\text { government subsidies, } \\
\text { bank loans, etc. The } \\
\text { state's special attention is } \\
\text { paid to the regulation and } \\
\text { promotion of voluntary } \\
\text { life insurance, pension } \\
\text { and health insurance. } \\
\text { The system is gradually } \\
\text { liberalized. }\end{array}$ & $\begin{array}{l}\text { Federal Financial } \\
\text { Supervisory Authority } \\
\text { Fundesanstalt fur } \\
\text { BaFin). }\end{array}$ & $\begin{array}{l}\text { Law on insurance } \\
\text { contract (1908); } \\
\text { Law on Insurance } \\
\text { Supervision } \\
\text { (1901); Law } \\
\text { on the Federal } \\
\text { Insurance } \\
\text { Supervisory } \\
\text { Authority (1951), } \\
\text { Directives of the } \\
\text { EU. }\end{array}$ \\
\hline $\begin{array}{l}\text { The regulatory system } \\
\text { combines state regulation } \\
\text { and self regulation. } \\
\text { Legislation is consistent } \\
\text { with the continental } \\
\text { model, and the content is } \\
\text { constituted by the British } \\
\text { centralized liberal model. }\end{array}$ & $\begin{array}{l}\text { Financial Market Authority } \\
\text { (AMF), Insurance } \\
\text { Supervisory Commission, } \\
\text { National Insurance Board. }\end{array}$ & $\begin{array}{l}\text { Insurance Code } \\
\text { (1976); } \\
\text { Directives of the } \\
\text { EU. }\end{array}$ \\
\hline
\end{tabular}

Source: developed by the author according to [8, p. 124]

which the most priority is the control of the financial resources of insurers, based on the analysis of financial statements, and there is no rigorous regulation of insurance contracts, tariffs, and other operating activities. The liberal model of state regulation of the insurance market has two varieties - centralized and decentralized. They differ in the degree of centralization of state regulation, depending on the principles of the state system in one or another country - whether it has a unitary system or federation. A decentralized model of state regulation of the insurance market within the British-American system of law, such as in the United States 
and Canada, is consistent with the principles of economic federalism. So in the US, each state has its own insurance system, which is subjected to state law, and there is no direct state regulation of the insurance market at the national level. In Canada, insurance supervision at the federal level is carried out by the Financial Institutions as the Control Department of the Canadian Finance Ministry, which provides licenses to insurers and regulates the activities of foreign insurers in Canada, and controls the volume of insurers' stock-holdings, their solvency and investment activities. Social insurance in Canada is exercised by the state, acting as an insurer, and citizens - as insured persons. The maintenance of an insurance business is under the jurisdiction of the control authorities of the provinces (Table 2). Insurance agents and brokers in Canada are subjected to federal and provincial regulations, with significant regulatory powers delegated to associations of insurance agents and brokers that are subjected to the National Association of Brokers. It should be noted that insurance brokers are required to have licensing, certification, examination, as well as their financial status and terms and conditions of performance of insurance contracts, which prevents occurrence of fraud, dumping, errors and promotes high level of efficiency of provision of insurance protection. A characteristic feature of the American system of state regulation of the insurance market is the lack of antitrust supervision due to the structure of the insurance market. US insurance brokers are also subjected to the regulations of insurance supervisors in each state, but many of their regulatory functions are delegated to a professional association of insurance brokers that have the status of self-regulatory organizations. This approach has its own contradictions in the aspect of vertical confrontation of federal and regional regulatory norms, as well as the horizontal confrontation of local supervisors (Table 2), but it allows US state and provincial insurers in Canada to focus on the peculiarities of their region to maximize the needs of policyholders and adapt existing legislation to them. At the same time, within a decentralized model of state regulation of the insurance market, most insurers do not cross the borders of their region, effectively perform the functions of providing insurance protection and do not face competition with industry insurers, who, due to the wide geographical spread and differentiated layout of losses among a large number of policyholders, can neutralize negative results in one region, provided positive results in others. 
Table 2
Decentralized liberal model of state regulation of the insurance market on the example of the USA, Canada and the United Kingdom

\begin{tabular}{|c|c|c|c|}
\hline Country & Features of state regulation & Supervisors & $\begin{array}{l}\text { Insurance } \\
\text { legislation }\end{array}$ \\
\hline USA & $\begin{array}{l}\text { A decentralized regulatory } \\
\text { system: each state has its } \\
\text { own standards of control, } \\
\text { duplication of regulatory } \\
\text { functions in each state and } \\
\text { national laws, there are } \\
\text { no common standards of } \\
\text { insurance activity, conflicts } \\
\text { of jurisdiction among } \\
\text { states, effective insurers' } \\
\text { concentration on the needs of } \\
\text { each state, local insurers do } \\
\text { not compete with the national } \\
\text { insurers-leaders. }\end{array}$ & $\begin{array}{l}\text { The federal } \\
\text { supervision is } \\
\text { absent, there are } \\
\text { state departments } \\
\text { of supervision. } \\
\text { National Association } \\
\text { of Insurance } \\
\text { Commissioners } \\
\text { (NAIC), Federal } \\
\text { Insurance Office, } \\
\text { Financial Stability } \\
\text { Oversight Council }\end{array}$ & $\begin{array}{l}\text { Each state has its } \\
\text { own insurance } \\
\text { legislation, on the } \\
\text { federal level there } \\
\text { are general rules } \\
\text { of law. }\end{array}$ \\
\hline Canada & $\begin{array}{l}\text { Decentralized system: } \\
\text { provincial legislation and } \\
\text { federal regulation, the last one } \\
\text { regulates: licensing, control } \\
\text { of reserve funds, investment } \\
\text { activity, foreign insurers. } \\
\text { There is a strict regulation of } \\
\text { insurance agents and brokers. }\end{array}$ & $\begin{array}{l}\text { Department of } \\
\text { Control of Financial } \\
\text { Institutions of the } \\
\text { Ministry of Finance. } \\
\text { National Association } \\
\text { of Insurance } \\
\text { Brokers. }\end{array}$ & $\begin{array}{l}\text { Federal law } \\
\text { and provincial } \\
\text { legislation. } \\
\text { Federal Insurance } \\
\text { Companies Act } \\
(1991) .\end{array}$ \\
\hline UK & $\begin{array}{l}\text { Optimal model: liberal } \\
\text { supervision, stimulating } \\
\text { taxation, absence of } \\
\text { restrictions on participation } \\
\text { in international investments, } \\
\text { etc.; most developed system } \\
\text { of self-regulation, linked } \\
\text { with state regulation. } \\
\text { High requirements for the } \\
\text { professionalism, competence } \\
\text { and business reputation of } \\
\text { insurers and insurance agents } \\
\text { and brokers. Regulatory } \\
\text { requirements for advertising. } \\
\text { Information transparency. } \\
\text { Audit of market participants. }\end{array}$ & $\begin{array}{l}\text { Financial Security } \\
\text { Authority (FSA); } \\
\text { Financial Conduct } \\
\text { Authority } \\
\text { (FCA); Insurance } \\
\text { Department, } \\
\text { Department of } \\
\text { Commerce and } \\
\text { Industry, Prudential } \\
\text { Regulation Authority } \\
\text { (PRA). }\end{array}$ & $\begin{array}{l}\text { Insurance } \\
\text { Companies Act } \\
\text { (1982); Financial } \\
\text { Services Act } \\
\text { (1986); Insurance } \\
\text { Brokers Act } \\
\text { (1977); Protection } \\
\text { of Insured Act } \\
\text { (1975); Rules of } \\
\text { insurance activity } \\
(1981) \text {. }\end{array}$ \\
\hline
\end{tabular}

Source: developed by the author according to [8, p. 142] 
It should be mentioned that in the East Europe, for instance in Ukraine, Georgia, the Russian Federation, Romania, Hungary, etc., such a problem significantly reduces the level of efficiency of regulation of the insurance market. The centralized liberal model of state regulation of the insurance market within the British-American system of law is characterized by the unity of the regulatory system. The most striking example of the implementation of such a model is the system of state regulation of the insurance market of the United Kingdom, where there is a single body of insurance supervision, all insurers are subjected to the actions of uniform laws, rules and regulations, which makes regulation clear and transparent, opens the national insurance market for effective cooperation with other economies, what becomes extremely important in the conditions of globalization (Table 2). At the same time, the British model of regulation system seems, at first glance, the most liberal to insurers. But it should be emphasized that an important place in the regulatory system takes the self-regulation mechanism of associations of insurers, and there is the delegation of certain regulatory functions of the state to such autonomous bodies, which creates the appearance of lack of regulation. The activities of insurers are licensed, while the insurance supervisory authorities pay the greatest attention to the state of the financial statements of insurers, the volumes of their reserve funds and assess their solvency. A well-developed system of state regulation of insurance agents and brokers was formed in the UK, where each insurer, in addition to a license application, indicates the insurance agents and brokers with which he plans to cooperate, provides samples of agreements with them, and so on. The relationship between the insurer and the insurance agents is reflected in the financial statements. Insurance brokers are subjected to registration and licensing in the Insurance Board of Insurance Brokers, which is a self-regulating entity, and also they bear financial responsibility for signed insurance contracts. The British model of the mechanism of state regulation of the insurance market has become the basis not only for the creation of a unified system of state regulation of insurance markets in the EU, as well as for Australia, New Zealand, Singapore, Jordan and Eastern European countries, in particular, Ukraine and Hungary. So Ukraine became the first CIS country to reform the mechanism of state regulation of the insurance market in the direction of creating a single body of insurance supervision and control, the so-called "mega-regulator of the financial market", the issue of which has not yet been resolved. 


\section{Non-typical models of state regulation of the insurance market}

In addition to the Continental and British-American systems of law, within which the consolidated and liberal models of the state regulation of the insurance market are mostly operating, there are also non-typical models of state regulations of the insurance market in the world. For example, the insurance market of the People's Republic of China is less than thirty years old, but during this time it made a huge leap in development. One of the reasons for the rapid development of the insurance market has been the greater economic openness of China, since 1985, when the policy of "open doors" has been introduced in some provinces. In 1998, the People's Bank of China was reorganized and then the Central Financial Workgroup for the control of banking structures and the Commission of Insurance Regulation of China (CIRC) have been introduced. Since 1999, the liberalization of the financial sector and the rapid growth of insurers and types of insurance have begun. The main functions of CIRC are: 1) development of insurance policy, regulating insurance rules; 2) insurance supervision; 3) sanctions, fines, quotas; 4) protection of policyholders; 5) prevention of dumping and monopolization of the insurance market; 6) monitoring of risks and prevention of occurrence of insurance events. The trend in recent years is an increase in the number of Chinese insurance companies in major provincial cities and the admission of foreign, mostly European and American, insurers to the market. At the same time, in each province there are strict directives concerning the activities of insurers. The main law in the insurance sector is the "Law on Insurance of the People's Republic of China". Responsibility for regulating and controlling the insurance market belongs to the Department of Financial Control and Regulation under the People's Bank of the People's Republic of China under the leadership of the State Council of the People's Republic of China [1, p. 45]. The difference in the insurance market of China is a small number of insurers, which makes their regulation simple and transparent and allows the government to monitor the results of insurers' activities and timely take the necessary measures to influence the insurance market. Another example of a non-typical model of the mechanism of state regulation of the insurance market is offshore zones, which are special territories where non-resident insurers benefit from a preferential registration, licensing and taxation regime. At the present time there are about 40 offshore zones in the world, in particular: Bermuda, Antigua, Barbados, Gibraltar, Hong Kong, Jersey, Dominican, Dubai, Cyprus, Liech- 
tenstein, Malta, Panama, Switzerland, Turks and Caicos Islands, Aruba, Bahamas, Mauritius, Nevis, Saint Vincent, Luxembourg, Ireland, Western Samoa, British Virgin Islands, Grenada, Cayman Islands, Seychelles, etc. The Bermuda Islands are a constant leader in the number of insurance operations, the diversity of insured risks and volume of capital. Most offshore companies are servicing American insurers and, to a lesser extent, European ones, but because of closed information, it's difficult to estimate the amount of capital in offshore zones [2, pp. 59-68]. The reasons why the insurance business goes to offshore zones are: low tax rates, or their absence; weak insurance supervision; simplified registration regime and getting licensing; low requirements to the amount of authorized capital and the possibility of its incomplete payment; confidentiality of information on participants of the offshore insurance market; simplified financial statements; easy introduction of new insurance products to the market; simplified opening of branches; lack of currency control, etc. In recent years, insurance supervision in offshore companies is gradually increasing, for instance, mandatory licensing fees, requirements for the amount of authorized capital, especially for life insurance operations, become more stringent. Most of the insurance operations involve the captive insurance of transnational corporations, business agglomerations and mutual insurance of financial associations. So offshore zones are an important part of the global financial system, the effectiveness of which regulation mechanism has been tirelessly growing since 40 years of the twentieth century. Another example of a non-typical model of a mechanism for regulating the insurance market is the Islamic insurance Takaful, which is governed by the rules of the Sharia. In the world there are about 200 insurance companies Takaful, the main vector for the development of this insurance market is the active economic growth of Asian countries with the majority of the Islamic population and the growth of the quantity of Muslims in Europe due to the external migration policy of the EU countries [9, p. 23]. According to Sharia, Muslims can not engage in classical insurance through elements of uncertainty, usury and excitement in it, which are prohibited. The uncertainty of classical insurance lies in the uncertainty of the directions of investment by insurers, when, according to Sharia standards, for example, it is prohibited to invest in the production of alcohol, casinos or pigs. The gamble consists in the fact that if an insured event happens, the insured person receives monetary compensation, and in the case if it doesn't happen - the insurer takes the insurance contribution 
to his own and wins. The usury is that some types of insurance provided with the receipt of interest income for insurance premiums. State regulation in Takaful is necessary for a number of reasons: protection of the interests of insurers, since the activities of insurers in Takaful are hidden; risks are insured on the principle of mutual insurance, which guarantees losses in the case of a large-scale insurance event happening, a possible conflict of civil law and norms of Sharia; financial statements, solvency assessment and financial stability in Takaful have certain features too. The principle of insurance Takaful consists in non-profit mutual insurance of the members of the insurance union. The Islamic Financial Market Authority is the main regulator of the Islamic financial market, which has been operating since 2006, and develops the basic standards for the insurance of Takaful. The minimum amount of required insurance policies, rules and requirements for insurance participants of Takaful has already been developed and operates in the international Islamic financial market. In general, the Islamic financial market is in its initial stage of development, but the insurance market Takaful is growing rapidly and is gaining momentum.

\section{Conclusions}

The state carries out the systemic influence of the insurance market through the effective mechanism of state regulation, which inherent in the essential qualities of the system: structuring, hierarchy, stability, emergence, etc. The mechanism of state regulation of the insurance market is a subsystem of the insurance market, the insurance market is a subsystem of the financial market, the financial market is a subsystem of the national economy, the national economy is a subsystem of the global economy. In addition, the mechanism of state regulation of the insurance market is also a subsystem of state regulation of the national economy. Elements of the system of the mechanism of state regulation of the insurance market are: specific methods, forms and instruments of influence on the insurance market. Methods of state regulation of the insurance market by the nature of the impact on the participants in the insurance market are divided into direct and indirect. Among the direct methods the most important are: the state economic management, the administrative and legal regulation, the strategic planning, the regulation of financial activities of insurers. Among the indirect methods, the most significant place has a monetary regulation. World economic practice highlights several principle approaches to the state regulation of 
the insurance market, which are implemented within the Continental (Germany, France, Italy, Spain, Japan) and British-American (US, Canada, UK) systems of law. In the Ukrainian national system of state regulation of the insurance market, which is formed according to the principles of the British model of regulation, it is appropriate to use the experience of Germany with the type of financing of the state regulator: the insurance companies pay for the costs associated with supervision. In Ukraine, insurance supervision is carried out by the State Commission for the Regulation of Financial Services Markets, similar structures exist in most countries of the world. In the United States, the regulation of insurance is diversified by territory, each state has its own laws and regulatory bodies, which allows maximum concentration on the needs of market participants in each state. Ukraine is large in size, so the regional factor matters. The current stage of development of the Ukrainian insurance market is characterized by low demand, low capitalization and unfair competition, so the centralized model of state regulation is suitable for it. However, taking into account the positive experience of the UK, some functions of the state, for example, preventing the bankruptcy of the insurer, could be transferred to the self-governing bodies. In order to attract investment and rapid capitalization of the insurance market, some states establish offshore zones on their territories. The possibility of establishing offshore insurance zones in Ukraine is questionable. The PRC has a strict system of state regulation of the insurance market, but due to a small number of insurers in the country, the state regulation is simple and transparent. Recent migration trends in Europe determine a possibility of introducing Islamic insurance Takaful, which is regulated by the Sharia Law, on the European insurance markets soon. Thus, despite the different systems of state regulation of insurance activities in developed countries, they are united by the fact that much attention is paid to this issue from the side of the state.

\section{References:}

1. Turbina K. E. (2000) Tendentsii razvitiya mirovogo rynka strakhovaniya [Tendencies of development of the world insurance market]. Moscow: Ankil. (in Russian)

2. Sudarikova I. A. (2014) Mezhdunarodnoe strakhovanie [International Insurance]. Saratov: RG Plekhanov University. (in Russian)

3. Ozhegov S.I. (2018) Tolkovyy slovar' russkogo yazyka. 100000 slov, terminov $i$ vyrazheniy [Explanatory dictionary of the Russian language. 100000 words, terms and expressions]. Moscow: Oniks-LIT. (in Russian) 
4. Tkachenko N. V. (2010) Derzhavne reghuljuvannja strakhovoji dijaljnosti [State regulation of insurance activity]. Bulletin of Sevastopol National University, vol. 109, no. 2010, pp. 157-162.

5. Javorsjka T. V. (2007) Orghanizacijno-pravovi formy strakhovogho pidpryjemnyctva [Organizational and legal forms of insurance business]. Scientific Bulletin of the National Forestry University of Ukraine, vol. 17, no. 6, pp. 226-231.

6. Javorsjka T. V. (2013) Konkurentne reghuljuvannja strakhovogho pidpryjemnyctva Ukrajiny [Competitive regulation of insurance business of Ukraine]. Money, finance and credit. Actual problems of economy, vol. 146, no. 8, pp. 115-122.

7. Furman V. M. (2005) Derzhavne reghuljuvannja strakhovogho rynku jak chynnyk jogho strateghichnogho rozvytku [State regulation of the insurance market as a factor in its strategic development]. Economy and Forecasting, vol. no. 2, pp. 115-122.

8. Adamchuk N. G. (2004) Mirovoy strakhovoy rynok na puti k globalizatsii [The world insurance market on the way to globalization]. The Russian Political Encyclopedia. Moscow: MSIIR-University. (in Russian)

9. El-Hawary D., Grais W., Iqbal Z. (2007) Diversity in the regulation of Islamic Financial Institutions. The Quarterly Review of Economics and Finance, vol. no. 46, pp. $778-800$. 


\title{
METHODOLOGICAL BASIS OF THE FORMATION OF EFFECTIVE FORMS OF INVESTMENT ACTIVITY IN THE CONDITIONS OF THE STRUCTURAL ADJUSTMENT OF THE ECONOMY
}

\section{МЕТОДИЧНІ ОСНОВИ ФОРМУВАННЯ ФОРМ ПРОВЕДЕННЯ ЕФЕКТИВНОЇ ІНВЕСТИЦИЙНОЇ ДІЯЛЬНОСТІ В УМОВАХ СТРУКТУРНОЇ ПЕРЕБУДОВИ ЕКОНОМІКИ}

\section{Zhukov Vladlen ${ }^{1}$ \\ DOI: http://dx.doi.org/10.30525/978-9934-571-28-2_13}

\begin{abstract}
Integration of Ukraine into the global society needs to develop its economy held by the generally accepted principles and laws of the State of economic science. In conditions of transition economy, when the process of overcoming internal crises in the enterprise is complicated by the unstable macro-economic environment, the problem takes on special significance. A generalization of the fundamental works of foreign and domestic scholars on this issue allowed to conclude that the question of methodological and conceptual approaches to solving the problem of organizing the management of the investment activity industrial enterprise has not found a suitable solution as in the scientific and organizational and practical aspects.

The aim of the article is the theoretical rationale and development of methodological approaches and practical recommendations for improving the management of the investment activities of industrial enterprises. To achieve this goal in the article was, and decided the following tasks: identify the organizational-economic features of the regulation of investment activity of industrial enterprises; development of methodical approaches to increase the effectiveness of the use of investment resources. Methodological and theoretical basis of the study is the provision of economic theory, the study of domestic and foreign scholars on the theory of investment entity, assessment of their effectiveness and financial support.
\end{abstract}

\footnotetext{
${ }^{1}$ Candidate of Economic Sciences,

Associate Professor of the Department of Banking,

Simon Kuznets Kharkiv National University of Economics, Ukraine
} 
Scientific novelty of the obtained results is the rationale of new approaches to improve the management of the investment activities of industrial enterprises in the face of economic transformation, namely:

- improved: the concept of "investment" on the basis of the analysis and generalization of theoretical principles and essence of investment activity of industrial enterprises taking into account the features of the transformation of the economy;

- the scheme of interaction of economic, institutional, legal, informational, organizational components of the enterprise strategy, which allow you to have a clear picture of the development and implementation of the investment strategy of the company.

The practical significance of obtained results is that implementation of the suggested proposals and recommendations in practical activity of enterprises is a structured set of several aspects, and in the first place, such as economic, institutional, normative-legal, informational, organizational. These aspects are interdependent, their structuring and allocation of priorities between them allow you to have a clear idea about the design and implementation of the investment strategy of the company.

One of the problems in the formation of the strategy of investment activity of the enterprise is to identify the necessary structural strategic changes, creating an effective organizational form of realization of investment problems. In the meantime, the best approach to the formation of the organizational structure of the enterprise necessary for the exercise of investment activities, is a systemic approach.

Strategy management of investment activity is inextricably linked to the effective use of investment resources. When the resource potential of the investment activity in many respects is defined as the presence of different financial sources necessary for the formation of investment resources and the ability of the enterprise to effectively and efficiently use each of the sources.

\section{1. Вступ}

Інвестування відіграє важливу роль в економіці, визначає значною мірою не тільки стійкий розвиток окремих підприємств, але і є базою, на якій грунтується економічний розвиток суспільства в цілому. Разом 3 тим успішний розвиток підприємства в умовах конкурентного оточення багато в чому залежить від ступеня його інвестиційної активності. При цьому прагнення підприємства не тільки вижити, але й одержати доход, 
достатній для відновлення і приросту економічного потенціалу, повинно спонукати підприємства шукати напрямок ефективного вкладення власних коштів і залучати інвесторів 3 метою створення індивідуальних переваг перед конкурентами в конкретній сфері виробництва.

Тому в основі інвестиційної діяльності будь-якого підприємства повинна знаходитися певна стратегія, що визначає цілі і задачі господарської структури в даній сфері діяльності. У той же час інвестиційна стратегія розробляється відповідно до загальних стратегічних задач, що постають перед підприємством. Це пов'язано з тим, що будь-який вид діяльності підприємства підпорядкований загальній стратегії, що має на увазі визначення довгострокових задач, прийняття курсу дій і розподіл ресурсів, необхідних для виконання поставлених цілей.

Теоретичні аспекти та проблеми здійснення інвестиційної стратегії роз-робляються відповідно до загальних стратегічних задач досліджувались як у зарубіжній, так і в вітчизняній літературі таких провідних учених-економістів: Путятин Ю.А., Фатхутдинов Р.А., Евенко Л.И., Овсиевич Б.Л., Оучи У., Беа Ф., Забродский В.А., Дихтла Э., Швайцера М., Пономаренко В.С., Виханский О.С., Ковалев В.В. та багатьох інших. При цьому у даних наукових працях розглядаються питання фінансування окремих інвестиційних проектів, однак у нинішніх ринкових умовах необхідно забезпечити подальше вивчення та обгрунтування методичних основ формування форм проведення ефективної інвестиційної діяльності в умовах перебудови економіки.

Мета статті - обгрунтувати напрями удосконалення методики проведення ефективної інвестиційної діяльності в умовах структурної перебудови економіки.

\section{2. Особливості формування інвестиційної стратегії підприємства}

Слід зазначити, що комплексні дослідження і розробку інвестиційної стратегії доцільно проводити тільки у взаємозв'язку з головними цілями функціонування підприємства. При цьому формування інвестиційної стратегії є трудомістким процесом, тому що перш за все вона повинна базуватися на прогнозуванні окремих умов здійснення інвестиційної діяльності (інвестиційного клімату) і кон'юнктурі інвестиційного ринку. Складність цього процесу полягає в тому, що він вимагає ретельного пошуку і оцінки альтернативних варіантів інвестиційних рішень, що найповніше відповідають підприємству і перспективам 
його розвитку. Особливості формування інвестиційної стратегії полягають також у тому, що вона не є незмінною, а вимагає періодичного коректування з урахуванням мінливих зовнішніх і внутрішніх умов іiі реалізації (рис. 1).

Прийняття раціональних інвестиційних рішень грунтується на викорис-танні різного роду кількісних і якісних показників оцінки доцільності реалізації тих чи інших проектів. Разом з тим формування інвестиційної стратегії, як і будь-якого багатогранного поняття, не вичерпується лише простим порівнянням певного набору показників, тому що інвестиційна стратегія з погляду стратегічного менеджменту $[1 ; 2 ; 3]$, є структурованою сукупністю декількох аспектів, у першу чергу таких, як економічний, інституційний, нормативно-правовий, інформаційний.

Ці аспекти є взаємозалежними, їх структурування і розподіл пріоритетів між ними дозволяють мати чітке уявлення про розробку i реалізацію інвестиційної стратегії підприємства. Слід зазначити, що доцільність розгляду стратегії управління інвестиційною діяльністю підприємства у вигляді структурованої сукупності різних аспектів ситуаціях і для вирішення будь-яких задач..

Як було зазначено вище, інвестиційна діяльність підприємства повинна будуватися на основі інвестиційної стратегії, яка розробляється з використан-ням різних фінансово-економічних методів, що у сукупності складають науково-фінансову методологію формування інвестиційної стратегії і являють собою економічний аспект інвестиційної стратегії. Базовими елементами економічного аспекту є сукупність різних економічних показників, що використовуються для оцінки інвестиційної стратегії. Наприклад, це можуть бути такі показники:

- обсяг випуску продукції;

- структура випуску продукції;

- динаміка реалізації готової продукції;

- динаміка інвестиційних витрат і доходів;

- строк окупності інвестиційних рішень тощо.

Поряд 3 цим економічний аспект також потребує вибору певних мето-дів і підходів до управління інвестиційною діяльністю, що дозволяють про-водити:

- аналіз можливостей підприємства для здійснення конкретних видів інвестиційної діяльності; 


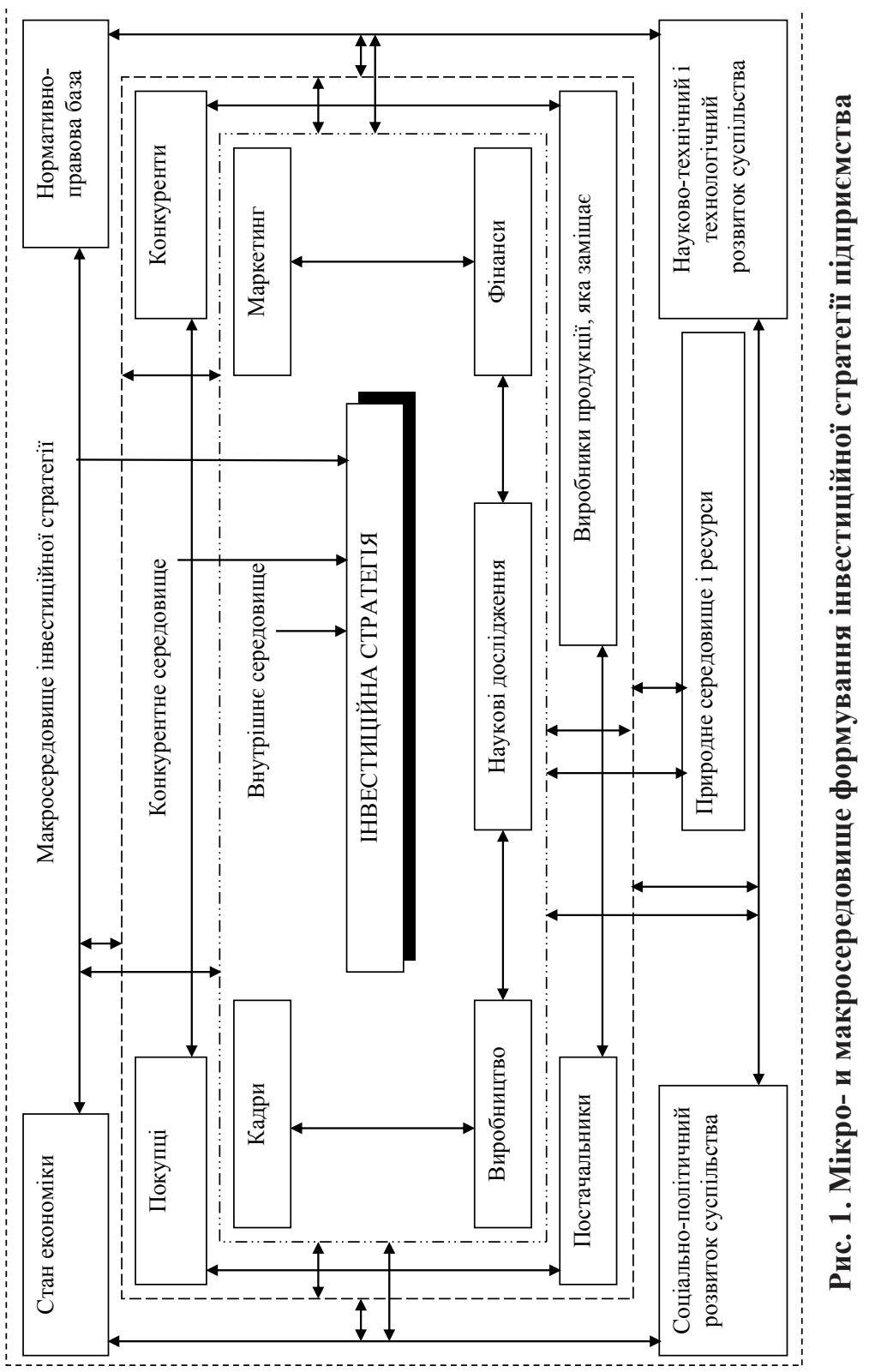


- планування інвестиційної діяльності;

- оперативне втручання і регулювання окремих етапів інвестиційної діяльності, що є особливо актуальним в період структурної перебудови;

- контроль за виконанням прийнятих рішень і т. ін.

У рамках інституційного аспекту інвестиційної стратегії здійснюється вибір інвестицій визначеного виду, формується інвестиційний портфель, оцінюється ризик проведення конкретних етапів і напрямків інвестиційної діяльності.

Нормативно-правовий аспект інвестиційної стратегії є взаємодією таких складових:

- законодавчі і нормативно-правові акти на рівні держави, що утворюють юридичну основу і формують фіскальне середовище, у рамках яких підприємство формує інвестиційну стратегію і здійснює інвестиційну діяльність;

- внутрішні регулюючі документи підприємства, що дозволяють забезпечувати безперервність інвестиційної діяльності в рамках усього підприємства.

Інформаційний аспект інвестиційної стратегії являє собою систему обробки інформації, що є базисом інформаційного обміну в рамках інвестиційної стратегії, дозволяє оперативно реагувати на зміни в юридичних установах і фіскальному середовищі, прогнозувати економічні перспективи ринків і планувати зміни в межах інституційного аспекту, коректувати певні частини інвестиційної стратегії.

Разом 3 тим, поряд 3 вище розглянутими питаннями, на погляд автора, важливим є управління організаційним аспектом проведення інвестиційної діяльності, тобто необхідно враховувати, наскільки структура підприємства сприяє досягненню поставлених цілей для реалізації стратегічних рішень підприємства, у тому числі й у сфері інвестиційної діяльності. Так, на думку Кнута Бляйхера, «організаційна політика як частина загальної концепції підприємства забезпечує його здатність до виживання і розвитку і стає, таким чином, відправною точкою конкретної організаційної діяльності у фазах планування, підготовки, реалізації і контролю прийнятих рішень» [4]. При цьому суть стратегічного управління полягає в тому, що на підприємстві, з одного боку, існує чітко організоване комплексне стратегічне планування з іншого, - організаційна структура управління підприємством адекватна «формальному» стратегічному плануванню [1]. 


\section{Zhukov Vladlen}

Суттєвим є і той факт, що розробка певної інвестиційної стратегії також впливає на формування організаційної структури підприємства, тому що в загальному плані стратегічне управління підприємством це орієнтована на майбутнє організаційна структура в межах концепції пристосованості підприємства до умов, що змінюються [5; 6]. Під організацією автор розуміє процес цілеспрямованої цілісної структуризації, а під організаційною структурою - різні типи і форми відносин між складовими елементами підприємства. Наприклад, відносини розподілу, що виникають через взаємозалежний розподіл задач, матеріальних і людських ресурсів при збиранні автомобілів, мають форму супідрядності, організаційна структура якої може бути подана лінійним типом.

У той же час організаційні принципи побудови підприємства визначаються його цілями і стратегією. Задача будь-якого підприємства полягає в досягненні цілей, для яких воно було створене. Ефективність вирішення такої задачі полягає в досягненні мети в конкретно обумовлені проміжки часу і при найменших витратах. Однак під впливом зміни споживчого попиту, високих темпів науково-технічного прогресу, збільшення масштабів і ускладнення виробництва, обмеженості ряду ресурсів і інших факторів може змінюватися характер і напрямки цілей, змінюються способи їх досягнення. Тому організаційні структури не тільки можуть змінюватися, але і повинні мати певну гнучкість і пристосованість. Разом з тим, розглянуті вище аспекти дозволяють формувати найбільш ефективні інвестиційні стратегії, пов'язані 3 розвитком підприємства, в умовах зміни зовнішнього і внутрішнього середовища, що сприяє вирішенню певних інвестиційних задач.

Інформаційний і організаційний аспекти дозволяють якнайкраще досягти погодженості інвестиційної стратегії підприємства із загальною стратегією його економічного розвитку. За рахунок додавання 3 урахуванням інституційного аспекту забезпечується внутрішня збалансованість інвестиційної стратегії. При цьому на основі економічної і нормативно-правової оцінки досліджується погодженість цілей, напрямків і етапів реалізації тих чи інших стратегій для різних напрямків діяльності підприємства. У процесі такої оцінки визначається, наскільки узгоджуються між собою окремі стратегічні цілі і напрямки інвестиційної діяльності, а також послідовність їхнього виконання. Взаємодія і взаємозв'язок інвестиційної стратегії з зовнішнім середо- 
вищем забезпечується нормативно-правовим аналізом на основі наявної інформації. При цьому також оці-нюється, наскільки розроблена інвестиційна стратегія відповідає прогнозова-ним змінам економічного розвитку й інвестиційного клімату країни, а також кон'юнктури інвестиційного ринку.

Поряд 3 цим найкраща реалізованість інвестиційної стратегії досягається за рахунок використання найбільш ефективної організаційної структури, що базується на урахуванні наявного ресурсного потенціалу підприємства. У процесі такої оцінки повинні бути проаналізовані потенційні можливості підприємства у формуванні фінансових ресурсів, оцінена кваліфікаційна підготовленість персоналу і технічна оснащеність підприємства 3 позицій задач реалізації інвестиційної стратегії. Також розглядається необхідність і можливість залучення до реалізації інвестиційної стратегії необхідних фінансових, технологічних, сировинних, енергетичних і інших ресурсів.

Розглянуті вище аспекти інвестиційної стратегії також дозволяють оцінити прийнятний рівень ризику, можливі фінансові наслідки результативності інвестиційних програм.

Таким чином, інвестиційна стратегія підприємства може бути подана у вигляді єдиної інтегрованої системи, що включає в себе економічний, інститу-ційний, нормативно-правовий, інформаційний і організаційний аспекти, що тісно пов'язані між собою критерієм досягнення головної мети підприємства. Слід також зазначити, що організаційний аспект зумовлює і напрямок руху інформаційних потоків між різними складовими елементами інвестиційної стратегії підприємства, що також впливає на ефективність формованої стратегії, яка формується, визначає тактику проведення інвестиційної діяльності.

При цьому вибір організаційної структури багато в чому визначається тими питаннями, які необхідно вирішити підприємству для досягнення поставлених інвестиційних задач і існуючих обмежень, що перешкоджають їх ефективному вирішенню. Однак, незважаючи на безліч проблем, які мають підприємства в процесі здійснення тих чи інших інвестиційних проектів, виділяють такі підходи, що лежать в основі визначення ефективної структури організації [7; 8]:

- орієнтація на вирішення конкретної інвестиційної задачі, що дозволяє в межах організаційного синтезу здійснювати розподіл окремих 


\section{Zhukov Vladlen}

підзадач інвестиційної діяльності по організаційних одиницях - ділянках, відділах, групах;

- орієнтація на особистість, де предметом дослідження стають елементи організаційних правил, пов'язаних з питаннями первинної мотивації, комунікацією, лідерством і ін.;

- орієнтація на інформаційну технологію, метою якої є своєчасне забезпечення достовірною інформацією всього процесу управління інвестиційною діяльністю.

Перераховані вище підходи є основою для побудови простих, як правило, лінійних організаційних структур. У лінійній структурі від кожного вищого керівника виходять вказівки підлеглим керівникам i виконавцям. Різновидом лінійних структур $є$ лінійно-штабна структура, що припускає автономне вирішення деяких задач під керівництвом загального центру. Недоліком лінійної організаційної структури $\epsilon$ тривалість у виконанні прийнятих рішень. Компенсувати ці недоліки допомагають багатолінійні (матричні) структури, у яких розподіл повноважень і прийняття рішень здійснюється у відповідності із специфікою рівнозначних спеціалізованих задач. Їх характерною рисою $є$ накладання на загальну вертикальну ієрархію деякої сукупності горизонтальних повноважень і комунікацій. У цілому матричні структури розподіляються таким чином:

- проектні - структури 3 динамічною горизонтальною системою супідрядності;

- продуктові, - горизонтальні системи управління виробництвом продукції передбачають створення матричних структур з «постійним положенням»;

- внутрішньофункціональні, - матричні механізми управління застосовуються на рівні окремих функцій і підрозділів.

Оскільки підприємство не може існувати поза складними і динамічними відносинами із зовнішнім середовищем, для вирішення задачі формування стратегії і тактики управління інвестиційною діяльністю необхідно розгляну-ти більш складні підходи, які застосовуються для визначення ефективної структури організації. Основу таких підходів складають уявлення про підприємство як про складну виробничу операційну систему, кінцевим продуктом стратегічного управління якої є внутрішня структура й організаційні зміни, що забезпечують чутливість підприємства до змін у зовнішньому середовищі. 


\section{Methodological basis of the formation of effective forms of investment...}

Таким чином, стратегічне управління інвестиційною діяльністю підпри-ємства спрямоване на забезпечення стратегічної позиції, що повинна забезпечити тривалу життєздатність підприємства в умовах, що змінюються. Отже, однією з задач при формуванні стратегії інвестиційної діяльності підприємства є виявлення необхідності проведення структурних стратегічних змін, створення ефективної організаційної форми реалізації інвестиційних задач.

Проведення всебічного аналізу організаційної структури для формування ефективної стратегії проведення інвестиційної діяльності можна здійснити з позицій концепції прийняття рішень. Ця концепція, основоположниками якої вважаються Р. Сайман, Д. Маргем і Р. Сайєрт, припускає, що в основі вивчення організаційних процесів повинно знаходитися «рішення» - акт цілеспрямованого вибору чи усунення деякої проблеми [7]. Однак для того щоб прийняти потрібне рішення, необхідно, як мінімум, знати вихідну (існуючу) структуру організації і ту структуру організації, що, з одного боку, визначається навкруги поставлених інвестиційних задач, а з іншого - здатна забезпечити виконання поставлених задач. Досягнення поставленої мети можливе за рахунок ситуаційного аналізу, за допомогою якого на основі порівняльних емпіричних даних дається опис впливу факторів зовнішнього середовища і підприємства на окремі параметри структури організації.

Як показує, проведений аналіз ряду теоретичних робіт в галузі організаційних структур $[1 ; 4 ; 5 ; 6 ; 8 ; 9 ; 10 ; 11]$, за основні параметри, з допомогою яких, на думку автора, може бути проведений аналіз організаційної структури вирішення задачі формування стратегії управління інвестиційною діяльністю підприємства (принаймні для існуючих умов господарювання), необхідно вибрати:

- ступінь забезпеченості підприємства фінансовими ресурсами для вирішення поставлених інвестиційних задач;

- ступінь інноваційної результативності інвестиційних задач підприємства, що припускає, у першу чергу, рівень створеної продукції і можливість їі конкурентоспроможності;

- тимчасову тривалість інвестиційного проекту;

- загальний ризик виконання інвестиційного рішення;

- вид орієнтації інвестиційного рішення - кадрова, об'єктна й інформаційна; 


\section{Zhukov Vladlen}

- нормативно-правову забезпеченість прийнятих інвестиційних рішень;

- рівень прийняття і реалізації управлінських рішень.

Проте застосування ситуаційного підходу для вирішення задачі форму-вання стратегії управління інвестиційною діяльністю утруднене тим, що вплив окремих параметрів на вибір визначеної організаційної структури не завжди можна оцінити однозначно.

\section{3. Системні підходи для визначення структури організації}

Для вирішення такої задачі, як правило, використовують системні підходи для визначення структури організації [7; 12], у рамках яких підприємство і зовнішнє середовище, в якому воно функціонує, розглядають як єдине ціле. Поряд з цим підприємство в цих підходах подається як мережа вирішальних центрів, пов'язаних між собою і 3 зовнішнім середовищем комунікаційними каналами (відділ збуту підприємства - потенційні покупці; плановий відділ, бухгалтерія, податкові служби, відділ роботи з інвесторами і кредиторами і та інші). При такому підході структура організації орієнтована на процес прийняття рішень, мотивацію і контроль.

Разом $з$ тим системний підхід заснований на тому, що в організаційних системах поведінка будь-якої частини врешті-решт впливає на всі інші частини. Однак не усі впливи істотні, частину з них неможливо знайти. Тому за одиниці виміру, що характеризують зміну розглянутих вище параметрів, доцільно використовувати так звані «лінгвістичні» змінні, котрі описують якісні сторони обраних параметрів. Якісна характеристика параметрів, запропонована автором, подана в табл. 1. Переваги такого підходу полягають у тому, що система поданих показників і їх характеристик є відкритою і може бути доповнена і змінена як у розрізі розв'язуваної інвестиційної задачі, так і з урахуванням тимчасового фактора (система показників і їх характеристик з часом може видозмінюватися).

Наочне відображення існуючої організаційної структури (відбиваються ті умови, що склалися на підприємстві в момент проведення відповідного аналізу) і необхідної організаційної структури для досягнення поставлених інвестиційних задач можна уявляти за допомогою пелюсткової діаграми, де на кожній осі розташовані якісні характеристики розглянутих параметрів. Така діаграма в загальному вигляді являє собою формальний опис організаційної структури підприємства і вказує ступінь 
відповідності між існуючими і необхідними умовами формування визначеної інвестиційної стратегії підприємства.

На рис. 2 подано діаграму, яка відображає існуючу і необхідну організаційну структуру для ефективного управління інвестиційною діяльністю, що спрямована на виробництво нових видів товарів на підприємстві. Тут осі 1, 2, ., 7 відповідають параметрам проведення аналізу організаційної структури підприємства, що подані в табл. 1. Кожна 3 осей має мітки 1, 2, 3, які відбивають якісні характеристики кожного 3 параметрів. Наприклад, вісь 1 відповідає забезпеченості підприємства фінансовими ресурсами. Мітки по цій осі означають 1 - незадовільна забезпеченість, 2 - задовільна забезпеченість, 3 - достатнє забезпечення (див. табл. 1).

За основу були обрані узагальнені результати опитування керівників різних рівнів. Вид опитувальних листків подано у табл. 2. Опитування проводилося відповідно до якісних характеристик параметрів, поданих у табл. 1 різних рівнів підприємства.

Основними напрямками, необхідними для досягнення бажаних результатів у сфері виробництва нових видів техніки у підприємства, є:

- достатня забезпеченість підприємства фінансовими ресурсами;

- автономна система управління орієнтована на прийняття самостійних рішень.

Виходячи $з$ аналізу рис. 2, можна припустити, що при формуванні стратегії управління інвестиційною діяльністю підприємства основну увагу варто приділити удосконаленню організаційної структури управління і прийняттю оперативних рішень на рівні окремих підрозділів за рахунок надання їм деякої самостійності, а також удосконаленню тактики управління залученням фінансових ресурсів. Разом 3 тим, як було зазначено вище, найкраща результативність інвестиційних рішень досягається за рахунок використання найбільш ефективної організаційної структури. Тому, далі необхідно докладніше зупинитись на вирішенні першого питання.

Як було зазначено вище, найкращим підходом у формуванні організаційної структури підприємства, необхідним для здійснення інвестиційної діяльності, є системний підхід. У той же час найбільш ефективною формою організаційної структури управління є матрична модель, за допомогою якої, зокрема, і можна організувати автономну систему управління, орієнтовану на прийняття самостійних рішень. Вибір 


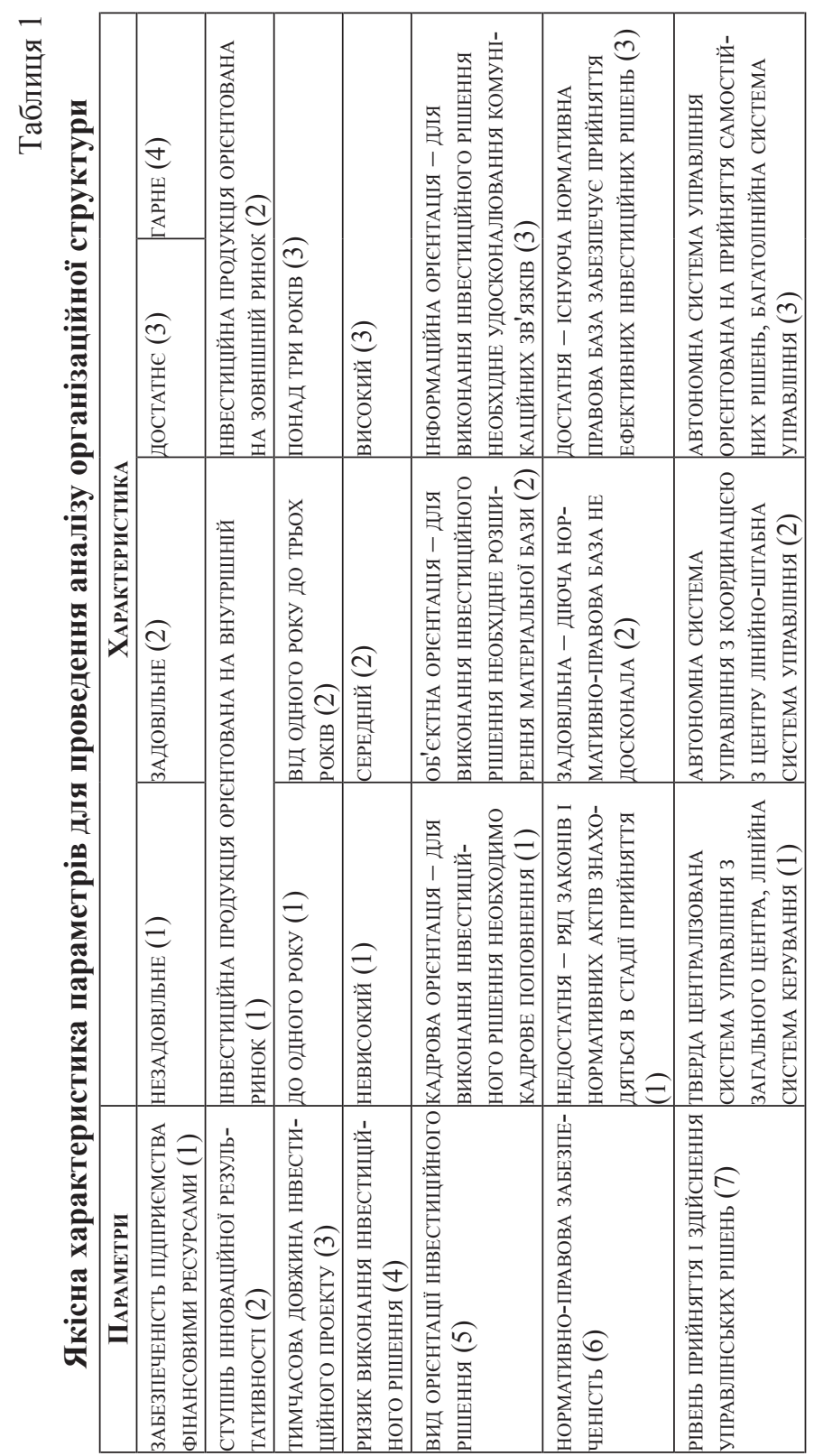


Таблиця 2

Опитувальний лист для побудови формального опису існуючої і необхідної організаційної структури підприємства для реалізації інвестиційних рішень, спрямованих на виробництво нових видів сільськогосподарської техніки

\begin{tabular}{|l|l|}
\hline \multicolumn{1}{|c|}{ Параметри опитування } & \multicolumn{1}{|c|}{$\begin{array}{c}\text { Характеристика } \\
\text { (існуюча/необхідна) }\end{array}$} \\
\hline $\begin{array}{l}\text { Яка, на вашу думку, забезпеченість підприємства } \\
\text { фінансовими ресурсами. Варіанти відповідей 1-4 } \\
\text { згідно з табл. 1. }\end{array}$ & Незадовільне/Достатнє \\
\hline $\begin{array}{l}\text { Основні ринки, для яких призначена інвести- } \\
\text { ційна продукція. Варіанти відповідей 1-2 згідно } \\
\text { з табл. } 1 .\end{array}$ & $\begin{array}{l}\text { Внутрішній ринок/ } \\
\text { Внутрішній ринок }\end{array}$ \\
\hline $\begin{array}{l}\text { Яким має бути період освосння інвестиційної про-- } \\
\text { дукції. Варіанти відповідей 1-3 згідно з табл. 1. }\end{array}$ & $\begin{array}{l}\text { Від одного до трьох років/ } \\
\text { Від одного до трьох років }\end{array}$ \\
\hline $\begin{array}{l}\text { Який ризик не виконання інвестиційних рішень. } \\
\text { Варіанти відповідей 1-3 згідно з табл. 1. }\end{array}$ & Середній/Середній \\
\hline $\begin{array}{l}\text { Які головні умови (крім фінансових), необхідні } \\
\text { для виконання інвестиційних рішень. Варіанти } \\
\text { відповідей 1-3 згідно з табл. 1. }\end{array}$ & $\begin{array}{l}\text { Необхідно кадрове поповнення/ } \\
\text { Необхідно кадрове поповнення }\end{array}$ \\
\hline $\begin{array}{l}\text { Яка нормативно-правова забезпеченість ефектив- } \\
\text { ного виконання інвестиційних рішень. Варіанти } \\
\text { відповідей 1-3 згідно з табл. 1. }\end{array}$ & Задовільне/Задовільне \\
\hline $\begin{array}{l}\text { Який рівень прийняття і виконання управлін- } \\
\text { ських рішень. Варіанти відповідей 1-3 } \\
\text { згідно з табл. 1. }\end{array}$ & 2/3 \\
\hline
\end{tabular}

матричної організаційної структури управління також обумовлений таким:

по-перше, існуючі умови господарювання визначили дуже високі вимоги в цілому до системи управління підприємством, що виявляється в необхідності вирішення цілого комплексу взаємозалежних задач;

по-друге, цілий ряд задач у сфері управління інвестиційною діяльністю має рівнозначне значення. Це і формування необхідної структури фінансового забезпечення інвестиційної діяльності, і організація виробництва готової про-дукції з найменшими витратами й успішною реалізацією виробленої про-дукції;

по-третє, підвищенням інформаційного перенавантаження простих систем управління і значимістю інформаційної складової в системі управління інвестиційною діяльністю; 

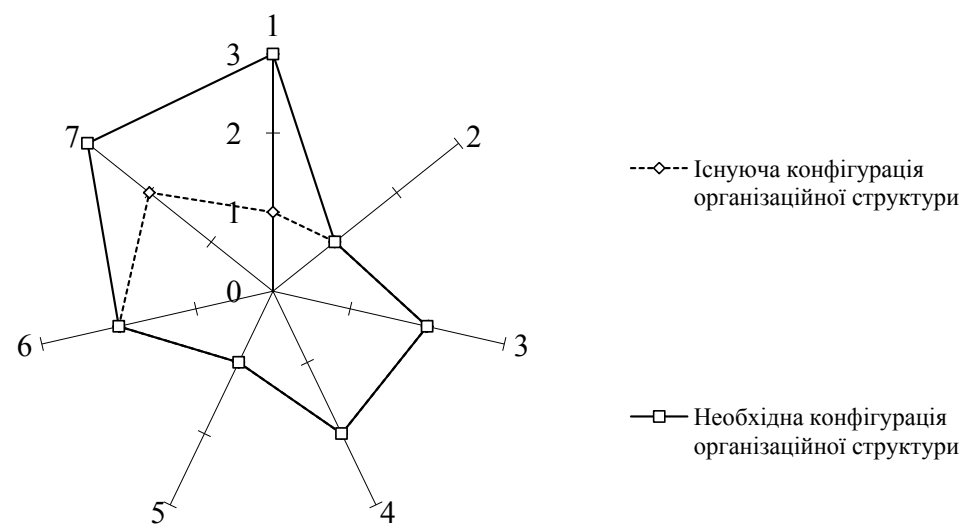

$\longrightarrow$ - Необхідна конфігурація організаційної структури

\section{Рис. 2. Формальний опис організаційної структури підприємства}

по-четверте, матрична організаційна структура системи управління голо-вним чином лише змінює повноваження і відповідальність існуючих служб і підрозділів, а не породжує істотно нових підрозділів.

На рис. 3 подано матричну організаційну структуру системи управління інвестиційною діяльністю підприємства, що розроблена автором і запропонована для впровадження на підприємстві. Виходячи 3 основних напрямків, необхідних для успішної реалізації інвестиційної діяльності в сфері виробництва нових видів техніки, у складі окремих структурних одиниць виділені такі відділи:

- відділ по роботі з науковими організаціями, що сприяе активізації роботи конструкторського відділу, систематизації існуючих розробок у сфері виробництва нових видів сільськогосподарської техніки; мінімізації витрат на придбання ліцензій на використання винаходів, прав на патенти, послуг технологічного змісту тощо, що загалом повинно сприяти більш раціональному використанню фінансових ресурсів;

- відділ по роботі з кредиторами й інвесторами, необхідний для безпосереднього забезпечення інвестиційної діяльності підприємства необхідним обсягом фінансових коштів, вирішення ряду оперативних питань, що виникають у процесі реалізації тактичних задач фінансового забезпечення інвестиційної дія-льності підприємства; 


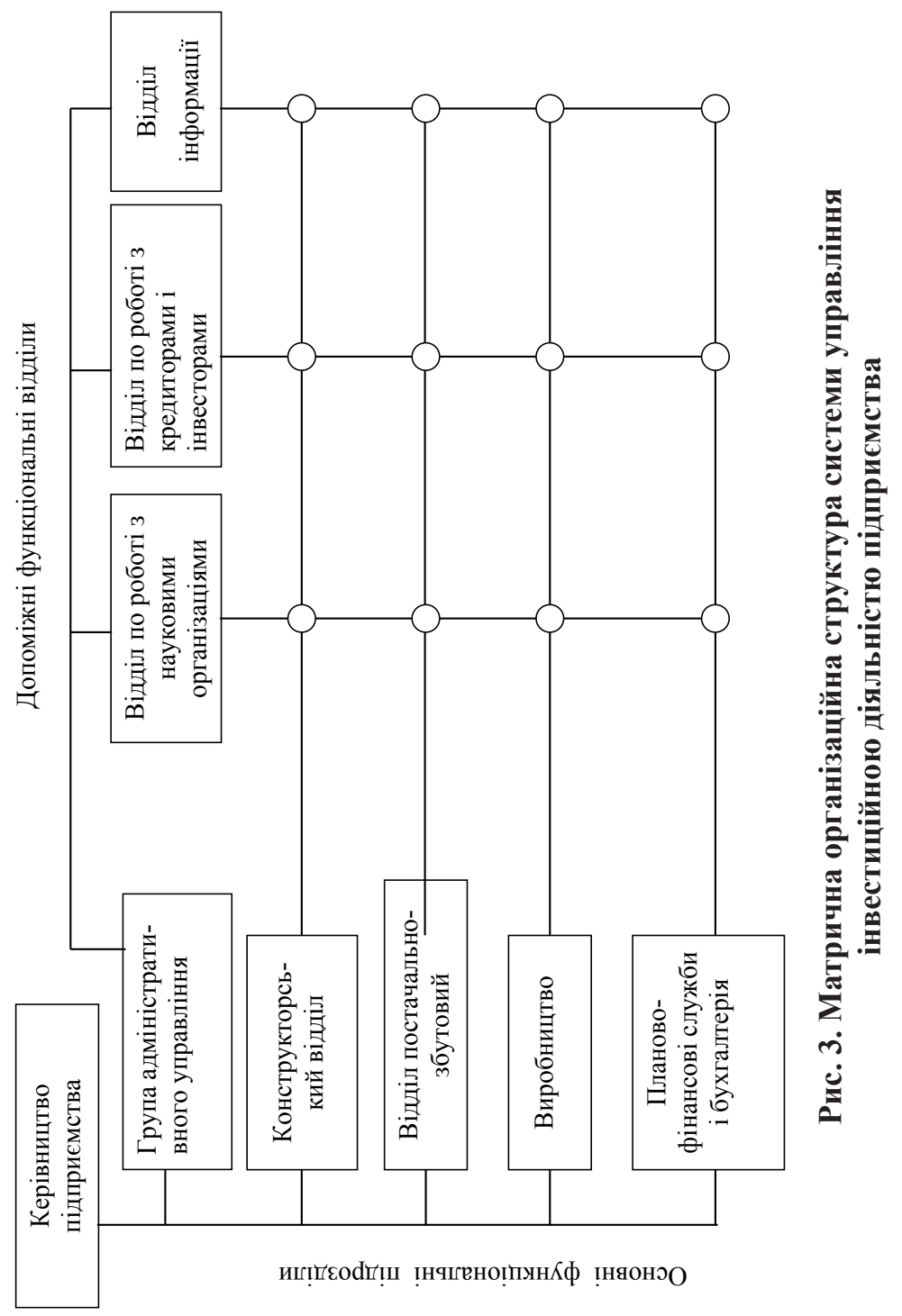




\section{Zhukov Vladlen}

- відділ інформації, що забезпечує удосконалення системи управління інвестиційною діяльністю підприємства на етапах забезпе-чення виробництва матеріальними ресурсами і реалізації готової продукції, систематизації різних джерел даних про ринки сировини і збуту готової продукції, конкурентах; всебічного аналізу маркетингової інформації.

Особливості даної структури полягають у такому:

- стратегічне управління інвестиційною діяльністю підприємства здійснює генеральний директор підприємства і його заступники;

- управління на тактичному рівні здійснює адміністративна група, до складу якої входять керівники основних підрозділів;

- оперативне управління здійснюється за допомогою допоміжних функціональних відділів, що безпосередньо підпорядковуються групі адміністративного управління.

За рахунок такого структурування, сполучення різних рівнів управління (стратегічного, тактичного й оперативного) досягаються:

- найкраща мобільність і автономність управління інвестиційною діяльністю;

- ефективне і раціональне використання інвестиційного потенціалу підприємства;

- збалансованість у прийнятті і реалізації управлінських рішень;

- ширше охоплення й урахування різних факторів, що впливають на інвестиційну стратегію підприємства при розробці конкретних управлінських рішень;

- оперативна гнучкість у реагуванні на зміну зовнішніх і внутрішніх факторів ринкової кон'юнктури;

- найбільш послідовний перехід до ринкової стратегії управління інвестиційною діяльністю пов'язаний $з$ перебудовою всієї системи розподілу ресурсів і внутрішньофірмового планування.

\section{4. Висновки}

Інвестиційна стратегія підприємства є структурованою сукупністю декількох аспектів, і в першу чергу таких, як економічний, інституційний, нормативно-правовий, інформаційний, організаційний. Ці аспекти є взаємозалежними, їхнє структурування і розподіл пріоритетів між ними дозволяють мати чітке уявлення про розробку і реалізацію інвестиційної стратегії підприємства. 
Однією із задач при формуванні стратегії інвестиційної діяльності підприємства є виявлення необхідності проведення структурних стра-тегічних змін, створення ефективної організаційної форми реалізації інвестиційних задач. У той же час кращим підходом до формування організаційної структури підприємства, необхідної для здійснення інвестиційної діяльності, є системний підхід.

Формування стратегії управління інвестиційною діяльністю не-розривно пов'язане з ефективним використанням інвестиційних ресурсів. При цьому ресурсний потенціал інвестиційної діяльності підприємства багато в чому визначається як наявністю різних фінансових джерел, необхідних для формування інвестиційних ресурсів, так і здатністю підприємства ефективно і раціонально використовувати кожне із джерел.

\section{Список літератури:}

1. Ansoff I. Implanting Strategy Management / I. Ansoff - Englewood Cliffs. 1984. $-516 \mathrm{p}$.

2. Путятин Ю. А. Финансовые механизмы стратегического управления развитием предприятия / Ю.А. Путятин, А.И. Пушкарь, А.Н. Тридед Харьков: Основа, 1999. -488 с.

3. Ковалев В.В. Финансовый анализ: Управление капиталом. Выбор инвестиций. Анализ отчетности / В.В. Ковалев - М.: Финансы и статистика, 1996. $-432 \mathrm{c}$.

4. Bleicher Knut. Organisation - Strukturen / K. Bleicher - Kulturen -Wies baden. $-1991 .-487 \mathrm{p}$.

5. Виханский О.С. Стратегическое управление / О.С. Виханский - М.: Изд. МГУ. $-1995 .-360$ с.

6. Пономаренко В.С. Стратегічне управління підприємством / В.С. Пономаренко - Х.: Основа, 1999. - 620 с.

7. Беа Ф. Экономика предприятия / Ф. Беа, Э. Дихтла, М. Швайцера - М.: ИНФРА-М. - 1999. - 928 с.

8. Оучи У. Методы организации производства (японский и американский подходы) / У. Оучи - М. - Экономика. - 1984. - 316 с.

9. Забродский В.А. Современные методы организации и управления промышленным производством / В.А Забродский, Н.А Кизим, Л.И. Янов Харьков: Бизнес-Информ. - 1997. - 64 с.

10. Овсиевич Б.Л. Модели формирования организационных структур / Б.Л. Овсиевич - М.: - Наука. - 1979. - 178 с.

11. Евенко Л.И. Организационные структуры управления промышленными корпорациями США / Л.И. Евенко - М.: Наука. - 1983. - 352 с.

12. Фатхутдинов Р.А. Стратегический менеджмент / Р.А. Фатхутдинов Москва: 3АО «Бизнес-школа «Интел-Синтез». - 1998. - 416 с. 


\section{Zhukov Vladlen}

\section{References:}

1. Ansoff I. (1984) Implanting Strategy Management - Englewood Cliffs.

2. Putyatin Yu.A., Pushkar A.I., Trided A.N. (1999) Finansovye mekhanizmy strategicheskogo upravleniya razvitiem predpriyatiya [Financial arrangements for the strategic management of development of the enterprise]. - Kharkov: Osnova. (in Ukrainian)

3. Kovalev V.V. (1996) Finansovyy analiz: Upravlenie kapitalom. Vybor inve-stitsiy. Analiz otchetnosti [Financial analysis: asset management. Choice of investments. Analysis reporting]. - Moscow: Finansy i statistika. (in Russian)

4. Bleicher Knut (1991) Organisation - Strukturen - Kulturen -Wies - baden.

5. Vikhanskiy O.S. (1995) Strategicheskoe upravlenie [Strategic management]. - Moscow: Izd. MGU. (in Russian)

6. Ponomarenko V.S. (1999) Strategichne upravlinnya pidpricmstvom [Strategic enterprise management]. - Kharkov: Osnova. (in Ukrainian)

7. Bea F., E. Dikhtla, M. Shvaytsera (1999) Ekonomika predpriyatiya [Economics of enterprise]. - Moscow: INFRA-M. (in Russian)

8. Ouchi U. (1984) Metody organizatsii proizvodstva (yaponskiy $i$ amerikanskiy podkhody [Methods of organizing production (japanese and american approaches)]. - Moscow: Ekonomika. (in Russian)

9. Zabrodskiy V.A., Kizim N.A, Yanov L.I. (1997) Sovremennye metody organizatsii $i$ upravleniya promyshlennym proizvodstvom [Modern methods of organization and control of industrial production]. - Kharkov: Biznes-Inform. (in Ukrainian)

10. Ovsievich B.L. (1979) Modeli formirovaniya organizatsionnykh struktur [Models of formation of organizational structures]. - Moscow: - Nauka. (in Russian)

11. Evenko L.I. (1983) Organizatsionnye struktury upravleniya promyshlennymi korporatsiyami SShA [Organizational management structure of industrial corporations United States]. - Moscow: Nauka. (in Russian)

12. Fatkhutdinov R.A. (1998) Strategicheskiy menedzhment [Strategic management]. - Moscow: ZAO «Biznes-shkola «Intel-Sintez». (in Russian) 


\section{INVESTMENT COOPERATION \\ THROUGH DIGITAL DEVELOPMENT}

\section{Kornieieva Iuliia ${ }^{1}$}

DOI: http://dx.doi.org/10.30525/978-9934-571-28-2_14

Abstract. The article analyses new investment opportunities created by digitalization for the development of cooperation between public and private sector. The influence of modern digital transformations of the world economic system on the directions and volumes of investment flows is investigated. The possibilities that create digital technologies in terms of attracting investment and realization of investment projects are analyzed. The increasing concentration of global investment models, which leads to the "digital gap" in global investments, is emphasized. The dynamics and directions of investments to the development of financial technologies are analyzed. The article outlines the role of the state in the context of the formation of a conducive to the development of the digital economy institutional environment. The author identified obstacles to the formation of a digital development model and underline difficulties in the process of digitalization of the state sector of the economy. The importance of using modern digital technologies in overcoming information asymmetry, increasing transparency of decision-making processes by state institutions and in the context of attracting investments is emphasized. Open information data bases are analysed as a mechanism for ensuring transparency of decision-making process by government institutions, which helps to improve the investment climate. It is noted that digital channels create opportunities for the establishment of cooperation between state-owned companies and private investors, while financial mechanisms allow the incorporation of private capital into investment projects. The importance of introducing an appropriate state investment policy considering avoidance of the negative impact of investment activity on the socio-economic life in the country is emphasized. The importance of the investment component in the implementation of digital development strategy under the scheme of "govern-

\footnotetext{
${ }^{1}$ Candidate of Economic Sciences, Doctoral Student, Academy of Financial Management, Ukraine

(C) Kornieieva Iuliia
} 
ment-to-government", "government-to-business", and "government-to-society" is emphasized. In order to improve the coordination of institutional transformations of the investment component of digital development in Ukraine, it is proposed to create a specialized coordinating institution the Council for the implementation of the investment component of the digital development strategy. In order to improve digital transformation of investment policy it is proposed to create the Innovation Platform for attracting productive investments, which will combine the foundations of the Crowdfunding platforms and Blockchain technologies and will work in accordance with the main principles of Sustainable Development.

\section{Introduction}

Nowadays rapid development and implementation of digital technologies radically changes certain economic processes. New financial instruments that arise as a result of the development of digital financial technologies create great opportunities for investors in the context of risk reduction and profitability growth. Digitalization creates unprecedented opportunities for the separation of the value chain and outsourcing services that go beyond the regulated administrative support. The role of the digital economy in investment processes is significant in the context of simplifying investment processes, and transaction costs reduction. The necessary for investment projects infrastructure is improved thanks to the use of the latest advanced digital technologies. The active development of digital platforms helps to reduce transaction costs and, at the same time, simplifies cross-border communications, enabling businesses to freely communicate with customers and suppliers in any country. Platforms promote the involvement of small companies in the international economic activity, so the minimum threshold size of the company required for global development is reduced nowadays if not generally disappeared. As a result, the benefits of globalization are not only used by large multinational corporations, as it used to be, but also by representatives of small and medium-sized businesses, which greatly enhances competition, stimulates investment in $R \& D$, and promotes the rapid implementation of innovative sustainable development [1, p. 11].

Current economic conditions favor investment in technology, as emerging markets increase their demand for technology to stimulate economic growth, and developed markets are looking for new ways to reduce costs and stimulate innovation. Experts agree that the 21 st century is a period 
of domination of the digital economy, when the industry is undergoing a digital transformation. The balance of power is also changing, the digital divide between developing countries and developed economies diminishes. Indeed, leading companies located in developing countries invest heavily in technology, often outperforming their partners in developed markets. Such technological companies are becoming extremely competitive in foreign markets (especially relevant for Asian countries), and in combination with aggressive marketing strategies, leave behind companies from developed countries.

The digital economy has a huge impact on the dynamics of investment flows, while investment is critical important for digital development. Investments in digital technologies contribute to rapid economic development. However, at the same time, the active development of the digital economy leads to fundamentally new challenges, against which we still haven't protective policy at national and supranational levels, and no protection instruments have been prescribed. The main challenge for Ukrainian government in the context of the formation of an investment policy of new generation is the development of such postulates and implementation of special tools that would correspond to the current digital development of the world economy.

\section{Investment challenges of digital transformation}

Digitalization of the world economy leads to structural changes in the international financial markets, which, in turn, requires the adaptation of investment policy to new conditions and challenges. Investment policy cannot remain invariant in the globalized dynamic world economic system. The United Nations Conference on Trade and Development (UNCTAD) experts note that today's rapidly changing digital environment creates new challenges for the system of state regulation of investment activity. Therefore, it is necessary to review the main principles of investment policy taking into account the current strategic and systemic challenges. Current Strategic challenges include preventing "overshooting" of reform, we can use the term overheated when the number of innovations negatively affects their quality, which results in the general strategy getting vague features. Multitasking in solving strategic challenges leads to the emergence of Systemic Challenges that arise due to gaps, duplications and fragmentation, which at the same time creates significant problems of coherence between the goals and instruments of the implementation of 
state investment policy. Coordination task (Coordination challenges) of investment agreements and projects require the identification of priority areas for reform, the search for the relevant partners, and ensuring coherence between efforts aimed at implementing reforms at different levels of investment policy formation [2, p. 13].

The digital transformations of the world economy stimulate, if not abrogation, that means the full abolition of out-dated norms, but at least derogation, that is, the partial abolition of existing regulatory investment rules; or obrogation, which involves making partial, minor changes to the current law; and subrogation - adding new amendments to existing laws that comply with the requirements of the digital economy.

Modern trends in the development of the digital economy are threatening the reduction of investment in the real sector. An example can be the active spread of cryptocurrencies that are not subject to government regulation, and, as experts admit, are often used in corruption schemes and money laundering. Leading world economists, such as Nobel laureates Joseph Stiglitz, Paul Krugman, the chairman and CEO of JPMorgan Chase Jamie Dimon, the founder of hedge fund Bridgewater Associates Ray Dalio, the chairman and CEO of BlackRock Larry Fink, openly opposed the cryptocurrencies in the press, describing them as a huge financial scam, "a soap bubble" and a major threat to potential investors around the world. The development and rapid spread of cryptocurrencies has led to the shift of huge amounts of capital from the real economy to the "virtual" one. Those funds that could be invested in modernization, expansion of production and development of innovation with increase in production capacity, actually go for the purchase of digital codes. Instead of investing in capital, investors invest in expectations. According to Coinmarketcap, the total market capitalization of crypto currencies was over 466 billion of USD on December 12, 2017; Bitcoin market capitalization - more than 285 billion USD. On December 14, 2017, total market capitalization reached 511 billion USD. On March 8, 2018, after significant fluctuations in the markets, the capitalization of cryptocurrencies amounted to over 398 billion USD, while Bitcoin's capitalization is over 166 billion USD. Such a dynamics only underlines the high riskiness of investments in these assets [3]. In fact, this is a waste of investment potential, a waste of public utility. Previously, such threats to world financial stability were created by financial derivatives markets, but there has never 
been such a rapid increase in the value of a particular asset and the rapid flow of capital from the real sector to the digital finance sector.

At the same time, the development of the digital economy creates significant prospects for overcoming the existing threats to global financial stability, which have an impact on the stability of public finances despite the insignificant level of integration of Ukraine's financial system into the global financial space.

UNCTAD offers the following components of the digital economy architecture: digital content, Internet platforms, the IT sector, telecommunications, digital solutions and e-commerce, that work closely together to develop and promote world economic digitalization processes [2, p. 181]. Current trends show that not only developed countries but also countries with emerging economies and developing countries, actively use digital technologies in areas such as e-commerce, agriculture, banking, etc $[4$, p. 23]. At the same time, analytical studies conducted by World Bank Group experts show that $42 \%$ of the world's population still do not have access to the formal financial system $[5$, p. 2]. This figure opens further prospects for the development of the digital economy, since access to the necessary financial services can be provided by modern technologies. Modern digital technologies are capable of solving such an urgent problem for Ukraine to provide banking services in areas with a low population, where maintenance of bank offices is unprofitable. This tendency changes the nature of investments that are directed not to capital assets such as buildings, computer equipment for workplaces to provide banking services in affiliates etc., but to the development of digital finance.

At the UNCTAD conference in Geneva held on June 7, 2017, it was noted that digital multinational enterprises, such as Internet platforms and firms engaged in e-commerce and digital information content, grow much faster than other multinationals. It is no longer possible to ignore the processes of digitalization of the world economy. During the period from 2010 to 2015 the number of high-tech corporations that use digital technologies in the UNCTAD top-100 largest corporations has more than been doubled. Over the relevant period, assets of these transnational corporations (TNCs) increased by $65 \%$, and their operating income increased by $30 \%$. At the same time, the role of digital multinational corporations for the development of the global economy, including Internet platforms, e-commerce companies and digital content firms, is growing, creating indirect, but pro- 
ductive, incentives for digital development [2, p. 13]. The average market capitalization of technological megacorporations is almost three times higher than that of other TNCs. At the end of 2015, 10 technological TNCs accounted for more than 26 percent of the total market capitalization of the UNCTAD top-100 TNCs. The United States technological MNEs from the UNCTAD top-100 in 2015 gained $62 \%$ of the total foreign earnings unremitted, which is almost three times higher than the share of other corporations from USA. At the same time, the concentration of global investment models is growing, as more than 60 of the 100 largest digital TNCs, according to UNCTAD, are companies from the United States of America, followed by the United Kingdom, Northern Ireland and Germany. Concentration is most pronounced among Internet platforms: 10 of the 11 largest digital multinational companies are based in the United States. And only 4 of the 100 largest digital companies are based in developing countries [2, p. 176-188].

Influence of technological innovations on the development of various sectors of the economy is uneven. Figure 1 depicts 10 industries that are most affected by digital technology.

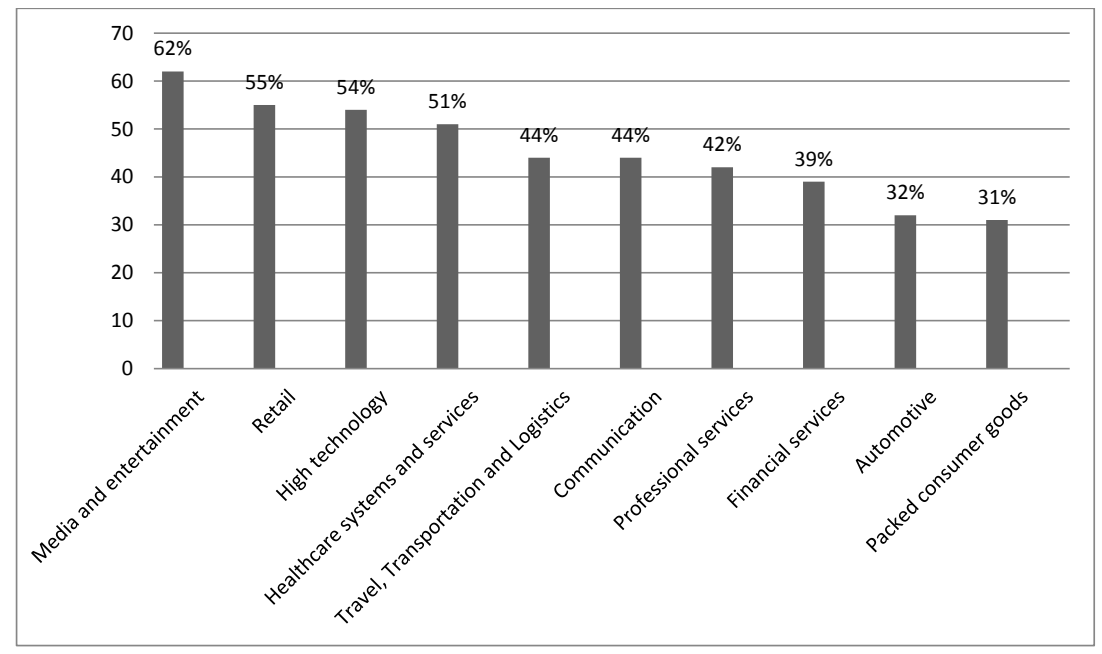

Fig. 1. The list of most-influenced by the development of digital technologies industries

Source: [6] 
Digital economy is a key factor for growth and development, as it can enhance competitiveness in all sectors, creating new opportunities for business and entrepreneurship, creating opportunities for access to foreign markets and participation in the global e-value chains [7, p. 13]. The use of modern digital technologies transforms the international operations of TNCs. Companies that are active-users of digital financial products can operate globally without significant physical investments in foreign markets, which has a significant impact on host countries. The analyses of statistical data confirm this statement, demonstrating the reduction for 11 percent up to 1 trillion USD of FDI outflow, mainly due to a drop in investment of European TNCs. In addition, if we analyze the 100 largest digital TNCs, only $13 \%$ of their affiliates are located in developing and transition countries; for comparison, for non-digital TNCs, this figure reaches a mark of $30 \%$ [2, p. 3]. High-tech corporations use a fundamentally different model of internationalization of their business, which has a significant impact on the direction and volume of investment. To enter external markets, such entities need to invest less in real assets and hire fewer employees. This reduces the economic impact on host countries in terms of physical investment and job creation. Such companies work almost completely in a virtual environment and characterized by limited physical connections to their markets. Tangible foreign assets in foreign markets are often confined to corporate offices and data centers. Purely digital TNCs, for example, Internet platforms or digital solution providers, show the biggest gap between foreign assets and foreign sales, a slightly smaller gap exists in digital TNCs operating on the basis of mixed models (digital content, e-commerce). The average share of foreign assets in digital companies among the top-100 UNCTAD corporations in 2015 is $41 \%$, while external sales account for $73 \%$. For the rest of TNCs, these figures are respectively $65 \%$ and $64 \%$, reflecting a certain balance between the invested resources and the profit received abroad. Only about $50 \%$ of the subsidiaries of digital multinational corporations are foreign affiliates, compared with almost $80 \%$ for other TNCs [2, p. 178-188]. New technologies have significantly accelerated business activity and influenced the speed of investment decisions. Companies are actively reorganizing to integrate into the digital economy, refusing from hierarchical decision-making system and moving to implementation of network structure that is market-driven in nature. The development strategies of traditional companies at an early stage were oriented on internal markets; instead modern start-up 
companies, especially from emerging markets, operate globally from the moment they were established, thanks to the large-scale digitalization of business activity [7, p. 3, 28-29].

According to UNCTAD, in 2017, the most attractive for investment is the IT sector, service sector and high-tech industries. [2, p. 22]. Global investment in companies operating in the sector of digital financial technologies (FinTech) are rapidly increasing over the past five years (2012-2017), only during 3 years from 2012 to 2015 their volume increased more than tenfold [8, p. 92-93]. In the 2nd quarter of 2017, the total investment in FinTech companies reached 8.4 billion of USD, and for the whole 2016 the amount of invested capital reached 23.5 billion of USD [9, p. 32, 44]. The analyses of geographical distribution shows that $40 \%$ of investments came from North America, 29\% from Europe, and the Asia-Pacific region accounted for $28 \%$ in 2016. In figure 2 it is possible to see the regions that are leaders in investments in the sphere of financial technologies in 2016.

The analysis of statistics over the 5 years from 2010 to 2014 during the period of active development of the financial technology sector shows

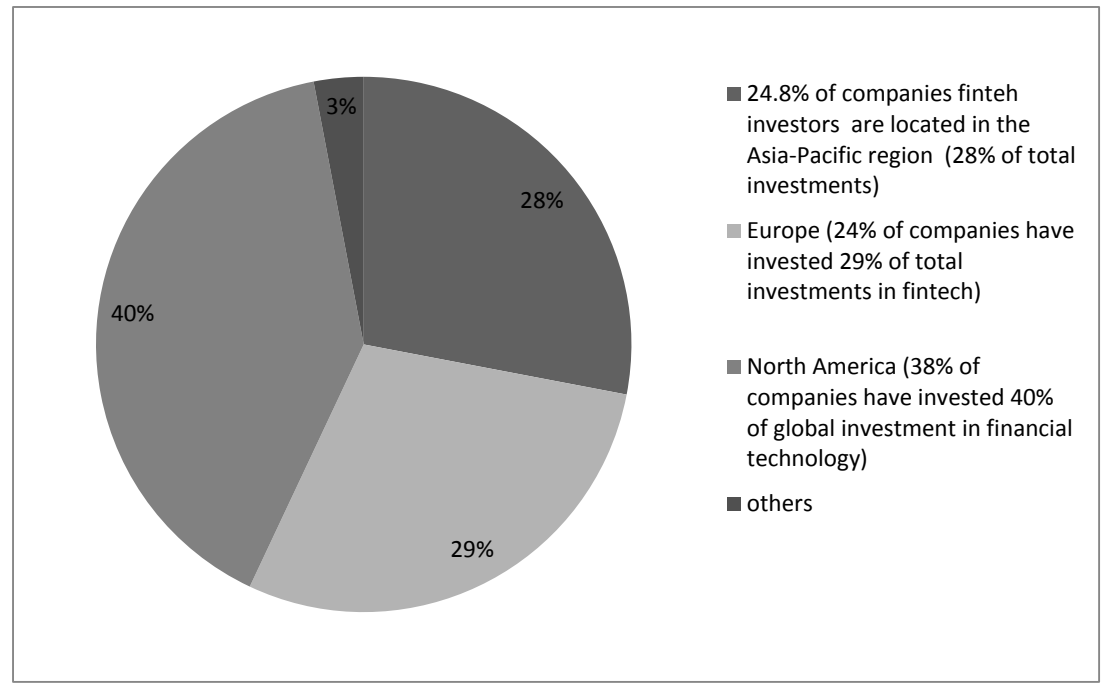

Fig. 2. Regional distribution of investors in financial technology in $\mathbf{2 0 1 6}$

Source: [5, p. 45-46] 
that North America accounted for $64.3 \%$ of total investments in financial technologies, Europe - 19.7\%, the Middle East - $1.8 \%$, Asian countries $13.3 \%$, Latin America - 0.3\%, Africa - 0.7\% [9, p. 103].

Figure 3 reflected regions which were the recipients of investment in the sector of financial technologies in 2016.

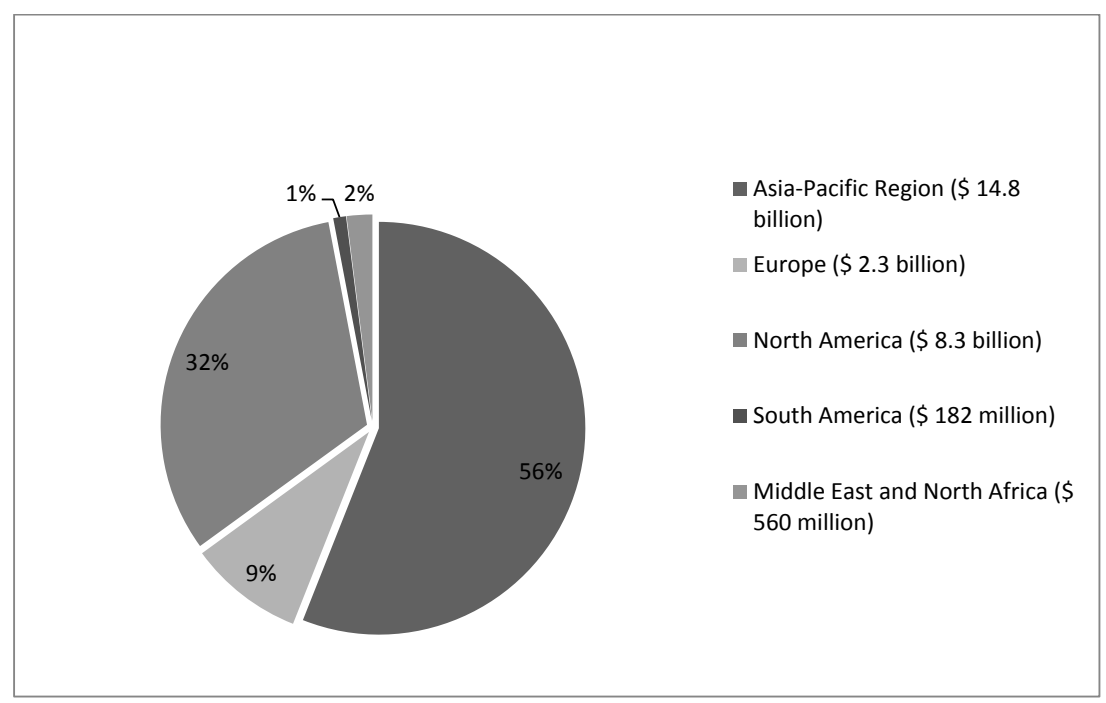

Fig. 3. Regional distribution of recipients of investment in financial technology in 2016

Source: [5, p. 45-46]

Modern financial technologies are capable of generating innovative tools for attracting financial resources, which is especially relevant for Ukraine in the context of finding alternative sources of funding. At the same time, a barrier to the development of financial technologies in Ukraine is the lack of private investment capital and venture capital, which is the basis for the growth of Finteh in advanced economies. Investments in the development of financial technologies are considered as the basis of the digitalization of economic activity.

\section{The impact of digital infrastructure on investment}

Finteh as defined by the Financial Stability Board, is a technology-based financial innovation that can lead to the creation of new business models, 
applications, processes or products that have a significant impact on financial markets and organizations, as well as for the provision of financial services and investment activities. Thus, it is a new industry, where modern technologies are used to improve the quality of financial services, which simplifies financial activity in general [8, p. 91-93].

Financial technologies cover an extremely wide range of tools and spheres that include: Cryptocurrency, E-money, Big Data Analytics, Consumer Finance, Banking Tech, E-banking, Enterprise Finance, Investment Tech, Remittance, Mobile Payments, Digital Wallets, Crowdfunding, InsurTech, Software for Institutional Investor, Robo-advisors, Cloud Computing, Supply-chain Management, Customer Relationship Management, Enterprise Resource Planning, E-sales, Online courses etc. [4, p. 30; 5, p. 33, 40; 9, p. 98]. All these technologies facilitate automation of operations in the field of insurance, banking, risk management, etc. Recently, significant innovations have been made to help financial institutions operate with large databases, which leads to cost reductions and can significantly improve operational efficiency. All these measures contribute to the innovative development of the back office of the company. Digital technologies help to improve the data analytics that is widely used by investors in making investment decisions under rapid changes on global markets. By 2020 , the total amount of digital information is expected to increase from 3.2 to 40 zettabytes. According to Moore's law, global data doubles every two years, while the cost of data storage decreases at about the same speed. In the sphere of infrastructure development of large databases actively involved more than 250 companies, whose total investments during the last 5 years (2012-2017) have reached 4.9 billion of USD. Among the most active investors are Data Collective, Accel, NEA, Intel Capita. More than 480 companies involved in the area of analysis of large databases have invested 5.78 billion of USD during 5 years (2012-2017). The most significant investors were In-Q-Tel, Accel Partners, Andreessen Horowitz, NEA, Intel [5, p. 23-28].

An important positive aspect of using modern financial technologies is the wide opportunity to increase transparency of operations, reduce corruption and lower risks. According to OECD experts, the use of Blockchain technology allows operations to be carried out without any trusted party, neglecting technical barriers and neutralizing political problems. In addition to supporting the exchange of information, this technology 
allows to keep cost-sharing protocols, legal contracts, etc. in public registries, which cannot be falsified and can be freely verified by interested parties. The combination of transparent transactions, rigid rules and ongoing oversight which are the characteristic for Blockchain based system, create opportunities for carrying transactions through the system without even involving a trusted authority or intermediary operator. The problems facing the implementation of this potential are the presence of certain regulatory obstacles. In particular, the question arises as to enforce the law in the absence of any intermediary and subsequently to bring legal liability for violations caused by non-fulfillment of contacts supported by systems based on Blockchain [4, p. 13].

In order to improve digital transformation of investment policy it is proposed to create the Innovation Platform for attracting productive investments, which will combine the foundations of the Crowdfunding platforms and Blockchain technologies and will work in accordance with the main principles of Sustainable Development. Improving public financial management system in terms of investment it is necessary to implement innovative mechanisms of the simplest and fastest ways to invest (the cryptocurrency experience), but in real projects, not digital codes that really create added value and generate public utility. Based on Blockchain technologies the platform working fully transparently will provide real opportunities for all investors to invest in real projects, even without the involvement of institutional intermediaries. Each investor will be able to make an online investment receiving not digital code and expectations, but a certain part of the company's profit. In addition to purely financial aspects, the proposed mechanism will carry out general social utility functions, since the emphasis will be on projects that are consistent with the ideas of sustainable development, which will enable to invest in a waste recycling plant, or wind power plants, etc. The functions of the state in implementing such an innovative project are significant. By launching the platform, the state acts as the guarantor of the reliability of the proposed mechanism.

The practical implementation of the digital transformation of investment policy requires the creation of appropriate institutional conditions that will allow taking advantage from the benefits of digital development. The advantages of digital development, which have a significant impact on investment activities, include the emergence of new financial instruments and channels of financial services, the growth of transaction speed, reducing of transac- 


\section{Kornieieva Iuliia}

tion costs, information asymmetry overcoming, etc. In this context, it is important to ensure the gradual transformation of the system of investment management regulation to the requirements of the digital economy; and to promote the development of an appropriate infrastructure covering important for investing the digital and financial segments.

The mechanism of interaction of some institutional infrastructure elements of the digital economy's investment segment is shown at Figure 4 with accent on public investments. The investment management system in the public sector covers both investment attraction and management of investment projects. The digital infrastructure has a significant impact on the process of investment projects selection in public sector or the choice of potential investors for state-owned enterprises (SOEs), depending on the requirements of state investment strategy to be implemented. Digital channels allow the rapid involvement of a wide range of independent experts to overcome ambiguity in selecting investment projects or potential investors. Open platforms will increase the transparency of the decision-making system, which will increase the confidence of investors and society. Digital communication channels create possibilities for fast connection between participants of investment processes, Data Centers contribute to overcoming information asymmetry. All these factors contribute to reducing the corruption component in the decision-making process and during the implementation of investment projects, as well as significantly improve the investment climate.

The scheme reflects the recombination of the financial and digital infrastructure of the investment segment of the digital economy. Financial infrastructure has a significant impact on the practical realization of selected investment projects through a financial mechanism. Digital channels provide opportunities for cooperation between SOEs and private investors, while financial mechanisms allow implementing the incorporation of private capital into investment projects.

Therefore, financial and digital infrastructure segments operate as a single coherent mechanism through recombination of their elements, creating a favorable environment for responsible investment. We consider public investment as "responsible" investments in the context of implementation of the strategy of sustainable economic growth. The category "sustainable economic growth" is the progress of the economic system, which allows maintaining a certain level and quality of life of the popu- 

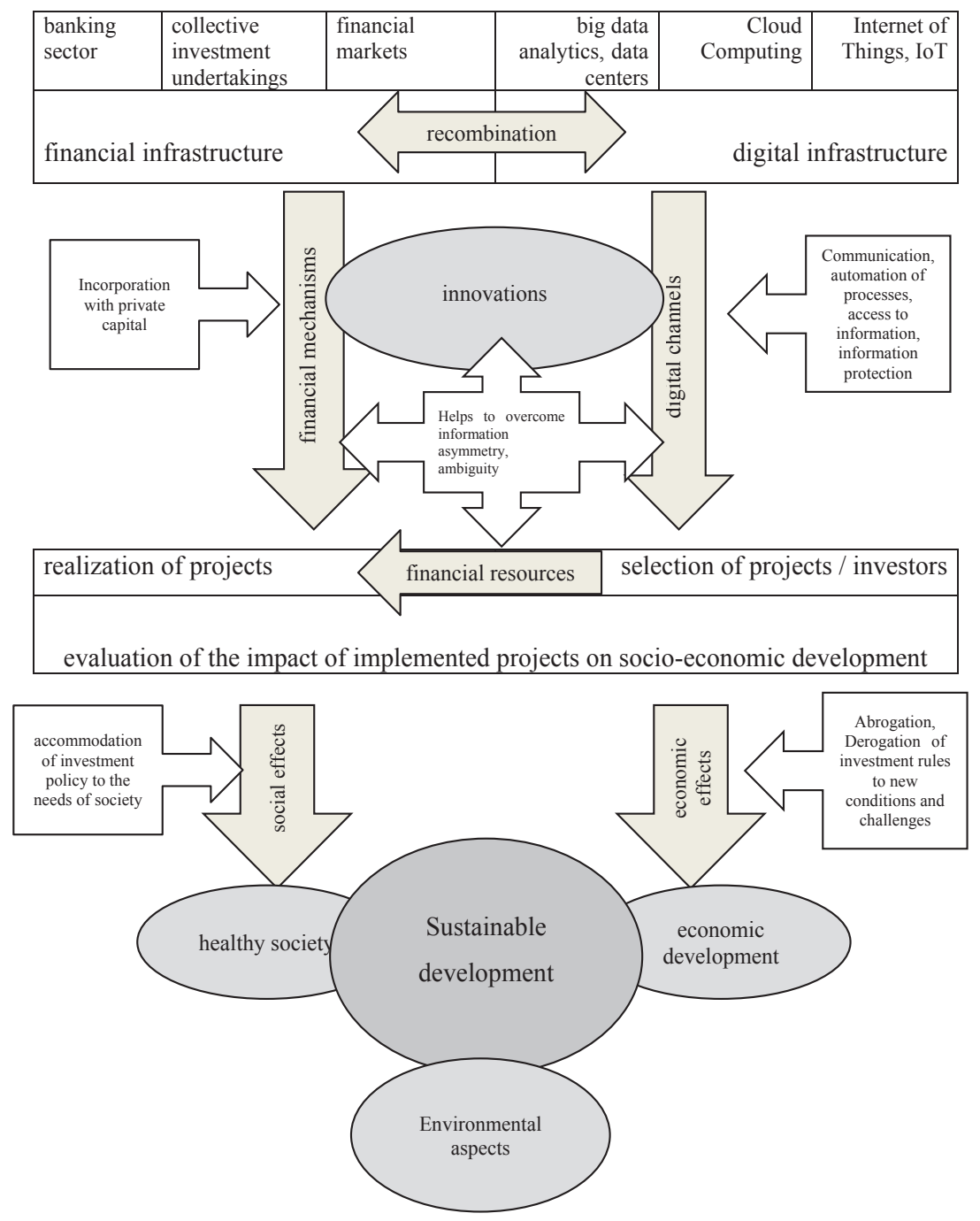

Fig. 4. Mechanism of interaction of elements of the institutional infrastructure of the investment segment of the digital economy

Source: developed by the author 
lation in the long-term, where qualitative and quantitative characteristics are provided on the basis of the balance of environmental safety of production and economic efficiency. It should be noted that the pursuit of the ideas of sustainable economic growth implies an organic combination of sociologization, commercialization and environmentalization of investment activity. Mechanism of interaction of elements of the institutional infrastructure of the investment segment of the digital economy allows realizing this strategy in the long-run.

Creation of new development models aimed at stimulating investment, based on the innovative technological solutions is a prerequisite for sustainable economic growth, in order to move to the economy of the 6th waves of innovation.

\section{State support of the investment digital development}

The challenges faced by governments in developing the digital economy are, first of all, the lack of knowledge about the peculiarities of the practical implementation of the digital development strategy. This problem exists due to the lack of the necessary skills needed for work with modern digital technologies. The latest research of digital strategies of 35 OECD member countries shows, that the development of the state digital strategy is assigned to a ministry or official body that are not able to provide professional solution due to the lack of necessary specialists who are knowledgeable in digital technologies [4, p. 37]. The practical implementation of the digital development strategy requires the presence of highly skilled professionals in the field of digital technologies.

Another serious problem of implementing institutional changes in the investment component of the digital development strategy is the lack of effective system for coordinating its implementation at all levels - governments, industries, regions, enterprises, etc. It should be noted that the problem of coordinating digital development is also typical for developed countries. Non-professional ministries deal with digital development issues in the 15 of the 35 OECD countries for which analysis was conducted; only 8 countries have set up a specialized government institution to develop and implement an appropriate strategy; in 6 countries several ministries and government agencies are directly concerned with the development of a digital strategy, without effective coordination of actions. Only four countries - Austria, Luxembourg, Mexico and the Slovak Republic - have 
been appointed high-level officials from the Presidential Administration, the Office of the Prime Minister or profile ministries, which coordinates all activities aimed at implementing the national digital development strategy. However, it should be noted that almost all sample countries actively involve private sector and specialized government agencies in developing a national digital strategy [4, p. 37]. Therefore, for the effective implementation of the state digital development strategy, it is extremely important to ensure reliable coordination of the work of various departments and institutions. In Ukraine, these functions are performed by the State Agency for E-Governance of Ukraine; the provisions of its activity were approved by the Resolution of the Cabinet of Ministers of Ukraine No. 492 dated October 1, 2014. According to the approved regulations, the Agency is a central executive body whose activities are coordinated by the Cabinet of Ministers of Ukraine and which implements state policy in the fields of informatization, e-government, the formation and use of national electronic information resources, and the development of the information society [10]. The Agency pays great attention to the challenges of promoting digital technologies in the public sector, modernizing of public services (e-services, e-identification, open data) and modernizing of public administration (electronic interactions of registries, electronic documents, e-governance by basic industries). The Cabinet of Ministers coordinates the activity of the Agency, however, the Regulation does not clearly specify the officials responsible for such activities. Therefore, the problem of coordinating the work of state institutions of different levels in the context of implementing the strategy of digital development is typical for Ukraine and requires further elaboration.

The Agency also participates in the organization of training and prepares proposals for improving the system of training and retraining of experts in the field of informatization and e-governance. In order to improve the implementation of this function, it is important to involve representatives of the Ministry of Social Policy and the Ministry of Education and Science, as well as leading experts in the field of digital technologies, into the work of the Agency. Such cooperation can allow the development of a permanent system of professional development of employees of state institutions and state companies involved in the practical implementation of the strategy of digital development, and also create preconditions for the adaptation of certain points of the strategy to the existing socio-economic realities. The 
system will require the development of appropriate training techniques, the creation of several training programs focused on various sectors of the economy, with emphasis on mastering various digital technologies, as well as the formation of clear schedules for retraining.

For the development of the digital economy, it is necessary to attract significant amounts of investment resources. In this context it is relevant to create a specialized coordinating institution - the Council for the implementation of the investment component of the digital development strategy, which will include representatives of the Ministry of Economic Development and Trade of Ukraine and the Ministry of Finance, as well as specialists in the field of IT and advanced digital technologies for joint coordination and implementation of the strategy. The creation of separate departments that deal with digital development in the above-mentioned ministries will complicate the process of coordinating joint efforts. At the same time, joint work of specialists on one platform would allow quick identification of priority sectors for financing (Ministry of Economic Development and Trade), implement effective financing mechanisms and choose effective instruments (Ministry of Finance), and involve to the process private investors and international donors if required. Such cooperation would significantly contribute to the rapid and effective implementation of investment projects.

In terms of lack of financial resources, it is important to promote the development of infrastructure conducive to attracting private capital. In order to stimulate investment activity in the context of the transition to the innovative digital development model, it is proposed to introduce state support for the development of specialized institutions for promoting investment to digital conversion. The successful examples of such institutional reforms are the development of specialized institutions such as incubators and accelerators. Due to the government support the access to finance in the early stages of development can be facilitated for new companies, so in this context it is important to create appropriate state-supported platforms that, through state guarantees, will foster the attraction of private investors' capital to innovative projects. The project selection principle will be based on a detailed analysis of the social utility, on the possible benefits in the field of digital technologies, which can simplify the system of data storage and processing for government institutions, which can promote the introduction of electronic document circulation, the development of online licensing systems, and allow to develop investment programs based on crowdfunding 
financing in the public sector. The factors that influence the formation of the digital and financial infrastructure necessary for the successful implementation of the state strategy of digital development are shown in Fig. 5

- compliance of the current legislation to the conditions of modern digital development

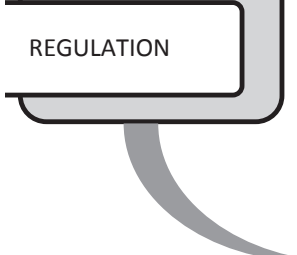

\section{STIMULATION}

- affiliate programs with private capital in the field of telecommunications infrastructure development

-e-governance

- support the development of specialized institutions of assistance

- advanced training system

- public investment in innovative technologies of the digital economy
- information and communication system for the exchange of information between government agencies and the private sector on the basis of on-line systems

- ensuring the connection of Databases between different government institutions

- coordination of the implementation of the strategy of digital development at different levels

- technological adaptation to the new conditions of digital development

Fig. 5. The main forms of state support for institutional transformations of the investment component of digital development

Source: developed by author

The main forms of government support for institutional transformations of the investment component of digital development are combined according to the functional component - regulation, stimulation, coordination - and are closely linked. The development of affiliate programs with private capital in the field of telecommunications and infrastructure will be based on a transparent information and communication system for 


\section{Kornieieva Iuliia}

exchanging information between government institutions and the private sector. The active development of e-government services will contribute to ensuring open access to data through on-line information portals and on-line windows. That will serve as a basis for reducing information asymmetry by connecting Databases between different government institutions that enhance the ability to process and analyse even greater amounts of data aggregated by different institutional units. That will also allow creation of an effective system for coordinating the implementation of the digital development strategy at different levels. Technological adaptation to the new conditions of digital development involves a high level of education of the society in the field of digital innovations, and therefore requires the introduction and coordination of a permanent system of advanced training, as well as constant correction of adaptive training programs to new technologies. Compliance of the current legislation with the conditions of modern digital development will ensure clear and transparent business rules, protection of investors' rights; also it will create preconditions for access to regional and international markets, for improvement of the investment climate and promotion of the development of venture investment.

\section{Conclusions}

The role of the digital economy in investment processes is significant due to the use of modern digital technologies which helps to reduce transaction costs, to simplify the investment process because of the improvement of the necessary for realization of investment projects infrastructure. The practical implementation of the digital transformation of investment policy requires the creation of appropriate institutional conditions that will allow enjoying the benefits of digital development. The financial and digital segments of the digital economy's infrastructure operate as a single coherent mechanism based on the recombination of their elements, creating a favorable environment for investment activity. The introduction of an electronic document flow system between government institutions is seen as a mechanism to ensure that information asymmetries are overcome, which positively affects the quality of administrative services for investors. Digital infrastructure has a significant impact on the process of selection of investment projects and potential investors in public sector; also it contributes to overcoming the ambiguity of the decision-making process through mechanisms that allow the rapid involvement of a wide range of independent experts. 
Digitalization creates new investment opportunities for the development of cooperation between public and private sector. In order to improve the coordination of institutional transformations of the investment component of digital development in Ukraine, it is proposed to create a specialized coordinating institution - the Council for the implementation of the investment component of the digital development strategy. In order to improve digital transformation of investment policy it is proposed to create the Innovation Platform for attracting productive investments, which will combine the foundations of the Crowdfunding platforms and Blockchain technologies and will work in accordance with the main principles of Sustainable Development.

\section{References:}

1. Manyika, J., Lund, S., Bughin, J., Woetzel, J., Stamenov, K., Dhingra, D. (2016). Digital globalization : the new era of global flows. McKinsey Global Institute.

2. UNCTAD. (2017). World Investment Report 2017: Investment and digital economy. URL: http://unctad.org/en/PublicationsLibrary/wir2017_en.pdf.

3. Coinmarketcap (2018). Cryptocurrency Market Capitalizations. URL: https://coinmarketcap.com/

4. OECD (2017). Digital Economy Outlook 2017. URL: http://dx.doi.org/ 10.1787/9789264276284-en.

5. PwC (2017). The state of fintech. PwC Report. URL: https://www.pwc.com/ sg/en/publications/assets/fintech-startupbootcamp-state-of-fintech-2017.pdf.

6. UNCTAD (2017). Digital economy radically changes global investment models. UNCTAD/PRESS/PR/2017/10. URL: http://unctad.org/en/ PressReleaseLibrary/PR17010_ru_WIR_Digital\%20Economy.pdf.

7. The New Digital Economy. How it will transform business. (2011). Oxford Economics.

8. International Monetary Fund (2017). Regional Economic Outlook Middle East and Central Asia. Washington.

9. KPMG (2017). The Pulse of Fintech Q2 2017: Global analysis of investment in fintech. URL: http://www.agefi.fr/sites/agefi.fr/files/fichiers/2017/08/pulse_of_ fintech-q2 2017 0.pdf.

10. Cabinet of Ministers of Ukraine (2014). Resolution of the Cabinet of Ministers of Ukraine No. 492 dated October 1, 2014 on the approval of the Regulation "On the State Agency for Electronic Government of Ukraine". 
CONSUMER AND ECONOMIC PROPOSALS OF BALANCES

ON THE MARKET OF TREATMENT AND RECREATION

TOURISM OF THE COUNTRIES OF THE CARPATHIAN REGION

\section{СПОЖИВЧІ ТА ЕКОНОМІЧНІ ПРОПОЗИЦІЇ \\ БАЛЬНЕОЛОГІЧНИХ ПОСЛУГ НА РИНКУ \\ ЛІКУВАЛЬНО-ОЗДОРОВЧОГО ТУРИЗМУ КРАЇН \\ КАРПАТСЬКОГО РЕГІОНУ}

\section{Kureda Nina ${ }^{1}$ \\ Yukhnovska Yuliya ${ }^{1}$ \\ DOI: http://dx.doi.org/10.30525/978-9934-571-28-2_15}

Abstract. Modern priorities of healthy lifestyle, prevention and treatment of pathologies ofhuman body systems make significantly actual the development of the national and international markets of medical tourism. The biggest concentration of natural recreational medical resources in Europe, in particular mineral waters is located on the territories of the Carpathian region.

The subject of this research is the resource capacity of Carpathian region European countries for the production of spa services, their consumer characteristics and economic conditions of the demand for them.

As the economic factor is essential for the most average consumers of medical and health services and balneological centers, so the main goal of this article is to compare consumer and price competitiveness of spa services on medical tourism markets of Carpathian region countries.

Fundamental researches of geodesy, medicine, economics, tourism experts have become the theoretical basis for this research. The following methods were used: empirical, analysis and synthesis, systematic approach and forecasting.

Summarizing the results, the authors make the following conclusions:

\footnotetext{
${ }^{1}$ Candidate of Economic Sciences, Associate Professor,

Municipal Higher Educational Establishment "Khortytska National Rehabilitational Academy" of Zaporizhzhya Regional Council, Ukraine

${ }^{2}$ Candidate of Economic Sciences, Associate Professor,

Municipal Higher Educational Establishment "Khortytska National Rehabilitational Academy" of Zaporizhzhya Regional Council, Ukraine
} 
1. Natural healing recreational potential of the countries of the Carpathian region and balneological resources, their different physicalchemical characteristics and medical indications for the treatment of human body system pathologies, create the necessary base for the production of spa services and allow to solve the population health problems.

2. Balneological complexes have been formed and successfully function on the basis of balneological resources of the countries of the Carpathian region, which have all necessary components: medicinal mineral water springs, Spa institutions, tourism infrastructure.

3. The combination of resource factor with advantageous geographical position of the Carpathian region countries in the center of Europe and welldeveloped transport network creates favorable conditions for activation of supply and demand on national markets of Spa services, because European countries are geographically close and the refore the related costs (e.g. transportation) have lessinfluenceontotal costs and potential con summers of spa services.

4. People treatment on foreign balneological resorts objectively accompany with their familiarization of traditions, history, culture, socioeconomic processes of these countries. International tourism promotes economic efficiency of functioning of many sectors of the national economies of the Carpathian region countries.

4. Spa services are the goods on the market of medical and health tourism. Therefore, the formation of offers of spa services and demand for them is based on economic factors: costs of treatment, transportation, food, entertainment, accommodation, etc.

5. Conformity of spa services offers of Carpathian region countries to the needs of citizens from different regions of the world in medical and health services on their consumer and economic factors is the condition of effective functioning not only of national markets of medical tourism in Carpathian region countries, but their national economies in general.

\section{1. Ветуп}

Висвітлення результатів досліджень щодо виробництва, попиту та пропозиції бальнеологічних послуг у Європейському регіоні здійснюється спеціалістами різних галузей в інформаційному просторі відповідно до сфери їх професійної діяльності, зокрема: 
- спеціалісти медичної галузі досліджують лікувальні характеристики природних мінеральних вод (як основного ресурсу для виробництва та надання бальнеологічних послуг), визначають їх лікувальний ефект при певних показаннях для лікування певних захворювань;

- спеціалісти лікувальних бальнеологічних закладів через свої інформаційні портали інформують ринок цільових споживачів про характер бальнеологічних послуг та їх якості, що виробляються ними;

- геологи, географи досліджують фізико-хімічні характеристики мінеральних вод, їх місцезнаходження, фізичні обсяги родовищ, визначають їх особливості як природного рекреаційного ресурсу;

- економісти, використовуючи досліджену інформацію щодо природних рекреаційних ресурсів спеціалістами різних галузей, визначають ринкову вартісну цінність цих ресурсів;

- туристичні оператори та агентства рекламують та просувають на ринок бальнеологічні послуги як правило у комплексі з перевагами супутньої інфраструктури - природи, клімату, матеріально-технічної бази, послуг розваг, історичних та культурних пам'яток, екскурсій, тощо.

Відзначаючи цінність названих галузевих напрямків досліджень, зауважимо, що на ринку лікувально-оздоровчих послуг (зокрема, бальнеологічних) взаємодіють виробники та споживчі і надання цих послуг можливе за наявності на території країни природних лікувальних мінеральних вод, виробничих потужностей лікувально-оздоровчих закладів та закладів інфраструктури. Попит на бальнеологічні послуги громадян 3 певними патологіями організму не обмежується національним ринком лікувально-оздоровчих послуг, оскільки важливість здоров'я змушує їх звертатись до пропозицій такого роду послуг i в інших державах. Актуальним є подальше дослідження з позицій ринкових оціночних критеріїв виробництва, реалізації та споживання бальнеологічних послуг. Це зумовлено тим, що ринок лікувально-оздоровчого туризму регулює попит та пропозиції своїх послуг оцінкою споживчих їх характеристик та економічними умовами (вартістю саме лікувально-оздоровчих послуг, трансферу, харчування, проживання, розваг, тощо).

Оскільки економічний фактор є суттєвим для більшості пересічних споживачів лікувально-оздоровчих послуг та самих бальнеологічних центрів, то в даній статті ставиться мета дослідити конкурентність 
споживчих та цінових пропозицій бальнеологічних послуг на ринках лікувально-оздоровчого туризму країн Карпатського регіону, які знаходяться територіально близько одні від одних, i, отже, супутні витрати (наприклад, на трансфер) в меншій мірі вплинуть на сукупні витрати та попит потенційних споживачів бальнеологічних послуг.

Мета дослідження реалізується через наступні завдання: проаналізувати ресурсні можливості та пропозиції бальнеологічних послуг країн Карпатського регіону, мотивацію попиту на бальнеологічні послуги, виявити специфіку бальнеологічних послуг на ринку лікувально-оздоровчого туризму, виявити напрямки впливу споживчих та економічних характеристик бальнеологічних послуг на їх попит.

Теоретичною основою для дослідження стали фундаментальні теоретичні дослідження фахівців у сфері геодезії, медицини, економіки, туризму. В ході дослідження були використані наступні методи: імперічний, аналізу та синтезу, системного підходу та прогнозування.

Дослідження теми здійснювалось в наступній логічній послідовності: визначено специфіки виробництва, реалізації та споживання бальнеологічних послуг, відзначено концептуальні підходи щодо ринкових умов функціонування сфери бальнеологічних послуг на ринку лікувально-оздоровчого туризму, проаналізовано умови виробництва та споживчі характеристики бальнеологічних послуг курортних закладів у Свропейських країнах Карпатського регіону, виявлено вплив економічних факторів на попит громадян на бальнеологічні послуги у країнах Карпатського регіону.

\section{2. Сутність та ринкові умови виробництва бальнеологічних послуг}

Бальнеологічні послуги це - специфічний продукт ринку лікувально-оздоровчого туризму, оскільки поєднує в собі наступні сутнісні складові:

1. Перша-наявність у регіонах країни таких природних рекреаційних ресурсів, як мінеральні води з певними лікувальними фізико-хімічними та іншими характеристиками.

2. Друга - функціонування у цих країнах лікувально-оздоровчих закладів, що спеціалізуються на виробництві бальнеологічних послуг, та певні рівень і можливості їх матеріально-технічного, фінансового, кадрового забезпечення. 
3. Третя - продуктивність лікувальних бальнеологічних закладів, які у відповідності до медичних протоколів надають бальнеологічні послуги, використовуючи лікувальні мінеральні води для вирішення проблем щодо певних патологій систем організму людини.

Природні мінеральні води та виробнича база для створення бальнеологічного продукту є частками національних економік країн i, зокрема, їх національних ринків. У Свропі Карпатський регіон має унікальні умови для розвитку лікувально-оздоровчого туризму та санаторно-курортної галузі. Чисельні природні угіддя, мінеральні родовища і джерела, горські масиви у цих країнах призначені саме для таких цілей Розвиток лікувально-оздоровчого туризму на основі природних рекреаційних ресурсів у країнах Карпатського регіону є однією з умов ефективності їх національних економік. Діяльність на територіях цих держав спеціалізованих лікувально-оздоровчих зон з європейським рівнем виробництва та надання бальнеологічних послуг, сервісу та комфортабельності принципово змінює їх функціонування, а саме вони активно працюють як складові частини не тільки національних, а й європейського та світового ринків.

Вивченню бальнеологічних ресурсів і пов'язаних із ними курортів на ринку лікувально-оздоровчого туризму України присвячено дослідження та публікації багатьох вчених, зокрема К. Бабова, А. Киселевської, О. Нікіпелової [1]; Б. Аксентійчука, Н. Алексєєнка, О. Андрієнка, К. Бабова, І. Бабова. [7]; М. Завядюка [3]; О. Стецюк [9]; В. Шестопалова [4].

У даному дослідженні перш за все акцентуємо свою позицію щодо бальнеологічних продуктів, а саме, що вони є товарами, які продаються та купуються як на національному, так і на міжнародному ринках лікувально-оздоровчого туризму. Продавець (власник, виробник) бальнеологічних послуг формує ціну на свій товар, яка б дозволила відшкодовувати витрати (в тому числі через зростання інфляції на ринках ресурсів для виробництва бальнеологічних послуг), стимулювати подальшу діяльність (наприклад, до збільшення обсягів надання послуг, до зростання та модернізації матеріально-технічної бази, залучення більш результативних технологій, до покращення сервісу, до фінансового посилення стимулювання праці спеціалістів, фінансування маркетингових заходів по просуванню товару на ринках збуту, тощо). Але в кінцевому результаті 
рівень ринкових цін на бальнеологічні послуги формується під впливом співвідношення платоспроможного попиту та вартісним рівнем їх пропозицій, конкуренції як зі сторони продавців, так і зі сторони споживачів.

Санаторно-курортні заклади, що використовують природні мінеральні води для лікування різних патологій систем організму людини, - бальнеологічні курорти формують відповідні лікувальні послуги. Уточнимо, що лікувальними мінеральними водами прийнято вважати лише ті підземні води, які завдяки великому вмісту розчинних газів, високій загальній мінералізації, наявності певних терапевтичних іонів або підвищеній температурі придатні для використання в лікувальних цілях.

Разом 3 типовими проявами закономірностей ринкових відносин ринок лікувально-оздоровчих (у частині бальнеологічних) послуг має свої особливості на відміну інших галузевих ринків. По-перше, бальнеологічні послуги з метою лікування створюються і безпосередньо надаються лікувально-оздоровчими закладами біля природних рекреаційних родовищ. Тому їх споживачі повинні територіально і на певний час (який визначається тривалістю курсу лікування чи оздоровлення) переїздити із своїх місць проживання до лікувально-оздоровчих закладів. По-друге, споживачі бальнеологічних послуг можуть знаходитись у більш чи менш критичних ситуаціях (у залежності від складності захворювання та терміновості лікування) і це визначає, коли саме пред’являти попит на бальнеологічні послуги і вирішувати тим самим життєво важливу проблему із здоров'ям. По-третє, на сукупний рівень витрат споживачів бальнеологічних послуг суттєво впливають такі їх супутні додаткові компоненти, як оплата діагностики, трансферу, проживання, харчування, діагностики, оплата витрат по супроводу сторонніми особами, візові витрати у випадку одержання послуги за кордоном та інші.

\section{3. Аналіз пропозицій бальнеологічних послуг у Польщі, Румунії, Словаччині, Угорщині, Чехії}

Значна частина пропозицій лікувально-оздоровчих послуг бальнеологічних закладів у Свропі сконцентрована у природній рекреаційній зоні Карпат на територіях таких країн, як Польща, Румунія, Словаччина, Угорщина, Чехія та Україна [12]. 
Проаналізуємо узагальнені показники щодо ресурсних можливостей країн Карпатського регіону в частині наявності та використання природних лікувальних мінеральних вод.

На території Румунії виявлено 2000 водопроявів, на базі яких функціонує 79 бальнеологічних курортів. У відповідності до певного типу мінеральних лікувальних вод сформувалась спеціалізація бальнеологічних курортів Румунії, а саме: на курортах Келіменешть, Сленік-Молдова, Беїле-Оленешть, Беїле-Фелікс, Келан, Моняса, Джоаджу-Бей, Ваца-де-Жос використовують поліметалічні мінеральні води для лікування захворювання опорно-рухового апарату, органів травлення, сечостатевої системи; на курортах Борсек, Зізін, Ковасна, Біборцень, Ватра-Дорней, Бузяш, Ліпова, Туш над використовують вуглекислі мінеральні води і лікують захворювання кишково-шлункового тракту, серцево-судинні, гіпертонію, артрит; на курортах Беїле-Херкулане, Сомешень, Окна-Сібіулуй, Сленік-Молдова, Синджорз-Бей, Белтецешть, Малнаш-Бей, Совата, Сленік-Прахова, Базна, Оленешть Хлоридні натрієві лікують хронічні бронхіти, захворювання органів травлення, ревматологічні; на курортах Сленік-Молдова, Серата-Монтеору, Ваца-де-Жос, Амара, Окна-Шугатаг, Белцетешть, Беїле-Говора, Келіменешть використовують сульфатні магнієві, кальцієві мінеральні води і лікують розлади органів травлення, порушення обміну речовинна курортах; Беїле-Херкулане, Келіменешть, Беїле-Оленешть, Пучоаса, Сечелу використовують сірчисті з хлоридними, сольовими компонентами мінеральні води і лікують захворювання верхніх дихальних шляхів, ревматологічні, астма, цукровий діабет, дерматоз; на курортах Ліпова, Хомород, Малнаш-Бей, Вилчеле, Біборцень, Тушнад, Ватра-Дорней використовують залізисті мінеральні води і лікують захворювання кишково-шлункового тракту $[13 ; 14 ; 16]$.

На території Словаччини виявлено 1300 водопроявів, що використовуються 55 курортами та купелями. Кількість термальних джерел країни відноситься до самих «багатих» в Свропі, а за якістю мінеральних вод випереджає багато європейських курортів. Словаччина належить до країн німецької школи курортології. Водолікарні розміщені по всій країні, зосереджуючись у відрогах гірських систем. Це курорти Смрдаки, Сляч, Пієштяни, Тренчанські Тепліце, Дудінце, Райецьке Тепліце, Турчіанське Тепліце, Бардеєвські Купелі, Лучки, Лучівна, Ружбахі, Чиж, Склень Тепліце, Німніца, Коритниця і Любохня. Тер- 
мальні пляжі є в селах Бешеньова і Ліптовський Ян, а джерела теплої і вуглекислої мінеральної води в селах Бешеньова, Лікавіт, Квачани, Жяр, Прібіліна, Заважна-Поруба, Ліптовський Ян, показані для лікування безлічі захворювань.

Особливістю бальнеології Словаччини є ії давня історична практика. Так, курорт Бойніце використовував ще з 1113 року термальні води для лікування хвороб опорно-рухомого апарату, неврологічних та гінекологічних захворювань. Курорт Бардейовске купеля (перша згадка про нього, як лікувальний заклад датується ще з 1247 року) використовує для лікування хвороб шлунково-кишкового тракту та органів травлення лужно-солоні кислі залізисті води 317 джерел. Курорт Вишне Ружбахи був побудований у 1595 році і до цього часу спеціалізується на лікуванні серцево-судинних, гінекологічних, онкологічних захворювань, захворювань органів травлення, нирок, сечовивідних шляхів, хвороб обміну речовин та залоз внутрішньої секреції. На курорті Тренчіанске Тепліце (цілющі джерела якого згадуються ще з 1242 року) з 1580 року використовують мінеральні джерела для лікування ревматичних захворювань, загальних захворювань хребта, неврології, післяопераційних станів. Курорт Раєцке Тепліце (відоме у лікувальній практиці ще з XIV ст.), відповідає всім європейським стандартам і використовує мінеральні води з високим вмістом солей гідрокарбонату кальцію та магнію для лікування хвороб рухомо-опорного апарату, хребта, неврологічні, гінекологічні захворювання.

На території Словаччини функціонує багато унікальних по лікувальних характеристиках бальнеологічних курортів [20]. Наприклад, курорт Склене Тепліце використовує лікувальні печерні термальні ванни 3 високим вмістом кальцію та магнію і є єдиним у своєму роді курортом у Європі. По концентрації сірководню мінеральна вода, що використовується Спа - курортом Смрдаки для лікування захворювань шкіри, є єдиним видом у Центральній Європі. Ізотермічна мінеральна вода 3 високою концентрацією вуглекислого газу використовується тільки на словацькому курорті Сляч (і тільки на курортах Австралії, Аргентини та Іспанії).

Угорщину називають країною термальних лазень, оскільки вона $€$ на 5-й позиції серед кращих термальних джерел світу. На іiі території розміщені 136 джерел лікувальної питної води, 1289 свердловин з термальною водою, 48 джерел мінеральної води. Свропейським центром 
водолікувального купання - гідротерапії Угорщина стала в XIX ст. Нині 22 міста і 62 угорських селища мають офіційно визнані лікувальні джерела [5; 19].

Ресурсною базою лікувальних мінеральних вод та якістю діяльності бальнеологічні курорти Угорщини стали конкурентними у Європі та світі.

Туристські потоки в Угорщині спрямовуються за двома напрямками: у Будапешт і на озеро Балатон. Столиця Будапешт ще в XIX ст. одержала статус міста лікувальних вод. Сьогодні це один з головних бальнеологічних курортів світу. На території міста щодоби зі 123 джерел одержують 70 млн. гарячої цілющої води, більше половини якої має температуру, що вища за $+40^{\circ} \mathrm{C}$. На території міста працює один 3 найбільших бальнеологічних комплексів у всій Європі - Сечені (тут були відкриті купальні ще у 1881 році), де лікують захворювання серцево-судинної системи, опорно-рухового апарату, суглобів. Курорт Мішкольц - Таполца (термальні джерела якого були відкриті ще у XV ст., а використовувати почали з XVI ст.) спеціалізується на лікуванні хвороб шлунково-кишкового тракту, серцево-судинної системи, опорно-рухового апарату та органів дихання. Будівництво термальних купалень Кирай почалось ще у 1665 році і нині тут лікують захворювання опорно-рухового апарату, здійснюють реабілітацію після операцій та травм, пов'язаних з ортопедією, лікування розладів нервової системи. Озеро Балатон - одне з найтепліших озер Європи. Щорічно сюди приїздить до 100 тис. туристів із різних країн. Комплекс бальнеології Лукач (заснований ще у XII ст.) опікується лікуванням захворювань нервової системи, опорно-рухового апарату, у випадках реабілітації після перенесених травм, операцій на суглобах і у цілому в ортопедичному напрямку. Бальнеокурорт Хевіз, розташований на березі однойменного найбільшого гарячого озера Угорщини і використовує його лікувальні води - сірчані та лужно-гідрокарбонатні, спеціалізується на хронічних захворюваннях і післяопераційних запальних процесах, проблемах з ожирінням, гормональними порушеннями. Особливо популярні оздоровлення і лікування на угорських курортах серед місцевих туристів та туристів із Німеччини, США, Австрії.

Польща на європейському ринку лікувально-оздоровчого туризму представлена бальнеологічними та кліматичними курортами [6]. Головні приморські бальнеологічні й бальнеогрязеві курорти - Сві- 
ноуйсьце, Камень-Поморськії, Колобжег - знаходяться на узбережжі Балтійського моря. Зараз у Польщі функціонує понад 40 курортів у різних регіонах країни: на Балтійському узбережжі та Помор'ї, центральній Польщі, в Судетах і Карпатах.

На території Польщі працюють бальнеологічні курорти 3 давньою медичною практикою. Наприклад, кремнисті терми курорту Цепліце-Здруй згадувались ще у XII ст., а у XIII ст. були побудовані перші бальнеологічні заклади. Цей курорт знаходиться на висоті 350 м над рівнем моря, в Слєнегурській улоговині, біля підніжжя гір Крконоше. Його лікувальний профіль - захворювання опорно-рухового апарату і ревматизм, очні захворювання, захворювання серцево-судинної системи у дітей, запалення суглобів. Природні лікувальні ресурси: фтористі термальні води $\left(21-62^{\circ} \mathrm{C}\right)$, лікувальні грязі. Протягом року в межах курорту відбуваються фестивалі: Віденської музики в Курортному театрі, Єлєнегурський вересень, Міжнародний фестиваль вуличних театрів, фестиваль польської та європейської музики. Функціонують два критих і три відкритих басейни, 17 тенісних кортів, школа верхової їзди, гірськолижні витяги в сусідніх населених пунктах Карпач, Шклярська-Поремба, Дзівішувє.

Бальнеологічний курорт Шавно (описаний ще у 1601 році, а початком функціонування закладу, як курорту, вважається 1776 рік) використовує мінеральні джерела типу холодних вуглекислих гідрокарбонатно-натрієвих вод з невеликою мінералізацією. Тут мінеральна вода використовується для ванн, питного лікування, інгаляцій та зрошення. Показання: хронічні захворювання органів травлення і порушення обміну речовин, хронічні катари сечових шляхів і функціональні порушення нервової системи. Курорт Душники існує 31769 року, хоча його мінеральні джерела були описані ще у 1468 році. По фізико-хімічному складу мінеральні води цього курорту відносяться до вуглекислих гідрокарбонатно-кальцієво-натрієво-магнієвих вод i використовуються для ванн, питного лікування, інгаляцій, промивань та зрошень. Медичними показаннями є захворювання серцево-судинної системи, порушення обміну речовин, жіночі хвороби, захворювання органів дихання.

Душникі-Здруй - курортна місцевість, розміщена на висоті 550 м над рівнем моря на межі Столових і Бистшицьких гір, поблизу польсько-чеського кордону. Мікроклімат створюють лісові масиви, що 
оточують курорт. Лікувальні чинники регіону: джерела вуглекислих, лужних і залізистих мінеральних вод з великим вмістом двоокису вуглецю, а також лікувальні грязі. Щорічно в серпні тут проходить Міжнародний фестиваль музики Шопена за участю видатних піаністів. Композитор виконував тут свої твори в 1826 р. під час лікування. Лікувальний профіль: захворювання органів дихання, системи травлення, гінекологічні.

Поляніца-Здруй розміщений на березі ріки Бистшица Душніцка на висоті 380-410 м над рівнем моря біля підніжжя Судетів. Із заходу місцевість оточена лісами. Влітку тут проходить Міжнародний турнір Шахістів пам'яті Акіби Рубінштейна. Лікувальний профіль: захворювання серцево-судинної системи, системи травлення.

Кудова-Здруй - курортна місцевість, розміщена в Клодській улоговині на висоті 390-400 м над рівнем моря біля підніжжя Столових гір. Клімат у цій місцевості м'який, помірний, гірський. Кліматичні особливості курорту мають позитивний вплив на кровообіг, дихання i травлення, функціонування м'язової і нервової систем. Джерела мінеральних вод використовують у лікувальних цілях з 1636 р. Перші наукові дослідження мінеральних вод почались в 1787 р. У 1921 р. кількість відпочиваючих становила 12000 осіб. Лікувальна база курорту складається 3 трьох курортних лікарень, дитячої гастрологічної курортної лікарні та двох санаторіїв. Щорічно тут проходить Міжнародний фестиваль музики Монюшко, виконуються його сольні твори, опери, оркестрові твори. Лікувальний профіль: у дорослих захворювання серцево-судинної системи, внутрішньої секреції і обміну речовин; у дітей - захворювання органів травлення.

Бальнеологічний курорт Устронь розміщений у верхній течії річки Вісли, на межі Силезької височини і Силезького Бескиду, на висоті 340-450 м вище рівня моря в оточенні хвойних лісів. Курортними чинниками є високотермальні хлоридо-натрієво-кальцієві, бромисті, борні, йодисті, радонові мінеральні води. В місті $є$ зал і амфітеатр у курортному парку, три музеї, галерея сучасного мистецтва. Протягом року організовують Фестиваль релігійної творчості, Устронське артистичне літо, Дні Устроня. Головні туристичні об'єкти: дерев'яний костел (1769), костел у стилі бароко (1787), традиційні гуральські хати (XIX ст). На курорті функціонує відкритий басейн, тенісний корт, гірськолижні витяги, літня санна траса, школа верхової їзди. 3 Устроня 
ведуть туристичні маршрути в Си-лезькі Бескиди. Взимку тут сприятливі умови для лижного спорту. Лікувальний профіль - захворювання опорно-рухового апарату, серцево-судинної системи, органів дихання, порушення обміну речовин, а також ревматичні захворювання.

Щавніца - курортна місцевість на висоті 435-520 м над рівнем моря на межі Пенінських гір і Сондецьких Бескидів з особливим мікрокліматом, схили покриті модриновими і буковими лісами. Головним лікувальним чинником є мінеральні води (йодисті, борні, бікарбонатно-натрієво-хлоридні). Лікувальний профіль - захворювання органів дихання і алергічні захворювання, пульмонологія, ларингологія, захворювання органів травлення, порушення обміну речовин, хвороб внутрішньої секреції. Поряд є Пенінський національний парк і Попрадський ландшафтний парк. Криніца - курорт розміщений на сході Сондецьких Бескидів в оточенні лісів на висоті понад 500 м над рівнем моря. Мінеральні джерела цього курорту були описані у першій половині XVIII ст., а перша бальнеологічна лікарня була відкрита у 1807 році. Цю місцевість називають «перлиною польських курортів». Лікувальними чинниками курорту є мікроклімат, мінеральні води і лікувальні грязі. Більшість санаторіїв розмістилася на схилах гір. Лікувальний профіль - захворювання серцево-судинної системи, шлунково-кишкового тракту, порушення обміну речовин, гінекологічні. В межах курорту знаходиться 5 природних джерел і 18 свердловин. Мінеральні джерела, крім внутрішнього використання, застосовуються у вигляді лікувальних ванн. У Криниці також знаходяться єдині в Польщі сухі ванни, які можна застосовувати для пацієнтів із хворобами серця і розладу кровообігу. Величка - курортне місто, розміщене за 14 км від Кракова. Під землею, в шахті функціонує санаторій. Максимальна глибина шахти 340 м, загальна протяжність понад 350 км. Лікувальні властивості солі з цієї шахти були відомі з XVI ст. На даний час специфічний мікроклімат підземелля Велічки використовується в лікуванні бронхіальної астми, різних видів алергії, захворювань верхніх дихальних шляхів, серцево-судинної системи, захворювань шкіри, внутрішньої секреції, порушення обміну речовин. На глибині 101 розміщена капличка, в 1999 р. тут було створено з соляної брили пам'ятник Іоану Павлу II.

Колобжег - найбільший курорт на Балтійському побережжі, розміщений в гирлі річки Парсенти, 40 км на захід від міста Кошаліна. 
Перша згадка про курорт датується 1710 р., а з XIX ст. - створено морську купальню міжнародного рівня. Тут працюють два оздоровчі центри, де використовуються фізіотерапія, а також курортні поліклініки, санаторії на березі моря або в оточенні соснових лісів. На курорті функціонують спортивно-профілактичні басейни, тенісні корти, тренажерні зали, спортивні стадіони, велосипедні доріжки. Головними лікувальними чинниками є: специфічний мікроклімат, який формується завдяки близькістю до моря, інтенсивне сонячне випромінювання, мінеральні джерела і родовища лікувальних грязей. Лікувальний профіль - захворювання серцево-судинної системи, органів дихання, опорно-рухового апарату, ревматизм, порушення обміну речовин.

Цехоцінек - найбільший бальнеологічний курорт розміщений у широкій долині річки Вісли. Його оточують луги і соснові ліси. Клімат помірний теплий, із невеликою кількістю опадів. Лікувальний профіль - захворювання серцево-судинної системи, верхніх дихальних шляхів, опорно-рухового апарату, ревматизм. Природні лікувальні ресурси: натрієво-хлоридні води, термальні мінеральні джерела $\left(26-27^{\circ} \mathrm{C}\right)$. На курорті функціонують: фізіотерапевтичні заклади, соляні та реабілітаційні криті басейни, відкритий термально-соляний басейн, соляна градирня довжиною 1740 м, яку використовують як відкритий інгаляторій.

В Чехії близько 40 різних бальнеологічних курортів [17; 18]. Найпопулярнішим курортом Чехії є Карлові Вари. Тут мальовнича природа, сильна лікувальна база з використанням природних лікувальних ресурсів, розвинена туристична інфраструктура. Основний напрямок лікування - захворювання шлунково-кишкового тракту, печінки, жовчних шляхів, порушення обміну речовин. Також застосовуються піші прогулянки, масажі, гімнастика, електро-, світло-та теплолікування.

Популярним курортом Чехії є Маріанські Лазні. Курорт оточений лісистими горами з холодними мінеральними джерелами, лікувальними грязями, торфом і так званим Маріїнським газом. Основні лікувальні властивості: лікують захворювання кровоносної та нервової систем, опорно-рухового апарату, сечовидільної та дихальної систем, шлунково-кишкового тракту. Також застосовуються: питна мінеральна вода, СПА-процедури, підшкірні ін'єкції газом Марії.

Ще одним місцем для лікувального відпочинку в Чехії вважається курорт Подєбради. Основними лікувальними властивостями цього 
курорту є холодні джерела сильно мінералізованої кислої води, а спеціалізується на лікуванні серцево-судинної системи. Також відпочинок тут робить позитивний вплив на опорно-руховий апарат, нервову систему, покращує обмін речовин і роботу залоз внутрішньої секреції.

Курорт Тепліце ще у XV ст. курорт переживав пік своєї популярності. Основні лікувальні властивості курорту Тепліце: теплі мінеральні джерела з високим рівнем фтору, лікують, в основному, нервову систему та опорно-руховий апарат, судинні захворювання. Курорт отримує позитивні результати у лікуванні дитячих порушень центральної нервової системи, а також дорослого і дитячого посттравматичного синдрому.

Один із найпопулярніших бальнеологічних курортів Чехії - Франтішкові-Лазне. Курорт отримав широку популярність завдяки тому, що це не просто лікувальний відпочинок, а лікування здебільшого жінок, зокрема - вирішення проблем безпліддя.

Лугачовіце - найбільший курорт Східної Чехії. Для лікування використовується не тільки мінеральна вода, а й лікувальні грязі. До основної групи хвороб, які тут лікують, належать хвороби дихальних шляхів, захворювання травного тракту та обміну речовин.

Янске Лазне - один із найпопулярніших бальнеологічних курортів Чехії, розташований на північному сході у районі Судет в області гірського масиву Крконоше. Курорт відомий тим, що в ньому був відкритий перший у Європі санаторій, який спеціалізувався на лікуванні дитячого паралічу.

До великих курортів міжнародного значення належать і Подебради, розташовані серед мальовничих парків у рівнинній частині Чехії. Курорт має 13 джерел. На ньому лікують захворювання серця. Крім перелічених, відомими курортами Чехії є Кінжварт, розташований за 8 км на північний захід від курорту Маріанське Лазне; Єсенік, що знаходиться на північному заході Моравії.

\section{4. Ресурсне забезпечення пропозицій бальнеологічних послуг в Украӥні}

Гідромінеральні ресурси України визначається наявністю таких мінеральних вод, як вуглекислі, сульфідні, радонові, залізисті та миш'яковисті, йодні, бромні та йодо-бромні, борні, кременисті води, з підвищеним вмістом органічних речовин та води без специ- 
фічних компонентів і властивостей. Радонові води різноманітного хімічного складу поширені на правобережжі Дніпра, на Побужжі та Приазов'ї. Радонові води найбільш широко використовуються як зовнішній засіб у вигляді загальних і місцевих ванн. Показами для лікування радоновими ваннами $є$ захворювання серцево-судинної системи, шкіри та органів опорно-рухового апарату. Найбільш відомі в Україні курорти, які використовують радонові води, це: курорт Хмільник (Вінницька область), санаторій у Черкаській області, водолікарні Житомира (Житомирська область), Білої Церкви (Київська область), Полонного (Хмельницька область). Йодні, бромні та йодо-бромні води переважно хлоридно-натрієвого складу поширені в Карпатах та Передкарпатті. Використовують їх у санаторіях Закарпатської області. Сульфідні мінеральні води використовують як ванни, меншою мірою для зрошення та інгаляцій. Позитивний ефект має лікування при захворюваннях органів опорно-рухового апарату, нервової системи, жіночих статевих органів, серцево-судинної системи.

В Україні найбільш відомі санаторії із сульфідними джерелами $є$ у Львівській, Івано-Франківській, Чернівецькій, Закарпатській областях. Вуглекислі мінеральні води поширені на південно-західному схилі Українських Карпат і на Закарпатті. Ці води використовують у санаторіях Закарпатської області, а також розливають як природні і лікувально-столові води.

Значна концентрація лікувальних бальнеологічних ресурсів України зосереджена у Закарпатті, при цьому кожний його район має свою специфіку щодо обсягів та складу основних груп мінеральних вод, а саме:

- основні бальнеоресурси Берегівської курортно-рекреаційної зони включають 6 (освоєно 4) родовищ мінеральних вод -азотно-вуглекислі, азотно-метанові, вуглекислі кремнієві хлоридні натрієві різної мінералізації - від слабко мінералізованих до розсолів;

- основними бальнеоресурсами Великоберезнянсько-Перечинської курортно-рекреаційної зони $є 7$ родовищ (66 водопроявів - 28 свердловин, 38 джерел) мінеральних вод (вуглекислі гідрокарбонатно-хлоридні натрієві та натрієво-кальцієві, у тому числі з вмістом мікро- та мікроелементів - (бору, брому, заліза кальцію, наявністю заліза та сірководню; 
- бальнеоресурси Іршавської курортно-рекреаційної зони - родовище термальних мінеральних вод (метанові йодо-бромні гідрокарбонатно-хлоридні натрієві мінеральні) - практично не освоєні (27 водопроявів - 17 свердловин, 10 джерел);

- у Мукачівській курортно-рекреаційній зоні розвідано 7 основних родовищ бальнеологічних ресурсів, освоєно 5 (31 водопрояв - 23 свердловин та 8 джерел). До складу основних груп мінеральних вод у цьому регіоні відносяться термальні хлоридні натрієві, йодо-бромні та борні розсоли; сульфідні води, азотні кремнієві терм;

- бальнеологічні ресурси Рахівської курортно-рекреаційної зони представлені вуглекисимиі середньо- та маломінералізованими хлоридно-гідрокарбонатні натрієвими (кальцієво-натрієвими), у т.ч. 3 високим вмістом миш'яку, заліза, бору; вуглекислими маломінералізованими гідрокарбонатними кальцієимиі, магнієвими мінеральними водами, у тому числі залізистими; слабосульфідними водами у 9 основних родовищах (142 водопрояви - 38 свердловин та 104 джерела), з них освоєно 3;

- бальнеоресурси Свалявської курортно-рекреаційної зони розвідані у 10 родовищах (94 водопрояви - 77 свердловин та 17 джерел), освоєно 9. Основними групами мінеральних вод тут $є$ переважно вуглекислі гідрокарбонатні натрієві різного складу та мінералізації (від 5 до 25 г/дм3 ), у тому числі з вмістом бору та фтору;

- основні бальнеоресурси Тячівської курортно-рекреаційної зони 9 родовищ мінеральних вод (67 водопроявів - 21 свердловина та 46 джерел), освоєно 3. Основними групами мінеральних вод у цьому регіоні є вуглекислі сильнозалізисті (у т.ч. міцно залізисті - 73 мг/дм3) маломінералізовані гідрокарбонатні натрієві (натрієво-кальцієві); азотно-метанові слабкосульфідні; хлоридні натрієві розсоли Солотвинської западини та Солотвинські соляні озера;

- особливісті складу основних груп мінеральних вод Ужгородської курортно-рекреаційної зони є низька мінералізація переважної більшості вод; високий та дуже високий вміст метакремнієвої кислоти; наявність біологічно значимого вмісту заліза, кальцію, інших мікро- та макроелементів; високомінералізовані термальні мінеральних вод. Основні бальнеоресурси у цьому регіоні представлені 6 родовищами мінеральних вод (38 водопроявів - 29 свердловин та 9 джерел), освоєно 3; 
- основні бальнеоресурси Хустсько-Виноградівської курортно-рекреаційної зони зосереджені у 4 родовищах мінеральних вод (91 водопрояв - 49 свердловин, 42 джерела) таких, як вуглекислі кремнієві маломінералізовані гідрокарбонатні натрієві, у тому числі з підвищеним вмістом сульфатів; вуглекислі середньомінералізовані хлоридно-гідрокарбонатні натрієві; вуглекислі, у тому числі кремнієві, борні та йодо-бромні хлоридні натрієві термальні розсоли; азотні кремнієві терми. Частково освоєні всі родовища.

Основними у дії питних мінеральних вод при внутрішньому їх прийомі є комплексні лікувальні ефекти, що з'являються в результаті регулюючої дії лікувальних мінеральних вод на органи шлунково-кишкового тракту, сечовиділення, на обмінні процеси; в результаті подразнення антрального відділу шлунку проявляються нейрогуморальні ефекти гастрину (I фаза), при впливі мінеральної води на слизові 12-перстної кишки - секретина, холецистокиніну, панкреозиміну, мотилину (II фаза); друга група ефектів пов'язана з реакціями взаємодії фізико-хімічного складу мінеральної води та вмісту шлунку. Параметри процедури: мінералізація - мала (2-5 г) л, середня (5-10 г) л, висока (10-15 г) л. [7; 11].

Оскільки ресурси лікувальних мінеральних вод кожного регіону України мають свою специфіку, то вони можуть зумовлювати індивідуальний бальнеологічний профіль лікувальних закладів кожної курортно-рекреаційної зони. Перші відомості про наявність лікувальних мінеральних вод на території сучасної України стосуються Передкарпаття і належать до кінця XVI - початку XVII ст. Так, джерела курортів Шкла, Великого Любеня, Немирова, Трускавця (Львівська область) описав видатний польський лікар В. Очко в 1578 р. Перші бальнеологічні курорти в Україні виникли на мінеральних водах у Шкло (1576р.), Трускавці (1827р.), Моршині (1877р.) Львівської області. На даний час бальнеологічні лікувальні заклади пропонують профільні послуги у всіх областях України, а саме: Львіській - Трускавець, Моршин, Східниця, Немирів; Закарпатській - Рахів, Нижнє Солотвино, Виноградів, Міжгіря, Кваси, Синяк, Свалява, Шаян, Поляна, Солочин; Полтавській - Миргород, Велика Багачка, Власівка; Вінницькій - Хмельник, с.Немирів, Бронниця; Донецькій- Словянськ; Одеській - Одеса, Сергіївка; Запорізькій - Бердянськ, Кирилівка; Дніпровській-Орловщина; Харківській - Березовське; Хмельниць- 
кій - Сатанів, Волочийськ; Івано-Франківській - Черче, Шешори; Ровенській-Жорбин; Сумській - Токари; Черкаській - Будище; Чернігівській - Мена; Херсонській - Генічеськ. Проаналізуємо споживчі характеристики бальнеологічних послуг деяких санаторно-курортних закладів областей України, зокрема, прилеглих до Карпат [2; 8; 10].

- Санаторії курорту «Поляна» (с.Поляна, Свалявський район, Закарпаття) спеціалізовані для лікування хворих з хронічними захворюваннями органів травлення. Формально перелік захворювань такий же, як і для інших гастроентерологічних оздоровниць, але є деякі особливості. В офіційному переліку захворювань вказано, що приймаються хворі поза фазою загострення. У санаторіях «Сонячного Закарпаття» та в «Поляні» без застосування медикаментів ефективно лікуються хворі на виразкову хворобу шлунку, дванадцятипалої кишки, ерозивні гастрити (дуоденіти) при наявності виразок, ерозій, якщо відсутні виразний больовий синдром і ускладнення, що вимагають хірургічного втручання.

- Мінеральна вода «Лужанська» в умовах санаторію «Квітка полонини» та «Кришталеве джерело» (м. Солочин) використовується для питного вживання, вуглекислих мінеральних ванн, кишкових промивань, інгаляцій та інших методів порожнинного введення. Медичні показання: хвороби оперованого шлунку, хронічні захворювання шлунково-кишкового тракту, печінки та жовчних шляхів, цукровий діабет легкого та середнього ступенів.

- У санаторіях с. Шаян Хустського району, Закарпаття використовуються такі мінеральні води, як вуглекисла, кремнієва, малої мінералізації, хлоридно-гідрокарбонатна, кальцієво-натрієва. Основний лікувальний фактор - вуглекисла холодно маломінералізована кремниста гідрокарбонатно-натрієва мінеральна вода «Шаянська», яка за загальним вмістом гідрокарбонатів наближається до мінеральних вод «Боржомі», «Ссентуки» і «Віші-Селестон» (Франція), проте належить до Диліжанського типу - наявність в її складі метакремнієвої кислоти. Для лікування є бювет мінеральної води, лікувальні кабінети (для зрошення кишківника, промивання шлунку), інгаляторій. Медичні покази: хронічний гастрит із секреторною недостатністю, виразкова хвороба шлунку і дванадцятипалої кишки, хронічний ентерит і ентероколіт, функціональні розлади кишечника, хронічний коліт і холецистит, дискінезія жовчних шляхів, гепатит. 
- У санаторію «Кваси» для лікування захворювання опорно-рухового апарату і периферичної нервової системи використовують миш'яковисті хлоридно-гідрокарбонатно-натрієві мінеральні ванни (зовнішне застосування мінеральної води цього типу).

- У санаторіях с. Солотвино Ужгородського району, Закарпаття використовується вода соляних озер Солотвино, яка за своїми лікувальними властивостями аналогічна водам Мертвого моря. Грязі дають позитивний ефект при лікуванні серцево-судинної системи, залишкових явищах флебітів, тромбофлебітів, органів руху, нервової системи, урологічних захворювань, псоріазу та ін. На базі соляних шахт проводять лікування хворих на бронхіальну астму й інші алергічні захворювання.

- Термальні джерела м.Берегове, Закарпаття 3 кремнієво-азото-вуглекисло-хлоридно-натрієвими водами високої мінералізації є унікальними для Європи, оскільки їх аналоги зустрічаються на Камчатці, Сахаліні, Ісландії та Новій Зеландії. Сприятливі температурні показники води берегівського басейну-купальні ніколи не опускається нижче 36 градусів, а мінеральна вода надходить у нього зі свердловини глибиною 1680 м. Ця вода добре впливає на здоров'я людей із серцево-судинними недугами, варикозом, артритом, остеохондрозом, захворюваннями нервової системи. Допомагає вилікуватися від наслідків травм кісткової тканини, м'язів та сухожиль.

- За своїм складом термальні води біля села Косонь Берегівського району, Закарпаття відносяться до високотермальних хлоридно-натрієвих вод середньої мінералізації. Вона схожа 3 водою всесвітньо відомого санаторію «Гайдусобосло» в Угорщині. Вода у басейнах. зі свердловини 16Т і вона витікає з температурою 60-80 градусів. А поки доходить до поверхні, охолоджується до 38-40 градусів. Допомагає лікувати органи опорно-рухового апарату, наслідки травм кісток та м'язів, серцево-судинну та нервову систему, шкірні захворювання; властивості води допомагають виводити солі з кісток та нирок.

- Основою санаторно-курортного лікуванняу м.Виноградів, Закарпаття $є$ природні лікувальні чинники - місцеві мінеральні води трьох типів, які мають широкий спектр показань для лікування захворювань опорно-рухового апарату, серцево-судинної і периферійної нервової систем, захворювань верхніх дихальних шляхів, а також ендокринної системи, обміну речовин, шлунково-кишкового тракту. Мінеральні води: «Теплиця» - гірко-солона високомінералізована вода, тер- 
мальна; «Олегівська» - кремнієва гідрокарбонатна кальцієво-натрієва слабомінералізована; «Кушницька» - маломінералізована борна гідрокарбонатна натрієва лікувально-столова.

- Бальнеологічні ресурси с.Довге Іршавського району, Закарпаття використовуються для лікування - захворювання: серцево-судинні, кишково-шлункового тракту, опорно-рухового апарату, периферійної нервової системи та обміну речовин.

- Основними лікувальними факторами у бальнеологічних лікувальних закладах селища міського типу Великий Любінь Городокського району, Закарпаття є сірководнева вода типу «Мацеста» і торф'яні грязі. У комплекс санаторно-курортного лікування входять електропроцедури, масаж, гідромасаж, гідропатичні процедури, рефлексотерапія, грязеві вагінальні тампони, вагінальні зрошення, інгаляції. У санаторії лікують паталогії систем організму людини за напрямками: кардіологія: ішемічну хворобу серця, стенокардію, гіпертонічну хворобу, ревматизм, після інфарктні кардіосклерози, облітеруючі ендартеріози, тромбофлебіти, варикозне розширення вен, вегетосудинні дистоніі; неврологія: функціональні розлади нервової системи - неврастенію, астеноневротичний синдром, психостенію, судинні захворювання мозку, наслідки перенесених інсультів, черепно-мозкових травм, енцефаліту, поліомієліту, невриту; артрологія: деформуючі артрози, артрити, поліартрити, остеохондрози, спондильози, хворобу Бехтерева, після травматичні ускладнення, контрактури та рубці після опіків і травм; гінекологія: хронічні запальні процеси жіночої статевої системи, вторинне безпліддя, спайкові хвороби; дерматологія: екзему, нейродерміт, кропивницю, псоріаз, парапсоріаз, червоний плоский лишай, склеродермію (вогнищеву), іхтіоз, іхтіозний дерматит, себорею, кератодерматози, фолікулярний дискератоз. Тут проводять реабілітацію дітей, хворих на ДЦП, у відділенні матері й дитини.

- У Трускавці, Прикарпаття активно використовуються 25 мінеральних джерел, найвідоміші у лікувальній практиці бальнеології-джерела мінеральної води «Нафтуся», «Марія», «Софія», «Юзя», «Бронислава». У бальнеологічних закладах цього регіону лікують захворювання шлунково-кишкового тракту, запальні процеси печінки та жовчовивідних шляхів у стадії ремісії, жовчнокам'яні хвороби без ускладнень, хронічні запальні процеси нирок та сечовивідних шляхів порушення обміну речовин, захворювання ендокринної системи та інші. 
- На основі мінеральних джерел Моршину, Прикарпаття функціонують бальнеологічні гастроентерологічні курорти. Завдяки жовчогінній, сечогінній і послаблюючій дії мінеральної води проходить очищення організму, підвищується імунний статус, тому ефективно лікуються захворювання органів травлення, сечовивідних шляхів, обміну речовин, алергічних станів. В арсеналі лікування вживання мінеральної води джерел № 1 - при пониженій кислотності, № 6 - при збереженій і підвищеній кислотності, № 4 - як сечогінна; ванни: мінеральні, перлинні, мінерально-хвойні, йодобромні, з лікарськими рослинами; душі: гідролазерний, циркулярний, висхідний, душ Шарко; кишкові зрошення, гінекологічні зрошення та спринцювання мінеральною водою. Медичні показання: хронічні гепатити, холецистити, холангіти, панкреатити без схильності до загострення; дискінезія жовчевивідних шляхів і кишечника; хронічні гастрити і гастродуоденіти, виразкова хвороба шлунку і дванадцятипалої кишки, хронічні коліти, ентероколіти, хвороби оперованого шлунку, хвороби обміну речовин (цукровий діабет, сечокислі діатези, ожиріння та ін); супутні захворювання (остеохондрози, гінекологічні захворювання, захворювання сечостатевої системи у чоловіків).

- Санаторно-лікувальні заклади Немирова, Прикарпаття використовують унікальні сірчановодородні води для зовнішнього використання та мінеральні води «Анна» для внутрішнього застосування. Тут знаходиться єдиний санаторій в Україні «Немирів», що спеціалізується на лікуванні шкіряних захворювань.

- Мінеральні води Східниці, Прикарпаття лікують цукровий діабет, діатези, захворювання нирок та печінки, підвищену та понижену кислотність шлунка, малокрів'я. На території Східницького родовища мінеральних вод налічується 38 джерел і понад 17 свердловин з різним фізико-хімічним складом.

\section{5. Вплив економічних факторів на попит на бальнеологічні послуги}

Співставлення пропозицій бальнеологічних послуг лікувально-оздоровчими комплексами країн Карпатського регіону потребує деякого суттєвого уточнення. Традиційно лікувальний тур у зарубіжних країнах (до такої методики побудови турів починають переходити і українські санаторно-курортні заклади) структуруються по набору різного 
характеру послуг (проживання, харчування, лікувальні процедури, огляд лікаря, діагностика, лікування, користування басейном, транспортний трансфер, тощо). Часто, по бажанню чи можливостях споживача, визначається термін оздоровлення чи лікування. Окрім класу (рівня якості, «зірковості») закладів, що надають відповідні послуги їх споживачам, на рівень кінцевої вартості лікувально-оздоровчого туру (циклу чи курсу) будуть впливати ціни на окремі послуги, їх кількість та якість. А у випадку оплати закордонного лікувально-оздоровчого туру на гривневий еквівалент ціни у інвалюті суттєво вплине валютний курс на платоспроможний попит вітчизняних споживачів бальнеологічних послуг. Як показує практика в останні роки стримуючим фактором у попиті українських громадян на лікувально-оздоровчі послуги за кордоном є зниження курсу гривні до долара чи євро.

Порівняємо цінові пропозиції бальнеологічних закладів країн Карпатського регіону на початок 2017 року (вони як правило є типовими для однакових наборів послуг та класу закладу). Так, термальний курорт Словаччини Пієштяни пропонує розширений лікувальний тур (7 ночей, проживання, повний пансіон, 4 лікувальні процедури на день крім вихідних) вартістю від 427 євро на одну особу. Супутні витрати, наприклад, курортний збір (1євро/з особи за 1 ніч), візова підтримка (35 євро), транспортний трансфер, медичний страховий поліс та інше це - додаткові витрати відпочивальника. Бальнеологічний курорт Бохня, Чехія на лютий 2017 року пропонує через туристичні агентства лікувальний тур за 8404 грн. (7 ночей), не враховуючи вартість перерахованих додаткових і обов'язкових витрат. Для порівняння - цінова пропозиція бальнеологічного лікування вітчизняним санаторієм «Райдуга» (Волочийськ, Хмельницької області ) на початок 2017 року складає від 330 грн. з однієї особи за добу до 390 грн. у залежності від категорії номеру проживання., включаючи у цю суму оплату проживання, харчування та лікувальні послуги. Санаторій «Кристал», м.Трускавець у цей же період здійснює цінову пропозицію від 405 грн. на одну особу за добу (однокімнатний номер класу «економ. лікувальний», 3-х разове харчування та лікувальні послуги за призначенням лікаря) до 850 грн.

Попит на бальнеологічні послуги можна активізувати активним інформаційним супроводом 3 поточним його оновленням. За своїми бажаннями чи можливостями споживачі бальнеологічних послуг можуть скористатись альтернативними пропозиціями послуг гос- 
тинності (проживання), вибираючи між пропозиціями лікувальних закладів чи малих готелів, чи приватних власників житла. Співставимо цінові рівні таких пропозицій у країнах Карпатського регіону. Наприклад, цінові пропозиції готельних послуг різної «зірковості» в Угорщині(наприклад, у Будапешті) станом на березень 2018 р. склалися у амплітуді від 37 євро за добу (двозірковий готель) до 86 євро (чотирьохзірковий готель) [15].

Ціни на вхідні квитки в бальнеологічні купальні, наприклад, купалень Сечені, Угорщина складають 14 та 15 євро у будень та вихідний дні. Для порівняння - вхідний білет на одного дорослого в зону термальних вод бази відпочинку Косино (с. Косино Берегівського району, Закарпаття, Україна) - 300 грн. (3 год. перебування). Вартість самостійно організованого харчування, наприклад, в бюджетному ресторані Угорщини складе 5,64 євро на одну особу, в ресторані середнього класу - 15,1 євро, що в 1,56 рази дорожче, ніж в Україні. Вартість харчових продуктів також дорожча, ніж в Україні - в 1,43 рази: хліб (0.5 кг) 0,74 євро, яйця (10 штук) - 1,72 євро, ковбаса (1кг) -11,54 євро, яблука (1кг) $-1,23$ євро [15].

Цінові пропозиції бальнеологічних курортів Чехії, наприклад, станом на березень 2018p. (включаючи 18 ночей проживання, лікувальних процедур від 31 до 46,3-х разове харчування, питний курс, 1-2 огляди лікаря) коливаються від 946 до 2058 євро за 1 дорослу людину. Якщо прорахувати гривневий еквівалент (у середньому по діючому валютному курсу 34 гривні за євро) тільки курс лікування за названими пропозиціями, то для пересічних українських споживачів така послуга буде дорогою-від 34 тис. грн. до 68 тис. грн. [17].

Обов'язковим елементом витрат у лікувальному туризмі із споживанням послуг на бальнеологічних курортах $є$ оплата транспортних послуг. 3 врахуванням рівня та коливань валютного курсу української гривні до долара чи євро можна зробити висновок про економічну вигідність оздоровлення та лікування громадян з Європи у бальнеологічних курортах України.

Економічною проблемою усіх суб'єктів ринку лікувально-оздоровчого туризму є недостатня (у тому числі комплексна) інформація щодо протипоказань під час лікування певними видами лікувальних мінеральних вод, необхідних для проходження лікування видів супроводжуючих документів (результатів діагностики, висновки лікарів 
щодо діагнозу та рекомендацій щодо терміну та режиму лікування), вартості супутніх послуг, транспортної логістики (яка б оптимізувала час, витрати та комфорт трансферу для туриста). Економічний фактор впливає на інформаційний сектор ринку лікувально-оздоровчого туризму, адже це діяльність господарських суб'єктів.

\section{6. Висновки}

Узагальнюючи результати проведеного дослідження, можна зробити наступні висновки:

Природний лікувальний рекреаційний потенціал країн Карпатського регіону у поєднанні з вигідним їх географічним положенням - у центрі Європи, досить розвинутою транспортною мережею є важливою передумовою активізації попиту та пропозиції на національних ринках бальнеологічних послуг країн Карпатського регіону. Для підтвердження цього можна навести наступні основні аргументи.

1. Наявність у країнах Карпатського регіону різнопланових за своїми фізико-хімічними характеристиками та медичними показаннями щодо лікування патологій систем організму людини бальнеологічних ресурсів.

2. На основі бальнеологічних ресурсів країн Карпатського регіону сформувалися (із значною історичною практикою) і успішно функціонують бальнеологічні комплекси, у структурі яких взаємодіють всі необхідні складові частини - родовища та джерела лікувальних мінеральних вод, курортні заклади, туристична інфраструктура.

3. Лікування на зарубіжних бальнеологічних курортах об'єктивно супроводжується ознайомленням громадян 3 історією, культурою, традиціями, соціально-економічними процесами в інших державах. В сукупності такий міжнародний туризм сприяє економічній ефективності функціонування багатьох галузей національних економік.

4. На динаміку міжнародного лікувально-оздоровчого туризму у зоні країн Карпатського регіону суттєво впливають економічні чинники та політична стабільність.

5. Відповідність пропозицій бальнеологічних послуг країнами Карпатського регіону потребам громадян з різних регіонів світу у лікувально-оздоровчих послугах є умовою ефективного функціонування не тільки національних ринків лікувально-оздоровчого туризму, а й національних економік цих країн. 


\section{Список літератури:}

1. Бабов К., Киселевська А., Нікіпелова О. Лікувальні води: сучасний стан міжнародної та національної нормативної бази // Стандартизація: методологія та практика, 2011. - № 5. - С. 3-11.

2. Дороговказ. [Електронний ресурс]. - Режим доступу: https:// ua.dorogovkaz.com/sanatorii_balneologicheskie.php.

3. Завадяк М. Бальнеологические курорты Закарпатской области / М. Завадяк, И. Мадрыга, М. Попович. - Ужгород : Ліра, 2012. - 256 с.

4. Лечебные минеральные воды типа «Нафтуся» Украинских Карпат и Подолья / В. М. Шестопалов и др. - Черновцы: Букрек, 2013. - 508 с.

5. Матвієнко Н.М., Матвієнко В.М., Ігнатенко А.В. Бальнеологічні курорти Угорщини на світовому туристичному ринку. Київський національний університет імені Тараса Шевченка. Збірник «Географія та туризм» № 18 [Електронний ресурс]. - Режим доступу: http://www.geolgt.com.ua/index. php?option $=$ com_content\&view $=$ article\&id $=54 \&$ Itemid $=40 \&$ lang $=u k$.

6. Медицинский справочник. Курорты. [Електронний ресурс]. - Режим доступу: www.medical-enc.ru/kurort/polska.shtml.

7. Мінеральні води України / Б. І. Аксентійчук, Н. О. Алексєєнко, О. І. Андрієнко, К. Д. Бабов, І. К. Бабова. - К.: Купріянов А., 2005. - 576 с.

8. Нафтуся Тур. [Електронний ресурс]. - Режим доступу: naftusia.com.

9. Оксана Стецюк. Карпатський регіон України в системі національного виробництва мінеральних вод. Львівський національний університет імені Івана Франка Вісник Львівського університету. Серія географічна. 2014. Випуск 47. С. 254-264.

10. Санаторії Закарпаття. [Електронний ресурс]. - Режим доступу: sanatorii-zakarpattia.com/ua.

11. Світ води. [Електронний ресурс]. - Режим доступу: svit-vody.com/ua.

12. Bavaria-tour. [Електронний pecypc]. - Режим доступу: www.bavaria-tour.com.ua.

13. Ianc Teodor Petre. Strategii dezvoltare a turismului balnear în România în perspectiva integrării Europene. Teză doctorat. - București: Academia de studii economice, 2006. - $351 \mathrm{p}$.

14. Glăvan Vasile. Geografia turismului / Vasile Glăvan. - București, Editura Fundației România de Mâine, 2005. - 336 p.

15. HikersBay. [Електронний ресурс]. - Режим доступу: hikersbay.com/ prices/hungari?lang=ua.

16. Munteanu C. Ape minerale terapeutice. - București: Editura Balneară, 2013. -64 p.

17. Sanatoriums.com. [Електронний ресурс]. - Режим доступу: // www. sanatoriums.com/ru/chehiya.

18. Součková Lucie. Analýza a rozvoj lázeňství v České republice: lázeňské a př́rodní léčivé zdroje / Lucie Součková [Електронний ресурс]. - Режим доступу: https://dk.upce.cz/bitstream/handle/10195/36098/SouckovaL_Analyza\%20a\%20 rozvoj_SB_2010.pdf?sequence $=1$ \&isAllowed $=\mathrm{y}$.

19. Spa \& Wellness in Hungary. [Електронний pecypc]. - Режим доступу: www.thermal.hu. 
20. Turtella клуб путешественников. [Електронний ресурс]. - Режим доступу: https://turtella.ru/Slovakia.

\section{References:}

1. Babov K., Kyselevska A., Nikipelova O. (2011) Likuvalni vody: suchasnyi stan mizhnarodnoi ta natsionalnoi normatyvnoi bazy [Medical water: the current state of the international and national regulatory framework] // Standartyzatsiia: metodolohiia ta praktyka, no 5. - pp. 3-11. (in Ukrainian)

2. Dorogovkaz. [Dorohovkaz] Available at: https:/ua.dorogovkaz.com/ sanatorii_balneologicheskie.php. (accessed 25 February 2018).

3. Zavadyak M. (2012) Bal'neolohycheskye kurorty Zakarpatskoy oblasty [Balneological resorts of the Transcarpathian region]. Uzhhorod: Lira, $256 \mathrm{p}$. (in Ukrainian)

4. Shestopalov V. M. (2013) Lechebnble myneral'nye vody typa "Naftusya" Ukraynskykh Karpat y Podol'ya [Therapeutic mineral waters of the type "Naftusya" of the Ukrainian Carpathians and Podillya]. Chernovtsy: Bukrek, 508 p. (in Ukrainian)

5. Matviienko N.M., Matviienko V.M., Ihnatenko A.V. (2012) Balneolohichni kurorty Uhorshchyny na svitovomu turystychnomu rynku [The balneological balneal resorts of Hungary in the world tourist market] Heohrafiia ta turyzm [Geography and Tourism]. (electronic journal), vol. 18. Available at: http://www.geolgt.com.ua/index.php?option=com_content\&view $=$ article\&id=54\& Itemid=40\&lang= $u$ (accessed 25 February 2018).

6. Medytsynskyy spravochnyk. Kurorty. [Medical reference book. Resorts]. Available at: www.medical-enc.ru/kurort/polska.shtml (accessed 27 February 2018)

7. Aksentiichuk B. I., Aleksieienko N. O., Andriienko O. I., Babov K. D., Babova I. K. (2005) Mineralni vody Ukrainy [Mineral waters of Ukraine]. - K.: Kupriianov A., 576 p. (in Ukrainian).

8. Naftusya Tur. [Naftusya Tur] Available at: naftusia.com (accessed 27 February 2018).

9. Oksana Stetsiuk. (2014) Karpatskyi rehion Ukrainy v systemi natsionalnoho vyrobnytstva mineralnykh vod. [Carpathian region of Ukraine in the system of national production of mineral waters] Visnyk Lvivskoho universytetu. [Visnyk of Lviv University] Seriia heohrafichna. vol. 47. pp. 254-264.

10. Sanatorii Zakarpattia. [Sanatoria of Transcarpathia.] Available at: sanatoriizakarpattia.com/ua (accessed 03 March 2018).

11. Світ води. [The world of water] Available at: svit-vody.com/ua (accessed 05 March 2018)

12. Bavaria-tour [Bavaria-tour] Available at: www.bavaria-tour.com.ua. (accessed 06 March 2018).

13. Ianc Teodor Petre. (2006). Strategii dezvoltare a turismului balnear în România în perspectiva integrării Europene. Teză doctorat. - București: Academia de studii economice, $-351 \mathrm{p}$.

14. Glăvan Vasile. (2005). Geografia turismului / Vasile Glăvan. - București, Editura Fundației România de Mâine, -336 p. 
15. HikersBay. [HikersBay] Available at: hikersbay.com/prices/hungari?lang=ua (accessed 03 March 2018).

16. Munteanu C. (2013). Ape minerale terapeutice. - București: Editura Balneară, $-64 \mathrm{p}$.

17. Sanatoriums.com. [Sanatoriums.com] Available at: https://www. sanatoriums.com/ru/chehiya. (accessed 27 February 2018).

18. Součková Lucie. (2010). Analýza a rozvoj lázeňství v České republice: lázeňské a př́rodní léčivé zdrojeю Available at: https://dk.upce.cz/bitstream/ handle/10195/36098/SouckovaL_Analyza\%20a\%20rozvoj_SB_2010.pdf? sequence $=1 \&$ isAllowed $=y$ (accessed 24 February 2018).

19. Spa \& Wellness in Hungary. [Spa \& Wellness in Hungary] Available at: www.thermal.hu. (accessed 09 March 2018).

20. Turtella klub puteshestvennykov [Turtella Travel Club] Available at: https://turtella.ru/Slovakia. (accessed 03 March 2018). 
Strategy of economic governance of metallurgical enterprise via innovative...

STRATEGY OF ECONOMIC GOVERNANCE

OF METALLURGICAL ENTERPRISE

VIA INNOVATIVE APPROACHES

\section{Levchuk Katerina ${ }^{1}$ \\ Romanyuk Roman ${ }^{2}$}

DOI: http://dx.doi.org/10.30525/978-9934-571-28-2_16

Abstract. In market economy, innovation is an effective means of competition, since it helps to reduce production costs, to increase profits, to invite investments, to improve the manufacturer's image, as well as to open and conquer new markets. In connection with this, it is vital to develop a complex of measures aimed at improving competitiveness, which will render the enterprise financially sustainable.

To address these challenges it is necessary to take into account the features of the metallurgical industry: significant investment inflow for functional and process changes, decent outsourcing potential of the branch, the need for support and improvement of material and technical maintenance of logical instruments, lack of skilled personnel who are capable of addressing high-level tasks with due expertise.

This research is devoted to innovative economic mechanisms of running metallurgical enterprise aimed at reducing production costs, and, accordingly, improving its competitiveness.

It is proposed to use indicators calculated by either matrix or tabular method in order to outline economical results of the enterprise, including generalized information about its technical and economic and financial condition, the dynamics of its development, changes in the evaluation of outcomes and action reserves.

Computing of indicators behind economic performance of the enterprise via the given algorithm allows to see interrelations of economic processes and their indicators, promotes transparency and efficiency of the analysis, clarity of perception, promotes the quality of results of the

\footnotetext{
${ }^{1} \mathrm{PhD}$ in Economic Sciences, Associate Professor, Dniprovsk State Technical University, Ukraine $2 \mathrm{PhD}$ in Technical Sciences, Associate Professor, Dniprovsk State Technical University, Ukraine 
adopted management solutions, allows for constant operational control and monitoring.

We also considered the method of reducing production costs resulting from improvements in the management of material flows of a steel enterprise via logistical approach. In this case, we used the correlation method to determine the duration of production streams. It intends to develop a mathematical model of the length of production stream. The conducted research allows to argue that improving the management of material flows based on logistic approach helps to eliminate the organizational and technical reasons that cause long idle time and delay in the moving of metal in all considered material flows.

The next component of reducing the cost of production is labor efficiency. When analyzing foreign experience, a certain system of indicators should be created in a market environment. This system should be public and common for all enterprises, should be regularly displayed in official sources. This will enable enterprises to analyze and plan their activities on a scientific basis, based on broad and truthful information about competitors. Addressing issues of labor efficiency will ensure: quality and profitability of labor, efficiency and intensity of expenses, stability and profitability of labor, efficient use of labor reserves, social security in the workplace, the necessary number of jobs in new areas of activity, decent standard of living, effective credit and monetary policy, investing in the human factor (in the social sphere), science and education, raising capital-labour ratio.

Thus, presented paper analyses innovative economic mechanisms to ensure effective performance of metallurgical enterprise. For the innovative system to be productive, all its components must work, and in close interconnection.

\section{Introduction}

The role of innovations in modern economy is immense. They ensure the overall competitiveness of produce and the enterprise, as well as promote high profits. In market economy, innovation is an effective means of competition, since it helps to reduce production costs, to increase profits, to invite investments, to improve the manufacturer's image, as well as to open and conquer new markets.

In connection with this, it is vital to develop a complex of measures aimed at improving competitiveness, which will render the enterprise financially sustainable $[1 ; 2]$. 
The basic indicators of ensuring financial sustainability are price, quality and actual cost of production. Therefore, the company needs to correlate closely methods of managing costs, the quality of produce and its price calculations.

The main components of innovative systems are:

- science and its research results, providing the source material (fundamentals) for the whole "chain of innovative development";

- innovative enterprises (organizations) that embrace innovations and create a new product that significantly affects the level and quality of the country's gross domestic product and its competitiveness;

- innovative management etc.

For the innovative system to be productive, all its components must work, and in close interconnection.

The purpose of the paper. This research is devoted to innovative economic mechanisms of running metallurgical enterprise aimed at reducing production costs, and, accordingly, improving its competitiveness.

\section{Business efficiency}

Attaining the desired economical results of the company's performance is one of the main objectives of its operation, the responsibility for addressing them is entrusted to the management apparatus. Therefore, we shall start by considering the main groups of indicators which can be used to assess the effectiveness of any enterprise.

As shown by literary sources, there are more than 100 points in the set of indicators, which allows the executive to see the full picture of the company's economic performance.

It is proposed to use indicators calculated by either matrix or tabular method [3; 4] in order to outline economical results of the enterprise, including generalized information about its technical and economic and financial condition, the dynamics of its development, changes in the evaluation of outcomes and action reserves.

Comparing indicators from short-term dynamic periods, the ones actually achieved with the ones forecasted and the achieved ones with the standard indicators serves as a basis for decision-making.

The calculation of indicators characterizing production-economic activity of the enterprise via the matrix method begins with the selection of qualitative indicators of work results. The number of indicators may be differ- 
ent, but it is expedient to use no more than 10 of the most important ones, which ensure control over economic activity and serve as basis to argue managerial solutions.

When analyzing the work of any enterprise it is expedient to apply the following indicators:

- production sales revenue (PSR), UAH;

- gross profit (GP), UAH;

- net (balance) profit (NP); UAH;

- material costs (MC), UAH;

- production costs (PC), UAH;

- capital goods (CG), UAH;

- labor costs (LC), UAH;

- average number of workers (ANW), people.

The selected indicators are then entered in the first line of the matrix table as output, and in the first column as factors influencing these results. In the intersections of columns and lines of the table we calculate relative indices by dividing the value of the column indicator by the one of the line indicator. Such elements of the table as profitability, material productivity, capital productivity, material intensity, capital-output ratio, labor productivity, capital-labour ratio, own product real wages, expenses per $1 \mathrm{UAH}$ of produce are well-known and often used in traditional analysis. Other items do not have widely known special names.

In the managerial analysis conducted in accordance with this algorithm, their names are given in table 1.

Similar tables are considered concerning the data from reporting and reference period. Given the ease of calculations and the availability of source data in current financial statements, the calculation period can be selected starting from 1 day.

Tables 2-4 contain input data and calculations for the system of indicators of an enterprise's performance, used in the matrix method of managerial analysis behind economic results, are given in. The initial data and calculations were performed for a metallurgical enterprise.

At the last stage, we compute relative changes in the indicators by dividing them in the reporting period into corresponding indicators of the reference period, we also fill the summary table with relative changes in the enterprise's indicators in the reporting period. Based on the changes computed, one can calculate the efficiency of performance of any enterprise. 
The system of performance indicators of enterprises used in the matrix analysis

\begin{tabular}{|c|c|c|c|c|c|c|c|}
\hline & \begin{tabular}{|c|} 
Production \\
sales \\
revenue \\
PSR
\end{tabular} & $\begin{array}{c}\text { Gross } \\
\text { profit GP }\end{array}$ & $\begin{array}{c}\text { Net } \\
\text { (balance) } \\
\text { profit NP }\end{array}$ & $\begin{array}{c}\text { Material } \\
\text { expenses } \\
\text { ME }\end{array}$ & $\begin{array}{c}\text { Production } \\
\text { costs PC }\end{array}$ & $\begin{array}{c}\text { Fixed } \\
\text { assets FA }\end{array}$ & $\begin{array}{l}\text { Labor } \\
\text { costs LC }\end{array}$ \\
\hline $\begin{array}{l}\text { production } \\
\text { sales } \\
\text { revenue } \\
\text { PSR }\end{array}$ & & $\begin{array}{c}\text { sales } \\
\text { profitability }\end{array}$ & $\begin{array}{c}\text { sales } \\
\text { profitability }\end{array}$ & $\begin{array}{c}\text { material } \\
\text { productivity } \\
\text { of of sales }\end{array}$ & $\begin{array}{l}\text { costs per } \\
1 \text { UAH of } \\
\text { profits }\end{array}$ & $\begin{array}{c}\text { capital- } \\
\text { output ratio }\end{array}$ & $\begin{array}{c}\text { own } \\
\text { product real } \\
\text { wages }\end{array}$ \\
\hline $\begin{array}{c}\text { gross profit } \\
\text { GP }\end{array}$ & $\begin{array}{c}\text { sales per } \\
1 \mathrm{UAH} \text { of } \\
\text { gross profit }\end{array}$ & & $\begin{array}{l}\text { gross profit } \\
\text { profitability }\end{array}$ & $\begin{array}{l}\text { material } \\
\text { intensity of } \\
\text { gross profit }\end{array}$ & $\begin{array}{c}\text { costs per } \\
1 \mathrm{UAH} \text { of } \\
\text { gross profit }\end{array}$ & $\begin{array}{c}\text { capital- } \\
\text { output ratio } \\
\text { of gross } \\
\text { profit }\end{array}$ & $\begin{array}{c}\text { own } \\
\text { product real } \\
\text { wages of } \\
\text { gross profit }\end{array}$ \\
\hline $\begin{array}{c}\text { Net } \\
\text { (balance) } \\
\text { profit NP }\end{array}$ & $\begin{array}{c}\text { profit per } 1 \\
\begin{array}{c}\text { UAH of net } \\
\text { profit }\end{array} \\
\end{array}$ & $\begin{array}{c}\text { net profit } \\
\text { profitability }\end{array}$ & & $\begin{array}{c}\text { material } \\
\text { intensity of } \\
\text { net profit }\end{array}$ & $\begin{array}{c}\text { profit per } 1 \\
\text { UAH of net } \\
\text { profit }\end{array}$ & $\begin{array}{c}\text { capital-out- } \\
\text { put ratio of } \\
\text { net profit }\end{array}$ & $\begin{array}{c}\text { capital-out- } \\
\text { put ratio of } \\
\text { net profit }\end{array}$ \\
\hline $\begin{array}{c}\text { Material } \\
\text { expenses } \\
\text { ME }\end{array}$ & $\begin{array}{c}\text { material } \\
\text { productivity }\end{array}$ & $\begin{array}{c}\text { material } \\
\text { profitability }\end{array}$ & $\begin{array}{c}\text { material } \\
\text { profitability }\end{array}$ & & $\begin{array}{c}\mathrm{PC} \text { to } \mathrm{MC} \\
\text { ratio }\end{array}$ & $\begin{array}{c}\mathrm{CG} \text { to } \mathrm{MC} \\
\text { ratio }\end{array}$ & $\begin{array}{l}\mathrm{LC} \text { to } \mathrm{MC} \\
\text { ratio }\end{array}$ \\
\hline $\begin{array}{c}\text { Production } \\
\text { costs PC }\end{array}$ & $\begin{array}{l}\text { return on } \\
\text { costs }\end{array}$ & $\begin{array}{c}\text { cost } \\
\text { profitability }\end{array}$ & $\begin{array}{c}\text { Cost } \\
\text { profitability }\end{array}$ & $\begin{array}{l}\text { MC share } \\
\text { in cost } \\
\text { price }\end{array}$ & & $\begin{array}{l}\mathrm{CG} \text { to } \mathrm{PC} \\
\text { ratio }\end{array}$ & $\begin{array}{l}\mathrm{LC} \text { to } \mathrm{PC} \\
\text { ratio }\end{array}$ \\
\hline $\begin{array}{c}\text { Fixed } \\
\text { assets FA }\end{array}$ & $\begin{array}{c}\text { capital } \\
\text { productivity }\end{array}$ & $\begin{array}{c}\text { capital } \\
\text { stock profit- } \\
\text { ability }\end{array}$ & $\begin{array}{c}\text { capital } \\
\text { stock profit- } \\
\text { ability }\end{array}$ & $\begin{array}{c}\mathrm{MC} \text { to } \mathrm{CG} \\
\text { ratio }\end{array}$ & $\begin{array}{l}P C \text { to } C G \\
\text { ratio }\end{array}$ & & $\begin{array}{l}\mathrm{LC} \text { to } \mathrm{CG} \\
\text { ratio }\end{array}$ \\
\hline $\begin{array}{l}\text { Labor } \\
\text { costs LC }\end{array}$ & $\begin{array}{c}\text { return on } \\
\text { labor costs }\end{array}$ & $\begin{array}{l}\text { Labor costs } \\
\text { profitability }\end{array}$ & $\begin{array}{l}\text { labor costs } \\
\text { profitability }\end{array}$ & $\begin{array}{c}\mathrm{MC} \text { to } \mathrm{LC} \\
\text { ratio }\end{array}$ & $\begin{array}{l}\mathrm{PC} \text { to } \mathrm{LC} \\
\text { ratio }\end{array}$ & $\begin{array}{l}\mathrm{CG} \text { to } \mathrm{LC} \\
\text { ratio }\end{array}$ & \\
\hline $\begin{array}{c}\text { Average } \\
\text { number of } \\
\text { workers } \\
\text { ANW }\end{array}$ & $\begin{array}{c}\text { labor } \\
\text { productivity }\end{array}$ & $\begin{array}{l}\text { gross } \\
\text { profit per } \\
\text { employee }\end{array}$ & $\begin{array}{l}\text { net profit } \\
\text { per } \\
\text { employee }\end{array}$ & $\begin{array}{c}\text { working } \\
\text { capital-to- } \\
\text { labor ratio }\end{array}$ & $\begin{array}{l}\text { expenses to } \\
\text { labour ratio }\end{array}$ & $\begin{array}{c}\text { capital- } \\
\text { labour ratio }\end{array}$ & $\begin{array}{c}\text { average } \\
\text { annual } \\
\text { salary }\end{array}$ \\
\hline
\end{tabular}

Table 2

Input data of the enterprise in the reporting and reference period

\begin{tabular}{|l|c|c|c|c|c|c|c|c|}
\hline & $\begin{array}{c}\text { PSR, } \\
\text { thous. } \\
\text { UAH }\end{array}$ & $\begin{array}{c}\text { GP, } \\
\text { thous. } \\
\text { UAH }\end{array}$ & $\begin{array}{c}\text { NP, } \\
\text { thous. } \\
\text { UAH }\end{array}$ & $\begin{array}{c}\text { MC, } \\
\text { thous. } \\
\text { UAH }\end{array}$ & $\begin{array}{c}\text { PC, } \\
\text { thous. } \\
\text { UAH }\end{array}$ & $\begin{array}{c}\text { CG, } \\
\text { thous. } \\
\text { UAH }\end{array}$ & $\begin{array}{c}\text { LC, } \\
\text { thous. } \\
\text { UAH }\end{array}$ & $\begin{array}{c}\text { ANW, } \\
\text { ppl }\end{array}$ \\
\hline $\begin{array}{l}\text { Reporting } \\
\text { period }\end{array}$ & 3508482 & 1156715 & 865417 & 2172027 & 2727277 & 2277216 & 143722 & 33421 \\
\hline $\begin{array}{l}\text { Reference } \\
\text { period }\end{array}$ & 2389639 & 261540 & -256368 & 1786971 & 2252578 & 2301891 & 102037 & 30665 \\
\hline $\begin{array}{l}\text { RpD to } \\
\text { RfD ratio }\end{array}$ & 1,47 & 4,42 & $-3,38$ & 1,22 & 1,21 & 0,99 & 1,41 & 1,09 \\
\hline
\end{tabular}




\section{Results of computing performance indicators} of the enterprise via matrix method

\begin{tabular}{|c|c|c|c|c|c|c|c|c|c|}
\hline \multirow{2}{*}{ Reporting period } & PSR & GP & NP & MC & PC & CG & LC & ANW \\
\cline { 3 - 11 } & 3508482 & 1156715 & 865417 & 2172027 & 2727277 & 2277216 & 143722 & 33421 \\
\hline \multicolumn{2}{|c|}{1} & 2 & 3 & 4 & 5 & 6 & 7 & 8 & 9 \\
\hline PSR & 3508482 & 1 & 0,329 & 0,246 & 0,619 & 0,777 & 0,649 & 0,040 & 0,009 \\
\hline GP & 1156715 & 3,033 & 1 & 0,748 & 1,877 & 2,357 & 1,968 & 0,124 & 0,028 \\
\hline NP & 865417 & 4,054 & 1,336 & 1 & 2,509 & 3,151 & 2,631 & 0,166 & 0,038 \\
\hline MC & 2172027 & 1,615 & 0,532 & 0,398 & 1 & 1,255 & 1,048 & 0,066 & 0,015 \\
\hline PC & 2727277 & 1,286 & 0,424 & 0,317 & 0,796 & 1 & 0,834 & 0,052 & 0,012 \\
\hline CG & 2277216 & 1,540 & 0,507 & 0,380 & 0,953 & 1,197 & 1 & 0,063 & 0,014 \\
\hline LC & 143722 & 24,411 & 8,048 & 6,021 & 15,112 & 18,976 & 15,844 & 1 & 0,232 \\
\hline ANW & 33421 & 104,978 & 34,610 & 25,894 & 64,989 & 81,603 & 68,137 & 4,300 & 1 \\
\hline \multirow{2}{*}{ Reference period } & PSR & GP & NP & MC & PC & CG & LC & ANW \\
\hline & 2389639 & 261540 & -256368 & 1786971 & 2252578 & 2301891 & 102037 & 30665 \\
\hline PSR & 2389639 & 1 & 0,109 & $-0,107$ & 0,747 & 0,942 & 0,963 & 0,042 & 0,012 \\
\hline GP & 261540 & 9,136 & 1 & $-0,980$ & 6,832 & 8,612 & 8,801 & 0,390 & 0,117 \\
\hline NP & -256368 & $-9,321$ & $-1,020$ & 1 & $-6,970$ & $-8,786$ & $-8,978$ & $-0,398$ & $-0,119$ \\
\hline MC & 1786971 & 1,337 & 0,146 & $-0,143$ & 1 & 1,260 & 1,288 & 0,057 & 0,017 \\
\hline PC & 2252578 & 1,060 & 0,116 & $-0,113$ & 0,793 & 1 & 1,021 & 0,045 & 0,013 \\
\hline CG & 2301891 & 1,038 & 0,113 & $-0,111$ & 0,776 & 0,978 & 1 & 0,044 & 0,013 \\
\hline LC & 102037 & 23,419 & 2,563 & $-2,512$ & 17,513 & 22,076 & 22,559 & 1 & 0,300 \\
\hline ANW & 30665 & 77,927 & 8,528 & $-8,360$ & 58,274 & 73,457 & 75,065 & 3,327 & 1 \\
\hline \multicolumn{2}{|l}{} & & & & & & & & \\
\hline
\end{tabular}

Table 4

Relative change in the indicators of enterprise's performance in the reporting period compared to the reference one

\begin{tabular}{|c|c|c|c|c|c|c|c|c|c|}
\hline \multicolumn{2}{|c|}{} & PSR & GP & NP & MC & PC & CG & LC & ANW \\
\cline { 3 - 10 } \multicolumn{2}{|c|}{} & 1,468 & 4,422 & $-3,375$ & 1,215 & 1,210 & 0,989 & 1,408 & 1,089 \\
\hline PSR & 1,468 & 1 & 3,012 & $-2,299$ & 0,827 & 0,824 & 0,673 & 0,959 & 0,742 \\
\hline GP & 4,422 & 0,331 & 1 & $-0,763$ & 0,274 & 0,273 & 0,223 & 0,318 & 0,246 \\
\hline NP & $-3,375$ & $-0,434$ & $-1,310$ & 1 & $-0,360$ & $-0,358$ & $-0,293$ & $-0,417$ & $-0,322$ \\
\hline MC & 1,215 & 1,207 & 3,638 & $-2,777$ & 1 & 0,996 & 0,813 & 1,158 & 0,896 \\
\hline PC & 1,210 & 1,212 & 3,652 & $-2,788$ & 1,003 & 1 & 0,817 & 1,163 & 0,900 \\
\hline CG & 0,989 & 1,484 & 4,470 & $-3,412$ & 1,228 & 1,223 & 1 & 1,423 & 1,101 \\
\hline LC & 1,408 & 1,042 & 3,139 & $-2,396$ & 0,862 & 0,859 & 0,702 & 1 & 0,773 \\
\hline ANW & 1,089 & 1,347 & 4,058 & $-3,097$ & 1,115 & 1,110 & 0,907 & 1,292 & 1 \\
\hline
\end{tabular}


Strategy of economic governance of metallurgical enterprise via innovative...

At the same stage, one can compute absolute changes in the indicators by deducting from the indicators of reporting period the corresponding indicators of the reference period and also one can fill the summary table of absolute changes in indicators of the enterprise's performance in the reporting period.

Economic performance of the enterprise is assessed for each indicator of the table along with the measuring the effect of various factors via the following formulas:

$$
\begin{aligned}
& \pm \Delta \Pi_{0}=\left(\Pi_{T}-1\right) 100 ; \\
& \pm \Delta \Pi_{u}=\left(\Pi_{T(4)}-1\right) 100 ; \\
& \pm \Delta \Pi_{3}=\left(\Pi_{T(3)}-1\right) 100,
\end{aligned}
$$

where $\Delta \Pi_{0}$ - relative total change of the table index the period analyzed, $\% ; \Pi_{T}$ - change of the table indicator, units; $\Delta \Pi_{u}-$ relative change of the indicator due to the change of the numerator in the calculation, $\%$; $\Delta \Pi_{3}$ - relative change of the indicator due to the change of denominator in the calculation, $\% ; \Pi_{T(4)}, \Pi_{T(3)}-$ the change of numerator and denominator respectively in the calculation of the indicator.

Computing results for relative indicators for assessing economic performance of the enterprise and the reasons behind their deviations are presented in Table 5 .

Table 5

Relative indicators for assessing economic performance of the enterprise

\begin{tabular}{|l|c|c|c|c|}
\hline \multirow{2}{*}{$\begin{array}{c}\text { Earnings per 1 UAH } \\
\text { of gross profit }\end{array}$} & \multicolumn{3}{|c|}{ Relative changes } & \multirow{2}{*}{ General } \\
\cline { 2 - 5 } & $\begin{array}{c}\text { Due to the } \\
\text { change of } \\
\text { numerator }\end{array}$ & $\begin{array}{c}\text { Due to the } \\
\text { change of } \\
\text { denominator }\end{array}$ & $\begin{array}{c}\text { Positive } \\
\text { changes }\end{array}$ \\
\hline Earnings per 1 UAH of gross profit & $-66,8$ & 4 & 4 & 5 \\
\hline Earnings per 1 UAH of net profit & $-143,5$ & 46,8 & $-342,3$ & Increase \\
\hline Material productivity & 20,8 & 46,8 & $-21,5$ & Increase \\
\hline Return on costs & 21,3 & 46,8 & $-21,1$ & Increase \\
\hline Capital productivity & 48,4 & 46,8 & 1,1 & Increase \\
\hline Return on labor costs & 4,2 & 46,8 & $-40,9$ & Increase \\
\hline Labor productivity & 34,7 & 46,8 & -9 & Increase \\
\hline Sales profitability & 201,2 & 342,3 & $-46,8$ & Increase \\
\hline
\end{tabular}




\begin{tabular}{|c|c|c|c|c|}
\hline \multicolumn{5}{|c|}{ Ending of Table 5} \\
\hline 1 & 2 & 3 & 4 & 5 \\
\hline Net earnings profitability & -231 & 342,3 & 437,6 & Increase \\
\hline Profitability of materials & 263,9 & 342,3 & $-21,5$ & Increase \\
\hline Profitability of expenses & 265,3 & 342,3 & $-21,1$ & Increase \\
\hline Profitability of CG & 347,1 & 342,3 & 1,1 & Increase \\
\hline Profitability of LC & 214 & 342,3 & $-40,9$ & Increase \\
\hline Gross profit per 1 employee & 305,8 & 342,3 & -9 & Increase \\
\hline Material intensity of earnings & $-17,2$ & 21,5 & $-46,8$ & Decrease \\
\hline Material intensity of gross profit & $-72,5$ & 21,5 & $-342,3$ & Decrease \\
\hline Material intensity of production costs & 0,4 & 21,5 & $-21,1$ & Decrease \\
\hline Material intensity of CG & 22,9 & 21,5 & 1,1 & Decrease \\
\hline Material intensity of LC & $-13,7$ & 21,5 & $-40,9$ & Decrease \\
\hline Working capital-to-labor ratio & 11,5 & 21,5 & -9 & Decrease \\
\hline Expenses per $1 \mathrm{UAH}$ of earnings & $-17,5$ & 21,1 & $-46,8$ & Decrease \\
\hline Expenses per $1 \mathrm{UAH}$ of gross profit & $-72,6$ & 21,1 & $-342,3$ & Decrease \\
\hline Expenses per $1 \mathrm{UAH}$ of net profit & $-135,9$ & 21,1 & 437,6 & Decrease \\
\hline Capital-earnings ratio & $-32,6$ & $-1,1$ & $-46,8$ & Decrease \\
\hline Capital-GP ratio & $-77,6$ & $-1,1$ & $-342,3$ & Decrease \\
\hline Capital-NP ratio & $-129,3$ & $-1,1$ & 437,6 & Decrease \\
\hline Capital-labour ratio & $-9,2$ & $-1,1$ & -9 & Decrease \\
\hline Wage intensity of earnings & $-4,1$ & 40,9 & $-46,8$ & Decrease \\
\hline Wage intensity of GP & $-68,2$ & 40,9 & $-342,3$ & Decrease \\
\hline Wage intensity of NP & $-141,7$ & 40,9 & 437,6 & Decrease \\
\hline Average annual salary & 29,2 & 40,9 & -9 & Decrease \\
\hline
\end{tabular}

Thus, computing of indicators behind economic performance of the enterprise via the given algorithm allows to see interrelations of economic processes and their indicators, promotes transparency and efficiency of the analysis, clarity of perception, promotes the quality of results of the adopted management solutions, allows for constant operational control and monitoring.

\section{Logistical systems and material flows.}

Next we shall consider the method of reducing production costs resulting from improvements in the management of material flows of a steel enterprise via logistical approach.

Efficient functioning of logistics systems is one of directions of innovative development in Ukrainian economy. Similar logistics systems should be developed alongside with $[5 ; 6]$ : 
- introduction of innovations and information technologies;

- development of single standards and unification of the running processes;

- reduction of the cost price of products and services provided;

- improving the efficiency of logistic business processes.

In conditions of dynamic development of the metallurgical industry where we observe the development and implementation of the mechanisms that enhance the efficiency of national economic policies via reengineering of existing organizational structures and business processes based on modern IT tools and logistics concepts; the following is gaining momentum:

- to determine and calculate the parameters of an effective logistic strategy of the metallurgical enterprise, based on its strategic and operational goals, on its methods of applying global logistic service, and also taking into account the current market conditions and situation;

- to introduce innovative information technologies to support logistic business processes of metallurgical enterprise. The solution to this problem involves the formation of an information system that in real-time mode is capable to accumulate, processe and present relevant data that ensure effective implementation of these logistic business processes;

- to launch centers of outsourcing interaction in order to construct an efficient system of management behind logistics business processes of the metallurgical industry as a whole.

To address these challenges it is necessary to take into account the features of the metallurgical industry:

- significant investment inflow for functional and process changes;

- decent outsourcing potential of the branch;

- the need for support and improvement of material and technical maintenance of logical instruments;

- lack of skilled personnel who are capable of addressing high-level tasks with due expertise.

The tool for solving the above-mentioned tasks is the concept of reengineering, which uses methods of process oriented management, economic and mathematical modeling as well as information technologies and systems.

Below are the main components in the mechanism of integrating logistics business processes into the management system of functional activity of metallurgical industry: 
- business logistics department;

- accounting;

- financial department;

- suppliers of operating resources;

- employees who, within the limits of their functional responsibilities, carry out logistic functions;

- integrated information system of electronic supply chain management.

The systems of material, informational, financial and other flows are the objects of research of both science and the sphere of entrepreneurship. The fundamental difference between the logistic approach and the management behind transferring material resources is that logistics manages the flow, that is, a number of objects that are perceived as a whole.

In logistics, the category of material flow is closely connected and practically can not exist without the "stock" category and from here it is expedient to consider flows and stocks as parity logistic categories that have their own specific characteristics. Hence, there is a close relationship between the dynamic characteristics of material flows and the statistical quantities of material stocks. The flow characterizes the changing of the stock, while the stock reflects the result of the change and accumulation of the flow.

Competition in market relations leads to the transformation of logistics systems, and in particular, it necessitates an increase in the speed of material flows, increases the intensity of their use, complicates the financial relations between logistic intermediaries and reduces the integrity of the logistic chain. At many enterprises, material inventories in production and in distribution networks almost run out.

These trends result in an increase of potential instability of logistics systems. Further research, analysis and study of behavior of logistics systems, their chains and flows contribute to increasing their sustainability and reliability in achieving strategic business goals.

\section{Research of material flows}

In order to improve the management (increased intensity of use) of material flows in a metallurgical enterprise there was carried out a research of their movement from raw materials to finished products. The purpose of the study is to determine the way various factors influence the length of the production cycle in the system of workshops and to search for ways to reduce them based on the logistics chain. 
The study of material flows was carried out within the framework of a steel mill with a full cycle of production (sinter-blast furnace, steelmaking, rolling) in the system of rolling mills [7;8].

The duration of the production cycle in the rolling mills depends on many factors. To determine their impact on the length of production cycle it is necessary to study the structure of production at this enterprise, determine the route of the metal flow from the moment it arrives in the shop till shipping to other enterprises.

The study of production structure yielded 6 main material flows, given in Table 6.

Table 6

Name and symbol of the main production flows

\begin{tabular}{|l|c|}
\hline \multicolumn{1}{|c|}{ Name of metal flow } & Symbol \\
\hline Blooming 1150 - merchant bar & 1 \\
\hline Blooming 1150 - PRM - merchant bar & 2 \\
\hline Blooming 1150 - PRM - mill “250" - rough forged axles & 3 \\
\hline Blooming 1150 - PRM - mill "400" - rolled section steel & 4 \\
\hline Blooming 1050 - RSSM - freight rails & 5 \\
\hline Blooming 1050 - RSSM - mill “400" - rolled section steel & 6 \\
\hline
\end{tabular}

Note: PRM - pipe rolling mill, RSSM - rail and structural steel mill

The duration of the production stream can be determined by several methods:

- calculation and analytical method according to which the flow duration is determined by the formulas, using planned data about production output and the actual operating time of the main machinery;

- determination of the length of production flow by monitoring and directly measuring the working time of individual operations;

- studying available accounting documents using economic and mathematical methods, for example, the method of multiple correlation.

In this case, we used the correlation method to determine the duration of production streams. It intends to develop a mathematical model of the length of production stream. This model looks as follows:

$$
y=a_{1} x_{1}+a_{2} x_{2}+\ldots+a_{i} x_{i}+6,
$$

where $a_{i}$-the duration of production stream; $x_{i}$-duration of individual operations; $\boldsymbol{\varepsilon}$ - variable number. 
All metal streams of this enterprise to be examined are divided into separate operations according to their structure, which means that $x_{i}$ factors are found.

To construct a correlation model for the duration of flows we select the factual data from the reporting documents, which define the start and end of the operation for a long time (six months).

Using these data, we made calculations using programs that were compiled in the Excel environment and the "Systat" package.

Based on the data obtained, multiple correlation equations were compiled for each flow, correlation coefficients were determined. These data are shown in Table. 7

Table 7

\section{The equation of multiple correlation}

for the duration of production flows

\begin{tabular}{|c|l|c|}
\hline $\begin{array}{c}\text { Flow } \\
\text { № }\end{array}$ & \multicolumn{1}{|c|}{ The equation of multiple correlation } & $\begin{array}{c}\text { Correlation } \\
\text { coefficients }\end{array}$ \\
\hline 1 & $y=x_{1}+0,999 x_{2}+0,999 x_{3}+0,01$ & 0,999 \\
\hline 2 & $y=0,96 x_{1}+1,09 x_{2}+0,99 x_{3}+0,94 x_{4}+x_{5}+x_{6}-0,16$ & 0,999 \\
\hline 3 & $\begin{array}{l}y=0,589 x_{1}+0,97 x_{2}+1,11 x_{3}+0,965 x_{4}+1,95 x_{5}+0,999 x_{6}+ \\
+0,76 x_{7}+0,33 x_{8}+0,506 x_{9}+0,961 x_{10}+7,3\end{array}$ & 0,99 \\
\hline 4 & $\begin{array}{l}y=1,04 x_{1}+1,53 x_{2}+0,98 x_{3}+0,999 x_{4}+0,93 x_{5}+1,05 x_{6}+ \\
+0,98 x_{7}-0,05\end{array}$ & 0,994 \\
\hline 5 & $y=0,73 x_{1}+0,71 x_{2}+0,76 x_{3}+0,96 x_{4}+0,63 x_{5}+3,06$ & 0,929 \\
\hline 6 & $y=13,7 x_{1}+3 x_{2}+1,25 x_{3}+1,8 x_{4}+0,065 x_{5}+7,17 x_{6}+1,32 x_{7}-39,8$ & 0,802 \\
\hline
\end{tabular}

Note: operations (production factors) $x_{i}$ are presented in tab. 8 .

The high correlation coefficient indicates the reliability of the models obtained and the close connection of the factors in the flow. Using these models, we determined the proportion of impact of each operation on the duration of the flows. In general, we established the following influence of operations (factors) on the duration of streams for all the work flows:

- technological operations make $5-20 \%$ of all time;

- transport - 2-39\%;

- operations related to handling and shipment $-43.5-90 \%$. 
Strategy of economic governance of metallurgical enterprise via innovative...

Table 8

Distribution of production factors

\begin{tabular}{|c|c|c|c|c|c|c|}
\hline \multirow{3}{*}{ The name of the operation } & \multicolumn{6}{|c|}{ Operations (factors) } \\
\hline & \multicolumn{6}{|c|}{ Flow № } \\
\hline & 1 & 2 & 3 & 4 & 5 & 6 \\
\hline 1. Expecting loading and heating in blooming mills 1050 & & & & & $\mathrm{x}_{1}$ & $\mathrm{x}_{1}$ \\
\hline 2. Heating time blooming mills 1050 & & & & & $\mathrm{x}_{2}$ & $\mathrm{x}_{2}$ \\
\hline 3. Expecting loading and heating in blooming mills 1150 & $\mathrm{x}_{1}$ & $\mathrm{x}_{1}$ & $\mathrm{x}_{1}$ & $\mathrm{x}_{1}$ & & \\
\hline 4. Cooling time in storehouse of blooming mill 1150 & & & $\mathrm{x}_{2}$ & & & \\
\hline 5. Rolling and cutting metal in blooming mill 1150 & $\mathrm{x}_{2}$ & $\mathrm{x}_{2}$ & $\mathrm{x}_{3}$ & $\mathrm{x}_{2}$ & & \\
\hline 6. Rolling and cutting metal on PRM & & $\mathrm{x}_{4}$ & $\mathrm{x}_{7}$ & $\mathrm{x}_{6}$ & & $\mathrm{x}_{6}$ \\
\hline $\begin{array}{l}\text { 7. Time for transportation of metal from blooming } 1150 \\
\text { to PRM, intermediate storage, including heating }\end{array}$ & & $\mathrm{x}_{3}$ & & $\mathrm{x}_{3}$ & & \\
\hline $\begin{array}{l}\text { 8. Rolling and cutting metal in blooming mill } 1050 \text { and } \\
\text { RSSM }\end{array}$ & & & & & $\mathrm{x}_{3}$ & $\mathrm{x}_{3}$ \\
\hline 9. Transporting operations & & & $\mathrm{x}_{4}$ & & & $\mathrm{x}_{4}$ \\
\hline $\begin{array}{l}\text { 10. Bloom's waiting time in PRM or RSSM receiving } \\
\text { warehouse }\end{array}$ & & & $\mathrm{x}_{6}$ & $\mathrm{x}_{4}$ & & $\mathrm{x}_{5}$ \\
\hline 11. Heating time in PRM continuous-type furnaces & & & $\mathrm{x}_{5}$ & $\mathrm{x}_{5}$ & & \\
\hline 12. Heating, rolling and cutting on mill " 400 ", shipping & & & & $\mathrm{x}_{7}$ & & $\mathrm{x}_{7}$ \\
\hline 13. Normalizing in RSSM & & & & & $\mathrm{x}_{4}$ & \\
\hline 14. Rolling and normalizing on mill " $250 "$ & & & $\mathrm{x}_{8}$ & & & \\
\hline 15. Finishing time on mill " 250 " or PRM & & $\mathrm{x}_{5}$ & $\mathrm{x}_{9}$ & & & \\
\hline 16. Shipping time on mill " 250 ” or PRM & & $\mathrm{x}_{6}$ & $\mathrm{x}_{10}$ & & & \\
\hline 17. Finishing and shipping on blooming 1050 or RSSM & $\mathrm{x}_{3}$ & & & & $\mathrm{x}_{5}$ & \\
\hline
\end{tabular}

Thus, we stress that it is operations related to processing and shipment that most significantly influence the duration of the operating cycle in the enterprise. Therefore, the main focus should be on the operations of group 3 in terms of reduction.

Based on reported and calculated data on the duration of production streams, there were complied operational maps showing the minimum, maximum, average and most likely duration of operations and flows in general (the most probable duration time is calculated via statistical package "Systat"). For example, tab. 9 features operations for the first flow.

The most probable duration of flows serve as template for calculating the standards for the duration of production cycles at the enterprise. On their basis, using the daily consumption of metal, we calculated working capital assets and the amount of their return as a result of bringing 
Table 9

Operational card for the duration of operations for the first flow

\begin{tabular}{|c|c|c|c|c|}
\hline \multirow[b]{2}{*}{ The list of operations } & \multicolumn{4}{|c|}{ Duration of the flow, hrs } \\
\hline & $\min$ & $\max$ & medium & $\begin{array}{c}\text { most } \\
\text { probable }\end{array}$ \\
\hline $\begin{array}{l}\text { Expecting loading and heating in bloom- } \\
\text { ing mills } 1150\end{array}$ & 2,2 & 5,7 & 5,0 & 5,0 \\
\hline $\begin{array}{l}\text { Rolling and cutting metal in blooming } \\
\text { mill } 1150\end{array}$ & 0,2 & 1,1 & 0,6 & 0,5 \\
\hline Finishing and shipping & 8,0 & 96,0 & 47,1 & 33,1 \\
\hline Total time of operation, including: & 10,4 & 102,8 & 52,7 & 38,6 \\
\hline $\begin{array}{ll}\text { - technological operations, } & \begin{array}{l}\text { hrs } \\
\%\end{array} \\
\end{array}$ & $\begin{array}{c}2,4 \\
23,1\end{array}$ & $\begin{array}{l}6,8 \\
6,6\end{array}$ & $\begin{array}{c}5,6 \\
10,6\end{array}$ & $\begin{array}{c}5,5 \\
14,2\end{array}$ \\
\hline $\begin{array}{r}- \text { finishing and shipping, } \mathrm{hrs} \\
\%\end{array}$ & $\begin{array}{c}8,0 \\
76,9\end{array}$ & $\begin{array}{l}96,0 \\
93,4\end{array}$ & $\begin{array}{l}47,1 \\
89,4\end{array}$ & $\begin{array}{l}33,1 \\
85,8\end{array}$ \\
\hline
\end{tabular}

the time of processing metal in the rolling mill to the level of projected standards.

The total amount of working capital released from stocks as a result of reducing the time of transferring metal equals $\$ 500$ thous. per production cycle in the enterprise researched.

The conducted research allows to argue that improving the management of material flows based on logistic approach helps to eliminate the organizational and technical reasons that cause long idle time and delay in the moving of metal in all considered material flows.

For practical implementation of logistic management principles it is necessary, for example, to turn the monitoring service of individual shops into the service for management of material flows of rolling mills or to create a separate logistic structure whose functions should be control and provision:

- of timely shipment of finished products;

- of order-based-production of appropriate quality and strict compliance of production plans to shipment timetables of finished products;

- timely delivery of vehicles during shipment of produce outside the enterprise and while transferring semi-finished products between mills.

An improved transport service management system that completely eliminates delays in moving metal flows, will serve a sound foundation for implementing logistic schedules based on optimal transport time specifications. Their implementation will minimize the duration of metal flow cycles, accelerate the return on working capital and increase the efficiency of their use. 


\section{Labor efficiency and productivity}

The next component of reducing the cost of production is labor efficiency.

Labor efficiency signifies socio-economic category, which determines the degree of achievement of this or another goal, correlated with the degree of rationality of resource expenses in this case.

Labor efficiency is a process of continuous, focused work on improving labor efficiency, or it is a process of searching the best solutions in one or another field of labor activity in order to achieve high results while reducing the cost per unit of these results.

The strategy of effectiveness signifies working out the main areas of improving labor efficiency based on the use of factors, reserves and resources to overcome economic crisis.

The essence of labor efficiency is represented by the concepts "labor productivity" and "labor profitability". The most common in theory and practice is the concept of "labor productivity".

Labor productivity is one of the decisive factors, which ensure an increase in the efficiency of production, reducing production costs. Therefore, the purpose of this study is to analyze the indicators that characterize the efficiency of enterprises, and to define the main and internal production reserves for its increasing.

It should be noted that enterprises that are actively trying to resist negative phenomena and lay the foundations for their future development, should apply the whole range of measures to improve the situation exactly in the present circumstances. Besides, it is impossible to achieve some stabilization of social production (let alone its growth) without stopping the slump and embracing the next cycle of growth of labor productivity. Addressing issues of labor efficiency should be the most important task of the entire socio-economic policy of enterprises. Without an increase in labor efficiency it is impossible to carry out structural adjustment, to create the necessary number of jobs in new areas of work, to ensure decent standard of living.

\section{System of performance indicators of the enterprise}

When analyzing foreign experience, a certain system of indicators should be created in a market environment. This system should be public and common for all enterprises, should be regularly displayed in official 
sources. This will enable enterprises to analyze and plan their activities on a scientific basis, based on broad and truthful information about competitors.

Tabl. 10 presents a system of performance indicators needed by any enterprise for analysis and planning, as well as for assessing its competitiveness [9-11].

The map of the organization enables to establish direct links with affiliated enterprises, to obtain additional information in case of need, to determine mutually beneficial terms of cooperation in the market conditions.

General economic indicators allow to estimate the level of enterprise's competitiveness, to correlate its scale of production, its financial capabilities, the level of social development with affiliated enterprises - its competitors.

Personnel indicators enable to assess the rationality of professional personnel structure, the correctness of staff placement. The average age of employees allows to draw conclusions about the potential of the employee community.

Personnel costs are new indicators for domestic enterprises.

Staff costs are an integral indicator that includes all the costs associated with the functioning of the human factor: salary costs, various types of social insurance, benefits, social infrastructure, education and staff development, dividend payments, etc. In this case, the cost of wages or basic expenses should be less than half of the total cost of personnel.

In this case, the salary costs or basic expenses should be less than half of the total personnel costs.

In addition, if the costs of an enterprise exceed the amount set by competitors, the further activity of such an organization becomes problematic.

Therefore, the planning of labor productivity is a prerequisite of finding ways to reduce staff costs.

When planning labor productivity, two methods are used: the method of direct calculation and the method of planning by factors.

Direct calculation method enables to calculate tolerable reduction in the number of personnel resulting from specific organizational and technical measures. Wherein, they firstly determine the planned number of staff according to certain categories, taking into account its possible reduction as a result of planned measures. Then, relying on calculations for planned staff 
System of performance indicators of the enterprise

\begin{tabular}{|c|c|}
\hline Name of the indicator & Indicator's characteristics \\
\hline $\begin{array}{l}\text { Map of the organization } \\
\text { (branch, types of produce, type of ownership, } \\
\text { address and telephone) }\end{array}$ & \\
\hline $\begin{array}{l}\text { General economic indicators } \\
-\quad \text { amount of produce; } \\
-\quad \text { amount of fixed assets; } \\
-\quad \text { proportion of fixed assets of non-manufac- } \\
\text { turing kind; } \\
-\quad \text { labor productivity (in kind and in cash); } \\
-\quad \text { profit; } \\
-\quad \text { proportion of consumption funds in profit }\end{array}$ & $\begin{array}{l}\text { Scope of production } \\
\text { Scope of production } \\
\text { Level of social development } \\
\text { Efficiency of resource usage } \\
\text { Financial state } \\
\text { Level of social development }\end{array}$ \\
\hline \begin{tabular}{ll}
\multicolumn{2}{l}{ Staff indicators } \\
$-\quad$ number of staff; \\
$-\quad$ proportion of employees; \\
$-\quad$ proportion of managers; \\
$-\quad$ proportion of experts and officers; \\
$-\quad$ staff turnover; \\
$-\quad$ average age of the staff
\end{tabular} & $\begin{array}{l}\text { the size of enterprise } \\
\text { Structure of personnel } \\
\text { Structure of personnel } \\
\text { Structure of personnel } \\
\text { Structure of personnel } \\
\text { Structure of personnel }\end{array}$ \\
\hline $\begin{array}{l}\text { Staff costs } \\
\text { - total cost; } \\
\text { - salary costs; } \\
\text { - average salary; } \\
\text { - salaries of managers; } \\
\text { - expenses for social payments in accordance } \\
\text { with the legislation; } \\
\text { - their share in costs; } \\
\text { - expenses for additional social benefits and } \\
\text { benefits; } \\
\text { - costs for the maintenance of social } \\
\text { infrastructure; } \\
\text { - expenses for the program "Participation in } \\
\text { profits"; } \\
\text { - average size of dividends; } \\
\text { - personnel costs, per unit of product; } \\
\text { - share of personnel costs in the company's total } \\
\text { costs }\end{array}$ & $\begin{array}{l}\text { costs for human factor } \\
\text { rational organization of wages } \\
\text { wage level } \\
\text { differentiation } \\
\text { degree of social protection of } \\
\text { workers } \\
\text { degree of social protection of workers } \\
\text { the degree of social protection of workers } \\
\text { level of social development } \\
\text { involvement of staff in management } \\
\text { staff revenue structure } \\
\text { the effectiveness of using the human factor } \\
\text { the effectiveness of using the human factor }\end{array}$ \\
\hline $\begin{array}{l}\text { Working conditions } \\
\text { - share of workers in harmful working } \\
\text { conditions; } \\
\text { - the level of injuries; } \\
\text { - the level of morbidity; } \\
\text { - losses on the payment of benefits and } \\
\text { compensations for poor working conditions }\end{array}$ & $\begin{array}{l}\text { care for workers' health } \\
\text { care for workers' health } \\
\text { care for workers' health } \\
\text { care for workers' health }\end{array}$ \\
\hline
\end{tabular}


and planned output, one can determine the level of labor productivity and its growth rate in comparison with the reference period.

In present conditions, the second method should be preferred - the one concerning productivity planning according to factors. In order to use it it is necessary to create a clear classification of factors applicable to all levels of management. The following factors are distinguished:

- external (not connected with the enterprise);

- internal (changes in volumes of production, structural changes in production, upgrade in technical level of production, improvement of management, production and labor organization, commissioning of new objects, etc.)

- socio-political (expectations of inflation, requirements for labor protection and waste management);

- social (level of social protection of workers).

Thus, planning labor productivity consists in working out the most accurate forecast in order to make the right decisions on the designing of factors to improve productivity.

\section{Reserves of improving labor productivity}

It is possible to identify the main and internal reserves of improving labor productivity at metallurgical enterprise (Table 11).

The most complete identification of reserves can only be obtained if all units are involved in planning and implementation of measures, and the costs will be calculated not for the whole enterprise, but in the areas where they are needed.

The unfavorable situation prevailing at domestic metallurgical enterprises has led to the fact that in order to survive they began to save on everything, primarily, on labor protection and conditions of work. This obviously causes great harm to the health of workers and generally adversely affects the motivation and efficiency of work.

Addressing issues of labor efficiency will ensure: quality and profitability of labor, efficiency and intensity of expenses, stability and profitability of labor, efficient use of labor reserves, social security in the workplace, the necessary number of jobs in new areas of activity, decent standard of living, effective credit and monetary policy, investing in the human factor (in the social sphere), science and education, raising capital-labour ratio. 


\section{Basic and internal reserves of improving labor productivity at metallurgical enterprise}

\begin{tabular}{|c|c|}
\hline \multicolumn{2}{|r|}{ Basic reserves of production } \\
\hline $\begin{array}{l}\text { Technical and } \\
\text { tangible }\end{array}$ & $\begin{array}{l}\text { 1. Introducing modern technologies in production. } \\
\text { 2. Optimizing fleet of cars, equipment via the replacement of } \\
\text { obsolete and modernizing the operating units. } \\
\text { 3. Development of complex automation and computerization of } \\
\text { production. } \\
\text { 4. Electrification and mechanization of auxiliary operations. } \\
\text { 5. Using forms of international exchange: licensing, consulting, etc. } \\
\text { 6. Equipping production facilities with basic materials, semi- } \\
\text { finished products and others based on procurement specification, } \\
\text { the use of economical types of raw materials and materials. } \\
\text { 7. Combine auxiliary products (required for operation, maintenance } \\
\text { and repair) into a single system for quality assurance and } \\
\text { performance in optimal time. } \\
\text { 8. Regular and purposeful use of by-products for obtaining } \\
\text { maximum return, the search for their various use in the production } \\
\text { of a wide range of products. }\end{array}$ \\
\hline Organizational & $\begin{array}{l}\text { 1. Development of the commodity nomenclature taking into } \\
\text { account market requirements. } \\
\text { 2. Implementation of the scientific organization of labor (division, } \\
\text { cooperation of labor, proper organization of work places). } \\
\text { 3. Improving the organization of production within the enterprise, } \\
\text { work on optimal schedules, etc. } \\
\text { 3. Implementation and development of systems for marketing } \\
\text { management of production. } \\
\text { 4. Thorough development of conditions in sales contracts. } \\
\text { 5. Permanent search of distribution channels and sales of produce. } \\
\text { 6. Support of reliable connections with real and potential consumers } \\
\text { of produce. }\end{array}$ \\
\hline $\begin{array}{c}\text { Economical } \\
\text { and social }\end{array}$ & $\begin{array}{l}\text { 1. Development of different forms of ownership. } \\
\text { 2. Permanent assessment of the company's capabilities compared to } \\
\text { competitors' results. } \\
\text { 3. The enterprise' strife for product range variability and its quality. } \\
\text { 4. Determination the main marketing strategy in the production system. } \\
\text { 5. Improving financial stability of the enterprise. } \\
\text { 6. Use of rational criteria for the selection and appointment of } \\
\text { production managers. } \\
\text { 7. Continuous improvement of workers' skills to ensure high } \\
\text { quality assortment of products. } \\
\text { 8. Establishing qualitative assessment of work, done by sales and } \\
\text { marketing agents. }\end{array}$ \\
\hline
\end{tabular}




\begin{tabular}{|c|c|}
\hline & Ending of Table 11 \\
\hline & Internal production reserves \\
\hline $\begin{array}{l}\text { Reserves of } \\
\text { bringing down } \\
\text { labor intensity } \\
\text { of production }\end{array}$ & $\begin{array}{l}\text { 1. Mechanization and automation of labor-intensive work. } \\
\text { 2. Replacement of obsolete equipment or its modernization. } \\
\text { 3. Typization and unification at restoration of commodity range. } \\
\text { 4. Introduction of advanced technologies. } \\
\text { 5. Improving the organization of production. }\end{array}$ \\
\hline $\begin{array}{c}\text { Reserves of } \\
\text { improving the } \\
\text { use of working } \\
\text { time }\end{array}$ & $\begin{array}{l}\text { 1. Improving surveillance over the downtime of workers. } \\
\text { 2. Rational organization of workplaces, continuous provision of all } \\
\text { the necessary means. } \\
\text { 3. Compatibility of the profession, studying and introducing } \\
\text { advanced technologies. } \\
\text { 4. Marketing management strategy. }\end{array}$ \\
\hline $\begin{array}{l}\text { Reserves of } \\
\text { rational place- } \\
\text { ment and use of } \\
\text { labor force }\end{array}$ & $\begin{array}{l}\text { 1. Introduction of professional selection scheme and professional } \\
\text { counseling of personnel. } \\
\text { 2. Reduction of the share of auxiliary work. } \\
\text { 3. Surveillance and prevention of labor discipline. } \\
\text { 4. Promoting favorable conditions for carrying out work and } \\
\text { obtaining another specialty. }\end{array}$ \\
\hline
\end{tabular}

\section{Conclusions}

Presented paper analyses innovative economic mechanisms to ensure effective performance of metallurgical enterprise. The authors suggest matrix method to determine indicators of economic performance, which includes more than 30 basic indicators, which ensures visibility and efficiency of analysis and allows for constant operational control and monitoring. The paper describes the sequence of logistics management for material flows of the enterprise, which completely excludes delays in the moving of flows and allows to accelerate the turnover of working capital. The research presents the system of labor indicators, required by the enterprise for analysis, planning and evaluation of its competitiveness. The authors define the main and internal reserves of increasing labor productivity, which ensure the improvement of quality, profitability and capital-labour ratio, efficiency of employed labor force and social security in the workplace.

\section{References:}

1. Asaul A.N, Karpov B.M., Perevyazkyn V.B., Starovoyto M.K. (2008) Modernizatsiya ekonomikina osnove tekhnologicheskikh innovatsiy [Modernization of the economy on the basis of technological innovations]. SPb: ANO IPEV, $606 \mathrm{p}$.

2. Hol'dshteyn H. Ya. (2004) Strategicheskiy innovatsionnyy menedzhment [Strategic innovative management: teach. aid]. Taganrog: Publishing House of TRTU, 267 p. 


\section{Strategy of economic governance of metallurgical enterprise via innovative...}

3. Levchuk E.A. (2010) Metodicheskoe obespechenie strategicheskogo planirovaniya deyatel'nosti predpriyatiya $\mathrm{v}$ usloviyakh nestabil'noy ekonomicheskoy sredy [Methodical support of strategic planning of enterprise activity in the conditions of unstable economic environment]. Herald of Volodymyr Dahl East Ukrainian National University, no 8, vol. 150, part 1, pp. 137-142.

4. Levchuk K.O., Romaniuk R. Ya. (2017) Alhorytm vyznachennia ekonomichnykh rezultativ roboty pidpryiemstva [The algorithm for determining the economic results of the enterprise's performance]. Mathematic modeling. no 1. pp. $88-91$

5. Levchuk E.A. (2010) Planirovanie autsorsingovoy logisticheskoy strategii promyshlennogo predpriyatiya [Planning outsourcing logistics strategy of an industrial enterprise]. Management modeling market economy: coll. of scient. works, vol. 13, pp. 76-82.

6. Andryenko V.N., Belopol'skaya T.V., Kyrylyshen Ya.V., Levchuk E.A., Plakhotnyk E.A. (2013) Effektivnye mekhanizmy autsorsinga promyshlennogo predpriyatiya: monohrafyya [Effective mechanisms of outsourcing of industrial enterprise: monograph]. Dneprodzerzhinsk: DGTU.

7. Levchuk K.O. (2010) Intehratsiia upravlinnia lohistychnymy protsesamy v zahalnu systemu upravlinnia vytratamy velykoho promyslovoho pidpryiemstva [Integration of logistics processes management into a single system for management of expenses of a large industrial enterprise]. Proceeding of the Modeling of regional economics: Coll. of scient works. (Ivano-Frankivsk: Plai, 2010), IvanoFrankivsk: Modeling of regional economics, pp. 115-121.

8. Fen M.I., Romaniuk R.Ya. (2010) Udoskonalennia upravlinnia materialnymy potokamy promyslovykh pidpryiemstv, vykorystovuiuchy lohistychnyi pidkhid [Improving the management of material flows of industrial enterprises using the logistic approach] / Collection of scientific works of DNU: (economy: problems of theory and practice) (Dnipropetrovsk, vol. 264, part IV, 2010), Dnipropetrovsk: Economy: problems of theory and practice. pp. 851-856.

9. Fen M.I., Romaniuk R. Ya. (2013) Effektivnost' truda v sovremennykh usloviya [Efficiency of labor in modern conditions]. Subsoil Use Problems: coll. of scientific works, part II, pp. 130-131.

10. Fen M.I., Romaniuk R.Ya. (2013) Osobennosty planyrovanyya proyzvodytel'nosty truda v sovremennykh uslovyyakh [Features of planning labor productivity in modern conditions]. Modern Scientific Herald: Economics, vol. 172, no 33, pp. 44-50.

11. Borodkina N.O., Levchuk K.O. (2014) Kompleksnyi analiz lohistychnykh protsesiv metalurhiinoi haluzi $\mathrm{v}$ mezhakh efektyvnoho hospodariuvannia pidpryiemstv [Complex analysis of logistical processes in the metalurgical sphere within efficient enterprise economy]. Herald of Zhytomyr State Engineering University. Series: Economic Sciences, no. 2 (68). pp. 90-94. 


\section{THE CURRENT STATE OF DEVELOPMENT}

OF AGRICULTURAL ENTERPRISES OF VINNYTSYA REGION

\section{Kaflevska Svitlana ${ }^{1}$ \\ Lysiuk Oleksandra ${ }^{2}$}

DOI: http://dx.doi.org/10.30525/978-9934-571-28-2_17

Abstract. During the last 20 years Ukrainian agricultural sector has undergone significant structural changes and shifts. Inefficient agricultural reforms and unrestrained economic policy of the state in agricultural have led to stagnation of the industry, which destroyed the production base and the system of material and technical support, undermined social and economic base of village. Agriculture is one of the most important and major branches of the economic complex of Ukraine. This sector plays an important role in development of economy of the country, increases standard of living of population and resolves social-economy problems. Agricultural industry creates a lot of job positions and also reduced the level of poverty of population. This sector of material production is very important for providing population with food and industry with raw.

The subject of the research is mechanisms of labour resource availability impact on long term economic growth pace in the modern global economic environment in Vinnytsia region and Ukrainian labor market in general. The aim of the research is theoretical justification and empirical testing of the thesis that post transformational stage of economic system development fundamentally changes labour resource availability impact on its economic growth, and increase of skilled labour availability is less significant factor of economic growth than institutional and structural reforms for post-socialist countries with weak institutions. In fact, for the most modern situation at Vinnytsya region we have analyze labor market of region, of rural territories and Ukrainian labor market in general. As a conclusion, we have analysed all these items and determine better ways of resolving all problems what can keep the development of agricultural sector of region. During researching

\footnotetext{
${ }^{1}$ Candidate of Economic Sciences,

Associate Professor of the Department of Agrarian Management,

Vinnytsya National Agrarian University, Ukraine

${ }^{2}$ Vinnytsya National Agrarian University, Ukraine
} 
we used observation, abstraction and comparison methods. These methods described us the current situation in agricultural labor market in Ukraine in general, at rural territories and at Vinnytsya Region. Thus, recognition of the human development as a decisive factor for specification the growth ratio of society's welfare, became a theoretical base for economy policies in developed countries. However, priority of creation of prime conditions for human potential development in agrarian sector of Vinnytsya region contradicts with short-term financial stabilization problems.

\section{Introduction}

The agricultural sector of Vinnytsya region has great potential for development and involving investment resources. Because in this region there are a big amount of fertile lands, high quality labor force, good natural and climate conditions. However, the region has the insufficiency of sector needs in domestic market and the rapid growing demand of food products in the world. As a result, the formulating of effective mechanism of social oriented agricultural economy of Ukraine has to balance the economic process, the development of rural communities and ensuring of food security in the society in general. Stabilization of economic situation and growing of effectiveness of agricultural development could be achieved by the stable development of agricultural enterprises which is impossible without involving new resources, innovations, additional financial investments which cannot be done by most of agricultural producers.

The aim of the research is theoretical and empirical testing of the thesis that post transformational stage of economic system development fundamentally changes in labour resource in Ukraine and Vinnytsya region. In fact, for the most modern situation at Vinnytsya region we have analyze labor market of region, of rural territories and Ukrainian labor market in general. During researching we used observation, abstraction and comparison methods. These methods described us the current situation in agricultural labor market in Ukraine in general, at rural territories and at Vinnytsya Region.

The state and development prospects, obviously, for every country depends on workforce. It is determined by population composition, their labor, productivity and creative possibilities. In fact, population is the main factor of every household and economy brand. According to the science literature the population is the amount of people, living on the certain 


\section{Kaflevska Svitlana, Lysiuk Oleksandra}

territory - in the district, the town, the region or the country. The main feature of the population is that being restored in the process of reproduction of life it is in the state of self - development through creation of material component of human society and creates the subject of human relations. The key element of development of all Ukrainian economy for getting high standard of living and the level of well-being of the population belongs to agricultural sector. And the central place of this belongs to people, who are called human resource. Only people can determine the strategy and direction of production development, organization and setting-up of work results. People as a work force with their abilities are the basic productive force and strategic resources, but they are not only productive element. Providing enterprises with needed labor force, its rational use of labor force, high level of production is of great importance for every enterprise [2, p. 224].

\section{The general situation of labor force} at the Ukrainian agricultural sector

The agricultural sector in the economy of any country occupies a special place. The importance of the role, allocated to agriculture determined by the production of high-quality and affordable food, and active participation in solving global problems of hunger. Therefore, the degree of agricultural production directly affects the level of economic security. The permanent economic instability, dominance of large high-tech agricultural formations (agricultural holdings), decline of the social infrastructure and lack of alternative types of productive employment led to such phenomena as high unemployment of rural residents and as a result chronic poverty in rural areas. Modern Ukrainian economic science and practice don't have clear mechanisms to influence of the formation of employment in agriculture, adequate modern European integration processes. Having some problems in this area and the lack of an integrated approach to their solution determined the choice of research topics.

The reduction of employment in agriculture takes place against the backdrop of rising unemployment throughout the economy. Official statistics suggests a relatively low unemployment rate of $7 \%-8 \%$. Calculations of the "estimated unemployment", conducted at the Institute of Economics and Forecasting of NAS of Ukraine, taking into account quasi-employed and migrants, who went in search of work abroad, give an index about $20 \%$, which corresponds to the problem of unemployment 
in European countries. In 2012, the Law of Ukraine "On Employment", which provides a number of measures to address this problem. Social and economic development of the village was and is a major focus of agricultural policy in Ukraine. According to the Law of Ukraine "On the Fundamentals of the State Agricultural Policy for the period up to 2015» from 18.10.2005, № 2982-IV, rural development is the strategic goal of agricultural policy in Ukraine. The main components are follows: foster the employment of the rural population; promoting the income level of the rural population and so on. Approved in 2013, the CMU development strategy of the agricultural sector for the period up to 2020 aims to "develop a viable, socially oriented agricultural sector, which should satisfy the needs of the domestic market and a leading position in the world based on its multiculturalism and priority support to businesses, whose owners live in rural areas, combine the right to land and work on it as well as their own economic interests with social responsibility to the community" [4, p. 112].

Comprehensive program of the development support to Ukrainian village until 2015 provided "creating organizational and economic conditions for the integrated development of rural areas and improving social level of residence rural population, in the first place, increasing its employment and income «. Consequently, problems of employment and social development in law is divided enough attention, but in most cases the existing regulatory acts are piecemeal in nature, which does not provide clear mechanisms for implementation of all the provisions and no specific indicators of socioeconomic development, which will be achieved during this period. The degree and nature of employment in agriculture is influenced by many different factors, classified into natural, institutional, economic, social, technological, legal, demographic, psychological, and others. Exploring the demographic factors revealed that Ukraine has been traditionally considered as agricultural country. But in recent decades, despite of active "rule-making", share of employment in agriculture has decreased steadily. During 2012 the total number of employed workers in Ukraine amounted to 12.2 million. (According to the specified number of employees is calculated as the average for the year). Of those in agriculture employed near 0.75 million, or just over $6 \%$. In comparison to the base year 2000 , number of people employed in agriculture fell by 2 million (according to different estimates of the proportion of the population employed in agriculture in the early twentieth century reached 80 per cent) [6]. 


\section{Kaflevska Svitlana, Lysiuk Oleksandra}

On the supply side the labor force is a reduction in the rural population, which basically satisfies the demand for labor farms. As of Q3 2013 proportion of the rural population in the total population of the entire population was $31.2 \%$ or 14.1 million people, and has a slight tendency to decrease. Reducing the number of rural and agricultural workers in a general sense of this process is seen and perceived by society as a natural, normal. Because technological possibilities for the development of the productive forces in all branches of material production, and to increase productivity on this basis allow fewer rural residents and those employed in agriculture to produce increasing amounts of agricultural production for food security of the entire population of the country. It is a common axiom. Meanwhile justified this view can only be on the relative decrease in the number of rural residents and workers of agricultural sector in the total population [4, p. 57-58].

Today labor force is the main element of competitive advantages at the modern economy situation. Not only natural resources are the key element in developing of agricultural industry. But education, studying process, using experience and gettingknowledge of a person can be accumulated for creating the material, which can be used as a base for creating good environment and strong strategy for growing agricultural industry.

To sum up, labor force is one of the most important part of the capital of any enterprise structure.

Labor force from the rural territory is the basic of labor potential of agricultural branches and the main subject of management processes of the government. And most of management processes has to focused on formulating both quantative and quality characteristics of labor potential. The quantative site can be presented by number and composition of people able to work and the quality site is made of demographic, intellectual, physiologic, educational and qualificational and other features. We have decided to analyze the state and using the labor potential of rural communities and have determined the negative trends of the last years [2, p. 224-225].

The main condition of social economic development of agricultural production is constancy of social - demographic processing in villages. But analyzing the tendency of the last years we determine the aggravation of these processes. Because of the long and negative demographic behavior of people from rural territory, 113 villages disappeared (tables 1) (from Ukrainian geographic maps) for the last years. 
The current state of development of agricultural enterprises of Vinnytsya...

Table 1

Population of Ukraine

\begin{tabular}{|c|c|c|c|}
\hline & \multicolumn{3}{|c|}{ Existing population } \\
\cline { 3 - 4 } & \multirow{2}{*}{ In all } & \multicolumn{2}{|c|}{ including } \\
\hline 2007 & 46646,0 & 31777,4 & 14868,6 \\
\hline 2008 & 46372,7 & 31668,8 & 14703,9 \\
\hline 2009 & 46143,7 & 31587,2 & 14556,5 \\
\hline 2010 & 45962,9 & 31524,8 & 14438,1 \\
\hline 2011 & 45778,5 & 31441,6 & 14336,9 \\
\hline 2012 & 45633,6 & 31380,9 & 14252,7 \\
\hline 2013 & 45553,0 & 31378,6 & 14174,4 \\
\hline 2104 & 45426,2 & 31336,6 & 14089,6 \\
\hline 2015 & 42929,3 & 29673,1 & 13256,2 \\
\hline 2016 & 42760,5 & 29585,0 & 13175,5 \\
\hline
\end{tabular}

Reduction of quantity of merkable people at the rural territories is a treat of normal playback of workforce potential for a long period and creates serious problems for the development of (agricultural sector). To avoid these problems, serious and strong steps from the government are needed. All efforts must be directed for keeping natural population growth at the rural territory and immigration growth. Now we have the opposite situation: in searching better working conditions the most perspective part of labor force leaves the rural areas and the number of dead people is bigger than the number of children born in the area. Active development of migration process started in the middle of the last century and is being continued.

Number of available rural population in 2007-2016 years dropped by 1 million 793,1 thousand people., or $16.5 \%$. Occurs the Depopulation of rural areas, deregistration of the sparsely populated settlements and as a result, chipping away at the rural settlement network. Thus, despite of the some leveling of mortality and fertility in the past 10 years, the current demographic situation in rural areas is alarming.

The problem of the existing inequality of income across population groups of Ukraine, including wages, is quite acute. The decline in real income and decreasing differentiation - two key trends in the change of people's lives over the years.

Serious problem of employment in agriculture is its informal nature. Informal employment is the set of socio-economic relations, which 


\section{Kaflevska Svitlana, Lysiuk Oleksandra}

are subject to social and neutral or positive nature; they relate with the activities of citizens under the law allowed economic activity, performed by them or on their own within a small production, the results of which for various reasons (basic - a high degree of bureaucracy) are not captured by statistics. By informally employed in the legal sector include: officially unsettled workers in registered factories and formalized employees, that engaged in several activities: primary and secondary (unrecorded) and receiving the second activity additional (unrecorded) income. The number employed in the informal economy in the first half of 2013 compared to the corresponding period in 2012 increased by 248.7 thousand people and was 4.8 million, or $23.3 \%$ of the total number of employed persons aged $15-70$ years. Employment in that sector is more common (48.7\%) among the rural population. In urban areas the amount of employment was low $(11.8 \%)$ due to a more favorable situation on the labor market. Among those employed in the informal economy, almost two-thirds were working in agriculture $(64.5 \%)$.

For employment in the informal sector, characterized by the fact that it is not registered, most manufacturers significantly restricted in entering the organized markets, not covered by social security, labor laws and safety regulations. This type of economic activity is actually not considered statistically because informal employment in the legal sector is not envisaged. In recent years reducing the demand for labor in the agricultural sector is largely "owes" the new economic environment, a slightly different structure for the bulk of landowners and land. Among the objective factors of the low level of employment in rural areas can be identified agroholdingization farms. The rise in unemployment among the rural population due to the displacement of labor-intensive agricultural products, transition to mono production and use super narrow agricultural machinery leads to the impoverishment of the rural population, development of migration and extinction of rural areas [4, p. 112].

Ukrainian labor markets are a subsystem of the world economy and directly affect the dynamism of economic growth and macroeconomic balance. But at the same time international labor market is under the influence of socio-economic indicators and dynamics of economic growth. In addition, a number of economic factors, such as globalization and regionalization, on the one hand, and global competition and technological progress, on the other hand, also wield influence on the current international 
labor market. All of them constitute a strong link between the parameters of the development and functioning of labor markets, social institutions, protection of national training and competitive position of individual countries regarding unified and liberalized markets.

Due to the fact that components of international (global) labor market are formed at the continental regional level where the region is considered as a large supranational entity that brings together a number of countries with similar socio-economic and socio-cultural features, it is much better to make the analysis of the dynamics of employment with the consideration of the regional aspect. Thus, despite the multidirectional trends in the number of employees in the global economy, the overall growth.

Long-term negative trends on the labor market in Ukraine generate economic and social problems associated with poverty and unemployment. They prevent creation of conditions for stabilization and economic growth, deepen social tension in society. The development of economic processes and events in Ukraine demonstrates the need for increased attention to the national labour market, which is an important element of the socioeconomic system of the country. The background for carrying out qualitative changes in the socio economic area is a systematic analysis of the dynamics of local labour market development, which will help to form an effective mechanism for the use of human potential. Therefore, the development of relevant dynamic structural economic and mathematical models will allow us to reveal the particular nature of the relationships between the main macroeconomic indicators of the labor market and to predict the future situation in the socio-economic sphere.

To achieve the objectives of the research and define an adequate specification of the labor market macromodel, we must first thoroughly analyze the main trends of the socio-economic development of the Ukrainian economy on the basis of the available statistical database of the national labor market indicators and key macroeconomic indicators for the past thirteen years, in particular the quarterly dynamics of changes in average wages, nominal employment, number of unemployed, economically active population, unemployment rate of the population, as well as the factors that determine their behavior in the long and short term.

The problem of employment in Ukraine can not be addressed in isolation from the global processes on the labor market. The entry of Ukraine into the world market could mitigate the impact of unemployment in it, and 


\section{Kaflevska Svitlana, Lysiuk Oleksandra}

exchange of human resources between Ukraine and other countries can be an effective way of lifting the country to the level of the most developed countries. However, joining the global labor market needs to overcome a kind of "entry barrier" to make Ukrainian workers competitive in the global labor market. But it will have to form a full labor market within the country itself, which will provide the necessary labor mobility. It should be tailored to suit effects of European integration processes in Ukraine. The current political instability in Ukraine may cause an increase in work migration, including domestic. Significant cross-border emigration flows have been present in Ukraine for years [5, p. 259-262].

Modern employers in the Ukrainian labor market consider a large number of applicants for a position as the most common problem. According to statistics, one of four graduates adds to his resume false information about professional and work experience, which leads to ineffective work and layoffs.

This happens because of the outdated technology of the job interviewing that has remained largely unchanged for many years, allowing the applicant examine the response before the interview. To overcome the identified problems it is appropriate to consider modern innovative ways of interviewing used in foreign practice. Innovators in developing new methods are companies in so-called Silicon Valley, California. The latest technique is called "Open-Ended Logic-Problem Screening Tools" (outdoor logical selection system tools). The main objective of the method is not to get a response to a question, but observe and analyze the applicant, who is trying to answer. There aren't correct and incorrect answers, the main emphasis is on creativity, innovative thinking, and deep analysis of the solution of the problem. The questions are formulated in such a way that the answers cannot be prepared in advance in order to help employers easily distinguish a professional applicant [4, p. 112].

Having analyzed the data's, the negative tendention of changing labor force f rural territories is obvious. It describes the depravation of quantative and quality characteristics. This situation was formulated by economical social and low reasons (pict. 1) and was created by noneffective and nonsystematic steps of market reforms. And if this item will not be managed, Ukrainian villages can lose the labor force potential.

The main way of creation social - economy transformation in the rural communities must be adapting and improvement of the regulatory 


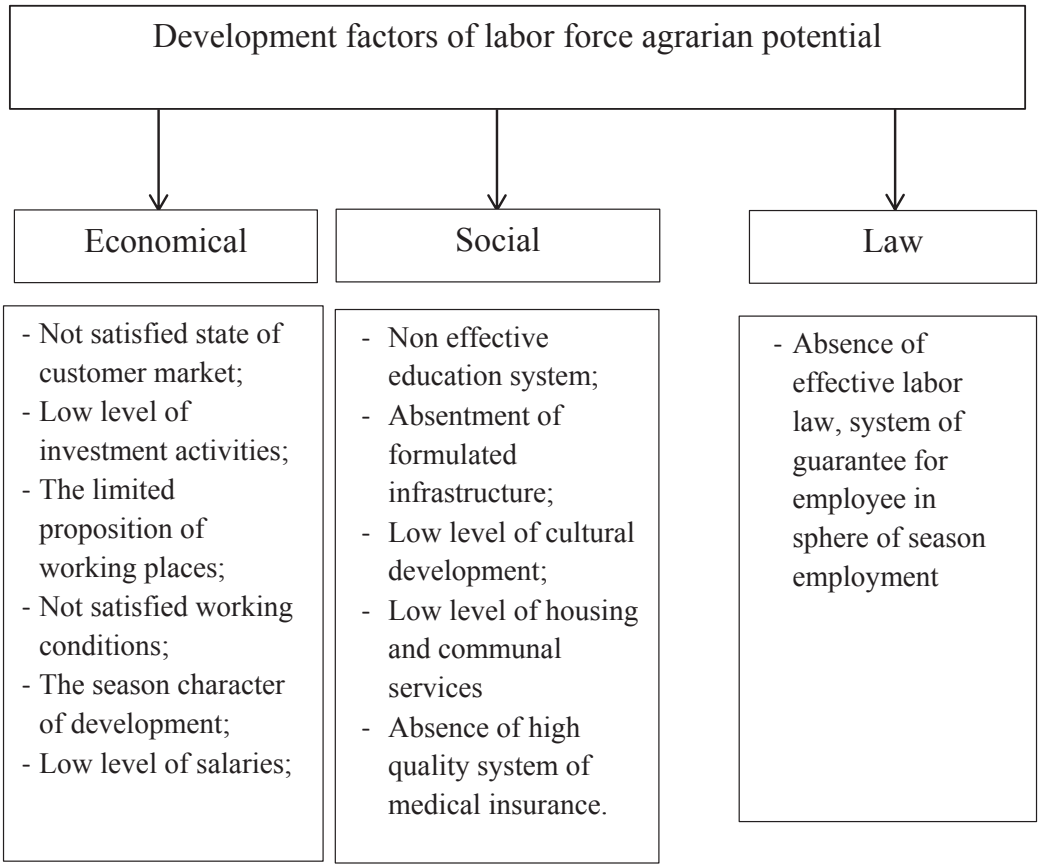

Fig. 1. Development factors of labor force agrarian potential

framework. The government must adopt laws which would promote development of entrepreneurial initiatives, search new perfect mechanism of motivation of employers for creating additional working places for the first working place employment, increasing qualification level of an employee, regulate items of part- time and seasonal employment. Positive influence on creating and formulation of labor potential will promote restoration of cultural establishments, carrying out of cultural and education events, realization of building programs and creating alternative employment

\section{Economic aspects of rural territory}

Ukraine belongs to one of the most ploughed countries in the world. In the structure of its land, the agricultural territories cover $70.9 \%$ of total area, while the arable land accounts for $53.8 \%$ (as of January 1, 2010). There are 0.9 hectares of agricultural land per capita in the country 


\section{Kaflevska Svitlana, Lysiuk Oleksandra}

and 0.7 hectares of arable land per capita (in Europe these figures are 0.37 and 0.21 respectively). The tendency to reduce the agricultural land area is maintained primarily by reducing the area under hayfields, pastures and perennial crops. The arable land, on the other hand, has constantly increased again, starting with the year 2007. Such situation is an environmental threat and requires additional control from the part of government regulators. As regards the structure of planted areas, the most noticeable tendency is the increase of areas used for industrial crops (due to the high external demand and positive price conjuncture) and a decrease of land used for forage crops, which is a result of the inefficient state policy in livestock sector development, leading to nonprofitability of the industry and significant diminution of livestock farms. In particular, by comparison with the year 2000, the land area under industrial crops increased 1.6 times, while the area under fodder crops decreased 2.7 times. The livestock sector decline not only undermines the foundations of food security, but does not allow the production of the required amount of organic fertilizers needed for the land. Another feature of Ukrainian rural development is also a high share of agricultural land owned by individual owners. At the end of 2009, it accounted for $37.7 \%$. This affected the high rate of agricultural production by individual farms: in 2010 more than $55 \%$ of the commodities were produced by small farms $(54.9 \%$ of crop production and $55.3 \%$ of animal products). Such data indicates the lack of development of alternative economic activities in the rural area, high dependence of most rural residents in the welfare issues on the state policy in the agricultural sector, aiming to offset potential losses from adverse weather conditions, the impact of price factors, formation of needed storage and trade infrastructure for agricultural products. At the same time, such a production structure does not allow for a proper food balance of the country, since most farms are not legal entities, and so their products are not taken into account. This greatly reduces the possibility of influence on the production of necessary agricultural products from the food security standpoint. According to a World Bank research study, agriculture in Ukraine does not fully use its production capacity, producing only $22 \%$ of the possible production volume. The growth of external demand for agricultural products contributed to the increase in profitability for the agricultural enterprises (as of 2010 it equalled 20.6\%). However, this tendency is not caused by the increase in the efficiency 
of agriculture: almost all types of crop products in 2010 experienced a drop in productivity, which can be explained by the non-compliance with the new production technologies, insufficient use of new machinery, lack of new approaches to production processes, wearing out of fixed assets (the current level is $45.7 \%$ ), mostly extensive production methods.

The favourable geographical position and the high-quality black soil (Ukraine owns 30\% of the world's black soil) are major reasons for investors to contribute to the country's agriculture. However, frequent changes of investment and agricultural legislation, freezing the agricultural land market, do not allow investors to consider agriculture in Ukraine as a reliable long-term investment. An important risk factor for the current state of rural territories development is an incomplete land cadastre and the expected creation of agricultural land market. Lack of information concerning the operating conditions of such market increases the pessimistic moods among market participants, especially residents of rural territories. At present, the studies of rural development processes are complicated by the lack of proper statistical information: rural territories are not an object of statistical observation. In Ukraine, there's only one scientific and analytic publication4 that provides indicators of rural territories development. However, it comes out only every five years and it is characterized by inconsistencies in statistical data. Such situation forces to search for other sources of adequate and accurate information. One of these sources of statistical information is a statistical observation.

The lack of adequate state regulation of agricultural area and the unavailability of financial resources for its development result in poor efficiency of agricultural production, which is maintained only at the expense of cheap labour and ruthless exploitation of the land. However, this situation cannot last indefinitely. The labour productivity increase, crop efficiency and profitability of the sector are possible only under the condition of using modern production technologies and machinery, application of new approaches to the production process, which are possible only by attracting both domestic and foreign investments. The creation of favourable and stable conditions for investments in the country's agriculture on a mutually beneficial basis for the state, investors and lessors will make full use of the existing potential for agricultural development in Ukraine. The main components of rural territory development policy should include: 


\section{Kaflevska Svitlana, Lysiuk Oleksandra}

- separation of support measures for agriculture and rural territories;

- support for rural territories with low level of agricultural development and adverse weather conditions;

- proper allocation of state support for the rural territory in order to increase the quality of its arrangements as a sphere of life, work and welfare of the rural inhabitants;

- development of alternative types of economic activities in the rural territories;

- regulation of issues concerning the proper use and protection of natural resources in rural territories;

- motivation of agricultural development and agrarian market by stimulating a substantial increase in the population's purchasing power through higher wages and pensions, as well as replacement of all privileges and discounts with direct state subsidiary payments;

- development of efficient and transparent system of state support to agriculture, which should be manifested not only by the decrease in the taxation level for this type of economic activity, but also by the use of grants, subsidies or reimbursement of agricultural activities, etc;

- ensuring equal support to all farmers regardless of their kind, type, size, ownership and management. Such support is currently received mostly by agricultural enterprises, while farmers and household agricultural producers practically don't receive any of such support. At the same time, $50 \%$ of crop production and $60 \%$ of livestock production in Ukraine is produced by small household farms;

- gradual convergence of state agricultural support to the WTO and European Union standards;

- elimination of the existing disparity in prices for industrial products, consumed by agriculture, and prices for agricultural products;

- approval of minimal guaranteed prices for basic agricultural products based on standardized costs, which should take into account the productivity of land, farm animals and the rate of return from resources used in production, including land;

- conduction of systematic forecasting of the conjuncture of world agricultural market on the medium and long term;

- formation of the balance of agricultural products in the country and its regions, determination of the self-sufficiency level and necessary import volumes, etc; 
- creation of incentives for increasing exports of agricultural products, primarily with a high degree of processing;

- creation of favourable and stable conditions for investments in the country's agriculture on a mutually beneficial basis for the state, investors and lessors;

- settlement on the issue of adequate state income distribution between sectors of the economy, in which the main recipients of income would be the producers, including the farmers, who would be able to direct the earned money to the stimulation of expanded reproduction processes [5, p. 260-261].

\section{The state of agricultural development of Vinnytsya Region}

Formulating of government regional strategy need more discovering of priority direction and ways for getting dynamic, balanced social economic development of the region, increasing standard of living, insuring compliance of government guarantee of social standards for all the citizens. In general, managing the tasks described above must be made by efficient actions for radical increasing of effective usage of all the resources in Vinnytsya region.

Vinnytsya region is an agricultural and industrial region of Ukraine, where the quantity of agricultural goods and manufacturing industries makes more than $50 \%$ of gross production in the area. The economic development of the region for a long perspective period is related to these branches and for their functioning, productive resource base, that mostly can be presented by regional agricultural entrepreneurs is needed.

Vinnitsya region make 4,4\% territory of Ukraine (2649,2 thousand hectares). By functional using the land fund of the region is divided into:

Agricultural land (2017,2 thousand hectares) 76,1\% from the general area.

- Forest and forestry areas makes 377,7 thousand hectares (14,3\% from all the area).

- Built land 106,2 thousand hectares (4,0\%).

- Swamp land 29, 5 thousand hectares $(1,1 \%)$.

- Open lands without plants or with minor (little) plants covering of 25,6 thousand hectares $(1,0 \%)$.

- Waters - 43,2 thousand hectares (1,6\% from all area).

Disturbance of territories of the region makes $65,3 \%$. The highest percentage of disturbance is in Bershadskyi (74,6\%), Chernivetskyi (74\%), Lypovetskyi (77,6\%), Teplytskyi $(68,1 \%)$ districts. 


\section{Kaflevska Svitlana, Lysiuk Oleksandra}

The most popular soil in the region is airborne soil. It makes 1214,3 thousand hectares $(65 \%)$ and about $90 \%$ of it is cultivated in the north - easten part of Vinnitsya region there is mostly black soil, that covers 487,3 thousand hectares, e $93 \%$ of which is cultivated.

In the region $6,3 \%$ of gross output of agricultural production of Ukraine is produced.

In 2016 more than 9,8 thousand of people were engaged (in small agricultural enterprises including farms), that makes $23,3 \%$ from the total number of workers employed in agriculture of the region.

One of the main features of livestock breading is that along with production there is reproduction of the stock of the main herd. Discarded livestock of the main herd is included into the amount of grown life weight of animals. In table 3 there are dates of plant-growing figures of agricultural enterprises of Vinnytsya Region.

The basic industry of Vinnytsya agricultural industry is plant growing. The most important is growing of: wheat (17\%), barley (near 14\%), sugar beets $(13 \%)$ and corn. The agricultural manufactures of Vinnitsya region provide raw materials for processing of other enterprises for such branches as: 13 alcoholic factories, 26 dairy factories, 39 sugar plants, 37 canneries, 6 meat - processing plants, 37 bakeries and small private bakeries, 1 confectionary factory and 1 oil complex.

For the last 10 years all the categories of domestic economy have increases agricultural production volumes from 4,9 to $77,2 \mathrm{UAH}$, that is 2,3 billion UAH (52\%), including plant growing production which makes $89,4 \%$. In the region $6,3 \%$ of gross output of agricultural production of Ukraine is produced.

It is worth to note, that during 2007-2016 years there was oscillation of indicators of stock-breeding and plant-growing production in Vinnytsya Region, in particular, during 2013-2014, there was rapid increase in the index of agricultural production was $6,5 \%$

According to dates of Table 3 during 2010-2013 in the agricultural production complex there was increasing of such seed areas as crops, legumes, sunflowers, open-ground vegetables which stimulates increasing of the production volumes of these agricultural crops. But it is worth to note that $\mathrm{n}$ spite of the shortening of seed area of sugar-beets, the yield capacity of sugar beets increased in 2010-2013 by 217 centneres per hectare, that is a positive tendency. 
The current state of development of agricultural enterprises of Vinnytsya...

$\frac{N}{\frac{0}{0}}$

\begin{tabular}{|c|c|c|c|c|c|c|c|c|c|c|c|c|c|c|}
\hline \multirow{6}{*}{\multicolumn{2}{|c|}{ 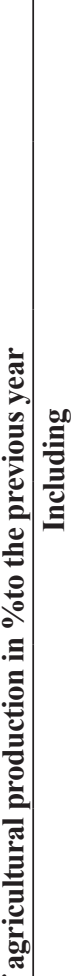 }} & \multirow{3}{*}{ 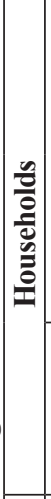 } & • & $\stackrel{\nabla_{0}}{\overrightarrow{0}}$ & â & $\stackrel{N}{0}$ & 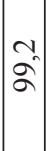 & $\left|\begin{array}{c}0 \\
\infty \\
\infty\end{array}\right|$ & $\vec{a}$ & $\overrightarrow{0}$ & $\begin{array}{l}0 \\
2 \\
2\end{array}$ & $\begin{array}{l}0 \\
\hat{\sigma}\end{array}$ & $\stackrel{1}{\hat{s}}$ & న⿱ \\
\hline & & & | & $\begin{array}{l}\dot{\sigma}^{\prime} \\
\hat{\sigma}\end{array}$ & $\begin{array}{l}n \\
\infty \\
\infty\end{array}$ & $\begin{array}{l}\tilde{n} \\
\hat{\Omega} \\
\end{array}$ & $\left|\begin{array}{l}0 \\
2 \\
2\end{array}\right|$ & $\begin{array}{l}\hat{\sigma} \\
\hat{\alpha}\end{array}$ & $\begin{array}{l}\tilde{c} \\
\tilde{c}\end{array}$ & స̃ & $\begin{array}{l}n \\
=\end{array}$ & $\begin{array}{l}0 \\
\stackrel{0}{O} \\
=\end{array}$ & $\frac{m}{a}$ & $\overrightarrow{0}$ \\
\hline & & & 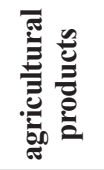 & $\left|\begin{array}{l}\infty \\
0 \\
2\end{array}\right|$ & $\hat{8}$ & $\mid \begin{array}{l}\infty \\
0 \\
0 \\
=\end{array}$ & $\mid \begin{array}{l}\dot{\sigma}_{n} \\
\sigma^{\prime}\end{array}$ & $\begin{array}{l}0 \\
2\end{array}$ & $\begin{array}{l}0 \\
\simeq \\
=\end{array}$ & ล̊. & $\begin{array}{l}\infty \\
\hat{0}\end{array}$ & $\begin{array}{l}\infty \\
\hat{0} \\
0\end{array}$ & $\begin{array}{l}\infty \\
2 \\
\swarrow\end{array}$ & ñ \\
\hline & & \multirow{3}{*}{ 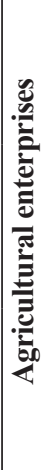 } & • & $\begin{array}{l}a \\
\tilde{\Xi}\end{array} \mid$ & $\begin{array}{c}0 \\
\hat{0} \\
0\end{array} \mid$ & $\hat{a}$ & $\begin{array}{c}\dot{\sigma}^{\prime} \\
\hat{\sigma} \\
0\end{array}$ & $\begin{array}{l}\overrightarrow{0} \\
0 \\
0\end{array}$ & 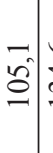 & 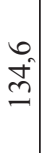 & $\begin{array}{l}0 \\
\vdots \\
2\end{array}$ & $\stackrel{\sim}{\sim}$ & $\begin{array}{l}0 \\
\equiv \\
=\end{array}$ & \begin{tabular}{l}
0 \\
\multirow{0}{0}{}
\end{tabular} \\
\hline & & & |을 & $\vec{\beth}$ & $\begin{array}{l}\infty \\
\dot{\sigma}\end{array}$ & $\vec{n}$ & $\begin{array}{l}\sigma \\
\hat{\sigma}\end{array} \mid$ & $\left|\begin{array}{l}0 \\
8 \\
8 \\
8\end{array}\right|$ & $\hat{\mathrm{I}}$ & $\begin{array}{l}n \\
8\end{array}$ & $\begin{array}{l}m \\
\sim \\
\sim\end{array}$ & $\hat{2}$ & $\stackrel{5}{\hat{2}}$ & $\begin{array}{l}0 \\
\infty \\
\end{array}$ \\
\hline & & & 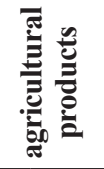 & $\begin{array}{l}\infty \\
\varrho \\
=\end{array}$ & $\begin{array}{l}\text { r. } \\
2 \\
2\end{array}$ & $\overrightarrow{\stackrel{f}{\Xi}}$ & $\begin{array}{l}\tilde{\sigma} \\
\dot{\sigma}\end{array}$ & $\left|\begin{array}{l}0 \\
0 \\
0\end{array}\right|$ & 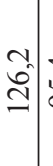 & $\begin{array}{l}\dot{ } \\
\check{a}\end{array}$ & $\begin{array}{l}\infty \\
6 \\
ల \\
=\end{array}$ & $\begin{array}{l}0 \\
\mathscr{b}^{\circ} \\
=\end{array}$ & $\begin{array}{l}\infty \\
\infty \\
\infty\end{array}$ & $\overrightarrow{0}$ \\
\hline 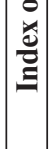 & $a^{\circ}$ & \multirow{2}{*}{ 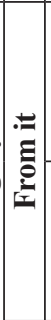 } & 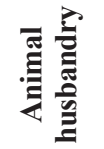 & $\left|\begin{array}{l}0 \\
\mathbb{0} \\
0\end{array}\right|$ & $\begin{array}{l}n \\
8 \\
8 \\
0\end{array}$ & $\begin{array}{l}+ \\
8 \\
8\end{array}$ & $\begin{array}{l}2 \\
8 \\
8 \\
8\end{array}$ & $\begin{array}{l}\dot{\sigma}_{n} \\
\Omega\end{array}$ & $\begin{array}{l}0 \\
8 \\
8\end{array}$ & $\hat{\mathrm{g}}$ & ๙ీ. & $\begin{array}{l}0 \\
\pm \\
\Xi\end{array}$ & $\vec{m}$ & $\stackrel{0}{0}$ \\
\hline & 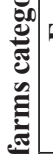 & & 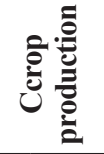 & $\mid \begin{array}{l}0 \\
0 \\
0 \\
0\end{array}$ & $\hat{\infty}$ & నू & ๙́ & $\mid \begin{array}{l}m \\
8 \\
8 \\
\delta\end{array}$ & 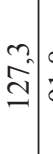 & $\stackrel{\infty}{a}$ & $\begin{array}{l}\infty \\
\stackrel{n}{\sim} \\
\mathcal{I}\end{array}$ & $\begin{array}{l}0 \\
\hat{\rho} \\
\hat{\rho}\end{array}$ & $\begin{array}{l}0 \\
\text { ¿ }\end{array}$ & $\begin{array}{l}\overrightarrow{0} \\
\stackrel{1}{1}\end{array}$ \\
\hline & $\Xi$ & & 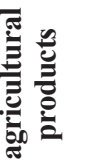 & $\left|\begin{array}{l}\infty \\
0 \\
0\end{array}\right|$ & $\vec{\sigma}$ & 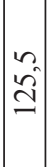 & $\begin{array}{l}0 \\
\hat{a}\end{array} \mid$ & \begin{tabular}{l}
0 \\
0 \\
8 \\
\hdashline
\end{tabular} & $\begin{array}{l}0 \\
\Xi \\
\Xi\end{array}$ & ๙ூ & $\stackrel{\overbrace{}}{\text { ஸे }}$ & $\stackrel{0}{\Xi}$ & $\stackrel{\infty}{a}$ & $\stackrel{0}{=}$ \\
\hline & & & & \begin{tabular}{l|} 
\\
\\
\end{tabular} & $\begin{array}{l} \\
\\
\\
\end{array}$ & 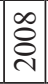 & 용 & \begin{tabular}{l|} 
\\
$\stackrel{0}{0}$ \\
N
\end{tabular} & $\begin{array}{l}\bar{Z} \\
\overline{\mathrm{\delta}} \\
\end{array}$ & 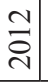 & $\begin{array}{l}m \\
\stackrel{m}{\sim} \\
\end{array}$ & $\underset{⿱ 亠}{\Delta}$ & $\stackrel{n}{\circ}$ & $\frac{0}{0}$ \\
\hline
\end{tabular}




\section{Summary data on the state of crop production at the agroidustrial complexes of Vinnitsya region during 2006-2016 years}

\begin{tabular}{|l|c|c|c|c|c|c|}
\hline & \multicolumn{7}{|c|}{ Crop area of the main crops } \\
\hline & $\begin{array}{c}\text { Grain and } \\
\text { leguminous } \\
\text { crops }\end{array}$ & $\begin{array}{c}\text { Sugar beet } \\
\text { (factory) }\end{array}$ & sunflower & potato & $\begin{array}{c}\text { Open soil } \\
\text { vegetables }\end{array}$ & $\begin{array}{c}\text { Forage } \\
\text { crops }\end{array}$ \\
\hline 2007 & 771,0 & 101,6 & 74,1 & 109,9 & 15,5 & 206,0 \\
\hline 2008 & 838,6 & 62,6 & 119,8 & 102,2 & 15,9 & 190,9 \\
\hline 2009 & 863,9 & 48,6 & 109,1 & 101,1 & 15,5 & 178,1 \\
\hline 2010 & 863,3 & 76,2 & 165,3 & 101,7 & 16,0 & 171,1 \\
\hline 2011 & 877,8 & 74,0 & 150,0 & 106,4 & 19,9 & 166,4 \\
\hline 2012 & 869,1 & 84,0 & 162,0 & 108,4 & 20,5 & 167,1 \\
\hline 2013 & 889,3 & 64,7 & 167,9 & 105,1 & 20,8 & 156,6 \\
\hline 2014 & 839,1 & 61,0 & 193,8 & 105,5 & 20,6 & 144,8 \\
\hline 2015 & 827,0 & 51,8 & 187,5 & 107,5 & 21,5 & 142,0 \\
\hline 2016 & 869,3 & 54,8 & 267,6 & 108,1 & 21,5 & 137,2 \\
\hline \multicolumn{7}{|c|}{ Yield of basic crops per 1 hectare of harvesting are } \\
\hline 2007 & 23,7 & 296 & 14,1 & 104 & 154 & 95,3 \\
\hline 2008 & 41,0 & 360 & 18,3 & 152 & 201 & 74,9 \\
\hline 2009 & 37,0 & 290 & 20,9 & 154 & 197 & 97,3 \\
\hline 2010 & 36,9 & 327 & 16,8 & 155 & 196 & 87,1 \\
\hline 2011 & 49,3 & 418 & 19,5 & 175 & 198 & 112,9 \\
\hline 2012 & 43,0 & 350 & 22,0 & 160 & 179 & 109,7 \\
\hline 2013 & 55,7 & 400 & 30,4 & 164 & 232 & 119,2 \\
\hline 2014 & 60,7 & 500 & 27,5 & 189 & 221 & 101,9 \\
\hline 2015 & 46,0 & 398 & 26,9 & 171 & 211 & 121,5 \\
\hline 2016 & 64,2 & 482 & 30,7 & 171 & 220 & 125,0 \\
\hline
\end{tabular}

It is worth to note that according to the annual structural analysis, carried out by specialists of the Main Development of Statistics in Vinnytsya Region, during 2016 about a quarter of the enterprises - juridical persons of the region were agricultural enterprises, $90 \%$ of which were engaged in plant-growing, 4,8\% - in stock breeding, 2,2\% were engaged in mixed farming and $2,3 \%$ of enterprises provided service in plant-growing and stock-breeding more than 42,0 thousand people of the Region are engaged in agricultural, which makes $25,2 \%$ from the total number of population engaged in enterprises of all kinds of economic activity. As for the enterprise 
sizes, almost $90,0 \%$ of agricultural enterprises are small enterprises, 4,0\% are big enterprises, the others are medium-sized enterprises [3, p. 58-59].

To sum up the analyses of the financial results of agricultural activity of enterprises of Vinnytsya Region should that the most favorable were 2012-2013 years, but in 2008 y there was a negative process which was related to the crisis, that was marked on all the parts of domestic agricultural production. Instead of it, it is worth to note the increasing of growing of quantity of profitable companies in the total structure of enterprises of Vinnytsya Region. During 2008-2011 the indicator value was increased by $14,31 \%$.

The profitability of total activity in agriculture in 2016 was about $20 \%$, operational was $25 \%$; there has been a tendency for substantial increasing in these indicators for the last 10 years. Production of livestock production was unprofitable until the last time.

The quality of unprofitable enterprises in 2016 reached its maximum point for the last 10 years namely $85,71 \%$ from the total quality. Similar tendency was traced in 2008 and 2010, namely 86,71\%.

In 2016, financial-economic status of the enterprises in agrarianproductivity complex in Vinnytsya region was significantly deteriorated. In particular, the amount of not profit comparatively with 2007 year decreased by 1358 thousand, that makes $46 \%$ the amount of profitable enterprises decreased to level of profitability of total activity decreased to $12,7 \%$.

\section{Conclusions}

Firstly, labour efficiency runup per unit of skilled labour resource availability of the economy in the group of researched developed countries do not represent the trends of decrease in long term period.

Lower flexibility of production growth pace at the change of the labour force availability for the group of post socialism countries circumstantially proves the second form the original hypothesis performance: countries taking part in the global labour division as users not creators of intellectual products face additional barriers in transforming better skilled labour availability in increase of economic growth pace.

Summing up the results of conducted research, clear cyclist in the dynamics of financial results of activity and the level of profitability of agricultural enterprises in Vinnytsya Region for the last years can be determined. That can be explained first of all by appropriate changes in 
volumes of gross production and valeted with them market conditions (offer and price for products). In development of agricultural enterprises in Vinnytsya Region, the positive tendency to increase the volume of sold products (both work and services) and improvement of financial results of activity can be observed. In particular, in 2016 the volume of sold products (both work and services) increased comparing with the previous year, which caused the improvement of financial results of the activity of agricultural enterprises.

\section{References:}

1. Bohynia, D. and Yakuba, K. (2011). "Ukrainian village dies: national security", Ekonomics of Ukraine, no. 4, pp. 56-66.

2. Koval L. (2014). Workforce of agricultural sector of Ukraine. Scientific bulletin of NLTU of Ukraine, 24.6: 223-228.

3. Lopatiuk R. (2013). Current state of development of agricultural complex of Vinnutsya Refion. Agrarian world, 6: 56-59.

4. Pivtorak M. (2014). The problem of employment in the agricultural sector of economy in Ukraine. Suitainable development of econmy, 4: 112-116.

5. Prytula K. \& Krupin V. (2015). Rural Realities n Ukraine. Agricultural Economics and Rural Development, 2: 255-266.

6. Yelets O., \& Garmash I. (2017). Workforce of enterprise and their approaches and assessments. Economics and business management, 9: 418-422.

7. Derzhavna sluzhba statystyky Ukrainy (2016) Sotsialni indykatory rivnia zhyttia naselennia [Social indicators of living], Kyiv: Informatsiino-analitychne ahentstvo. 


\section{ОПТИМІЗАЦІ ТЕХНОЛОГІЧНОГО РОЗВИТКУ ВУГЛЕВИДОБУВАННЯ В УКРАЇНІ}

\section{Makarov Vitaliy ${ }^{1}$}

DOI: http://dx.doi.org/10.30525/978-9934-571-28-2_18

Abstract. The theoretical generalization was carried out and a new solution of the actual scientific problem of optimization of the technological development of the coal industry was made, taking into account the requirements of competitiveness in the world markets for coal products.

The purpose of the study is to develop mathematical models and tools for optimizing the technological development of coal mining based on the use of energy and economic indicators of the effectiveness of the introduction of advanced technologies.

A mathematical model for the optimization of the technological development of coal mining has been created, which, in contrast to the wellknown industry-wide balance optimization models, is aimed at increasing the production efficiency of the selected subsystems of the industry by the criterion of their overall productivity. The model, constructed as a problem of mixed-integer programming, made it possible to determine the optimal set of options for the technical re-equipment of mines that would ensure the industry's competitiveness in the world coal market.

A new method has been developed for the formation of a multitude of promising options for technological re-equipment of mines, which, with the help of comparing the numerical values of integrated quality criteria, makes a decision to choose options for equipping mines with high-performance mining equipment that best meets the geological and geological conditions with maximum efficiency and reliability of its operation. Unlike the existing approaches to justifying the choice of types of mining equipment, the proposed method uses in the integral quality criteria not only indicators of compliance with the mining and geological conditions of specific mines,

\footnotetext{
${ }^{1}$ Candidate of Technical Sciences, Senior Researcher, Institute of General Energy of the National Academy of Sciences of Ukraine, Ukraine 


\section{Makarov Vitaliy}

but also predicted ash content of extracted coal, indicators of energy and economic efficiency of its operation.

Calculations of the optimal option for the re-equipment of the coal industry have proved the possibility of finding promising state mines at the level of profitability through the introduction of efficient coal mining technologies. This will allow to increase the volume of coal mining by 2 times, and in conditional fuel - by 2.3 times due to the reduction of ash content of extracted coal and on this basis to achieve the competitiveness of the industry as a whole.

The developed model and software tools for optimizing the technological development of the coal industry are intended to select the optimal options for the modernization of mines in forecasting the development directions of the coal industry.

\section{1. Вступ}

Україна належить до енергодефіцитних країн, де імпорт органічного палива перевищує 50\% від загальної потреби. Кризові явища в галузях пали-вно-енергетичного комплексу країни, анексія Криму та окупація частини територій Донецької і Луганської областей, брак валютних коштів для імпорту енергоносіїв в необхідних обсягах призвели до появи дефіциту палива, порушень стабільного енергопостачання i, як наслідок, до значних суспільних збитків. За таких обставин основним напрямком посилення енергетичної безпеки на сучасному етапі економічного розвитку є збільшення обсягів видобутку власних енергоносіїв.

В Україні вугілля - це єдиний енергоресурс, покладів якого достатньо на сотні років, що визначає його провідну роль в забезпеченні енергетичної безпеки держави. Проте сучасний технічний і технологічний стан вуглевидобування вкрай незадовільний і потребує докорінного оновлення.

За таких умов актуальним $є$ проведення досліджень 3 прогнозування технологічного і технічного розвитку вуглевидобування за умови впровадження у виробництво досягнень науково-технічного прогресу та з оцінки економічної, енергетичної та екологічної ефективності таких заходів.

Методичними питаннями оптимізації розвитку вугільної промисловості займалось багато українських та зарубіжних вчених: Кіяшко Ю.І. 
(оцінка ефективності роботи шахт при різних варіантах використання очисного обладнання) [1, с. 24-26], Кулик М.М., Алавердян Л.М. (оптимізація розвитку вугільної промисловості) [2, с. 4-15; 3, с. 121-123], Павленко I.I. (прогнозування розвитку вугільної галузі при обмежених інвестиціях) [4, с. 93-97], Каплін М.І., Білан Т.Р. (моделювання розвитку вугільної промисловості в умовах світового ринку) [5, с. 17-21], J. Henderson (модель попиту і пропозиції на ринках вугільної продукції) [6, с. 336-346], W. Suwala (модель реструктуризації вугільної галузі) [7, с. 41-49] та інші.

На нинішньому етапі розвитку науково-технічного прогресу запроваджені у виробництво, знаходяться на стадіях, близьких до впровадження, або розробляються різноманітні технології видобутку вугілля iз застосуванням різних видів гірничої техніки та устаткування, кожний з яких має певні обмеження у використанні по гірничо-геологічних умовах вугільних родовищ, відрізняється різною енергетичною та економічною ефективністю. Від правильного вибору техніки і технологій вуглевидобутку, своєчасної заміни морально і фізично застарілого устаткування залежить ефективність функціонування вуглевидобувних підприємств і галузі в цілому.

У зв'язку з цим задача створення математичних моделей і програмних засобів оптимізації технологічноо розвитку видобутку вугілля в Україні є актуальною.

Метою дослідження є розроблення математичних моделей та засобів оптимізації технологічного розвитку вуглевидобування на основі використання енергетичних та економічних показників ефективності застосування прогресивних технологій видобутку вугілля.

Мета роботи зумовила необхідність вирішення наступних задач:

- розроблення математичної моделі оптимізації технологічного розвитку вуглевидобування в умовах світового ринку;

- розроблення методу формування множини перспективних варіантів технологічного переоснащення шахт за показниками енергетичної та економічної ефективності;

- визначення напрямів та оптимальних обсягів впровадження ефективних технологій вуглевидобування в Україні в умовах світового ринку.

В роботі застосовані наступні методи дослідження: змішано-цілочисельне лінійне програмування - для розробки моделі оптиміза- 
ції розвитку технологічних систем вуглевидобування; апроксимація залежностей та регресійний аналіз - для визначення прогнозної собівартості вугільної продукції; багатокритеріальна оптимізація та порівняльний аналіз - для формування множини перспективних варіантів технологічного переобладнання шахт; експертні оцінки - для визначення коефіцієнтів значимості критеріїв якості.

\section{2. Модель оптимізації технологічного розвитку вуглевидобування}

Більшість моделей розвитку вугільної промисловості України спирається на достатньо деталізовану інформацію стосовно всіх вуглевидобувних підприємств, зокрема, економічні показники їх діяльності. Очевидним для інформаційного наповнення таких моделей є врахування собівартостей видобутку для всіх без виключення шахт, у тому числі й приватизованих, а також тих, що належать фінансово-промисловим групам тощо. Необхідність такого врахування спричинена перш за все обмеженнями загального балансу вугільної продукції на основі прогнозних значень потреби.

3 іншого боку, поточний період розвитку й трансформації вуглевидобування в Україні характеризується змінами інституційного устрою галузі, зокрема, приватизацією найбільш рентабельних підприємств, й, відповідно, майже повною відсутністю інформації щодо економічних аспектів їх виробничої діяльності.

У цих умовах загальні моделі балансу вугільної продукції в країні виявляються інформаційно незабезпеченими як у частині економічних показників, так і щодо можливих перспективних досліджень впливу інвестування (капіталовкладень) на технологічні та економічні показники роботи шахт.

Крім того, в країні намітився стійкий дефіцит вугілля, пов'язаний із загальною кризою в економіці, втратою частини виробничих потужностей, високим рівнем витрат держави на потреби оборони.

Тому, виходячи $з$ цих особливостей поточного стану вугільної галузі, при моделюванні технологічного розвитку вуглевидобування обрано клас моделей оптимізації виробничої потужності, які дозволяють виділяти виробничі підсистеми галузі, зокрема ті, що надають необхідну техніко-економічну інформацію. Конкурентоспроможність підприємств в розробленій моделі запропоновано враховувати шляхом співставлення вартостей вугілля власного видобутку при прогнозова- 
них заходах з розвитку та технічного переоснащення та відповідних видів вугільної продукції на світових ринках.

Виходячи з пріоритетності підвищення рівня енергетичної безпеки країни найважливішою метою реформування й розвитку вугільної промисловості в сучасних умовах $є$ збільшення обсягів власного видобутку вугілля при забезпеченні беззбитковості функціонування галузі, iii конкурентоздатності на світових ринках вугільного палива.

Математична модель оптимізації технологічного розвитку вуглевидобування, розроблена для вирішення цієї задачі, передбачає попереднє формування множини всіх розглядуваних варіантів переобладнання, для яких розраховуються вектори показників оцінки технологічного розвитку. Ці показники використовуються для визначення параметрів задачі вибору оптимального набору варіантів технологічного переобладнання шахтопідприємств за критерієм загального обсягу видобутку галузі.

Під варіантом технологічного переобладнання шахтопідприємства в моделі розглядається множина векторів стану іiї технологічних видобувних одиниць - лав, оснащених комплексами видобувного обладнання нового технічного рівня (НТР). Лави можуть бути переоснащені новими видами гірничо-видобувної техніки, або зберегти своє діюче обладнання в залежності від наявності новітніх видів устаткування, що відповідають гірничо-геологічним умовам шахти. В обох таких випадках лава описується вектором стану, елементами якого є прогнозні параметри іiі функціонування після реконструкції. Відповідно, стан функціонування шахти вцілому описується інтенсивностями виробничої діяльності лав з прогнозованими технологічними параметрами. Ці інтенсивності являють собою бінарні змінні, які показують доцільність використання окремої лави шахтопідприємства після переобладнання. Вектор таких інтенсивностей будемо називати варіантом переоснащення досліджуваної множини шахтопідприємств (галузь в цілому, шахти, що знаходяться у державній власності тощо).

Очікуваним необхідним наслідком переоснащення має бути конкурентоздатність підприємств вугільної галузі на світовому ринку вугільного палива. У загальному випадку конкурентоздатним має бути кожне окреме видобувне підприємство. Проте, в наявних наразі умовах збитковості вугільної промисловості України та обмежених інвестиційних коштів у даній моделі розглядається кон- 


\section{Makarov Vitaliy}

курентоздатність групи підприємств в цілому. Збитковість окремих шахт вважається допустимою 3 метою забезпечення стратегічної вимоги підвищення рівня енергетичної безпеки шляхом зростання власного видобутку вугілля. Така умова конкурентоздатності має вигляд:

$$
\Delta_{K}=\sum_{j=1}^{N_{\amalg}}\left(\left(1+R_{j}^{n p o z}\right) \cdot S_{j}^{n p o z}\left(X_{j}^{n p o r}\right)-\bar{C}_{p, j}\right) \cdot X_{j}^{n p o z} \leq 0,
$$

де $\Delta_{K}-$ конкурентна різниця вартостей вугілля власного видобутку та імпортованого зі співставними споживчими характеристиками, грн; $R_{j}^{\text {nрог }}$ - прогнозна рентабельність шахтопідприємства $j ; S_{j}^{n p o z}-$ прогнозна собівартість вугільної продукції шахтопідприємства $j$, грн/т; $X_{j}^{\text {прог }}$ - прогнозна виробнича потужність шахти $j$, т/рік; $\bar{C}_{p, j}-$ прогнозне значення ціни на імпортоване зі світового ринку вугілля, вид та споживчі характеристики якості якого є співставними із відповідними показниками вугілля, що видобувається шахтопідприємством $j$, грн/т; $N_{\text {II }}$ - число шахт розглядуваної групи.

Собівартість вугільної продукції співставляється шахті вцілому і розраховується за апроксимаційною залежністю від сукупного обсягу видобутку шахти, представленою на рисунку.

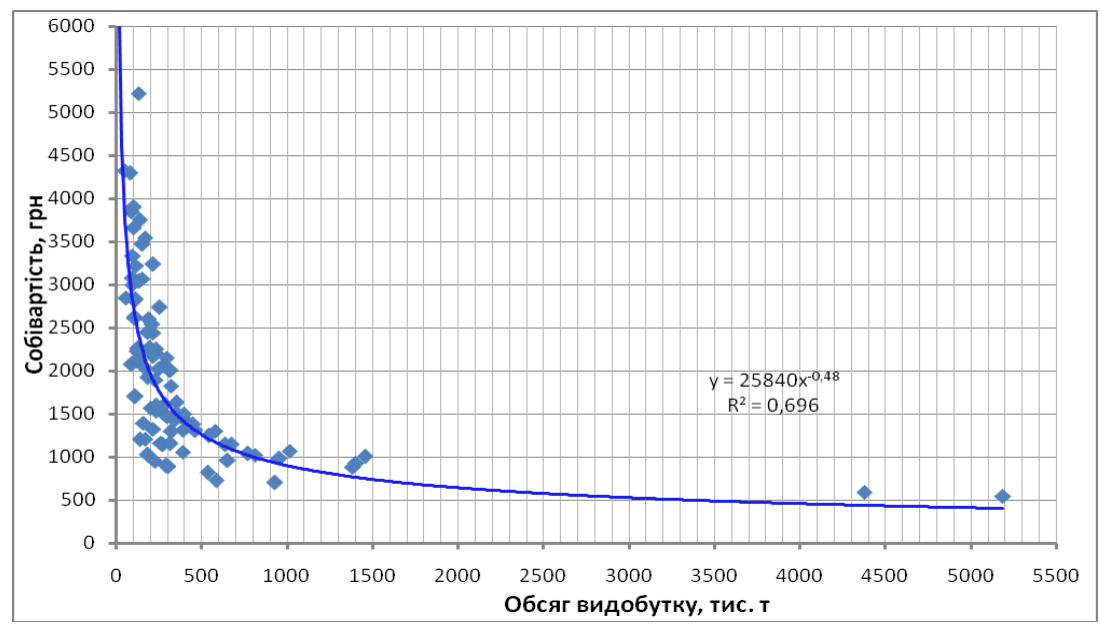

Рис. 1. Залежність собівартості вугільної продукції від обсягів видобутку вугілля 
Ця залежність отримана за результатами обробки даних технікоекономічних показників методами математичної статистики з використанням кореляційно-регресійного аналізу. Для шахт 3 різним рівнем механізації, плановими та прогнозними показниками видобутку вугілля, гірничо-геологічними і геомеханічними умовами вказана залежність найбільш достовірно описується степеневою функцією:

$$
S(X)=25840 \cdot X^{-0,48},
$$

де $S$ - собівартість, грн/т; $X$ - видобуток, тис. т/рік.

Враховуючи (2) в (1) для конкурентної різниці цін маємо:

$$
\Delta_{K}=\sum_{j=1}^{N_{\amalg}}\left(\left(1+R_{j}^{n p o z}\right) \cdot 25840 \cdot\left(\sum_{v_{j}=1}^{V_{j}} x_{v_{j}} \cdot \xi_{v_{j}}\right)^{-0,48}-\bar{C}_{p, j}\right) \cdot\left(\sum_{v_{j}=1}^{V_{j}} x_{v_{j}} \cdot \xi_{v_{j}}\right) \leq 0,
$$

де $x_{v_{j}}$ - прогнозна виробнича потужність лави при здійсненні реконструкції або технічного переоснащення за варіантом $v_{j}$, т/рік; $\xi_{v_{j}}$ - шукана бінарна змінна вибору варіанта $v_{j}$ технічного переоснащення шахти $j ; \xi_{v_{j}}=1$, якщо варіант $v_{j}$ обрано в оптимальному плані переоснащення галузі і $\xi_{v_{j}}=0$ в протилежному випадку; $v_{j}-$ індекс варіанта технічного переоснащення лави шахти $j ; V_{j}-$ число варіантів технічного переоснащення шахти $j$.

Як видно з (3) умова конкурентоздатності групи вугільних підприємств є нелінійною функцією бінарної змінної інтенсивності використання варіанта переобладнання лави. Врахування цієї умови при оптимізації вибору варіанта переоснащення призводить до нелінійної задачі цілочисельного програмування. Розв'язання таких задач відомими методами оптимізації може призвести до хибних розв'язків і потребує застосування складних оптимізаційних алгоритмів. Тому в пропонованій моделі умова конкурентоздатності враховується в наближеному лінеаризованому вигляді із використанням мінімального значення собівартості видобутку у множині допустимих варіантів переоснащення. Для визначення цієї множини в роботі передбачено апріорне вирішення двох оптимізаційних задач:

- розрахунку мінімально допустимих виробничих потужностєй шахт після модернізації за умови перевищення їх вихідних встановлених потужностей; 
- концентрації виробництва, тобто визначення мінімальної кількості лав шахт, при роботі яких після переоснащення досягається задане значення видобувної потужності.

3 допомогою розв'язків цих задач та відповідних їм значень виробничої потужності шахти отримується нижча межа собівартості видобутку, що використовується в остаточній моделі вибору варіантів переоснащення за критерієм сумарної видобувної потужності, що максимізується.

Задачу визначення мінімально допустимого видобутку після переосна-щення можна записати у наступному вигляді. Необхідно знайти множину бінарних змінних $\left\{\eta_{v_{j}}\right\}$ інтенсивностей використання варіанту переоснащення лави $v_{j}$ шахти $j$, що надає мінімуму прогнозній виробничій потужності шахт

$$
\sum_{j=1}^{N_{u}} \sum_{v_{j}=1}^{V_{j}} x_{v_{j}}^{n p o z} \cdot \eta_{v_{j}} \rightarrow \min
$$

за умови перевищення загальним прогнозованим обсягом видобутку $x_{v_{j}}^{n p o z}$ після переобладнання його поточного значення $X_{j}^{\text {вcm }}$

$$
\sum_{v_{j}=1}^{V_{j}} x_{v_{j}}^{n p o z} \cdot \eta_{v_{j}}-X_{j}^{\text {scm }} \geq\left. 0\right|_{j=1, N_{u}} .
$$

Отриманим розв'язкам цієї задачі $\eta_{v_{j}}^{*}$ відповідають прогнозні видобувна потужність

$$
\bar{X}_{j}^{\text {видоб }}=\sum_{v_{j}=1}^{V_{j}} x_{v_{j}}^{\text {nрог }} \cdot \eta_{v_{j}}^{*},
$$

та собівартість видобутку

$$
\bar{S}_{j}^{\text {видоб }}=25840 \cdot\left(\bar{X}_{j}^{\text {видоб }}\right)^{-0,48} .
$$

Задача концентрації виробництва записується у вигляді:

$$
\begin{gathered}
\sum_{j=1}^{N_{u}} \sum_{v_{j}=1}^{V_{j}} \zeta_{v_{j}} \rightarrow \min , \\
\sum_{v_{j}=1}^{V_{j}} x_{v_{j}}^{n p o 2} \cdot \zeta_{v_{j}}-X_{j}^{\text {scm }} \geq\left. 0\right|_{j=1, N_{u}} .
\end{gathered}
$$

Тут необхідно знайти вектор бінарних інтенстивностей $\left\{\zeta_{v_{j}}\right\}$ використання варіанта переоснащення лави vj шахти $\mathrm{j}$, що надає мінімум кількості діючих лав при задоволенні умови перевищення прогнозованої виробничої потужності шахт. Розв'язкам цієї задачі $\zeta_{v_{j}}^{*}$ співставляються відповідні прогнозна виробнича потужність шахти 


$$
\bar{X}_{j}^{\text {кони. вироб }}=\sum_{v_{j}=1}^{V_{j}} x_{v_{j}}^{\text {прог }} \cdot \zeta_{v_{j}}^{*},
$$

а також собівартість видобутку

$$
\bar{S}_{j}^{\text {кони, вироб }}=25840 \cdot\left(\bar{X}_{j}^{\text {конц. вироб }}\right)^{-0,48}
$$

Умова допустимого збільшення встановленої потужності шахти після переоснащення (модернізації) записується наступним чином:

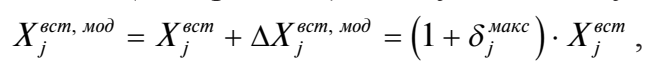

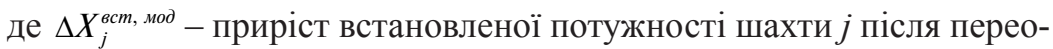
снащення всіх лав за вибраними варіантами, т/рік; $\delta_{j}^{\text {макс }}=0,3-$ допустиме перевищення встановленої потужності шахти після переоснащення.

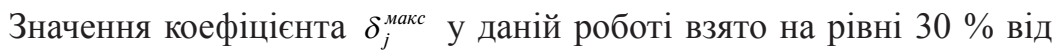
потужності шахти, що можна вважати цілком допустимим за наявних наразі середньогалузевих рівнів коефіцієнтів використання машинного часу.

Розв'язки вказаних задач дозволяють визначити мінімальну

$$
\bar{X}_{j}^{\text {мин }}=\min \left(\bar{X}_{j}^{\text {видоб }}, \bar{X}_{j}^{\text {кони. вироб }}, \bar{X}_{j}^{\text {вст, мод }}\right)
$$

та максимальну

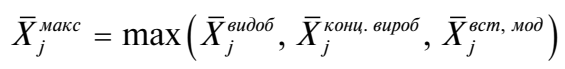

виробничі потужності шахти $j$ після переобладнання і мінімальну прогнозну собівартість видобутку в множині допустимих варіантів переобладнання

$$
S_{j}^{*} \text { прог, мін }=25840 \cdot\left(\bar{X}_{j}^{\text {макс }}\right)^{-0,48} .
$$

Ці величини використовуються для формування обмежень остаточної моделі оптимізації технологічного розвитку вуглевидобування. Модель може бути записана у вигляді наступної задачі змішано-цілочисельного лінійного програмування. Необхідно визначити таку множину бінарних інтенсивностей $\xi_{v_{j}}$ використання варіанта $v_{j}$ технологічного переобладнання шахти $j$, що надають максимум прогнозованому внаслідок модернізації загальному обсягу видобутку вугілля

за умов:

$$
\sum_{j=1}^{N_{u}} \sum_{v_{j}=1}^{V_{j}} x_{v_{j}}^{n p o z} \cdot \xi_{v_{j}} \rightarrow \max
$$




\section{Makarov Vitaliy}

- збільшення прогнозної виробничої потужності шахти

$$
\sum_{v_{j}=1}^{V_{j}} x_{v_{j}}^{n p o z} \cdot \xi_{v_{j}}-X_{j}^{n o m} \geq\left. 0\right|_{j=1, N_{u}},
$$

- обмеження прогнозної виробничої потужності шахти її мінімальним та максимальним значенням, що визначаються вихідною множиною варіантів переобладнання

$$
\begin{aligned}
& \sum_{v_{j}=1}^{V_{j}} x_{v_{j}}^{\text {nрог }} \cdot \xi_{v_{j}}-\bar{X}_{j}^{\text {мiн }} \geq\left. 0\right|_{j=1, N_{u}}, \\
& \sum_{v_{j}=1}^{V_{j}} x_{v_{j}}^{\text {npoz }} \cdot \xi_{v_{j}}-\bar{X}_{j}^{\text {макс }} \leq\left. 0\right|_{j=1, N_{u}},
\end{aligned}
$$

- конкурентоздатності вугільної промисловості на світовому ринку вугілля, що виражається меншою загальною ціною вугілля власного видобутку відносно ціни імпортованого вугілля відповідних марок та показників якості

$$
\Delta_{K}^{\max }=\sum_{j=1}^{N_{\amalg}}\left(\left(1+R_{j}^{n \text { poz }}\right) \cdot S_{j}^{* \text { nрог, мін }}-\bar{C}_{p, j}\right) \cdot \sum_{v_{j}=1}^{V_{j}} x_{v_{j}}^{n p o z} \cdot \xi_{v_{j}} \leq 0,
$$

- обмеженого обсягу капіталовкладень у переобладнання шахти $j$

$$
\sum_{v_{j}=1}^{V_{j}} K_{v_{j}}^{T} \cdot \xi_{v_{j}} \leq K_{j}^{T}
$$

- обмеженого обсягу капіталовкладень у переобладнання всіх шахт галузі

$$
\sum_{j=1}^{N_{u}} \sum_{v_{j}=1}^{V_{j}} K_{v_{j}}^{T} \cdot \xi_{v_{j}} \leq K_{\Sigma}^{T} .
$$

В моделі (16) - (22): $x_{v_{j}}^{\text {nрог }}$ - прогнозна виробнича потужність лави при здійсненні технічного переоснащення за варіантом $v_{j}$, т/рік; $X_{j}^{\text {nom }}$ - поточна виробнича потужність шахти $j$, т/рік; $\Delta_{K}^{\max }-$ максимально досяжна в допустимій множині варіантів переобладнання конкурентна різниця цін вугілля власного видобутку та імпортованого зі співставними споживчими характеристиками, грн; $K_{v_{j}}^{T}-$ обсяг інвестицій у варіанті $v_{j}$ технічного переоснащення шахти $j$, грн; $K_{j}^{T}-$ граничний обсяг інвестицій у технічне переоснащення шахти $j$, грн; $K_{\Sigma}^{T}-$ загальний обсяг інвестицій у технічне переоснащення розглядуваної групи шахтопідприємств за період інвестування $T$, грн. 
Цільовою функцією моделі є сукупний прогнозний видобуток всіх шах-топідприємств (16), а змінними оптимізації - бінарні змінні інтенсивності використання варіантів модернізації окремих ділянок - лав шахти. Сумарний видобуток лав обмежується прогнозованим значенням видобутку шахти (19), а необхідні для модернізації інвестиції - загальним планованим обсягом інвестицій у шахту (20). Обмеження (18) подає умову конкурентоздатності розглядуваної підмножини в цілому на світовому ринку вугілля. Вона виражається співвідношенням неперевищення сукупною вартістю вугільної продукції цих шахт вартості вугільного палива, яке може потенційно постачатися за імпортом.

Описана вище модель оптимізації технологічного розвитку вуглевидобування поєднує можливості довгострокового та короткострокового прогнозування розвитку виділеної групи вуглевидобувних підприємств. 3 метою визначення найбільш оптимальних короткострокових варіантів переобладнання спочатку знаходиться розв'язок задачі довгострокового прогнозування з використанням в обмеженнях (21-22) обсягів інвестицій довгострокової програми модернізації. Надалі отриманий розв'язок розглядається як допустима область оптимізаційних задач послідовних короткострокових періодів 3 відповідними інвестиційними обмеженнями.

\section{3. Метод формування варіантів переоснащення шахт}

При формуванні множини перспективних варіантів технологічного переоснащення шахт використовується запропонований автором підхід до вирішення задачі вибору обладнання, який дозволяє за допомогою порівняння числових значень інтегральних критеріїв якості обгрунтовано прийняти рішення про вибір найбільш перспективного варіанту оснащення лави високопродуктивною видобувною і транспортною технікою, яка максимально відповідає гірничо-геологічним умовам конкретної лави при максимальній ефективності і надійності iii експлуатації.

При порівнянні декількох варіантів комплектації видобувних комплексів, а також окремих їх складових в числі критеріїв qi були прийняті:

\section{I. Кріплення:}

- відповідність потужності пласта $q_{1}, \mathrm{M}$;

- відповідність характеристикам покрівлі і грунту $q_{2}$; 
- питома вартість секції кріплення $q_{3}=W_{K P}$ визначається за формулою:

$$
W_{K P}=\frac{\bigsqcup_{K P}}{M_{K P}}, \Gamma \mathrm{pH} / \mathrm{T},
$$

де $\bigsqcup_{K P}$ - ціна секції кріплення, грн; $M_{K P}$ - вага секції кріплення, т.

II. Комбайн:

- можливість спільної роботи з кріпленням $q_{4}$;

- відповідність потужності пласта $q_{5}$, м;

- технічна продуктивність впровадженого обладнання $q_{6}=Q_{\Gamma}$, яка обчислюється за формулою [8, с. 68]:

$$
Q_{\Gamma}=60 \cdot b \cdot m_{p} \cdot V_{\Pi} \cdot K_{M} \cdot \gamma, \text { т/год, }
$$

де $b$ - ширина захоплення робочого органу, м; $m_{p}-$ потужність пласта, м; $V_{\Pi}$ - середня швидкість руху комбайна, м/хв; $K_{M}$ - коефіцієнт машинного часу $\gamma$; об'ємна вага вугілля, т/м³

- зольність видобутого вугілля $q_{7}=A_{e}^{d}, \%$, яка обчислюється за форму-лою $[9$, с. 6]:

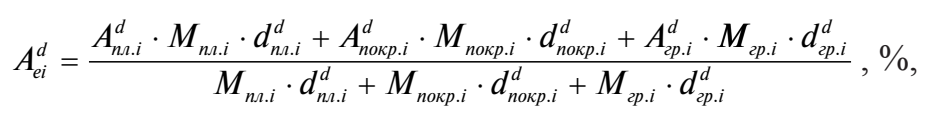

де $A^{d}{ }_{n л . i}, A^{d}{ }_{n o к p . i}, A^{d}{ }_{\text {гр.i }}-$ зольність пласта, порід покрівлі, грунту $i-\mathrm{i}$ лави, $\% ; M_{n л . i}, M_{\text {покр. } i}, M_{\text {гр.i }}$ - потужність пласта, потужність засмічення від покрівлі, потужність засмічення від грунту $i$-ї лави, м; $d_{n л . i}, d^{d}{ }_{\text {nокр. } i}$, $d^{d}{ }_{2 p . i}-$ дійсна густина вугільного пласта, порід покрівлі, порід грунту $i$-ї лави, т/ $\mathrm{M}^{3}$;

- ефективність видобутку 1 т ресурсного вугілля $q_{8}=E_{B}$, визначається за формулою:

$$
E_{B}=\frac{\coprod_{B}}{R_{B}}, г \mathrm{pH} / \mathrm{T}
$$

де $Ц_{B}$ - ціна видобувної машини (комбайна, струга), грн; $R_{B}-$ середній ресурс видобувної машини до капітального ремонту, т;

- енергоозброєність видобувної машини $q_{9}=P_{B}$ визначається за формулою:

$$
P_{B}=\frac{N_{B}}{M_{B}}, \mathrm{\kappa BT} / \mathrm{T},
$$

де $N_{B}$ - потужність приводу видобувної машини, кВт; $M_{B}-$ вага видобувної машини, т.

III. Конвеєр:

- можливість спільної роботи з кріпленням і комбайном $q_{10}$; 

т/год;

- відповідність конвеєра з комбайном по продуктивності $\left(V_{\text {конв. }}>V_{I}\right) q_{1 l}$,

- ефективність транспортування по лаві 1 т ресурсного вугілля $q_{12}=E_{T}$, визначається за формулою:

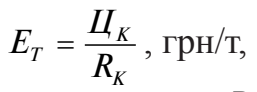

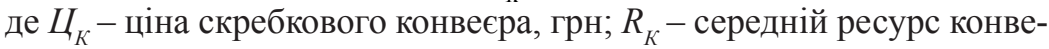
єра до капітального ремонту, т.

Критерії $q_{1}, q_{2}, q_{4}, q_{5}, q_{10}, q_{11}$ відносяться до групи одиничних якісних критеріїв, оцінка яких формується на основі антонімів абсолютного характеру типу «ТАК» $\mathrm{i}$ «II» $\left(q_{1} \equiv q_{K A 1}, q_{2} \equiv q_{K A 2}, q_{4} \equiv q_{K A 4}, q_{5} \equiv q_{K A 5}\right.$, $\left.q_{10} \equiv q_{K A 10}, q_{11} \equiv q_{K A 11},\right)$. На основі цих критеріїв формуються варіанти комплектації очисних комплексів (кріплення - комбайн - конвеєр) для конкретних гірничо-геологічних умов виїмкової ділянки шахти.

До групи одиничних кількісних критеріїв $\left(q_{K}\right)$ відносяться такі критерії якості, для яких по кожному варіанту порівняння можуть бути визначені їх абсолютні чисельні значення. В нашому випадку до цих критеріїв відносяться критерії $q_{3} \equiv q_{K 3}, q_{6} \equiv q_{K 6}, q_{7} \equiv q_{K 7}, q_{8} \equiv q_{K 8}, q_{9} \equiv q_{K 9}$ i $q_{12} \equiv q_{K 12}$. За допомогою цих критеріїв проводиться порівняння $\mathrm{i}$ визначення найкращого варіанту комплектації очисного комплексу для проведення технічного переоснащення шахти.

Після формування пакету одиничних критеріїв і одержання їх конкретних оцінок виконується порівняння конкуруючих варіантів і у ряді випадків відразу вдається прийняти рішення про відсіювання неперспективних варіантів і обрання найбільш раціонального варіанту.

Якщо оцінки обраних одиничних критеріїв якості проявляють антагоністичність, то виконується ранжування по рівню значимості за допомогою інтегрального критерію якості.

Безрозмірний інтегральний критерій якості визначається по залежності:

$$
K_{n}=\sum_{i=1}^{m}\left(\bar{q}_{i}^{(n)} \cdot a_{i}\right),
$$

де $n$ - номер порівнюваного варіанту; $m$ - кількість одиничних критеріїв якості; $\bar{x}_{i}$ числове значення і-го одиничного критерію приведеного до співставного вигляду; $a_{i}-$ безрозмірний коефіцієнт значимості $i$-го одиничного критерію якості, який відображує ступінь важливості цього критерію з позицій його впливу на техніко-економічний рівень техніки. 
Приведення абсолютних числових значень кількісних критеріїв $q_{K i}$ до співставного вигляду здійснюється згідно з однією з залежностей:

$$
\begin{aligned}
& \bar{q}_{i}=\frac{x_{K i}}{x_{K b i}}, \\
& \bar{q}_{i}=\frac{x_{K b i}}{x_{K i}},
\end{aligned}
$$

де $q_{K Б i}$ - абсолютне числове значення $i$-го кількісного критерію для варіанту, обраного в якості базового.

Залежність (30) використовується, якщо бажаним є підвищення значень $q_{K i}\left(q_{K 6}, q_{K 9}\right)$, а (31) - пониження $\left(q_{K 3}, q_{K 7}, q_{K 8}, q_{K 12}\right)$ значень критеріїв групи.

При визначенні інтегрального критерію якості $K_{n}$ в якості базового обирається варіант оснащення очисного комплексу, який на даний час експлуатується на шахті і потребує модернізації.

В результаті порівняння числових значень інтегральних критеріїв якості приймається рішення про вибір найбільш перспективного варіанту, який має найбільше значення $K_{n}$.

\section{4. Алгоритм моделювання}

Застосування розробленої моделі для вирішення задачі технологічного переобладнання групи вуглевидобувних підприємств передбачає виконання наступних етапів моделювання:

1. Розробка вихідної множини потенційно можливих варіантів устатку-вання лав шахтопідприємства видобувними комплексами нового технічного рівня із врахуванням гірничо-геологічних умов окремої шахти, ii проектної виробничої потужності. Розрахунки технологічних, експлуатаційних та економічних показників функціонування підприємства за варіантами. Створення бази даних таких показників.

2. Визначення обсягових меж видобутку вугілля за технологічно-прийнятних варіантів переобладнання шляхом попереднього розв'язання задач мінімального видобутку та максимальної концентрації виробництва.

3. Вирішення задачі вибору оптимального варіанту переобладнання за критерієм сукупного обсягу видобутку вугілля групою вуглевидобувних підприємств та за обмежень виробничої потужності, отриманих на етапі 2. 
4. Уточнена оцінка конкурентоздатності за обраного варіанту переобладнання або вирішення питання щодо можливості їі досягнення в межах допустимих змін виробничої потужності та первинно запропонованої вихідної множини варіантів устаткування лав.

5. Розподіл заходів переобладнання за часовими етапами в межах планованого довготермінового періоду модернізації групи підприємств.

Алгоритм формування варіантів технологічно-узгодженого застосування ефективних технологій у вугільній промисловості побудований на використанні функціональних особливостей програмно-інформаційного комплексу «Вугілля України» і його бази даних, створених в Інституті загальної енергетики НАН України.

\section{5. Результати розрахунків}

Для проведення розрахунків технологічних та економічних показників впровадження ефективних технологій видобутку вугілля в Україні визначено перелік державних шахт, які потребують модернізації $з$ використанням ефективних технологій видобутку вугілля. До цього переліку ввійшли державні шахти, що на даний час знаходяться на підконтрольній українській владі території (21 шахта).

Зазначимо, що сумарний видобуток вугілля на цих шахтах в 2013 році становив 7,7 млн тонн при середньодобовому видобутку 944 тонн. Середня потужність пластів на цих шахтах становить 1,46 м.

В 38 лавах застосовується прогресивна технологія видобутку - довгими стовпами, в 20 - суцільна система розробки, в 6 - комбінована. Механізовані комплекси нового технічного рівня використовуються у $56 \%$ лав, комбайни НТР у $47 \%$ лав.

За результатами розрахунків визначено ефективні технології та оптимальну комплектацію очисних комплексів для переоснащення державних шахт за умови досягнення ними максимальних прогнозних обсягів видобутку в 2030 році. Всі варіанти передбачають використання найбільш прогресивної стовпової системи розробки пластів 3 довжиною лав на пологих пластах 200-350 м. На крутих пластах використовуються щитові агрегати.

За визначеними оптимальними варіантами впровадження ефективних технологій видобутку вугілля виконано аналіз показників технологічного рівня шахт України, які знаходяться в державній власності на контрольованій українською владою території. 
Makarov Vitaliy

Показники технологічного рівня державних шахт

(на контрольованій українською владою території)

\begin{tabular}{|c|c|c|c|c|}
\hline Показник & $\begin{array}{c}2013 \text { p. } \\
\text { (базовий) }\end{array}$ & $2020 \mathrm{p}$. & 2025 p. & $2030 \mathrm{p}$. \\
\hline Кількість лав: & $\begin{array}{c}64 \\
39,1 \\
\end{array}$ & $\begin{array}{c}30 \\
20,6 \\
\end{array}$ & $\begin{array}{c}34 \\
25,2 \\
\end{array}$ & $\begin{array}{c}35 \\
28,3 \\
\end{array}$ \\
\hline $\begin{array}{r}\text { Обсяг видобутку, } \\
\text { млн т у.п. }\end{array}$ & $\begin{array}{l}7,7 \\
5,2\end{array}$ & $\begin{array}{c}10,8 \\
8,5\end{array}$ & $\begin{array}{l}13,1 \\
10,4\end{array}$ & $\begin{array}{l}15,0 \\
11,9\end{array}$ \\
\hline $\begin{array}{l}\text { Середньодобова продук- } \\
\text { тивність шахти, т }\end{array}$ & $\begin{array}{c}944 \\
(72-3726)\end{array}$ & $\begin{array}{c}1406 \\
(521-3836)\end{array}$ & $\begin{array}{c}1704 \\
(521-4164)\end{array}$ & $\begin{array}{c}2055 \\
(521-4685)\end{array}$ \\
\hline $\begin{array}{l}\text { Рівень концентрації гірни- } \\
\text { чих робіт, лав/1000 т }\end{array}$ & $\begin{array}{c}6,0 \\
(0,4-16,3)\end{array}$ & $\begin{array}{c}1,3 \\
(0,3-2,6)\end{array}$ & $\begin{array}{c}1,2 \\
(0,2-2,6)\end{array}$ & $\begin{array}{c}1,2 \\
(0,2-2,6)\end{array}$ \\
\hline $\begin{array}{l}\text { Рівень інтенсифікації гір- } \\
\text { ничих робіт, м²/год }\end{array}$ & $\begin{array}{c}9,8 \\
(1,3-36,1) \\
\end{array}$ & $\begin{array}{c}38,4 \\
(9,6-96,3)\end{array}$ & $\begin{array}{c}37,1 \\
(9,6-96,3)\end{array}$ & $\begin{array}{c}39,2 \\
(12,7-96,3) \\
\end{array}$ \\
\hline $\begin{array}{l}\text { Зольність видобутого } \\
\text { вугілля, \% }\end{array}$ & $35(12-52)$ & $25(5-49)$ & $25(5-49)$ & $25(5-49)$ \\
\hline $\begin{array}{l}\text { Питомі витрати електрое- } \\
\text { нергії на видобування } 1 \text { т } \\
\text { вугілля, кВт·год/т }\end{array}$ & $\begin{array}{c}13,9 \\
(3,6-49,3)\end{array}$ & $\begin{array}{c}5,2 \\
(1,5-10,3)\end{array}$ & $\begin{array}{c}5,1 \\
(1,5-10,3)\end{array}$ & $\begin{array}{c}5,3 \\
(1,5-10,4)\end{array}$ \\
\hline $\begin{array}{l}\text { Питомі витрати електрое- } \\
\text { нергії на видобування } 1 \text { т } \\
\text { вугілля в умовному паливі, } \\
\text { кВт·год/т у.п. }\end{array}$ & $\begin{array}{c}20,5 \\
(5,6-67,2)\end{array}$ & $\begin{array}{c}6,6 \\
(1,7-19,9)\end{array}$ & $\begin{array}{c}6,5 \\
(1,7-19,9)\end{array}$ & $\begin{array}{c}6,7 \\
(1,7-17,1)\end{array}$ \\
\hline $\begin{array}{l}\text { Розрахункова собівартість } \\
1 \text { т готової вугільної про- } \\
\text { дукції, грн }\end{array}$ & $\begin{array}{c}2166 \\
(809-5369)\end{array}$ & $\begin{array}{c}1454 \\
(798-2082)\end{array}$ & $\begin{array}{c}1236 \\
(767-2082)\end{array}$ & $\begin{array}{c}1231 \\
(725-2082)\end{array}$ \\
\hline $\begin{array}{l}\text { Розрахункова ціна } 1 \text { т } \\
\text { готової вугільної продукції, } \\
\text { грн, } \\
\text { в т.ч.: }\end{array}$ & $\begin{array}{c}2383 \\
(890-5906)\end{array}$ & $\begin{array}{c}1600 \\
(878-2290)\end{array}$ & $\begin{array}{c}1360 \\
(844-2290)\end{array}$ & $\begin{array}{c}1354 \\
(798-2290)\end{array}$ \\
\hline енергетичної & $\begin{array}{c}2409 \\
(1047-5906)\end{array}$ & $\begin{array}{c}1567 \\
(986-2047)\end{array}$ & $\begin{array}{c}1353 \\
(871-2047)\end{array}$ & $\begin{array}{c}1262 \\
(798-2047)\end{array}$ \\
\hline коксівної & $\begin{array}{c}2278 \\
(890-3196)\end{array}$ & $\begin{array}{c}1739 \\
(878-2290)\end{array}$ & $\begin{array}{c}1726 \\
(844-2290)\end{array}$ & $\begin{array}{c}1720 \\
(820-2290)\end{array}$ \\
\hline $\begin{array}{r}\text { Вартість модернізації шахт, } \\
\text { млн \$ } \\
\text { млрд грн } \\
\end{array}$ & & $\begin{array}{c}35,34 \\
0,85 \\
\end{array}$ & $\begin{array}{c}20,92 \\
0,5\end{array}$ & $\begin{array}{l}5,11 \\
0,12 \\
\end{array}$ \\
\hline
\end{tabular}

Аналіз показників оцінки ефективних технологій видобутку вугілля показує що:

- загальна кількість лав скорочується на 45 \%, кількість діючих лав - на 28 \%. При цьому середньодобова продуктивність шахти зро- 
стає у 2,2 раза до 2055 т, зольність видобутого вугілля зменшується до $25 \%$ (на $10 \%$ );

- підвищується обсяг видобутку вугілля у 2 раза, а в умовному паливі за рахунок зменшення зольності видобутого вугілля в 2,3 раза. Обсяг видобутку вугілля в 2030 р. досягне 15 млн т;

- при використанні ефективних технологій вуглевидобування рівні концентрації і інтенсифікації гірничих робіт покращуються у 5 та 4 раза відповідно;

- питомі витрати електроенергії на видобування скорочуються у 2,6 раза в натуральному вимірі, та в 3,1 раза в умовному паливі;

- розрахункова собівартість однієї тонни готової вугільної продукції зменшується в 1,8 раза;

- розрахункова ціна однієї тонни готової вугільної продукції при рентабельності 10\% зменшується в 1,8 раза і досягає 1165 грн для енергетичного вугілля та 1720 грн для коксівного;

- вартість модернізації шахт становить 94 млн дол. США, або 2,3 млрд грн за курсом 24 грн за один дол. США в 2015 р.;

- після модернізації майже всі з розглянутих державних шахт до 2025 року виходять на рівень рентабельності більше $10 \%$.

\section{6. Висновки}

1. Розроблено математичну модель оптимізації технологічного розвитку вуглевидобування, яка, на відміну від загальногалузевих балансових оптимізаційних моделей, що використовують економічні показники, орієнтована на підвищення виробничої ефективності виділених підсистем галузі за критерієм їх загальної продуктивності. Модель, побудована як задача змішано-цілочисельного програмування, дозволила визначити оптимальну за критерієм максимізації обсягу власного видобутку множину варіантів технічного переобладнання шахт, що забезпечують конкурентоздатність галузі на світовому ринку та підвищення рівня енергетичної безпеки країни.

2. Розроблено новий метод формування множини перспективних варіантів технологічного переоснащення шахт, який дозволяє за допомогою порівняння числових значень інтегральних критеріїв якості обгрунтовано прийняти рішення про вибір доцільних варіантів оснащення лав шахт високопродуктивною видобувною і транспортною технікою, яка максимально відповідає гірничо-геологічним умовам 
конкретних лав при максимальній ефективності і надійності іiі експлуатації. На відміну від існуючих підходів до обгрунтування вибору типів видобувного обладнання, запропонований метод використовує в інтегральному критерії якості не тільки показники відповідності гірничо-геологічним умовам конкретних лав, а й прогнозну зольність видобутого вугілля, показники енергетичної та економічної ефективності його експлуатації.

3. Розрахунки оптимального варіанту переоснащення вугільної галузі довели можливість виведення перспективних державних шахт на рівень рентабельності за рахунок впровадження ефективних технологій вуглевидобування. Це дозволить підвищити обсяги видобутку вугілля у 2 раза, а в умовному паливі - в 2,3 раза за рахунок зменшення зольності видобутого вугілля і на цій основі досягти конкурентоспроможності галузі в цілому.

\section{Список літератури:}

1. Кияшко Ю.И. Оценка эффективности работы шахт при различных вариантах применения очистного оборудования. Уголь Украины. 2001. № 5. C. 24-26.

2. Кулик М.М. Роль вугілля у формуванні паливно-енергетичних балансів та оптимізація розвитку вугільної промисловості України. Проблеми загальної енергетики. 2002. № 6. С. 7-16.

3. Алавердян Л.М. Економіко-математична модель оптимального розвитку вугільної промисловості України. Вісник МНТУ, серія «Економіка». 2010. № 1. C. 121-123.

4. Павленко I.І. Механізм розвитку вугільної галузі при обмежених інвестиціях. Економіка промисловості. 2007. № 1. С. 93-97.

5. Білан Т.Р., Каплін М.I. Моделювання постачання енергетичного вугілля за марками в економіку країни в умовах світового ринку та скорочення обсягів власного видобутку. Проблеми загальної енергетики. 2016. Вип. 2(45). C. $16-25$.

6. Henderson J.M. A short-run model for the coal industry. The Review of Economics and Statistics. 1955. vol. 37, no. 4, pp. 336-346.

7. Suwala W. Models of Coal Industry in Poland. Gospodarka surowcami mineralnymi. 2010. Tom 26. pp. 41-52.

8. Пирский А.А. Эффективность подземной добычи угля. К.: Вища школа, 1982. 184 с.

9. СОУ 10.1.00185755.001-2004. Вугілля буре, кам'яне та антрацит. Методика розрахунку показників якості. К.: Мінпаливенерго України. 2004. $39 \mathrm{c}$. 


\section{References:}

1. Kiyashko Yu. I. (2001) Otsenka effektivnosti raboty shakht pri razlichnykh variantakh primeneniya ochistnogo oborudovaniya [Estimation of the efficiency of the mines in various applications of treatment equipment]. Ugol' Ukrainy, no. 5, pp. 24-26.

2. Kulyk M. M. (2002) Rol vuhillia u formuvanni palyvno-enerhetychnykh balansiv ta optymizatsiia rozvytku vuhilnoi promyslovosti Ukrainy [The role of coal in the formation of fuel and energy balances and optimization of the development of the coal industry in Ukraine]. Problemy zahalnoi enerhetyky, no. 6, pp. 7-16.

3. Alaverdian L. M. (2010) Ekonomiko-matematychna model optymalnoho rozvytku vuhilnoi promyslovosti Ukrainy [Economic-mathematical model of optimal development of the coal industry of Ukraine]. Visnyk MNTU, seriia «Ekonomika», no. 1, pp. 121-123.

4. Pavlenko I. I. (2007.) Mekhanizm rozvytku vuhilnoi haluzi pry obmezhenykh investytsiiakh [Mechanism of development of the coal industry with limited investments]. Ekonomika promyslovosti, no. 1, pp. 93-97.

5. Bilan T. R., Kaplin M. I. (2016) Modeliuvannia postachannia enerhetychnoho vuhillia za markamy v ekonomiku krainy v umovakh svitovoho rynku ta skorochennia obsiahiv vlasnoho vydobutku [Modeling the supply of energy coal by brands to the economy of the country in the world market and reducing the volume of own production]. Problemy zahalnoi enerhetyky, vol. 2(45), pp. 16-25.

6. Henderson J. M. (1955) A short-run model for the coal industry. The Review of Economics and Statistics, vol. 37, no. 4, pp. 336-346.

7. Suwala W. (2010) Models of Coal Industry in Poland. Gospodarka surowcami mineralnymi, Tom 26, pp. 41-52.

8. Pirskiy A. A. (1982) Effektivnost' podzemnoy dobychi uglya [Efficiency of underground coal mining]. Kiev: Vishcha shkola. (in Russian)

9. SOU 10.1.00185755.001-2004. (2004) Vuhillia bure, kamiane ta antratsyt. Metodyka rozrakhunku pokaznykiv yakosti [Coal is brown, rocky and an-thracite. Methodology for calculating quality indicators]. Kiev: Minpalyvenerho Ukrainy. (in Ukrainian) 


\title{
THE IMPACT OF THE INTEGRATION OF COOPERATION WITH THE EUROPEAN UNION ON THE DEVELOPMENT OF THE AGRARIAN SECTOR OF UKRAINE
}

\section{Markova Ievgeniia ${ }^{1}$ \\ Shestakovska Tatyana ${ }^{2}$}

DOI: http://dx.doi.org/10.30525/978-9934-571-28-2_19

\begin{abstract}
The article examines the trends and prospects of the development of relations between Ukraine and the EU with using modern assessment methods. It outlines the geopolitical priorities of Ukraine's integration strategy, determines the legal aspects of relations between Ukraine and the EU, analyses the main directions of cooperation between Ukraine and the EU. The state of modern Ukrainian European integration policy is investigated, too. The article substantiates the peculiarities of the development of the agrarian sector of the economy in the context of integration into the EU, which confirms that the modern global society is undergoing transformational processes, in which Ukraine must take and takes part. The current problems of national integration strategies in the context of the main aspects of the modern EU are also analyses. The study of the positive experience of the EU countries regarding the use of raw materials for energy agricultural resources and the awareness of the objective need for finding alternative kinds of fuels and energy for Ukraine has given rise to the need to develop a bioenergy industry, which, in its turn will allow the introduction of an environmental ideology in the field of the production and consumption of bioenergy. The methodological approaches are determined, the theoretical conclusions are obtained which can be used in the process of development of the strategy of agricultural development of Ukraine in the conditions of European choice while preserving its own identity. The use of an econometric method for predicting the effectiveness of the integration of cooperation between the EU and Ukraine is offered. The theoretical effects of Ukraine's integration with the EU and the possibility of their implementation in practice are determined as well.
\end{abstract}

\footnotetext{
${ }^{1}$ Doctor of Economics,

Kherson F.F. Ushakov Maritime Institute of Postgraduate Education, Ukraine

${ }^{2}$ Candidate of Economic Sciences, Senior Lecturer,

Chernihiv National Technological University, Ukraine
} 


\section{Introduction}

A characteristic feature of the modern world development of the countries is increasing of integration processes in the world and Europe in particular. However, even those countries that are not the part of the integration associations inevitably feel y their considerable influence. Following the last enlargement of the EU Ukraine has become a direct neighbor of the European Union. This opens up new opportunities for extending cooperation between Ukraine and the EU.

The question of the integration of choice was an important part of the national development strategies of Ukraine since the very beginning of the country's existence as a sovereign state. Geopolitically Ukraine is located between large integration associations: the European Union (EU) in the west and the associations of the countries of the former Soviet Union in the east, the most important of which are the Eurasian Economic Union (YEAES) and the Commonwealth of the Independent States (CIS). Ukraine's relations with these associations have expanded so far. For a long time promoting Ukraine's cooperation with the EU was seen as a major development strategy as the integration within the CIS had proceeded slowly through a complex restructuring of the economies of member countries of the association. The study of the influence of extending integration with the EU on the economy is important for working out the strategy of development of Ukraine. The issue is complicated by the fact that since 2013 Ukraine has been going through a deep economic crisis that significantly affected the change of starting positions of the country entering a deep and comprehensive free trade area with the EU. The signing of the Association Agreement actually became an important event in bilateral relations between Ukraine and the EU.

The development of integration at the European level is a modern sign of progressive changes in the agrarian sector and a relatively new direction in the research of the national agrarian science. The European landmarks provide the agrarian sector with an appropriate vector of development and open up new opportunities for the revival of agriculture, create additional comparative advantages in the agro-food market in the conditions of globalization of the economy. In order to successfully solve the problems of European integration, the agrarian sector of Ukraine's economy has sufficient prerequisites: a rich natural resource and export potential, a significant human capital, a gradually growing investment attractiveness, a preserved pattern of rural life and centuries-old traditions of agriculture. Consequently, 
the level of readiness of the domestic agrarian sector of the economy to the conditions of European integration, as compared to the countries which joined the EU in the last wave of expansion, testifies that similar transformational changes in our country did not take place, which has caused the urgency of this article [1-2].

Setting objectives. The determination of the directions of transformation of the state policy in the conditions of European integration in the context of ensuring the ecological safety of the agrarian sector of the national economy.

\section{The main directions of economic cooperation between Ukraine and the EU in the framework of the Association Agreement}

Since 01/01/2016 p. the Association Agreement of Ukraine has come into force with the EU, which is conditionally divided into two parts - political and economic. It is the economic part of the agreement that is worked out in detail and proven as the most important in the extending of the integration of cooperation between Ukraine and the EU because it is designed to give Ukrainian economy new opportunities for growth and development.

It should be emphasized again that the integration between Ukraine and the EU is formed according to the model of asymmetrically deep and comprehensive free trade area. Accordingly, from the author's point of view, all the changes that have to take place by the virtue of the Agreement can be divided into five key areas:

1) the formation of a free trade area;

2) the expansion of the trade area in services;

3) the regulation of the trade with intellectual property rights;

4) the regulation of trade with energy and cooperation in the energy sector;

5) the harmonization of the legislation of Ukraine in accordance with the EU regulations [3].

One of the major results of fulfilling the Agreement should be the abolition of import duties, which will theoretically allow Ukrainian goods to enter the European markets on more favorable terms. This will also have to promote and consolidate the application of the national treatment. However, taking into account the main articles of the Ukrainian export to the EU, significant opportunities for expanding its presence in the European markets will not arise in Ukraine.

For a variety of the agricultural products "import quotas", or size limits admissions are set by the EU. According to experts, these quotas subject to 
no more than $10 \%$ of Ukrainian corn export, $25 \%$ of confectionery, juices $40 \%, 50 \%$ wheat, etc subject under these quotas. To the extent protected in the EU there are 40 headings, whereas there are only three in the whole Ukraine - pork, poultry and sugar. So, not physical amounts of exports but the profits of some Ukrainian agricultural exporters will potentially increase. As for the Ukrainian commodity exports (ore, coal, wood, etc.), at the time of signing the Agreement, import duties on most of these headings were not applied. This refers to the metallurgical industry production [4-5].

Mutual cooperation in the energy sector between the EU and Ukraine includes a number of areas, as reflected in Article 338 of the Treaty. The most important, from the author's point of view, are as follows:

1) "modernization and gradual integration of the electricity system of Ukraine to the European electricity grid, creating a new energy infrastructure in order to diversify energy suppliers";

2) "conducting reforms based on the EU rules and standards for the development of competitive, transparent and non-discriminatory energy markets";

3) "promoting energy efficiency and conservation in line with the EU standards";

4) "revitalization and strengthening of the long-term stability and security of trade in energy goods, their exploration, extraction, purification, production, storage, transit, transmission, distribution and marketing";

5) "promoting mutual investment to the energy sector and establishing attractive stable investment climate";

6) "the development and support of renewable energy";

7) "Scientific and technical cooperation and the exchange of information for the development of technologies in the field of energy production, its transportation and end use."

Thus, in the future Ukraine is expected to do important work in changing laws and making reforms that will have to bring the energy sector to European standards.

One of the major potential benefits for Ukraine may become the possibility of solving the problem of extremely high physical and moral depreciation of fixed assets, gas transportation system (GTS). According to 2009 more than $70 \%$ of the total length of gas pipelines and about $80 \%$ of gas pumping compressor stations worked more than 20 years, the technical conditions of most storage facilities did not satisfy the requirements for 
their operation $85 \%$ of the basic equipment, $62 \%$ of wells and $84 \%$ of special hardware at the moment of state inventory worked for half its life. This is displayed in the low efficiency of the GTS, large current transmission losses and high probability of accidents during operation.

One of the most expensive destinations for Ukraine, most likely, will be the harmonization of national legislation of the country in accordance with the EU norms. The most important is the introduction of the European technical standards as national (Section 4, Chapter 3, Article 56) and the maximum approximation of the laws of Sanitary and Phytosanitary Measures (Section 4, Chapter 4, Article 64). However, the Agreement framework also stated the approximation of legislation in other areas public procurement (Section 4, Chapter 8, Article 153), competition (Section 4, Chapter 10, Article 256), statistical calculation (Section 5, Chapter 5, Article 356), environmental protection (section 5, chapter 6, article 363 ), transport (section 5, chapter 7, article 368), electronic communication (section 5, chapter 14, article 394), consumer rights protection (section 5, chapter 20, article 417) [6].

It was the introduction of European technical standards as national ones causing the greatest concern to domestic producers. The country operates many businesses that do not work on exporting and supplying its products exclusively to the domestic market. However, with the beginning of action of the European standards all producers, without exception, will have to either put them into production, or exit the business in connection with the incompatibility of their products to necessary quality indicators.

Since 11.01.2014 Ukrainian goods were given preferential access to European markets. The main advantage of partial entry of the agreement into force for Ukraine was receiving trade preferences on the EU markets (canceled almost $95 \%$ of tariffs on the EU goods in industrial production and $80 \%$ - for agricultural products) while maintaining its duties on European goods. However, the expected growth of Ukraine's exports to the EU did not happen.

Due to the unfavorable economic and political situation in Ukraine during 2014-2015 years granting trade preferences with the EU has not made a positive impact on Ukrainian exports. If in 2014 as a whole, its volume increased by $1.5 \%$ and 16 countries out of 28 , showed positive trend in 2015 this dynamic was shown by only three countries: Slovenia (slight 1.8\%), Denmark (15\%) and Malta (655.6\%), which characterizes 
not so much a real deepening of trade relations between the countries but unprecedented intensification of Ukrainian business in terms of the use of offshore schemes. On average, in individual countries falling exports from Ukraine amounted to $20-30 \%$, and a total export to the EU countries in 2015 decreased by $23.3 \%$. In the short term Ukraine will certainly expect problems with the whole set of adverse effects, and to receive any benefits in the long run requires the development of methods of forecasting assess of the effectiveness of the Agreement, taking into account the current state of the economy and significant financial problems in Ukraine [3].

The evaluation of the main political, economic, social, environmental, scientific and technical and educational and professional factors of the model of European integration, whose analysis gives reasons to consider the integration process in the agricultural sector of the economy not as a one-time change in the quality of socio-economic environment, but as a complex and permanent process, directed to macroeconomic stabilization, creation of a favorable investment climate, development of competition, the improvement of labor quality, the diversification of rural economy of the price equilibrium of the agrarian market and stable funding [2].

The purpose of the agrarian European integration is to combine the agrarian potentials of the member states (first of all, their agrarian markets and economic actors) with the subsequent modernization of agriculture and ensuring economic efficiency through mutual responsibility for the final results at all stages of agrarian cooperation and mutual interest of all participants of the integration process in a high level of food security of the countries-members of the association.

The folliwing basic principles of the process of European integration in the agrarian sector, are allocated: 1) the food security and sustainability of development; 2) efficiency and competitiveness; 3) the unity of purposeful and valuable rationality of the behavior of participants used by the countries-integrators in view of the existing natural-biological and socio-economic conditions of the functioning of the agricultural sector [7-8].

The modern principles of European integration in the agrarian sector of the economy represent an organic system and add certainty as for ensuring the sustainability of its development, allow to solve specific problems of the industry for a certain period of time, promote the creation of competitive environment, taking into account the interconnection of exogenous and endogenous factors. 


\section{Markova levgeniia, Shestakovska Tatyana}

Joining the EU gives the opportunity to use the communitarian mechanism for solving the problems of agricultural development, creates the necessary conditions for increasing the effect of integration measures and stimulates economic growth. But it would be wrong to assert that the benefits of integration are immediate and are obtained automatically by all countries without exception. Summarizing the main achievements and losses of the CEE countries as a result of the influence of the EUSAP on them, made it possible to highlight the most important steps towards European integration for Ukraine's agriculture. No matter how controversial was the experience of the countries of the last two waves of EU enlargement, the differences and problems in the development of the domestic agricultural sector are no more than in each separate country of this association.

The harmonization of the standards of the quality and safety of agricultural products with the requirements of the COP and the EU legislation is necessary. Harmonized standards for a domestic agricultural commodity producer are the only way to withstand the competition in the foreign market. The conducted studies indicate a low level of management system the quality of agro-food products and make it possible to reveal the main reasons for such a situation. The most important are the following: the existence of technical barriers; the uncertainty of approaches to strategic management of the system of managing the quality and the provision of appropriate methods for improving the safety of agri-food products.

The solution of the above mentioned problems is complicated due to the functioning of a complex, non-transparent, three-level standardization system in Ukraine. In order to have concrete bases for their implementation, integration and coordination of actions of all stakeholders involved in this process, strengthening of state supervision and control throughout the food chain; environmentalization of agrarian production are necessary. Ignoring the ecological factor in the agrarian reforms in Ukraine has led to a violation of the parity of economic, social and environmental interests that underlie the strategy of sustainable development. Compared to the EU, ecological agriculture has not been properly promoted in our country [9-10].

It is necessary to form the system of ecological agriculture in the medium term, which should meet the needs of the domestic market, taking into account the features of the European model of environmentalization of the industry. Since the organic production is not profitable and it is necessary 
to use high-value marketing measures for its development and support, we assume that in the short-term prospects, the traditional importers of organic products will take the leading position in the market.

The development of overseas markets for environmentally friendly products is a real but long-term prospect for Ukraine. First of all, the system of public administration in this area should promote the development of the ecological direction in agriculture through the support of scientific development, harmonization of standards, development of technological and organizational regulations, as well as the state programs of ecologization with the provision of financial support. As a long-term perspective, taking into account the peculiarities of the European agrarian model, the strategy of ecologization of agrarian production is proposed; the formation and development of bioenergy markets.

\section{Results and discussion}

The results of cooperation between Ukraine and the EU in the framework of the Association Agreement, first of all, should reflect the volume of foreign trade of Ukrainian goods. To assess these potential changes we will build the appropriate gravity model. The advantage of using this econometric method in this case is the inclusion in the model dummy variable to assess the impact on exports and imports of the presence or absence of preferences in trade relations of the country with its major partners.

The model of J. Tinbergen proposed in 1962, is considered a classic one and is as follows:

$$
\mathrm{E}_{\mathrm{ij}}=\alpha_{0} \operatorname{GDP}_{\mathrm{i}}^{\alpha 1} \mathrm{GDP}_{\mathrm{j}}^{\alpha 2} \mathrm{DIS}_{\mathrm{ij}}^{\alpha 3},
$$

where Eij - the volume of exports from country $i$ to country $j$, money units; $\alpha 0$ - free term, constant;

GDPi - GDP i, money units;

$\alpha 1, \alpha 2, \alpha 3$ - indicators that show that factors and productive feature need not be directly proportional;

GDPj - GDP $\mathrm{j}$, money units;

DISij - the distance between country $i$ and country $j, \mathrm{~km}$.

The model of X. Linneman has a more general view, as it is assumed that the trade is influenced by not only GDP and the distance between them, but a number of other factors that can be expressed either numerically or by entering the model dummies. So we applied later model expressed by (2): 


$$
E_{i j}=\alpha_{0} \operatorname{GDP}_{i}^{\alpha 1} \operatorname{GDP}_{j}^{\alpha 2} \mathrm{POP}_{\mathrm{i}}^{\alpha 3} \mathrm{POP}_{\mathrm{j}}^{\alpha 4} \mathrm{DIS}_{\mathrm{ij}}{ }^{\alpha 5} \mathrm{PREF}_{\mathrm{ij}}^{\alpha 6} \text {, }
$$

where POPi - the population of the country i, people.;

POPj - the population of the country $j$, people.;

PREFij - trade preferences between countries; if there are no Preferences, PREFij $=0$ if there are preferences, then PREFij $=1$

According to common practice, for ease of calculation we transform formula (2) to form a multiplicative additive through logarithms:

$$
\begin{gathered}
\ln E_{\mathrm{ij}}=\ln \alpha_{0}+\alpha_{1} \operatorname{lnGDP}_{\mathrm{i}}+\alpha_{2} \operatorname{lnGDP}_{\mathrm{j}}+ \\
+\alpha_{3} \operatorname{lnPOP}_{\mathrm{i}}+\alpha_{4} \operatorname{lnPOP}_{\mathrm{j}}+\alpha_{5} \operatorname{lnDIS}_{\mathrm{ij}}+\alpha_{6} \mathrm{PREF}_{\mathrm{ij}}
\end{gathered}
$$

Based on the formula (3), for the country i take Ukraine and build a gravity model $\operatorname{lnEij}$ of exports and imports lnIij. This we will take into account the following conditions:

1) the model includes data on $28 \mathrm{EU}$ countries (including data for Croatia for the entire study period), the countries of the free trade zone of the CIS, the countries, whose share in total exports / imports of Ukraine is on average less than $1 \%$. This geographical sample covers $83.2 \%$ of total exports and $88 \%$ of total imports in 2016 ;

2) the model is focused on Ukraine, that is the mutual trade flows of economic partners of Ukraine are not captured;

3) the observation period, 2009-2016 (8 years);

4) according to the conventional method, as an indicator of the distance between the countries, the distance in a straight line between the capitals of states is used;

5) the construction of models is made by a panel data with cross-platform software package for econometric analysis "Gretl".

The coefficient of determination of the model is $80 \%$. Thus, the mathematical description of gravity model export lnEij Ukraine is as follows:

$$
\begin{aligned}
& \operatorname{lnE}_{\mathrm{ij}}=-37,61+1,08 \operatorname{lnGDP} \mathrm{IP}_{\mathrm{i}}+8,21 \operatorname{lnPOP}_{\mathrm{i}}+ \\
& +0,24 \ln \text { POP }_{\mathrm{j}}-1,49 \ln \operatorname{liS}_{\mathrm{ij}}+0,52 \mathrm{PREF}_{\mathrm{ij}}
\end{aligned}
$$

Testing the constructed model for heteroskedasticity has also revealed its presence. Let us construct a model LnIij adjusted for heteroskedasticity.

The coefficient of determination of the model is $86 \%$. Thus, the mathematical description of gravity model of import lnIij Ukraine is as follows:

$$
\begin{gathered}
\operatorname{lnI}_{\mathrm{ij}}=-30,45+1,21 \operatorname{lnGDP} \mathrm{P}_{\mathrm{i}}+0,63 \operatorname{lnGDP} \mathrm{j}_{\mathrm{j}}+ \\
+6,17 \operatorname{lnPOP}_{\mathrm{i}}+0,33 \ln \mathrm{POP}_{\mathrm{j}}-1,42 \ln \ln _{\mathrm{ij}}++0,42 \mathrm{PREF}_{\mathrm{ij}} .
\end{gathered}
$$


Let us predict the volume of foreign trade of Ukraine for 2017 based on the following changes in the availability of preferential trade regimes:

1) the cancellation of preferences in bilateral trade between Ukraine and Russia;

2) the provision of European goods preferential conditions for access to the Ukrainian market.

Note that due to the high unpredictability of current trends adequate forecasting is possible only in the short term.

As a result of calculations based on the models built by the author of the models (4) and (5) of possible volumes of foreign trade of Ukraine with selected countries in 2017 the following predictions were received:

1) the drop in exports to the countries - the main partners, compared to 2016 will amount to $13.3 \%$ (from 31.7 billion. US dollars to 27.5 billion US dollars);

2) the drop in imports from the countries - the main partners, compared to 2016 will amount to $8 \%$ (from 32.6 billion. US dollars to 30 billion US dollars);

3 ) the growth of exports to the EU compared to 2016 will be $2.8 \%$ (from 13 billion. US dollars to 13.4 billion US dollars);

4) the increase in imports from the EU compared to 2015 will amount to $30.4 \%$ (from 15.3 billion. US dollars to 20.1 billion US dollars);

5 ) the recovery of preferential trade conditions with Russia may increase the volume of Ukrainian exports to 2.1 billion US dollars (6.6\%), imports by 2.3 billion US dollars (1\%).

On the basis of the calculations several important findings can be made. First, as a whole in 2017 a further decline in the Ukrainian foreign trade (especially - exports) will be observed. Second, the growth of Ukraine's foreign trade with the EU countries (especially - imports) is predicted. Thirdly, the abolition of preferential regime in mutual trade between Ukraine and Russia will seriously affect the change in the total volume of foreign trade of Ukraine (especially - for export).

The possibilities for expansion of Ukraine's exports are limited. Unilateral preferences regime in relations between Ukraine and the EU has also acted in 2016, but the effect of the opening of European markets for Ukrainian goods, was fully offset by a huge drop in the economy of the country. So the primary task for the Ukrainian economy is to achieve the pre-crisis volume of exports, that can contribute to the mutual lifting of 


\section{Markova levgeniia, Shestakovska Tatyana}

trade barriers. In any case, we should not expect a significant increase in exports.

There is a theoretical threat of a sharp increase in imports associated with the opening of the national market for European producers. However, from a practical point of view it is unlikely to happen. The fact is that the gravitational model does not account for reducing the solvency of the Ukrainian population. Even if there is a significant increase in the number of products manufactured in Europe, due to the sharp devaluation of the currency the prices will significantly grow. The population of Ukraine, in its turn, does not have enough money to buy either expensive goods, or the goods of the middle class. According to the State Statistics Service of Ukraine, in $20159.4 \%$ of the population had income below the subsistence minimum. It should be noted that the growth rate of the subsistence minimum does not correspond the rate of growth of consumer price index. For example, in 2014 the living wage increased by 5.6\% against rise in prices of $12.1 \%$. In 2015 price increase as for 2014 was $48.7 \%$, while the cost of living for the year rose by only $13.1 \%$. This means that according to the results of 2015 the proportion of the population with low incomes significantly increased. Ultimately, in the short and medium term, European manufacturers will have little interest in such a broad increase in exports to Ukraine.

Cooperation between Ukraine and the EU is asymmetrical due to the fact that the partners differ not only in the size and level of economic development, but also in the role played by each other. Therefore, one should take into account that by theoretical implementation of the Association Agreement Ukraine should get relatively more advantages than the EU. The expected effects of the implementation of the Agreement and the author's evaluation of their feasibility in the current crisis are shown in Table 1.

One of the major trends of 2017-2019, will likely remain the decline in the volumes of industrial production. If in 2013 the share of industry in the economic structure of Ukraine comprised $29 \%$, then by 2015 it had dropped to $24.4 \%$. The violation of the production chain "coal-coke-metal" leads to a decline in production volumes in a leading steel industry. Existing enterprises experience the disruption in the supply of raw materials and export of manufactures. There has been a sharp decline in production in areas where cooperation has been developed, particularly in engineering. The production in the mining industry only during 2014 dropped by $35 \%$, and chemical - by $36 \%$. 
These negative trends occur due to the influence of a combination of factors that facilitate and hinder the development of industry in the country. On the one hand, there is a theoretical chance of carrying some European industries in Ukraine because of the relatively low cost of labor. On the other hand, as it was mentioned above, European manufacturers will have little interest in expanding production in the face of shrinking demand. In addition, there are high risks of the default investments.

Table 1

The theoretical effects of Ukraine's integration with the EU and the possibility of their implementation in practice

\begin{tabular}{|l|l|l|}
\hline $\begin{array}{c}\text { The theoretical } \\
\text { effect }\end{array}$ & $\begin{array}{l}\text { The expected realization } \\
\text { of The theoretical } \\
\text { effect in practice after } \\
\text { signing the Association } \\
\text { Agreement }\end{array}$ & $\begin{array}{c}\text { Author's assessment of the feasibility } \\
\text { of implementing the desired effect } \\
\text { in practice }\end{array}$ \\
\hline 1 & \multicolumn{1}{|c|}{2} & \multicolumn{1}{c|}{3} \\
\hline $\begin{array}{l}\text { The effect } \\
\text { of "trade } \\
\text { expansion" }\end{array}$ & $\begin{array}{l}\text { - expanding the range of } \\
\text { quality goods of the } \\
\text { European production on } \\
\text { the domestic market; } \\
\text { - an increase in exports } \\
\text { of goods and services in } \\
\text { the EU }\end{array}$ & $\begin{array}{l}\text { 1) A significant increase in imports is } \\
\text { unlikely of reasons: } \\
\text { - Reducing of the demand on the } \\
\text { domestic market; } \\
\text { - Reducing purchasing power; } \\
\text { - An increase in import prices due to the } \\
\text { devaluation of the national currency. }\end{array}$ \\
$\begin{array}{l}\text { 3) The imported products are likely to } \\
\text { be substituted by uncompetitive goods } \\
\text { domestic production. } \\
\text { 2) Failure to expanding trade } \\
\text { in manufacturing due to its low } \\
\text { competitiveness. } \\
\text { 3) Weak expand of agricultural trade due } \\
\text { to the existence of "import quotas". }\end{array}$ \\
\hline $\begin{array}{l}\text { The effect } \\
\text { of the } \\
\text { "revitalization } \\
\text { of investments" }\end{array}$ & $\begin{array}{l}\text { - the improvement of the } \\
\text { investment } \\
\text { climate, resulting in } \\
\text { the increase of the } \\
\text { volumes of foreign } \\
\text { Investment in the economy } \\
\text { of Ukraine }\end{array}$ & $\begin{array}{l}\text { 1) Thrent state of the investment } \\
\text { climate promotes the capital outflow } \\
\text { from Ukraine. } \\
\text { 2) The interest in investing in } \\
\text { Ukraine's economy is unlikely in other } \\
\text { countries. } \\
\text { 3) In the long run the European intensive } \\
\text { production may remove geographically } \\
\text { close to the Ukrainian mining enterprises, } \\
\text { however, it is difficult to estimate } \\
\text { the rationality of this redislocation. }\end{array}$ \\
\hline
\end{tabular}




\begin{tabular}{|c|c|c|}
\hline & & Ending of Table 1 \\
\hline 1 & 2 & 3 \\
\hline $\begin{array}{l}\text { The effect } \\
\text { of the "scale" }\end{array}$ & $\begin{array}{l}\text { - The abolition of customs } \\
\text { duties will } \\
\text { help to increase } \\
\text { the production volumes; } \\
\text { - The production costs } \\
\text { will } \\
\text { decrease due to the } \\
\text { "Effect of the scale" }\end{array}$ & $\begin{array}{l}\text { 1) The current state of crisis of the } \\
\text { industrial complex will not contribute to } \\
\text { significant expansion in output. } \\
\text { 2) A significant expansion of production } \\
\text { of goods of uncompetitive manufacturing } \\
\text { is unlikely due to low demand for them } \\
\text { in Europe. } \\
\text { 4) A significant expansion of agricultural } \\
\text { production is unlikely because of the } \\
\text { existence of "import quotas". }\end{array}$ \\
\hline $\begin{array}{l}\text { The effect } \\
\text { of the } \\
\text { "employment } \\
\text { growth" }\end{array}$ & $\begin{array}{l}\text { - the opening of } \\
\text { production } \\
\text { units on the territory of } \\
\text { Ukraine by European } \\
\text { companies; } \\
\text { - the recognition of the } \\
\text { Ukrainian diplomas and } \\
\text { qualifications in the EU; } \\
\text { - facilitating the migration } \\
\text { of Ukrainian citizens to } \\
\text { the EU. }\end{array}$ & $\begin{array}{l}\text { 1) It is difficult to predict how European } \\
\text { companies will be interested in } \\
\text { transferring their production to Ukraine } \\
\text { in the current economic crisis. } \\
\text { 2) The text of the Association Agreement } \\
\text { between Ukraine and the EU has no } \\
\text { direct links to facilitating migration } \\
\text { regime or recognition of Ukrainian } \\
\text { qualifications; there is the only reference } \\
\text { to the inclusion of these issues to } \\
\text { the agenda of the talks on further } \\
\text { cooperation. }\end{array}$ \\
\hline $\begin{array}{l}\text { The effect } \\
\text { of "increasing } \\
\text { productivity" }\end{array}$ & $\begin{array}{l}\text { upgrading and } \\
\text { modernization of national } \\
\text { production }\end{array}$ & $\begin{array}{l}\text { In the current crisis conditions the } \\
\text { Ukrainian companies are practically } \\
\text { deprived of the financial capacity } \\
\text { of upgrading and modernization of } \\
\text { production. }\end{array}$ \\
\hline $\begin{array}{l}\text { The effect } \\
\text { of "increasing } \\
\text { income" }\end{array}$ & $\begin{array}{l}\text { 1) Lower prices for the } \\
\text { products by European } \\
\text { production. } \\
\text { 2) Increasing incomes of } \\
\text { the population through the } \\
\text { realization of the effect of } \\
\text { "increasing employment". }\end{array}$ & $\begin{array}{l}\text { Reduced incomes of the population due } \\
\text { to the devaluation of the currency, the } \\
\text { rising of prices and utility tariffs. }\end{array}$ \\
\hline
\end{tabular}

There are other factors as well. Ukrainian producers will have to switch to European standards of production quality, and it requires considerable financial costs. Most businesses need to spend almost complete modernization of the production process and train the staffs to work with new technologies. The Agreement empowers enterprises potentially to access to European credits, but many manufacturers are on the verge of bankruptcy and, accordingly, are high risk, so they are unlikely to qualify for all European 
credits, not to mention the impossibility of obtaining any credit facilities. There is a tendency to increase the country's exports towards low trade processing. The EU is generally more interested in preserving raw orientation of Ukrainian exports.

Probably, in 2017-2019 the difficulties in attracting investments in Ukraine, both in the public and in the private sector will continue. The investors are not interested to invest in the country for several reasons: it is a high risk of loss of investment, high levels of corruption, unpredictable economic and political climate. Alongside with a decrease of investments in Ukraine's economy the outflow of domestic capital abroad is likely to continue.

We can't help mentioning negative social trends. The continued deterioration of Ukraine's economy will lead to higher unemployment, which in its turn will trigger a new round of emigration. Above 300 thousand of people emigrated to the EU in 2015, mainly in Poland, Czech Republic, Germany. On the whole, the likely volume of emigration will increase. Moreover, the tendency of transition of temporary labor migration, focused on returning to Ukraine in the constant migration is observed. Also a negative impact on the population, especially the young and able-bodied has holding of military actions.

The foregoing facts enable us to conclude that in the current conditions of Ukrainian economic reality, especially in the short term period a significant expansion of cooperation between Ukraine and the EU is unlikely to happen, despite the fact that the signed Agreement creates necessary conditions for this. The European integration course for Ukraine has no alternative, but on the way the country expects many difficulties, trials, disappointments, awareness of the need of a healthy national egoism and the prediction of the consequences of foreign policy and economic decisions and getting rid of the illusions of receiving significant foreign assistance and rapid resolution of external agents of our internal depth problems. The economic integration as a process of development of sustainable relationships and deepening the division of labor, as a form of convergence and strengthening of cooperation of national economies could provide the impetus for the development of productive forces and modification of production relations. However, the integration is not able to replace a healthy economic policy aimed at the development of the internal market and the accumulation of domestic savings, the increase of national competitiveness and intensification of 
investments and innovations, attracting long-term foreign investments and the formation of strong and effective national companies [10].

In the 'Doing Business 2016' rating, Ukraine ranks 83 out of 189 seats (Poland -25, Germany -15), rising 4 positions compared to 2015. The exports of Ukrainian agricultural products to the European Union increased by $\$ 68.2$ million in 2016 and amounted to $\$ 4.12$ billion. It is reported by the press service of the Ministry of Agrarian Policy and Food of Ukraine. It is noted that in 2015 the deliveries to the European Union amounted to $26,6 \%$ of all agrarian exports of the country. Mostly agricultural profucts were exported to the EU: Cereals (corn, wheat, barley) - 1279.5 million dollars; - Oil (sunflower, rapeseed, soya) - 1185 million dollars; - Seeds of oilseeds (flaxseeds or rape seeds, soybeans, sunflower seeds) - \$ 587.5 million; - Residues and wastes of the food industry (cakes and other solid wastes obtained during the extraction of oil, soybean oil, waste from starch production, sugar, beet pulp, etc.) - $\$ 439.2$ million.

In 2016-2017, the marketing year compared with the previous period Ukraine increased sugar exports by 33 times - up to 344 thousand tons [3]. The main products of the Ukrainian export to European countries last year were (on cost indicators): cereals, oil, oilseeds, fruits and nuts. Also, among Ukrainian consumers, Ukrainian honey, meat, confectionery and juices were in great demand last year. Today we see an increase in the Ukrainian agrarian exports due to an increase in the supply of commodity groups such as sunflower oil by $\$ 505$ million, sunflower seeds by $\$ 36.1$ million, sugar by $\$ 16.5$ million. The most interesting for us is a significant increase in exports "Niche" fresh or processed products. Such as, for example, preserved tomatoes - by $\$ 14.3$ million, or twice, fresh and chilled vegetables -4 times, cucumbers -2.7 times, fresh fruits -2.5 times, margarine products -9 times, cocoa paste and cocoa butter, as well as ice cream, which in 2015 did not come to the EU at all. For Ukraine, this means a tendency towards diversification of the commodity structure of exports, which is a positive aspect. The imports of the European products to Ukraine also increased in 2016 and amounted to $\$ 1904.5$ million. The main products of import were food products such as sauces, coffee, tea and others $\$ 233.6$ million, cocoa beans and chocolate $-\$ 113.7$ million, as well as cereals $-\$ 105.6$ million, etc [3-4].

The trade surplus of bilateral agricultural trade between Ukraine and the EU in 2016 amounted to over $\$ 2.3$ billion. The foreign trade turnover of 
agricultural products between Ukraine and the EU countries amounted to $\$ 6182.9$ million in 2016. The major trade partners with the largest share in trade are: Spain $-15,3 \%$, Poland $-14.3 \%$, the Netherlands $-14 \%$, Italy $12.6 \%$, Germany $-10.1 \%$, France $-8.4 \%$, Belgium $-3.2 \%$, Great Britain $3 \%$, Portugal $-2.7 \%$, Romania $-2.2 \%$, Greece $-2 \%$, Hungary $-1.96 \%$ [8].

Gradually, go away references to the past, mainly aimed at economic results and the implementation of scientific advances, innovative technologies without taking into account the priority of the development of environmental and social factors. According to many scholars, all signs of an ecological crisis are observed in Ukraine, which is already considered as a crisis of the philosophy of being, the crisis of spirituality. The environmental degradation is the consequence of not only anthropogenic pressure on it, but also the impoverishment of the morality of the society, short-sightedness as for the future conflicts of an established standard of living. In this view, the main directions of the science of agroecology are at the forefront of overcoming the environmental problems in the agrarian sector [11-12].

Agroecology in the current difficult ecological and economic conditions should define a strategy for the development of agrarian production, aimed at preserving and reproducing, first of all, soil, water and biological resources, protecting the natural environment and providing people with high-quality food products in the necessary quantity [13].

By defining agroecology as a comprehensive and interdisciplinary science, ignoring its biogeochemical component is becoming increasingly irrelevant. The biocentric strategy of agriculture, as a condition for the formation of a balanced nature, utilization requires a comprehensive study of the living matter of the agrosphere.

For the evaluation and forecasting of agroecological processes it is important to calculate the coefficients of biogenic and physico-chemical migration of nutritive chemical elements - the coefficients of their biogenic accumulation, concentration, the coefficients of water mobility. The scientific value of the State monitoring of the lands can increase tenfold if we pass from the administrative and agro-soil zoning to the natural-functional, as well as increase the non-parametric part of the agro-chemical passport of the field and the number of investigated chemical elements-biofilms. The methodology of biogeochemical zoning makes it possible to estimate and predict the consequences of the ecological danger of most chemical elements for living organisms and endemic diseases of the population and is a 


\section{Markova levgeniia, Shestakovska Tatyana}

significant criterion for shaping the territorial prospects for the development of food industry [14].

\section{Conclusions}

The need for developing an integration strategy for Ukraine was caused by the desire of our country to meet the requirements of modern global economic and political system as well as finding additional means to counter threats to international security. The specific geopolitical position and a long history of cooperation with European countries contribute to Ukraine's interest in active participation in integration processes in Europe. Thus, the European integration is officially declared the key priority of Ukraine's foreign policy. For Ukraine, European integration is the way of modernizing the economy, overcoming technological backwardness, attracting foreign investments and new technologies, creating new jobs, increasing competitiveness of domestic producers, access to world markets.

However, our study of the results of the Association Agreement between Ukraine and the EU leads us to the following conclusions. First, the stage for the growth of the Ukrainian economy and improvement of the living standards of its population are not created. Second, joining the Agreement in full force until it has improved economic conditions for Ukraine is not achieved. Thirdly stabilization and the settlement of internal political and military conflicts are essential for a favorable economic development of the country.

The political benefits of the integration of Ukraine into the EU are related to the creation of reliable mechanisms of political stability, democracy and security. Moreover, the EU membership will open the way for collective structures of common security of the European Union, ensure a more effective coordination with European countries in the field of export controls and non-proliferation of weapons of mass destruction, help to intensify cooperation in combating terrorism, organized crime, smuggling, illegal migration, drug trafficking and so on. The European choice of Ukraine opens new prospects for cooperation with the developed countries of the continent, providing opportunities for economic development, strengthening Ukraine's position in the global system of international relations. However, the success of any integration policy is not in the statements and declarations of the European choice, but in the banal pursuing the principles and objectives of this policy. The rapprochement with the EU is a guarantee, 
and the implementation of its requirements a tool for building democratic institutions in Ukraine.

The domestic agrarian policy needs to be interpreted from the standpoint of the triple approach, which is widely used in the EU member states and takes into account the importance of not only economic, but also social and ecological components of the national economy, meets the requirements of the EU and confirms the overwhelming influence on the efficiency of agrarian production of a balanced system of measures and means of the state influence in close connection with rural development, agro-ecological requirements, full protection of the rural population and be continued to explore. The implementation of the proposed socio-economic and environmental priorities will provide an opportunity for an adequate transition of the agrarian sector of the economy to the European agrarian model of development and will promote the competitiveness of agriculture in the medium and long-term perspective of eurointegration.

\section{References:}

1. Gryshova I. Yu., Mityay O.V. (2016) Competitiveness of agricultural enterprises as a key factor in sustainable development of agricultural sector. Ukrainian Journal of Applied Economics. Vol. 1, no. 2., pp. 25-35.

2. Markova Ie.Yu. (2016) Strategichne upravlinnya vy'robny'chogospodars 'koyu diyal'nistyu pidpry'yemstv ry'bogospodars'kogo kompleksu: problemy' teoriyi i prakty 'ky' 'The strategic management of the production and economic activity of enterprises of the fishing industry: the problems of theory and practice]. Kherson: Ayalant [in Ukrainian]

3. The official site of the Ministry of Economic Development and Trade of Ukraine [Electronic resource] - Access mode: http://www.me.gov.ua/ Documents/Detail?lang=en-UA\&id $=5867 \mathrm{bbb} 048-4922-\mathrm{a} 3 \mathrm{~b} 4 \mathrm{ff} 2 \mathrm{~d} 1 \mathrm{bb} 731 \mathrm{a} 6 \& \mathrm{title}=$ PokaznikiExportUkraine Za2016-Rik

4. Bighdan O.V. (2013) Naprjamy rozvytku ekologhoorijentovanogho aghrovyrobnyctva $\mathrm{v}$ mizhnarodnij praktyci [Areas of development of ecologically oriented agricultural production in international practice]. AgroSvit. Vol. 4. pp. 29-31.

5. Association Agreement between the European Union and its Member States, of the one part, and Ukraine, of the other part. Official Journal of the European Union. Available at:http://eeas.europa.eu/ukraine/docs/association_agreement_ ukraine_2014_en.pdf

6. Strielkowski W., \& Lisin E., \& Gryshova I. (2016) Climate Policy of the European Union: What to Expect from the Paris Agreement? Romanian journal of European affairs Vol. 16, no. 4, pp.87-90.

7. Gryshova I.Yu., \& Shestakovska T.L. (2017) The asymmetry of the resource configuration and its destructive impact on the capitalization of agribusiness. The 


\section{Markova levgeniia, Shestakovska Tatyana}

Scientific Papers of the Legislation Institute of the Verkhovna Rada of Ukraine, no. 2. pp. 128-133.

8. Gryshova I. Ju., \& Yanchuk A. O., \& Shestakovska T. L. (2017) The mechanism for implementing the functions of consumerism in market conditions. Scientific bulletin of Polissia, no. 1(9). pp. 93-101.

9. Sabluk P.T. (2007) Ekonomichnyj mekhanizm APK u rynkovij systemi ghospodarjuvannja [Economic mechanism of agroindustrial complex in the market economy system]. Economy of agroindustrial complex. no. 2. pp. 3-6.

10. Moghyljnyj O. M. (2014) Osoblyvosti derzhavnogho reghuljuvannja zajnjatosti v umovakh ekologhizaciji aghrarnogho vyrobnyctva [Features of state regulation of employment in conditions of ecologization of agrarian production]. Economy and the state. no. 6. pp. 6-12.

11. Gryshova I. Yu., Shestakovska T. L., Glushko O. V. (2017) The economic measurement of convergence of institutional impact on the sustainability of development. Scientific notes of the Institute of Legislation of the Verkhovna Rada of Ukraine, no. 4, pp. 75-80.

12. Nikoliuk O., Gryshova I., Shestakovska T. (2017). The organic production in the context of improving the ecological safety of production of the food industry. Food Science and Technology, Vol. 11, no. 4, pp. 103-111.

13. Markova Ie. (2017). Modern condition of agrarian sector of economy of Ukraine in conditions of implementation of public-private partnership. Economic forum. Lutsk national technical University, no.4, pp. 30-38.

14. Markova Ie. (2016). The Management of sustainable development of socioecological-economic system. Bulletin of Sumy national agrarian University. Series "Economy and management", Vol. 8, pp. 26-31. 


\title{
Mykolaichuk Mykola ${ }^{1}$ \\ Mykolaichuk Natalia ${ }^{2}$
}

DOI: http://dx.doi.org/10.30525/978-9934-571-28-2_20

\begin{abstract}
The purpose of the study is to analyse the degree of use of potential opportunities for the development of the Ukrainian economy, determine the factors influencing it and the necessary actions for the implementation of positive changes. Realizing the goal will bring Ukraine closer to the leading European countries in terms of socio-economic development. Methodology. The research is based on the essential analysis of the correlation of the phenomena of economic systems of different countries, the conditions of their development, the possibilities of purposeful change of existing trends. A consistent analysis of the potential of successful countries in the world, the importance of its specific components in ensuring significant economic achievements, the features of their economic policies and mechanisms of state regulation, is a guideline for defining Ukraine's development priorities and the establishment of mechanisms for managing the necessary changes. Results Ukraine has a natural-resource potential sufficient to enter in the group of the most developed European countries. Therefore, the optimistic mood for the rapid development of a sovereign state was grounded. However, the actual development of events was quite different: a rapid decline in industrial production, lower incomes of the bulk of the population. The first impetus to this was the breakdown of economic ties with other republics of the former Soviet Union. Ukraine has not gained economic independence, whose aspiration is to be defended even by military methods. It turned out that the reason for the economic downturn is, first of all, managerial gaps.
\end{abstract}

\footnotetext{
${ }^{1}$ Doctor of Science in Public Administration, Professor, Head of Department of Public Administration,

Ukrainian Catholic University, Ukraine;

Professor at Department of Economic and Finance Policy,

Odesa Regional Institute for Public Administration of National Academy

for Public Administration Under the President of Ukraine, Ukraine

${ }^{2}$ Doctor of Economic Sciences, Professor,

Director of the Centre for Retraining and Skills Upgrading,

Kherson National Technical University, Kherson, Ukraine
} 


\section{Mykolaichuk Mykola, Mykolaichuk Natalia}

In the process of privatization, a significant start-up capital for business development was formed by people whose moral qualities allowed them to "seize" the property, earn money through questionable commodity-money schemes, the consequences of which were detrimental to the Ukrainian economy. As a result, the management elite were formed from oligarchs, whose mind and talent are aimed at protecting their personal interests and not the prosperity of the state. The intellectual elite were ashamed to deal with shadow capital, criminality and bribes. Therefore, it remained aside from the transformational processes of the country. The current state of the Ukrainian economy is anxious. Its characteristic features were the irrational structure of the economic complex. There are too high expectations for economic gains due to the development of agriculture and ignoring the development of industrial production. World experience proves that countries with a large share of agriculture in the economic structure belong to the poorest category. The modern structure of the industrial complex does not meet the developmental requirements, because contributes to the preservation of raw material specialization and threatens the loss of the opportunity to enter nonraw markets with demand for products V and VI. At a critical level, the state of the shadow economy, the outflow of capital and the migration of the able-bodied population are in the state. An increase in the tensions in society is facilitated by too much discrepancy in the socio-economic development of the regions. Therefore, it is urgently necessary to solve the problems of structural adjustment of the economic complex of the country and regions, preventing the outflow of capital and returning already withdrawn funds to the Ukrainian economy, and to reduce the disproportion in the development of regions. To do this, it is necessary to increase the competitiveness of the institutional component of the public administration system, including at the expense of updating the personnel potential of civil servants who will be able to independently and competently solve the problems of Ukraine's economic development rather than own enrichment. Practical meaning. The proposed methodological approaches to a phased change in the structure of economic complexes of regions, improvement of financial and economic mechanisms of state regulation and staffing of state administration will lead Ukraine's economy to a path of sustainable development. Value / originality. The proposed methodological approaches to the transformation of the economy of Ukraine and its regions, stimulation of structural changes through the influences that contribute to the development of self-regulatory processes that 


\section{Potential possibilities, gaps and prospects for development of economy...}

generate resonance positive effects, has a scientific novelty and contributes to sustainable development of the country.

\section{Introduction}

Ukraine is one of the sovereign states that emerged as a result of the collapse of the Soviet Union (and the Russian Empire before). However, the people's expectation that the natural-resource potential will allow rapid economic upsurge has not materialized. Ukraine holds honourable position among European countries only in the size of territory - 603,5 thousand square kilometres (the second after Turkey with 774,8 thousand square kilometres) and 7 with a population of 42,8 million people. In 2014, more people were in Spain - 46,5 million people, Italy - 60,8 million people, the United Kingdom - 64,6 million people, France - 66,2 million people, Turkey - 77,2 million people and Germany $-81,0$ million people. But the socio-economic achievements of Ukraine are much worse in comparison with these countries. Thus, the expected life expectancy at birth in Ukraine was 76,4 years for women and 66,3 years for men. In other large countries, the life expectancy at birth is over 80 years old, the highest in France is 86 years; for men in these countries, life expectancy rates are also lower than for women, but approaching to 80 years old. In Germany - 78,7 years, France $-79,5$ years. The highest figure in Italy is 80,7 years old. Average wages in Ukraine in USD was almost 10,4 times smaller than in Spain and 15,2 times lower than in the UK. Significant lag and GDP per capita - from 3,8 to 5,2 times [1, p. 541-542; 545-548, 551, 561].

Such a situation in the Ukrainian economy may be considered a kind of "economic miracle." Only in other countries the essence of the economic miracle was the rapid development of the economy despite the limited natural resources. Ukraine is marked by inability to effectively use its powerful natural resource potential. A potentially wealthy state is surprised by the low level of social and economic development. Therefore, the essential analysis of the correlation of the phenomena of the economic systems of the countries, the conditions of their development, the possibilities of purposeful change of the existing tendencies through the influences that contribute to the development of self-regulatory processes, which have a resonant positive impact, becomes of particular relevance. The purpose of the study is to analyze the degree of use of potential opportunities for the development of the Ukrainian economy, determine the factors influencing it and 
the necessary actions for the implementation of positive changes. Realizing the goal requires assessment of the potential and real achievements in the development of the Ukrainian economy. In order to determine the factors of influence on the use of the potential, the main problems in economic development, the formation of the program of action, it is necessary to carry out a comparative description of the conditions of development of the countries of the world, which have achieved significant successes, with distinctive features of the Ukrainian economy. According to the results of the analysis, it is necessary to justify the directions of transformation of the Ukrainian economy and changes in the financial and economic mechanism of state regulation of the personnel policy of the state administration.

\section{Potential and real achievements of economic development.}

Potential is a complex, dynamic, multicomponent system that characterizes potential economic development opportunities. At the same time, it is expedient to divide the whole spectrum of possibilities into two categories: "given by nature" and "created by a person". A peculiar gift of the country can be considered a geographical location, climate and natural resources in the form of various resources: land, biological, water, recreational, mineral deposits, and others. However, the formation of industrial and agro-industrial complexes, services, industrial infrastructure, human capital, and a capable public administration system depends on the activity of the population. Further detail, depending on the purpose of the study, distinguishes material and technical potential, innovative, investment, financial, and others.

It deserves attention to the consideration of the peculiarities of the modernization potential and the proposal for the allocation of the readiness block of the country (regions) for socio-economic transformations: the socio-psychological (population and power structures); normative-legal, scientific-methodical [2, p. 37].

Ukraine has an advantageous geographical location, because it is at a crossroads between Europe and Asia, the West and the East, the North and the South. It has Black Sea ports that do not freeze in winter, as well as ports of the Azov Sea, the Danube and the Dnieper rivers. Therefore, through the territory of Ukraine there are international transport corridors, it has the highest transit rate in Europe, which contributes to the development of the transport sector and tourism [3, p. 3; 4, p. 10]. 


\section{Potential possibilities, gaps and prospects for development of economy...}

Natural resource potential is an important component of the overall development potential; its condition significantly affects the ecological and economic security of countries. Natural resource potential (NRP) may provide a cost estimate, according to which Ukraine per capita exceeds US potential in 1,5-2 times, Germany - in 4 times, Japan - in 12-15 times [5, p. 120]. In the integrated potential, Ukrainian experts give such an assessment to individual resources: land $-44,3 \%$, mineral $-28,3$, water $13,1 \%$, natural recreation $-9,6 \%$, forest $-4,2 \%$, faunal $-0,5 \%$ [6, p. 28$]$.

One of the most valuable natural resources is considered land, which is not only a means of production in agriculture and forestry, but also a necessary territorial resource for the development of many types of social activities. The total land fund of Ukraine is 5,7\% of the territory of Europe [7, p. 8]. Conditions of effective use of land resources are considered by their level of development (agricultural production, urban and rural settlements, industrial development, etc.), preservation of soil fertility and park areas. In Ukraine is the extremely high level of the developed area $-92 \%$. At the same time, agricultural development is one of the highest in the world and reaches $70 \%$. Among the European countries, Ukraine has the largest agricultural land area per capita $-0,9$ hectares (of which 0,7 hectares of arable land), the average European values are 0,44 and 0,25 hectares, respectively. The area of agricultural land reaches $19 \%$, and arable land $27 \%$ of pan-European [7, p. 9]. A significant part of Ukraine's land is particularly valuable (hump humus, etc.) $-38 \%$ of agricultural land and $44,5 \%$ of arable land. However, there is a tendency for land degradation as a result of unsustainable nature management, and the proportion of degraded land already reaches $20 \%$ of the area of arable land [7, p. 19].

Ukraine has unique natural opportunities for recreation and rehabilitation. The area of the recreational and recreational purposes reaches $12.8 \%$ of the country's territory. According to expert estimates, another $6 \%$ of the territory can be mastered for recreational purposes, because their favorable and climatic conditions are among the best [8, p. 11]. They differ in variety: the average annual temperature in the Carpathians $(00 \mathrm{C})$ with a favorable period for resting 90-120 days; the duration of summer holidays in the northwestern regions is 140-145 days, on the seacoast of the steppe zone - 180-190 days, on the southern coast of the Crimea, where the average annual temperature corresponds to the temperature of the Mediterranean coast of France $(12,50 \mathrm{C})-$ up to 220 days [8, p. 17,18]. Ukraine also 
has significant reserves of mineral medicinal waters, whose reserves are only used for $8 \%$. Among them became world-wide values: Mirgorodskaya, Kuyalnik, Polyana Kvasova, Naftusya, Rodonovy waters, Berezivsky mineral waters $[8$, p. 13, 14]. Large reserves in different regions and therapeutic mud. But the most valuable recreational resources include seaside beaches, the total length of which is $1160 \mathrm{~km}$, or $47 \%$ of the coastal strip. According to the experts on the coast of the seas it is possible to organize a simultaneous holiday 4.1 million people, and recreational territories of different landscape species - 48 million people [8, p. 18]. In fact, in 2016, 35071 foreign tourists and 453561 internal tourists (citizens of Ukraine) were served. Traveling for recreation and treatment was 374789 people [9, p. 12]. That is, potential opportunities were used only at $0,8 \%$.

Ukraine had a rather high level of development of agriculture, industry. Agriculture provided raw materials for the food industry, light (flax, wool, leather). However, over the period from 1990 to 2015, the resource supply of the industry significantly deteriorated. The total crop area decreased from 32406 thousand hectares to 26902 thousand hectares. The area of sowing of flax has decreased in 49 times - from 98 to 2 thousand hectares. The number of agricultural animals also significantly decreased: cattle - from 24623 to 3750 thousand head; pigs - from 19427 to 7079 thousand heads; sheep and goats - from 8419 to 1325 thousand heads [1, p. 307, 308, 327].

The industrial complex was focused on the production of high-tech military products and the satisfaction of the primary needs of the population with products of average quality. There was no competition between producers in the planned economy. Only 15-20\% of fixed assets at the technical level corresponded to foreign counterparts. More than $25 \%$ of the equipment was morally obsolete and physically worn [5, p. 39]. Now the situation has only worsened. Substantial updating of production assets did not take place. The degree of wear and tear of fixed assets in 2014 was 83,5\% and exceeded $50 \%$ for strategically important activities: industry $-60,3 \%$, scientific and technical activities $-58,8 \%$, information and telecommunications $-57.4 \%$, threatening the level of wear of transport - 97,9\% [1, p. 252].

During the first years of independence, due to the break of most economic ties, there was a catastrophic decline in production - in 1995, only $50.3 \%$ of the 1990 level remained. In the production of building materials, losses amounted to $65.8 \%$, and in light industry $-70.8 \%$. [5, p. 705]. Further rates of decline in production have decreased, and in recent years, gradual 
recovery has begun. Transportation, too, decreased significantly. For example, transportation of goods from 1990 to 2015 decreased in rail transport from 974 to 350 million tons, automobile - from 4897 to 1021 million tons, offshore - from 53 to 3 million tons, river - from 66 to 3 million tons. The same is true for passenger transport: from 669 million vehicles to 390 cars, from railways - from 8331 to 2244 million passengers, from sea to sea from 26 million people to 0 , for the river - from 19 to 1 million people, for aircraft - from 15 to 6 million people [1, p. 377, 384].

According to the characteristics of intellectual potential in the early 90's Ukraine occupied a place of honour in the top ten countries [12, p. 361]. At the world level, there were indicators of the number of highly skilled personnel (candidates and doctors of sciences), expenditures on science development, and others.

The consequence of ineffective use of the country's potential is the low level of achievement in sustainable development, which is estimated on the basis of the Human Development Index (HDI). In 1993, Ukraine ranked 45 th in the ranking of countries, but in 2001 moved to 74th place. According to the latest report, Ukraine occupies 84th place [5, p. 43; 10 p. 199]. This state of affairs threatens the perception of our country by the world community as a weakly developed. However, Ukraine is significantly different from the underdeveloped countries by the level of education, the development of science. It has "all the industries inherent in the economy of a large, European scale, modern country" [5, p. 120]. However, the long period of instability in production, the lack of implementation of advanced technologies, deterioration of nutrition, medical care, living conditions can lead to negative changes in the psychology of those people who remain in the country. Then, indeed, the country will lose its chance to raise the level of socio-economic development to world achievements.

\section{Gaps in the development of the Ukrainian economy}

One of the main gaps that had devastating consequences for the Ukrainian economy is the economic dependence on the former Soviet republics. Thus, the textile industry was left without raw materials for the production of cotton fabrics, previously supplied by Asian republics. Kherson Cotton Factory, one of the largest in Europe, which produced a wide range of fabrics (furniture, decor, terry, world-known fabrics in the cell, thin chiffons and batistes), which were supplied to more than 80 countries of the world, 
did not cope with this problem and stopped its existence. Machine-building, aircraft engineering used component parts and materials from Russia, Kazakhstan and other former republics of the Soviet Union. There are also problems with sales markets. Depending on the supply of Russian gas significantly affected the competitiveness of products, welfare of the population, gave rise to political conflicts.

The gaps in the development of the economy are connected with the irrational structure of the economic complex. First of all, it has a large share of agriculture, which in 2011 reached 19.4\% [calculated from 1, p. 209]. Ukraine has always been perceived as a breadbasket, nurse. However, global experience proves that countries with a large share of agriculture are among the poorest. The dependence of economic development of the country on the structure of its economic complex offers to consider on the basis of a sectoral model of economy, which characterizes the peculiarity of the structure at different stages of technological development and human needs. To this end, five sectors (levels) of the economy are allocated: the first (agriculture and forestry, hunting, fishing, extractive industry); second (processing industry, construction); the third (transportation and communications, trade, utilities, repair of cars and household products); the fourth (activity of hotels, restaurants, financial institutions, services for entrepreneurs, real estate transactions); the fifth (public administration, education and science, culture and sports, health care). At the pre-industrial stage in the low-income countries, satisfaction of urgent needs prevails due to the development of the first sector. In the countries of the industrial stage of development, which include Ukraine, the second and third sectors predominate. In the most developed countries of the post-industrial development stage, the second sector continues to grow, the first and third sectors are shrinking, and the fourth, but predominant, fifth sector is expanding. In the period from 1970 to 2011, the share of agriculture in developing countries has decreased from $25,0 \%$ to $9,4 \%$; on average in the world - from $9,8 \%$ to $4,4 \%$; developed countries - from $4,7 \%$ to $1.4 \%$. That is, the share of agriculture in the Ukrainian economy is much higher than in developing countries [12, p. 9-11; 13, p. 99].

Important sense also has the structure of the industrial complex. In the developed countries, the manufacturing industry is growing at a faster pace. The share of extractive industries in the total cost of industrial products in these countries over the period from 1970 to 2010 decreased from $17,9 \%$ to 
$5,9 \%$, while processing increased from $77,5 \%$ to $87,7 \%$. In the manufacturing industry, the leading industry is mechanical engineering, whose share increased from $20,7 \%$ to $45,3 \%$ over the period. The production of electronic equipment is growing, its share increased in 4,6 times (from 4,3\% to $19,8 \%$ ). The share of production of vehicles and equipment increased significantly from $5,7 \%$ to $10,3 \%$. However, the share of metallurgical production and finished metal products declined somewhat - from $6,8 \%$ to $4,2 \%[13$, p. 110,111$]$.

During the years of independence in the structure of the industrial complex of Ukraine there were negative changes. The share of metallurgical production increased from $11,0 \%$ in 1990 to $26,5 \%$ in 2004 . During this period, the share of machine building decreased from $30,7 \%$ to $13,7 \%$ [14, p. 98$]$.

In 2015 , the share of extractive industry amounted to $10,9 \%$, processing $-64,6 \%$. Somewhat decreased the share of metallurgical production - up to $15,9 \%$. There is catastrophically low share of mechanical engineering $6,5 \%$, production of vehicles $-2,3 \%$, production of computers, electronic and optical products $-0,4 \%$ [1, p. 270].

A generalized characteristic of structural parameters of economic development is provided by means of assessing national wealth (NW). The volume and structure of the national wealth of Ukraine corresponds to low and middle income countries. Thus, NW per one person of the population of Ukraine amounted to 29,3 thousand US dollars in 2005. Of these, natural capital amounted to $23,5 \%$, produced $24,7 \%$, intangible capital of less than $60 \%$. In countries with low and average income, the NW per capita reached 27,3 thousand US dollars, the share of natural capital was $21,1 \%$, produced was $19,9 \%$. On average, in the world, the NW per capita amounted 115,6 thousand US dollars. In its structure natural capital is $6,2 \%$, and $17,6 \%$ is produced. In high-income countries, the average indicator of NW per capita is 561,1 thousand US dollars. The share of natural capital is $2,5 \%$, capital generated $17 \%$, intangible capital amounted to more than $80 \%[15, \mathrm{p} .74]$.

The large share of natural capital in the NW shows a low level of GDP and low efficiency of capital and intangible assets use. Indeed, in the global volume of NB, which was conditionally determined on the basis of settlements in 154 countries, the share of Ukraine in 2005 was $0,2 \%$, Poland $-0,7 \%$, Russia - 1,5\%, China - 3,5\%, United States - 30,7\% [15, p. 74].

The level of GDP and NW of the country depends on the innovative development and technological structure of production, which in Ukraine 
does not meet the requirements of time. World leaders to accomplish the formation of new industries and markets products based on innovative technologies using VI technological mode. In Ukraine, 95\% of the technologies belong to the III and IV modes, the characteristic features of which are the use of rail transport, inorganic chemistry, electricity, coal, and the development of universal machine building. In the developed countries, in the mid1970s, it exhausted the IV technological mode that is stored in our country in the production of polymer materials, non-ferrous metallurgy, oil refining, instrument making, and others. Only $3-5 \%$ of the structure of the national economy is occupied by production, which corresponds to the $\mathrm{V}$ technology: complex computer technology, aviation industry, software, advanced weapons, robot construction, and others [15, p. 149].

Another gap in the Ukrainian economy is the poor utilization of resources. Energy intensity of GDP is higher than in economically developed countries in 3-5 times [14, p. 99].

Labour productivity in Ukraine is in 23 times lower than in France, in 22,5 times less than in Finland, in 18 times less than in Japan, in 5,5 times less than Slovenia and Estonia, in 4,5 times lower than in Poland [16, p. 23].

In order to change the situation, it is necessary to attract investments for the renewal of production on an innovative basis. But you need to solve the problem of improving the business climate.

The comparative characteristics of business climate in different countries provide international indices of economic freedom and ease of doing business.

The Index of Economic Freedom (IEF) assesses the level of state liberalization in its interaction with business, the existence of restrictions and obstacles in the implementation of economic activity. The level of economic freedom in Ukraine is too low in comparison with the countries of Europe and with the countries of the post-Soviet space. For the period from 2010 to 2015, Ukraine's rating was kept at 162 positions from 186 countries. Only in 2014, in anticipation of positive changes after the events on EuroMaydan, he rose to 155 seats. Compared to 2011, the situation with the protection of property rights deteriorated (from 99 positions the country moved to 138 position), the level of corruption remained unchanged (148-149 position), public spending increased (changes from 155 to 163 positions), the situation improved only with the regulation of prices (from 163 positions Ukraine moved to 68 place) [17, p. $14 ; 18$, p. 88]. 


\section{Potential possibilities, gaps and prospects for development of economy...}

Unfortunately, in 2016, Ukraine remained 162 in the world and 44 in Europe. Depending on the index value, which is determined by the 100-point system, countries are divided into five categories: a free economy -80 points and above, mostly free - from 70 to 79,9 points, moderately free - from 60 to 69,9 points, mostly non-free - from 50 to 59,9 points, suppressed (despotic) - less than 50 points [19, p.33]. Ukraine belongs to the last category. Moreover, the achievements of many post-Soviet countries are much better. By the last category, together with Ukraine, were Belarus, Uzbekistan and Turkmenistan. The economy of Russia, Kyrgyzstan and Tajikistan is considered to be largely non-liberal. Countries with a moderately free economy are Azerbaijan, Armenia and Kazakhstan. The economy of Georgia, Latvia, Lithuania and Estonia is generally considered to be free $[20$, p. 58].

Consequently, the gaps in Ukraine's economic development are, in most cases, gaps in management.

\section{Directions for transformation of management of economy of Ukraine}

Management problems need to be addressed through fundamental changes in the formation of personnel potential of public administration and conceptual approaches to governance.

Among the proposals for changing the paradigm of governance is the development of Ukraine as a multi-disciplinary corporation [21, p. 285]. The advantage of such an approach is the systemic and balanced management. However, we need to pay attention to the fact that the purpose of corporations is to make a profit. Attention to the person is only one of the means of increasing the efficiency of the use of human potential. In the public administration, according to the paradigm of sustainable development, the main attention should be paid to human development and environmental protection, and economic results are a prerequisite for resource support for achieving the goal.

The entrepreneurial approach has led to the involvement of oligarchs in the government. The logic was that a person who can effectively manage his own capital would successfully manage state development. However, their own interests prevail and their formula for success is: "that is beneficial to the oligarch, is unprofitable for Ukraine" [21, p. 291].

In our view, the thesis that a high (exceeding the amount of bribes?) salary is a counteraction to bribery on the part of judges and other officials 
is considered false. Since a person who seeks to make "easy money" in any way will never stop.

Much higher than the average in Ukraine salaries of deputies, additional payments for recreation during the rest, the possibility of lobbying someone's interests leads to the fact that the gap between the standard of living of the majority of the population and deputies is increasing. It is therefore appropriate to create conditions under which the deputies follow the vocation and not for the sake of benefit. It is logical that the deputies of the Verkhovna Rada of the parties receive wages at the level of the average in the country, and from the region (by majority system) - the average wage of the appropriate region.

The deputies choose the population of the country; therefore, their preferences depend on the age structure and awareness of the possible consequences of giving preference to a certain political force. Population o Ukraine in the age of 20-54 years was, in $2016,50,6 \%$ of the total population, 55years and older $-29,5 \%$. That is, in the best years of youth almost $37 \%$ of potential voters were in Soviet times. Then people were the "cogs" of the system that shaped the country's future and limited the possibilities for interference by an average citizen in this process. The era of total deficits was "a paradise pleasure" for those involved in its distribution. Therefore, they strive at any price to return the past. Much of the retirement age, despite the turn and deficit, also wants to "have past" for cheap food, free education and health services. They were not able to travel to other countries and compare the conditions of the existence of two worlds: the "planned" and "market" economies. In addition - the most accessible means for obtaining information for the elderly - television during the planned economy created a positive mood for people, because it systematically informed about the achievements of the country in various spheres. In today's conditions, in pursuit of "hot" news, journalists have flooded the screens with terrible episodes of accidents, fires, and violence. It creates an atmosphere of fear, negatively affects the health and mental state of people. The technical progress of many frightens, because they are not able to use ATMs, the Internet. Therefore, it is necessary to create conditions for the full participation of the elderly in social processes. It is possible to start with study programs on television that compare the peculiarities of everyday life, programs and conditions for the preparation of children in pre-school institutions, schools, med- 
ical care, and others. It is advisable to create centres where pensioners can get consultations, use the Internet for free, etc., which will enable them to understand the benefits of new technologies, to feel the need of a modern country.

Young people like the modern lifestyle. Therefore, a significant part of young people are trying to leave the country in search of "better luck." A significant number of Ukrainians have already made such a choice. Official statistics do not provide accurate information on the number of emigrants, because only those who are officially employed abroad send their relatives a remittance. According to the results of surveys carried out from 2008 to 2012, the number of migrant workers abroad in 2012 amounted to 1,95 million people. According to unofficial data, their number is approaching 7 million people [22, p. 174; 23, p. 45].

Among the factors driving migration, they are considered the most important: the lack of income $(68,4 \%)$, the lack of employment opportunities $(55 \%)$, the desire to make money quickly $(34,5 \%)$, poor housing conditions $(25,8 \%)$, example of relatives or friends $(11,0 \%)$ [24, p. 96$]$.

Demographic situation in European countries contributes to labour migration, which complicates the process of population recovery. Therefore, according to experts' forecasts, to maintain the number of able-bodied population at the required level for the EU by 2050, 79 million migrants will be required [23, p. 44].

Migration processes have both negative and positive consequences. Among the positive effects for Ukraine is a reduction in unemployment, a transfer of funds, which are a more reliable source of currency than investment. Thus, in 2013, foreign direct investment amounted to 4,4 billion US dollars and money transfers $-8,5$ billion US dollars $[25$, p. 6]. On average, income from labour migrants in Ukraine is about 3\% of the population's income, and in the western regions this ratio is much higher. Thus, in Ivano-Frankivsk and Ternopil regions it reaches $12-19 \%$, while in the Zakarpatska and Chernivtsi regions it exceeds $23 \%$ of the population's income [22, p. 177]. Nevertheless, the negative effects are more significant. Emigrants from Ukraine are many scholars and specialists with higher education, for which many years and public funds have been spent. It is these people who would have to build a new effective state economy. However, the Country Competitiveness Report 2017-2018 states that Ukraine takes up a lasting place by the ability of the country to attract talent (attract foreign 
specialists) and retain talent - the corresponding positions in the ranking of 106 and 129 of 137 countries [26, p. 297].

Most immigrants from the less developed countries of Asia and Africa immigrate to Ukraine, which creates epidemiological and other problems rather than improves their human potential. Therefore, it is necessary to create conditions for the preservation of skilled personnel.

The main hope of the country for the part of active youth, which selflessly protects the country's independence, seeks to revive economic development and bring Ukraine to the circle of developed European countries. To this end, it is necessary to involve patriots with appropriate professional training in the government. Thus, the composition of the Cabinet of Ministers should be formed not by quotas, but by professional qualities.

What changes in economic development are necessary? To reduce social tension in society, it is necessary to reduce the differences between the level of socio-economic development of the regions, to provide them with certain self-sufficiency in meeting the primary needs of the population, providing social services, creating conditions for comfortable living and personal development. Positively affects the economic security of the country and its regions, employment, growth of its welfare, development of the domestic market. But this process must be managed in order to provide the necessary structural changes in the economy in order to obtain a synergistic effect from the interaction of different industries and fields of activity, increasing competitiveness and forming a positive image of the state in the world community. In this case, it is advisable to make phased changes in the structure of economic complexes of regions.

The development of agriculture should be aimed at ensuring the needs of the population in food products according to rational norms and needs of the light industry in the raw materials subject to rational nature management, conservation of soil fertility and environmental cleanliness. The preservation of the rural population will contribute to the development of rural tourism, quality drinking water, educational and medical services, and the development of high-quality roads.

The next step should be the restoration of light industry. After all, through the trade network of enterprises only $8,6 \%$ of clothing manufactured in Ukraine, 3,1\% of footwear is sold [1, p. 432]. By the fall of production after the collapse of the USSR, the light industry enterprises of the Kherson region provided a significant contribution to the region's bud- 
get, to meet the needs of the population in products, employment of the population, balancing demand for male and female labor. Among these enterprises were: one of the largest cotton mills in Europe, a sewing factory for tailoring men's wear, a shoe factory, and the production of leather and articles made of it.

At the third stage, it is necessary to restore machine-building enterprises on an innovative basis. It is important to provide the needs of agricultural machinery, equipment of enterprises, vehicles.

At the state level, it is necessary to solve the problems of ensuring the production of equipment for widespread implementation in the management of information technology. So far, the share of domestic production sold through the retail chain is only $0,8 \%$ in the category of computers, peripheral equipment, software, and even less in the category of "audio and video equipment, telecommunication equipment" - $0,3 \%$ [1, p. 432].

It is necessary to change the structure of foreign trade. Thus, in 2015, $24,8 \%$ of exports consisted of non-precious metals and products, $20,9 \%-$ plant products, $8,1 \%$ - mineral products, $10,3 \%$ - machinery, equipment and mechanisms, electrical equipment, 5,6\% - production of chemical and related industries. At the same time, $31,2 \%$ of total imports consisted of mineral products, $16,7 \%$ machinery, equipment and machinery, $13,4 \%$ chemical products, $4,6 \%$ land transport vehicles, aircraft and floating means $[1$, p. 403]. Consequently, instead of exporting raw materials, it is necessary to give preference to meeting the needs of their own production.

Consequently, in the context of globalization, the development of the internal market of goods and services at the expense of its own production can become the basis for stabilization and further development of the economy. But financial support for development, investment of own production by business structures and not the withdrawal of funds abroad are of special importance. To do this, it is necessary to create barriers for the hidden withdrawal of capital, since only in 2013 from Ukraine to the offshore more than 40 billion hryvnias were withdrawn [27, p. 64]. Such barriers are the conditions under which the legal transfer of profits from countries that directly produce goods or services into tax havens should be more costly than paying taxes at the place of production and illegal to be accompanied by prosecution. One of the interesting proposals of specialists of Ukraine is the introduction of a tax payment of $15 \%$ of transactions with non-residents [27; 28, p. 156]. 
An urgent problem is the return of previously withdrawn funds to Ukraine. To this end, it is proposed to build a system that will provide for tracking, freezing, seizing and confiscating illegally withdrawn funds from the country [27, p. 19]. An alternative can be to stimulate the return of previously withdrawn funds to the Ukrainian economy in the form of investments.

In agriculture, it is necessary to stimulate livestock development. This will have a positive effect on meeting the needs of meat and dairy products, providing farms with organic fertilizers, raw materials for the textile industry and leather enterprises. For the formation of the forage base, it is necessary to reduce the farmers' benefits from the cultivation of technical crops, sunflowers, which adversely affect the soil fertility. Facilitating the solution of this problem is obligatory to compensate farmers for the costs of restoring humus content on land leased to them.

In addition to increasing production it is necessary to take care of the growth of solvency of the population. After all, even with the consumption of meat and dairy products, much less than rational standards, in 2015, the population spent on food products $57,9 \%$ of income [1, p. 94].

Some experts believe that the improvement of the economy contributes to the utility of wages, especially during the period of depression. There is fear that wage increases will not improve the living standards of the population due to rising inflation. However, avoiding the negative consequences of increasing the incomes of the population may be due to the faster growth of supply of goods.

It is also mistaken for managers of enterprises to solve economic problems and increase the competitiveness of products at the expense of reduction of wages. On the contrary, a higher wage level contributes to a reduction in personnel turnover and the costs associated with the search, training and adaptation of new employees to the business environment; attraction of more qualified specialists; the motivation of labour and the corresponding increase in its productivity; reducing the unit cost of production and increasing sales of products, profits. These provisions are also confirmed by World Bank data. In the 15 years (from 1984 to 1999), the average annual wage in the US manufacturing industry increased by $51,5 \%$, while the added value created by employees increased by $86,7 \%$. Similar trends have also been observed in Japan, Germany, the United Kingdom, France, and Canada [14, p. 388]. 


\section{Potential possibilities, gaps and prospects for development of economy...}

The success of management of economic processes in the region depends on trust in the government, the establishment of interaction between all interested groups: representatives of the authorities, business, academics, and the public. At the same time, the formation of a positive image of the region, creation of conditions for the residents to feel the care of their fate, and the pride of their "Little Fatherland" is gaining great significance.

With the general desire to make it almost impossible, despite all the hardships and obstacles, to achieve the real goal of ensuring sustainable development of the region in accordance with world standards, the main task of the regional administration is the formation of development goals, the justification of the ways of their achievement, stimulation of available means of activity of business entities, aimed at realizing the strategic tasks of the region.

Training for the renewal of the economy should be carried out by providing the second higher education in public administration on the basis of basic technical, agrarian, economic, with compulsory mastering of the state language and foreign language.

\section{Conclusions}

Ukraine's natural and resource potential has given rise to hopes for a rapid economic outburst as a result of sovereignty. But due to his imbalance, the significant economic dependence on Russia and other former Soviet republics, the result was the opposite. The decline in industrial production, corresponding to a decline in living standards, led the country to the poorest countries. It differs from Ukraine as a scientific potential, a high level of education of the population, which, unfortunately, migrates to more developed countries. Therefore, problems in the socio-economic development of Ukraine are mainly managerial. They relate to the formation of a management elite among the oligarchs, whose own interests are contrary to the interests of the state. This also contributes to the mentality of a significant part of voters who are accustomed to being "cogs" of a mechanism that does not perceive "interference" in its work. Infusion of means of information of fear, a feeling of disaster, adversely affects the health of the population, the psychological state of people. These voters (mostly retirement age), consider themselves "abandoned" by the state, seek to turn back the times of planned economy, believe in deceptive promises. Therefore, it is necessary to create conditions for the awareness of the elderly of the ben- 


\section{Mykolaichuk Mykola, Mykolaichuk Natalia}

efits of "European choice", the possibility of their participation in positive changes.

In order to reduce migration, it is necessary to restore economic development, create new jobs. This will be facilitated by the development of the domestic market of goods and services, filling of its products with domestic producers. The priority directions of development should be intensification of agricultural production, increasing the share of organic products, improving the quality of products in the food industry, the revival of light industry, development of tourism activities.

Such actions will positively affect the employment of the population, its welfare, will allow to accumulate funds for the development of science-intensive production V, VI forms. State regulation should be carried out by stimulating the necessary changes by financial and economic levers. People who sincerely want Ukraine's prosperity and not their own enrichment have to manage these processes. Therefore, work in the parliamentary corps should be carried out "on the call of the soul", but not in commercial interests. The pay of the deputies from the parties should be at the level of the average in Ukraine, and from the districts - the average in the region. The Cabinet of Ministers should be formed on professional grounds, and not by party quotas. Further researches should be aimed at finding ways to reduce the outflow of capital from Ukraine, the return of already withdrawn funds in the form of investments in the most important projects for the development of the economy of the country and regions.

\section{References:}

1. Zhuk I.M. (Ed.). (2016) Statystychnyi shchorichnyk Ukrainy za 2015 rik [Statistical Yearbook of Ukraine for 2015]. Kyiv: State Statistics Service of Ukraine. Available at: http://www.ukrstat.gov.ua/druk/publicat/kat_u/publ1_u.htm (accessed 20 December 2017).

2. Hedz M.Y. (2012) Sutnist ta struktura sotsialno-ekonomichnoho potentsialu modernizatsii rehioniv [The essence and structure of the socio-economic potential of modernization of the regions]. Financial space, 2 (6), 33-38. Available at: https://fp.cibs.ubs.edu.ua/files/1202/12gmjsts.pdf. (accessed 20 October 2017).

3. Zhalilo Ya.A.(Ed.). (2013) Modernizatsiini priorytety reformuvannia transportno-dorozhnoho kompleksu v Ukraini: analitychna dopovid [Modernization Priorities of the Transport and Road Complex Reform in Ukraine: An Analytical Report]. Kyiv: NISS. Available at: http://www.niss.gov.ua/content/articles/files/ Modern TDK-6b534.pdf. (in Ukrainian). (accessed 20 December 2017).

4. Pysarevskyi I.M. (Ed.). (2014) Tendentsii ta napriamky rozvytku turystychnoi industrii Ukrainy: monohrafiia [Trends and directions of development 


\section{Potential possibilities, gaps and prospects for development of economy...}

of tourist industry of Ukraine: monograph]. Kharkiv: O.M. Beketov National University of Urban Economy in Kharkiv. Available at: http:/eprints.kname.edu.ua/ 39483/1//2012\%20печ\%20.\%2023МН\%20Монографія\%20колективна \%20 Каф.\%20ТіГГ.pdf. (in Ukrainian). (accessed 20 October 2017).

5. Heiets V.M. (Ed.). (2003) Ekonomika Ukrainy: stratehiia i polityka dovhostrokovoho rozvytku [Economy of Ukraine: strategy and policy of long-term development] Kyiv: Phoenix. (in Ukrainian).

6. Rudenko V.P. and Rudenko S.V. (2015) Otsinka miry svoieridnosti (unikalnosti) struktury pryrodno-resursnoho potentsialu pryrodnykh rehioniv Ukrainy [Assessment of the degree of uniqueness (uniqueness) of the structure of natural resources potential of natural regions of Ukraine]. Ukrainian Geographic Magazine, 1, 27-32. Available at: https:/ukrgeojournal.org.ua/sites/default/files/ UGJ_2015_1_27-32.pdf (accessed 22 October 2017).

7. Martyn A.H., Osypchuk S.O. and Chumachenko O.M. (2015) Pryrodnosilskohospodarske raionuvannia Ukrainy: monohrafiia [Natural-agricultural regionalization of Ukraine: monograph]. Kyiv: Comprint. Available at: https://zsu.org.ua/ files/Monograph_Natural_agricultural_zoning.pdf. (in Ukrainian). (accessed 20 October 2017).

8. Kraievska A.S., Moroz O.O. and Hrabovetskyi B.Ye. (2012) Rekreatsiini resursy sanatorno-kurortnykh pidpryiemstv: sutnist ta perspektyvy vykorystannia: monohrafiia [Recreational resources of sanatorium and resort enterprises: essence and perspectives of use: monograph] Vinnitsa: VNTU Available at: http://kraevska.vk.vntu.edu.ua/file/185bce2b74211289bc2f6ba76a19489b.pdf (in Ukrainian). (accessed 23 October 2017).

9. State Statistics Service of Ukraine (2017) Statystychnyi biuleten Turystychna diialnist v Ukraini u 2016 rotsi [Statistical bulletin Tourism activity in Ukraine in 2016] Kyiv: State Statistics Service of Ukraine. Available at: http://www.ukrstat.gov.ua/ druk/publicat/kat_u/publtur_u.htm (accessed 23 December 2017).

10. UNDP (2016) Human Development Report 2016 (Web resourse). United Nations Development Programm (UNDP), 2016 http://hdr.undp.org/sites/default/ files/2016 human_development_report.pdf (accessed 23 December 2017).

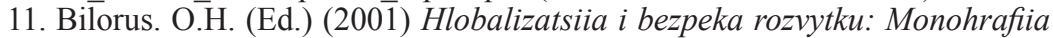
[Globalization and development security: Monograph]. Kyiv: KNEU. (in Ukrainian).

12. Kuzmin O.Ye. and Pyroh O.V. (2013) Sektorna model rozvytku natsionalnoho hospodarstva Ukrainy $\mathrm{V}$ umovakh postindustrialnoho suspilstva [Sectoral model of the development of the national economy of Ukraine in the conditions of postindustrial society]. BUSINESSINFORM, 7, 8-13. available at: http://www.business-inform.net/pdf/2013/7_0/8_13.pdf (accessed 24 December 2017).

13. Kindzerskyi Yu.V. (2013) Promyslovist Ukrainy: stratehiia i polityka strukturno-tekhnolohichnoi modernizatsii: monohrafiia [Ukrainian industry: strategy and policy of structural and technological modernization: monograph]. Kyiv: IEF NAS of Ukraine. available at: http://ief.org.ua/docs/mgCтратегія\% 20 модернізації\%20промисловості_Кіндзерський_536c.pdf. (in Ukrainian). (accessed 24 November 2017).

14. Heiets V.M., Semynozhenko V.P. and Kvasniuk B.Ye. (Ed.). (2007) Stratehichni vyklyky KhKhI stolittia suspilstvu ta ekonomitsi Ukrainy: $V$ t. 


\section{Mykolaichuk Mykola, Mykolaichuk Natalia}

(T. 3: Konkurentospromozhnist natsionalnoi ekonomiky) [Strategic Challenges of the 21st Century for Society and the Economy of Ukraine: 3 volumes. (Vol. 3: Competitiveness of the national economy)]. Kyiv: Phoenix. (in Ukrainian).

15. Shynkaruk, L.V. (Ed.). (2015) Strukturni transformatsii v ekonomitsi Ukrainy: dynamika, superechnosti ta vplyv na ekonomichnyi rozvytok: naukova dopovid [Structural Transformations in the Ukrainian Economy: Dynamics, Contradictions and Influence on Economic Development: Scientific Report], Institute of Economics and Forecasting of the National Academy of Sciences of Ukraine, Kyiv, available at: http://ief.org.ua/docs/sr/288.pdf. (in Ukrainian). (accessed 12 November 2017).

16. Khaminich S.Yu. (2007) Konkurentospromozhnist natsionalnoi ekonomiky: osoblyvosti, priorytety ta problemy [Competitiveness of the national economy: peculiarities, priorities and problems]. Actual problems of the economy, 4, 20-26.

17. Moroz, V.V. and Shepetko, R.I. (2015) Instytutsiine seredovyshche neoindustrializatsii ekonomiky Ukrainy $\mathrm{v}$ svitli hlobalnykh kompleksnykh indeksiv [Institutional environment of neoindustrialization of the Ukrainian economy in the light of global integrated indices]. Economic annals-XXI, 7-8 (2), 12-14. Available at: http://soskin.info/userfiles/file/2015/7-8_2_2015/Moroz_Shepetko. pdf (accessed 10 November2017).

18. Okhota, V.I. (2015) Konkurentospromozhnist Ukraini na svitovii ekonomichnii areni [Competitiveness of Ukraine in the world economic arena]. Economic analysis: a collection of scientific works, TNEU, Vol19, 1, 84-90. Available at: http://nbuv.gov.ua/UJRN/ecan 2015 19\%281\%29 13. (accessed 2 November2017).

19. Mytsiuk S. (2016) Stan ekonomichnoi svobody v Ukraini ta yii vplyv na konkurentospromozhnist [The state of economic freedom in Ukraine and its impact on competitiveness]. Bulletin of Taras Shevchenko National University of Kyiv. Economics, 9(186),30-35.DOI: https://doi.org/10.17721/1728-2667.2016/186-9/4. (accessed 8 November2017).

20. Yerina, A.M. (2016) Mizhnarodni reitynhy: statystychni aspekty obchyslennia ta zastosuvannia. Chastyna 1. Indeks ekonomichnoi svobody ta hlobalnoi konkurentospromozhnosti [International ratings: statistical aspects of calculation and application. Part 1. Index of Economic Freedom and Global Competitiveness]. Statistics of Ukraine, 3, 56-64 available at: http://194.44.12.92:8080/jspui/bitstream/123456789/1987/1/11.pdf. (accessed 19 November2017).

21. Budzan B. (2001) Menedzhment v Ukraini: suchasnist i perspektyvy [Management in Ukraine: Present and Future]. Kyiv: Osnovy. (in Ukrainian)

22. Pozniak O.V. (2016) Otsiniuvannia naslidkiv zovnishnoi trudovoi mihratsii v Ukraini [Assessing the Consequences of External Labor Migration in Ukraine]. Demography and Social Economy, 2(27), 169-182. available at: http://nbuv.gov.ua/ UJRN/dse 20162 15. (accessed 1 November2017).

23. Pitiulych ${ }^{-}$M.I. (Ed.). (2015) Rehuliuvannia trudomihratsiinykh protsesiv $\mathrm{v}$ transkordonnomu rehioni: monohrafiia [Regulation of labor migration processes in the transboundary region: a monograph]. Mukachevo: MSU available at: http://dspace.msu.edu.ua:8080/bitstream/123456789/263/1/01_Monohrafiya\%20. pdf. (in Ukrainian). (accessed 7 November2017). 


\section{Potential possibilities, gaps and prospects for development of economy...}

24. Sadova U.Ya. (Ed.). (2015) Naslidky mihratsiinykh protsesiv: novi vyklyky ta mozhlyvosti dlia rehioniv [Consequences of Migration Processes: New Challenges and Opportunities for Regions]. Lviv: Dolishniy Institute of Regional Research of NAS of Ukraine. available at: http://ird.gov.ua/irdp/p20150804.pdf. (in Ukrainian). (accessed 17 November2017).

25. Nadtochii A.O. (2015) Prychyny zovnishnoi trudovoi mihratsii ta otsinka yii naslidkiv dlia ekonomiky Ukrainy [The reasons for external labor migration and the assessment of its consequences for the Ukrainian economy]. Theory and Practice of Public Administration: Collection of Scientific Works, 1(48), 106-113. available at: http://www.kbuapa.kharkov.ua/e-book/tpdu/2015-1/doc/2/06.pdf. (accessed 17 November2017).

26. World Economic Forum (2017) The Global Competitiveness Report 2017-2018. Web page. available at: https:/www.weforum.org/reports/the-global-competitiveness-report-2017-2018. (accessed 21 February 2018)

27. Novytskyi V.A. (2015) Otsinka efektyvnosti protydii vykorystanniu nyzkykh podatkovykh yurysdyktsii u skhemakh ahresyvnoho podatkovoho planuvannia [Evaluating the effectiveness of counteracting the use of low tax jurisdictions in aggressive tax planning schemes]. The mechanism of counteraction to aggressive tax planning: world experience and practice of Ukraine: a collection of materials of the scientific methodological seminar, December 10, 2015. - Irpin: USFSU, available at: http://ir.nusta.edu.ua/jspui/bitstream/doc/275/1/239_IR.pdf (accessed 1 February 2018).

28. Tyshchuk, T.A. and Ivanov, O.V. (2012) Shliakhy protydii prykhovanomu vidplyvu kapitalu z Ukrainy: analitychna dopovid [Ways of counteracting the hidden outflow of capital from Ukraine: an analytical report]. The National Institute for Strategic Studies, Kyiv, available at: http:/www.niss.gov.ua/ content/articles/files/ Kapital_Tuschuk-72ec2.pdf. (in Ukrainian). (accessed 21 February 2018).

29. Diachenko, Ya.Ya. (2015) Zasoby derzhavnoi protydii neproduktyvnomu vidplyvu kapitalu za mezhi Ukrainy [Means of the state counteraction to the unproductive outflow of capital beyond Ukraine]. RFI Scientific Papers, 2 (71), 149-157. Available at: http://nbuv.gov.ua/UJRN/Npndfi_2015_2_13. (accessed 11 January 2018) 


\section{THE DEFENDENCE INDUSTRIAL COMPLEX OF UKRAINE IN AN ECONOMY OF POSTINDUSTRIAL SOCIETY: ANALYSIS AND PERSPECTIVES}

\section{ОБОРОННО-ПРОМИСЛОВИЙ КОМПЛЕКС УКРАЇНИ В УМОВАХ ЕКОНОМІКИ ПОСТІНДУСТРІАЛЬНОГО СУСПІЛЬСТВА: АНАЛІЗ ТА ПЕРСПЕКТИВИ}

\section{Otsabryk Iryna ${ }^{1}$}

DOI: http://dx.doi.org/10.30525/978-9934-571-28-2_21

Abstract. Subject of study. The term of "postindustrial economy" was defined. The DIC of Ukraine was analyzed in the current economic conditions of postindustrial society during 2014-2017 years. The report about globalization was explored from Credit Suisse and Rating of Global Firepower 2016, which became the basis for conclusions about the state of the defense department of leading countries. The legislative base of the defense sector in Ukraine and prospects of the defense industry were studied, and suggestions for improving its operations were made.

The purpose. To explore the status of the defense industrial complex of Ukraine and to formulate proposals for solving these problems.

The tasks. To explore features of the defense industrial complex of Ukraine in modern conditions of postindustrial economy, to analyze the possibilities and perspectives and improve its mechanism of work.

The results of research. Today, according to the report about globalization from Credit Suisse and Rating of Global Firepower 2016, where analyzed armed forces of 126 countries, Ukraine took the 30th place in the world (the first places took the USA, Russia, China, Japan and India accordingly) and the $8^{\text {th }}$ place in Europe (winners: France, UK, Germany).

Conclusions. Despite some problems and a number of difficulties, which Ukraine is experiencing today, being able of "hybrid warfare", DIC has all the prerequisites for a substantial expansion of its powers in terms of postindustrial economy not only through knowledge development and

\footnotetext{
${ }^{1}$ Postgraduate Student,

Lviv Regional Institute of Public Administration of the National Academy of Public Administration under the President of Ukraine, Ukraine
} 
innovation, but also through knowledge, skills and gained experience in recent years. Due to new developments of the Ministry of Defense of Ukraine, the DIC has own vector of development for decades to come. Also the path is defined for implement the State program of reform and development of the DIC of Ukraine. In addition, revenues from export of Ukrainian weapons and services for military purposes are showed that Ukrainian DIC's products in general responsible to international standards and is not inferior to their counterparts of the largest countries-exporters of military equipment.

\section{1. Ветуп}

Новизна теми. Одним із напрямів визначення структурних зрушень в економіці України є використання резервів оборонного потенціалу держави. Існуючі наукові розробки та практичні рекомендації не враховують належною мірою вплив оборонного виробництва на розвиток багатьох галузей національної економіки. Вагомість такого впливу визначається, перш за все, сучасним станом виробничої і науково-технічної діяльності оборонно-промислового комплексу та прогнозом їх розвитку на найближчу перспективу.

Сьогодні перед Україною стоїть складна науково-економічна проблема - як в умовах скорочення обсягів оборонного бюджету забезпечити розвиток оборонно-промислового комплексу та необхідний рівень воєнно-економічної безпеки держави. Визначення основних напрямів трансформаційних зрушень потребує насамперед розробки глобальної концепції воєнно-технічної політики України, узгодженої 3 програмою економічного розвитку України та окремих іiї галузей. На рівні Концепції до 2014 року залишалась стратегія структурної перебудови оборонно-промислового комплексу. Не узгоджена з Державною програмою промислової політики України, структурна перебудова оборонно-промислового комплексу знову зникає з державного рівня i переходить на рівень вирішення проблем відомчого характеру.

Ситуація ускладнюється відсутністю до цього часу прагматичного визначення економічних умов реалізації Державної програми розвитку озброєнь і військової техніки. Ресурсно-економічне обгрунтування обрису Збройних Сил та інших військових формувань України згідно 3 планом проведення оборонного огляду в Україні було визначено лише на початку 2004 року. 
Актуальність наукових рішень. Дослідження оборонно-промислового комплексу в постіндустріальній економіці $є$ актуальним у зв'язку зі змінами у чинному законодавстві, а саме у зв'язку зі схваленням Стратегії розвитку оборонно-промислового комплексу. Враховуючи зміни, внесені у нормотворчі документи, актуальним $є$ вивчення основних шляхів фінансового оздоровлення галузі.

Вперше запропоновано створити Асоціацію виробників/розробників продукції оборонного призначення, яка буде працювати у напрямку модернізації національного законодавчого поля, організації тісної співпраці з партнерами та організаціями, в тому числі і за кордоном, представлятиме Уряду альтернативні можливості розвитку оборонно-промислового комплексу України на основі передового західного досвіду.

Удосконалено механізм фінансового забезпечення та оздоровлення оборонно-промислового комплексу на сучасному етапі існування.

Набуло подальшого розвитку трактування поняття «панівна група постіндустріального суспільства» - інтелектуальні працівники, які займаються передачею та використанням знань і приймають участь у економіці, заснованої на знаннях.

Мета. Дослідити стан оборонно-промислового комплексу України, визначити його місця серед передових країн світу, проаналізувати його потужність та сформулювати пропозицій щодо розв'язання наявних проблем.

Завдання. Стаття має наступні завдання:

- визначити економічну сутність фінансового забезпечення підприємства у оборонно-промисловому комплексі в сучасних умовах постіндустріальної економіки;

- проаналізувати та виділити проблеми у повноцінному функціонуванні механізму фінансового забезпечення підприємства в оборонно-промисловому комплексі в Україні;

- надати пропозиції та рекомендації щодо ефективної реалізації механізму фінансового забезпечення діяльності підприємства в оборонно-промисловому комплексі в сучасних умовах постіндустріальної економіки;

- вивчити зарубіжний досвід щодо вдосконалення механізму фінансового забезпечення діяльності підприємства в оборонно-промисловому комплексі; 
- виділити найефективніші шляхи вдосконалення фінансового забезпечення діяльності підприємства в оборонно-промисловому комплексі в сучасних умовах постіндустріальної економіки в Україні.

Методологія дослідження. Методологічними засадами наукової статті $є$ положення економічної теорії, наукові праці вітчизняних і закордонних вчених-економістів, які стосуються проблематики оборонно-промислового комплексу та постіндустріальної економіки. У статті використано такі методи дослідження: метод сходження від абстрактного до конкретного (при описі поняття постіндустріального суспільства, визначенні особливостей постіндустріальної економіки та іiі ознак); експериментальний метод - експеримент (при спостереженні за історією зародження постіндустріального суспільства та права на існування постіндустріальної економіки, історії оборонно-промислового комплексу та конкретного опису щодо стану на сьогодні); метод порівняння (при аналізі реформування оборонно-промислового комплексу країнами Свропейського Союзу).

Логіка подання досліджуваного матеріалу. Оборонно-промисловий комплекс як галузь $є$ унікальним, індивідуальним та специфічним. Багато матеріалу має гриф «таємно», що ускладнює дослідження та унеможливлює досконале вивчення деяких питань.

\section{2. Постіндустріальне суспільство та його ознаки}

Людство перебуває в постійному і динамічному розвитку. Спочатку воно спиралося на первіснообщинні підвалини, а вже зараз у його основі - новітні технології та інформація. В кінці минулого століття настала так звана епоха постіндустріального суспільства. Концепція про постіндустріальне суспільство була розроблена ще в далекому 1919 році вченим Даніелем Беллем у його праці під назвою «Прийдешнє постіндустріальне суспільство». Його ознаки, згідно з теорією Бела, проглядаються насамперед у розмірі та структурі ВВП держави. На його думку, етап постіндустріального цивілізаційного розвитку повинен початися якраз у XXI столітті. Такий прогноз виявився точним, адже даний етап обумовлений розвитком новітніх комунікаційних технологій і сервісів, впровадженням інновацій, переходом до електроніки на всіх рівнях виробничої діяльності. Ще однією важливою особливістю постіндустріального суспільства $є$ високий рівень розвитку сфери послуг в економіці. 
Ознаки постіндустріального суспільства:

- домінування абстрактних, теоретичних знань над практичними;

- збільшення загального числа інтелектуалів (науковці, дослідники, оратори);

- бурхливий розвиток новітніх технологій та інновацій;

- посилення значущості інформації у всіх сферах життя і діяльності;

- домінування сфери послуг у економіці;

- розробка та впровадження ресурсозберігаючих, екологічних виробництв;

- поступове стирання класових меж і відмінностей;

- формування економічно стійкого прошарку суспільства, так званого середнього класу;

- зростання ролі освіти і науки в житті суспільства;

- зміна ролі жінки у суспільстві (фемінізація);

- плюралізм думок і точок зору в політиці та культурі.

У сучасному світі країни стійкого постіндустріального суспільства - це США, Канада, Японія, Південна Корея, Сінгапур, Ізраїль, Нідерланди, Німеччина, Велика Британія, Люксембург.

\section{3. Постіндустріальна економіка}

Постіндустріальна економіка - це глобальна і національна реальність, яка заснована виключно на знаннях та складається з інформації, послуг та контролю управління у сфері економіки. Особливістю постіндустріальної економіки $є$ знання, енергія і організація - це те, чим володіли та володіють люди [1].

Економіка постіндустріального суспільства, яка заснована на знаннях, відрізняється від попередніх формацій наступними ознаками:

- по-перше, левову частку вартості продуктів та послуг формують саме знання. Цей процес $\epsilon$ невідворотним у зв'язку зі зростанням наукомісткості продукції, що виробляється і розвитком ринку інтелектуальних товарів та послуг. Саме інтелектуалізація технологій, які використовуються, забезпечує підвищення продуктивності праці. Як приклад, у промислово розвинених країнах, частка зайнятих в сільському господарстві не перевищує 10\%, в матеріальному виробництві - 20\%.

- по-друге, в економіці постіндустріального суспільства діяльність, пов'язана з виробництвом, зберіганням, передачею та використанням знань, тісно переплітається 3 освітньою діяльністю. Починаючи 3 
60-х років XX століття, витрати на освіту фінансуються в основному 3 державного бюджету на рівні $з$ обороною, охороною здоров'я та соціальним захистом населення. На сучасному етапі освіта розглядається як форма інвестицій в людський капітал, від якого залежить його якість та успіх.

- по-третє, головною ознакою економіки, заснованої на знаннях, є перетворення працівників, зайнятих виробництвом, передачею i використанням знань, в панівну групу в загальному числі зайнятих. Чисельність таких груп у промислово розвинених країнах оцінюється по-різному, оскільки залежить від причетності до цієї категорії. Але дослідження показують, що по своїх розмірах вона перевершила групу індустріальних робочих, крім того, третина «робочих знань» є зайнятою в економіці США [2].

\section{4. ОПК та його історія}

Оборонно-промисловий комплекс - суспільний феномен, у підгрунті якого лежить збіг інтересів керівництва воєнних корпорацій, вищого командного складу Збройних Сил і високих посадових осіб держави, а одним із головних проявів є лобіювання бізнес-інтересів оборонної промисловості на вищому державному рівні та посилення іii впливу на суспільні процеси.

Оборонно-промисловий комплекс уперше виник у США та СРСР у період «холодної війни», але в той час під назвою військово-промисловий комплекс, коли за відсутності активних воєнних дій між ними розгорнулась безпрецедентна «гонка озброєнь», і на перший план виступив такий чинник могутності, як спроможність розробляти і виготовляти озброєння та військову техніку на сучасному рівні та у незалежній кількості.

Першим із провідних політиків термін військово-промисловий комплекс використав Дуайт Ейзенхауер у своєму виступі у 1961 році, коли залишав посаду президента США. Він зазначав, що тандем, який утворився між колосальним військовим апаратом і великою воєнною промисловістю є чимось новим у історії Америки. Крім того, було наголошено, що державні справи потрібно вести обережно, щоб ВПК не вийшов 3-під контролю.

В СРСР термін ВПК використовувався лише для капіталістичних країн і лише в негативному плані. Однак у цілому і військово-промисловий комплекс, і США, і так звана «воєнна промисловість» СРСР 
слугували опорами агресивної зовнішньої політики цих держав. На відміну від США (де навіть у регулюванні ВПК певна роль відводилася ринковим принципам), у СРСР існувала жорстка централізована система планування і управління ВПК, в якій головним плануючим органом виступав оборонний відділ Державного комітету планування народного господарства, контролюючим - Державна комісія РМ СРСР 3 воснно-промислових питань, а виконуючим - 9 міністерств.

Зменшення міжнародної напруги з середини 1980-х років змусило уряди США та СРСР реформувати військово-промисловий комплекс. У СРСР ці реформи звелися переважно до конверсії (переводу оборонних підприємств на випуск цивільної продукції), що обернулося кризою у ВПК й обвалом виробництва в суміжних галузях промисловості. У США та інших індустріально розвинутих країн магістральним напрямком реформування оборонної промисловості стала диверсифікація (розширення номенклатури товарів, послуг) військових компаній (у т.ч. цивільними організаціями).

Результатом перетворень військово-промислового комплексу в країни з постіндустріальною економікою став перехід моделі високотехнологічного комплексу, за якої вчорашні воєнні корпорації, значно збільшившись у розмірах і довівши частку цивільної продукції в своїх замовленнях до рівня не менше 50\%, упевнено відчувають себе в умовах скорочення державних воєнних замовлень і світового ринку озброєння та військової техніки.

\section{5. Світовий ОПК}

Аналізуючи звіт про глобалізацію від Credit Suisse, слід зазначити, що незважаючи на скорочення бюджету і зменшення розміру, США підтримали свою позицію найсильніших збройних сил у світі, витративши за минулий рік на оборону 601 млрд. дол. США. Америка має найбільший повітряний флот у світі (не враховуючи власних 10 авіаносців), загороджувальні гармати військово-морського флоту, багаточисленні та підготовлені людські сили та найбільший у світі ядерний арсенал. Російська Федерація вклала в оборону 84,5 млрд. дол. США протягом минулого року, зайнявши друге місце рейтингу за рахунок найбільшого парку танків у світі, другого за величиною парку літаків після США та третього за величиною флоту після США та Китаю. Третю сходинку зайняв Китай, витрачаючи за минулий рік 216 млрд. дол. США на оборону. Армію 
Китаю протягом останніх десятиліть прийнято вважати найбільшою за рахунок чисельності «сирої» людської сили. Країна також має другий за величиною танковий парк після Росії і другий за величиною флот після США, розробляє ряд потенційних ігрових змін у військових технологіях, включаючи балістичні ракети і літаки п'ятого покоління. Четверту шпальту посіла Японія, яка витратила на свої відносно невеликі збройні сили близько 41,6 млрд. дол. США. Японія має 4 авіаносці та четвертий за величиною флот гелікоптерів після Китаю, Росії та США. Наступною, п’ятою, у рейтингу опинилась Індія, яка є однією з найбільших військових держав на планеті та витратила на свою оборону протягом 2016 року майже 50 млрд. дол. США. Вона має найактивнішу людську силу будь-якої країни, крім Китаю і США, на додаток до більшої кількості танків і літаків від будь-якої країни, крім США, Китаю та Росії. Індія також має доступ до ядерної зброї [6].

За даними Міжнародного інституту дослідження проблем миру в Стокгольмі (SIPRI), останніми роками найбільшим споживачем української продукції військового призначення були Росія (32\% у 2016 році, переважно завдяки двигунам), Китай (17\%), Таїланд (13\%) та В'єтнам (6\%). Корпоративна звітність підприємств українського оборонно-промислового комплексу свідчить, що у 2015 році з усієї продукції на 13,8 млрд. грн. 93,1\% було реалізовано на експорт. Можна припустити, що левова частка колишніх поставок до Росії лишається, нехай і з використанням досконаліших схем, зокрема посередництва компаній із третіх країн. Наприклад, частина двигунів спрямована на російсько-китайські спільні підприємства і формально вважається експортом до КНР, однак фактично може через цю країну потрапляти до Росії. Схемою з обходом підприємствами українського оборонно-промислового комплексу режиму санкцій на торгівлю продукцією військового призначення називають і постачання відповідних товарів через фірми Молдови. Доки в українських компаній не буде альтернативних покупців або постачальників тих чи інших критично важливих комплектуючих чи матеріалів, так чи інакше з'являтимуться схеми з обходу будь-яких обмежень і заборон.

\section{6. Стан ОПК України}

Сучасний український оборонно-промисловий комплекс є досить потужною і високотехнологічною галуззю економіки України, при тому що протягом останнього десятиліття український оборонно-про- 
мисловий комплекс працював переважно на зовнішній ринок через відсутність фінансування внутрішнього попиту. Результатом відсутності стратегічного планування чинників посилення обороноздатності українського війська та відповідної політики у сфері оборонно-промислового комплексу стало фактичне роззброєння армії та звана залежність оборонно-промислового комплексу та суміжних галузей від кооперації Російської Федерації. В умовах розгортання збройного конфлікту на Сході із залученням російського оборонно-промислового комплексу до підтримки терористичних угруповань Донецької народної республіки та Луганської народної республіки керівництво країни поступово трансформує політику щодо розвитку оборонно-промислового комплексу: скасовано українсько-російські програми виробничої кооперації у секторі оборонно-промислового комплексу, збільшено фінансування як армії в цілому, так і розробки та виробництва озброєння, амуніції, військової техніки тощо. Разом з тим спостерігається невизначеність позицій влади щодо напрямків реформування та моделі функціонування сфери оборонно-промислового комплексу України, яка в умовах військової загрози та відмови з боку західних партнерів надати летальну зброю стає визначальною у підтриманні національної безпеки та збереження державного суверенітету.

Фінансове забезпечення оборонно-промислового комплексу України раніше здійснювалось через Міністерство промислової політики, а після його скасування така функція передана до Міністерству економічного розвитку. При цьому самі підприємства в його підпорядкуванні не перебувають, а зібрані в ДК «Укроборонпром». Варто зазначити, що в самому міністерстві не створено підрозділів з достатньою кількістю фахівців для виконання фінансування оборонно-промислового комплексу. Отже, Міністерству економічного розвитку не здійснює управління зазначеними підприємствами та не володіє достатньою інформацією про діяльність, стан, потреби, стратегії та плани розвитку оборонно-промислового комплексу. Поряд з цим міністерство не має достатньої кількості людських ресурсів з відповідною кваліфікацією для якісного фінансового забезпечення оборонно-промислового комплексу.

Отже, головними одержувачами коштів з державного бюджету є оборонні підприємства ДК «Укроборонпром». 3 боку держави фінасовим забезпеченням оборонно-промислового комплексу опікується переважно Міністерство економічного розвитку. Підприємства Концерну 
укладають прямі договори $з$ міністерством; міністерство перераховує гроші на підприємства; останні, у свою чергу, закуповують потрібне для них обладнання для виконання оборонних контрактів або проектів. Єдиною доступною інформацією для громадськості є та, що міститься у державному бюджеті. Однак при укладанні договорів та прийманні робіт міністерство перевіряє лише фінансові документи і наявність придбаної продукції. Ретельно ж перевіряти усі суми фінансування підприємств ДК «Укроборонпром» Міністерство економічного розвитку невзмозі.

Міністерству економічного розвитку, відповідно до закону, є координатором державного оборонного замовлення для всіх силовиків-замовників озброєння, яким видіялються кошти на фінансове забезпечення. Міністерство затверджує цей таємний план закупівель на три роки, при необхідності вносить в нього зміни, контролює дотримання силовиками законодавства, отримує від силовиків регулярні звіти про витрачені кошти та укладені договори, тобто, слугує незалежним контролером виконання оборонного замовлення. Тепер же Міністерство економічного розвитку також є замовником - поєднавши в собі фунції координатора державного оборонного замовлення та замовника 3 власним фінансуванням. Отже, Міністерство економічного розвитку в такій ситуації себе контролює та звітує перед самим собою, що створює конфлікт інтересів.

Наприклад, щоб створити новий вид озброєння потрібно профінансувати закупівлю обладнання для його виробництва. Замість того, щоб направити фінансування на головного виконавця, відповідального за створення озброєння, а після закінчення проекту отримати звіт про досягнення мети в результаті витрачення коштів, міністерство перевіряє закуплене підприємствами обладнання, яке функціонально не пов'язане між собою та не об'єднане в одну технологічну лінію. При цьому, Міністерство економічного розвитку виступає лише джерелом фінансування. ДК «Укроборонпром» не є органом влади і не може бути розпорядником бюджетних коштів, щоб фінансувати оздоровлення чи розширення своїх підприємств. Отже, фінансуючи таким чином підприємства ДК «Укроборонпром», Міністерство економічного розвитку просто виконує роль передавальної ланки.

За даними сайту Верховної Ради України в 2018 році державне фінансування програм реформування і розвитку оборонно-промислового комплексу, розробку, освоєння і впровадження нових технологій, 
нарощування наявних виробничих потужностей для виробництва оборонної продукції передбачено в розмірі 2 млрд 343,7 млн грн. У 2017 році відповідне державне фінансування складало 785,18 млн грн.

В Україні обсяги продукції оборонного призначення, що замовляється та поставляється у оборонній сфері, а також завантаженість оборонних підприємств на порядки менше, ніж у минулому столітті. Обсяги фінансування створення нових та нарощення існуючих виробничих потужностей складають незначну частину загального фінансування державного оборонного замовлення. Саме існування додаткового фінансування тих процесів, що безпосередньо пов'язані 3 розробленням та виробництвом озброєнь, має атавістичний характер та ризик корупції.

\section{7. Фінансування потреб ОПК України}

Тенденція до збільшення фінансування потреб оборонного відомства в Україні з'явилась лише у 2014 році в зв'язку зі складною ситуацією на Сході. Таким чином, витрати державного бюджету було збільшено у 2014 році до 27,3 млрд грн. Рада національної безпеки та оборони України в 2015 році ухвалила рішення про збільшення витрат на безпеку і оборону відповідно до нової Стратегії національної безпеки і оборони та Військової доктрини. Сукупні видатки у державному бюджеті на сектор безпеки і оборони не повинні бути менші за 5\% від ВВП (Указ Президента України від 26.05.2015 № 287) [5]. У Законі України «Про Державний Бюджет України на 2016 рік» (зі змінами) загальний ресурс на оборону і безпеку було збільшено проти факту 2015 року на 26,1 млрд грн. або 27,2\% і встановлено у сумі 121,3 млрд грн. або 5,1\% від ВВП [3]. У Законі України «Про Державний Бюджет України на 2017 рік» загальний ресурс на оборону i безпеку держави збільшено проти факту 2016 року на 13,2 млрд грн. і передбачалось у сумі 134,5 млрд грн., що складає 5,2\% від ВВП [4].

\section{8. Досвід реформування ОПК країнами СС}

Проаналізуємо досвід реформування оборонно-промислового комплексу провідними країнами Свропейського Союзу, а саме:

- Німеччина. Найбільш актуальними завданнями Збройних Сил $є$ місії з розв'язання міжнародних конфліктів - вони найбільше вплинули на їх структуру та можливості. Оборонні видатки у 2010 році в 
країні становили 5,43 млрд євро, до 2013 року їх було збільшено до 5,56 млрд євро. В цей же час, Парламент ФРН затверджує рішення довгострокової програми закупівлі озброєнь, куди ввійшли: 31 винищувач «Тайфун» (2,8 млрд євро), 405 бронемашин «Пума» (3,1 млрд євро), 5 безпілотних підводних апаратів для розмінування «Сі Фукс» (37,9 млрд євро) та інших видів озброєння та військової техніки нового покоління.

- Великобританія. В умовах світової фінансової кризи уряд не скорочував затверджені видатки на оборону протягом трьох років (2008-2009 фінансовий рік - 34 млрд фунтів стерлінгів, 35,3 млрд - на 2009-2010 pр., 36,9 млрд - на 2010-2011 рр.). Міністерство фінансів фінансує бойові операції (стаття, яка не входить до бюджету Міністерства оборони) та перерозподіляє кошти, передбачені на фінансування управлінського апарату, на користь забезпечення підготовки бойових підрозділів.

- Франція. В умовах світової фінансової кризи видатки оборонного бюджету на перерозподіл та модернізацію озброєння та військової техніки (ОВТ) становили 101 млрд євро на рік. Найбільшу в Європі армію (320 тис. військовослужбовців) скоротили до 54 тис. осіб - економія коштів склала 12 млрд євро. Разом 3 тим збільшили кількісний склад (на 700 осіб) та видатки спеціальних підрозділів, які задіяні в антитерористичних операціях.

\section{9. Аналіз та перспективи ОПК України}

У зв'язку з подіями на Сході України, сподіватись на повноцінне державне фінансування та цілковите покриття витрат в оборонно-промисловому комплексі не варто [8]. Загалом відчувається зростання інтересу до вітчизняного оборонно-промислового комплексу з боку зарубіжних підприємств, зокрема збільшуються кількості пропозицій, що можуть бути корисними для українського війська. В останні роки збільшились ініціативні розробки приватних оборонних підприємств, що можуть бути затребувані в сучасних умовах бойових дій.

Слід зазначити, що «панівна група» постіндустріального суспільства, про яку зазначалося раніше, в оборонно-промислового комплексі готова активізувати українсько-румунське співробітництво у сфері безпеки і оборони та співпраці в напрямку кібербезпеки та кіберзахисту, особливу увагу приділивши питанням протидії гібридній, зокрема, 
інформаційній війні. При чому Міністерство національної оборони Румунії готове надати як практичну, так і політичну підтримку у цьому напрямку. Бюро Національної безпеки Республіки Польща готове співпрацювати в секторі безпеки і оборони, реформування Збройних Сил та інших силових структур і переходу на стандарти НАТО з урахування польського досвіду. Провідні оборонні компанії Великобританії продемонстрували стратегію реформування оборонно-промислового комплексу України, де акцентували увагу на необхідності вирішення законодавчих перепон щодо розвинення співпраці, адже іноземні компанії зацікавлені у спільних проектах.

Над стратегією реформування оборонно-промислового комплексу в Україні працює також Державний Концерн «Укроборонпром», який вже розробив власний чіткий план щодо подальших дій, який передбачає одночасну роботу у юридичній, технологічній та виробничій площинах, що дозволить інтегрувати оборонно-промисловий комплекс України в світову спільноту, забезпечивши його надійну та високотехнологічну роботу.

Крім того, у минулому році була підписана угода про співпрацю між словацькою компанією Grand Power s.r.o. та ДП «Укроборонсервіс», яке входить до ДК «Укроборонпром», у виробництві вогнепальної зброї. Враховуючи членство Словаччини у НАТО та Європейському Союзі, це дозволить направити спільні зусилля на створення нових зразків сучасного вогнепального озброєння за стандартами НАТО та підвищити рівень взаємовигідної співпраці та партнерства із західними партнерами України.

Також у минулому році була підписана угода про співпрацю у виробництві пасивної радіолокаційної станції на потужностях підприємств «Укроборонпром» між турецькою компанією Havelsan Hava Elektronik Sanayi та ДФ «Укрінмаш», що входить до складу ДК «Укроборонпром».

Слід згадати також про Державну програму реформування та розвитку оборонно-промислового комплексу України - основний середньостроковий план проведення системної реформи. Проект програми має гриф обмеження доступу, оскільки розголошення відомостей про потреби та можливості оборонної промисловості є реальною загрозою національній безпеці України, тим більше в умовах ведення бойових дій. Хоча, запровадження трирічного планування 
державного оборонного замовлення, яке нещодавно вперше в історії було прийнято в Україні на 2017-2019 рр., є одним із запланованих заходів реформи. Така Програма дасть змогу спростити виробничу та управлінську діяльність підприємств оборонно-промислового комплексу шляхом затвердження порядку формування ціни на продукцію оборонного призначення, створити підстави для отримання підприємствами кредитів під державні гарантії, зменшити норми відрахувань до державного бюджету з 75 до 35 відсотків чистого прибутку підприємств-учасників ДК «Укроборонпром». Зараз Програму реформування та розвитку опрацьовує Секретаріат Кабінету Міністрів України.

Процеси завоювання Україною нових ринків озброєння відбуваються в непростому міжнародному контексті, який безпосередньо впливає на ці процеси. Найголовнішою причиною такого стану є те, що по закінченні «холодної війни» різко загострилась конкурентна боротьба між основними експортерами озброєння, де поки що для України немає місця. Основними ж перешкодами розвитку оборонно-промислового комплексу в Україні є передусім фінансова слабкість країни, несвоєчасна розробка та прийняття законодавчих актів, що визначають державну оборонну концепцію, та несвоєчасне і поверхневе проведення маркетингу.

Проте, незважаючи на окремі проблеми та цілу низку труднощів, які переживає сьогодні Україна, перебуваючи в стані «гібридної війни», оборонно-промисловий комплекс має всі передумови для значного розширення своїх повноважень в умовах постіндустріальної економіки не лише за рахунок знань, розробок та інновацій, а і за рахунок знань, вмінь та набутого за останні роки досвіду. Доходи від експорту українського озброєння та послуг військового призначення доводять, що продукція українського оборонно-промислового комплексу в своїй більшості відповідає світовому рівню і не поступається своїм аналогам з найбільших країн-експортерів військової техніки.

Стратегія розвитку оборонно-промислового комплексу - це довгостроковий документ оборонного планування, який має базуватись на аналізі досвіду функціонування сфери протягом тривалого періоду. Досвід українського оборонно-промислового комплексу до 2014 року це спадщина СРСР. Російська агресія внесла свої корективи, і Україна вимушена постійно змінювати підходи та шукати ту модель розвитку, 
яка $є$ більш прийнятною з урахуванням існуючих ресурсів та політичної ситуації загалом.

Сьогодні Україна проводить реформи, вивчає міжнародний досвід, адаптує його до українських реалій, одним словом, створює підгрунтя для розробки довгострокової стратегії розвитку оборонно-промислового комплексу. Чинне законодавство у цій сфері потребує істотних змін - не лише у частині удосконалення системи планування у секторі безпеки й оборони, оборонно-промисловий комплекс, а і системи державного стратегічного планування, як це і передбачено Концепцією розвитку сектору безпеки і оборони України, Воєнною доктриною та Стратегією національної безпеки і оборони України.

\section{0. Фінансове оздоровлення ОПК України}

Згідно дій України у 2017 році було визначено три основні шляхи фінансового оздоровлення галузі:

- закладення до бюджету на розвиток оборонно-промислового комплексу 785 млн грн;

- зменшення норм відрахувань до державного бюджету частини чистого прибутку підприємств ДК «Укроборонпром» (кошти спрямують на розвиток виробничої галузі);

- збільшення обсягу банківських кредитів під державні гарантії до 7 млрд грн (у 2016 р. було виділено 4,35 млрд грн). Продукцію закуповують як у державних підприємств, так і у приватних, а кредити видають лише державні банки зі ставкою 19\% річних на термін не менше 3-х років;

- внесення змін до законопроекту «Про перелік об'єктів права державної власності, що не підлягають приватизації (щодо деяких об'єктів оборонно-промислового комплексу)», де планується включити 67 підприємств ДК «Укроборонпром» у перелік тих, які можуть бути корпоратизовані. Такий крок дозволить залучити на їх розвиток кошти як вітчизняних, так і закордонних інвесторів.

\section{1. Висновки і перспективи подалыших розробок}

Щоб покращити оборонно-промислового комплекс в Україні, необхідно створити Асоціацію виробників/розробників продукції оборонного призначення, яка буде працювати у напрямку модернізації національного законодавчого поля, організації тісної співпраці з парт- 
нерами та організаціями, в тому числі і за кордоном, представлятиме Уряду альтернативні можливості розвитку оборонно-промислового комплексу України на основі передового західного досвіду. Таке об'єднання $\epsilon$ вкрай актуальним з огляду на кількість у країні приватних підприємств, які працюють на безпеку і оборону. Варто нагадати, що понад дві третини продукції оборонного призначення виробляє саме приватний сектор (у реєстрі виконавців державного оборонного замовлення зареєстровано більше 120 підприємств, 3 них більша половина приватні компанії). Така Асоціація має бути відкритою до співпраці 3 державними підприємствами та інституціями як на державному рівні, так і за кордоном, оскільки саме інноваційні розробки та співпраця 3 іноземними партнерами можуть реформувати та вивести на високий рівень оборонно-промислового комплекс України.

Державним оборонним замовленням передбачено забезпечити Збройні Сили України та інші воєнізовані формування новим перспективним озброєнням і військовою технікою: сучасними та артилерійськими системами, броньованими ракетними катерами, безпілотними літальними апаратами, бронетанковою технікою, засобами спостереження, прицілювання та нічного бачення, планується також модернізація літаків, вертольотів та іншої військової техніки тощо. Крім того, рішенням РНБО України передбачено розпочати «Державну цільову програму створення та освоєння виробництва боєприпасів і продуктів спеціальної хімії на період до 2021 року». Кабміну України доручено, з урахуванням недофінансування державного оборонного замовлення в 2016 році, внести відповідні корективи до «Державної цільової програми розвитку озброєння та військової техніки на період до 2020 року». 13 лютого 2017 року Президентом України було введено в дію рішення РНБО від 27 січня 2017 року «Основні показники державного оборонного замовлення на 2017 рік та 2018, 2019 роки».

Керівництво Міністерства оборони України пропонує в 2018 році збільшити фінансовий ресурс на розвиток озброєння та військової техніки в два 3 половиною рази та перейти таким чином від «бюджету утримання» до «бюджету розвитку». Таким чином, якщо в бюджеті 2017 року на модернізацію і закупівлю озброєння та військової техніки було виділено 6,4 млрд грн, то в 2018 році Міністерство оборони планує отримати на зазначені цілі 15-16 млрд грн. Отже, парламент підтримав пропозиції Кабміну, тим самим українська армія отримала 
самий великий бюджет за всю історію свого існування. Він дійсно дає змогу хоча б у невеликих кількостях перейти до закупівель нової зброї, що свідчить про технічне переобладнання армії. Крім того, цей бюджет, скоріше за все, дозволить покращити мотивацію військовослужбовців шляхом підвищення їх грошового забезпечення, що піде на користь обороноздатності нашої країни.

\section{Список літератури:}

1. Економічна енциклопедія:У трьох томах. Т. 3./ Редкол.: С.В. Мочерний К.: Видавничий центр «Академія», 2002. - С. 952-963.

2. Нова парадигма влади: Знання. Багатство. Сила. К.: Видавничий центр «Наукова думка», 2008. - С. 55-99.

3. Закон України «Про Державний Бюджет України на 2016 рік» (зі змінами) [Електронний ресурс]. - Режим доступу: http://www.mil.gov.ua

4. Закон України «Про Державний Бюджет України на 2017 рік» (зі змінами) [Електронний ресурс]. - Режим доступу: http://www.mil.gov.ua

5. Указ Президента України від 26.05.2015 № 287 «Стратегії національної безпеки і оборони» [Електронний ресурс]. - Режим доступу: http://www.mil.gov.ua//287.html

6. Звіт про глобалізацію від Credit Suisse [Електронний ресурс]. - Режим доступу: http://www.credit.suisse.com/org

7. Рейтинг Global Firepower 2016 [Електронний ресурс]. - Режим доступу: http://www.global.fire.power_2016.com

8. Сайт Державної казначейської служби України [Електронний ресурс]. Режим доступу: http://www.treasury.gov.ua/main/uk/index

\section{References:}

1. Economic encyclopedia: In three volumes. The editorial board: S.V. Mochernyy - K.: Publishing center "Academy”, 2002. - 952-963 p.

2. The new paradigm of power: Knowledge. Wealth. Power. K.: Publishing center "Scientific thought", 2008-55-99 p.

3. The law of Ukraine "About the state budget for 2016 year" (with changes) access mode: $\mathrm{http}: / /$ www.mil.gov.ua

4. The law of Ukraine "About the state budget for 2016 year" (with changes) access mode: http://www.mil.gov.ua

5. Presidential decree of Ukraine from 26.05.2015 287 "Strategy security and defense national": access mode: http://www.mil.gov.ua//287.html

6. The report about globalization from Credit Suisse: access mode: http://www.credit.suisse.com/org - [Electronic resource]

7. The rating Global Firepower 2016: access mode: http://www.global.fire. power_2016.com

8. Site from The state treasury service of Ukraine: access mode: http://www.treasury.gov.ua/main/uk/index 
Features of fiscal stimulation of sustainable development of regions...

\section{FEATURES OF FISCAL STIMULATION \\ OF SUSTAINABLE DEVELOPMENT OF REGIONS IN MODERN CONDITIONS}

\section{Polishchuk Vadym ${ }^{1}$}

DOI: http://dx.doi.org/10.30525/978-9934-571-28-2_22

Abstract. The purpose of the article is to study the conceptual foundations of sustainable development at the present stage, to determine the theoretical aspects of the fiscal space of the state, to analyze fiscal innovations regarding financial sustainability of sustainable development.

Methodology. The methodological basis of the research is the fundamental provisions of the theory of regional development, as well as the theory of motivation A. Maslow, K. Alderfer, V. Vroom, S. Adams, D. McGregor and K. Hallat et al. In general, the content and procedural theories are investigated. We have investigated that procedural theories are most suitable for motivating the development of regional socio-ecological and economic (CEE) systems, and they answer the question: "How should sustainable development of the region be stimulated?". In the process of research, we used the following methods: logical analysis - to generalize the theoretical foundations of stimulating the sustainable development of the region; graphic methods - to present the results of empirical studies in visual form (in particular, the schematic form); methods of analysis, synthesis and comparison - for the set and structure of indicators for analysis of the stimulation of sustainable development of the region.

Research results. We have added an understanding of the sustainable development of the regions. In particular, we understand this as a process of continuous transformation of the qualitative and quantitative characteristics of a regional (CEE) system aimed at achieving a dynamic balance between society, the economy and the environment, while respecting the principles of equilibrium. We have identified theoretical and methodological aspects of the fiscal space, in particular, we have defined the subjects of such financial relations in detail, we also define the content of fiscal policy and its types, tools and mechanism of fiscal policy as an indispensable component

\footnotetext{
${ }^{1}$ Candidate of Economic Sciences, Associate Professor, Lutsk National Technical University, Ukraine

(C) Polishchuk Vadym
} 
of financial incentives for sustainable development of regions. We have investigated that the modernized national fiscal system introduced such tax innovations as the development of the electronic document flow infrastructure as a set of processes for the creation, processing, transmission, receipt, storage, use of electronic documents used for checking integrity and remote auditing; introduction of electronic service and electronic verification; as well as creation of a taxpayer's electronic cabinet with the aim of improving the conditions of the payer in the electronic service.

Practical implications. We propose theoretical and methodological researches of fiscal stimulation of sustainable development of regional socio-ecological-economic systems and they have practical significance. In particular, they can serve as a modernization of fiscal architectures, the development of new legislation relating to modern tax administration, and the improvement of knowledge on sustainable development. We have studied the basic principles of sustainable development of the region: equality, balance, harmony, stability, competitiveness, security. We also identified the main strategic guidelines for the fiscal policy concept: improving the efficiency of using fiscal instruments through their orderly and systematic use and harmonizing the use of fiscal policy tools with the need to improve the well-being of citizens.

Value / originality. This research continues to develop the theory of stimulation of sustainable development of the region proposed by Gerasymchuk Z.V. and Polishchuk V.G. in 2010. Emphasis is put on fiscal stimulation, the search for new approaches to effective financial provision in terms of tax application in order to achieve the supported development of regional socio-ecological and economic systems in this study.

\section{Introduction}

Confirmation of the sustainable development of regional socio-ecological and economic systems becomes very relevant for Ukraine at the present stage of development. First of all, this is due to the difficult socio-economic and ecological condition of the regions, as well as the need to meet the priority needs of the regions. This can be achieved through the introduction of effective stimulus tools. We can attribute to them the effective tools of financial and economic direction - tax instruments. A large set of tax incentives and skillful implementation of tax policies have led to the rapid provision of sustainable development in foreign countries. An important role in this case 
is given to environmental taxes (eco-taxes). Unfortunately, all the benefits of environmental taxation are not fully used today in our country, which hinders the progress of Ukraine's regions towards sustainable development. Environmental taxation is an important tool for increasing the country's ecological safety, it is able to ensure the efficient use of natural resources, to finance environmental protection measures at the state and local levels, to stimulate economic interest of economic entities through tax incentives for investment in energy and resource saving technologies, etc. Such levers are, of course, used in the tax system of Ukraine, in particular, the Tax Code of Ukraine has introduced tax deductions, exemptions (exempted from: excise tax on sales of electric energy produced by coherent installations and using renewable sources, PIT funds provided by the international a financial institution for increasing energy efficiency, VAT when importing energy-saving equipment and materials into the customs territory of Ukraine, equipment used in renewable sources of energy, etc.) and others. [8]. We will try to find out the content of fiscal support during a stimulating impact on the regional systems of Ukraine in order to eliminate these inappropriateness.

\section{Conceptual bases of sustainable development of regions at the present stage}

In 1987, the International Commission on Environment and Development (ICED) in the report "Our Common Future", chaired by the former Prime Minister of Norway Brundland H.K. focused on the need for "sustainable development". They understood sustainable development as a development that would meet the needs of the present generation without compromising the ability of the future generation to meet their own needs. This wording concept is now widely used as a base in many countries. In addition, she argued that the main idea of human societies should be to revitalize the search for better life, well-being [2]. That is, it is quite understandable to us that without the stimulation of sustainable development, the welfare of the present, and especially of future generations, is impossible.

The term "sustainable development" was defined at the 1992 Rio Conference in the framework of the adoption of the "Agenda for the 21 st Century" as "development that meets the needs of the present, without endangering the ability of future generations to meet their own needs" [11]. All subsequent definitions of concepts assumed the very basis of this interpretation of sustainable development. Actually, the term "sustainable develop- 
ment" is quite controversial. This concept corresponds to constant / stable development, and even supported development. Quite interesting is the French version of this term $\mathrm{m}$ "developpment durable" - "durable / longterm development".

Sustainable development of the region in terms of Gerasymchuk Z.V. and Polishchuk V.G. can be understood as a process of constant conversion of qualitative and quantitative characteristics of the regional socio-ecological and economic (CEE) system aimed at achieving a dynamic balance between society, economy and the environment, while ensuring the welfare of present and future generations, while respecting the principles of equilibrium, balance, harmony, stability, competitiveness and security of the region [5].

The basic principles of the sustainable development of the region as a system to which stimulating tools are to be applied are as follows:

1. The principle of equilibrium of a regional socio-ecological-economic system involves the achievement of a state of dynamic equilibrium of a regional socio-ecological-economic system aimed at overcoming intra-system and external threats by activating internal potential opportunities.

The principle of equilibrium should be the key to the movement of the regional CEE system to sustainable development.

2. The principle of balancing economic, social and environmental subsystems within the framework of sustainable development of the region causes the consideration of the regional CEE system in the context of achieving the optimal balance of qualitative and quantitative characteristics of the regional socio-ecological and economic system.

3. The principle of harmony means the maintenance of harmony, or the interrelation between the social, economic and environmental spheres of the region. This is manifested in the fact that all the goals of regional development, which are to be achieved, the methods of their achievement are interconnected and aim at achieving the ultimate result of sustainable regional development. In the broad sense, harmony must exist between a person and his or her surrounding world.

The principle of harmony is especially important because a large number of researchers in the sustainable development of the region proceeded precisely from the harmonization of processes within the socio-ecological and economic system.

4. The principle of stability of all subsystems of sustainable development requires maintaining for the longest possible period the positive parameters 
of the development of the CEE system. Stability of regional development as an integral part of the country's economic stability consists of economic, political, social and other types of stability.

Stability of the social component of the CEE system implies stability of population dynamics, minimization of dependence on adverse environmental conditions, and ensuring social justice. The stability of the ecological subsystem of the CEE system involves a limitation as they are due to the need to protect the environment in order to preserve biodiversity and the quantity of flora and fauna. The stability of the economic subsystem of the socio-ecological and economic system implies economic development, which ensures the ability to meet future generations in natural resources, that is, the balance of satisfaction of energy flows and information between social and environmental subsystems.

5. The principle of competitiveness of subsystems of sustainable development envisages enhancement of the potential of the region to increase and effectively use competitive advantages in each subsystem of the region in order to ensure sustainable development of the region, as well as introduction of new achievements of scientific and technological progress in production, environment and social sphere of the region. It should be noted that the scientists understand the competitive ability of the region, its ability to provide competitive advantages in the productive use of resources and benefits to enhance human development, without violating the economic security of other regions and the country as a whole.

6. The principle of sustainable regional development security implies the use of the potential of the regional socio-ecological and economic system, its ability to self-redevelopment and the prevention of destabilizing factors.

The security of the region is also the strength of interconnections between the elements of the regional system, which promotes satisfaction of the interests of the population of the region in the key of national interests.

The complex of measures stimulating the character will contribute to the achievement of the state of equilibrium regional system and the emergence of the nonequilibrium state of the regional socio-ecological and economic system.

We understand that the sustainable development of regions is the object of stimulation. Sustainable development is not the current state of the regional system, or even the national one. Instead, the sustainable devel- 
opment of the region is a prospect, a priority, to which one must strive. It should be remembered that the stimulating tools influence the system's aspirations to achieve sustainable development of the region and to get out of the present state of the regional system. It is clear that any regional system seeks to prevent the state of imbalance. However, due to the actions of various factors (external and internal), the initiative to achieve sustainable development of the region may be stopped at the beginning.

Therefore, sustainable development needs to be stimulated:

1)for the achievement of the sustainable development as a strategic goal;

2) for the achievement of the dynamic equilibrium of the regional socio-ecological and economic system;

3) for the achievement of the optimal ratio of qualitative and quantitative characteristics of the regional CEE system, namely, achieving the balance of sustainable development of the region;

4)for the achievement of the relationship between the social, economic and environmental spheres of the region, that is, the achievement of harmony;

5) for the maintenance of the long-term positive parameters of the development of the regional CEE system, namely the achievement of the stability of sustainable development of the region;

6)for the intensive of the potential of the region to increase and effectively use competitive advantages in the social, economic and environmental spheres of the region, that is, to achieve the competitiveness of the region;

7) for the achievement of the ability of the regional CEE system to self-replicate and prevent the action of destabilizing factors, namely the achievement of the security of sustainable development in the region.

Research on the sustainable development of regional CEE systems and the activation of entities engaged in financial and economic activities in their territory was conducted on the basis of the theory of regional development, as well as such well-known theory of motivation as:

a) content (reflect the content of needs): the theory of needs by Tugan-Baranovsky M.; the needs hierarchy theory by Maslow A.; theory of existence, relations and growth by Alderfer K., the theory of " $\mathrm{X}$ " and " $\mathrm{Y}$ " by McGregor D.; the theory of counter needs by McClelland D.C., two-factor theory of motivation, by Hertzberg F.;

b) procedural (reflect the rewarding process): theory of expectations by Vroom B.; theory of justice (impartiality) y Adams S.; the theory of participative (common) management; the theory of productive valence by Atkin- 
son J.; the theory of material incentives for labor; theory of reinforcement by Skinner B.F.; the complex theory by Porter L. and Lawler E.

The content theories of motivation that reveal the content of the needs of the regional system, answer the question - "Why do we need to stimulate?" However, the most suitable for motivating the development of regional socio-ecological and economic systems are procedural theories, answering the question: "How do we it is necessary to stimulate the sustainable development of the region?".

The main features of the above theories and their interpretation in the context of stimulating the sustainable development of the region are given in Table 1.

Table 1

\section{Characteristics of some theories of motivation in the context} of the promotion of sustainable development in the region

\begin{tabular}{|c|c|c|c|}
\hline Access & $\begin{array}{l}\text { Theory of } \\
\text { motivation }\end{array}$ & $\begin{array}{c}\text { Content theories of } \\
\text { motivation }\end{array}$ & $\begin{array}{l}\text { Content theory of motivation (at } \\
\text { the regional level in the context } \\
\text { of the promotion of sustainable } \\
\text { development) }\end{array}$ \\
\hline 1 & 2 & 3 & 4 \\
\hline \multirow{3}{*}{ 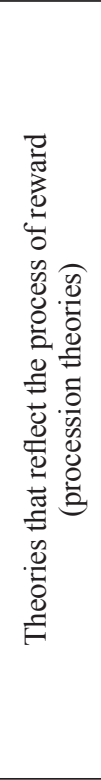 } & $\begin{array}{l}\text { Vroom's } \\
\text { Expectancy } \\
\text { Theory }\end{array}$ & $\begin{array}{c}\text { Man directs its efforts } \\
\text { on achieving any goal } \\
\text { in the extent to which } \\
\text { estimates the probability } \\
\text { of reward for it. }\end{array}$ & $\begin{array}{l}\text { Implementation of the scheme } \\
\text { "incentives-sustainable development" } \\
\text { x "sustainable development, obtain } \\
\text { benefits for the region" x "satisfying } \\
\text { benefits in regional CEE system" = } \\
\text { motivation (the desire for sustainable } \\
\text { development). }\end{array}$ \\
\hline & $\begin{array}{c}\text { Equity } \\
\text { theory on job } \\
\text { motivation }\end{array}$ & $\begin{array}{c}\text { Workers have compared } \\
\text { their rewards to the } \\
\text { effort and reward other } \\
\text { employees who perform } \\
\text { similar work. }\end{array}$ & $\begin{array}{l}\text { Terms of achieving sustainable } \\
\text { development for all regions } \\
\text { should be equal. However, to } \\
\text { achieve sustainable development } \\
\text { of the region need to use different } \\
\text { approaches, methods and tools, but } \\
\text { their use should be fair for everyone. }\end{array}$ \\
\hline & $\begin{array}{l}\text { The } \\
\text { theory of } \\
\text { participatory } \\
\text { management }\end{array}$ & $\begin{array}{l}\text { Active participation } \\
\text { of employees in the } \\
\text { organization's life, } \\
\text { communicating with } \\
\text { colleagues, enhances } \\
\text { job satisfaction, thus } \\
\text { increasing the quality of } \\
\text { their work. } \\
\end{array}$ & $\begin{array}{l}\text { Involvement of regional management } \\
\text { and implementation of policies to } \\
\text { stimulate sustainable development } \\
\text { of the region business community, } \\
\text { financial institutions, public } \\
\text { asset territorial unions, research } \\
\text { institutions. }\end{array}$ \\
\hline
\end{tabular}




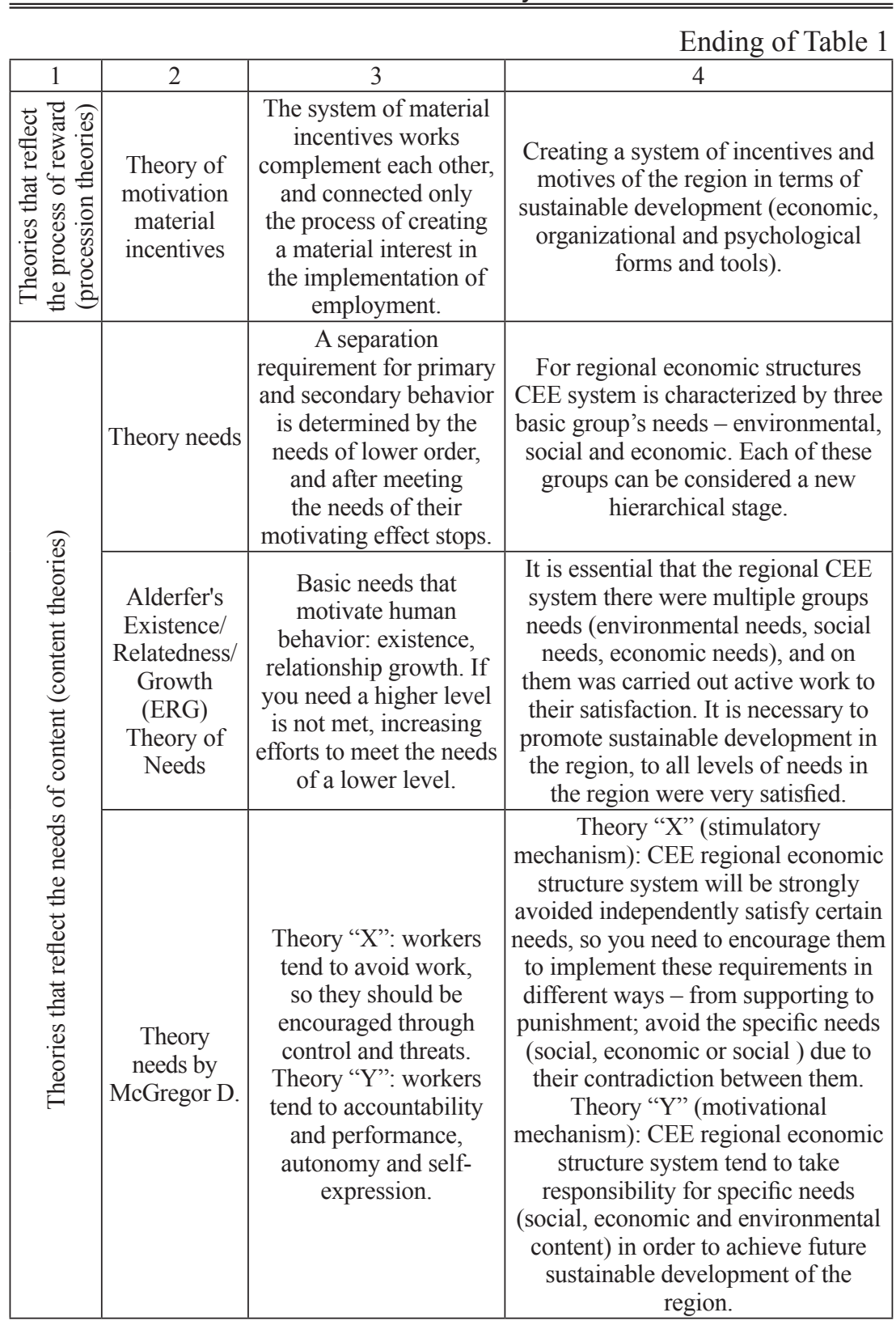


Features of fiscal stimulation of sustainable development of regions...

Result is the last link in the chain, but it is extremely difficult to achieve. An active entity (state and regional authorities) aims to fulfill its functions and duties related to providing social, economic and environmental development at present and in the future - sustainable development. It is safe to say that the activities of the subjects are behavioral in nature. The activity of all subjects to stimulate the region provides a synergistic effect, since all efforts to improve the situation in the region, according to the theory of participatory management, provide even greater results.

However, this scheme is general, and reflects the basic positions of the theory. Consider it in more detail in terms of each element of sustainable regional development - economic, social and social (see Figure 1).

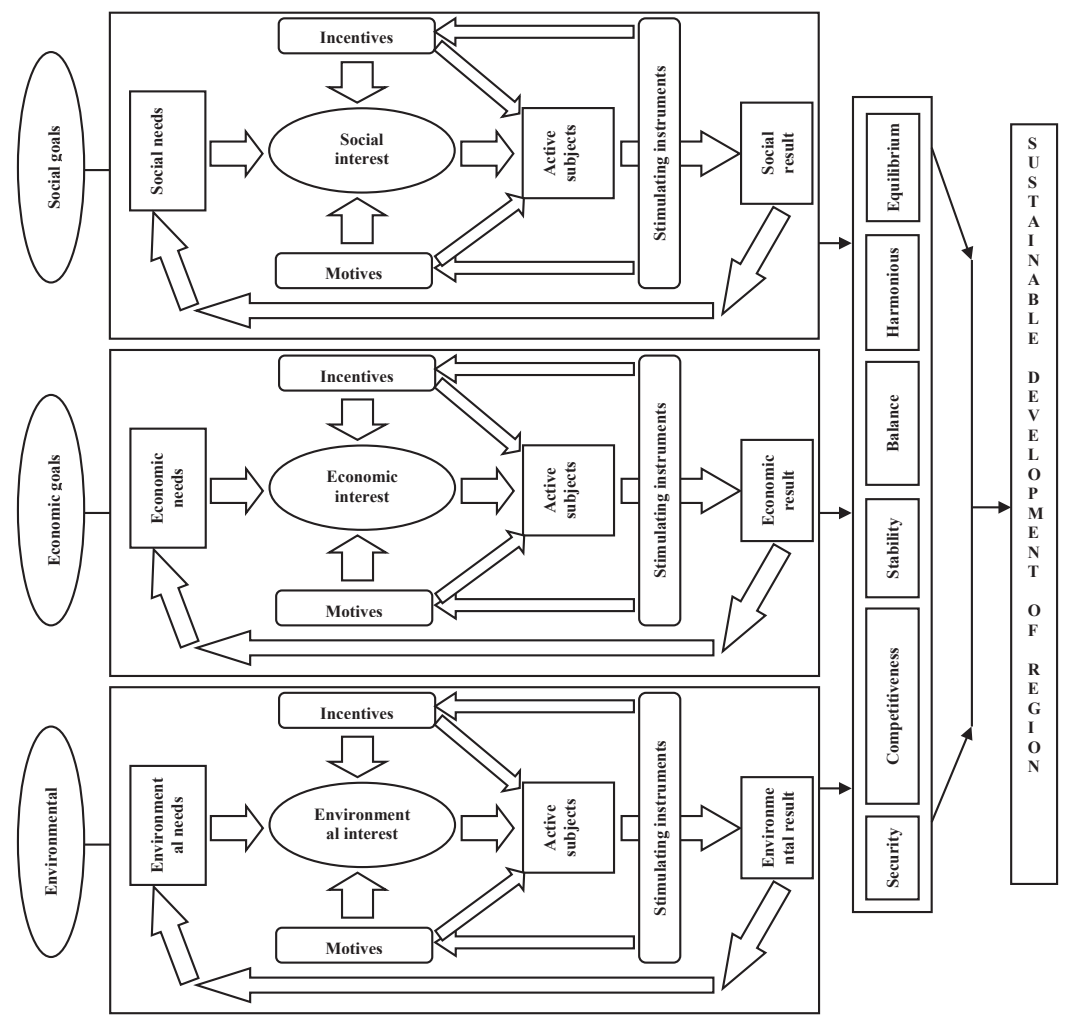

Figure 1. The theoretical approach to stimulation of sustainable development in the region 
Selection policy of stimulation of sustainable development of the region consists in taking into account the level of stimulation sustainable development in the region and the level of sustainable development in the region and allows to distinguish different types of policy of stimulating [12].

\section{Theoretical aspects of the fiscal space of the state}

According to Krisovaty A.I., Sidorovych O.Yu., complex processes and complementary interactions occurring at different levels of the fiscal space determine its essence through the prism of measurements of social being, with which it is in a constant dialectical relationship. The fiscal space as a derivative of the economic space in general is a form of realization of economic phenomena and processes that take place as a result of the existence of certain types of interactions carried out in accordance with established norms, "rules of the game", status roles and interests of the participants.

In this context, fiscal interactions are specific forms of interaction between individuals and their groups with the state or state institutions regarding the creation, distribution and redistribution of value added, which are implemented within tax institutions at a certain level of fiscal space in accordance with the multidimensionality of interaction models, their forms of implementation, status roles, positions and interests of the participants [15].

It is worth agreeing with the statements of the aforementioned scholars that fiscal space, depending on the spatial-temporal coordinates and the spectrum of propagation, can be global, interstate, state and local, each of which is characterized by tendencies of expansion and collapse. The collapse of the fiscal space of the state is conditioned by the dysfunction of the institutions, the termination of the fulfillment of their established and defined tasks. At the same time, the complete elimination of individual tax institutes is impossible, since it is conditioned by the stable, long-lasting nature of existence, the presence of a kind of "institutional memory", which directly depends on the peculiarities of the previous development. Even with the termination of an individual institution, its influence remains in the institutional space as an experience potentially existing in it.

The tax policy of any state should be determined not by the current needs of filling the revenue part of the budget, but, as Shnipko S. rightly observes, "to be based on long-term goals of stimulating the competitiveness of domestic producers, and hence of the national economy as a whole" [17]. 
The tax policy of the state should regulate the tax policy of regional systems, meet the needs of regions, promote the development of production and services in the region, and ensure social welfare. In addition, it must regulate the ecological processes in the region through economic mechanisms.

Therefore, the tax policy of the region involves choosing the composition and structure of taxes and fees, defining taxpayers, setting tax rates, benefits, etc. In the opinion of Gerasymchuk Z.V., the tax policy of the region is an integral part of fiscal policy, the content of which is to optimize the revenues and expenditures of budget funds for the purposes of sustainable development [4].

The state is the only entity that conducts fiscal policy in the person of individual authorities. This concept is considered in the world fiscal theory as a change in government expenditures and taxation [7]. Therefore, at first glance, the impression is that the main government body conducting fiscal policy is the government. However, legislative power is dominant in fiscal policy implementation. This is explained by the fact that important changes in the taxation process, which determine fiscal policy, are clearly realized through the adoption of certain normative legal acts by the legislature. The same applies to the policy of state expenditures, the strategic guidelines of which are laid down in the budget law for the relevant year.

The State Fiscal Service of Ukraine is the regulatory body in the field of taxation, the main task of which is the implementation of the state tax policy and policy in the field of state customs business, implementation within the limits of authority control over the receipt of taxes and duties, customs and other payments, etc.

Taxpayers as subjects of fiscal policy perform the function of calculation and payment of taxes, duties, and obligatory payments. According to the Tax Code of Ukraine, taxpayers are individuals (residents and non-residents of Ukraine), legal entities and their separate units that have, receive tax objects or carry out activities that are subject to taxation. Such individuals and legal entities must pay taxes and fees in a timely manner [9].

Financial relations reflect the interaction between the subjects of fiscal policy in the process of formation (the interaction of the state and economic entities and individuals - taxpayers and their carriers), distribution and use (interaction of state and citizens receiving public goods) of funds of funds. That is, the interests of the subjects of fiscal policy encourage them 


\section{Polishchuk Vadym}

to interact with each other in financial relations, resulting in one or another behavior.

The state applies appropriate tools for fiscal policy. Tax revenues and budget expenditures refer to such instruments, and more precisely tax regulation and regulation by means of expenditures, since the State Budget envisages both revenues and expenditures. Such a thesis is held by Banton V.D. and Konovalova I. [1; 6].

Transfer regulation and regulation of public debt also belong to the list of fiscal policy instruments. We agree with this thesis, because transfers are a redistributive mechanism for the formation of expenditures of individual budgets, on which the efficiency of financing public goods depends. Accordingly, the debt policy of the state is a means of generating budget revenues, which in modern socio-economic conditions is widely used by many states to finance the budget deficit.

The main tasks of the fiscal policy of the state are to change the real volume of national production and employment, control over inflation and accelerate economic growth.

Fiscal policy instruments can also be applied differently depending on the type of fiscal policy that is divided into discretionary and non-discretionary. Discretionary fiscal policies affect real output, employment and inflation through changes in tax revenues, budget expenditures and other instruments. Non-discretionary fiscal policy manifests themselves by the fact that tax revenues have the property to grow in proportion to GDP growth.

The conditions for the formation of financial relations as an element of the fiscal space system are determined by a number of factors. The most important conditions are the economic, social and environmental conditions of formation.

Fiscal space as a peculiar shell of the functioning of subjects of fiscal policy, defines the behavior of subjects. Each subject of fiscal policy decides how to act in certain situations and how to react to the behavior of other subjects under the influence of the described conditions for the formation of financial relations.

The state needs to take into account the mentality and cultural traditions of the nation when applying the tools of fiscal policy, to analyze the behavior of society in certain situations.

We need to clearly define not only tactical, but also, especially important, strategic goals for the formation of an effective fiscal policy. The 
fiscal policy concept must take into account the following strategic orientations:

- improving the efficiency of the use of fiscal instruments through their orderliness and system use;

- harmonization of the use of fiscal policy tools in order to improve the well-being of citizens;

- legal regulation of the mechanism and tools of fiscal policy, regardless of socioeconomic status and political factors of influence;

- scientific and economic justification of the relation between current expenditures and development expenditures.

\section{Fiscal innovation in financial support to sustainable development}

Financial innovations, as well as any other innovation, can also be divided into the following:

- crisis innovations, the main feature of which is the solution of the problem of the sale of goods (works, services) in connection with falling demand for it and reducing its sales, as well as a more complex problem the survival of the entity in the market in conditions of severe competition. Crisis innovation is aimed at eliminating the organizational, industrial, economic or financial crisis of the business entity;

- development innovations aimed at increasing the competitiveness of the product and the economic entity itself in the future. Such innovations are caused by promising forecasts of economic activity, such as forecasts of loss of competitiveness of goods, falling image of the business entity, possible bankruptcy;

- new financial transactions, which include forms of control and accounting of cash flows and securities (money changers), financial planning methods, methodology for drawing up financial plans of different types (balance of incomes and expenses, cash flow plan, budgeting, operational financial plans and etc.), methods of financial analysis, forms of organization of financial work of the business entity, interactive and other similar investment of capital and other actions related to an attempt to seize an economic entity, actions from catching up of new financial markets;

- new financial products, which are a form of materialization of such financial transactions that are intangible, therefore they can't be sold. They are embodied in the form of instructions, rules, guidelines, formulas, graphs, 
that is, some kind of document, which, in turn, is a financial product, and therefore, the object of sale [3].

The introduction of new effective tax instruments will have an impact on the promotion of innovative economic development. Innovations should become the basis for increasing the competitiveness of the national economy in general and all subjects of the regional socio-ecological-economic system in particular, which is impossible under the current tax system. However, there is no proper effect from the ongoing reforms in this area, since the taxes generally remained high and the tax base is too narrow. Therefore, opaque schemes, in particular regarding the reimbursement of value added tax on export operations, as well as tax legislation are generally too unstable, continue to apply. Therefore, the need to update the constructive and effective mechanisms of financial, in particular, tax, stimulation of innovation activity, is actualized.

In Ukraine, the government has long used such tax innovations as VAT bonds. They are government bonded bonds, as well as the special financial instruments that were created by the state to partially offset the violated rights of economic entities that are violated by the state itself. Such a violation consisted of the arbitrary use by the state of working capital of enterprises by holding a budget reimbursement of VAT [14].

The quality of taxpayer servicing by the bodies of the State Fiscal Service of Ukraine is constantly increasing due to the introduction of electronic document circulation and new reporting mechanisms by submitting tax reporting by electronic means. We also consider this a type of tax innovation.

The bodies of the State fiscal service of Ukraine are constantly introducing innovative transformations for continuous operational control of the formation of the revenue part of the State Budget. Thanks to such a transformation, the state body introduced a system of electronic administration of value added tax (SEA VAT).

From July 1, 2015, VAT payers should not only submit VAT reporting electronically, but also register the tax invoices electronically in the Unified Register of Tax Bills. SEA VAT is intended to destroy tax evasion schemes, in particular through the creation of offshore companies or the use of settlements through the conversion of commercial banks. Thus, the established SEA VAT is an effective step towards harmonization of the mechanism of VAT charging to a similar mechanism in the countries of the European 
Union when payment is made on the fact of consumption in a timely manner and in full [16].

Today, the modernized national fiscal system has introduced the following tax innovations:

- development of the electronic document flow infrastructure as a set of processes for the creation, processing, transmission, receipt, storage, use of electronic documents used for the verification of integrity and remote auditing;

- introduction of electronic service and electronic check-up;

- creation of a taxpayer's electronic cabinet in order to improve the conditions of the payer in the electronic service;

- providing tax consultations at the lowest level;

- formation of tax knowledge base;

- establishment of service centers for taxpayers;

- introduction of the system of electronic administration of VAT payers;

- creation of a mechanism for transparent electronic control of returning VAT payers;

- introduction of the possibility of receiving a taxpayer in electronic form a certificate of the absence of tax arrears;

- convergence of accounting and tax accounting when taxing corporate profits;

- reducing the number of tax audits of taxpayers by controlling bodies.

Today it is worth moving on to an effective innovation-investment model of the economy. For this purpose, the state should use a set of incentives, primarily of a fiscal nature. One of the most effective and most popular tools for support and tax incentives for innovation is tax breaks, including investment tax credit, research tax credit and investment tax rebate. At the same time, a tax credit is considered a sufficiently effective tax advantage - the amount at which taxes may be reduced, in connection with the implementation of innovation activities. The state, by providing tax privileges, works to increase the competitiveness of the country's economy and the rivers, which results in further chain effects on various components of socio-economic development, in particular the introduction of energy saving and innovative technologies, and modernization. In the long run, the state forms the potential for increasing the welfare of citizens.

The financial support of the policy of stimulating sustainable development in the region is a purposeful process that involves attracting, distributing and redistributing funds to finance incentive measures to achieve 
the social, economic and environmental goals of the region, with the main objective being the achievement of a sustainable development of the region with respect for all signs of constancy. The main subjects of the financial support of the policy of stimulating the sustainable development of the region are the subjects of the economy of the region, state and regional authorities and households. In accordance with this, the objects of financial support will be the finances of business entities in the region, public finances of the region and the finances of households in the region [13].

One of the types of financial support for a policy of stimulation of sustainable development of regional systems is tax stimulation of sustainable development of the region. The tax stimulation of sustainable development of the region have a significant impact: the finances of commercial enterprises of all forms of ownership operating in the region, the finances of the social institutions operating in the region, the finances of public institutions and charitable foundations operating in the region, as well as the finances of households in the region ( the funds of such business entities should be taxed in accordance with the current legislation of Ukraine in accordance with the established procedure); consolidated budget of the region and funds of state-owned trust funds operating in the region (redistribution of received taxes, fees and payments is made and directed to current and capital expenditures of the region).

Tax reform is a key task in solving job creation and environmental issues. It is especially important in the context of financial support for sustainable development of the region. Depending on the type and size, eco-taxes promise several benefits: introduce the principle of "paying the polluter" - internalize externalities associated with depletion and pollution, transforming them into internal production costs; provide incentives for more efficient use of energy and resources (reducing the flow of resources) and promoting technological innovation.

That is, environmental tax revenues should be reallocated through the budget (state or local budgets), contributing to the following objectives:

1) reduction of harmful emissions into the environment (air, water environment);

2) reduction of morbidity and increase of population productivity;

3 ) increase the revenue part of budgets of different levels.

The tax mechanism, which is an independent link of the economic mechanism and an important component of the financial mechanism, determines 
and legally establishes the forms of resource mobilization through taxes, fees and other tax payments.

On the one hand, taxes, providing revenue part of the state budget, determine the scale of social development, public financing of innovation projects, etc. On the other hand, the greater degree of toughness of the tax regime has a deterrent effect on the increase in output (and income), contributes to the growth of the shadow economy and thus, in the end, reduces the tax base.

One of the permanent and always topical issues in the aspect of tax incentives for sustainable development is the taxation of corporate profits. Taking into account the peculiarities of the Ukrainian economy, the stimulating mechanism of the corporate profit tax should be set up in such a way that it contributes to the development of production, the accumulation of capital and the return of the economy towards science and capital intensive industries, which in turn requires: the definition of the object of taxation; the establishment of tax rates; definition of a list of tax privileges and conditions for their provision of business entities.

The experience of developed countries (Denmark, Italy, Netherlands, Norway, Great Britain, Finland, Switzerland, Sweden, Belgium, Austria, United States, South Korea and Japan) shows that highly relevant today promoting sustainable development through tax instruments. Therefore, Ukraine should, taking into account the experience gained in these countries, take over and adapt it to our conditions.

A clear and balanced fiscal policy in this regard will allow in the shortest time to overcome the negative processes in the socio-economic and environmental sphere, and in the short term - to achieve sustainable development of regional socio-ecological and economic systems. The primary measures for this purpose are: the introduction of amendments to existing regulations (codes, laws, regulations), supplementation of the Tax Code of Ukraine (taking into account elements of tax incentives-through environmental taxes, environmental tax privileges), elaboration of the method of tax incentive measures within the tax politics [10].

\section{Findings}

Tax innovations will lead in the near future to improve the situation with the fiscal space of the state, and hence stable regional socio-ecological and economic. The development of partnerships between taxpayers 
and fiscal authorities will be one of the prerequisites for stabilizing the socio-economic development of the state as a whole, and the sustainable development of regional systems in particular. The current infrastructure of electronic document circulation as one of the indications of fiscal stimulus for sustainable development of the region will allow for the transition to a remote audit without additional costs for both the budget and taxpayers.

In view of the innovative development of the national tax system, some aspects of the transformation of the field of tax legal relations can be formulated: the gradual transition from the purely administrative-fiscal to the service model of relations between taxpayers and tax authorities; codification of tax knowledge with their respective internal distribution into special regimes; application of the relevant tax regimes by the state and their use by taxpayers to choose the best approach to fulfilling tax obligations.

\section{Conclusions}

In the process of theoretical and methodological research, we propose the main approaches to understanding the fiscal stimulation of sustainable development of regional socio-ecological and economic systems. We have identified a qualitatively new instrument of fiscal policy with the need to improve the well-being of citizens. We identified the main strategic guidelines for the fiscal policy concept, namely: improving the efficiency of using fiscal instruments through their orderliness and system use.

\section{References:}

1. Banton V. D. L., Tarangul V.I. (2010) Fiskalna polityka ta mekhanizm yii realizatsii [Fiscal policy and the mechanism of its realization]. Investments: practice and experience, no. 21, pp. 30-35. [in Ukrainian]

2. Bilorus O.G. (2005) Hlobalna perspektyva i stalyi rozvytok [Global Perspective and Sustainable Development]. K.: MAUP. [in Ukrainian]

3. Vakhnovskaya N.A., Ishchuk L.I., Polishchuk V.G. (2015) Suchasni podatkovi innovatsii yak priorytetna skladova finansovoho inzhynirynhu biznes-protsesiv v Ukraini [Modern tax innovations as a priority component of financial engineering of business processes in Ukraine]. Actual problems of the economy, no. 8, pp. 337-342. [in Ukrainian]

4. Gerasymchuk Z.V. (2008) Rehionalna polityka staloho rozvytku: teoriia, metodolohiia, praktyka: Monohrafiia [Regional Policy of Sustainable Development: Theory, Methodology, Practice: Monograph]. Luck: Nadstyr'ya. [in Ukrainian]

5. Gerasymchuk Z.V., Polishchuk V.G. (2011) Stymuliuvannia staloho rozvytku rehionu: teoriia, metodolohiia, praktyka: Monohrafiia [Stimulating the Sustainable Development of the Region: Theory, Methodology, Practice: Monograph]. Luck: RVV LNTU. [in Ukrainian] 


\section{Features of fiscal stimulation of sustainable development of regions...}

6. Konovalova I. (2014) Transformatsiia zmistu fiskalnoi polityky: tsili ta vzaiemozviazky [Transforming the content of fiscal policy: goals and interconnections]. Securities Market of Ukraine, no. 9-10, pp. 11-24. [in Ukrainian]

7. McConnell K.R., Brue S.L. (1992) Jekonomiks: principy, problemy i politika [Economics: principles, problems and politics]. M.: Respublika. [in Russian]

8. Nikitshin A. (2017) Podatkove rehuliuvannia yak instrument derzhavnoi ekolohichnoi polityky [Tax regulation as an instrument of state environmental policy]. Foreign Trade: Economics, Finance, Law, no. 2, pp. 128. [in Ukrainian]

9. Podatkovyi kodeks Ukrainy [Tax Code of Ukraine] Retrieved from: http://zakon2.rada.gov.ua/laws/show/2755-17/paran785\#n785 (accessed 08 March 2018)

10. Polishchuk V.G. (2010) Perspektyvy podatkovoho stymuliuvannia staloho rozvytku rehioniv Ukrainy [Prospects for tax incentives for the sustainable development of Ukrainian regions]. Economy and the State, no. 4, pp. 59-61. [in Ukrainian]

11. Intelsfera (2000) Prohrama dii "Poriadok dennyi na KhKhI stolittia": Ukhvalena konferentsiieiu OON z navkolyshnoho seredovyshcha i rozvytku $v$ Riode-Zhaneiro (Samit "Planeta Zemlia”, 1992 r.) [Agenda 21: Adopted by the UN Conference on Environment and Development in Rio de Janeiro (Summit "Earth", 1992)]. K.: Intelsfera [in Ukrainian]

12. Polishchuk V.G. (2017) Theoretical foundations of the concept of stimulating sustainable development of regions in the context of financial security. Economics and Society, no. 11, pp. 363-370.

13. Vakhovich I.M. (ed.) (2014) Finansove zabezpechennia staloho rozvytku rehioniv Ukrainy: mizhbiudzhetni vidnosyny ta innovatsiini instrumenty stymuliuvannia: Monohrafiia [Financial Support to the Sustainable Development of Ukrainian Regions: Intergovernmental Fiscal Relations and Innovative Incentive Tools: Monograph]. Lutsk: Volynpolihraf.

14. Sokhatska O.M. (ed.) (2011) Finansovyi inzhynirynh: Navchalnyi posibnyk [Financial engineering: Textbook]. K: Kondor.

15. Krysovatyi A.I. (ed.) (2016) Fiskalnyi prostir staloho sotsialno-ekonomichnoho rozvytku derzhavy: Monohrafiia [Fiscal space of sustainable socio-economic development of the state: Monograph]. Ternopil: TNEU.

16. Khatniuk N.S. (2016) Innovatsii $\mathrm{v}$ podatkovykh pravovidnosynakh yak umova rozvytku y optymizatsii podatkovoi systemy Ukrainy [Innovation in tax relations as a condition for the development and optimization of the tax system of Ukraine]. Scientific Herald of the International Humanitarian University, no. 23, pp. 80-83. [in Ukrainian]

17. Shnypko O.S. (2003) Natsionalna konkurentospromozhnist: sutnist, problemy, mekhanizmy realizatsii [National competitiveness: the essence, problems, mechanisms of realization]. K.: Naukova dumka. 


\title{
THE MODERN STATUS OF NORMATIVELY-LEGISLATIVE REGULATION OF TAX CONTROL IN UKRAINE AND PROPOSALS FOR ITS IMPROVEMENT
}

\section{Puhalsky Vadym ${ }^{1}$}

DOI: http://dx.doi.org/10.30525/978-9934-571-28-2_23

\begin{abstract}
Among the main tasks of the State fiscal service of Ukraine, the systematic control over compliance with tax discipline by economic entities is taking place. The decisive importance here is the adoption of relevant laws and regulations on tax control in Ukraine, which must be harmonized with European norms and be perfect and stable in European integration. The imperfection of the current legislation in the area of tax control in Ukraine is evidenced by its frequent changes and amendments, which have a negative impact for business well as for regulatory bodies.

The purpose of the work is to study the current state of regulatory and legislative regulation of tax control in Ukraine and to develop scientifically substantiated theoretical positions on this basis on the directions of its improvement in order to increase its effectiveness.

It was necessary to solve the following tasks to achieve the goal: to carry out meaningful and definitive analysis of the terms of the legislation, the legal act; to identify the features, to generalize the legal regulation of tax control in Ukraine and to substantiate its shortcomings; to propose directions for improvement of the regulatory and legislative regulation of tax control in Ukraine in order to eliminate flaws and increase the effectiveness of its conduct.

In accordance with the goals and objectives subject of the article is theoretical and methodological principles of analysis and improvement of regulatory and legislative regulation of tax control in Ukraine in order to increase its efficiency.

In the process of scientific research, the methods of theoretical generalization and comparison regarding the development of the conceptual apparatus in the field of regulatory and legislative regulation in general and tax control in Ukraine in particular were used.
\end{abstract}

\footnotetext{
${ }^{1}$ Candidate of Economic Sciences, Associate Professor, Khmelnitsky National University, Ukraine
} 


\section{Introduction}

An important functioning condition of tax control in Ukraine is the favorable and detailed regulatory and legislative regulation of the procedure for its implementation, which, firstly, should be stable, and secondly, mutually consistent with other norms of legislation, thirdly - perfect, fourthly - detailed. These characteristics are important from the point of view of avoiding opaque inspection schemes, organization and implementation of this direction of control.

Recent research and publications analysis. Problems of the tax control regulation were considered in the works of domestic scientists- T. M. Kravtsova, M. P. Kucheryavenko, D. V. Reva and in the works of foreign scientists A. V. Bryzgalin, E. Yu. Grachova, I. I. Kucherov, A. M. Ukraintseva and others.

There is chapter 5 "Tax Control" in the Tax Code of Ukraine (TCU) that is devoted to the tax control, which describes the interpretation of tax control, defines the powers of state authorities and sets out the methods of tax control. However, it is worth to note, that Ukraine has no special law regulating the mechanism of tax control, clearly defining the types, forms, methods, and instruments for its implementation. In this regard, it is important to analyze the current legislation of Ukraine that regulates tax control procedures in order to eliminate the fuzziness of the regulatory control of tax control in Ukraine.

The purpose of the article is to develop scientifically substantiated theoretical positions regarding the directions of improving the regulatory and legal regulation of tax control in Ukraine.

\section{The main research material}

The need to improve the legal regulation of tax control is conditioned by the imperfection of tax legislation, its constant changes (about 100 changes in the TCU for the period from 02.12.2010 to 01.01.2017) do not contribute to the creation of a stable tax system, therefore, and also, for a number of other reasons, there are preconditions for ambiguous interpretation of tax legislation, which leads to tax evasion and the implementation of various tax offenses on the part of both individuals and legal entities, and it makes the supervisory authorities to make decision not in favor of taxpayers. It is appropriate to note that the TCU established that the principle of the tax legislation of Ukraine is the principle of stability (Article 4.1.9, Article 
4), which means that "changes to any elements of taxes and fees can not be made later than six months before the start of a new budget period, in which new rules and rates will apply. Taxes and fees, their rates, as well as tax breaks can not be changed during the budget year" [1]. However, this rule of law is not fulfilled; changes are made without taking into account the above law norm.

The analysis of TCU in the part of tax control, shows that Art. 19 "Functions of controlling bodies" of Section I "General Provisions" was changed and supplemented 20 times, Art. 20 "Rights of controlling bodies" 12 times, Art. 21 "Responsibilities and responsibilities of officials of controlling bodies" - 5 times, Art. 41 "Supervisory authorities and penalties" Chapter $1-5$ times, Art. 61 "Definition of tax control and powers of state authorities on its implementation" of Chapter 5 "Tax control" - 4 times, Art. 62 "Methods of tax control" - 1 time [1].

First of all, we will examine the content of some definitions, namely: legislation, normative legal act. The "legislation" term is often referred to in regulatory legal acts of Ukraine. In the Basic Law of Ukraine - the Constitution, the term "legislation" is used in art. 9 "national legislation", in art. 19 "provided by law", in art. 118 "Other legislative acts", in Section XV "Transitional Provisions" "in accordance with the current legislation". However, in the Constitution of Ukraine there is no interpretation of the definition of "legislation", which, of course, leads to a different interpretation of this term [2].

The essence of the term "legislation" is given in the decision of the Constitutional Court of Ukraine in the case of the constitutional petition of the Kyiv City Council of Trade Unions concerning the official interpretation of part three of Article 21 of the Code of Labor Laws of Ukraine (the case on the interpretation of the term "legislation") of 09.07.1998, No. 12-p / 98 The term "legislation" is widely used in the legal system, mainly as a set of laws and other normative legal acts that regulate one or another sphere of social relations and are sources of a certain field of law. In laws, depending on the importance and specificity of regulated social relations, this term is used in different meanings: in some, only laws are meant; in others, first of all codification, the term "legislation" includes both laws and other acts of the Verkhovna Rada of Ukraine and acts of the President of Ukraine, the Cabinet of Ministers of Ukraine, and in some cases also the normative legal acts of central executive authorities [3]. 
Hence, "legislation" can be viewed in a narrow and broad sense. In the narrower sense, the term "legislation" refers to the system of laws of Ukraine, which is established by the Verkhovna Rada of Ukraine as the sole legislative authority. This category also includes international treaties agreed upon by the Verkhovna Rada of Ukraine through the adoption of a law on ratification of the relevant treaty (Article 9 of the Constitution of Ukraine) [2].

In the broad sense, the term "legislation" means a system of laws and other normative acts adopted by the Verkhovna Rada of Ukraine and the highest organs of the executive power - decrees of the President of Ukraine, decrees and regulations of the Cabinet of Ministers of Ukraine, decrees of the President of Ukraine, decrees and regulations of the Cabinet of Ministers of Ukraine, as well as regulations of ministries and departments, city councils and local state administrations

Thus, the notion of "legislation" on the one hand is one of the main methods of the state's exercise of its functions through the laws issuance by the state authorities, and on the other hand, as a set of existing legal norms regulating social relations through laws, by laws statutory acts (decrees, decrees, decrees, orders, instructions, etc.). With regard to tax legislation, the SFS gives the following interpretation: tax legislation - legislation that establishes and regulates tax collection and tax payments, and in relation to the tax law, the SFS considers it as a legal act of the highest legislative body, which obliges the legal individuals and citizens to pay to the budget payments in the form of taxes in a certain amount and in precisely specified terms [4].

The following term used in reference to the practice of tax control is a normative act. In the legal terminology we find: a nominative act is an official written document, which establishes, amends or abolishes the rules of law, is general or local in nature and is repeatedly applied by the authorized state or other body within its competence. The normative acts include: regulations, rules, instructions, decisions, etc., which are entered into force by order [5].

In the legal encyclopedia, the normative act is an imperious order of state bodies, which establishes, amends or abolishes the rules of law (law, code, resolution, instruction, etc.). It is one of the main sources of law of the modern state, the predominant form [6].

In the dictionary of business terms, a normative act is understood as law, a code, a regulation, instruction, and other imperious order of state bodies, which establishes, modifies or abolishes the rules of law. The prescriptions of normative legal acts have a general character and are aimed at regulation [7]. 
Legal act - an official written document adopted by the competent authority of the state, in which the legal norms are formulated [4].

State legal regulation of tax control is necessary in order to create uniform rules, approaches to the organization, conduct and adoption of the decision-making on its results.

The foreign literature distinguishes three main elements in the system of legal regulation of tax control:

- legal norms, through which tax authorities receive the information necessary for tax control both from the taxpayer and from third parties;

- legal norms, which give the tax authorities the necessary powers for tax control and execution of tax duty on a compulsory basis;

- legal norms that establish the rights and guarantees of the taxpayer [8].

In Ukrainian legislation in the area of tax control, the above elements are grouped into TCU.

In addition, foreign researchers divided all laws that may be subject to tax control into three groups.

- general laws that define the powers of the tax authority, as well as the rights and obligations of the taxpayer in the part of tax control in respect of all taxes established in the respective state - in this case it may be an act that codifies most of the tax the legislation of the state, including the regulation of tax control, or a special law that combines the rules for the implementation of tax control;

- special laws, regulating the legal status of the tax authority and the taxpayer in relation to the implementation of tax control in terms of paying a separate tax (eg VAT);

- other non-tax laws, including provisions relating to tax control [8].

The legal and regulatory basis for tax control in Ukraine includes two levels (Figure 1):

Ukraine's integration processes in the international community are accompanied by the introduction of the practice of tax control of international standards, the harmonization of national and international law, and the use of best international practice. However, the introduction of international standards is a complicated and ambiguous process, due to its own problems with the state. Among the international instruments that relate to tax control, it is necessary to highlight the Lima Declaration of the Principles of Control (1977) INTOSAI (International Organization of Supreme Audit Institutions acting under the auspices of the United Nations or its spe- 


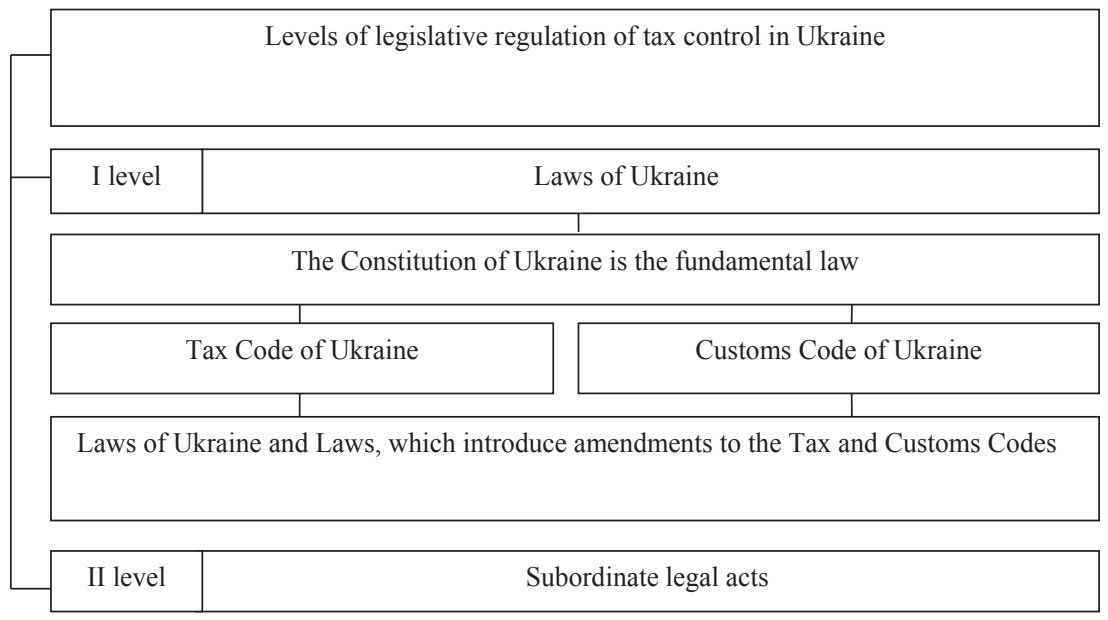

Fig. 1. Levels of legislative regulation of tax control in Ukraine

cialized agencies, which plays the main role in the audit of public finances and the development of transparent financial systems and the accountability of governments of 192 countries, within which there are regional organizations), the norms of which are recognized as a benchmark for assessing the level of organization of financial control [9].

International tax acts should include international agreements on the avoidance of double taxation, which are the most important source of international tax law (an integral part of the legislation on taxes and fees). In its recommendations, the UN explicitly states that the conclusion of bilateral agreements on the avoidance of double taxation on income and property is by far the most optimal option for solving international tax problems [9]. International tax agreements, the consent of which is granted by the Verkhovna Rada of Ukraine, are more forceful than national tax laws (Section 3.2, Article 3 of the Tax Code) [1].

It is appropriate to pay attention to such a direction of tax control as control of the keeping of the principle of "elongated hand". It is the area of tax control that has rapidly started to develop in Ukraine since 2013, due to the adoption of a number of legal acts.

The main international acts that establish and explain the methodology, procedure, procedures and peculiarities of the implementation of the reg- 
ulation and supervision of compliance with the principle of an "elongated hand" are:

- OECD Transfer Pricing Guidelines for Transnational Companies and Tax Services (OECD Transfer Pricing Guidelines for Multinational Enterprises and Tax Administrations, Paris, 22 July 2010);

- Modular (typical) OECD Convention on Income and Capital Tax (Model Tax Convention on Income and on Capital: Condensed Version, OECD, Paris, 22 July 2010; Model Tax Convention on Income and Capital: Full Version (as it read on 22 July 2010) OECD (2012), Paris);

- Methodological recommendations on the development of legislation on transfer pricing in order to harmonize the approach used (OECD Transfer Pricing Leasing Regulation - A Recommended Approach, Paris, June 2011).

Therefore, the above-mentioned normative acts are an integral part of the tax control regulation.

As part of the first level of legal regulation of tax control in Ukraine, we have identified the Basic Law - the Constitution of Ukraine, which consolidates the social and state structure of the country, the functions of state authorities, the basic rights and duties of citizens. One of the constitutional duties of citizens of Ukraine is the obligation of each to pay taxes and fees in the order and amounts established by law, as well as annually submit to the tax inspectorates at the place of residence the declaration of their property status and income for the last year in the manner prescribed by law (Article 67 of the Constitution of Ukraine) [2].

The Constitution as the main source of tax legislation contains the legal principles governing the normative regulation of central and local taxes and are the basis for procedural tax legislation; establishes legal bases of tax activity of the state and competence of central and local authorities in the field of tax relations. The Constitution of Ukraine explicitly refers to the legal form of the introduction of the tax, in particular, in paragraph 1 of part two of Article 92 it is determined that only the laws of Ukraine set the tax system, taxes and fees. In Art. 98 of the Constitution of Ukraine states that the Accounting Chamber carries out control on behalf of the Verkhovna Rada of Ukraine for the receipt of funds into the State Budget of Ukraine and their use [2].

The state budget filling, realization of tasks and functions of the state directly depends on the effective performance of all subjects of the tax legislation of the tax duty. The role of the SFS of Ukraine in this process is key because they are required by the rules of the current legislation to monitor 
their timeliness and completeness of payment of taxes, fees (other mandatory payments).

The implementation of this control is primarily aimed at creating conditions for the voluntary fulfillment of the constitutional duty for the taxpayer to pay the corresponding amounts to the budget and reduce the cases of coercive measures. Therefore, one of the main tasks of tax authorities in the process of declaration is the prompt provision of information and consulting services to the citizens.

The constitutional provisions on tax control have their particulars in the TCU, which serves as the main legislative act in the field of tax control. According to Art. 3 "Tax Legislation" of the Tax Code specifies that the tax law of Ukraine consists of the Constitution of Ukraine, the Tax Code, the Customs Code and other laws on customs matters and other laws on customs matters in terms of regulating legal relations arising from relocation goods through the customs border of Ukraine; current international treaties, the consent of which is binding on the Verkhovna Rada of Ukraine; normative legal acts adopted on the basis and on the basis of TCU and laws on customs matters, decisions of the Verkhovna Rada of Ukraine, local self-government bodies on local taxes and fees, adopted under the rules of the TCU [1].

The content, authority of the bodies and methods of tax control are presented in Chapter 5 "Tax Control" of the TCU, which includes two articles, each of which consists of 3 and 4 sub-paragraphs, respectively. Chapter 8 "Inspections" defines the types and regulates the procedure for conducting documentary, factual checks, examinations and generalization of the results of inspections. Although chapter 5 of the TCU is intended to detail the tax control, certain rules that should be included in this chapter are found in other chapters and articles, in addition, there is no interpretation of the types, forms, principles, methods, tools of its implementation, ie not made the only concept of tax control in Ukraine, which impedes the formation and development of an integrated system of tax control.

Prior to the adoption of the Tax Code, tax control was regulated by a number of subordinate legal acts (instructions, orders, methodological recommendations, etc. of the State Tax Service of Ukraine). TCU has, to a certain extent, generalized the procedures of mutual relations between tax authorities and taxpayers during the conduct of tax audits.

Some articles focus on the application of customs legislation to tax control (inclusion in the collection of taxes and duties - a special mandatory 
payment, which is part of the tax system of Ukraine, is made when crossing the customs border of Ukraine and is regulated by customs legislation, the imposition of the value-added tax and excise tax upon crossing the customs border of Ukraine, which is regulated, including by the customs legislation). In this regard, tax legislation regulates the collection of such payments on the of financial and administrative law. In general, the Customs Code of Ukraine regulates the external economic activity of business entities, along with which separate articles $(302,303,345-355,467,474,475,485)$ relate to tax audits of subjects of foreign economic activity [11].

The Tax and Customs Codes of Ukraine are constantly being amended by a number of laws of Ukraine. So the PKU is supplemented by Art. $19^{1}$ Functions of the bodies of the State Tax Service in accordance with the Law of Ukraine "On Amendments to the Tax Code of Ukraine regarding the State Tax Service and in connection with the conduct of administrative reform in Ukraine" dated 05.07.2012, No. 5083-VI [12]. The Law of Ukraine "On Amendments to the Tax Code of Ukraine regarding Improvement of the Investment Climate in Ukraine" of 21.12.2016, No. 1797-VIII [13] entrusted new responsibilities to officials of the controlling bodies. According to Art. $19^{1}$ TCU functions of state tax inspections defined: the implementation of service-servicing of taxpayers; realization of registration and accounting of taxes on single tax payers and taxpayers, taxation objects and objects related to taxation; formation and maintenance of the State Register of Natural Persons - Taxpayers, the Single Data Bank on Taxpayers - legal entities, registries, which are entrusted by law to the controlling bodies; performance of other functions of service of taxpayers defined by law. This law of Ukraine does not provide for the right to conduct tax and documentary inspections of taxpayers by tax inspectors. That is, the corresponding changes are made in Art. 191 $19^{2}, 19^{3}$, distinguishing between the functions of the controlling bodies and the Ministry of Finance of Ukraine.

In order to avoid the tax liabilities minimization and withdrawal of profits outside Ukraine, the Law of Ukraine "On Amendments to the Tax Code of Ukraine on Improving Tax Control of Transfer Pricing" was adopted on January 28, 2014, No. 72-VIII [14]. Tax control over transfer pricing provides for adjusting taxpayer's tax liabilities to the level of tax liabilities calculated on condition that the commercial and / or financial conditions of the co-controlled transactions are commensurate with the commercial and / or financial conditions that occurred during the carrying out comparable 
operations provided for in this Article, the parties of which are not related parties. For a deeper understanding of the content of this law of Ukraine and the relevant actions of the tax control body of the DFSU by its letter of 07.07.2015, No. 24525/7 / 99-99-22-01-02-17 “On Tax Control of Transfer Pricing in the Communications Together with the introduction of amendments to the Tax Code of Ukraine, details of certain issues related to the application of tax legislation on the control of transfer pricing [15].

The second level of legislative regulation of tax control in Ukraine is represented by bylaws, which include the message of the President of Ukraine, the CMU Orders, orders of the SFSU, etc.

Among subordinate regulatory acts, first of all, it is necessary to include the message of the President of Ukraine, which regularly raises issues of improving tax administration and tax control. This group of legal regulation of the tax control procedures includes both subordinate regulatory acts of the Cabinet of Ministers of Ukraine and the Ministry of Finance, which are required for execution by the tax authorities. Here are some of them. First of all, they include the "Regulation on the State Fiscal Service of Ukraine" dated 21/05/2014, No. 236, which defines the tasks and rights of this service [16].

Order of the MFU "On Approval of Amendments to the Procedure for Submitting Tax Notices to Taxpayers" dated May 23, 2016 No. 498 [17], which, in particular, supplemented the types of liability of taxpayers, which are subject to tax authorities by the controlling bodies message-decision, new types of penal (financial) sanctions (fines), introduction of a tax notification-a decision for the use by the controlling bodies of sanctions (fines) imposed by the TCU (including on established violations CCU) application which are not directly related to the definition of tax liabilities. In particular, these are sanctions for non-submission or late submission of tax returns, for violating the established deadlines for storing documents, failure to submit or violate the timing of submission of tax information, the order of reckoning (registration) in supervisory bodies.

By order of the MFU "On Approval of the Procedure for Inspection on Taxpayer Compliance with the Extension of the Principle of "Elongated Hand" dated March 10, 2016 No. 344 [18] it was determined that the form of tax control is to establish the conformity of the conditions of control operations with the principle of an "elongated hand" etc.

In order to properly organize the work on the holding and implementation of documentary checks results on compliance with the requirements 
of the legislation of Ukraine on the state customs business, an order was issued to the SFSU "On approval of methodological recommendations on the interaction between the divisions of the State Fiscal Service in the Organization, holding and implementation of documentary materials inspections of compliance with the requirements of the Ukrainian law on state customs issues" dated October 12, 2016, No. 856 [19].

In accordance with clause 73.5 of Art. $73 \mathrm{TCU}$, in order to introduce a unified procedure for organizing work on the exchange and processing of tax information in the implementation of tax control, the submission of requests for the conduction of counter checks, as well as the design, transfer and accumulation of materials for counter-checks, the SFS authorities adopted an order of the SFSU "On approval of methodological recommendations on organizing and conducting organs of the state fiscal service of counter-inspections, exchange of tax information in the course of tax control "dated July 17, 2015, No. 511 State fiscal and service of Ukraine [20].

Legal acts of state authorities and local self-government bodies in the area of taxes and fees that are taken within their powers do not directly regulate tax control procedures, but they are used by tax authorities when verifying the correctness and timeliness of calculating and paying local taxes.. In Khmelnytsky, in 2018, the following local taxes and duties were set: personal income tax (tax rate 18\%), profit tax on enterprises and organizations belonging to municipal property of the city (tax rate 18\%), tax on immovable property other than land, land tax, transport, tourist tax (rate $1 \%$ of the cost of living), excise tax on realization by retailers of excisable goods, payment for the provision of others administrative services (the size of the installment fee are enrolled by various departments (State Migration Service, State Statistics Service, State Registry Service, Ministry of Internal Affairs, etc.), and their monthly revenues are not constant, a single tax (depending on the group to which entrepreneurs belong) and a single social contribution ( the rate is $22 \%$ ) [21].

In the context of these taxes and fees, control procedures should be carried out, however, due to the moratorium on tax inspections for 2015-2017, the controlling bodies inspect enterprises, institutions, organizations and individuals entrepreneurs with an income volume of up to UAH 20 million for the previous calendar year exclusively: with the permission of the Cabinet of Ministers; at the request of the entity for its verification; in accordance with the decision (requirements) of the Criminal Procedure Code of Ukraine. 
It should be noted that within this article we have not examined and analyzed all the regulatory and legislative acts of tax control, since their number is significant and gradually changing.

\section{Conclusions}

The study of regulatory and legislative regulation in the field of tax control allowed some conclusions to be drawn and suggested practical recommendations for its improvement, namely: firstly, changes and additions are frequently made to the TCU, especially their number increased in 2016., which indicates a large number of ambiguous norms that allow regulatory authorities to manipulate legislation, make decisions not in favor of taxpayers; Second, Chapter 5 of the TCU is designed to precisely detail the tax control of certain rules that should be included in this chapter in other chapters and articles, in addition, there are no interpretations of the types, forms, principles, methods, tools of its implementation, the procedures of the organ tion and implementation of tax control, ie, the unified concept of tax control in Ukraine has not been developed, which impedes the formation and development of an integrated system of tax control. In our opinion, they need to be presented in a complex way in the TCU as a separate section "Conceptual bases of tax control"; Third, the SFSU sends letters of various kinds, develops methodological recommendations that specify the procedure for the implementation of tax control, which is not covered in the TCU, that is, such detail should also be contained in the TCU, this information should be owned by taxpayers in order to unambiguously interpret the rules of the current tax law, Fourth, it is necessary to allocate authorities of bodies in the field of tax control, as they are contained only in the title of Art. $61 \mathrm{TCU}$, fifth, to determine the cases when the results of tax control are considered invalid because of gross violation of the current legislation during its conduct. Thus, the development and proposed recommendations will promote the orderly and unambiguous regulatory framework of tax control, will help to make opaque audit schemes impossible and improve the organization and implementation of tax control in Ukraine.

\section{References:}

1. Podatkovyi kodeks Ukrainy vid 02. 12. 2010. № 2755-VI (red. 07.09.2017) [Tax Code of Ukraine dated 02. 12. 2010. № 2755-VI (as amended on 07.09.2017)]. Available at: http://zakon5.rada.gov.ua/laws/show/2755-17.

2. Konstytutsiya Ukrainy vid 28. 06. 1996. № 254k/96-VR (red. 30.09.2016) [The Constitution of Ukraine dated 28.06.1996. № 254k/96-VR (as amended on 


\section{Puhalsky Vadym}

30.09.2016) Available at: http://zakon3.rada.gov.ua/laws/show/254\%D0\%BA/96$\% \mathrm{D} 0 \% \mathrm{~B} 2 \% \mathrm{D} 1 \% 80$.

3.. Rishennia Konstytutsiinoho Sudu Ukrainy u spravi za konstytutsiinym zvernenniam Kyivskoi miskoi rady profesiinykh spilok shchodo ofitsiinoho tlumachennia chastyny tretoi statti 21 Kodeksu zakoniv pro pratsiu Ukrainy (sprava pro tlumachennia terminu “zakonodavstvo") vid 09.07.1998, №. 12-rp / 98. [The judgement of the Constitutional Court of Ukraine in the case of the constitutional appeal of the Kyiv City Council of Trade Unions concerning the official interpretation of part three of Article 21 of the Code of Labor Laws of Ukraine (case on the interpretation of the term "legislation")] since 09.07.1998, No. 12-rp / 98. Available at: http://zakon2.rada.gov.ua/laws/show/v012p710-98.

4. Slovnyk osnovnykh terminiv. Derzhavna fiskalna sluzhba. Ofitsiinyi portal. [Basic terms glossary. State Fiscal Service. Official portal]. Available at: http://sfs.gov.ua/korisni-posilannya/slovnik.

5. Yurydychnyi terminolohichnyi slovnyk [Legal terminology dictionary]. Available at: http://www.marazm.org.ua/document/termin/index.php?file $=\% \mathrm{C} 7 \% \mathrm{E} 0 \% \mathrm{EA} \% \mathrm{EE} \% \mathrm{ED} . \mathrm{txt}$

6. Yurydychna entsyklopediia v 6 t. (2002) [Legal encyclopedia in 6 volumes]. Edit: Yu.S. Shemshuchenko, etc. K. : "Ukr. Entsykl.”, 736 p.

7. Slovnyk biznes-terminiv [Business terms glossary]. Available at: https://dic.academic.ru/dic.nsf/dic economic law/9066/\%D0\%9D\%D0\%9E\%D0

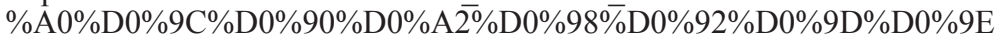

8. Kylynkarova E. V. (2017) Nalohovoe pravo dlia zarubezhnыkh stran : uchebnyk dlia bakalavrata y mahystratury [Tax law for foreign countries: a textbook for undergraduate and postgraduate studies] M. Yurait, $318 \mathrm{p}$.

9. Limska deklaratsiia kerivnykh pryntsypiv kontroliu (1977 p.) INTOSAI [The Lima Declaration of Guidelines on Auditing Precepts]. Available at: http://zakon2.rada.gov.ua/laws/show/604_001.

10. Borovyk S. (1991) Suchasna praktyka zastosuvannia uhod po unyknenniu podviinoho opodatkuvannia dokhodiv maina [Modern practice of agreements to avoid double taxation of property income] Zovnishnia torhivlia. No. 1-2.

11. Mytnyi kodeks Ukrainy vid 13.03.2012 r. № 4495-VI (redaktsiia vid 03.12.2017 r.) [Customs Code of Ukraine dated March 13, 2012 No. 4495-VI (as amended on 03.12.2017)]. Available at: http://zakon3.rada.gov.ua/laws/ show/4495-17.

12. Zakon Ukrainy "Pro vnesennia zmin do Podatkovoho kodeksu Ukrainy shchodo der-zhavnoi podatkovoi sluzhby ta $\mathrm{u}$ zviazku z provedenniam administratyvnoi reformy v Ukraini” vid 05.07.2012 r. № 5083-VI [Law of Ukraine “On Amendments to the Tax Code of Ukraine regarding the State Tax Service and in connection with the conduct of administrative reform in Ukraine" dated 05.07.2012, No. 5083-VI]. Available at: http://zakon3.rada.gov.ua/laws/show/5083-17.

13. Zakon Ukrainy "Pro vnesennia zmin do Podatkovoho kodeksu Ukrainy shchodo pok-rashchennia investytsiinoho klimatu v Ukraini" vid 21.12.2016 r. № 1797-VIII [The Law of Ukraine "On Amendments to the Tax Code of Ukraine for the Promotion of the Investment Climate in Ukraine" dated December 21, 2016, No. 1797-VIII]. Available at: http://zakon3.rada.gov.ua/laws/show/1797-19. 


\section{The modern status of normatively-legislative regulation of tax control...}

14. Zakon Ukrainy "Pro vnesennia zmin do Podatkovoho kodeksu Ukrainy shchodo udo-skonalennia podatkovoho kontroliu za transfertnym tsinoutvorenniam” vid 28.12.2014 r. № 72-VIII [The Law of Ukraine “On Amendments to the Tax Code of Ukraine for the Adoption of the Tax Control for Transfer Pricing" dated 28.12.2014, No. 72-VIII]. Available at: http://zakon2.rada.gov.ua/laws/show/72-19.

15. Lyst DFSU "Pro podatkovyi kontrol za transfertnym tsinoutvorenniam u zviazku iz vnesenniam zmin do Podatkovoho kodeksu Ukrainy" [Letter to the SFSU "On Tax Control of Transfer Pricing in Connection with the Amendment to the Tax Code of Ukraine"']. Available at: https://www.pard.ua/uk/news/3549-dfsu-rozyasnyuye-deyaki-pytannya-shchodo/.

16. Postanova KMU "Polozhennia pro Derzhavnu fiskalnu sluzhbu Ukrainy" vid 21.05.2014 r. № 23 [Elektronnyi resurs]. - Rezhym dostupu: http://zakon3.rada.gov.ua/ laws/show/236-2014-\%D0\%BF.

17. Nakaz MFU "Pro zatverdzhennia Zmin do Poriadku nadislannia kontroliuiuchymy orhanamy podatkovykh povidomlen-rishen platnykam podatkiv" vid 23.05.2016 r. № 498 [Order of the MFU "On Approval of Amendments to the Procedure for Submitting Tax Authorities to Taxpayers by the Supervisory Bodies" dated May 23, 2016, No. 498]. Available at: http://zakon3.rada.gov.ua/laws/show/ z0846-16.

18. Nakaz MFU "Pro zatverdzhennia Poriadku provedennia perevirky z pytan do-trymannia platnykom podatkiv pryntsypu "vytiahnutoi ruky" vid 10.03.2016 r. № 344 [Order of the MFU “On approval of the procedure for conducting an audit of the issues of keeping a taxpayer with the principle of" extended hand "from March 10, 2016, No. 344]. Available at: http://zakon2.rada.gov.ua/laws/show/z0497-16.

19. Nakaz DFSU "Pro zatverdzhennia Metodychnykh rekomendatsii shchodo poriadku vza-yemodii mizh pidrozdilamy orhaniv derzhavnoi fiskalnoi sluzhby pry orhanizatsii, provedenni ta realizatsii materialiv dokumentalnykh perevirok dotrymannia vymoh zakonodavstva Ukrayiny z pytan derzhavnoi mytnoi spravy" vid 12.10.2016 r. № 856 [Order of the SSSU “On Approval of Methodological Recommendations on the Procedure for Interaction Between Subdivisions of the State Fiscal Service Bodies in the Organization, Implementation and Implementation of Materials for Documentary Inspections of Compliance with the Laws of Ukraine on State Customs Matters" dated October 12, 2016, No. 856]. Available at: http://sfs.gov.ua/yuridichnim-osobam/podatkoviy-kontrol/nakazi/69970.html.

20. Nakaz DFSU "Pro zatverdzhennia Metodychnykh rekomendatsii shchodo orhanizatsii ta provedennia orhanamy derzhavnoi fiskalnoi sluzhby zustrichnykh zvirok, obminu podatkovoiu informatsiieiu pry zdiisnenni podatkovoho kontroliu” vid 17.07.2015 r № 511 [Order of SSSU “On Approval of Methodological Recommendations on the Organization and Conduct by the Bodies of the State Fiscal Service of Combat Inspections, the Exchange of Tax Information in the Implementation of Tax Control" dated July 17, 2015 No. 511]. Available at: http://sfs.gov.ua/yuridichnim-osobam/podatkoviy-kontrol/nakazi/print-66306.html.

21. Pro proekt biudzhetu mista Khmelnytskoho na 2018 rik [About the budget of the city of Khmelnitsky for 2018]. Available at: http://khmelnytsky.com/index. php?option $=$ com_content $\&$ view $=$ article $\& i d=40205 \% 3 \mathrm{~A}-2018-\&$ catid $=330 \% 3 \mathrm{~A} 2$ 011-09-30-07-09-51\&Itemid=251 


\title{
GENERAL APPROACHES TO THE FORMATION OF MODEL OF LOGISTICS OPERATORS IN SUPPLY CHAINS
}

\section{Saiensus Mariia ${ }^{1}$}

DOI: http://dx.doi.org/10.30525/978-9934-571-28-2_24

\begin{abstract}
The paper considers the theoretical and methodological foundations of the system organization of the functioning of logistics systems based on modern technologies. The results of the research presented in the work allow us to substantiate scientifically: measures to develop domestic logistics systems of companies to the level of $3 \mathrm{PL}$ and $4 \mathrm{PL}, 5 \mathrm{PL}$ - service providers; model management options for a company operating as part of a logistics chain; optimize the structure of the enterprise based on the goals and tasks in the field of logistics; to study the possibilities of introducing information technologies of fixing the company to the level of $3 \mathrm{PL}, 4 \mathrm{PL}$, 5PL - service providers.
\end{abstract}

For this purpose, the paper studies the theoretical foundations of the management of logistics systems by companies, based on the outsourcing of logistics and information technology level 3 PL and 4 PL, 5PL service providers. The subject of the study is the organization of the logistics systems of companies in the conditions of economic globalization.

The following research methods were used in the work: structural analysis, synthesis, comparison, economic and mathematical methods, research method related to target and synergetic principles, scientific methods and methodological apparatus of logistics management, the theory of material flow management of the methodology of economic efficiency evaluation of management and logistics technologies. The research was based on data obtained from the following sources of information: scientific publications and monographic publications of domestic and foreign scientists, materials of scientific conferences and studies, materials of periodicals, reports and analytical materials from official websites.

Recently there has arisen and is becoming more and more popular a new vision of acquisition of the logistics services - the so called 4PL model. The

${ }^{1}$ Candidate of Economic Sciences, Associate Professor,

Odessa National Economic University, Ukraine 
4PL model represents a further development of the 3PL-service providers, or Third Party Logistics, concept.

In the approach of a 4PL-service model, a logistics chain is a joint venture of a corporate customer and a logistic service provider that uses the 3PL procedures.

A 4PL provider is the only link between a customer and many 3PL providers. A 4PL provider becomes an integrator of a supply chain that joins its resources with those of its subcontractors. 4PL providers unite the possibilities of 3PL providers and companies managing the business processes in a manner that a customer receives all solutions related to organisation of a supply chain through a centralized contact management system using any managerial and information technology services.

Logistics supply chain development strategies are the basis for the development of the 5PL-service providers supplier as an independent, conceptually new and from all previous logistics operators, the highest level of outsourcing in the classification of the logistics operator.

\section{Introduction}

The overall trend of the logistics is linked to expansion of its functioning. The general framework of its activities is embracing more and more issues that were dealt with by separate companies and firms earlier. Such development determines creation by the very functions of logistics of its value added based on the systemic outsourcing.

This particular systemic character is due to the fact that certain clusters of companies' functioning converge on a common scheme organised on the specific-purpose and synergetic principles. The experience of the industrialised countries evidences that the systemic outsourcing is taking on greater and greater importance giving rise, in its turn, to an upgrowth of the value-added logistics.

\section{Formation of the problem}

Development of the conception of logistics outsourcing is driven by the trends of the economic globalization. Separate organisations become mainstreamed into the worldwide production network. The processes of supply and marketing become more complicated, too, and the level of logistics knowledge turns into the key factor of success for all the value chain partners. Consumers' increasing demand induces companies to 


\section{Saiensus Mariia}

apply such an instrument as outsourcing [10, p. 130-134] in their business activities.

The outsourcing of logistics functions lies in a transfer of any logistics functions (supply, production, sales) that may be fully or partially separate, and/or of any complex logistical business processes to an external outsourcer company.

All in all, it can be deduced that presently the definitions used in the field of outsourcing (in particular, the outsourcing of logistics functions), as well as the forms of interaction between any members of an outsourcing project have not been definitely established or accepted because partnering relationship within the framework of any particular outsourcing agreements can differ to a considerable extent. This is due to the rapid pace of development of this sector of business and the uprise of some new forms of relationship under the conditions of economic globalization and the legal restrictions imposed by some countries, etc.

\section{Description of the peculiarities of the concept "outsourcing of logistics functions"}

A Logistic Service Providers is a specialised commercial organisation carrying out some particular operations or complex logistics functions (warehousing, transportation, order management, physical distribution, etc.), as well as effecting an integrated supply chain management for its corporate customers.

A classification of logistic service providers including insourcing may be represented as follows:

1PL - First Party Logistics - refers to an autonomous logistics when an organisation performs a whole complex of logistical operations on its own;

2PL - Second Party Logistics - presupposes contraction of services of any monoline logistic service providers (such as carriers, forwarders, customs brokers, insurance companies, warehouses, and cargo terminals that perform separate logistics functions);

3PL - Third Party Logistics - means that all the logistics functions are outsourced to a logistic service provider that gives an all-around logistics support;

4PL - Fourth Party Logistics - is a logistic service provider performing a supply chain management (SCM) for a corporate customer; 


\section{General approaches to the formation of model of logistics operators...}

5PL - Fifth Party Logistics - means a "virtual logistic service provider" that assumes the functions of a 4PL applying at large the internet and any know-how as a single virtual platform ensuring a more profound and comprehensive interaction and coordination of work with the customers serviced.

In practice, the term "1PL" ("first party logistics") refers to any companies that specialise in some separate lines of activity in the field of logistics business. They focus on providing services in carrying out some separate operations upon delivery of cargo: transportation, storage, customs clearance, etc. As a rule, this segment of the logistics business is occupied by carriers, customs brokers, port authorities, stevedoring companies, transloading companies, etc.

Freight owners (both consignors and consignees) may enter into any contracts with any first party logistic company, whether directly or through any intermediaries which are usually determined in practical terms as 2PL-level providers representing the subsequent level of logistic services. Among companies providing services at the 2PL level are any forwarding, or freight forwarding companies that perform the role of intermediaries between buyers (freight owners) and sellers (1PL providers) of such services.

As opposed to the 1PL-type companies, the 2PL model implies providing complex services in several lines all at once. Thus, it can be illustrated with a situation when cargo is carried by several kinds of transport within a transportation system, customs clearance services being provided, as well. It should be mentioned that today such a business paradigm applied by the domestic forwarding companies is one of the most desirable.

Transition to a level of higher quality has resulted in origination of the term "a third party logistics", or "3PL", which refers to any outsourcer companies that sell an integrated service in delivery of cargo on the door-todoor principle accomplishing also all the operations required. Nevertheless, their functions exclude any management of freight traffic: in this case all issues will be assumed by a buyer, i.e. a consignor or consignee.

Depending on functions performed, all 3PL models are classified as:

1) standard (a standard service) ensuring performance of such functions as packaging, storage, and delivery of cargos;

2) service developer (an advanced service), which provides additional services in tracking cargos and transloading in case of an intermodal transportation; 


\section{Saiensus Mariia}

3) customer adapter (a service adapted to a consumer's needs), which provides complex services, mainly to small-business customers, in an efficient building of a logistic system, but does not develop any new kinds of services;

4) customer developer (an advanced service adapted to a consumer's needs) encompassing not only an external, but also internal logistics for a customer [1, p. 278-281].

Firms owning real assets own or acquire leasing vehicles, warehouses. Firms that use outsourcing services enter into agreements with other firms that provide all or part of the services in the field of physical distribution. Firms providing information services are a type of companies without physical assets that act as intermediaries in optimizing the logistics systems of enterprises and interact with other asset-owning firms on a contract basis.

A 3PL model implies a whole complex of logistics services, from delivery and cell-based storage to order management and goods tracking. A 3PL provider's functions include organisation and management of cargo shipping, stock record and management, preparation of import and export documents, warehouse storage, cargo handling, and delivery of an ultimate consumer.

Turning to the experience of the Western market, it is possible to note the key problems arising in the interaction with 3PL-providers or are constraining factors for such interaction. The first is the unrealized conditions fixed in the SLA, and the absence of the expected cost optimization (Table 1, Table 2).

The task of management of many companies as a single system in logistics should be understood, first of all, as a service for supply chain partners. In theory, there is a settled notion "a fourth-level logistic service provider", similarly to and as extension of the notion "a third-level logistic service provider". When a customer deals with a logistic service provider of this type, the former may rely on a comprehensive service and assistance with an adaptation to the ever-changing conditions of the external situation, which is an additional factor for an enhancement of such a logistic service provider's competitiveness. However, a provider of the 3PL generation does not solve any problems related to freight traffic: this function is still performed by a freight owner.

Therefore, appearance of a 4PL provider on the market of logistics services can be qualified as expected and foreseeable. The term "4PL" was registered for the first time by a consulting company styled Andersen Consulting, now renamed Accenture, in 1996, as having the meaning as follows: "A fourth-level logistic service provider is a supply chain manager 
General approaches to the formation of model of logistics operators...

Table 1

Problems faced by companies, referring to the 3PL-provider, \%

\begin{tabular}{|c|l|c|c|c|}
\hline №№ & \multicolumn{1}{|c|}{ Problems with 3PL Providers } & Europe & America & Asia \\
\hline 1. & Unrealized agreements and services agreements & 46 & 43 & 46 \\
\hline 2. & $\begin{array}{l}\text { The shortage of long-term, constant improvements } \\
\text { and achievements in the proposals }\end{array}$ & 41 & 37 & 41 \\
\hline 3. & Cost reductions have not been achieved & 37 & 37 & 34 \\
\hline 4. & Unsatisfactory IT services capabilities & 31 & 38 & 38 \\
\hline 5. & Lack of experience in project management & 35 & 31 & 36 \\
\hline 6. & $\begin{array}{l}\text { Unsatisfactory transition period in the process of } \\
\text { implementation }\end{array}$ & 28 & 34 & 33 \\
\hline 7. & $\begin{array}{l}\text { Ineffective management of key performance } \\
\text { indicators }\end{array}$ & 27 & 28 & 31 \\
\hline 8. & Too many problems related to the human factor & 28 & 30 & 32 \\
\hline 9. & Lack of consulting, intellectual skills & 23 & 22 & 34 \\
\hline 10. & Impossibility of providing services on a global scale & 19 & 16 & 20 \\
\hline 11. & $\begin{array}{l}\text { Insufficient integration of business processes across } \\
\text { regions and across the supply chain }\end{array}$ & 18 & 21 & 28 \\
\hline 12. & Inability to build a purposeful and reliable relationship & 13 & 15 & 19 \\
\hline 13. & $\begin{array}{l}\text { Weak information integration with the acquired } \\
\text { companies }\end{array}$ & 13 & 12 & 21 \\
\hline 14. & Lack of problems & 16 & 17 & 5 \\
\hline
\end{tabular}

Source: the table was compiled by the author on the material [11]

Table 2

Reasons why companies do not address the services of 3PL operators (\%)

\begin{tabular}{|c|l|c|c|c|}
\hline №№ & \multicolumn{1}{|c|}{ Reasons } & Europe & America & Asia \\
\hline 1. & Logistics is a key activity of our company & 28 & 34 & 26 \\
\hline 2. & Abbreviations costs are not expected & 44 & 39 & 36 \\
\hline 3. & Level of service agreements will not be implemented & 28 & 34 & 32 \\
\hline 4. & Logistics is too important to outsource & 30 & 30 & 24 \\
\hline 5. & Decrease in control over outsourced functions & 23 & 32 & 8 \\
\hline 6. & Better practice than most 3PL operators & 26 & 23 & 12 \\
\hline 7. & Corporate ideology excludes access to 3PL operators & 16 & 11 & 20 \\
\hline 8. & $\begin{array}{l}\text { Need to improve the capabilities of 3PL operators } \\
\text { globally }\end{array}$ & 23 & 16 & 8 \\
\hline 9. & $\begin{array}{l}\text { Security-related issues transportation and shipment } \\
\text { of goods }\end{array}$ & 7 & 18 & 20 \\
\hline 10. & $\begin{array}{l}\text { The inability of 3PL providers to build a focused and } \\
\text { trusting relationship }\end{array}$ & 14 & 14 & 8 \\
\hline
\end{tabular}

Source: the table was compiled by the author on the material [11] 


\section{Saiensus Mariia}

that brings together its own resources, capabilities, and technology with the resources, capabilities, and technology of another logistics service provider and manages the same in order to offer a solution of tasks in a supply chain to its customers to the fullest possible extent" [1, p. 197].

It is important that all the 4PL providers, or fourth-level providers, be by all means involved in a manufacturing process. As a rule, a 4PL provider is a major logistics service provider having a large infrastructure and advanced supply chain management systems and accomplishing high-technology processes and complicated logistic schemes.

In order to achieve the level of a 4PL provider, there are possible ways as follows: a third-level logistic service provider may develop until the level of a 4PL one. A manufacturer of an ultimate product may organise a business on the principle of a 4PL model for solution of any similar tasks. A consulting company may assume the role of a $4 \mathrm{PL}$ provider. A company engaged in providing services in the field of IT may become a 4PL provider. A supply chain partner may become a 4PL provider.

The evolution of a third-level logistic service provider seems the most appropriate. Given the business contacts with customers established by a company, it will be the most likely. Parallel to planning of their own routes, these companies shall fulfil such tasks as planning of coordination of transport, warehouse and stock management for their customers, as well as shall render any other services implying emergence of a value added.

Nevertheless, there may arise some problems with customers, who can misunderstand the new role of such a company:

- on the one part, a consignor may be doubtful of impartiality of a logistic company ;

- on the other part, today the information technology structure of many potential 3PL logistic providers only reflects the needs of a logistic company itself, but does not allow effecting the overall management, even if there are appropriate interfaces, that may function perfectly well, for exchange of data with customers and subcontractors.

\section{Variants of achievement 4PL - Fourth Party Logistics}

Let us consider some variants:

Variant "Transportation Provider". A transportation service of the manufacturers of an ultimate product (a holding company) that was rendering cartage services earlier will turn into a 4PL provider. 


\section{General approaches to the formation of model of logistics operators...}

A goods manufacturer, being usually a holding company or a transnational corporation (TNC) or a financial industrial group (FIG), shall found a subsidiary transportation company as a 4PL-level provider. They will implement a partial strategic and day-to-day management for their parent company and, in some cases, will assume in full all the logistic processes related to supply and marketing.

They will also organise a horizontal and vertical structure of the system optimising constantly the processes, providing their information technology structures for carrying out any processes to be implemented, and integrating partially the IT systems of their parent company and those of their previous and subsequent supply chain partners. However, since the management systems of a parent company dominate the systems of any similar logistic service provider, an all-round optimisation of the supply chain seems hard to be achieved.

Variant "Consulting Company". Another opportunity for a start-up of a 4PL provider is there when the tasks related to management and coordination are committed to a consulting company. In many instances, such companies are actively involved in creation of a strategic configuration of a supply chain and provide backstopping upon deployment and operation of the software for SCM.

Besides, consulting companies usually have a proper competence in holding tenders and issuing orders for logistics services for any 3PL and 4PL providers. Commonly, similar tasks form part of a standard service package offered by a consulting firm. Large consulting companies, however, that are engaged in the field of strategic research often become knowledgeable of a whole supply chain, but have little understanding of the business processes. Therefore, only such consulting companies that advise their customers at the level of logistics business processes and manage all the internal processes by means of their own interfaces are in a position to organise management of a whole supply chain. To this extent, they should be involved in development of a strategic vision by their parent company.

Variant "IT Providers". Software manufacturers and IT providers also stand a chance of becoming a 4PL provider. Supply chain management very often requires specific software with an enormous number of interfaces to integrate the enterprise resource planning systems belonging to supply chain partners. Any know-how in the field of information technologies becomes all the more important for a successful supply chain management. 


\section{Saiensus Mariia}

Therefore, IT providers seem to have the best background to solve any and all issues including the functioning of e-commerce, through a supply chain portal. This portal is intended to connect all the partners through the Internet in order to implement any physical processes, which also implies the integration of logistic service providers. Such a portal can also ensure the transparency in the network which is necessary for an optimum supply chain.

Variant "Synthesis". This variant implies that a parent company takes over some lines of business activities that already form part of an existing supply chain. It means that some joint ventures may be organised, whether on the basis of any IT firms or any consulting companies and third-level logistic service providers. In this case, the independence of a subsidiary company from its parent one in respect of any specific plans involving its participation in a supply chain and a possibility to avoid any conflict of interests takes shape as the vital task.

\section{Modeling features 5PL - Fifth Party Logistics}

In the modern educational and scientific-methodical literature, many authors distinguish 5PL logistics providers (Fifth Party Logistics) as a separate element in the classification of logistics operators $[1 ; 2 ; 8 ; 10]$. Under the 5PL, a provider is generally understood to be a logistics operator whose activities are based on the use of a complex of modern information and communication technologies that allow the database of consignors, consignees and transport companies to be interactively operated, plan transportation, dispatch and monitor the execution of orders in a virtual logistics system $[1 ; 9 ; 10]$. Many authors, and in particular A.V. Ivashchenko and D.G. Peysahovich, is understood by the operator's 5PL provider, which basically manages the flow of information about orders, resources, plans and the actual state of the transport network in the integrated supply chain [7, p. 153-158].

If we consider 5PL providers from the point of view of the integration approach, as do Loshnev K.O., Taraskina E.P., Zarudnev D.I., Dikinov A.H., Honchukaeva L.V. and Aitbagin E.R., then under 5PL-provider it is necessary to understand management of all components of the integrated supply chain, and not only information flows. Such management is understood within the framework of a single information space, using the Internet as a unifying virtual platform $[10$, p. 320]. Such a system is also called "virtual logistics" or "Internet logistics" $[1 ; 2 ; 4 ; 6 ; 10]$. 


\section{General approaches to the formation of model of logistics operators...}

In this case, the 5PL provider is already defined as a "service company that performs integrated services for managing integrated processes in supply chains on the basis of outsourcing without the use of physical mechanisms for managing material and other logistical flows" [11, p. 70-72].

According to Aitbagina E.R. The 5PL provider is a logistic operator that takes over the functions of the 4 PL operator and provides deeper and more comprehensive interaction and coordination of the clients' services in real time with extensive use of the Internet [3, p. 14-17]. However, this interpretation of the 5PL provider also does not make it possible to separate it as a separate, independent element of the classification of logistic operators.

This seems impossible in view of the fact that according to the experience of practitioners themselves, 3PL - and 4PL-providers themselves several years ago already switched to maximizing the full informatization and virtualization of their activity and without giving up their material and technical base, but, on the contrary, strengthening it and automating it.

Virtualization, informatization and automation of 3PL and 4PL providers has become a routine and necessary practice of the modern market today and does not cause a significant expansion or radical change in the range of logistics services providers, goals and processes of their services, therefore, does not change their species, process or functional composition and does not allow to allocate such kind of "virtual" or "Internet providers" as a new type of logistic operators.

This is also confirmed by the words of Cedric Alambert that the features of Internet commerce and Internet logistics today are mostly related to the positioning of products and services, but business-logistics technologies, developed with traditional formats of sales, largely in e-commerce are simply repeated $[2$, p. 16]. This point of view was first substantiated by Professor Sergeev V.I. in the textbook on supply chain management $[5 ; 10$, p. 120]. He notes that changes related to the development of the Internet and electronic business have a strong impact on various segments of the logistics services market, which as a whole develop integratively.

However, e-commerce is not a new segment or a new criterion for classifying supply chain management solutions. It leads only to the formation of a wider range of offers of integrated services 3PL- and 4PL level in supply chains [10, p. 261].

The emergence of this concept is primarily due to the fact that the rapid development of modern information systems and technologies makes it 


\section{Saiensus Mariia}

possible to introduce the most powerful and progressive technologies into the sphere of economy, business and logistics service, providing an unprecedented, previously impossible level and scale of data processing that forms the basis To make decisions not only operational level, but also strategic.

These technologies include not only embedded in the field of logistics outsourcing Internet technologies and electronic document management technologies. Changes in strategic logistics planning are primarily related to the introduction of intelligent systems based on neuro-cybernetic data analysis technologies, as well as expert technologies of automated machine management decision-making and impact on subordinate objects.

However, one can add to this that the development of expert systems and neurocybernetics, as well as the ever wider and more active use of cloud computing, distributed computing, remote and distributed databases, will allow the transition to a fundamentally new level of information processing and decision making, consisting in their automation and implementation without any permanent human intervention [8, p. 54-56].

Technologies of distributed computing will allow processing practically unlimited volumes of information and, consequently, serve logistic chains and logistic networks of any scale, both national, international, and planetary.

This will allow us to cover and integrate logistics networks and supply chains in each country, economic or geographical alliance, as well as on different continents, in the future creating and servicing a single global economic-distributive network of commodity economy. In turn, artificial intelligence technologies will automate the decision-making process in logistics networks of this scale, replacing in this issue the intellectual abilities of a person who in this case will not be physically able to cope with the scale of such activities.

Modern reality can be absolute impartiality and maximum optimality from the point of view of the effectiveness of the functioning of the entire logistics network, the life activity of states and economic unions. The society will be able to approach the optimal food and commodity supply of the national economy and consumer, environmental and energy security and economy. The use of artificial intelligence technologies will solve the problems and eliminate the bottlenecks associated with the issues of interorganizational logistics coordination in supply chain chains and networks arising from the opposite of the interests of the network participants, and will also 
allow not only the most effective operational accounting, control and planning of the logistics networks, but also to carry out tactical and strategic management of logistics networks based on self-learning expert systems.

At the present stage, the 5PL -provider has the opportunity to move from the ordinary link of the logistics supply chain, performing for it a certain list of logistics functions, to a full-fledged entity managing logistics chains and supply chains [10], to the subject of political and economic management. At this stage, its process and functional composition is changing, the range of services and goals is expanding and drastically changing.

The 5PL provider begins to determine the policy of development of the global logistics service, and, consequently, the policy of economic development. With the use of these technologies, the 5PL provider has the opportunity to set the system of co-ordinates of activities for the participants of logistics chains and supply networks, act as an integrating factor, and find a very mobile and constantly changing balance between the multidirectional interests of states, consumers and commercial participants of logistics networks of food and industrial goods.

And, it can be concluded that in this context it is the conceptual changes in the goals, tasks, functions and scope of activity, as well as the place, role and purpose of the logistics provider in the supply chains that allow us to talk about a really new step and a new level in the classification of logistics operators.

It is the enumerated possibilities of independent determination of the strategy for the development of logistics chains and supply chains based on a given, chosen political concept and automated compulsion of the participants in the supply chain to execute it, are the basis for distinguishing the 5PL provider as an independent, truly conceptually new and fundamentally different from all previous logistics operators, the provider of the highest level in the classification of operators of logistics outsourcing.

A logistic intermediary represents an essential element in a logistic service provider company because the cooperation with the former allows a company to get any competitive advantage for account of:

- a reduction in operational logistics costs, overall increase in efficiency of the functioning of a logistics system and, as a consequence, reduction in prime cost of goods;

- enhancement of flexibility and adaptation of a company to the ever-changing environment; 


\section{Saiensus Mariia}

- mitigation in logistics risks; reduction in duration of the operational and logistics cycles.

Whereas previously the field of logistics represented, at the most, the classical kinds of logistical services, such as stockpiling, transportation, and cargo handling which take shape as a particular physical operation, now the logistic activities are deemed to include any coherent business processes having a coordinating and strategic nature.

All logistic service providers are divided into classes reasoning from the nature of their activities; it may be operating, coordinating or strategic:

- monoline logistic intermediaries (transportation companies, forwarding agents, jointly occupied depots, cargo terminals, customs brokers, agents, stevedoring companies, insurance companies, providers of any information and consulting services in the field of logistics);

- 3PL providers, which embrace any firms rendering a coherent logistics service for a customer (being a manufacturing company, commercial partnership or a service provider);

- 4PL providers representing any systems logistics integrators.

Monoline logistics intermediaries focus on the operating activities. A 3PL providers carry on the operating and partially coordinating activities (which means integration and coordination of the operating functions in a single provider). A 4PL providers tackle the coordination and strategic activities (which presupposes a systematic approach to the management of any core logistics business processes, integration and coordination of actions undertaken by a target company and key contracting parties in a supply chain).

At present, transportation companies often take on lease or build their own distribution centres, warehouse operators include any transportation departments in their infrastructure, and customs brokers and forwarders offer services in delivery, storage, and batching of the flows of goods.

Modern 3PL providers have traversed the course of a synergetic amalgamation of some specific services. 3PL service represents a multidisciplinary adviser offering and implementing appropriate solutions for the supply chain management. Major companies having large turnovers and flows of goods purport to obtain the necessary services from a single provider.

The development of a 3PL model has led to the next step - emergence of the 4PL services. 4PL provider addresses the tasks related to a strategic planning, management and control of all the logistics processes of a corporate customer. 


\section{General approaches to the formation of model of logistics operators...}

\section{Creation of a common information space}

for expansion of the outsourcing of logistics functions

Creation of a common information space as an environment for an integrated planning and management of any supply chain interactions and as a tool for perfection of a supply chain management system is fundamental for expansion of the outsourcing of logistics functions. The crucial factor determining the prospects and opportunities a company has in order to develop its models of integrated planning and management of its supply chains on the basis of the outsourcing of logistics functions is the state of the information technologies.

The main objective of managing logistic communications is to provide a favorable attitude to the manufacturer of goods by creating a common motivational field of exchange participants which is focused on the rational use of available resources and harmonization the interests of the parties. The modern concept of logistic communications is the concept of integrated logistic communications, actively explored and developed today by the researchers of the problems of interaction of subjects in the logistic.

Methodological weakness of the concept of integrated logistic communications is that it implies the implementation of integration only on instrumentality level, regardless of the set of participants in the interaction and their characteristics (motivation, resource, organizational, technical, innovation, etc.). Depending on our opinion, integration should have a response in the form of conjugation motives of participants, their resources, actions logisticing in satisfaction the needs of consumers differ in their behavior under various conditions of logistic conditions and the particular communication area.

The concept of integrated logistic communications, which provides large-scale use of low-budget tools logisting communications, should be transformed into the concept of the integrated logisticing communications [1, p. 134-145]. The last implies the creation and development conducive for the initiator communicative environment providing modification of consumer perceptions and behavior of target groups and to achieve the strategic goals of the enterprise.

The main objective of managing logisticing communications is to provide a favorable attitude to the manufacturer of goods by creating a common motivational field of exchange participants which is focused on the rational use of available resources and harmonization the interests of the parties. 


\section{Saiensus Mariia}

The objectives of the management of logisticing communications in the context of disclosure of key management components by the manufacturer of the goods (its philosophy, mission, vision, features subculture, image, reputation) may include the following:

- determining the level of permeability of logisticing actions;

- monitoring of "susceptibility" logisticing efforts with regard to the promotion of products by manufacturer; adjustment of properties and characteristics of integrated communication cycle.

The solution of the challenges in business requires effective management of increasingly complex system of logisticing communications, supporting mutually beneficial exchanges between suppliers, intermediaries, customers and various contact audiences.

When the business rises the manufacturer expands the circle of perspective for him the participants of logisticing process, thereby expanding the scope of the entire interaction. In front of a enterprise there is the task of forming its logisticing communications field in the sense in which we have identified and marked economic nature of communication.

This consequence requires consideration of communication tools, determining the boundaries of their applicability and systematization of different scientific approaches to the study of proper communication as the essential foundation for an effective interaction. Introduced new concepts to a better understanding of the components of the communication area, and on this basis provide a framework for consumer benefit and achieve satisfaction exchanges through intensified logisticing process. Achievement the satisfaction with the exchange interaction between the participants can only be achieved in a single motivational field, which established a balance of interests in respect of resources defined by the level of profitability and the desired values of the created product that can satisfy the needs of the target customer segments.

Corporate of logisticing takes the form of an open logistic for dialogue partnership; innovation does not reject the action as a complex resource factor for competitiveness entities increasing in the process of establishing constructive communication between them. The mechanism of interaction management links the determining factors in the context of a single communication cycle, a custom adaptation of business structures to logistic requirements [1, p. 78-82].

Changing the amount and composition of logisticing communications, and an array of quality broadcast through them information, we proposed 
a mechanism for adjusting the behavior of consumers in the direction favorable to the enterprise. As part of the anthropocentric approach cognitive dimension of consumer behavior acquires the properties of instrumental function.

Priority is given to understanding rather than explanation or prediction. Under the influence of factors of different orders it generates a set of alternatives to buying. Mass logisticing is targeting producers to logistic segments, taking into account the profile of the user and their responses to the impact of the enterprise.

Personalization of communications by the company assumes knowledge of consumer reaction and adequate assessment of the proposed values. The company creates the conditions for access to the individual through the activation of the tools of logisticing communications. At the same time, the company is building its information field through memorization of response of the consumer and stores this information in one of its subsystems [1, p. 22-28]. Differentiation of target groups of consumers on the factor "type of competitive behavior" [10] makes it necessary to differentiate the content and logisticing channels broadcast information aimed at consumers (modification of consumer perceptions and behavior) and logistic agents (modification of the Counterparty on the activities of the enterprise). Simulation of communication processes is developing mainly representatives of social and humanitarian sciences and engineering in the direction of building models on the basis of analogy, while the area of economic and mathematical modeling remains largely unexplored. Offer relevant solutions in this field allows you to expand the scientific tools in the management of the enterprise communication, increase its precision and focus, identify typical application situation of communication tools in competitive strategy and conduct scenario of economic-mathematical calculations to assess the feasibility and effectiveness of the investment of resources in the communicative sphere of business.

Management of many companies as a single system requires: introduction of a common management platform; determination of all tasks, rights, and duties to be vested in a single management towards any supply chain partners that are legally and financially independent businesses. Companies owning real assets possess or acquire, by way of hire purchase leasing, any vehicles, warehouses, etc. 


\section{Saiensus Mariia}

Those companies that contract the outsourcing services enter into agreements with any other providers of services, whether in a full or partial scope, in the field of physical distribution. Firms rendering any information services represent a type of companies not having any physical assets and carrying on the business of intermediaries in optimisation of the logistical systems of any other companies and interacting with any other firms or companies that have real assets, on a contractual basis. The criterion of segmentation of the market, the so called logistics assets, does not exclude the third variant, either: one's own logistics capacities and outsourcing. In this context, depending on the actual conditions of a company's business activity on the market of logistics services, it is not always possible to put into operation all the logistics capacities.

\section{Conclusion}

1. Logistic outsourcing is a consequence of the evolution of a modern enterprise. The change in general methodological approaches to the organization of the production process, systems and management process is associated with such factors as: greating an internal competitive environment; transition from functional to technological specialization; reengineering of production processes; changing the system of internal and external communications; intensification of information exchange; striving to reduce costs. The methodology of logistics outsourcing develops and is reflected in all modern types of organizational structures.

2. The structure of the process of logistics outsourcing presupposes a strategic and economic justification for the need to delegate authority for certain processes and activities. The choice of the provider of logistics outsourcing services is carried out as a result of the analysis of the available services market.

3. Modeling the process of logistics outsourcing requires the formalization of socio-economic factors that influence the decision on logistics outsourcing. Modeling the process of logistics outsourcing allows to formulate a general methodical approach to making managerial decisions about the use of certain types of outsourcing.

4. There has arisen and is becoming more and more popular a new vision of acquisition of the logistics services - the so called 4PL (Forth Party Logistics) model.

5. The 4PL model represents a further development of the 3PL, or Third Party Logistics, concept. In the approach of a 4PL model, a logistics chain 
is a joint venture of a corporate customer and a logistic service provider that uses the 3PL procedures.

6. 4PL provider is the only link between a customer and many 3PL providers. A 4PL provider becomes an integrator of a supply chain that joins its resources with those of its subcontractors. 4PL providers unite the possibilities of 3PL providers and companies managing the business processes in a manner that a customer receives all solutions related to organisation of a supply chain through a centralized contact management system using any managerial and information technology services.

7. It is these listed opportunities for independent determination of the logistics supply chain development strategy that are the basis for allocating the 5PL provider as an independent, truly conceptually new and fundamentally different from all previous logistics operators, the highest level provider in the classification of logistics outsourcing operator.

\section{References:}

1. Anikin, B. A., Rudaya I. L. (2009) Autsorsing $i$ autstaffing: vysokie tekhnologii menedzhmenta [Outsourcing and outstaffing: high technology management]. Moscow: INFRA-M. (in Russian)

2. Amblar S. (2016) Dlya uspekha biznesa e-commerce neobkhodim edinyy provayder [For the success of e-commerce business, a single provider is needed]. Logistika. No. 2, pp. 14-17.

3. Aytbagina E.R. (2016) Rol' logisticheskikh posrednikov i provayderov (operatorov) [The role of logistics intermediaries and providers (operators)]. Engineering and technology of construction, vol. 2, no. 6, pp. 2-3.

4. Baginova, V. V., Kuz'min D. V. (2013) Osobennosti razvitiya kontreylernykh perevozok v Rossii [Peculiarities of the development of piggyback traffic in Russia]. Modern problems of the transport complex in Russia, vol. 4, no 4, pp. $49-52$.

5. Dybskaya V.V., Zaytsev E.I., Sergeev V.I., Sterligova A.N. (2013) Logistika. Polnyy kurs MVA [Logistics. Full MBA course]. Moscow: Eksmo. (in Russian)

6. Dikinov A.Kh., Khonchukaeva L.V. (2014) Problemy razvitiya logisticheskogo autsorsinga $\mathrm{v}$ Rossiyskoy Federatsii [Poblems of development of logistics outsourcing in the Russian Federation] Bulletin of the Mordovian University, vol. 24, no 4, pp. 94-102.

7. Ivashchenko A.V., Peysakhovich D.G. (2013) Pro aktivnaya dispetcherizatsiya resursov transportnogo operatora 5RL [Proactive dispatching of transport operator resources 5PL] Intelligence. Innovation. Investments, no 3, pp. $153-158$.

8. Kuramshin N.D. (2016) 5PL - novyy uroven' logisticheskogo autsorsinga [5PL - a new level of logistics outsourcing]. Successes of modern science and education, vol. 3 , no. 8 , pp. 54-56. 


\section{Saiensus Mariia}

9. Lishnev K.O. (2012) 5PL-provaydery kak perspektivnyy etap razvitiya logisticheskogo autsorsinga [5PL-providers as a promising stage in the development of logistics outsourcing]. Proceedings of the Materials of the International Interuniversity Scientific Master Conference: a collection of reports. Under the ed.: T.I. Tumarova, I.N. Samonova, N.S. Slavetskaya. Collection: Russia in the modern world: in search of an innovative strategy; new growth models. (Russia, Nizhny Novgorod, March 20-23, 2012), pp. 244-246.

10. Sergeev V.I. (2015) Upravlenie tsepyami postavok: uchebnik dlya bakalavrov $i$ magistrov [Supply Chain Management: A Textbook for Bachelors and Masters]. Moscow: Yurayt (in Russian)

11. Tityukhin N. (2007) Byt' li v Rossii 4PL provayderam : tendentsii logisticheskogo rynka [Do 4PL providers in Russia: trends in the logistics market?] Loginfo, no. 12 , pp. $20-28$. 
Social-economic estimation of competitive positions formation of ukrainian...

SOCIAL-ECONOMIC ESTIMATION

OF COMPETITIVE POSITIONS FORMATION OF UKRAINIAN

REGIONAL RESIDENTIAL REAL ESTATE MARKETS

\section{Strishenets Olena ${ }^{1}$ \\ Pavlov Kostiantyn ${ }^{2}$}

DOI: http://dx.doi.org/10.30525/978-9934-571-28-2_25

Abstract. In the conditions of obtaining new market economy-oriented vibrancy with the pursuit of integration into the European community, the issues of regional self-development on the principles of transparent competition are becoming increasingly topical. The lack of effective approaches to the implementation of the competition regulation mechanism in the regional residential real estate markets caused a significant construction sector monopolisation, the emergence of its development disproportions and social tensions within the population. The regional policy formation for the competitive relations regulation in construction should take place in compliance with state priorities. This, conversely, leads to the study of issues related to the assessment of the social-economic potential of the regions and the degree of the regional residential real estate markets competitiveness, taking into account fundamental research and analysis of the developed national theoretical and practical approaches. Consequently, the objectivity of the social-economic assessment of the competitive environment of the country regions depends on the immediate regional market systems functioning, including the residential real estate market.

Methodology. In order to carry out a profound research, we have studied a wide range of social-economic indicators of certain regional real estate markets of Ukraine, which in one way or another characterise a particular region society economic status. In the process, a comparative method, method of constructing integral construction market indices of was applied. The specificity of the study required application of such indicators in the calculating process: market concentration ratio, the Her-

\footnotetext{
${ }^{1}$ Doctor of Economic Sciences, Professor,

Head of the Department of Analytical Economics and Natural Resources, Lesya Ukrainka Eastern European National University, Ukraine

${ }^{2}$ Candidate of Economic Sciences, Associate Professor, Doctoral Student,

Lesya Ukrainka Eastern European National University, Ukraine

(C) Strishenets Olena, Pavlov Kostiantyn
} 
findahl-Hirschman index, the market shares variance, the market shares entropy and the Gini index.

The main task of this study. The purpose of this research is to provide social-economic research and estimation of the regional residential real estate markets competitiveness of Ukraine. Moreover, special attention is paid to the estimation and analysis of a wide range of social-economic indicators of regional residential markets based on the immediate region development. The competitive positions of residential markets have been determined through the regional aspect, as well as the degree of their monopolisation, the vector of antimonopoly policy as an integral part of competitiveness increase in the regions with monopolistic competition domination.

The results of the study enabled us to elucidate the clear relationship between the factors influencing certain regional real estate markets competitive position from the point of view of both construction organisations and ordinary living space buyer-consumer. As a result, it was possible to find out the functioning efficiency increase or decrease tendencies and housing objects purchase availability in regional markets.

Study conclusions. The author tries to highlight peculiarities regarding competitive advantages in the regional markets of residential real estate of Ukraine, as a result of the influence of social-economic factors of the region itself, while taking into account the important problem of regional prices imbalance and influence factors on the demand and supply of housing. To study this goal, we have used new theoretical and practical approaches oriented not only to obtain the basic provisions of the relationship between the social-economic ranking of the region and its markets competitiveness intensity, but also to the practical manifestations of necessary government regulation of monopolisation features. However, some of the provisions of the aforementioned problems require further refinement and experimental research being a prerequisite for further scientific developments.

\section{Introduction}

In the related scholarly literature, certain competition forms of residential objects are found in the consideration of problems by such scholars as A.M Asaul [1], E.A Bozhko [2], O.A. Gritsenko [3], T.Yu. Ovsyannikova [6], V.I. Pavlov [7, 8], R.A. Fatkhudinov [16]. However, a significant amount of work by leading scientists is rather insufficient to assess the 
existing approach and form a new holistic one to the process of competitive relations regulating in the regional residential real estate markets, which determines the importance and need for further substantial research.

In particular, it concerns new approaches to residential real estate markets regionalisation in Ukraine, as reflected in the author's methodological approaches to territorial and administrative division, the assessment of the competitiveness level of regions and the application of the results obtained in the process of ensuring antimonopoly regulation in residential markets of various regional significance.

\section{General characteristics of the regions of Ukraine}

Our state - Ukraine, is one of the largest European countries in terms of area and population. The territory of Ukraine covers 603766 sq. km, which makes about $6 \%$ of the whole territory of Europe. By the territory extent Ukraine exceeds the indices of such countries as Spain, France, Poland.

The latitudinal extent of our state is no more than $1300 \mathrm{~km}$ and longitudinal is about $890 \mathrm{~km}$. The territory of Ukraine in the southern part is washed by the Black Sea and the Sea of Azov; is located in temperate latitudes and borders with such countries as: Poland, Slovakia, Hungary, Romania, Moldova, Belarus and the Russian Federation. The length of the border is about $6500 \mathrm{~km}$, of which the sea borders exceed a little over a thousand (Draw. 1).

In general, the nature of economic and industrial territorial development of the state is clearly traced in the specificity of the regional economy profile of certain areas. In the western and central parts of the country, agriculture is concentrated in beet and sugar, canned and canned food industries, as well as light and chemical industry, mechanical engineering.

The eastern and northern parts of our state are characterised by the functioning of electrical engineering, transport engineering and agriculture. At the same time, the machine-building complex "dominates" in this territory.

The south-eastern part of the country's territory is characterised by the high level of industrial development, especially in the branch of heavy machinery, metallurgy, and chemical production. Meanwhile, the northern region is associated with food and agricultural industries, highly developed recreational potential, as well as marine-economic opportunities.

As already noted, Ukraine occupies a leading position among the European countries in terms of population. According to the State Statistics Ser- 


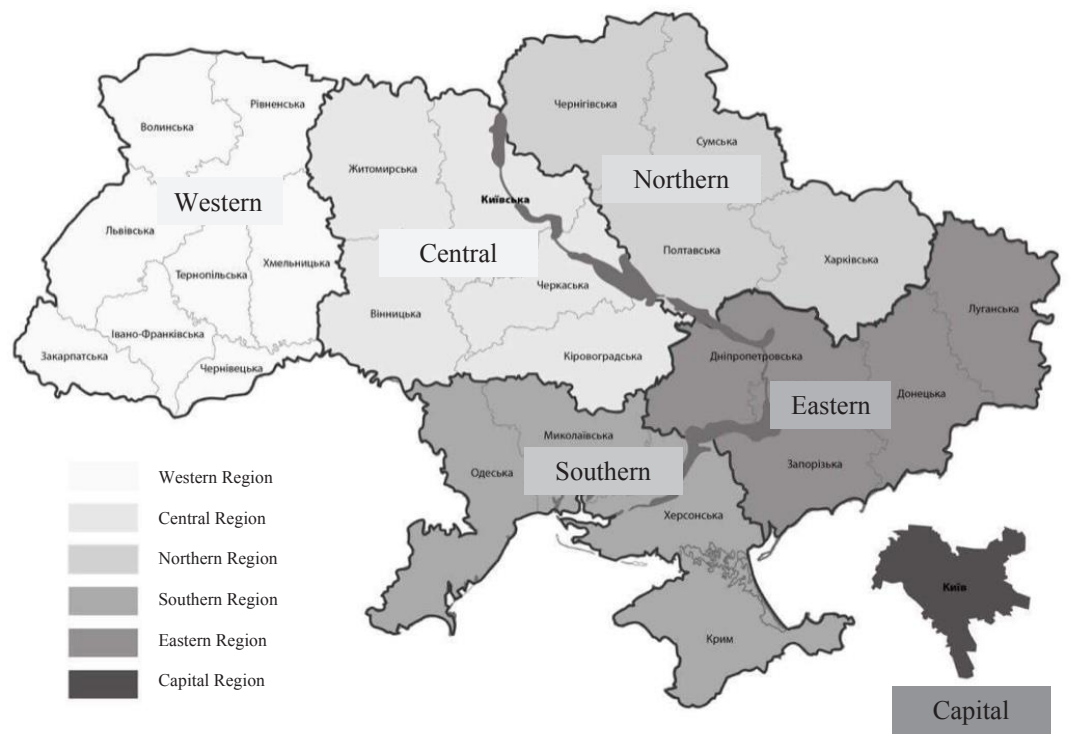

Drawing 1. Regional real estate markets of Ukraine

Source: developed and systematised by the author (Pavlov K.)

vice, as of January 1, 2018, the total population of Ukraine was almost 42.7 million. $69 \%$ of the population live in cities and respectively $-31 \%$ in rural areas [4].

The general pattern of the settlement system of Ukraine is represented by settlements different by their form and character, as a result of historical, social, agricultural, and economic peculiarities (Table 1).

The western region is characterised by high indicators of the individual settlements density, a low urbanisation level and high population density.

The central region is characterised by high figures of the population directly in the capital of the country and in its surroundings; low population density of other adjacent areas, insignificant population density, average and high population indicators in rural settlements.

The northern region can be characterised by the medium population density, the low level of countryside settlement and a significant urbanisation level. 
Social-economic estimation of competitive positions formation of ukrainian...

Table 1

General characteristics of the geographical and demographic indicators of the regions of Ukraine, as of January 1, 2018

\begin{tabular}{|c|c|c|c|c|c|}
\hline \multirow[b]{2}{*}{$\begin{array}{l}\text { Regions } \\
\text { (Oblasts) }\end{array}$} & \multicolumn{5}{|c|}{ Average numbers } \\
\hline & $\begin{array}{c}\text { Square, } \\
\mathbf{k m}^{2} \text {. }\end{array}$ & $\begin{array}{c}\text { in \% to } \\
\text { Ukraine } \\
\text { population }\end{array}$ & $\begin{array}{c}\text { Population } \\
\text { number, } \\
\text { thsd. } \\
\text { persons }\end{array}$ & $\begin{array}{c}\text { in \% to } \\
\text { Ukraine } \\
\text { population }\end{array}$ & $\begin{array}{c}\text { Population } \\
\text { density } \\
\text { pers. } / \mathbf{m}^{2}\end{array}$ \\
\hline 1 & 2 & 3 & 4 & 5 & 6 \\
\hline \multicolumn{6}{|l|}{ Western Region } \\
\hline Volyn & 20143 & 3,4 & 1041,8 & 2,4 & 51,64 \\
\hline Rivne & 20047 & 3,3 & 1162,3 & 2,7 & 57,98 \\
\hline Lviv & 21833 & 3,6 & 2534,1 & 5,9 & 115,98 \\
\hline Ternopil & 13823 & 2,2 & 1062,4 & 2,5 & 76,53 \\
\hline Khmelnytskyi & 20629 & 3,4 & 1289,8 & 3,0 & 62,21 \\
\hline Transcarpathian & 12777 & 2,1 & 1259,0 & 3,0 & 98,48 \\
\hline Ivano-Frankivsk & 13928 & 2,3 & 1381,1 & 3,2 & 99,01 \\
\hline Chernivtsi & 8097 & 1,4 & 909,0 & 3,1 & 112,07 \\
\hline Region average & 16409 & - & 1329,9 & - & 84,24 \\
\hline Subtotal by region & 131277 & 21,7 & 10640 & 25,8 & - \\
\hline \multicolumn{6}{|l|}{ Central Region } \\
\hline Kyiv & 28131 & 4,7 & 1733,3 & 4,0 & 61,60 \\
\hline Zhytomyr & 29832 & 4,8 & 1244,0 & 2,9 & 41,53 \\
\hline Vinnytsia & 26513 & 4,4 & 1596,3 & 3,7 & 59,88 \\
\hline Cherkasy & 20900 & 3,6 & 1237,1 & 2,9 & 58,83 \\
\hline Kirovograd & 24588 & 4,1 & 969,5 & 2,3 & 39,22 \\
\hline Region average & 25993 & - & 1356,0 & - & 52,21 \\
\hline Subtotal by region & 129964 & 21,6 & 6780,2 & 15,8 & - \\
\hline \multicolumn{6}{|l|}{ Northern Region } \\
\hline Chernihiv & 31865 & 5,3 & 1039,2 & 2,4 & 32,35 \\
\hline Sumy & 23834 & 3,9 & 1108,9 & 2,6 & 46,26 \\
\hline Poltava & 28748 & 4,8 & 1432,9 & 3,3 & 49,55 \\
\hline Kharkiv & 31415 & 5,2 & 2709,9 & 6,4 & 85,95 \\
\hline Region average & 28965 & - & 1572,7 & - & 53,52 \\
\hline Subtotal by region & 115862 & 19,2 & 6290,9 & 14,7 & - \\
\hline
\end{tabular}


Strishenets Olena, Pavlov Kostiantyn

\begin{tabular}{|c|c|c|c|c|c|}
\hline & & & & \multicolumn{2}{|c|}{ Ending of Table 1} \\
\hline 1 & 2 & 3 & 4 & 5 & 6 \\
\hline \multicolumn{6}{|l|}{ Southern Region } \\
\hline Odesa & 33310 & 5,5 & 2388,4 & 5,6 & 71,59 \\
\hline Mykolaiv & 24598 & 4,1 & 1154,2 & 2,7 & 46,67 \\
\hline Kherson & 28461 & 4,7 & 1059,0 & 2,5 & 37,03 \\
\hline Crimea & 26081 & 4,3 & - & - & 75,43 \\
\hline SEVASTOPOL & 1079 & 0,2 & - & - & 357,65 \\
\hline Region average & 28112 & - & 1533,9 & - & 57,68 \\
\hline Subtotal by region & 112450 & 18,6 & 4601,6 & 10,8 & - \\
\hline \multicolumn{6}{|l|}{ Eastern Region } \\
\hline Dnipropetrovsk & 31914 & 5,8 & 3242,6 & 7,3 & 101,06 \\
\hline Zaporizhzhia & 27180 & 3,6 & 1746,6 & 4,1 & 63,89 \\
\hline Donetsk & 26517 & 4,6 & 4254,6 & 9,7 & 159,89 \\
\hline Luhansk & 26684 & 4,6 & 2200,3 & 5,0 & 82,19 \\
\hline Region average & 28074 & - & 2861,0 & & 101,75 \\
\hline Subtotal by region & 112295 & 18,6 & 11444 & 26,1 & - \\
\hline \multicolumn{6}{|l|}{ Capital Region } \\
\hline KYIV & 839 & 0,1 & 2916,2 & 6,8 & 3490,1 \\
\hline Total & 603766 & 100 & 42672,9 & 100 & 75,15 \\
\hline
\end{tabular}

*Developed and systematised by the author (Pavlov K.) using sources: [4, 5]

** Indicators of the temporarily occupied territory of the Autonomous Republic of Crimea, the city of Sevastopol, Donetsk and Luhansk regions (oblasts) as of 01.01.2014.

The southern region has a low urbanization level, a high population level in the countryside and low density of both the population and settlements in general.

The eastern region is characterised by high indicators of urban settlements density, as well as the general population density.

The capital region is "special" to a certain extent, since it just includes the city of Kyiv. This is due to the fact that according to its social-economic indicators, such as income of the population, gross domestic product, index of investment support, population, etc., it is comparable to separate administrative regions, and sometimes even to entire regions.

Summarising the above-mentioned facts, while taking into account the significant differences in the economic and social development of Ukrainian territories and the territorial settlement system peculiarities, we have identified six separate regional real estate markets including Western, Central, Northern, Southern, Eastern and Capital (Table 2). 
Social-economic estimation of competitive positions formation of ukrainian...

$\frac{\tilde{e}}{\frac{0}{0}}$

.

$>$.

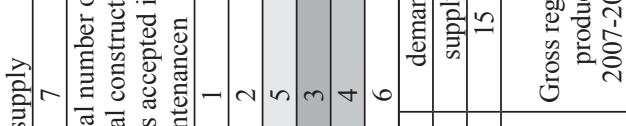

$m \ln \theta-2-2$

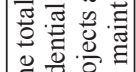

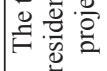

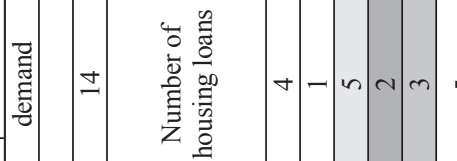

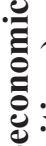

$\dot{0}+$

ㄱ.

㝞

吾惑

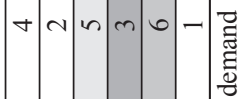

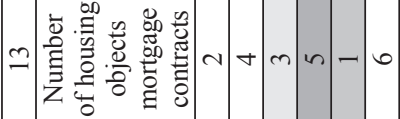

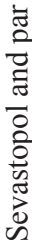

$\frac{7}{2}$

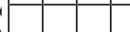

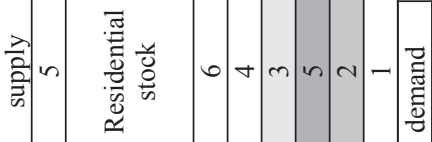

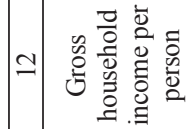

\begin{tabular}{ll|l|l|l|l|l|l|l|l|} 
& & & &
\end{tabular}

ह

을

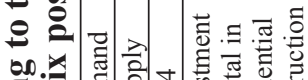

.

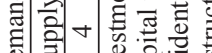

둔

8ㄹ

ช

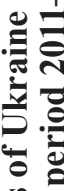

है

क ख त्ञ

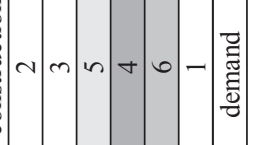

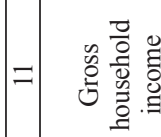

$0+\operatorname{mon} n-$

들

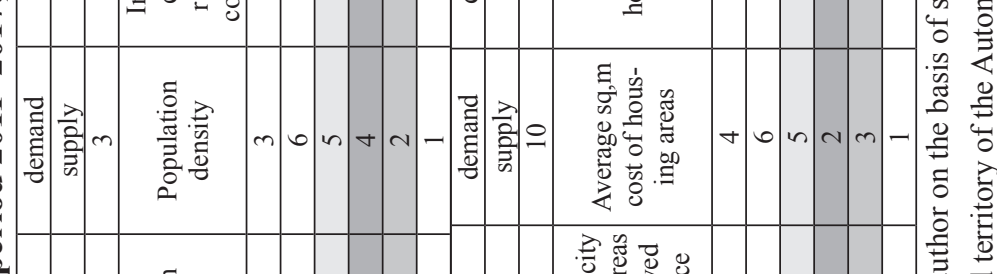

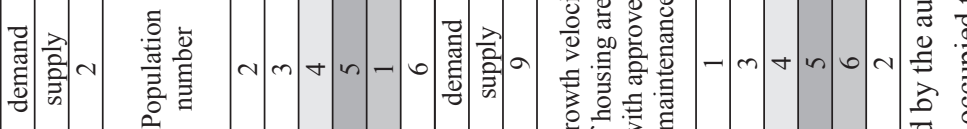

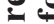

•

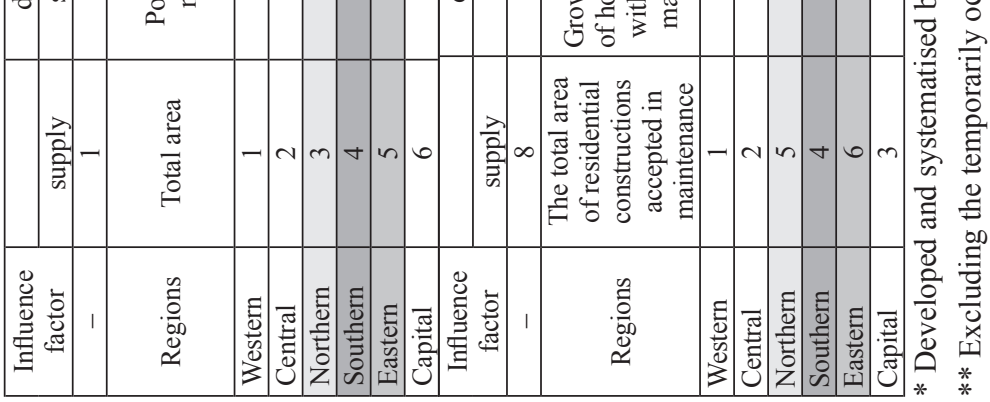




\section{An overview of the social-economic characteristics of the regional real estate markets of Ukraine}

Western Region. Western region includes eight oblasts: Volyn, Rivne, Lviv, Ternopil, Khmelnytskyi, Transcarpathian, Ivano-Frankivsk and Chernivtsi.

This region occupies the first position among other regions that we have singled out $-13,127$ sq. $\mathrm{km}$, or $21.7 \%$ of the territory of Ukraine, and the second as regards the number of population - 10640 thousand people. This is the region which includes the largest number of oblasts which is eight. There are 298 urban-type settlements and the largest number of localities in rural areas -8082 units [4].

A characteristic feature of this region is that 6 oblasts out of the 8 within the region border on other states. Consequently, the prospects of social-economic development of the region largely depend on the level of relations with neighbouring states. It is also worth mentioning that gas, oil pipelines and electricity lines run through this region. What is more, the region is the transit platform for important international highways and railways.

It should be noted that Volyn Oblast (its southwestern part), which is part of the region, is considered to be a highly developed recreational center because of a large number of lakes and Shatskyi National Park.

Western Region, according to the indicators of the national gross regional product (GRP) occupies the third place among other regions, and its share in relation to the national level makes about $14 \%$. According to the GRP per capita, this region is considered insufficiently developed, since its average indicator amounted to $28899 \mathrm{UAH}$ in actual prices in 2016 [4].

Western Region in the structure of national economy is basically represented in the branches of material production. Despite the fact that construction, transport, and public administration occupy a special place among the social sectors in the region, it is primarily agrarian.

If this region is considered through territorial division of labor perspective, then it is necessary, to predominantly distinguish between machine building, light industry, chemical, oil refining and gas industry, agriculture, production of specialised technological equipment, forestry and timber processing industry.

In general, the agrarian-industrial complex in the Western region is quite diverse. As a result, most of the areas in its scope specialise in the production of vegetable, fruit, beet sugar, milk and meat and crops. 
As regards manufacturing in the region, agriculture and processing industry are predominant. Among the public sectors, transport, trade and educational services should be distinguished.

Central Region. As mentioned, we included 5 oblasts: Kyiv, Zhytomyr, Vinnytsia, Cherkasy and Kirovograd into the Central Region. It should be emphasised that the city of Kyiv doesn't constitute its part because according to its social-economic indicators, as well as in connection with its metropolitan positioning as the capital of Ukraine, it corresponds to separate oblasts, and even entire regions. Central Region occupies the second position in the proposed territorial division, covering an area of 129964 square kilometers and 5 administrative regions of Ukraine. There are 228 localities of the city type, and 5,991 localities of rural type. In this region there are about $15.8 \%$ of the population of the state, which makes up 6780.2 thousand people [4].

This region is generally distinguished among others, due to its advantageous geographic location and social status. The peculiarity of its territorial division lies in the proportional distance from other regional centres, separate raw material bases, and industrial centers of the state. It is important that a lot of national routes run through its territory, as well as major international transport connections joining the countries of the Caucasus, Eastern Europe, the Baltic countries, and Russia.

The Dnieper River flows through three regions out of five included in Central Region, which characterises the region to be having a significant recreational potential. Another peculiarity of this region is that the Capital Region is in its heart.

On a national scale, the regional gross national product of the Central Region is about $14.6 \%$ [4].

As already mentioned, an important advantage for this region is the fact that Kyiv, the capital of the country, is located in its centre. This factor contributes to the formation of substantial significance of the region in the areas of financial activity, public administration, trade, hotel and restaurant business as well as operations with residential real estate and its lease.

The industrial specialisation of Central Region is machine-building, chemical, light industry, non-ferrous metallurgy, food industry, highly developed construction industry, timber processing industry, and agriculture.

Agricultural positions of Central Region are especially highlighted in the cultivation and processing of sugar beet, sunflower, potatoes, cereals, berries, hops, flax, meat and dairy products. 
Northern Region. Northern Region covers 4 administrative oblasts of Ukraine (Chernihiv, Sumy, Poltava, Kharkiv) and ranks third with total area of about $19.2 \%$ of the territory of Ukraine, or 115862 sq.km. Compared to other regions, it is characterised by a relatively low population, which as of January 1, 2017 amounted to 6265957 people of whom 4492804 live in cities whereas 1673153 in rural areas. Northern Region includes 184 urban localities and 6407 rural type localities [4].

It should be noted that the special distinction of this region is that there is a room for investment attractiveness, a highly developed metropolitan city of Kharkiv.

An important aspect of the Northern Region's superiority over other regions is its geographical and social status. The three oblasts within the region are bordered on important strategic partners of the country: Belarus and Russia. Meanwhile, due to current state of affairs, the peculiarity of the territorial neighbourhood with the Russian Federation should be considered a rather negative feature. In fact, cities such as Sumy and Kharkiv are constantly under the social and political influence of the eastern neighbour. This characteristic impairs the positive impact of a potential buyer of a residential property and a separate investor in the construction business from other regions of the country.

Not less important is the availability of powerful networks of road and railroad connections. Significant international lines of electric transmission and gas pipelines run through the territory of Northern Region.

Southern Region. Southern Region, occupies the country's fourth position by its area, -112450 sq. Km. (18.6\%) and the last place in the number of population -4601.6 thousand people (10.8\%). The regional grouping comprises the Odesa, Mykolayiv, Kherson regions, the Autonomous Republic of Crimea and the city of Sevastopol [4].

Within it is the largest number of localities, namely: 184 localities of city type, one of which, the city of republican significance - Sevastopol and the smallest number of localities of rural type - 3628 units [4].

First and foremost, this region is characterised by the fact that all the united regions and the Crimea have a seacoast, being the recreational centre of Ukraine. In addition, this region is marked by an important transport and maritime connection of the state with other states of the world.

Southern Region has a favourable territorial location and excellent public positions. One of the features of this region is the existence of land bor- 
ders with Romania and Moldova. Meanwhile, such countries as Bulgaria, Turkey, and Georgia are adjacent to this region via water-delineation. In addition, due to the existence of a well-developed river transport network, the region has transport links with most European countries.

The seaports located on the coast of the region, the banks of which are washed by the Black Sea and the Sea of Azov, are of great importance, especially when it comes to the question of the implementation of economic activity of the country at the international level. Excellent transport and geographic characteristics of Southern Region are also highlighted by the developed network of transport connections and corridors operating on its territory.

As already mentioned, there is a developed network of transport connections by rivers in the Southern region: the Dnieper, the Danube, the Southern Bug. Transit pipelines of different specific purposes are also laid through the territory of the region.

The economic part of Southern Region is based on the transportation of cargoes, the construction industry, as well as fishing. This is an industrial-agrarian region in which the total share of the industrial sector is twice as big as that of agriculture.

The region commonly specialises in recreation, cultivation and processing of various crops. The machine-building complex of the region is characterised by the production of specialised equipment for food and light industry, instrumentation and machine-building, and transport.

Besides, one of the leading industries is the food industry, accounting for about a third of the share of total industrial production. A slightly smaller share belongs to machine-building, chemical industry, and electric power. In the general structure of the machine-building complex, the shipbuilding should be singled out, since the region has a highly developed port complex. Separately, in the Mykolayiv oblast, it is necessary to highlight non-ferrous metallurgy, which occupies about a quarter of all its industrial production in the state. Another important feature of the overall economic structure of the industries is that the majority is occupied with communication, transport, recreation, etc.

Eastern Region. Eastern Region, on the basis of population figures, occupies a leading position among other regions $-26.1 \%$, which is 11.4 million against the national average, of which about 4 million live on a territory which is beyond the control of the Ukrainian authorities. In the meantime, 
it is the smallest area in the region, because its territory is equal to $-18.6 \%$ relative to the national value, which equals $-112,3$ thousand sq. $\mathrm{km}$. Of these, at the end of 2017, those occupied by the Russian Federation were about 15.8 thousand sq. km, Donetsk oblast- 7.5 thousand sq. km, or $28 \%$ of the total territory of the region; Lugansk oblast $-8,3$ thousand sq. $\mathrm{km}$ or $31 \%$ of the total territory of the region [4].

It is also worth noting that within this region, in comparison to other regions, there is the largest number of urban-type localities - 431 units, as well as 4247 units - localities of rural type (about half of which is under the influence of Russian occupation today) [4].

Eastern Region is formed on the basis of the author's (K. Pavlov) approach to the conditional unification of the territory of four oblasts: Dnipropetrovsk, Zaporozhzhya, Donetsk, Lugansk oblasts, two of which are washed by the waters of the Dnipro River. In general, in peacetime, the peculiarity of this region lies in its investment attractiveness and is characterised by a high level of development of the manufacturing-industrial complex. The advantageous position of the geographical and social situation of Eastern Region is due to its border and coastal location; neighborhood with highly developed Central and Northern Regions.

The development of a wide network of railway connections in the region allows to fully take advantage of its transit potential, as well as to establish new external and internal transport links. In addition, oil and gas pipelines, railways and motorways run through Eastern Region.

As noted earlier, today some districts of Donetsk and Luhansk oblasts are under occupation of the Russian Federation, and on the territory of these oblasts continual armed conflicts are occurring. In this connection, the peculiar "instability" in the residential property market is transferred to two neighbouring oblasts, which are also within the boundaries of the specified region. On this basis, the situation in the region relative to obvious investment-market operations is extremely uncertain and doubtful.

Capital Region. The city of Kiev is the largest city in Ukraine. We consider it separate in our model of regional division of the residential real estate market, as a "sixth" region, since according to its parameters (the population, the share of investment in residential property, GDP, income of the population, etc.), it is comparable to the separate administrative regions, which are much larger by their territory, and according to individual param- 
eters, the city of Kyiv (Capital Region) is comparable to the entire regions of the country.

Kyiv, by area, ranks seventh in Europe and holds leading positions in terms of population density in Ukraine - 3490.1 people / sq. m. Meanwhile, the number of its population as of January 1, 2017 was - 2916.2 thousand people, which is about $6.8 \%$ of the total population. It is necessary to mention that the above indicator is constantly increasing. Besides, it should be noted that the city of Kyiv, together with its suburbs, forms the so-called Kyiv agglomeration with a population of about 3.4-4 million citizens [4].

In general, the capital - Kyiv, the city having a special status in the state, which is singled out at the administrative and territorial levels, is the center of Kyiv Region. This city is located in the north-central part of the country flanking the Dnieper River. The city of Kiev covers 847 sq. km. total area. The major part of the city is located on the right bank of the Dnieper river.

The city of Kyiv, the territory of which forms the basis of Capital Region, is one of the most important economic, political, religious, cultural and educational centres of Europe, due to central authorities and affiliated centres of political parties, public organisations, as well as judicial, legislative, and executive bodies located within.

Capital Region is one of the main centres of industry in the country. Most of all, it is food, tobacco, electricity production as well as distribution of gas and water. Industrial efforts of the region in such areas as chemical, light industry, and machine building are associated with the region.

The construction complex of Central Region is the largest by volume in the state. A large number of developer organisations, contracting construction and installation companies as well as small construction cooperatives and organisations operate on its territory.

Capital Region is the largest transport hub of the state. there are two international airports at its disposal "Borispol", "Kyiv", as well as one cargo destination - "Gostomel". In fact, this region is a large railway junction, which combines 13 passenger and cargo stations in five main directions: Korostenskyi, Nizhyn, Mironovskyi, Fastovskyi and Hrebinkivskyi with the head office of the (Pivdenno-Zakhidna) Southwest Railway. A functioning river port is also at the disposal of the region.

The territory of Capital Region, is the point of departure for the following major main roads of international importance: "Kyiv-Sumy-Yunakivka"; "Kiev-Kharkiv - checkpoint Dovzhansky"; "Kiev-Odessa"; "Kiev-Cherni- 
hiv - checkpoint New Yarilovichi"; "Kiev-Lviv-Mukacheve-Chop", "Kyiv-Kovel - checkpoint "Yagodyn","Kyiv-Znamianka". Long-distance bus passenger service is focused on the Central Automobile Station and six bus stations network around the region.

As already mentioned, Capital Region is the largest educational and scientific centre in the country. Indeed, there are more than 120 higher educational institutions, the National Academy of Sciences of Ukraine and various branch research institutions within its territory. It is also a powerful centre of financial and credit systems in Ukraine. There is the head office of the National Bank, about 150 directorates, branches of commercial and state banks. There are more than a dozen commodity and stock exchanges in the region.

Besides, it should be noted that there is a developed system of horticulture, the basis of which is, in its kind, a unique water-green center, with the diameter of 30 by 5 kilometres. It includes an aquatory part of the Dnieper River with adjoining islands and coastal areas. The formation of climatic spaces: Koncha-Zaspa and Puscha-Voditsa was undertaken due to the favorable natural conditions of the region. In general, the greenery territory, which is in general use, is just over 5.5 thousand hectares, including the reservoirs of the region, which cover more than 2.3 thousand hectares [4].

In general, the built-up part of the specified region is about more than $40 \%$ of its total area, including: the land occupied by residential multi-storey buildings - about 6,5 thousand hectares; public housing construction -6.8 thousand hectares; buildings of industrial purpose $-6,0$ thousand hectares [4].

\section{Findings}

Thus, having analysed the peculiarities of the social-economic development of these regions, it should be noted that the regional markets of residential real estate within these regions develop in accordance with the specifics of the region and are predisposed to a variety of factors, in particular: the volume of the total area; population; population density; volumes of capital investment in construction; residential stock; average sq, $\mathrm{m}$ cost of housing areas; gross household income per person; number of housing objects mortgage contracts; number of issued mortgages; gross regional product. As a result of the study, it was possible to estimate the competitiveness of the results of the regional ranking by social-economic indicators for 2011-2017 (Table 2). It was found that the Capital Region is the most 


\section{Social-economic estimation of competitive positions formation of ukrainian...}

competitive, and in relation to the development of regional real estate markets Northern and Southern regions proved to be the least competitive.

\section{Conclusions}

The current state of the economy of our country has embarked on the reform movement and requires all the qualitative structural changes that contribute to the formation of a favorable competitive environment for the regional residential markets functioning.

Actually, the presence of signs of monopolisation of the construction industry leads to a social imbalance and deformation of the real estate market. When developing the antitrust component of regional policy, it is important to carry out a social-economic assessment of the status of the regions, identifying the limits of the competitive market potential availability.

Therefore, the study attempts to identify the impact of various factors on improving social-economic determinants of the region, highlighting priority areas for the successful existence of regional residential markets. The research is guided by theoretical, practical results, which is confirmed by the final theoretical conclusions and methodological variability of the applied approaches.

\section{References:}

1. Asaul A., Gordeev D.A., Ushakov E.I., (2008) Razvitiye rynka zhiloy nedvizhimosti kak samoorganizuyushcheysya sistemy [Development of the residential real estate market as a self-organizing system]. SPB: GASU, 334 [In Russian].

2. Bozhko E. A. (2008). Orhanizatsiyno-ekonomichnyy mekhanizm doslidzhennya rehional'nykh rynkiv nerukhomosti [Organizational and economic mechanism of research of regional real estate markets] (PhD Thesis), Kharkiv [In Ukrainian].

3. Gritsenko O.A. (2003). Rynok nerukhomosti: zakonomirnosti stanovlennya ta funktsionuvannya. [Real estate market: regularities of formation and functioning] (D Thesis), Kyiv, 334 [In Ukrainian].

4. Derzhavna sluzhba statystyky Ukrayiny. Ofitsiynyy sayt. [State Statistics Service of Ukraine. Official site], [In Ukrainian].

5. Derzhavna sluzhba statystyky Ukrayiny (2016). Zhytlove budivnytstvo v Ukrayini u 2011-2015 rokakh [Housing construction in Ukraine in 2011-2015], Kyiv: Informatsiiino-analitychne ahenstvo. [In Ukrainian].

6. Ovsyannikova, T.Yu., (2012). Konkurentnaya sreda na rynke zhiloy nedvizhimosti: osobennosti i zakonomernosti [Competitive environment in the residential real estate market: features and patterns]. Bulletin of Tomsk State University. Economy, 1 (17), 187-193, [In Russian]. 
7. Pavlov V.I., Pylypenko I.I., Kryvov'yazyuk I.V. (2008). Nerukhomist' v Ukrayini [Real estate in Ukraine]. K: State Academy of Statistics of Accounting and Auditing, 765 [In Ukrainian].

8. Pavlov, V.I., Asaul, A.M., Pilipenko, I.I. \& other (2006). Rynok nerukhomosti: Navchal'nyy posibnyk [Real Estate Market: Textbook]. Kyiv: Kondor, 336 [In Ukrainian].

9. Pavlov K.V. (2016). Vplyv konkurentnykh vidnosyn na rehional'ni rynky nerukhomosti $\mathrm{v}$ umovakh instytutsiynoho zabezpechennya [Influence of competitive relations on regional real estate markets under the conditions of institutional support] Ekonomichnyy chasopys Skhidnoyevropeys'koho natsional'noho universytetu imeni Lesi Ukrayinky, 4 (8), 89-93 [in Ukrainian].

10. Pavlov K.V. (2017). Zmistova kharakterystyka funktsionuvannya rehional'nykh rynkiv nerukhomosti [Content characteristic of functioning of regional real estate markets]. Ekonomichnyy chasopys Skhidnoyevropeys'koho natsional'noho universytetu imeni Lesi Ukrayinky, 1 (9), 102-109 [in Ukrainian].

11. Pavlov K.V. (2013). Rehulyuvannya investytsiyno-zhytlovykh vidnosyn $v$ Ukrayini [Regulation of investment and housing relations in Ukraine]. Rivne: NUWM, 250 [in Ukrainian].

12. Portal nedvyzhymosty domik.ua [Portal of real estate domik.ua], [In Ukrainian].

13. Strizenets O.M., Pavlov K.V. (2016) Osoblyvosti konkurentnykh vidnosyn na rehional'nykh rynkakh nerukhomosti [Features of competitive relations in the regional real estate markets]. Naukovyy visnyk uzhhorods'koho universytetu. Seriya "Ekonomika". Zbirnyk naukovykh prats' 1 (47), 35-38 [in Ukrainian].

14. Strizenets O.M., Pavlov K.V. (2017) Teoretychni aspekty konkurentsiyi na rehional'nykh rynkakh zhytlovoyi nerukhomosti [Theoretical aspects of competition in the regional markets of residential real estate]. Ekonomichnyy chasopys Skhidnoyevropeys'koho natsional'noho universytetu imeni Lesi Ukrayinky 3 (11), 7-12 [in Ukrainian].

15. Drapikovs'kiy O.I., Ivanova I.B. (2012). Tendentsiyi rynku nerukhomosti Ukrayiny: realiyi ta prohnozy, 2007-2013 [Trends in the Ukrainian real estate market: realities and forecasts, 2007-2013], K.: "Art Economics", 240 [in Ukrainian].

16. Fatkhudinov F. (2002). Upravleniye konkurentosposobnost'yu organizatsii [Management of the competitiveness of the organization]. M: Yeksmo, 544 [In Russian]. 


\section{ESTABLISHMENT AND DEVELOPMENT \\ OF ECONOMIC WELFARE THEORY}

\section{Tomchuk-Ponomarenko Nataliia ${ }^{1}$}

DOI: http://dx.doi.org/10.30525/978-9934-571-28-2_26

Abstract. The article provides analysis of evolution of scientific approaches towards the meaning of the category "living standards of the population" and some methodological aspects of its investigation. Basic research areas of welfare economics in the history of living standards of the population investigation have been determined. The characteristics influencing the research and living standards of the population estimation have been proposed. Logical and historical methods are applied in the article for the purposes of underpinning of primary tendencies of development of welfare economics and living standards, determination of the essence of these categories at current stage; systematic approach meaning the analysis of the target of research is provided on the basis of its organic continuity and simultaneous internal differentiation to relatively independent elements. The latter is possible for the reason that fundamentally any local system is a split whole consisting of not one element but a significant number of differing elements connected with each other the integrity of which conditions the appearance of new integrated features which are not peculiar to severally taken elements comprising the system. The goal of the research is the analysis of scientific approaches towards the essence of social and economic category of "living standards of the population" and some methodological aspects of its investigation by both native and foreign scientists. Realization of the goal conditioned the necessity of solving of the tasks as follows: expound the essence of the "living standards" category and show its interrelation with other synonymic categories; underpin scientific tendencies of welfare theory and living standards of the population development basing on fundamental analysis of the research papers related with the issue of living standards of both native and foreign scientists starting from the times of classic political economy and till present.

\footnotetext{
${ }^{1}$ Candidate of Economic Sciences, Associate Professor at the Department of Economic Theory, Macro- and Microeconomics, Taras Shevchenko National University of Kyiv, Ukraine

(C) Tomchuk-Ponomarenko Nataliia
} 


\section{Tomchuk-Ponomarenko Nataliia}

The above analysis of the history of living standards investigation has been proving its actuality and practical effect for many centuries. The specifity of "living standards" category lies first of all in impossibility of its rendering by any single relation or index. For that reason there exist a burning necessity of structuring the integral system of characteristics and indexes providing overall estimate of the investigated category. Present-day realities of Ukraine encourages to develop a unique concept of living standards, perfection of theoretical and methodological approaches towards its investigation with social-economic, cultural and spiritual differentiations with each particular region taken under consideration.

\section{Introduction}

Active furtherance of rising of living standards of the population, growth of national prosperity is a top-priority task arising and is to be solved by each state the policy of which is oriented towards the implementation of fundamentals of social-oriented market economy development. When determining the current living standards of the population within the state, analyzing its basic structural components, quality characteristics and specific quantity indicators it is necessary to consider the full range of current peculiarities and objectives immanently inherent in the process of growth of both national prosperity in general and living standard of a particular person or family severally. Essentially the category "living standards" unites a wide array of social and economic relations which characterize the peculiarities of living conditions of a person, family, social organizations (social stratums and classes) and also the population of the state as a whole. The uniqueness of the category "living standards" lies in the fact that it can't be rendered by a single index and is objectively determined by a wide range of characteristics, each of which is related to a separate element solely or a certain aspects of relations arising during the process of operation of a single and multifaceted social organism. For that reasons a distinct determination of the essence of the "living standards" category during the research is of prime importance. This precisely is worth attention as far as analysis of the evolution of approaches which is traced in researches concerning deepening of understanding of the "living standards" category at different points of history evidences the availability of rather wide range of approaches. Essentially these approaches differ significantly and sometimes contradict each other that's why determining of a content-related essence of the "living standards" category and underpinning 
of basic directions of welfare economics and living standards is of crucial importance at the time being.

The history of evolution of human civilization suggests that the problems of welfare and rising of living standards were permanent concerns of humanists and scientists. In particular, the above issues concerned the philosophers of ancient times however nothing save for statement of contour of things as at that time, revealing of substantial violation of social justice in the distribution of common weal and drawing attention to escalation of social antagonisms between poor and reach social stratums has been done; real development of theoretical problems of welfare and mechanisms of its support have not been worked out.

\section{Literature Review}

The issue of living standards investigation involved such prominent Soviet and Ukrainian scientists as Abalkin L.I., Bobkov V.N., Kapustin Ye. I., Mayer V.F., Mozhyna N.O., Rabkina M.Ye., Raitsyn V.Ya., Rymashevska N.M., Sygov I.I., Zherebin V.S. and others. Significant contribution into the solution of theoretical and applied aspects on the issues of living standards of the population during the transition period in Ukraine was made by Basyliuk O.V., Boginia D.P., Bondar I.K., Geits V.M., Goleusova G.Z., Danylenko O.I., Dolyshnii A.V., Kvasniuk B.Ie., Kirian T.M., Kolot A.M., Kutsenko V.I., Libanova E.M., Lukinov I.I., Mandybura V.O., Novikov V.M., Onikienko V.V., Pirozhkov S.I., Revenko A.X. and Timofeev V.O. At the same time as at present analysis of scientific approaches of the representatives of different theoretical schools dealing with the issue of welfare, level, quality and value of living of different social stratums and the population of the country in general, estimation of scientific objectiveness of the view the theorists has been kept to and defended, their understanding of the core of social and economic justice and the possibilities for realization and providing of distribution and consumption of the required amount of common weal between different categories, stratums and classes remains to be an important aspect.

\section{Material and method}

Logical and historical methods are applied in the article for the purposes of underpinning of primary tendencies of development of welfare economics and living standards, determination of the essence of these categories 
at current stage; systematic approach meaning the analysis of the target of research is provided on the basis of its organic continuity and simultaneous internal differentiation to relatively independent elements. The latter is possible for the reason that fundamentally any local system is a split whole consisting of not one element but a significant number of differing elements connected with each other the integrity of which conditions the appearance of new integrated features which are not peculiar to severally taken elements comprising the system.

The goal of the research is the analysis of scientific approaches towards the essence of social and economic category of "living standards of the population" and some methodological aspects of its investigation by both native and foreign scientists. Realization of the goal conditioned the necessity of solving of the tasks as follows: expound the essence of the "living standards" category and show its interrelation with other synonymic categories; underpin scientific tendencies of welfare theory and living standards of the population development basing on fundamental analysis of the research papers related with the issue of living standards of both native and foreign scientists starting from the times of classic political economy and till present.

\section{Results}

Real scientific understanding of the wide range of the problems of welfare and rising of living standards of the population, investigation of the issues related to both simple and extended operational force renewal (on personal-family and social levels) in fact was coincident with the period of foundation of capitalistic social and economic formation. At that very period the researches related to the determining of composition, structure and scope of the required social weal which must satisfy the living needs of the population and the estimation of the required sources capable to provide personal-family reproduction at the level of different social groups within society were started. Under the conditions of establishment and development of capitalistic social and economic formation the class structure of society underwent considerable changes as a result of two leading classes formation - the owners of the capital and employers class, primarily consisting of workers (proletarians). After the victory of bourgeois revolution in the majority of European countries the former social class, in addition to economic power, acquired political power thus becoming dominant. 
In the course of development of economic theory of welfare and living standards it is possible to point out political and economic directions as follows: right (liberal democratic), centrtist (social democratic), left (socialistic), estimation and statistical (budgetary-estimative and regulatory-budgetary) and regulatory-economic. They were based on the understanding of basic components of social welfare, issues on ensuring respective living standards for capital owners class and employers class in the course of the defense of their interests in the sphere of final reproductive consumption. Conscious political and economic position of the scientists lied in the following: 1) underpinning of "normality of the existing abnormality" of the circumstances of extreme polarization of living and consumption standards of different social classes, i.e. normality of simultaneous existence of wealth and luxury, poorness and poverty within the society; 2) development of scientific fundamentals of providing of maximum congruence of interests of labor and capital in the sphere of meeting the requirements of final consumption, rising living standards for poor and poverty classes; 3) unconditional critics of the existing major inequality of final social product distribution when on the one part there was a miserable providing of the needs of the reproduction of employed and self-employed labor and on the other part - wealth and luxury of social dominant class living.

The right (liberal democratic) direction coincides with the first half of XIX century which is synchronous with the period of the establishment of classical political economy and foundation of capitalistic relation on the West. Its representatives are U. Petty, F. Quesnay, D. Ricardo and others. The representatives of this concept tried to establish the correlation between the wages amount received and satisfaction of employers' needs; explain the reasons for the differences in the level of the income received and the factors influencing growth of employers' salary. Living standards were treated on both micro- and macrolevel (as a welfare of the nation).

U. Pettirealno The founder of the English classical political economy school, being an irrevocable apologist of the dominant class of capital owners in his "Tractate On Taxes and Dues" underpinned theoretically the mechanisms of settling wages which guaranteed the employer's income providing his living standards on the level satisfying minimal existence requirements (theory of the minimum of funds). The latter he rationalized as follows: "if the employers are paid twice more the minimum determined they will work twice less" [1, p. 21]. The limitation of the theory of min- 
imum of funds lied first of all in the fact that under such conditions not only those needs related to the extension of labor force reproduction could be met but also its simple reproduction failed. Consequently pursuing this approach "historical and moral elements" of the formation of employers" demands were entirely included.

The scientists investigated preferably the efficiency of social support system and its impact on living standards of the population. He outlined the role of a state under the conditions of market economy and the necessity of targeted aid for the purposes of exclusion of dependence and excessive use on the part of the population. "When all helpless and weak people are supported and idlers and criminals are curbed and punished we'll finally find certain permanent engagement for all the rest people who may demand sufficient amount of food and clothes" [2, c. 20].

He also unraveled the impact of taxation of living standards of the population and came to the conclusion the the increase of tax burden results in population welfare deterioration [2, c. 23].

David Ricardo in his work "The Fundamentals of Political Economy and Taxation" approached the problem of wages amount and its adequacy for the satisfaction of employers' needs. "The natural labor cost is that necessary for employers to have the possibility to exist and continue their generations without increase or decrease of their quantity" [2, c. 459]. There were raised the problems of real and nominal salary "The ability of an employee to support his family and himself ... depends not from the amount of money earned as a salary but from the amount of food, items of vital necessity and comfort which became essential for him as a result of getting used to them which are possible to purchase for that money amount" [2 p. 460]. For that reason the inherent value of labor is directly proportional to the price for food and non-consumer goods. Under the conditions of the growth of the prices for food and services the value of labor force increases as well. On the other part the scientist didn't ignore the influence of market mechanism of correlation between the supply and demand.

An outstanding representative of economic thought of England Thomas Malthus (1766-1834) contributed sufficiently into the first concept. Interpreting the poorness as a natural phenomenon he asserted that people must mostly blame themselves in their sufferings. The basic thought of its theoretical concept was that there existed a principal of population the essence of which is "constant striving specific for all living things to multiply faster 
than it is allowed by food amount available" (known geometrical and arithmetical progressions). Denying the philanthropy he asserted that any bounties on the part of the rich, especially monetary, are incapable to eliminate or prevent lower classes poverty. He was convinced that the major and permanent reason for the poorness is little dependent on or independent at all of the mode of government or unequal allocation of property.

T. Malthus as well as D. Ricardo was against "The Laws of Poor" and pointed out that the latter "First, ... stimulate the growth of population without a respective increasing of the amount of consumer goods" Second, the amount of provisions consumed in working houses by the idlers which cannot be treated as useful social units decreases the share of people which are more useful for the society by the share consumed" [2]. T. Malthus saw the role of the state in taking various preventive measures for the purposes of establishment of such a correlation between the population and the means for its existence which would not "result in struggle between them" [2].

The theory of "harmony of interests" of basic classes of capitalistic society became a crucial concept of the right-liberal apologetics. The founder of this theory is deemed to be Claude Frederic Bastiat (1801-1850). The scientist, in his opinion, phrased the main question: are the interests of people, left on their own, in harmony with each other or are they directly opposed to each other? F. Bastiat determined market economy as the world of will and harmony, economic freedom and mutual cooperation of different classes. Pursuing the theory of economic harmony by F. Bastiat, the interests of labor and capital are associated. He overemphasized the ideas of economic liberalism and free competition principles. Defending social inequality as coercion in respect of people unwilling to work F. Batistat was convinced by permanent meddling the government twists labor relations and remuneration for it, interfere with the principles of industry and exchange, misleads capitals and labour forces and causes unprecedented waste of human resources.

The development of "harmony of interests" conception was furthered by the representative of the USA economic thought of XIX century Henry Charles Carey (1793-1879). He asserted that capitalism creates the conditions for economic growth and sustainable development of the society. The researcher outlined that along with bourgeois society development due to the growth of the efficiency of labor productivity and growth of capital the share of employers in national product grows both absolutely and relatively 


\section{Tomchuk-Ponomarenko Nataliia}

and the share of capitalists while increasing absolutely decreases relatively. "Out of all the principles established by the science - as H.C. Carey wrotethis is the most brilliant principle for the operation of this principle lies in the harmony of true interests of different classes of human society" [3].

Francois Quesnay (1694-1774) a founder of French physiocrats school should be pointed out. He investigated real sources of the growth of living standards of the population. He created the concept of the necessity of "equal exchange of goods" where he proved: exchange of trade does not generate wealth; nothing is produced in the process of exchange".

The latter he explained that in the sphere of exchange under the conditions of free competition an equivalent exchange of equal value inherent in goods prior to their entering a market takes place and concluded: in the course of exchange material wealth as the source of living in not created that's why profit appears [4, c. 48].

Consequently, the investigation of the right concept can't be treated as multi-method research for it concerned only separate aspects of understanding of living standards. The burning social problems as of that time were such as sufficiency of wages received, state support for needy families, factors of national welfare growth, underpinning of the role of the state in public relations regulation.

The second centrists (social democratic) concept changes the accents from political and economic to economical and statistical concept of analytical assessment of living standards; moving from macro- to microlevel of economic welfare theory investigation takes place. Attention is focused on the issues of living standards determining, real living value of working population in particular and consequently establishment of the required salary amount with the consideration of branch and regional distinctions.

The founder of the centrists, social democratic, concept of economic welfare theory may be deemed a classic of the English political economy Adam Smith (1723-1790). Smith was engaged with the problem of widening of poorness phenomenon within working class and thought that "a human must have a possibility to exist with the help of its labor and his salary must be at least sufficient for his existence" [5 p. 64]. He determined the reasons for the differentiation of employers pursuing their wages amount, the primary among which were: pleasantness or annoyance of work; simplicity and cheapness or complexity and expensiveness of acquiring the needed expertise; permanent or casual employment; bigger or less trust 
given to those persons engaged in certain business; probability or impossibility of success in activity. Analyzing the factors determining the level of wages he outlined the immaturity of the theory of living minimum wage rationalizing that this is the lowest standard barely compatible with basic humanism. He established the ground for understanding of social justice asserting that "undoubtedly, no society can't flourish and be happy in case its major part is poor and miserable. Moreover, simple justice requires that people who provide food, clothes and build dwelling for the entire nation receive the share of their own labor product allowing them to have deserved food, clothes and dwelling themselves" [5, p. 64].

To the representatives of centrists' conception in political-economic welfare theory we can also refer the theorists of social reformism as follows: E. Bernstein, O. Bauer, K, Kautsky, R. Hilferding.The main topic of their programs of social-democratic reformations were the issues of rising of living standards and welfare of the population including working classes of social sector, equitable distribution of social product among all the members of society etc.

To the prominent investigators of this concept we can refer V. Pareto, A. Marshall, A. Pigou and others. Thus, in his work "Political Economy Textook" (edition of the year 1906) V. Pareto basing on the analysis of statistic data deducted the principal of profits allocation ("the principal of Pareto") which expresses the dependence of living standards of the population on the amount of income and the number of the receivers. Starting out from "social heterogeneity" based on "physical, moral and intellectual" inequality of people the scientist stated that "this inequality which is inherent in human being is met by economical and social inequality" [6, p. 273]. In this way, in the scientist's opinion, the society returns to the type of income allocation specific for it. The major part of income is accumulated by the majority of population while high income make insignificant share of national income. He saw the problem of poorness first of all in the lack of production. The best way to improve the situation of poor classes of the population is to arrange for the wealth grow faster than population and the basis of state income must become taxation of the income of the majority and not the big incomes.

A. Marshall deepening theoretical investigation analyses the issue of financial support of the growth of living standards of the population through the perspective of differential approach towards the evaluation of 


\section{Tomchuk-Ponomarenko Nataliia}

the amount of personal savings and determining the best regimes of temporary limitation of consumer levels of any given population stratum. In the work "Principles of economic science" he focused on the investigation of the mechanism of the allocation of wealth between current consumption and suspended conditions of the use of monetary incomes of population and also clarifying of motivation towards "curb" of current consumption of the population for the sake of funds accumulation which are designated for the purposes of economic growth in future. A. Marshall asserts that one of the conditions forcing people to cut their current consumption and stimulating the accumulation of savings is family relationships. This is due to the fact that people work and save monetary funds mainly for the purposes of rising of living standards of their families and not their personal welfare [7, p. 201].

The successor of A. Marshall is A. Pigou who developed neoclassical ideas, underpinning of the concept of economic welfare and factors influencing it. Thinking over the problematics of researches the scientist made an accent on the feasibility of economic science which sphere of interests must be determined by practical needs of society. The science must provide applicable instrumentarium for the growth of citizen's welfare. He consciously restricted his own research by "the frames of the sphere of social welfare within which it is possible to directly or indirectly apply a measuring scale with the help of money" [8, p. 73-74] which he named economical welfare. The scientist accented that the notion of personal welfare is not limited by the sole economic aspect and includes such indexes of quality of living as conditions of environment, labor and recreation, availability of education, public order, medical treatment etc. Economical welfare of the society the researcher explained by the amount of national dividend (the share of material income which may be expressed in money) and the way of its allocation between the members of the society. He was among the first who paid attention to the imperfection of national income index for economical welfare determining.

In this way at the given stage of interpreting of living standards statistic methods were deepened and furthered, basic principles of consumer behavior as a result of the growth (deterioration) of the living standards of population were formed and the research gained practicability.

The founder of the left (social) concept of political and economical welfare theory is Karl Marx. In his works economical and social aspect of the 
category "living standards" and "welfare" gained deep theoretical underpinning. Thus in "The Capital" the author mentioned: "Working class, in order to maintain its usual living standards must obtain at least former amount of the needed means of subsistence, although it may be also changed in respect of the nature of goods it is comprised of..."[9]. K. Marx treated "living standards" as a social and economic theory which specified the level of satisfaction of physical, spiritual and social needs of people. Thus characterizing "traditional living standards" he pointed out that this level provides not only satisfaction of physical needs and also satisfaction of those needs derived from social conditions people exist and are educated in. Analyzing the functioning of the pattern of labor work force value determining he was the first scientist who underpinned that it "includes historical and moral elements". The scientist underpinned inevitable alienation of work and its results under the conditions of capitalism where exploitation rises not from individual, casual situation of market exchange but is a result of the very logics of capitalistic unequal appropriation. K. Marx directed his economic research to the underpinning of the conclusions about the inevitability of perishing of capitalistic social-economical formation the first motivating force of which is economic fear (competition) and the second is economic voracity (i.e. aiming for unlimited appropriation of profits). He focused his attention on the analysis of antagonistic social-class contradictions and social conflicts their extrapolation for revolutionary future of the humanity, underpinned the tendency of constant absolute and relevant deterioration of working class living standards; he considered proletariat itself to be the tomb of the capitalism.

Theoretical interpretation of the issues of living standards of the population by contemporary left radicals considerably differs from its interpretation from the positions of market liberalism theory which is entertained by neoclassicists. Thus the radicals criticize traditional theories of common weal as inhuman by nature for their chasing unlimited consumption destroy moral values, ignore harmonious personal development and do not further the solution of the problems of mankind humanism-based development. Denying traditional welfare theories R. Edwards and others state that the new theory must be based first of all on the refusal of market rationalism inherent in capitalistic society. The main focus at solving the problem of social welfare must be paid to inclusive development of a person, its consciousness, perfection of the structure of needs and advantages in consumption. 


\section{Tomchuk-Ponomarenko Nataliia}

Evaluation-statistical concept of economical welfare theory focuses attention on the issues of living standards and welfare of the most economically wretched and socially vulnerable groups of the population. An important constituent part of this theoretical concept lies in comparison of incomes and expenditures of the poor population stratums with incomes and expenses of the rich socially dominant classes and determining of the coefficients of social-economical differentiation.

Historical development of the society at the given stage resulted in the necessity of working out a theoretical basis for scientific evaluation of real living value which was crucial for the reproduction of labor potential and providing of material sources for reproduction of the needy stratums of population. This concept was based on the determining of specific set of weal - market basket of consumer goods which were developed on the basis of respective composition and structure required for the satisfaction of living needs for a person or a family at tolerance level.

The analysis proves that evaluation-statistical concept of economical welfare theory development is divided into budgetary-evaluating (ascertaining-statistical) and normative-budgetary. Budgetary-evaluating aims at practical realization of the two basic and mutually related tasks. The first task lies in the evaluation of the welfare level of social stratums by reference to statistically recorded amounts of actual consumption of consumer and non-consumer goods pursuing the established composition and structure, determining of the composition and structure of consumption most unique to the families of different levels of income and social status (the level of monetary and natural incomes, number of family members, level of household naturality, impact of ethnic-national and moral-religious factors on the consumption etc.). The second task lies in engagement and practical use of the given household budgets in general system of economic-statistical analysis of local economies for the purposes of investigation of complex social and economical mass processes through them: differentiation of households pursuing production and consumption volume, estimation of dynamics and volumes of property and monetary households accumulation; share of the population pursuing consumption level, income and property; determining of the standards of purchasing activity of the families with different levels of income and their impact on market demand and proposition etc. The first steps of budgetary-statistical analysis of welfare of the population in Europe were made by 
Gregory King (1648-1712) who in his work "Natural and Political Observations and Conclusions on Terms and Conditions in England" (1696) paid much attention to the analysis of average incomes and expenditures of the families belonging to different social classes.

Similar nature had budgetary researches of Joseph Massie (1711-1784), the English economist who in his work "Calculation of Year Taxes for the Families of Different Social Status and Class" (1756) along with the analysis of the level of prices for consumer goods and trade condition in England he endeavored to clarify the meaning of indirect taxes for the budgets of nobility, merchants, landowners and municipal and village workers.

Aurthor Young (1741-1820) - English economist and politician investigated living standards of agricultural workers, analyzed the reasons for their poverty relying on self-developed approximate budget for the family consisting of spouses and three children. AS the basis of his work he used data of four budgets of really existing farm laborers families.

In 1795 appeared a big work of Irish canon Davis David (1741-1719) "Consumer Basket of Farm Workers in Different Part of the Kingdom". The work included investigation of the budgets of more than one hundred households which were united in groups in accordance with the program preliminary developed with the help of questionnaires structured in advance. At this the author thoroughly and fundamentally investigated the reasons for existing poverty seated in restricted possibility to satisfy even minimum requirements of people. This very work is considered to be the beginning of the entire epoch of extended budget investigations aiming at investigation of living standards, requirements and the rate of their satisfaction within wretched, mostly marginal population stratums.

Further historical analysis of budgetary statistics development included the investigation of the works by Friedrich Morton Eden "The Standing of the Poor or the History of English Workers" (1797). The momentum for the writing of the book by F. Eden was famine of 1794-1795 which revealed extreme poverty of hired farm workers (farm servants). Basing on the assistance of parishes the researcher collected 73 budgets of farm workers pursuing detailed plan and thoroughly processed those data in compliance with the established by him classification of needs estimated according to 12 articles of budgetary expenses. The works by F. Eden, I. Dukpesio "Budgetary Economy of Classes of Belgium" (1855), Le Play "Working Population of Europe" (1855) and others showed extreme poverty of country peo- 


\section{Tomchuk-Ponomarenko Nataliia}

ple and farm workers, arouse active disputes within society and furthered the establishment of the International partnership for the investigation of social-economic practice which aimed at continuing budget investigations and publishing of their results in "The Two Worlds Workers" magazine. The works became classic scientific achievements which were of great importance for further development of statistical-evaluating or budget-consumer concept of economic welfare theory.

Only in the end of XIX the beginning of XX century active researches which gave rise to normative-budget concept began. The primary task of this concept lied in creation and perfection of the necessary methodological approaches and development of methodologies allowing delivering respective calculations of the cost of consumer baskets. Such consumer baskets by their composition and structure had to meet minimal living standards the representatives of hired workers, and base of their formation was objective necessity for providing of work force renewal and reproduction.

It is possible to assert that the development of normative-budget concept is explained by the emergence of the burning need of rising of the level or representativity of determining of real living cost of working population and consequently establishment of the required wages amount (taking into account branch and local peculiarities and differentiations) in compliance with the needs of the process of work force reproduction. The above was implemented for the purposes of reduction of social tension, restriction of the potential for escalation of social antagonisms and conflicts which in the beginning of XX century began to extremely negatively influence the stand of social stability and dynamics of economic development of society.

The next concept which may be pointed out as a separate within the framework of economical welfare theory and living standards is normative-economical. In the economic science of the West it investigates the issues of market economic efficiency and social attractiveness of alternative economical solutions, defines the ways of increasing of social usefulness and was named "welfare economy". Normative-economical concept was considerably developed after World War II for its principles were often declared as an important constituent part of the politics of governments of countries with developed capitalistic economy which competed with socialistic system including that concerning population welfare gain. The development of this concept has two streams. The first stream is related to the games theory and starts from the appearance of the work by J. von 
Neumann and O. Morgenstern "The games theory and economic behavior" and is treated as an instrument of the investigation of economic behavior, social cooperation and strategic analysis. The second stream appears on the basis of the theory of collective choice and individual estimations which allows investigating aggregation of the politics with economic decisions. The peculiarities of this stream lie in the follows: 1) it avoids the investigation of relations, processes and phenomena occurring in the sphere of final consumption economics i.e. that final stage of social reproduction where the completeness of satisfaction of objective existential needs and full development of the human personality (family, social stratums and the entire population) is provided; 2) it scarcely investigates the existing levels of people differentiation according to their needs and does not determine the ways and mechanisms of overcoming poorness and poverty and respective limitation of wealth and luxury; 3 ) its increased focus is on the analysis of hypothetic macrodependencies determining the Pareto efficiency depending upon the following the pattern of utilitarian possibilities, applying of the principles of compensation and variants of choice between economic efficiency and social justice and also investigates market failures in solving the problems of welfare and possibilities of the influence of the state on the elimination of negative market externalities which bar welfare gain; has no distinct developed welfare criteria (cost-natural borders of extended reproduction) in respect of an individual, family, social group, class or the entire society. Thus, normative-budget concept relates the essence of its scope of research with making of decisions basing mostly on value judgments and relates to what must be in difference from positive economy which gives an opportunity to give scientific credence to the functioning of economy and relates to what exists or what may exist.

Consequently, during the second half of XIX century till the 20s of XX century the main focus in "living standards" investigation was on the extension of its interpretation, determining the factors causing inequality of the material welfare of people, the issue of poverty reduction. The researches became more practical each year.

Starting from the following period and up to nowadays the scientists continued the perfection of researches definitions and directed them into more social-oriented framework. Along with "living standards" category appeared such as "poverty rate", "wage rates", "unemployment rate", "way of living", "quality of living", "development of humanity" etc. 
The middle of the XX century was marked by the appearance of the living quality concept which underpinned that economic welfare gain of the population does not result in social, moral and spiritual growth. The most precise definition of the term "quality of living" nowadays is given by I.V. Gukalova. Quality of living is the category characterizing the living conditions and the stand of population in the specific environment from the point of view of its capability of providing reproduction and sustainable society development. This is territory-specific social-environmental-economic efficiency of the realization of needs the main of which is the need for sustaining of life and health [12].

In the early 80 s the ideas of quality of living concept provided the basic human development concept. Its foundation was determined by the strengthening of social orientation of economic development in advanced countries on the one part and by the problems of inequality of the countries of the world - on the other part. This resulted in the understanding that development characteristics may be not only traditional macroeconomic indexes, GDP amount in particular and income per head of population. In the above concept personal development is determined as not only as the achieved level of welfare but also as the process of personal possibilities growth - a person has to live a long life, be healthy, educated, use political and economic freedom, human rights and social respect towards personality.

Ukrainian scientists of that time made their contribution into the theoretical study of "living standards" category. They suggested treating the definition of "living standards" category in the narrow and broad sense. In the narrow sense living standards is determined by the level of satisfaction of personal needs and respective level of personal income providing personal consumption. In the broad sense it is the characteristic of social and economic stand of life of population and is determined by the actual level of consumption of material, spiritual and social weal and services, level of satisfaction of rational (intellectual) needs. At the same time there appeared the first regional theoretic-methodological researches of living standards of the population of the state. A concept of living standards of the population was also developed what promoted inclusive development of all the members of the society.

A number of outstanding scientists of the Institution of social-economic problems of the population RAS headed by N.M. Rimashevska considered the widest category to be "welfare of the population" which generalizes 
"conditions", "level", "way" and "quality of living". Consequently Soviet scientists provided a clear definition of "living standards" category, deepened theoretic-methodological aspect of its investigation, completed it with the synonymic definitions which are widely applied nowadays. Within Ukrainian scientific circles the most popular are the researches concerning living standards of the population although this branch still remains insufficiently investigated. The majority of the researches reflect different social economic aspects of transformations mostly at the state level. Investigated are the phenomena of poverty, analysed are incomes and expenses, property differentiation and the issues of the determining of middle class criteria. The problems of living standards are only began to be investigated. At present among the modern Ukrainian researches prevails the approach towards living standards in the narrow and broad sense. Thus, O. Bogutsky suggests differentiating the category in the narrow sense - in order to refer to personal needs of people solely; in broad sense - actual level of consumption of material, spiritual and social weal and services, level of intellectual needs satisfaction etc. Personal needs are one of the basic categories in the process of living standards analysis which differ a personality from others in physical, intellectual and social aspects. The sources of their satisfaction are incomes of society [10, c. 43]. V. O. Mandybura treats living standards in broad sense as "... the totality of relations and conditions determining life, labor, living and intellectual-cultural personal development, characterizes the level of satisfaction of various needs of population achieved in the society for a certain period of time (not only physical but also social, intellectual and spiritual) and also determines and estimates real economic sources and social-legal warranties of population activity" [11, p. 18]. In the researcher's opinion this category is relative as far as depends not only on the level of real income and consumption and also on the extent of the development of needs themselves. In other words, the dynamic of living standards is determined. It is also specified that living standards is a multilevel category with its own structure where the three basic levels are outlined: integrated, social differentiated and individual-personalized (or family). Challenging is the idea of F.B. Uzunov who suggests that living standards of the population is qualitative and quantitative characteristics of the level of achievements, human life component. From O.G. Topchiev's perspective living standards of the population are the main component-wise specifications of activity conditions. I. V. Gukalova under the notion of "living standards" means the 


\section{Tomchuk-Ponomarenko Nataliia}

scope of realization of the needs of population which appear to be the basic unit of measurement [12]. O.Iu. Miroshnychenko asserts that at present living standards is a multicomponent social-economic category with complex interior structure the essence of which is not limited to material living conditions. According to the results of research-methodological development in respect of living standards of the population development the author suggested classification of the factors influencing living standards of the population comprised of six groups: economic, social-political, social-legal, intellectual-cultural, environmental-climatic and historical [13].

Consequently living standards of the population is one of the most complex social economic categories explaining the existence of its different interpretations: from philosophic-worldview including statistical. The major characteristics influencing the investigation of living standards are as follows: 1) dynamism of the category; 2) wide and narrow interpretation; 3 ) outlining of macro- and microlevel of researches; 4) individual and social load of the category; 5) satisfaction of certain category of needs of the population (material or spiritual); 6) taking into account objectives differences in living standards of the population as a result of labor application in different spheres of economic activity and regional development differentiations [14].

\section{Conclusions}

1. The above analysis of the history of living standards investigation has been proving its actuality and practical effect for many centuries. The specifity of "living standards" category lies first of all in impossibility of its rendering by any single relation or index. For that reason there exist a burning necessity of structuring the integral system of characteristics and indexes providing overall estimate of the investigated category. Present-day realities of Ukraine encourages to develop a unique concept of living standards, perfection of theoretical and methodological approaches towards its investigation with social-economic, cultural and spiritual differentiations with each particular region taken under consideration.

2. The state social policy, aimed at raising the standard of living of all segments of the population, should be connected with such tasks of stable economic development as ensuring real growth of production, improvement of the situation on the national labor market, containment of inflation processes, effective use of budget funds and means of special extrabudgetary funds. It is the effective macroeconomic development that provides the 
foundation for the country's social development and ultimately determines the level of well-being of its population.

3. The most important direction of the social and economic policy of the government and the state should be the achievement of a stable positive dynamics of the welfare of the population on the basis of increased demand for money, the development of a system of social standards that would really ensure a decent standard of living for the population and meet European standards, and its implementation should include gradual stages of achievement these standards for several years separately for each category of the population.

\section{References:}

1. Petty U. (1940). Ekonomicheskiye i statisticheskiye raboty. M.: Socekgyz, pp. 70-71. (in Russian)

2. Anthology of Economical Classics: V. Petti, A. Smith, D. Ricardo / Sost., Aut. prelude IA Joiners - Moscow: Ekonov,: Key, 1993. P. 475. (in Russian)

3. Keri G. CH. Rukovodstvo $\mathrm{k}$ sotsial'noy nauke. per. $\mathrm{s}$ angl. kn. L. N. Shakhovskoy. - Sankt-Peterburg: Izdaniye kn. Shakhovskogo, 1869. P. 704. (in Russian)

4. Kene F. (2008). Selected economic works. Moscow, Sotsekgiz. P. 1198. (in Russian)

5. Smith A. (2001). The Wealth of Nations. An Inquiry into the Nature and Causes of the Wealth of Nations. - K.: Port-Royal. P. 594. (in Ukrainian)

6. Pareto V. (1999). Manuale di economia politica (Book of Political Economy). - Ural LTD, P. 273.

7. Marshall A. (1993). Principles of Economics - M.: Progress, vol. 2, p. 219. (in Russian)

8. Pigou A. (1985). Economics of Welfare. - M.: Progress, vol. 1. pp. 73-74. (in Russian)

9. Marx K. (1963). Kapital. Capital. T.1 - K.: State Publishing House of Political Literature of USSR, pp. 23-26. (in Ukrainian)

10. Bogutskiy O. (1998). Analysis of socio-economic category of living standards of Ukraine // Ukraine: aspects of work. - no. 2. - pp. 43-47. (in Ukrainian)

11. Mandybura V. (1998). The living standards of Ukraine and problems of reforming the mechanisms of its regulation / D. P. Bohynya (executive editor). - K.: Parliamentary publisher, P. 255. (in Ukrainian)

12. Gukalova I. (2009). Yakist zhyttya naselennya Ukrayiny: suspilno-geografichna konceptualizaciya. Monografija - K., pp. 77-81. (in Ukrainian)

13. Miroshnychenko O. (2008). Statystychne ocinyuvannyja rivnya zhyttya naselennya: avtoref. dis. kand. ekon. nauk: 08.00.10 / O.Yu. Miroshnychenko. - K., pp. 1-5. (in Ukrainian)

14. Riven zhyttya naselennya Ukrayiny (2006). NAN Ukrayiny. In-t demografiyi ta soc. doslidzh., Derzh. kom. statystyky Ukrayiny; Za red. L.M. Cherenko. - K.: TOV "Vydavnytstvo "Konsultant", 2006, pp. 1-8. (in Ukrainian) 


\title{
THE MAIN THEORETICAL ASPECTS OF SYSTEM OF CRISIS MANAGEMENT AT THE ENTERPRISE
}

\section{Chupryna Natalia ${ }^{1}$ \\ Haievskyi Vladyslav ${ }^{2}$ \\ DOI: http://dx.doi.org/10.30525/978-9934-571-28-2_27}

\begin{abstract}
In national economy more and more attention is paid to research of effective ways of elimination of crisis situations. This situation which has arisen for today's period in domestic economy leads to active development of the crisis phenomena both on macro- and at the micro level, having carried out the activity analysis of business subjects, becomes obvious that many enterprises works is unprofitable, the amount of bankruptcies increases. All these questions demand from the enterprises to use those tools which will help to overcome the crisis phenomena in the activity and not to allow further bankruptcy of these enterprises. It has given an impetus for development and research of rather new type of management, it is anti-recessionary. A research object of this article is the analysis and the choice of the best management crisis methods by the enterprise.

Relevance research of crisis management for the Ukrainian enterprises demands a certain method by which it is possible to decide what methods will be necessary to a certain enterprise for an exit from a crisis.

The purpose of this article is studying of theoretical approaches to research of the concept "crisis management by the enterprise", consideration of the main problems of efficiency's crisis management by the subject of any business and lighting of the main instruments of crisis management by the enterprise.

Each enterprise has to carry out constantly monitoring as on a certain segment of the market where it conducts the direct activity, and to carry out introspection for prevention's emergence of the crisis phenomena. Enough
\end{abstract}

\footnotetext{
${ }^{1}$ Candidate of Economic Sciences. Associate Professor,

Dean of the Faculty of Economics,

Ukrainian State University of Chemical Technology, Ukraine

${ }^{2}$ Postgraduate Student of the Department of Marketing,

Ukrainian State University of Chemical Technology, Ukraine
} 
attention was paid to research of a question of crisis management. But, having conducted researches of methods' crisis management known for today omit at this stage of economy development for the domestic enterprises such method of crisis management as a benchmarking will be the best. For this reason the administrative board of any enterprise has to realize a role of system's crisis management at the enterprise as constantly existing subsystem.

\section{Introduction}

In national economy throughout the last period more and more attention is paid to research of a question of opportunities of an economic crisis and effective ways of her elimination. This situation which has arisen for today's period leads to active development of the crisis phenomena both at the macro level, and at the micro level as, having carried out the analysis of activity of subjects of any business, becomes obvious that many enterprises works is unprofitable, the amount of bankruptcies increases, grows creditor and debit debts. All these questions demand from the enterprises to use those tools which will help to increase efficiency of their current activity in the activity, to overcome the crisis phenomena and not to allow further bankruptcy of these enterprises. Therefore, before many owners of subjects of business there was a key question: "It is worth operating a subject of business which at this stage is on the verge of bankruptcy and whether it is necessary to do it in general?" It has given an impetus for development and research of rather new type of management - anti-recessionary which allows investigating the crisis phenomena during the certain period, to take certain measures for overcoming bankruptcy and development of this strategy which will allow not to allow creations of new crisis factors which will have much influence on financial economic activity of the enterprise.

Now many scientists-economists paid to a question of research of crisis management and its development attention. The big contribution to development of this research was lit in the works by an amount foreign and domestic scientists, namely: E. Altman, R. Keller, I. Ansoff, T. Taffler, A. Bolshakov, M. Pashuta, T. V. Bulovich, S. V. Kudlayenko, A. M. Tkachenko, A. V. Mikhaylenko, V. V. Kovalenko, M. V. Suganyaka, V. I. Fuchedzhi, A. A. Tereshchenko, V. A. Vasilenko, P. Ivanov, V. I. Koshkin, A. Galchinsky, V. Geyts, I. Zyatkovsky, M. Bilyk, V. Biver, 
J. Akerlof, R. Coase, K. Errou, M. Spens, J. U. Sharp, J. Schumpeter, P. Uotermen, A. Smith, E. M. Korotkov, Koretsky S. L., G. Birman, G. Brele, J. Finnera, S. Schmidt, R. lust, Gasanov S. S., Arefyev A. V., Koltsov, D. A. Ryabykh. However, despite a huge number of works in this direction of a research of an above-mentioned question, the research of a problem of crisis management and its main tools demands a further research. It can be explained with an economic and political crisis, development of economy of the state in general, well, and, of course, absence effective the institutional environment.

The purpose of this article is studying of theoretical approaches to research of the concept "crisis management by the enterprise", consideration of the main problems of efficiency of crisis management by the subject of any business and lighting of the main instruments of crisis management by the enterprise.

\section{Determination of class "crisis management" and its components}

Today it is possible to find the most various concepts of economic class "crisis management" in scientific literature. This economic class I have stayed it is widespread in many branches, such as: the right, law, economy, and marketing and is a lot of other social sciences. The research of the essence of crisis management usually consists in studying of his characteristic, certain features, tools, mechanisms and elements of process of crisis management.

We have tried to generalize the analysis of research of an interpretation of an essence of economic class "crisis management", is carried out by outstanding scientists-economists and to say it by means of the table.

\begin{tabular}{|l|l|}
\hline \multicolumn{1}{|c|}{ Author } & \multicolumn{1}{c|}{ Definition of the concept "crisis management" } \\
\hline Tulenkov N. V. & Any management of the organization has to be anti-recessionary \\
\hline $\begin{array}{l}\text { Minaeva E.S., } \\
\text { Panagushena V.P. }\end{array}$ & $\begin{array}{l}\text { Crisis management is not only the management focused on a } \\
\text { conclusion of the enterprise from a condition of crisis, and man- } \\
\text { agement which is capable to predict and prevent insolvency of } \\
\text { the enterprise according to the developed strategic program of } \\
\text { increase in competitive advantages and financial improvement } \\
\text { in advance. }\end{array}$ \\
\hline Meskon M. & $\begin{array}{l}\text { As the process of planning, the organization, motivation and } \\
\text { control necessary to formulate and make the goal facing the } \\
\text { organization. }\end{array}$ \\
\hline
\end{tabular}


The main theoretical aspects of system of crisis management at the...

Continuation of Table

\begin{tabular}{|c|c|}
\hline Ligonenko L.O. & $\begin{array}{l}\text { Permanent process of identification of signs of the crisis phe- } \\
\text { nomena and implementation of the master plan of prevention of } \\
\text { distribution of the crisis phenomena and stagnation of develop- } \\
\text { ment of the enterprise is carried out during the entire period of } \\
\text { his functioning. }\end{array}$ \\
\hline Vasilenko V.O. & $\begin{array}{l}\text { The management referred on predictions of danger of crisis, } \\
\text { the analysis of its symptoms and elimination of threats of emer- } \\
\text { gence of crisis situations, and in case of their emergence - the } \\
\text { analysis and acceptance the fast of measures of liquidating char- } \\
\text { acter with the smallest losses and negative consequences. }\end{array}$ \\
\hline $\begin{array}{l}\text { Keins Dj., } \\
\text { Kujel V.V. }\end{array}$ & $\begin{array}{l}\text { System of the measures from the state for providing restoration } \\
\text { and stabilization of development of economic system. }\end{array}$ \\
\hline $\begin{array}{l}\text { Damb. A., } \\
\text { Koshkin A., } \\
\text { Kryukova I. }\end{array}$ & $\begin{array}{l}\text { Anti-recessionary regulation is considered as the mechanism of } \\
\text { avoidance of bankruptcy and improvement of a financial condi- } \\
\text { tion of the enterprise. }\end{array}$ \\
\hline $\begin{array}{l}\text { Balashov A., } \\
\text { Ilin S. }\end{array}$ & $\begin{array}{l}\text { Crisis management - system of actions for restoration of sol- } \\
\text { vency of the enterprise. }\end{array}$ \\
\hline Bondar-Pidgirska O.V. & $\begin{array}{l}\text { Crisis management through creative activity of the enterprise } \\
\text { for the prevention of the crisis phenomena and recovery from } \\
\text { the crisis if the enterprise has already got into a crisis. }\end{array}$ \\
\hline Mahovka V. & $\begin{array}{l}\text { Crisis management as specific function has to be implemented } \\
\text { through performance of anti-recessionary actions, the ways } \\
\text { directed to the prevention, overcoming the crisis phenomena, } \\
\text { improvement of economic activity and restoration of stable } \\
\text { development of the enterprise, interacting with other main } \\
\text { functions of management; as process consists in interrelation } \\
\text { of all administrative activity directed to preparation and real- } \\
\text { ization of crisis response solutions on restoration and stabi- } \\
\text { lization of functioning of the enterprise in the conditions of } \\
\text { crisis; as the structure consists in definition of management } \\
\text { rules by the enterprise, allows defining hierarchy of levels } \\
\text { of management and communication between them, the level } \\
\text { of centralization and decentralization in the course of dis- } \\
\text { tribution of functions, powers, duties and responsibility of } \\
\text { employees of the enterprise of all levels during realization of } \\
\text { the actions directed to overcoming crisis; as the qualified and } \\
\text { professional administrative people having the corresponding } \\
\text { vocational training which main task is implementation of con- } \\
\text { tinuous monitoring of a condition of subsystems of the enter- } \\
\text { prise, early identification of signs of crisis and prevention of } \\
\text { her expansion (expeditious localization), holding preventive } \\
\text { improving actions. }\end{array}$ \\
\hline
\end{tabular}




\begin{tabular}{|c|c|}
\hline & Continuation of Table \\
\hline $\begin{array}{l}\text { Korotkov E., } \\
\text { Kotenko I. }\end{array}$ & $\begin{array}{l}\text { Management where it is properly adjusted crisis predictions, the } \\
\text { analysis of its symptoms, measures for minimization of nega- } \\
\text { tive impact and use of positive factors for further development } \\
\text { of the enterprise. }\end{array}$ \\
\hline $\begin{array}{l}\text { Bilovol R., } \\
\text { Ligonenko L., } \\
\text { Tereschenko O. }\end{array}$ & $\begin{array}{l}\text { Crisis management is considered as a part of the general system } \\
\text { of management at the enterprise at emergence of a crisis. }\end{array}$ \\
\hline Gryaznova A.G. & $\begin{array}{l}\text { It is such control system which has complex character and it is } \\
\text { directed to prevention or elimination of the phenomena, undesir- } \\
\text { able to business, by use of all potential of modern management, } \\
\text { development and realization at the enterprise of the special pro- } \\
\text { gram having strategic character and allows liquidating temporary } \\
\text { complications, to keep and increase market positions under any } \\
\text { circumstances, when using generally own resources. }\end{array}$ \\
\hline Ligonenko L. O. & $\begin{array}{l}\text { It is a part of management of the enterprise in general that rep- } \\
\text { resents the special, constantly organized management for the } \\
\text { most quick identification of signs of crisis state and creation of } \\
\text { the corresponding prerequisites for his timely overcoming for } \\
\text { ensuring restoration of viability of the separate enterprise, pre- } \\
\text { vention of emergence of a situation of his bankruptcy. }\end{array}$ \\
\hline Keller R. & $\begin{array}{l}\text { It is the special form of government which priority task is the } \\
\text { prevention or overcoming all processes which are capable to } \\
\text { create essential threat for activity of the enterprise or even to } \\
\text { exclude his functioning. }\end{array}$ \\
\hline Pokritan P. A. & $\begin{array}{l}\text { Is engaged in studying of system of the economic relations con- } \\
\text { nected with emergence of the crisis phenomena in the course of } \\
\text { functioning of subjects of economy. }\end{array}$ \\
\hline $\begin{array}{l}\text { Belyaev S., } \\
\text { Koshkin V. I. }\end{array}$ & $\begin{array}{l}\text { Makes set of forms and methods of implementation of anti-re- } \\
\text { cessionary ways according to the concrete enterprise debtor. }\end{array}$ \\
\hline $\begin{array}{l}\text { Minaev E. S., } \\
\text { Panagushin V. P. }\end{array}$ & $\begin{array}{l}\text { It is necessary to understand as crisis management not only the } \\
\text { management focused on a conclusion of the enterprise from } \\
\text { a condition of crisis, but also management which in advance } \\
\text { to predict and prevent insolvency according to the developed } \\
\text { program of increase in competitive advantages and financial } \\
\text { improvement. }\end{array}$ \\
\hline Utkin E. A. & $\begin{array}{l}\text { This management directed to the prevention of possible heavy } \\
\text { complications in market activity of the enterprise, ensuring his } \\
\text { stable, successful managing with orientation to expanded resto- } \\
\text { ration omit and own savings. }\end{array}$ \\
\hline $\begin{array}{l}\text { Burii S. A., } \\
\text { Maceha D. S. }\end{array}$ & $\begin{array}{l}\text { Crisis management is a system of constant system actions of the } \\
\text { managers directed to all elements of the organization for quick } \\
\text { and prompt response to possible external and internal threats at } \\
\text { effective functioning or development of the organization. }\end{array}$ \\
\hline
\end{tabular}


The main theoretical aspects of system of crisis management at the...

Ending of Table

\begin{tabular}{|l|l|}
\hline Shpachuk V. V. & $\begin{array}{l}\text { The administrative system based on the strategic principles is also } \\
\text { directed to maintenance of a steady, stable condition of any social } \\
\text { and economic system during the entire period of her functioning, } \\
\text { has complex character, is capable to adapt and change quickly } \\
\text { depending on external conditions, the environment. }\end{array}$ \\
\hline Dovgan D. A. & $\begin{array}{l}\text { Effective management gives the chance to bring firm out of cri- } \\
\text { sis, set of the actions directed to achievement or restoration of } \\
\text { solvency, liquidity, profitability and competitiveness of firm and } \\
\text { capable to lead firms to financial improvement. }\end{array}$ \\
\hline Blank I.O. & $\begin{array}{l}\text { System of the principles and methods of development and } \\
\text { implementation of the special administrative decisions directed } \\
\text { to the prevention and overcoming financial crises of the enter- } \\
\text { prise, and minimization of their negative consequences. }\end{array}$ \\
\hline Sitnik L.V. & $\begin{array}{l}\text { It is ability to develop best ways of an exit from a crisis, to decide } \\
\text { priority values of the enterprise in the conditions of crisis, to coor- } \\
\text { dinate activities of firm and its workers for crisis anticipation, to } \\
\text { try to get efficiency of their work in extreme conditions. }\end{array}$ \\
\hline
\end{tabular}

As we see, all definitions of this concept take place and at the current development of economy, and, having grouped them, it is possible to note that today crisis management by the subject of any business is used as for the prevention of development of the enterprise of crisis situations, and for control system adaptation to changes in external market environment of firm that will allow firm not to lose the positions in that segment of the market in which it functions. Because of it in firms it is necessary to create system of crisis management, will allow controlling the crisis phenomena, to carry out planning, the organization and realization of crisis response measures for effective functioning of the enterprise.

\section{The main making systems of crisis management}

Subject of crisis management are predictable and real reasons of crisis state of the enterprise, factors, the causing crises, consequences which involve crisis, which is all this what leads to equilibrium disturbance that causes threat of offensive and development of crisis. Main goal of crisis management - providing a stable financial position of business thanks to well-timed response to the changes caused by the external environment (it can be economic, social, political, demographic, international changes, etc.) by means of enforcement of anti-recessionary tools which will give well-timed elimination of financial complications in firm and will provide 
prevention of symptoms of bankruptcy on it. On the basis of researches of works of outstanding scientists-economists we will divide the main groups of the purposes of crisis management by the enterprise. The financial, staff, production, marketing and organizational purposes belong to such purposes.

The financial group of the purposes understands as itself rising of level of solvency of the subject of business, body height and prevention of reduction of the liquidity, and also minimization of consequences of financial crisis. The personnel purposes become clear of the name of group of the purpose. The main objectives of these purposes are depression of a current of staff and prevention of emergence of various crises through various negative factors (psychological, social, demographic, indifference, etc.). The staff purposes as the group of the purposes of crisis management at the enterprise is a depression of level of marriage of the made goods and the rendered services, preventions of obsolescence of the equipment, introduction of a know-how on production for the purpose of improvement of production and reduction of expenses, adjustment of the organization of production without the compelled stoppings. The marketing group of the purposes is that series for the enterprise, referred on definition of symptoms of crisis of activity of sale. Here it is possible to carry prevention of decrease of customers of goods, prevention of decline in quality of production in comparison with competitor companies, the analysis of the prices of similar goods, continuous monitoring of quality and costs of goods of the leading firms on certain segments of the market.

On the basis of research the formulated purposes of the enterprise it is possible to divide the following key tasks of crisis management of the subject of business:

1. Research of the external environment and internal activity of the subject of business and choice of strategy of his development on the basis of the forecast of a financial condition of the enterprise; 2. A research of the causes of the crisis phenomena in a certain segment of functioning of firm and in the enterprise; 3. Planning of an exit of the enterprise from a crisis; 4. Prevention of a current of skilled workers from the enterprise, constant improvement of activity of staff for improvement of indicators of activity of the enterprise at all stages of his activity; 5. Implementation of ways of crisis management of the enterprise and control of their unconditional performance. 6 . Introduction of the anti-recessionary program at the enterprise and control of her performance; 7. Analysis of results of introduction of 
the anti-recessionary program; 8. Implementation of continuous monitoring further with an opportunity to avoid crisis situations.

On the basis of researches of a number of works on crisis management of subjects of business it is possible to define the main methods of crisis management which can be divided on tactical and strategic. To tactical methods of crisis management of the enterprise it is possible to carry: diagnostics; monitoring; outsourcing; benchmarking; dutting; repolarization; controlling; audit of business processes; restructuring. Treat strategic methods: sanitation (external and internal) bankruptcy; merges; diversification; reengineering.

\begin{tabular}{|c|l|}
\hline $\begin{array}{c}\text { Method } \\
\text { of crisis } \\
\text { management }\end{array}$ & Essence and application \\
\hline Tactical methods & $\begin{array}{l}\text { Crisis can strike any of subsystems of the enterprise, and it means } \\
\text { that process of overcoming the crisis phenomena has to offer system } \\
\text { vision of all processes of development of anti-recessionary actions } \\
\text { and management of them. It is expedient to consider diagnostics as a } \\
\text { complex method of crisis management which will include the analy- } \\
\text { sis of activity of the enterprise in general, namely: situation, financial } \\
\text { and economic, organizational and administrative, production and eco- } \\
\text { nomic analyses. It should be noted that complex diagnostics will allow } \\
\text { revealing the problems caused by crisis, their reasons, the center and } \\
\text { to define the direction of crisis response measures which have to be } \\
\text { realized within restoration of a pre-crisis condition of the enterprise, or } \\
\text { improvement of management and functioning of the enterprise }\end{array}$ \\
\hline Monitoring & $\begin{array}{l}\text { The system of monitoring of crisis represents specially organized } \\
\text { actions for determination of chance and real possibility of a crisis } \\
\text { situation and is necessary for her timely identification. }\end{array}$ \\
\hline \multirow{5}{*}{ Outsourcing } & $\begin{array}{l}\text { The major reason of modern business caused by sharp changes of the } \\
\text { used technologies; optimization of activity and reduction of expenses } \\
\text { of the enterprise or organization on the basis of concentration on the } \\
\text { main fields of activity and transfers of secondary or non-core func- } \\
\text { tions to third-party performers. Outsourcing use as method of crisis } \\
\text { management will give the chance to the enterprise which is in crisis } \\
\text { state, to concentrate attention and the available resources on over- } \\
\text { coming the problems caused by crisis ensuring implementation of } \\
\text { primary activity and will allow transferring some risks to the com- } \\
\text { panies outsourcers, to increase controllability the enterprise in the } \\
\text { conditions of crisis, to improve organizational structure, to cut costs } \\
\text { of service and business processes and to increase profit. }\end{array}$ \\
\hline
\end{tabular}




\begin{tabular}{|c|c|}
\hline & Continuation of Table \\
\hline Benchmark & $\begin{array}{l}\text { The instrument of management, uses comparisons of data own and } \\
\text { the enterprises competing with him taking the advanced positions in } \\
\text { a certain segment of economy and allocation and introduction of the } \\
\text { best the practicing for development of own enterprise }\end{array}$ \\
\hline Dutting & $\begin{array}{l}\text { Reduction of production capacities and the number of production and } \\
\text { administrative staff of the enterprise according to real demand and } \\
\text { market opportunities. Use of this method leads to much reduction of } \\
\text { constant expenses, reduction of product cost. }\end{array}$ \\
\hline Regularization & $\begin{array}{l}\text { Introduction of modern approaches to business management. Treat } \\
\text { such approaches: formation of system of strategic planning and man- } \\
\text { agement accounting, creation of complex system of financial control } \\
\text { and planning, the automated system of the account, full-fledged mar- } \\
\text { keting services and so forth. By means of this method the enterprises } \\
\text { form the control systems capable to solve large volume of the complex } \\
\text { problems connected with work in market conditions, an exit to inter- } \\
\text { national markets. New control systems allow aiming resources of the } \\
\text { enterprises at the further stable development. }\end{array}$ \\
\hline Controlling & $\begin{array}{l}\text { Rather effective by method of crisis management it is possible to call } \\
\text { controlling that represents synthesis of continuous monitoring of sig- } \\
\text { nificant changes, control, the economic analysis and diagnostics of a } \\
\text { financial state, planning, the organization of information streams for } \\
\text { adoption of administrative decisions that will allow predicting most } \\
\text { fully future crisis situations and to exercise effective crisis manage- } \\
\text { ment by the enterprise. Application of controlling in anti-recession- } \\
\text { ary managements will allow carrying out, first, information support } \\
\text { of decision-making for best use of the available opportunities and } \\
\text { resources, an appropriate assessment positive and the negative enter- } \\
\text { prises of activity, and prevention and avoidance of bankruptcy and cri- } \\
\text { sis situations; secondly, to increase the speed of reaction of managers } \\
\text { to changes of external and internal environment, to increase flexibil- } \\
\text { ity of the enterprise, to pass on control of the past to the analysis and } \\
\text { forecasting of the future. The set of works on studying of activity of } \\
\text { the enterprise directed to obtaining information on current state of his } \\
\text { affairs, to check of compliance of the operating business processes to } \\
\text { the requirements to business processes established in normative and } \\
\text { organizational and administrative documents of this enterprise, and } \\
\text { also carrying out the analysis and an assessment of efficiency busi- } \\
\text { ness - processes on certain indicators. Use of these methods in crisis } \\
\text { management to promote high-quality improvement of characteristics } \\
\text { of activity of the enterprise and acceptance to his fast getting out of } \\
\text { crisis state Implementation of the organizational and economic, legal, } \\
\text { technological actions directed to change of structure of the enterprise, } \\
\text { his management, managing forms which can offer to the enterprise } \\
\text { financial improvement, increase in volumes of release of competitive } \\
\text { production, increase in production efficiency. }\end{array}$ \\
\hline
\end{tabular}




\begin{tabular}{|c|c|}
\hline & Ending of Table \\
\hline Controlling & $\begin{array}{l}\text { It is expedient to apply at early stages of life cycle of the enterprise } \\
\text { and when crisis is inevitable, however at this stage restructuring takes } \\
\text { place more difficult. It is carried out for the purpose of overcoming } \\
\text { the reasons of strategic crisis and crisis of profitability. }\end{array}$ \\
\hline $\begin{array}{l}\text { Audit of busi- } \\
\text { ness processes }\end{array}$ & $\begin{array}{l}\text { The set of works on studying of activity of the enterprise directed to } \\
\text { obtaining information on current state of his affairs, to check of com- } \\
\text { pliance of the operating business processes to the requirements to busi- } \\
\text { ness processes established in normative and organizational and admin- } \\
\text { istrative documents of this enterprise, and carrying out the analysis and } \\
\text { an assessment of efficiency business - processes on certain indicators. }\end{array}$ \\
\hline Restructuring & $\begin{array}{l}\text { Implementation of the organizational and economic, legal, tech- } \\
\text { nological actions directed to change of structure of the enterprise, } \\
\text { his management, managing forms which can offer to the enterprise } \\
\text { financial improvement, increase in volumes of release of competitive } \\
\text { production, increase in production efficiency. It is expedient to apply } \\
\text { at early stages of life cycle of the enterprise and when crisis is inevi- } \\
\text { table, however at this stage restructuring takes place more difficult. It } \\
\text { is carried out for the purpose of overcoming the reasons of strategic } \\
\text { crisis and crisis of profitability. }\end{array}$ \\
\hline & \\
\hline $\begin{array}{l}\text { Sanitation: } \\
\text { - external } \\
\text { - interior }\end{array}$ & $\begin{array}{l}\text { System of the financial and economic, technological, organizational } \\
\text { and legal and social actions directed to achievement of solvency, } \\
\text { liquidity, profitability and competitiveness of the enterprise of the } \\
\text { debtor in long-term period. It is applied at emergence of threat of } \\
\text { bankruptcy; } \\
\text { Set of all possible actions which are capable to lead the enterprise to } \\
\text { financial improvement at the cost of own sources. } \\
\text { It is applied at bankruptcy threat emergence. }\end{array}$ \\
\hline Bank & $\begin{array}{l}\text { The inability of the debtor recognized by economic court to restore } \\
\text { the solvency and to meet the requirements of creditors recognized } \\
\text { by court precisely through application of the liquidating procedure. }\end{array}$ \\
\hline Merger & $\begin{array}{l}\text { Association within one organization of various stages of produc- } \\
\text { tion and distribution, different types of activity. Application of this } \\
\text { method becomes expedient when such integration leads to essential } \\
\text { economy at a scale or to much reduction of transaction expenses. }\end{array}$ \\
\hline Diversification & $\begin{array}{l}\text { Expansion of a field of activity of the enterprise in any direction not } \\
\text { to be dependent on one market. It is applied at the beginning of cre- } \\
\text { ation of the enterprise and at the first signs of crisis. }\end{array}$ \\
\hline Reengineering & $\begin{array}{l}\text { Consists in a redesign of business processes of the enterprise. Due } \\
\text { to reduction of excess links and operations in business processes, } \\
\text { excess expenses of time and other resources, reengineering allows } \\
\text { reaching sharp, spasmodic increase in indicators efficiency of activ- } \\
\text { ity, such as labor productivity, holding time or production of produc- } \\
\text { tion, prime cost and so forth. }\end{array}$ \\
\hline
\end{tabular}




\section{Indicators of efficiency of use of crisis management by the enterprise}

Success of crisis management of the enterprise directly depends on performance of certain functions. Functions of crisis management - it is separated from each other the directions of administrative activity which essence consists in prevention of emergence of anti-recessionary actions. If to pass to a specification of definition of the main functions of crisis management, then note that all of them are set of certain actions and operations which aim at anti-recessionary character and which are carried out for coordination of the main actions of firm at an exit from a crisis. Having carried out the detailed analysis of works of outstanding economists we will allocate the main functions of crisis management: planning, organization, motivation and control. It can be explained with the fact that it is rational to investigate crisis management of the subject of any business as one of the functional directions of management of firm and to define him as the process of planning, the organization, motivation and control necessary for formation and achievement of the tasks defined before the enterprise. By definition of efficiency of crisis management by the enterprise and factors, it defining that should be noted that the matter was subject slightest to research though becomes clear that determination of such key categories as result, efficiency indicators, effect are key questions in formation of a control system of any subject "object of business. The research of problems of efficiency and the main approaches to an assessment of efficiency was subject to studying by many famous scientists-economists that has given the soil for formation of several directions of determination of these categories and formation of estimated indicators of efficiency of crisis management of the enterprise.

Now the following types of efficiency are created: 1 . Depending on the achieved results - economic which in the general sense means a ratio of the achieved results and the spent materials necessary for their achievement and, also, social efficiency which considers social indicators (improvement of working conditions, healthy psychological climate in the enterprise, preservation of jobs, etc.); 2. Depending on the place of obtaining effect - shares on economic, belonging to society or commercial effectiveness which can be, also, divided into efficiency of firm, efficiency of division (department, service), efficiency of separate operation, etc.; 3. Depending on a calculation method - absolute efficiency that gives the general or specific the characteristic of efficiency of activity of the subject of business for the certain 
period, and comparative efficiency defining results of comparison of alternative options and the choice of the best of them; 4 . Depending on approach to an assessment - partial, indicative and full efficiency; 5. Depending on an assessment object - it can be production efficiency, efficiency of use of labor, material and financial resources, efficiency of the organization of any administrative process of activity, system effectiveness of management of firm; 6. Depending on extent of increase effects - is divided into primary (first) efficiency, animated and work together efficiency. We will pass to more complete definition of above-mentioned types of efficiency: Primary efficiency - is disposable effect which is defined at the initial stage thanks to realization of certain actions (technological, economic, social, organizational, technical, etc.).

Animated efficiency is a result of repeated use of innovations not only at subjects of business, but also in other fields of activity. Animated efficiency lights the activity in the following forms:

1. Effect of "starting explosion" that in essence means a geometrical progression of increase in effect under the influence of primary impulse; 2 . The resonant effect is an effect which arises with activation and stimulation of development of the positive phenomena both on own, and in competitor companies (spheres of economy); 3. The effect of acceleration is an effect which in essence characterizes acceleration of rates of distribution of a certain positive result; 4 . The effect of accompanying opportunities - this effect is shown in a section of intermediate and side positive effects; 5 . The diffusion effect is an effect which can be received by means of the greatest distribution to other spheres of activity. Synergy efficiency represents cumulative influence of all innovations on a financial and economic condition of the enterprise exceeds the arithmetic sums of the effects gained from all executed actions.

After we to define the main components of crisis management by the enterprise, we will try to define the main criteria by which it is possible to define efficiency of crisis management by the subject of business: 1 . Changes to the best key indicators of financial and economic activity in general and a financial condition of the company in general during definition of crisis and performance of the main actions for her elimination; 2. A gain of the main indicators of financial and economic activity for a certain time period (week, month, quarter, decade, etc.); 3. Definition of profitability of obtaining result, which is an assessment of a ratio of the achieved results of financial and economic activity of the enterprise to the volume of all expenses 
necessary for an exit from an anti-recessionary situation; 4. The analysis of the reached indicators with those which have been defined for achievement by firm for the purpose of an exit from a crisis and studying of results with the next conclusion about sufficiency of changes for restoration of activity of firm. These criteria allow defining the main indicators of efficiency of crisis management by the enterprise by means of which it will be possible to estimate all system of crisis management by the enterprise.

\section{Conclusions}

Expediency and efficiency of crisis management by the enterprise it is caused by the general influence of the following factors: 1. Professionalism and enough vocational training, and personal qualities of the subject of crisis management; 2 . A possibility of formation of the anti-recessionary team capable to carry out the tasks set for her in the conditions of crisis ; 3. Support of managers of the company who are responsible for efficiency of her activity by workers and owners of the company, enthusiasm and ability of all to work as a unit with the exit purpose from crisis situations which have arisen before the enterprise; 4 . Development of administrative decisions which will allow overcoming the crisis phenomena; 5. Validity of carrying out receptions and analytic researches which take place at all stages of implementation of crisis management by the enterprise; 6 . Sufficient efficiency of crisis management by the enterprise during implementation of anti-recessionary actions; 7. Existence at the enterprise of programs which will allow carrying out holding diagnostic and predictive rules and researches for definition of the best options for creation of effective system of crisis management. Having considered the making systems of crisis management becomes obvious that activity of all subjects of business has to be directed to crisis management. Process of an exit of firm of a crisis situation it has to be carried out not chaotically, and it is consecutive according to all above-mentioned stages of carrying out crisis management at the enterprise. Each enterprise has to carry out constantly monitoring as on a certain segment of the market where it conducts the direct activity, and to carry out introspection for the purpose of prevention of emergence of the crisis phenomena. But at this stage of development of economy for the domestic enterprises such method of crisis management as a benchmark will be the best. For this reason the administrative board of any enterprise has to realize a role of system of crisis management at the enterprise as constantly existing subsystem. 


\section{References:}

1. Barinov V. A. Crisis management: studies. Grant, Moscow: IDES FBK Press, $488 \mathrm{p}$.

2. Bondar Pidgurska O. V. (2013) Innovative activity of the industry in the conditions of global crisis. Technological audit and reserves of production. Kharkiv. № 2/2 (10), p. 18-22.

3. Vasilenko V. O. (2003) Crisis management by the enterprise: Studies. grant, Kiev: TsUL, 2003, p. 289-299.

4. Mahovka V. M. (2013) Methodology of formation of system of crisis management by the enterprise, All-Ukrainian scientific and practical magazine Innovative economy, No. 1 (39), p. 102-105.

5. Mahovka V. M. (2012) Process, methods and functions of crisis management at the enterprise. Scientific bulletin of the Poltava university of economy and trade, No. 1 (52), p. 219-225.

6. Mihova A. V. (2009) Crisis management by personnel a condition of effective functioning of the company during crisis. Retrieved from: http://www.confcontact.com/2009_03_18/ek6_mihova.php

7. Sheremet O. O. (2005) Financial analysis: Manual, Kiev, p. 117-120.

8. Yakovleva Yu. S. (2006) Assessment of financial stability of the enterprise for criterion of indicators of stability, Finance of Ukraine, No. 5, p. 29-31. 


\title{
BANKS FOR BRICS ECONOMIC DEVELOPMENT
}

\section{Yarygina Irina ${ }^{1}$}

DOI: http://dx.doi.org/10.30525/978-9934-571-28-2_28

\begin{abstract}
The article deals with important issues within BRICS international economic relations and displays the role of banks as intermediaries that supply clients with financial instruments and contribute to successful development of economic entities. Assessment of market demands of BRICS displays the necessity of the long-term financing and project management, based on transparent information flow. Common economic interests and public support back effective BRICS relationship. Expertise of the Central and Eastern European countries developments has proved that intergovernmental support and sustainable banking activity promote progressive actions in international economic relations. The results of the complex study provides a strong case for inter - banking within BRICS, which should be taken into consideration by public and private institutions while constructing economic and political approach to financial infrastructure. Economic needs and mutual interests are certainly a step in the right direction.
\end{abstract}

\section{Introduction}

Actually, BRICS economic development plays the key strategic role in its banking and finance. There is no denying the fact, that effective banking strategy depends on accurate assessment of common problems and a search for mutual solutions to increase quality of life in member countries.

From the European experience, fast liberation of financial-economic relationships leads to decline in some areas of economy, including strategically important ones, and to slowdown of government regulation of key industrial areas, which leads to increase of bank speculations and high-risk level of economic environment. To find the way in turbulence is the main task for the government that has to use different vehicles, intergovernmental monetary and fiscal measures including.

${ }^{1}$ Doctor of Economic Sciences, Professor,

Professor at Department of World Economy and World Finance, Head of Programs,

Financial University under the Government of the Russian Federation, Russian Federation 


\section{Banks for brics economic development}

\section{Literature review}

The theory of fiscal federalism identifies main functions for the public sector: macroeconomic stabilization, income distribution and resource allocation(Oates, 1999) [1]. The problem of fiscal decentralization in developing countries are carefully studied by Fukasaku and de Mello (1999), Manor, Crook and Manor (1998-1999), that tried to give reason to the restructuring of government and market functions. Some scholars within the public choice school consider that decentralization tends to increase competition among jurisdictions (Brennan and Buchanan, 1980; Breton, 1989). Anyway, in globalized economy developing countries (Ahmad, 1997) require the mechanism of intergovernmental grants transfers. Thus, the intergovernmental financial institutions can contribute to it, supplying the country-members with unconditional, conditional and equalization grants (Brosio, 2000).

There is no denying the fact, that only international experience can provide useful methods for policy makers (Bird and Vaillancourt 1998), but the approach of laissez-faire or market fundamentalism has a week potential to solve most economic and social problems (Stiglitz, 1998). Market fundamentalism was popularized by George Soros in "The Crisis of Global Capitalism" (1998) with its trust in a free market mechanism. That is a privilege of a genius, but practice has proved the approach of J. E. Stiglitz, who criticized the IMF, advocating a set of policies, which is generally referred to the market fundamentalism, "based on an incorrect understanding of economic theory and as an inadequate interpretation of the historical data." The correct understanding means reasonable regulation and cooperation in solving mutual problems and meeting new challenges. There is an on-going process of reengineering international cooperation within globalized economic environment. The speed of cooperation depends on macro and microeconomic factors, as well as participation in the global market, supply of the products and political support. Mutual aims of any government are linked with economic and social developments, as well as successful production, safe banking, financial stability and effective debt management that is the main feature of globalization. The goals can be reached within BRICS cooperation.

\section{Research methods}

The study of financial institutions' role within BRICS is based on complex research methods, based on gathering and analyzing data, needed 


\section{Yarygina Irina}

to answer the research goal. Mostly used were qualitative and mixed methods. Within these categories, more specific approaches, including an array of options, case studies, self-reporting and surveys were applied. The mixed methods of research, that included contextual understanding like interviews or observations, were combined with facts and statistics, that contributed to the investigation of the subject on multiple levels, gaining different views and a comprehensive look at the research, An applied mixed methodology led us to the integration of different theories and ideas. While carrying out the qualitative research, there was a goal to explore specific phenomena, not to prove a prediction, according to qualitative research methods. The assessment of interviews, focus groups and observation of main developments and contract arrangements were also used to collect data. Used qualitative methods provided rich, contextual explorations of the topic that is culturally meaningful.

\subsection{BRICS banking}

\section{Research results}

BRICS developing economies play a special role in contemporary world. They are characterized by a dynamic development, which is particularly important in situations of post-crisis development. BRICS have advantages in economic activity which is distinguishing them from the other countries, including big human potential; vast reserves of natural resources (water, forest, bio-resources, minerals, energy, etc.); large domestic market, etc. Financial markets are of particular importance for the development of the economies of the BRICS. They has constantly improved, actively developing. Experts believe that in the near future due to the growth and development of financial and credit institutions of the BRICS the world economy and stock markets will grow rapidly. In this regard, of particular interest is the banking sector. On the form of ownership of the banking sector introduced the BRICS by private banks, public (which occupy leading positions on deposit and loan transactions), as well as banks with foreign capital.

In Brazil there are about 180 private commercial banks. One third of these banks have deposits of more than 100 billion. dollars. United States. Along with commercial banks operate about 30 commercial government development banks and public banks, savings and loans, investment banks and 20 others. A key part of Brazil's banking system is the Banco Central 


\section{Banks for brics economic development}

do Brasil (Central Bank of Brazil), founded in 1808. It is considered to be the oldest Bank in Brazil and one of the oldest in Latin America. The Bank is a company with mixed capital, $68.7 \%$ of shares belongs to the Federal Government of Brazil. The Bank's shares are traded on the San Paulo Stock Exchange. Currently, the Bank has 9200 branches in Brazil and 32 representative offices abroad. The size of Banco do Brasil's assets exceeds $17 \%$ of banking assets in the country. Federal Savings Bank (Caixa Economica Federal), founded in 1861, is the second largest bank in the country at the $100 \%$ owned by the state. The third position is held by Bradesco Bank, founded in 1943. Currently the Bank is one of the largest banks in Brazil. The Bank Bradesco offers its customers a wide range of banking operations and services in Brazil and abroad. Ten largest banks in Brazil include have assets over 100 billion dollars. The State controls 10 Brazilian banks, 6 of which are owned by the Federal Government and the 4- Governments of states. Under the supervision of the State are the biggest credit institutions (in particular, Banco do Brasil and Caixa Economica Federal), while the others run by private capital-Brazilian and foreign.

Russia since 1987 has a two-tier banking system provided by the Central Bank of the Russian Federation (Bank of Russia) and credit organizations. In April, 2017 the State Duma adopted the Federal law on the division of banks of the second level of banking system: a) with the base license and b) banks with universal license that allows commercial banks to carry out a specific (under license) a list of banking operations and services. The Bank of Russia is implementing now a differentiated supervision of these banks in accordance compliance with prescribed obligatory standards of banking activities. In Russia prevail joint-stock commercial banks: a) the state-controlled banks); b) controlled by foreign capital; c) major private banks; d) medium and small regional banks. The number of state-controlled banks include: Sberbank (Savings bank), VTB, Rosselkhozbank (Russian agricultural bank), Gasprombank, etc.

Over the past 10 years (from 01.01.2007 to 01.01.2017) number of Russian banks has fallen almost doubled from 1143 to 575 . At the same time:

- the proportion of top-5 banks in total assets increased from $42.5 \%$ to $55.3 \%$ (a percentage of banks with 201 seats and below dropped from $8.2 \%$ to $2 \%)$; 
- the ratio of large credit risks to the capital remained almost unchanged (240.6\% and became 236.3\%);

- capital adequacy has declined from $14.9 \%$ to $12.7 \%$; return on assets fell from $3.2 \%$ to $0.9 \%$;

- the percentage of credit as a source of capital investment fell from $8.7 \%$ to $5.9 \%$;

- asset dynamics completely unfolded: with $+43.3 \%$ to-3.5\%;

- the proportion of established reserves for possible losses increased from $3.2 \%$ to $7 \%$ of the total volume of banking assets.

The state-owned banks account for the major proportion of the total banking assets (about 50\%)/ These credit institutions occupy a significant share of the market of bank services. In particular, according to the Central Bank of Russia, at the beginning of 2017, they accounted for about $45 \%$ of all deposits and other borrowed funds of companies and $70 \%$ of deposits of the population. Now about 100 banks, controlled by non-residents operates in Russia. They have $25 \%$ of all bank assets. This is mainly credit institutions with $100 \%$ foreign participation. A total of 136 large private banks. The most numerous group-medium and small regional banks. But despite their dominant numbers, they occupy a modest place in the banking sector, focused $5.4 \%$ of all assets, about $3 \%$ of the deposits of enterprises and organizations, $7 \%$ of deposits and loans to corporate borrowers and to the population, make up less than 5\%. Russia's banking sector for a number of reasons the macroeconomic and national level (including the change of economic formation in the 1990-ies, the successive economic crises (1998, 2005), the global banking crisis 2008-2010, Ukrainian and Crimean crisis (2013-2014) and subsequent sectoral sanctions) is behind in the development of the leading countries in Western Europe and the United States as well as China, India and Brazil. A key issue for the development of the Russian banking system is the slow growth of GDP in Russia, the country's sovereign rating, low volatility in the financial markets and a high level of risk.

India operates a two-tier banking system. The first level of which is the Central Bank - Reserve Bank of India. It manages the public debt of the Central Government and State Governments, holds hard currency reserves of the country and oversees the repatriation of export proceeds, the return of invested capital abroad for investments inside its country and payments for imports. Reserve Bank provides short-term loans to State Governments and 


\section{Banks for brics economic development}

registered banks, and provides short-and medium-term credit to cooperative banks in the states and to financial and industrial institutions. The banking sector of India includes commercial, cooperative, regional rural banks and non-bank financial institutions. Commercial banks are divided into state-controlled, private and foreign. Of commercial banks $27 \%$ are statecontrolled, 30\% private banks and $40 \%$ are foreign. In India there are restrictions on the participation of foreign capital in Indian banks. Nonresident shareholders may have up to $74 \%$ of shares. Currently, ICICI Bank, which controls a quarter of the entire market of banking services in India, $68 \%$ of shares are owned by non-residents. For the state banks of India the proportion of foreign shareholders is limited and may not exceed $20 \%$. State-controlled banks dominate the banking sector in India, they account for about $75 \%$ of assets, $79 \%$ of deposits, $78 \%$ of loans, $79 \%$ of banking capital. State banking sector comprises 28 credit organizations, led by State Bank of India (State Bank of India, SBI). On the sizes of the leading Indian banks are not inferior to the world-class banks. India currently operates 36 foreign banks, as well as 68 corporate banks (small companies serving predominantly farmers, artisans and small entrepreneurs; issue is usually short-term and medium-term loans).

China's banking system is represented by the Central Bank, banks for special public funding, state commercial banks, joint-stock banks, city commercial banks and non-banking financial institutions (urban and rural credit cooperatives, trust investment companies). Credit institutions for public funding are specialized banks, that should support economic policy of the Government. Among them there are China Development Bank, Export-Import Bank of China and Agricultural Development Bank of China. Through them, the State allocates funds to stimulate the development of priority sectors or objects. There are four largest bank in China with the state capital: the Bank of China (Bank of China), Industrial and Commercial Bank of China (ICBC), the Agricultural Bank of China and China Construction Bank (CCB). More than 10 joint-stock commercial banks were opened in China mainly by enterprises on a mutual basis. In most cases, a majority stake is owned by the State, represented by the Government agencies or state enterprises.

Total assets of the commercial structures represent $15 \%$ of the total banking assets. The main objective of urban commercial banks issuing loans to support and develop local infrastructures. Similar financial institutions 
exist only in major cities (Shanghai, Beijing, Zhengzhou). There are more than 100 urban cooperative banks or urban commercial banks in China, whose activities are limited to these cities. Their total assets account for $10 \%$ of all bank assets. These credit unions have a long history and have developed branch network in China and a large number of affiliates abroad. Other financial institutions include urban and rural credit cooperatives, rural commercial banks, investment, finance and credit trust companies, foreign banks and others. The non-bank institutions segment occupies a significant place in the financial markets of China, there are more than 36 thousand (they accounted for $27 \%$ of all bank assets).

The pillars of the banking system of the Republic of South Africa can be attributed to South African Reserve Bank (Central Bank), commercial banks and specialized financial institutions (the State Development Bank of Southern Africa (financing of infrastructure projects in the region SADC (the Southern African development community), the Industrial Development Corporation (industrial projects), Land and Agricultural Bank (agricultural lending). The banking system of the Republic of South Africa is well developed and effectively regulated. In recent years, many foreign banks and investment companies began to work in South Africa. In South Africa operates: 17 registered banks, 3 credit union banks, 1 cooperative bank and 14 branches of foreign banks. Major banks in South Africa are: ABSA (Absa Group Limited), FirstRand Group, FNB (First National Bank), Standard Bank Group, South African Reserve Bank. ABSA (Absa Group Limited) is one of the leading financial groups in South Africa, formed in 1991; the Bank serves more than 11.7 million customers and is a division of Barclays Bank from 2005, 55.2\% of shares belongs to the group. FirstRand Group (founded in 1988) has assets of more than 125 billion dollars, provides investment banking, asset management, wealth management and advisory services. FNB (First National Bank) is the oldest South African Bank, founded in 1838. It is part of the "big four" banks in South Africa and has branches in Mozambique, Botswana, Namibia, Swaziland and Zambia. Currently is a division of FirstRand Group. Standard Bank Group (Standard Bank) from 1862 is the largest bank in South African Republic in terms of assets and profits. The Bank operates in 33 countries around the world, including 17 African countries and has more than 600 offices in South Africa and more than 400 outside the country within the continent. The Bank employs over 50 thousand employees worldwide, of whom about 


\section{Banks for brics economic development}

35 thousand are in South Africa. South African Reserve Bank is the Central Bank of South Africa established by Parliament in 1921. The primary function of a bank is to provide financial stability for the achievement of sustained economic growth in the country.

Analysis of BRICSvnational banking systems allows to draw some conclusions. Firstly, all BRICS countries are characterized by significant government involvement in the banking sector. The largest banks that define the state and development of banking systems of BRICS are under the control of governments. This feature allowed BRICS credit institutions to overcome global financial and banking crisis 2007-2009 easier than the developed countries.

Secondly, it is clear that different scales, structure and degree of involvement in transnational activities on the world markets characterize these countries' banking systems.

\subsection{BRICS banking facility}

Research proves that banks of emerging markets are in a race towards "fast profits" and cut down on traditional operations (project financing, loans, etc.). Vast amount of operations is attributable to expatriation of capital into offshore zones. According to the World Bank, absence of banking support for economic development in ex-USSR countries lead to manufacturing decline of $65 \%$. However, in countries with government involvement and gradual market transformation - economy recovered faster (Belorussia, Kazakhstan, Uzbekistan). Use of reasonable government regulation of economy, as a whole, is a vital condition of development and formation of new approach to the realisation of commercial relationships and aids development of international banking. Effective cooperation between participants of BRICS countries is also influenced by the amount of government support given to economy during formation of market relationships. Under growing economic co-operation manufacturing feel pressure from their clients that require quality goods and services and from competition, which are able to offer better quality at a lower price. Sensible regulation of inter-state relationships encourage economic co-operation. In its tern, creation of common legislation base, which provides effective banking servicing of BRICS economy, will create stable foundation for collaboration. Establishment of essential conditions for interaction between credit institutions requires time and political power. The analysis 
of current developments of emerging markets has proved that banks are able to support economy sectors during growth of partnership by backing economic interest of countries and encouraging trade development that increases cooperation. Banking support for the least protected market participants - SMEs, entrepreneurships - driver and buffer of any economy will create favourable conditions for effective economic operations, creating employment, production of goods that are under market demand.

Effective global cooperation of BRICS countries connected with necessary design of common banking support strategic developments. Consequently, creation of a reasonable international strategy is possible by using holistic analysis of economic demands of each member-country. Reality has shown that absence of economic forecasting in banking activity leads to negative consequences. For example, "tax holiday" policy, granted to banks by state of Brazil when dealing with foreign investors caused overproduction of cars, which created stagnation of number of economical segments.

According to the European experience, it is important to provide legal coverage for property of economic partners - a key business component taking into consideration specifics of each country.

Formation of mutual economic strategy increases importance of banking intermediary, especially in the area of financial risk management, liquidity financing and management of financial capital. Country's economic development depends on the level of banking business involvement, attributable to customers and market partners.

Rating of market demands of BRICS shows that implementation of joint growth programme demands long-term financing, project financing, inclusive of syndicates and constant information flow in all segments of economy. Effective relationships between entities are built on foundation of common economic interests and governmental support. Expertise of many countries from Central and Eastern Europe has proved that public support and substantial banking activity desire to minimise change and promote progressive actions in restoration of economic ties.

During the formation of a mutual economic strategy, it is important to consider the experience of CEE countries, which overcome the consequences of market reforms in the economy, which showed that countries are not concerned with prospect of banking reform but how they are going to be implemented in reality. In this regard, presence of 


\section{Banks for brics economic development}

objectivity in progressive actions towards available financial resources is very important. Governments support of entrepreneurs who are dealing in area of international trade, unification of banking activity and policies will create favourable conditions for economic cooperation within BRICS.

Growth of economic ties of member-countries based on common values and development goals suggests a long-term strategic alliance of private credit institutions in the field of international trade, taking into account customer flexibility. Sound financial management, modernisation of banking technology will also contribute to the development of the BRICS market.

Support of the balance of interests of public and private structures, growing capacity of joint investment financing, strengthening the legal framework and improving the legal support of business - processes contributes to the development of economic cooperation of economic entities. In addition, banks' activities supporting economic cooperation among BRICS countries should be transparent and accessible to the customer, regardless of the place of accreditation if their business activities executed in the economic environment of these countries.

One of the important directions of banks - participants of international economic cooperation is a support programme of trade relations ("Trade Finance Promotion"), which assists customers in selecting contractors for International Cooperation.

Actually, small and medium-sized enterprises of BRICS membercountries have to apply adverse cooperation schemes, including an advance payment for imports. In other cases, the completion of foreign trade contracts is prevented by excessive pricing conditions for underwriting and insurance payments. In this regard, using interstate status, a number of banks members of the BRICS can help to achieve favourable agreements with banks - exporters to improve the conditions for international cooperation.

One of the most important trends of banks is to provide payment guarantees to exporters, ensuring pre-export financing and cooperation with insurance companies. It seems appropriate for BRICS international banks to move towards the development of special operations primarily related to export - import activities of economic entities and to provide customers and their counterparties with a variety of banking services on the agreed "flexible" terms of cooperation.

Namely, it can be provision of documentary operations, organisation of the bank syndicate to finance exporters / importers, financial market 
transactions, advising stakeholders during contract finalisation. Banks can also assist clients in calculating the limits for dealings with exporters and importers, confirmation of letters of credit and guarantees, issuance of guarantees and counter-guarantees, use of intergovernmental opportunities, taking into account documentary instruments, promissory notes, drafts, etc.

In order to maximise demand of economic entities, BRICS banks are expedient to: acceptance of drafts drawn by exporter / importer, financing exporters against documentary letters of credit, provision of agreed overdrafts, insurance of credit lines for exporters / importers, financing of drafts drawn by exporters, financing of collection documents with recourse to the borrower, provide trade financing against contract documentation. Financing of goods supply in the initial stage of the implementation of contracts (for up to 180 days), financing of importers/exporters, financing of the fulfilment of contractual obligations, financing documents against acceptance, implement pre-export funding are of an interest to BRICS banks' clients.

It is worth, while mentioning, that BRICS balance of payment specificity contributes to cooperation, based on national currencies, namely: clearing payments and services, multicurrency accounts facilities, with the possibility of strengthening account liquidity in national currencies from the surplus balances and manage clients' short-term liquidity, as well as management of accounts through mutual telecommunication system, maintain escrow accounts, etc.

Considerable attention is to be payed to corporate clients and consultancy on monetary and financial conditions and payment of export-import contracts in national currencies, as well as to BRICS currency regulation and control. Administration of short and medium term financing, transactions in national currencies, syndicated loans, currency risk management, provision of trust operations in national currencies and other currencies on behalf of BRICS banks clients can be of an interest to consumers.

An important component of creating a common economic space for BRICS countries is a presence of an intergovernmental insurance programme with participation of intergovernmental agencies for export insurance and guarantee of international operations. Specialised agencies of BRICS are able to promote effectively multilateral cooperation of business partners.

Banks involvement in encouraging formation of joint leasing companies with the public support also contributes to international relations. An important area of governments - sponsored cooperation is financing of 


\section{Banks for brics economic development}

innovative and knowledge-intensive projects, as well as socio - economic programmes: environmental protection, infrastructure development, energy - supply and health programmes, etc. At the same time, an important activity of BRICS banks can be linked with modernisation and engineering support of innovations, as well as in supporting joint credit lines in order to ensure the economic benefits and enhance the living standards of citizens of BRICS countries - members. In turn, the formation of the multilateral clearing system stimulates the development of BRICS' payment system. At the same time, BRICS monetary cooperation ameliorates the global financial infrastructure and makes it more reliable.

\subsection{Priorities for BRICS banking}

Currently, the main priority of the BRICS group is the formation of a common currency and investment reserves, as well as the development of mutual settlements in national currencies, that involves not only the currency instability on world markets, but also because many states out of BRICS want to develop business ties with the countries of this group. This, in turn, necessitated the establishment of the General monetary reserve and the BRICS Investment Bank in conjunction with the development of mutual settlements in national currencies and the need to increase competitiveness. BRICS have initiated a number of global proposals aimed at strengthening the stability of world financial markets, including the creation of BRICS New Development Bank, BRICS Reserve Monetary Fund, Insurance Pool, Exchange Alliance, etc. The creation of BRICS New Development Bank is a key to the successful development of the real sector of economy and further industrialization of BRICS. One of the priority objectives of any Bank is to provide systemic support to medium and small businesses, as well as public sector organizations and enterprises under the privatepublic partnership. These projects benefit all member countries of the group. Declaration on the New Development Bank establishment with a capital of $\$ 100$ billion is signed by the member countries in 2014. It is expected that the Bank may become a rival to the World Bank and other international and intergovernmental financial institutions. Currently, the New Development Bank mainly specializes in infrastructure projects in the territories of the member countries. The first President of the Bank became the representative of India. And its headquarters is located in Shanghai. In recent years, the Development Bank of the BRICs (and worldwide) is 
being actively discussed the problem of "bad debts", which is impossible without post-crisis recovery, sustained growth and development of BRICS credit market. Among the urgent problems which are to be resolved - the crisis of confidence that must be overcome together, otherwise enterprises will continue to make problem debts. In the expert community there are consultations on establishment a multilateral information system, similar to SWIFT. BRICS Finance Ministers and Central Bank Governors are discussing the whole range of issues, including setting up a clearing system and transition to payments in national currencies. The purpose of establishment of such a system is to convey sustainable clearing for BRICS.

\section{Analysis and discussions}

Actually, BRICS market participants assess the role of public institutions in modern economy: either it is a "pilot star" of the risky market or a bureaucratic vehicle, that enforces economic entities for non - profit behavior. What is it? EU has given examples of a reasonable contribution of governments to economic progress. The experience of countries, bridged over transformations, pushes forward the idea of fruitful correlation of public and private entities, achieving economic development and profitable activity. Actually, the government of the Russian Federation is keeping the way of economic supervision, not for the sake of reforms but in order to improve standards of living. Starting from the nineties of the XX century Russia entered the period of reforms. Within next fifteen years the market economy and its transparency has been growing. During the period of 2000-2007 standards of living have been improved as a result of a reasonable state participation in economic developments. International experience has been approved in the countries of the Central and Eastern Union:

1.Uncontrolled market (1991-1999) has brought the country to social tension, polarization and unemployment. Based on international experience reasonable measures has contributed to the positive effect on price formation and structure of the economic development. The world economic crisis has also proved the hypothesis of the predominate role of the state in regulation of the market economy.

2. Market participants are doing their best in achieving short-term results, guided by "selfish" demand of profit, that sometimes contradict the socio economic interest. Thus, it is impossible to back totally on the "wheels" of the market. 


\section{Banks for brics economic development}

3. Spontaneous change of the market economy is linked with financial discrepancies and accompanied by systemic and functional risks. To ensure social demand under these circumstances public institutions cannot, but support private entities to manage risks.

4. Public supervision does not mean involvement into activities of private entities - intention is to challenge society interests, such as:

- economic growth, production increase, development of innovations, improvement of supply and demand structure;

- decrease of unemployment rate, support of price level;

- social responsibility: respect of regulation and profitable activity within the market environment.

There is no denying the fact, that the challenge of any government is the efficiency of macroeconomic supervision, provision of flexible rates for the economic growth, improvement of legislation, unification of business standards and increase of living standards. Main problems to be solved by any government are the insurance of economic development; stimulation of public private partnership; reasonable regulations. Actually, developing countries are adopting to international standards, taking into consideration current economic environment that contributes to easy BRICS business contacts. To ensure positive developments the countries adopt laws of the market development and its supervision that protects economic entities make their activity transparent. New challenges for public and private entities within the market are linked with responsibility of its activity: financing and insurance of export credits, production/promotion of goods and services, intellectual property and innovations. BRICS private entities take into consideration the international experience: special attention is paid to the early European capitalism in Germany, for example, that has proved the effectiveness of a centralized control over prices, quality of goods and services, tax and rates regulation. The historic "merry-go-round" produces lessons that should be put into local environment in accordance with its specificity. For example, there is a variety of proportion of monopolism and liberalism in different states and sometimes the necessity of state regulation of economy is considered to be doubtless. At the same time, the succession of economic cycles shows that self-curing of the recession is impossible without public finance involvement. More than that, during the crisis the ties between the state and its entities deepens. Within the economic breakdowns or sustainable development, any state bears responsibility for its economic 
and social background. Public authorities have a vast range of instruments to influence the situation: taxation, monetary policy, legislation, etc. For example, the government of the countries of Central and Eastern Europe pay great attention to implementation of efficient fiscal policy initiating the economic growth, such as: state expenses on social programs; maintenance of strategic development; reasonable taxation. The main challenge of the governments is to improve living standards, backed by the steady economic growth. An important role in providing financial support play financial intermediaries. At the same time an efficient banking strategy depends on the adequate estimation of economic peculiarity of its clients. European experience shows that speculative banking activity leads to great problems: cutback of production, abrupt economic deregulation, etc. Being in pursuit of fast earning, private banks often cut down traditional banking and capital outflow to offshore zones. Reasonable regulation and supervision of the banking sector helps to reinstate economic background that is reinforced be international cooperation. At the same time, efficient international cooperation of private and public entities depends on instruments of economic and financial support. There is no denying the fact, that market participants are under pressure of client's demand of high quality goods and services and the competitors are able to offer consumers goods of a better price and quality. Under these circumstances, equal treatment of all market participants and transparent determination of general principles of activities can push forward international cooperation. Unified legislative base, efficient bank support of economic entities creates steady background for regional cooperation within the integrated economic area. However, formation of effective conditions for cooperation takes time. In general, underdeveloped countries are too enthusiastic and they underestimate the period of adoption to the level of the industrial growth. At the same time, some researches point out the lack of a "political will" that usually spoils the situation. Actually, it reveals through economic sanctions that are not productive for the market participants.

EBRD experts conclude, that, for example, the some of the CIS members are facing considerable decline of standards of living. This fact requires immediate action within the programs of international economic cooperation of the countries that have deep economic and cultural roots. Some of the post-soviet countries are suffering from bankruptcy, merges, acquisitions, lack of resources, etc. Solid banking support can help to 


\section{Banks for brics economic development}

recover. Regional programs of public support of non-protected participants of the market - small and medium enterprises (SME), for example, create favorable conditions for enterprises, capable to reach economic goals with public support. Unification of financial and banking rules helps to implement efficient support of SME's activity and effective international cooperation is connected with the unanimous international banking strategy. Putting it into action depends on a complex analysis of economic demands and challenges of market participants. The analysis confirms also, that there is a stable tendency within the emerging financial markets: mergers of institutions, based on different motives. In general, the possibility of future profits is the most common motive for a merger. Firms will perform certain measures if it is the most profitable way of enhancing capacity, entering new product or geographic areas, acquiring new knowledge or skills, or reallocating assets into the control of the most efficient managers or owners. International experience suggested motives for mergers and acquisitions include efficiencies, financial and tax benefits, market power effects, management greed, obtaining a good buy and stakeholder expropriation. In terms of efficiencies firms and banking institutions of BRICS can combine their operations through mergers of firm's/bank's assets in an effort to reduce production costs, increase outputs, improve product quality, acquire new technology and/or produce new products. Aside from the new and improved products and output possibilities, mergers can create a market for corporate control that can safeguard against inefficient management. This can be made possible by reallocating resources from firms with inefficient management to firms with efficient management especially in turbulent ages. This helps to keep profits stable and reduce the risks. Another wellknown motive refers to is stakeholder expropriation where shareholders gain at the expense of stakeholders. An example of this would be if a firm is looking to be acquired in order to escape financial problems or to back out of unfavorable labor contracts. One of the basic motives for BRICS mergers is the consolidation of ownership. In advanced market economies, this can be seen through takeovers in Central and Eastern Europe. There is no denying the fact, that takeovers help to solve corporate governance problems and due to the merger, the firm values actually increases in the process, suggesting that profits may increase afterwards. An important factor of mergers is that they require a liquid capital market in order for the bidder to have access to large amounts of capital in the short term in order to 
manage it in common interests. The only one thing worthwhile mentioning: acquisitions and mergers announced in a hot merger market can end up having declines in the bidder's stock price in the end. This can be tempting for managers to make bad acquisitions if they are rewarded with short-term performances. Sustainable banking activity and their support of BRICS economic entities will also expand the economic ties.

\section{Conclusions}

The results of the study provide a strong case for banking support of BRICS economic developments, which should be taken, into consideration while creating mutual approach to the restructuring of global infrastructure. Economic needs and mutual interests are certainly a step in the right direction of cooperation. However, setting and meeting the needs depend on banking and finance. It is also recommended to take into consideration the international experience and to introduce the required instruments and harmonized regulation for BRICS banking. Presented results of the study can benefit regulators and banks by providing new vehicles for BRICS economic cooperation.

A further novel concept introduced in this study is the use of techniques to distinguish between short-term and long-term relationship and to formulate corporate strategy, based on real requirements of economic entities. The concept can be generalized in future studies of BRICS and their entities in assessing probabilities and the ways of cooperation.

Finally, insight is provided into how mutual interests affect banking and BRICS economic goals.

\section{References:}

3. Ahmad, E. (1997). Intergovernmental transfers - an international perspective, chapter 1 in Ahmad (ed.) Financing decentralized expenditures. An international comparison of grants. OECD Publishing, http://dx.doi.org/10.1787/5k9csfs90fr4-en

4. Bird, R. \& Vallencourt, F. (1998). Fiscal Decentralization in developing countries. Cambridge: Cambridge University Press. https://www.cambridge.org/ core/services/authors/journals.pdf

5. Brennan, G. \& Buchanan, J.M.(1980).The power to tax: Foundations of a fiscal constitution. New York: Cambridge University Press. http://oll.libertyfund.org/ titles/buchanan-the-collected-works-of-james-m-buchanan-vol-9-the-power-totax.pdf

6. Breton, A. (1989). The growth of competitive governments. Canadian Journal of Economics, vol. 22. http://onlinelibrary.wiley.com/doi/10.1111/caje.12281/abstract 
7. Brosio, G (2000). Decentralization in Africa. The African Department. Washington DC: International Monetary Fund. https://www.bookstore.imf.org/ books/title/collapse-and-revival?redirected=true.pdf

8. BRICS and Africa (2013): partnership for development, integration and industrialization Collection of information and analytical materials on the theme of the Summit of the BRICS 2013 in South Africa. http://www.unido.ru/upload/files/s/ sbornik_pic.pdf.

9. Crook, R.C. \& Manor, J. (1998). Democracy and decentralization in South Africa and West Africa. Participation, accountability and performance. Cambridge: Cambridge University Press. ttps://books.google.co.uk/books?id=4Xn3c7X-xk$\mathrm{kC \& printsec}=$ frontcover\&hl$=\mathrm{ru} \&$ source $=\mathrm{gbs} \_\mathrm{ge} \_$summary_r\&cad $=0 \# \mathrm{v}=\mathrm{onep}-$ age\&q\&f.pdf

10. Fukasaku, K. \& L.de Mello Jr. (1999), Fiscal decentralization in emerging economies. Governance Issues. Paris: OECD, Development Centre. http://unpan1.un.org/intradoc/groups/public/documents/UNTC/UNPAN018217.pdf

11. Oates, W. (1999). An essay on fiscal federalism. Journal of Economic Literature, vol.37, no.3 http://econweb.umd.edu/ oates/research/fiscalfederalism.pdf

12. Russian Federation: Financial Sector Assessment July 2016 [Electronic Resource] / The World Bank, 2016 - p. 10. Mode of access: http://documents. worldbank.org/curated/en/936001472672149654/pdf/Russian-FederationFSA-07272016.pdf.

13. Shavshukov, V.M., Developing markets in the BRICS in global finance system/V.M. Shavshukov//Vestnik St. Petersburg University. - 2012. No. 5 (1). S. 119-136.

14. Soros, George (1998). The Crisis of Global Capitalism: Open Society Endangered. New York: Public Affairs. ISBN 978-1-891620-27-0 https://www.amazon.com/Crisis-Global-Capitalism-Society-Endangered/dp/ 1891620274

15. South African Banks [Electronic Resource]. - 2014. - Access mode: http://www.wbanks.ru/africa/south-africa.html. Access date: 01.11.2014

16. Stiglitz, Joseph (1998). Redefining the Role of the State - What should it do? How should it do it? And how should these decisions be made? Paper presented at the Tenth Anniversary of MITI Research Institute, Tokyo. http://people.ds.cam.ac.uk/ mb65/library/stiglitz-1998.pdf 
Izdevniecība "Baltija Publishing"

Valdeķu iela 62 - 156, Rīga, LV-1058

Iespiests tipogrāfijā SIA "Izdevniecība "Baltija Publishing"

Parakstīts iespiešanai: 2018. gada 29. Aprīlis

Tirāža 300 eks. 